\title{
Transitions to Adulthood: A National Survey of Adolescents in Egypt [1st edition, Arabic]
}

Sahar El Tawila

Omaima El-Gibaly

Barbara L. Ibrahim

Population Council

Fikrat El Sahn

Sunny Sallam

See next page for additional authors

Follow this and additional works at: https://knowledgecommons.popcouncil.org/departments_sbsr-pgy How does access to this work benefit you? Let us know!

\section{Recommended Citation}

El Tawila, Sahar, Omaima El-Gibaly, Barbara L. Ibrahim, Fikrat El Sahn, Sunny Sallam, Susan M. Lee, Barbara Mensch, Hind Wassef, Sarah Bukhari, and Osman Galal. 1999. "Transitions to Adulthood: A National Survey of Adolescents in Egypt [1st edition, in Arabic]." Cairo: Population Council. 


\section{Authors}

Sahar El Tawila, Omaima El-Gibaly, Barbara L. Ibrahim, Fikrat El Sahn, Sunny Sallam, Susan M. Lee, Barbara Mensch, Hind Wassef, Sarah Bukhari, and Osman Galal 


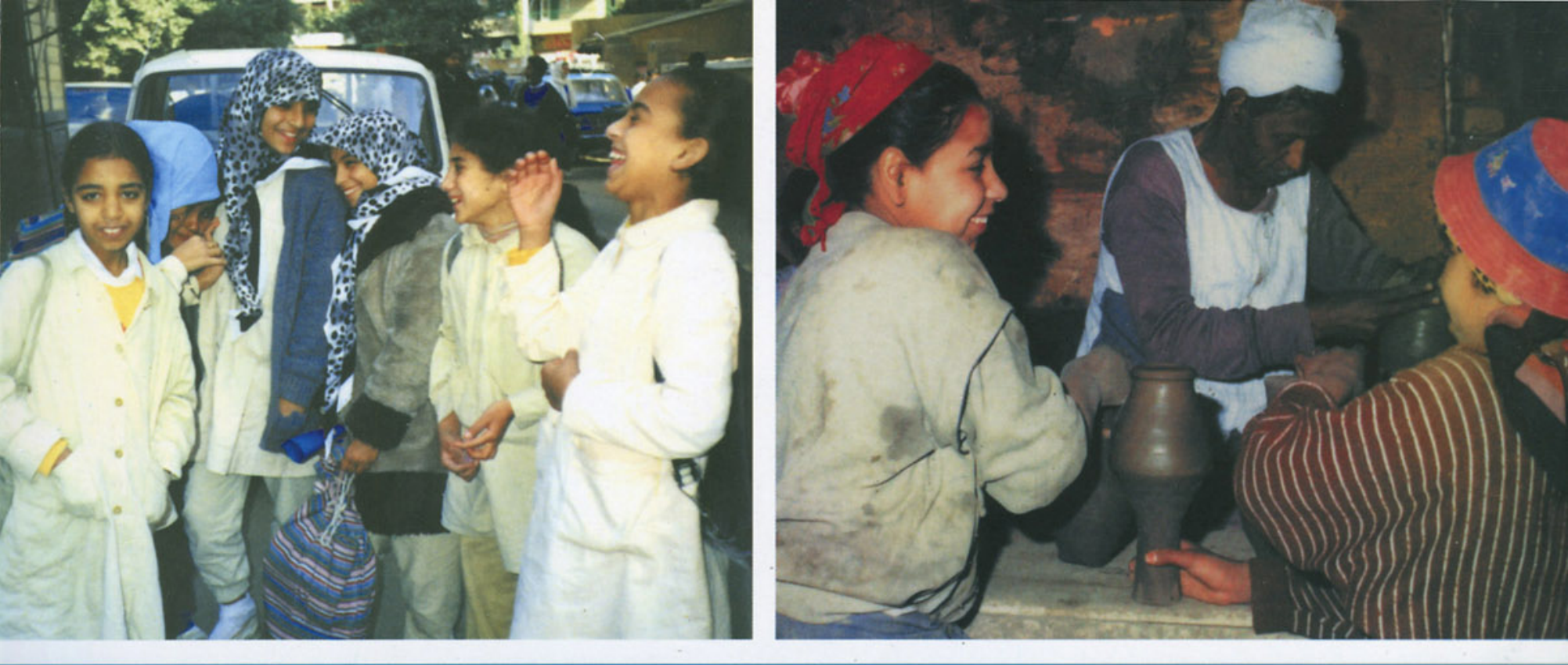

\section{Population Council}
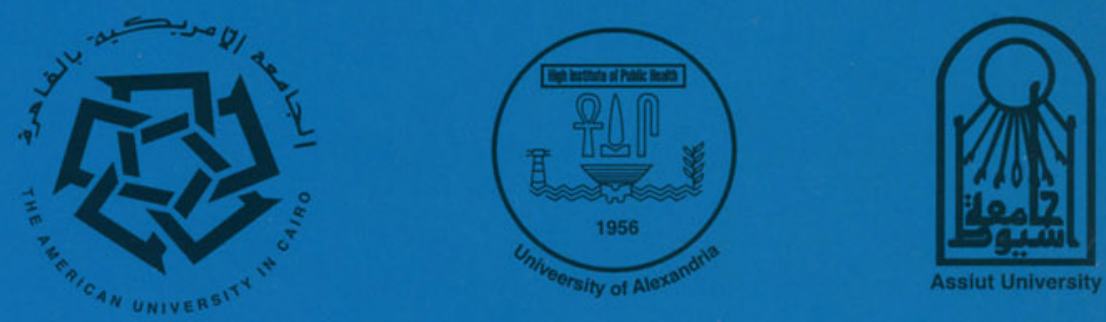

يلقى هذا التقرير الضوء على نتائج مسح ممثل على القى

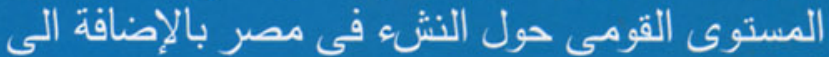

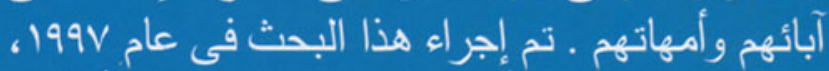
بهدف الوصول لفهم أعمق للتجارب التنموية الأساسية التانية التى يمر بها النشء في مرحلة الانتقال إلى النضعج ـ يركز

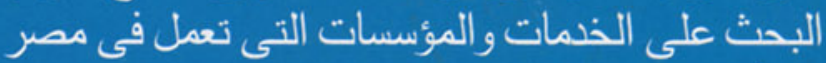
من أجل دعم هذه المرحلة الانتقالية ـ يتصنمن التقات التقرير

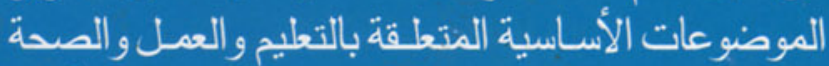
والتنشئة الاجتماعية والتكيف النفسى بالإضفافة إلى الألوار المتعلقة بالنوع والتأهيل للزوراج . 


\section{الانتقال إلى مرحلة النضج \\ مسح قومي حمل النشء في مصر}

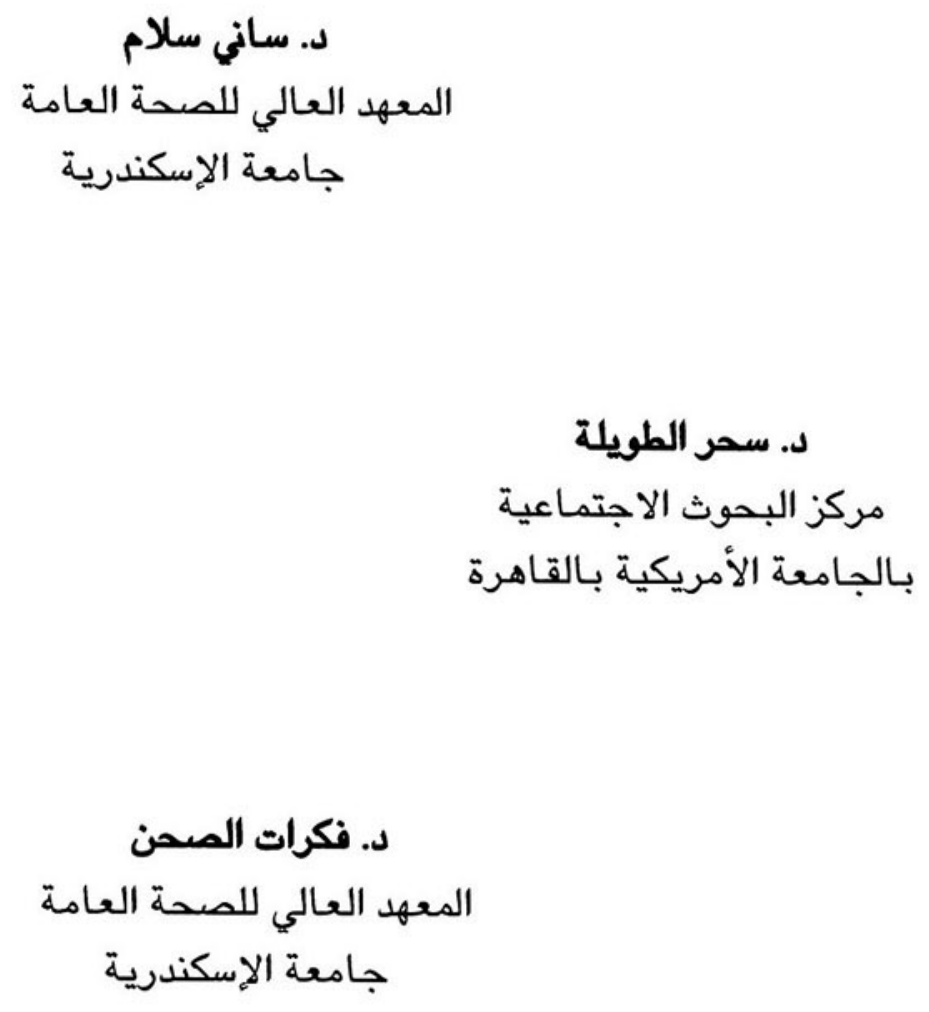

$$
\begin{aligned}
& \text { د. باريارا إبراميم } \\
& \text { مكتب مجلس السكان الدولي } \\
& \text { لمنطقة غرب آسيا وشمال } \\
& \text { أفريقيا }
\end{aligned}
$$

$$
\text { بالجامعة الأمريكية بالقاهرة الاعتماعة }
$$

$$
\text { جا دامعة الإسكندرية الصحة العامة }
$$

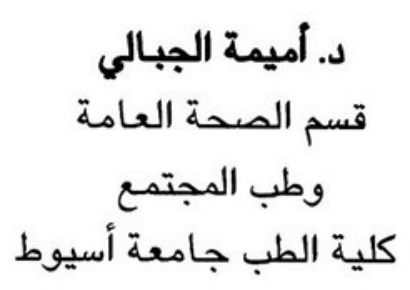

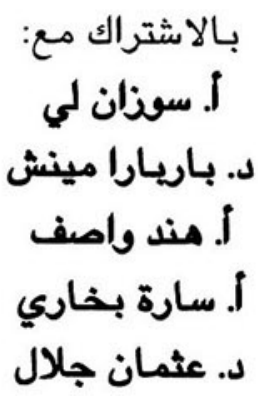

r.. 1 ، 1999

الطبعة الثانية 


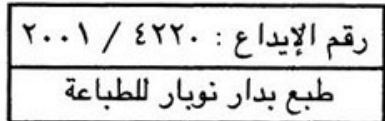




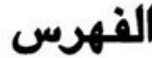

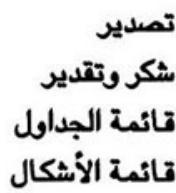

الفمل الأمل: نحو فهم أفضل للنشء فى مصر

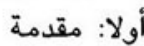

ثانيا: أهداف الدراسة وتعريف المصطلحات

ثالثا: التعاون المؤسسى / فريق البعان البحث

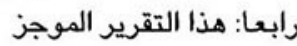

الفمل الثانى: منهج ونطاق الدراسة

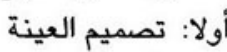

ثانيا: أدوات الدراسة ومنهجها ثالثا: تنفيذ الدراسة وجمع البيانات رابعا: دروس العمل الميدانى تئي خامسا: السمات الفريدة للدراسة سادساً: بعض الملاحظات الفنية

الفمل الثالث: خمائم العينة أولا: مدى تمثيل مجتمع النشء في مصني مصر العين ثانيا: خصائص عينة البالغين المسئولين

YI

rY

ro

rv

$\varepsilon r$

01

o
الفمل الرابع: الصورة المحية العامة للنشء الممرى

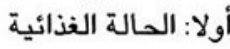

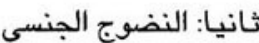

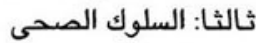
رابعا: الصحة العامة الصحئ خامسا: السعى للرعاية الصحية الرامية

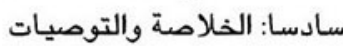

الفمل الخامس: المودة التعليمية العامة للنشء فى ممر

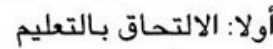
ثانيا: الأداء المدرسى اللفتيات والفتيان

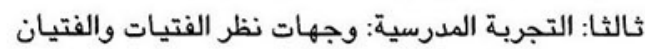
رابعا: السياق الاجتماعى للتعليم: رؤية جيلين التراتين خامسا: نقاش للآثار المتصلة بالسياسات

الفمل السادس: الأدوار الاقتمادية للنش. أولا: مشاركة النشء في الأنشطة الاقتصادية: الإدارية التجرية الحالية ثانيا: الصورة العامة للنشء العاء العامل

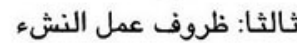
رابعا: الأجور 
11.

IIT

IIr

110

IIV

Irr

ITV

irr

ire

$1 \varepsilon$.

IEr

$1 \varepsilon r$

100

ITr

171

IVI

ivr

ivo

IVV

iva

INI

110

IAV

I9r

190

191

199

199

r.

$r \cdot 1$

$r \cdot r$

$r \cdot V$

$r \cdot q$

PII

YIO

rIV

$$
\begin{aligned}
& \text { خامسا: الصورة العامة لأسر النشء العامل }
\end{aligned}
$$

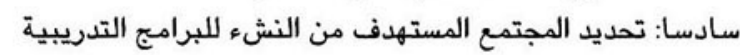

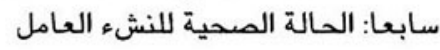

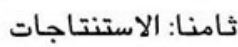

الفمل السابع: عوامل التنشنة الاجتماعية

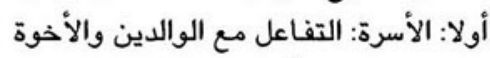
ثانيا: علاقات الأقران

ثالثا: الصورة النفسية العامة للنشء والاقدان الدعم من جانب الأسرة/الأقران

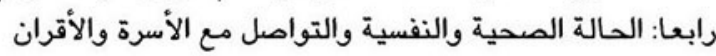

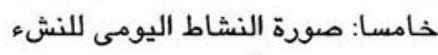

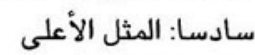
سابعا: الاستنتاجات المثل الاعل

الفمل الثامن: الانتقال الى النفاج والأدوار الانجابية أولا: المعرفة بالصحة الانجابية الانية الصالية ثانيا: ممارسات الصحة الانجابية

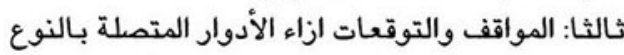

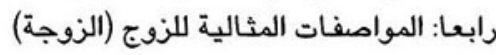
خامسا: المعرفة بعقد الزواج سادسا: الطلاق: الطعاق سابعا: الاستنتاجات الطات الفمل التاسع: نواج الفتيات أولا: تصنيف زواج الفتيات وتحديد مدى شيوعه الفيات ثانيا: وصف عينة المتزوجات ثالثا: سمات زواج الفتيات رابعا: الأدوار المتصلة بالنوع زواج في الفيات الأسرة خامسا: الصحة الانجابية سادسا: الاستنتاجات الصحة الانجابت

الفمل العاشر: بعض الاستتباعات الخاصة بالدعوة والعمل

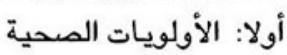

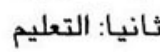

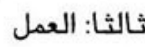
رابعا: الصحة الانجابية الصمل خامسا: زواج الفتيات الانيات سادسا: الاستنتاجات : واجيات

الملحق رقم 1

الملمق رقم بمق رقم

الملمق رقم المق رقم

الملحق رقم ع

المراجع

المظافنف 


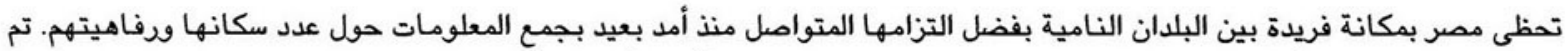

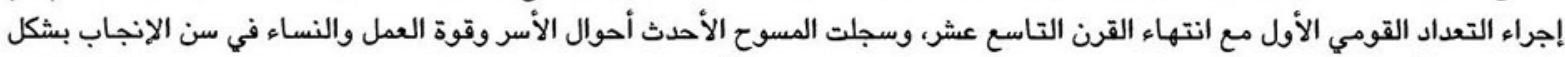

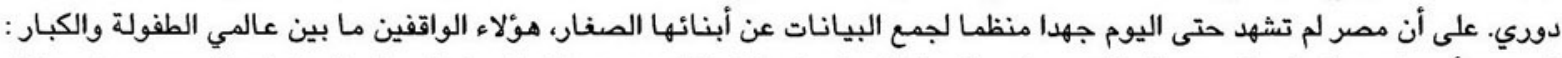

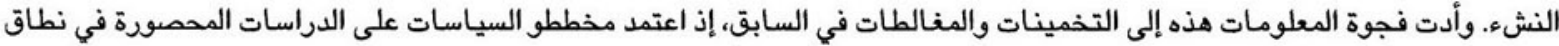

محلي ضيق أو الاستنتاجات الصحفية عند تحديد احتياجات ومشكلات أبناء هذه الفئة العمرية.

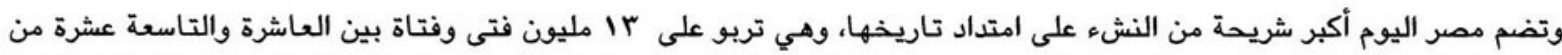

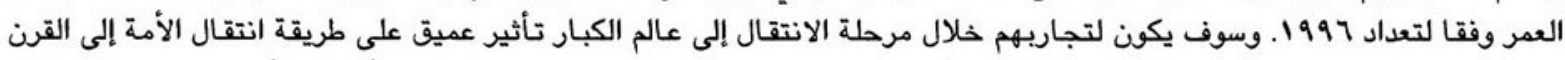

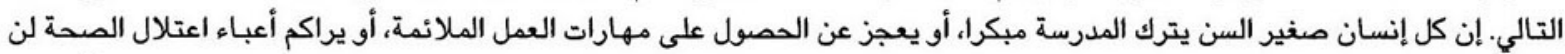

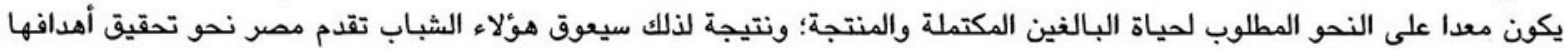

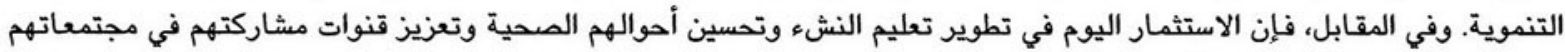
المحلية، سيكون له تأثيرات إيجابية بعيدة المدى في المستقبل.

وإنه لمن دواعي سرورنا أن نسهم في الاهتمام المتزايد بحاجات النشء في مصر من خلال تقديم هذا التقرير البحثي. وهو يضم النقات النتائج

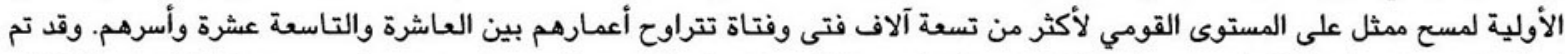

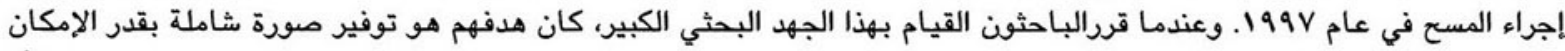

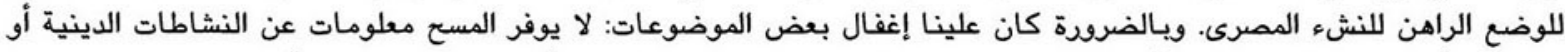

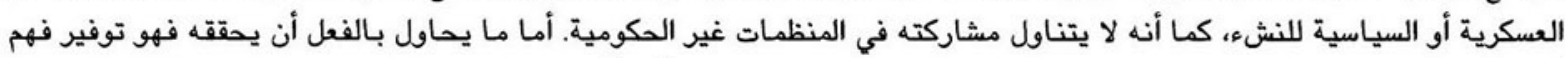

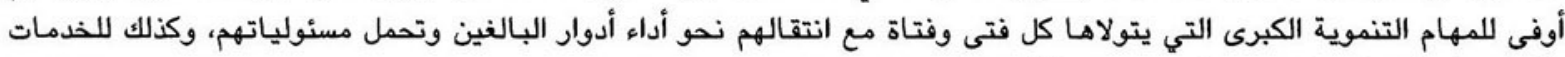
والمؤسسات المتوفرة في مصر التي تدعم هذا الانتقال.

نرجو مخلصين أن تكون المعلومات المتوفرة في هذا التقرير مفيدة لنطاق واسع من الجمهور. سيجد الباحثون مناطق عدة فيما توصلنا

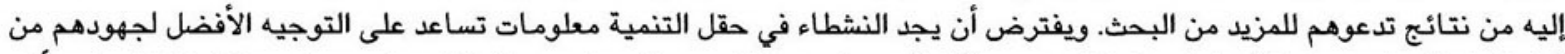

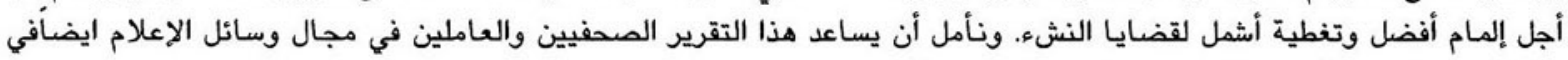

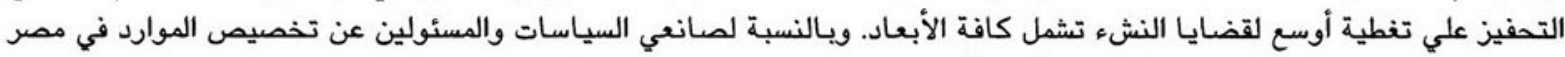

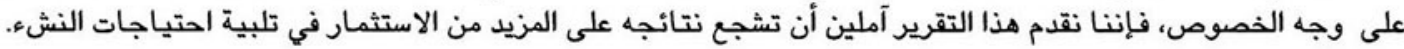

باريارا إبراهيم

القاهرة، مارس 1999 


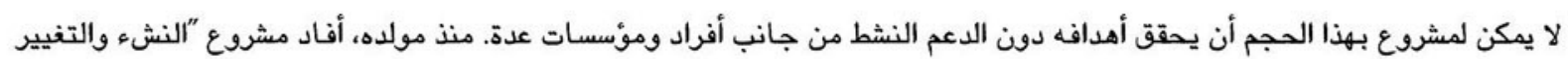

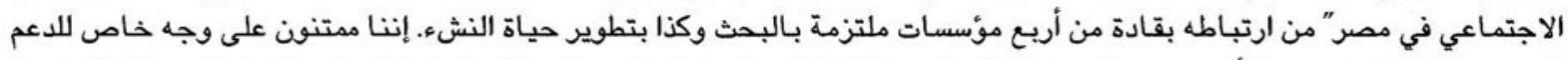

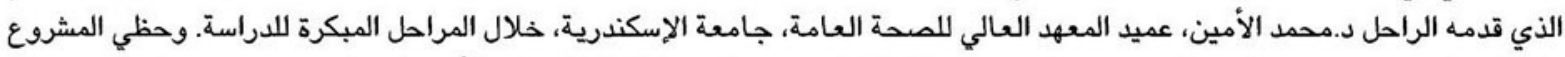

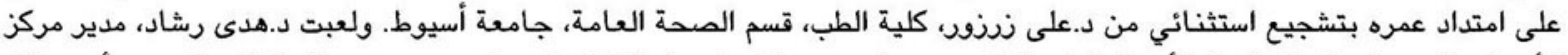

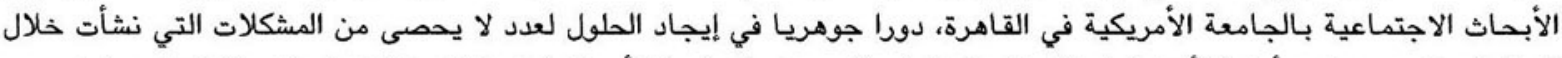

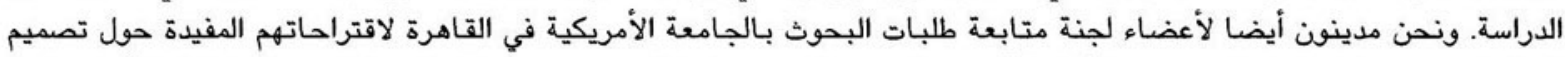

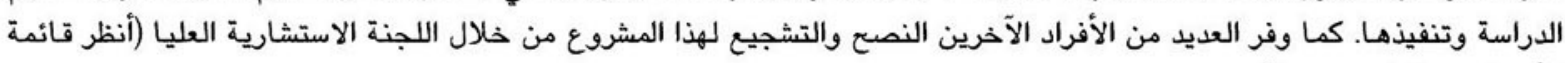

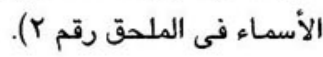

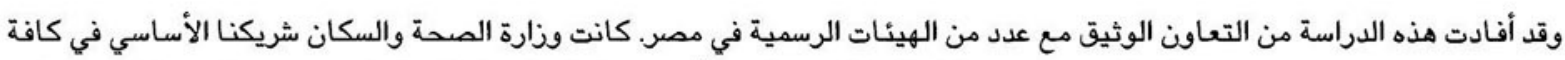

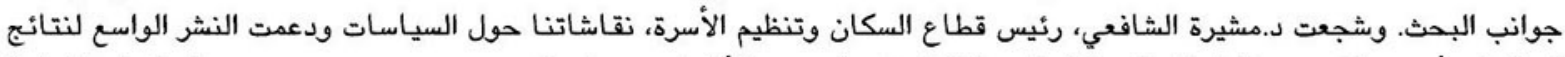

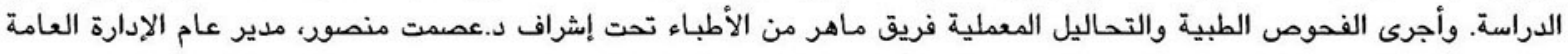

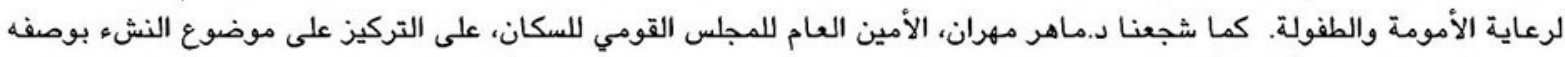

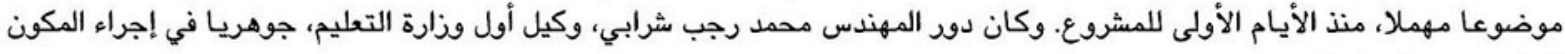
التعليمي من الدراسة.

وفرت مجموعة من المانحين التمويل والتشجيع على امتداد مراحل تخطيط المشروع وإجراء العمل الميداني والتحليل. تلقينا دعما مبكرا

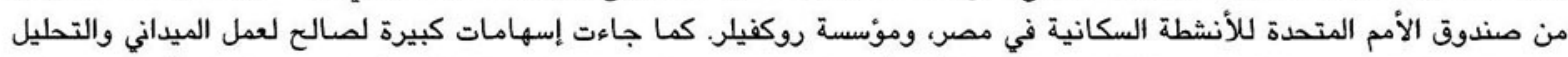

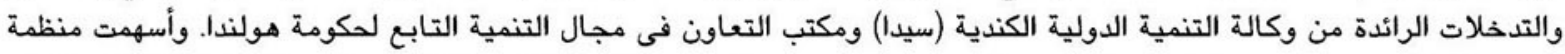

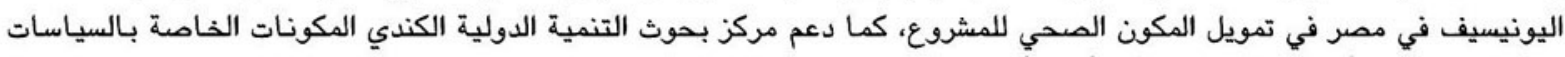

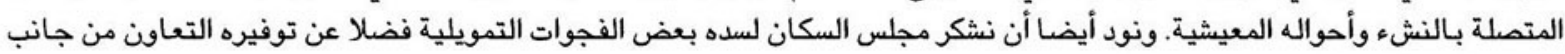

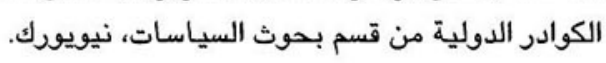




\section{قانمة الجدوال}

الفمل الثاني: منهج ونطاق الدراسة

$1 \varepsilon$

$1 \varepsilon$

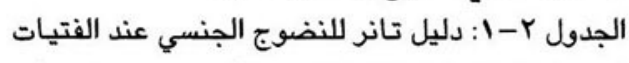

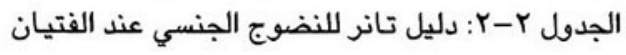

الفمل الثالث: خمعانص العينة

الجدول r-اتوزيع السكان بناء على بيانات التعداد العام للسكان لعام 1997 وتوزيع أفراد الأسرة المعيشية داخل العينة طبقا لبعض 19

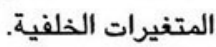

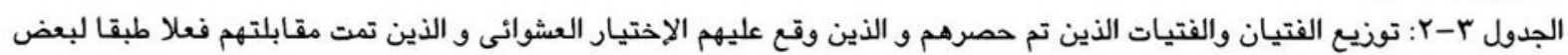

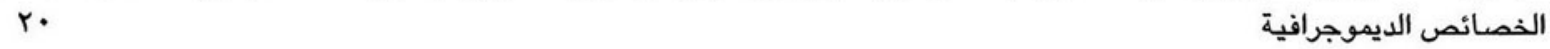

الجدول r-r : : توزيع الفتيان والفتيات فى العينة الفرعية الذين تم اختيارهم لاستكمال إستبيان الحالة الصحية طبقا لبعض المتغيرات

YI

الخلفية

rr

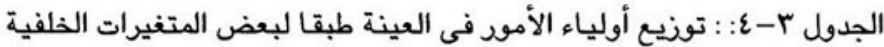

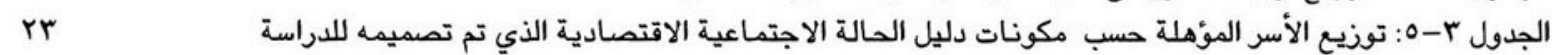

ru

rา

ن (بالنسب rq

rr

$r \varepsilon$

ra

ra

$\varepsilon$.

$\varepsilon$

$\varepsilon$

$\varepsilon$

$\varepsilon r$

$\varepsilon r$

$\varepsilon \varepsilon$

$\varepsilon \varepsilon$

$\varepsilon 0$

$\varepsilon 1$

$\varepsilon v$

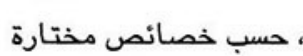

¿1

○.

○.

01

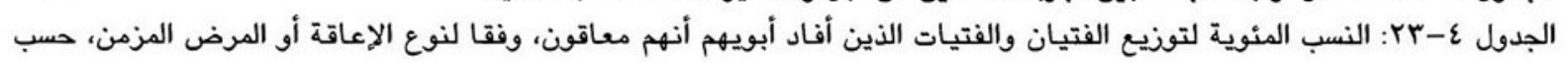

or

07

or

ov

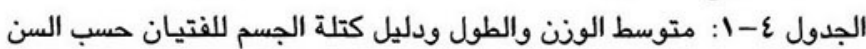

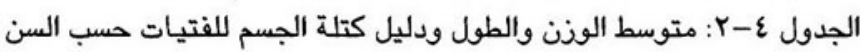

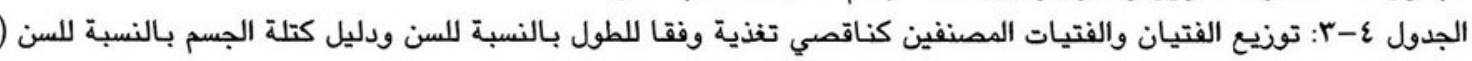

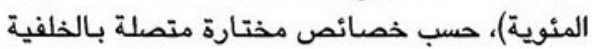

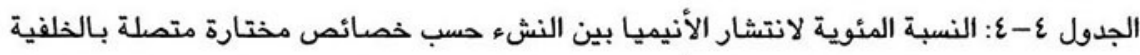

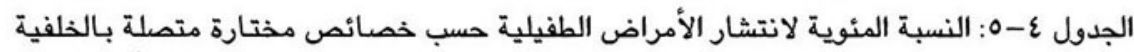

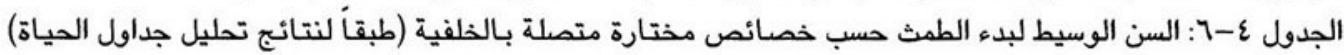

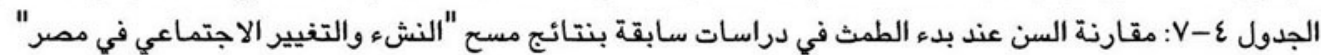

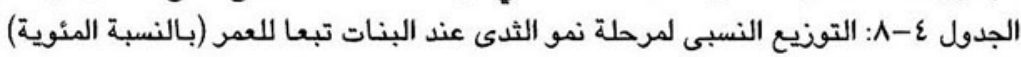

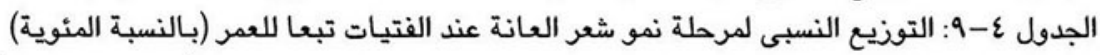
الجدول ع- • ا: التوزيع النسبى لمرحلة نمو شعر العانة عند الفتيان تبعان العبعان للعمر (بالنسبة المئوية)

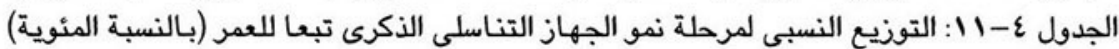

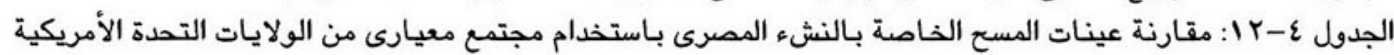

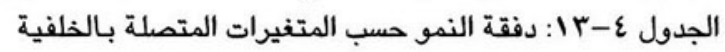

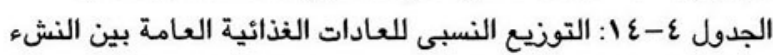

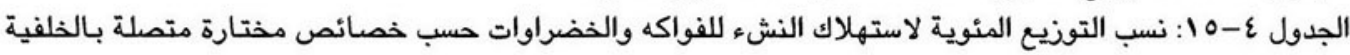

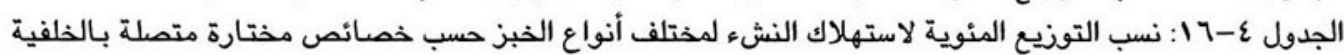

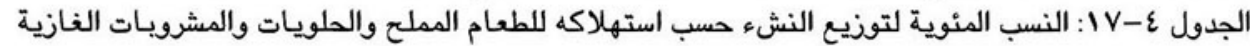

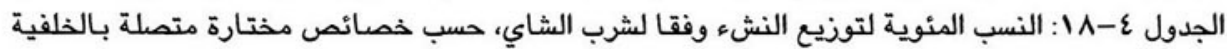

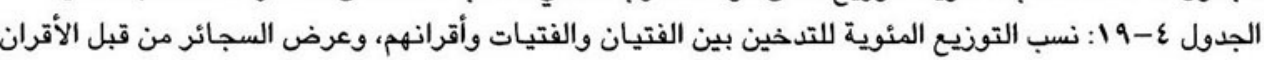
متصلة بالخلفية

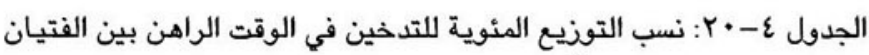

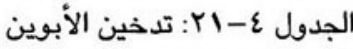

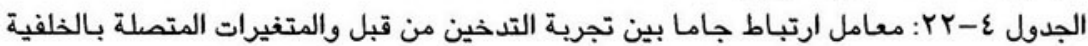
خصائص مختارة متصلة بالخلفية النوانية

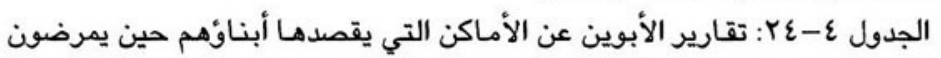

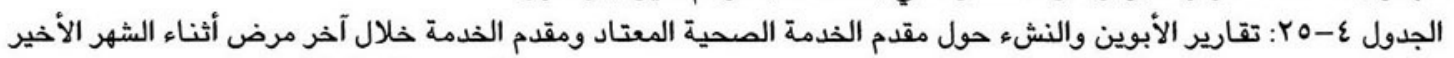

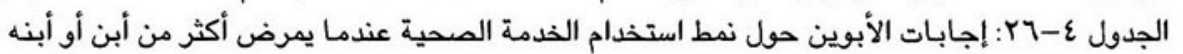

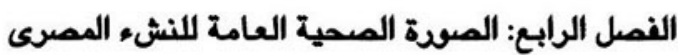


الجدول ع-rV: تقارير الطلاب حول وجود طبيب أو ممرضة (بالنسبة المئوية)؛ وامتلاك بطاقة نظام التأمين الصحي على طلاب المدارس؛

०ᄉ

$0 \wedge$

09

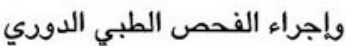

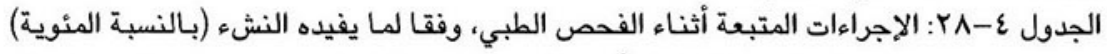

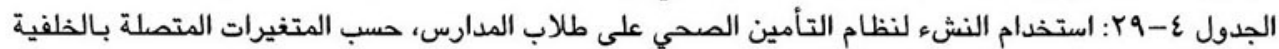
$\circ 9$

المتغيرات المتصلة بالخلفية (بالنسبة المئوية)

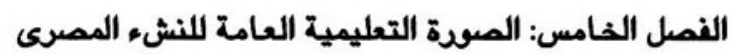

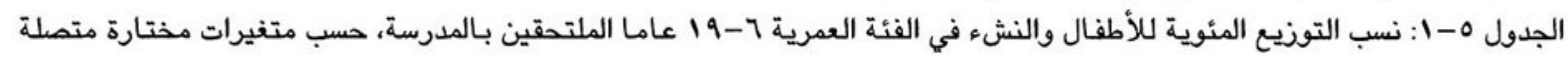
Ir

بالخلفية

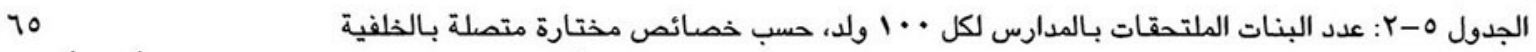

الجدول ه-r: التوزيع النسبى اللفتيان والفتيات غير الملتحقين جاليا بالددرسة أو الذين لم يسبق لهم الالتحاق مطلقاً طبقاً لبعض

المتغيرات الحلقية 19

الجدول ه-ع: المواقف والخبرات السابقة للنشء الذى لم يلتحق بالمدرسة من قبل بخصوص فبصول محو الأمية طبقاً لبعض المتغيرات

v9

الخلفية

الجدول ه-ه: التحصيل الدراسي كما تبينه نتائج الامتحانات المدرسية واختبارات التحصيل في اللغة العربية والرياضيات، النسب

Al

Ar

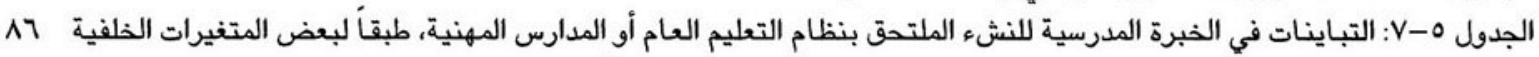

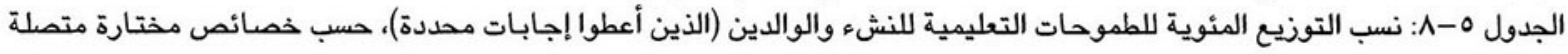

$\Lambda \mathrm{V}$

19

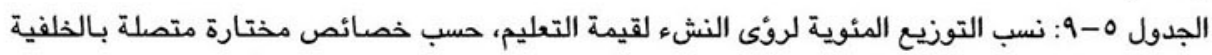

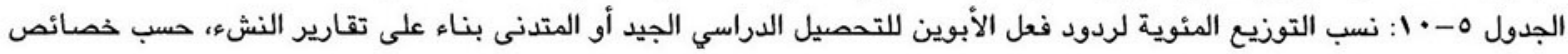

مختارة متصلة بالخلفية التوان

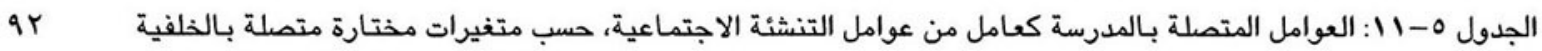

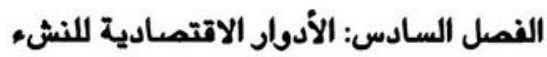

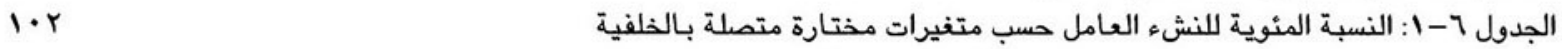

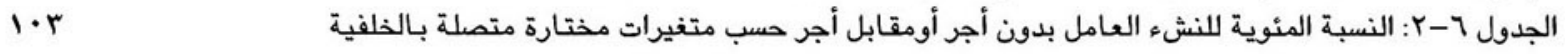

$1 \cdot r$

$1 \cdot \varepsilon$

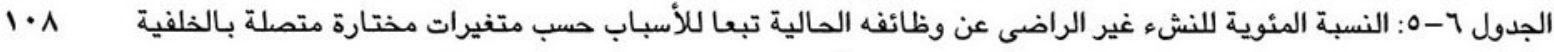

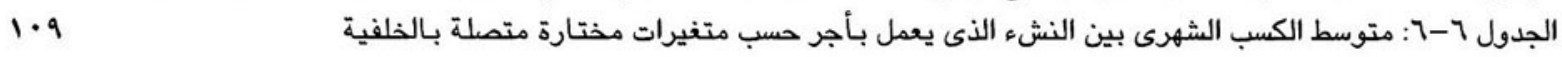

الجدول III

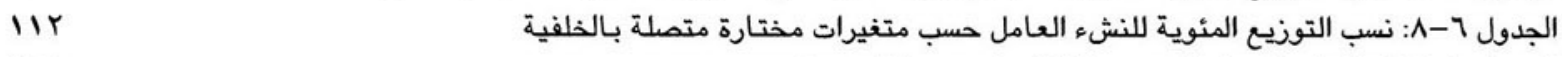

$11 \varepsilon$

الجدول 1-9: العلاقات المتداخلة بين حالة العمل وصحة النشء العامل في مصر

الفمل السابع: عوامل التنشئة الاجتماعية

الجدول V-1ا: النسب المئوية للنشء للفتئيان والفتئيات الذين يعبرون عن آرائهم صراحة مع أسرهم وردود فعل الأسر، طبقاً لبعض 111

المتغيرات الخلفية المختارة

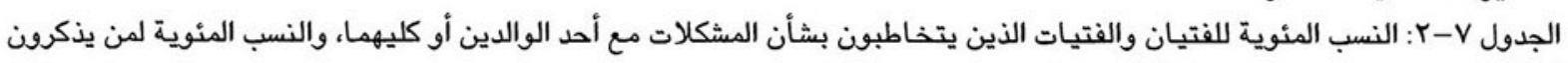
ir.

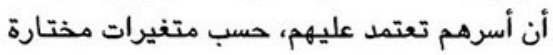

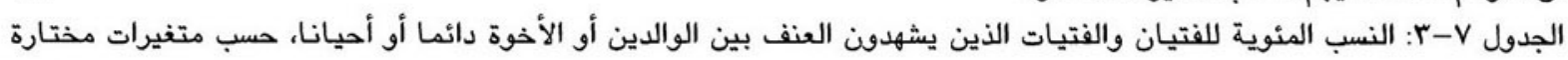
$|r|$

متصلة بالخلفية

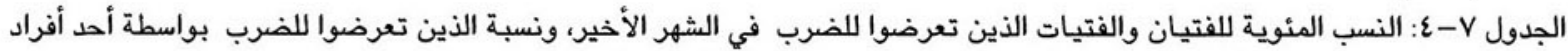

IrY

I $Y \varepsilon$

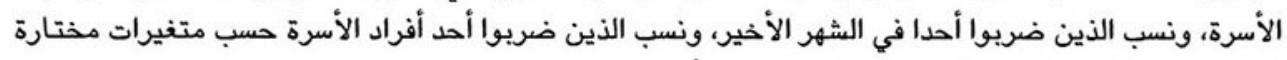

الجدول V-0 : النسب المئوية لانفتاح النشء على الفي الأقران، حسب متغيرات مختارة متصلة بـالخلفية 


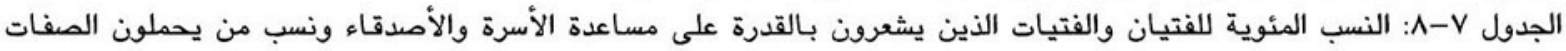

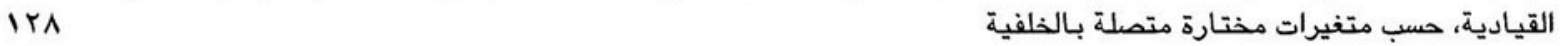

ir.

الجدول V-9: انتشار المشاعر السلبية بين النشء حسب مسب متغيرات مختارة متصلة بـالخلفية

ITI

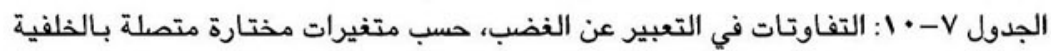

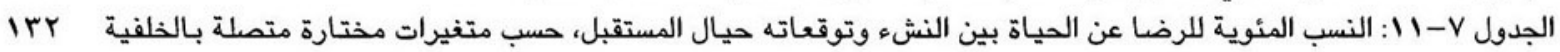

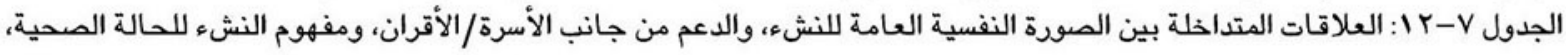
irr ومرحلة النضوج البيولوجي iro الجدول V- I I : تقارير النشء عن الأنشطة خلال اليوم السابق

iry

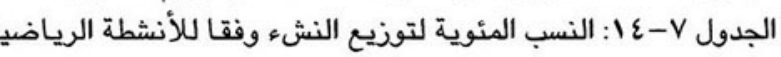

irv

irs

irq

irq

|हा

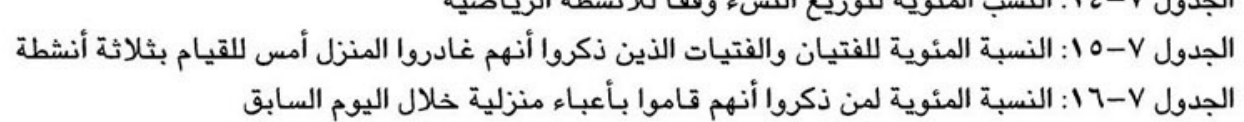

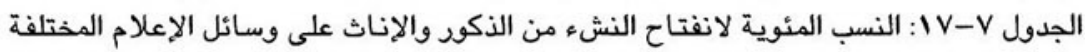

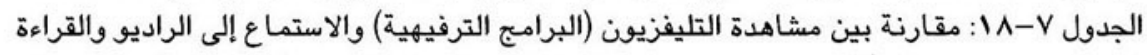

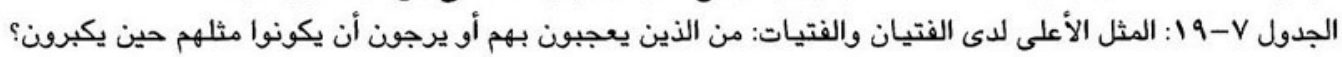

$1 \varepsilon 7$

الفمل الثامن: الانتقال إلى النواج والأدوار الانجابية

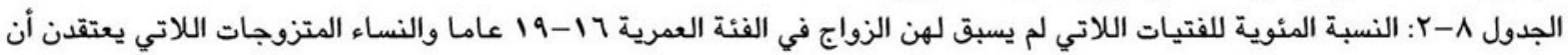
IधV

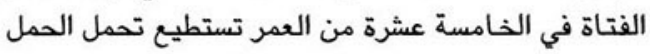

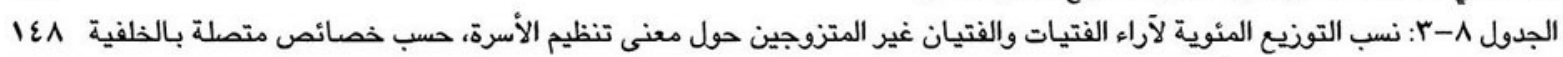
$1 \varepsilon q$

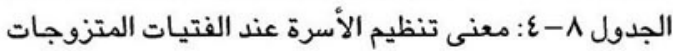

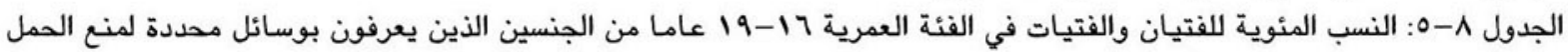
10 . (ممن أفادوا بمعرفتهم بتنظيم الأسرة)

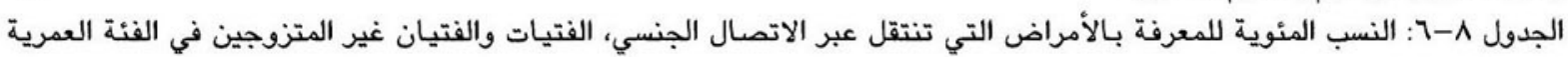
10r

19-17

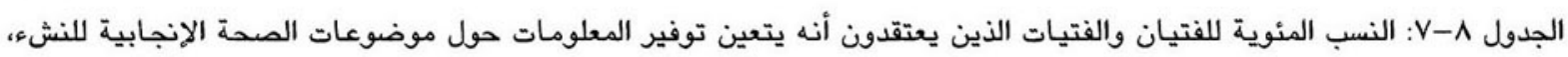
$10 \varepsilon$ وترتيب المصادر الملائمة وتوقيت توفير المعلومات الفئي

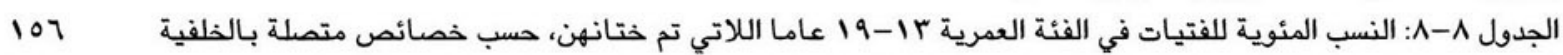

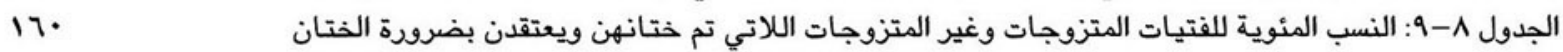

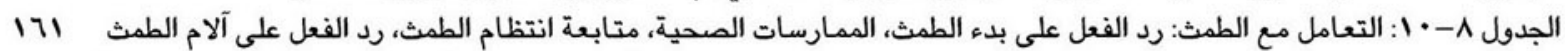

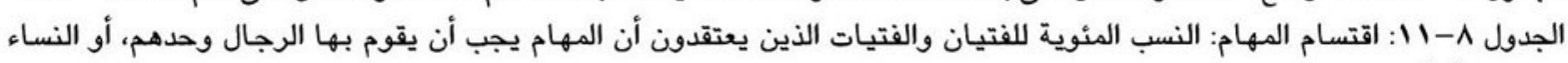
$17 r$

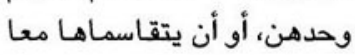

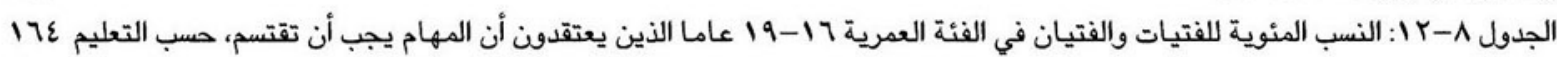

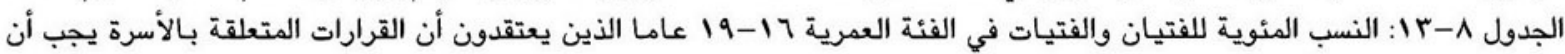
170

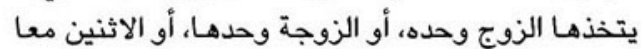

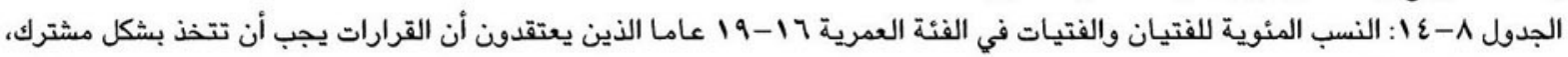
170

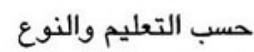

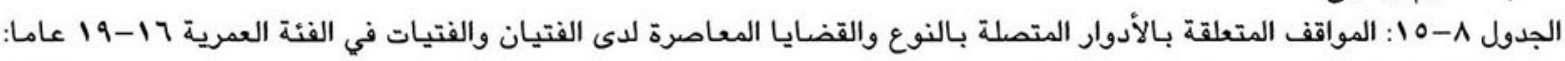
177 النسب المئوية للموافقين على العبارات التالية

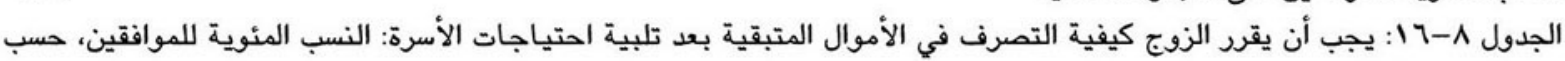
178

171

179 متغيرات مختارة

179

179

IV.

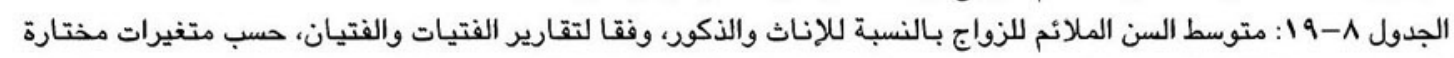

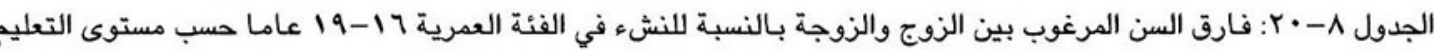




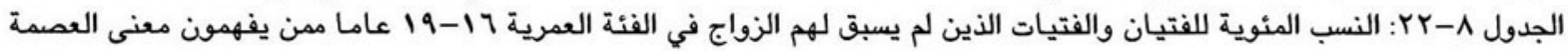
IVT

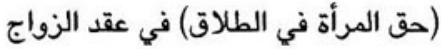

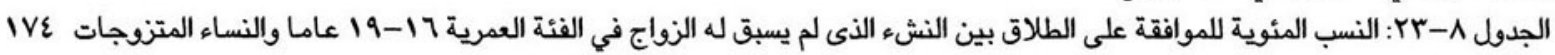

\section{الفمل التاسع: نواج الفتيات التهار}

IVA

IVA $1 \Lambda \cdot$

$1 \wedge \cdot$

$\mid \wedge 1$

$|A|$

IAY

$1 \wedge \varepsilon$

thition 117

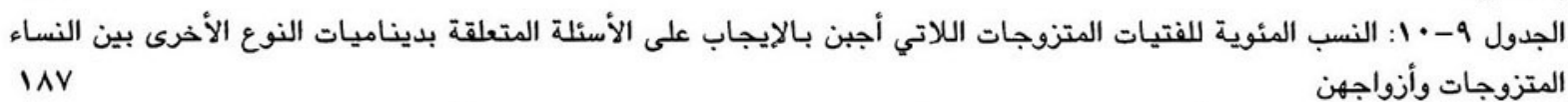
IAV

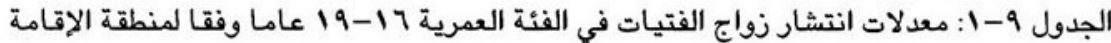

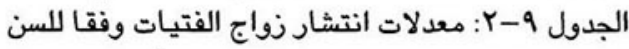

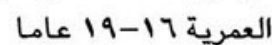

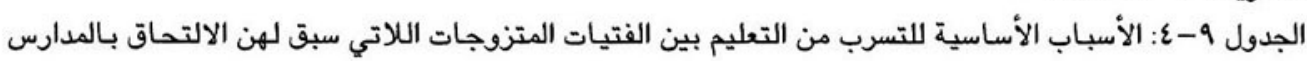

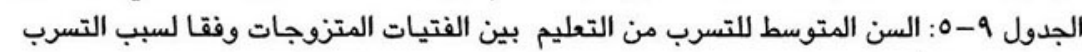

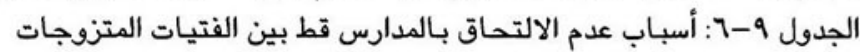

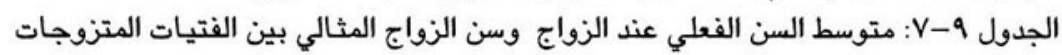

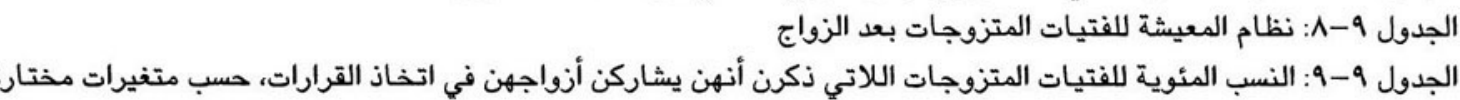

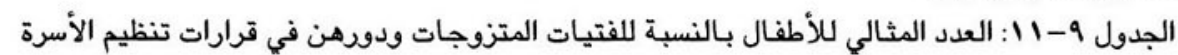

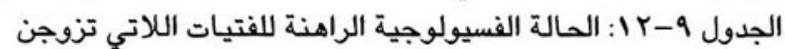

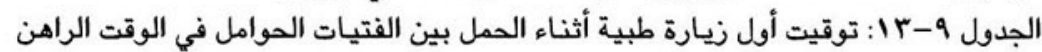

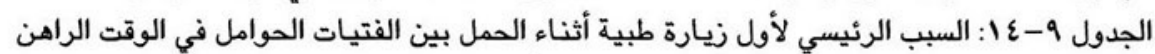

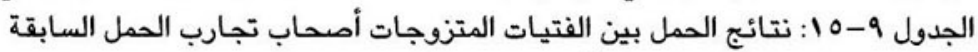

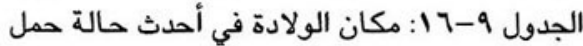

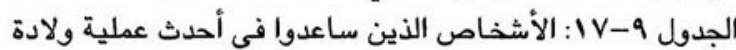

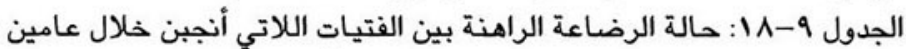

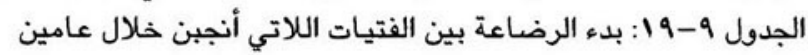

الملحق الرابع: نوعية البيانات

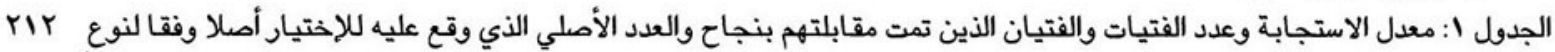

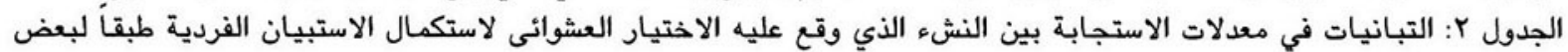
rir 


\section{قائمة الأشكال}

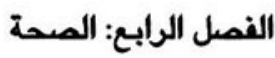

الشكل ع-1 : مقارنة دليل كتلة الجسم للفتيان المصريين بالبيانات المرجعية لمنظمة الصحة العالمية/المركز القومي الأمريكي rV

للإحصائيات الصحية الشكل ع-r : مقارنة دليل كتلة الجسم للفتيات المصريات بالبيانات المرجعية لمنظمة الصحة العالمية/المركز القومي الأمريكي

rA

rI

rr

rr

ro

ry

rq

$\varepsilon$.

$\varepsilon 9$

0.

01

or

Ir

Ir

ir

ㄷ

IV

IV

ปA

بعر

v. v.

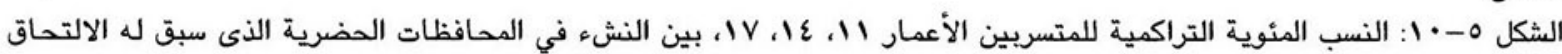
Vi

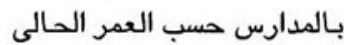

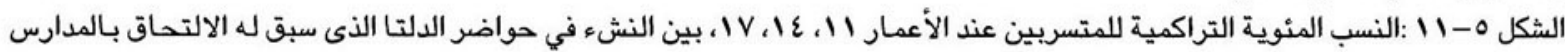
VI

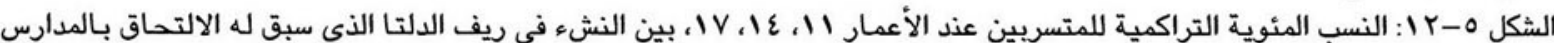
VI

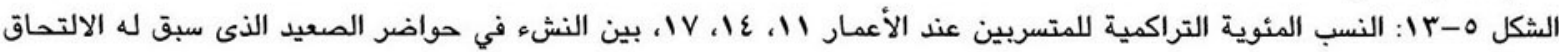
ri

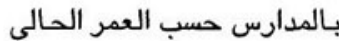

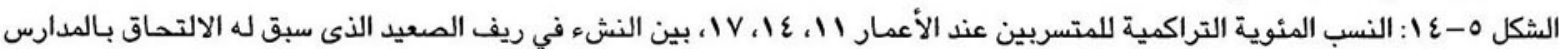
VI

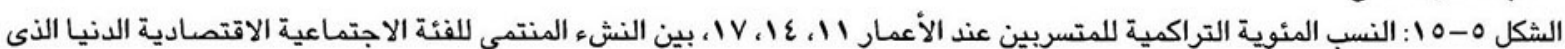
VY

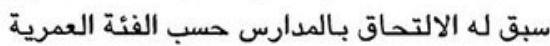

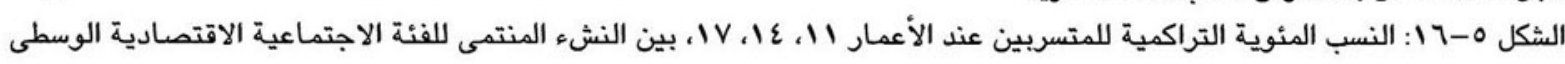
VY

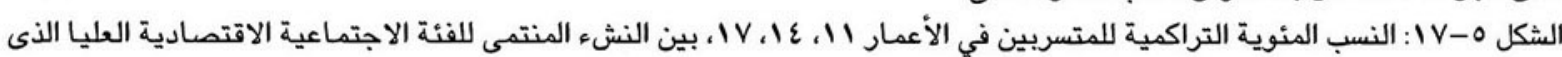
Vr

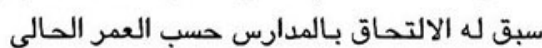


vา

vา

Vา

vV

VA

VA

VA

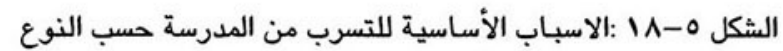

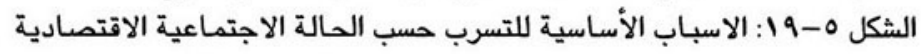

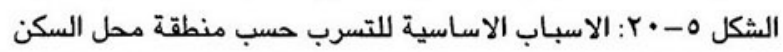

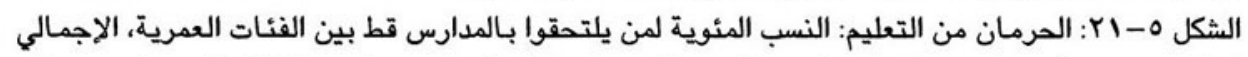

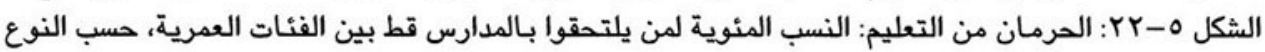

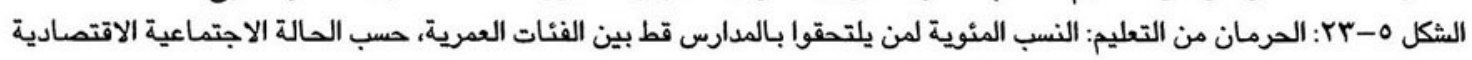

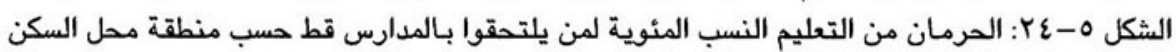

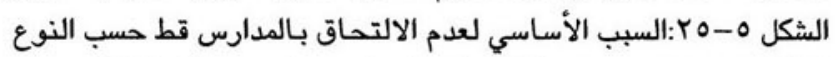

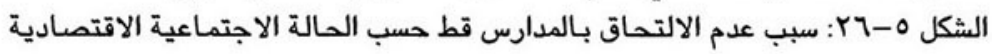

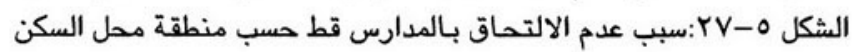

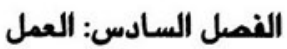

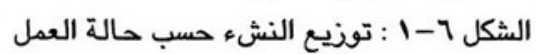

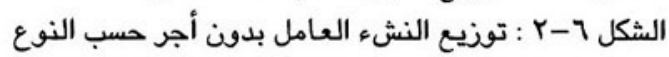

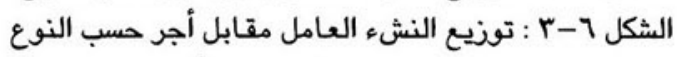

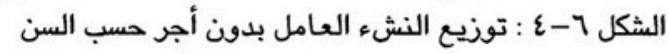

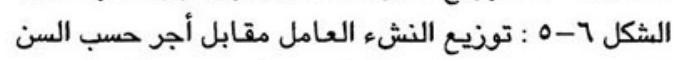

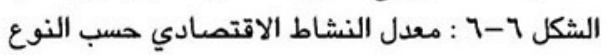

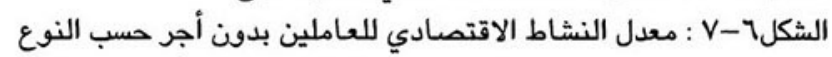

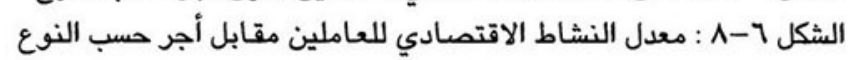

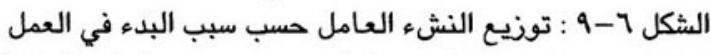

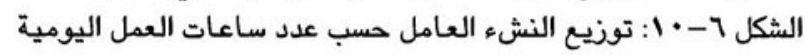

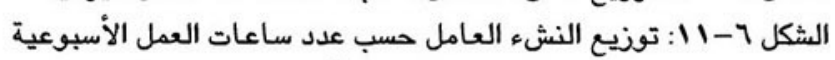

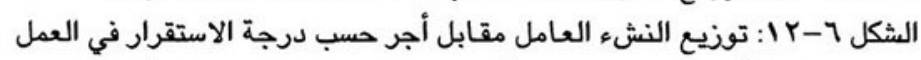

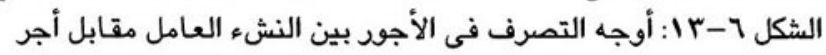

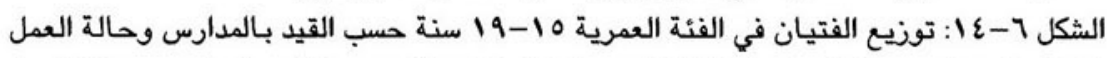

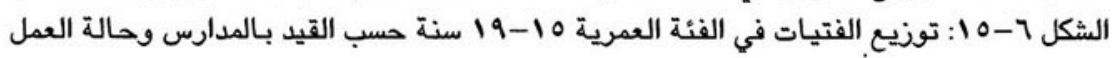

الغمل الثامن: الانتقال إلى النواج والأدوار الانجابية

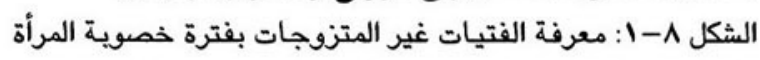

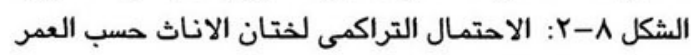

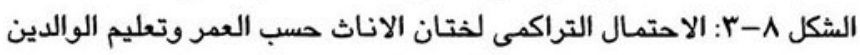

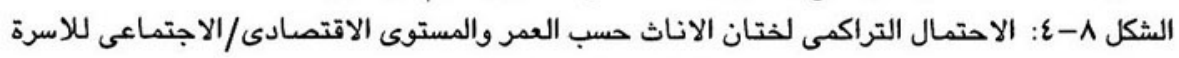
الشكل ^-0 : الاحتمال التراكمى لختان الاناث قبل بلوغ الاناث 10 عام لمجموعتين عمريتين مختلفتين لالاعتين

الملحق الرابع:نوعية البيانات

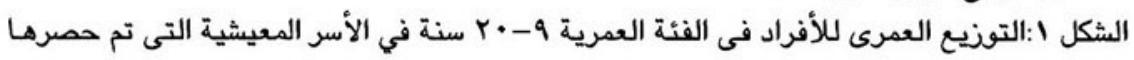


ترجمة الأستاذ عمر الشافعى

ترجمة الفمل الحامس والفمل السادس الدكتود محمد أحمد عبد العليم 


\section{نحو فهم أفضل للنشء في مصر}

\section{أولا: مقدمة}

تعد المراهقة كإحدى مراحل التطور الإنساني مفهوما جديدا نسبيا، وهي تقابل تقريبا العقد الثاني من العمر. فمع زيادة سنوات

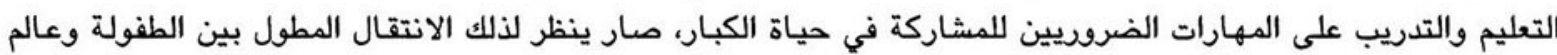

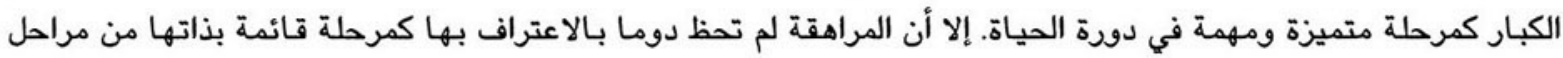

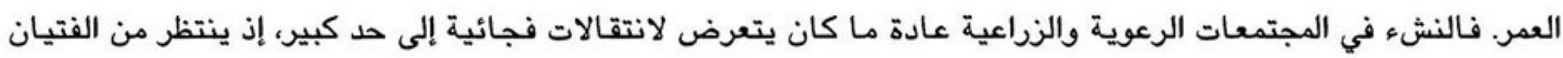

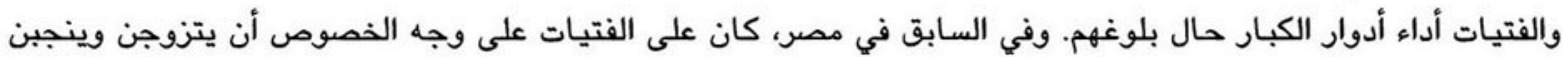

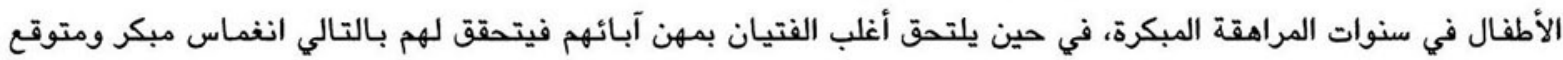
نسبيا في مهام الكبار.

امتد التعليم الأساسي في مصر اليوم ليشمل كل الأطفال تقريبا، وتعقدت متطلبات أداء أدوار الكبار مثل العمل وتربية الأطفال.

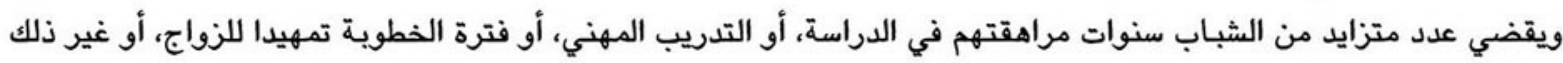

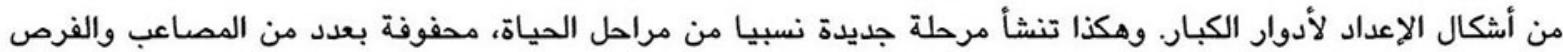

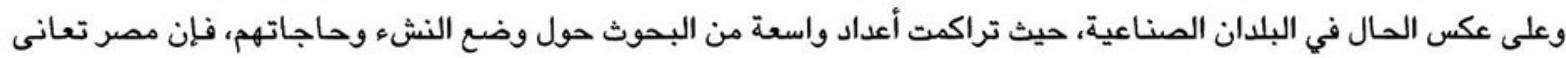

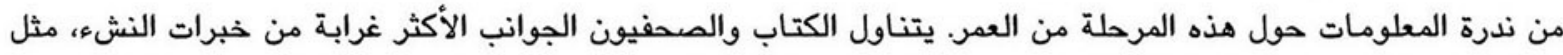

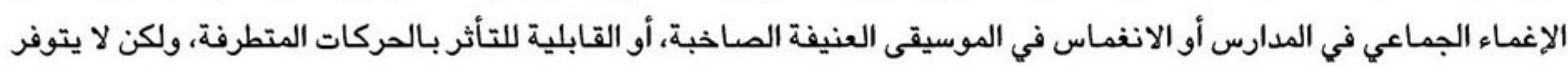

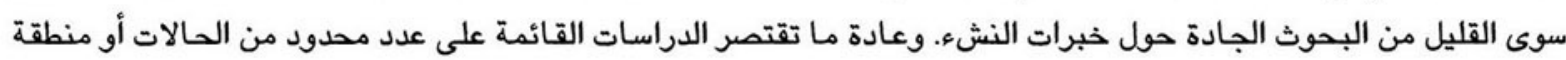

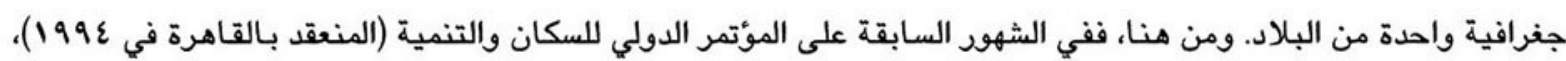

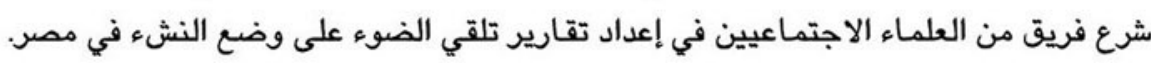

تولى مكتب مجلس السكان الدولي لمنطقة غرب آسيا وشمال أفريقيا تنسيق هذه الجهود التي أثمرت دراسة حول زواج المراهقين

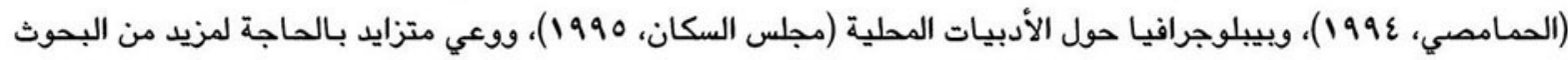

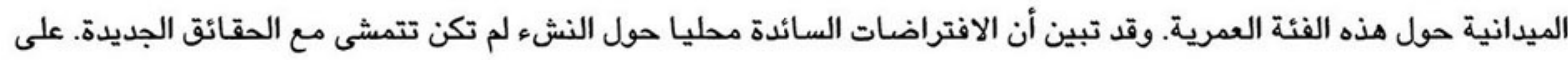

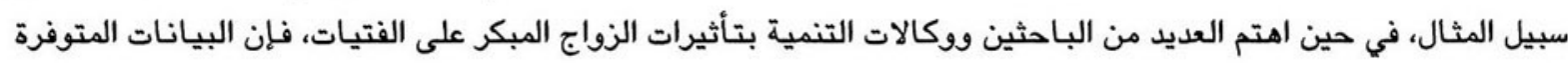

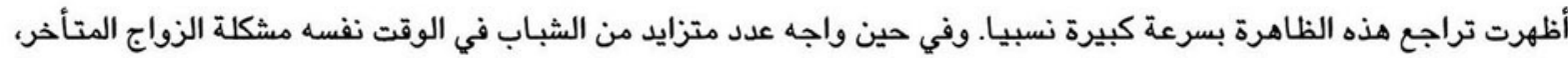

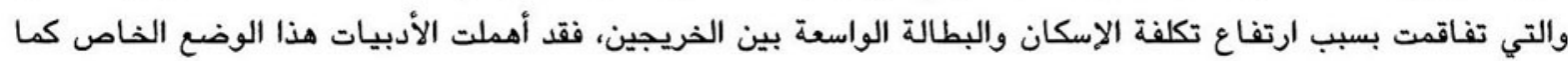
أهملته غالبية الهيئات المعنية بقضايا الشباب.

في غضون ذلك، لم توفر الأدبيات الدولية سوى القليل من النماذج المفيدة بـالنسبة للتفكير حول واقع النشء المصرى. ركزت

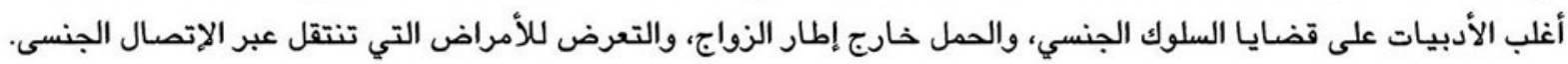

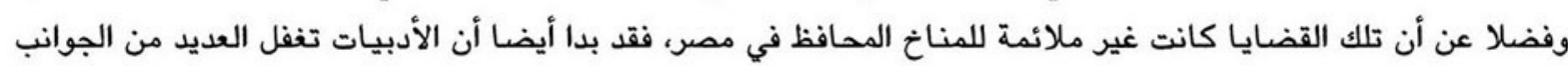


المهمة لحياة النشء والتى تؤدي إما إلى الحرمان أو تحسين الفرص في المستقبل، مثل ترك المدرسة، وشغل الأدوار المتصلة

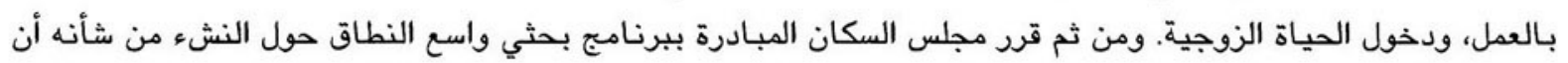
يستجيب لأوسع مدى ممكن من القضايا البارزة.

واقتضى القيام بمثل تلك المهمة الاعتماد على خبرات عدد من الأطراف. وخلال 1990-1997 199، دعا المجلس فريقاً من العلماء

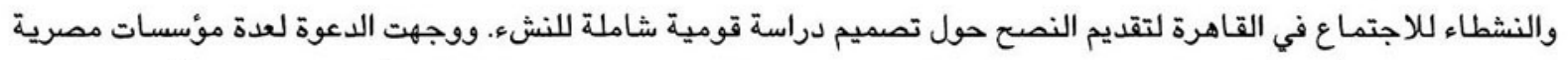
(مذكورة تفصيلا أدناه) للمشاركة في الدراسة، كما انعقدت ورش العمل لتعريف المصطلحات الأساسية، ووضع أهداف لهداف البحث،

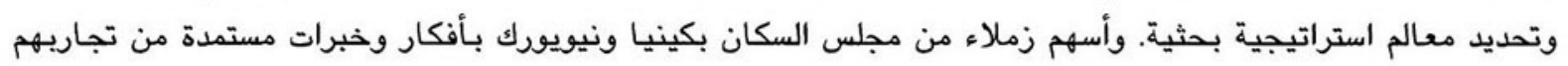

البحثية والبرنامجية.

توجت هذه العملية في صورة اقتراح بإجراء مسح قومي كبير يتناول الجوانب المهمة لحياة النشء في مصر، في محاولة لربط

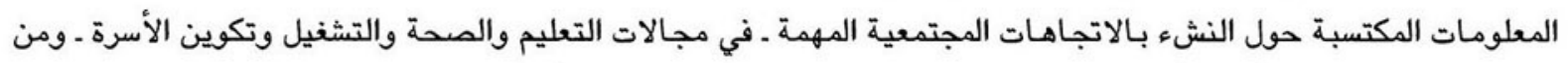

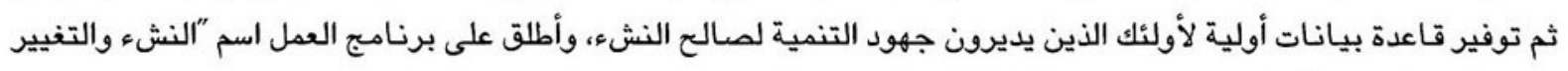

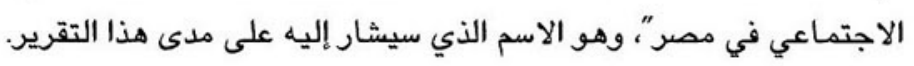

\section{ثانيا: أمداف الدراسة وتعريف المصطلحات}

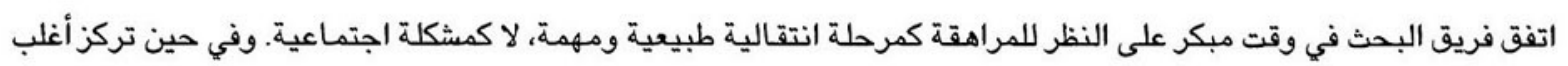

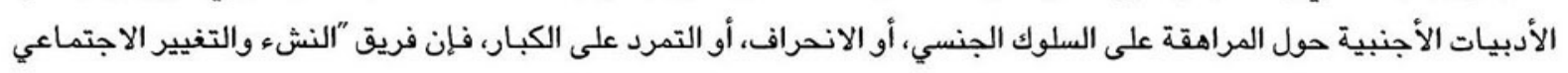

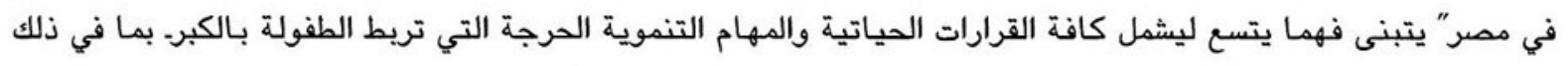

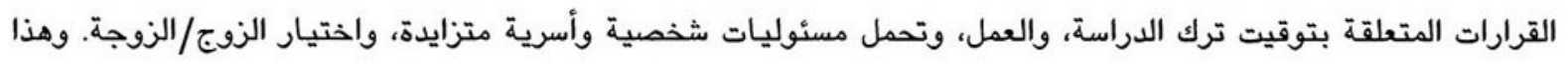

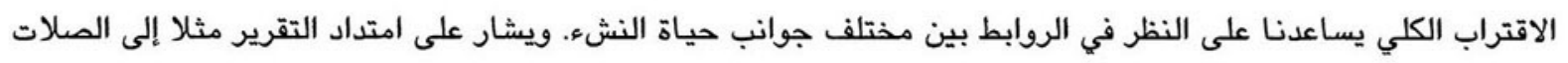
القوية بين إتمام الدراسة والجوانب الأخرى من حياة النشء الأي ونحن على قناعة بأن هذا الاقتراب مثمر أكثر من آخر يركز كليا على مشكلة مثل الزواج المبكر أو السلوك الجنسي.

إن القرارات المتعلقة بتحديد مجتمع الدراسة كانت وثيقة الصلة بالجدل داخل فريق البحث حول التعريف الإجرائي للمراهقة

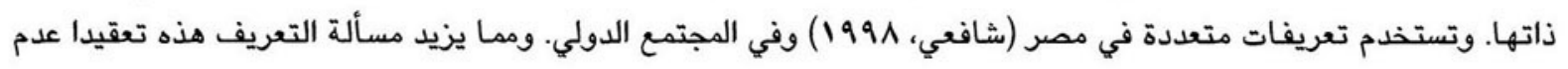

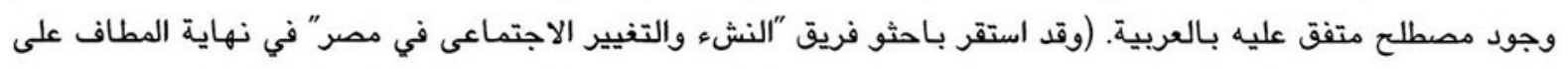

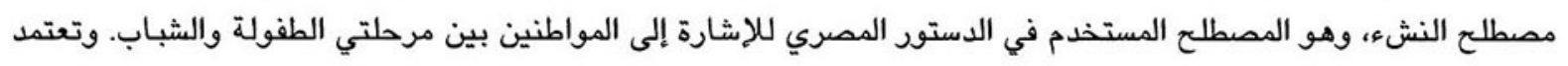

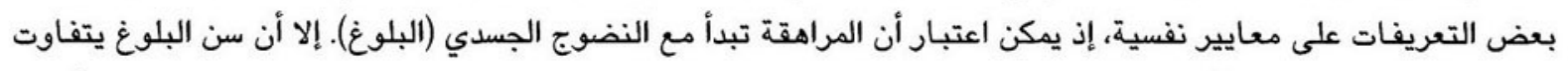

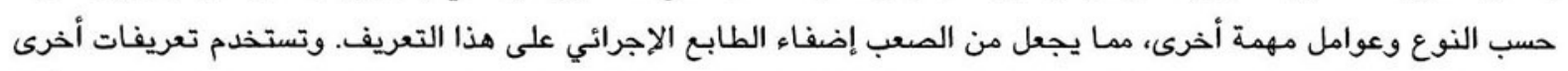

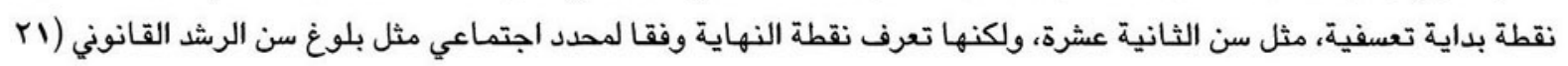
عاما في مصر).

وفي الحقيقة، ليست للمراهقة نقطة بداية أو نهاية واضحة التعريف. وقد أراد فريق البحث استكشاف المفاهيم الاجتماعية

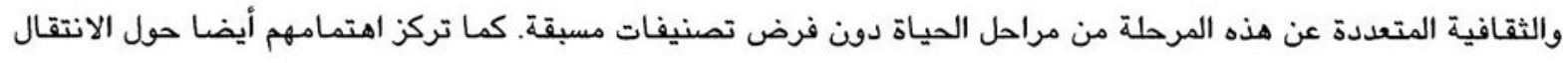

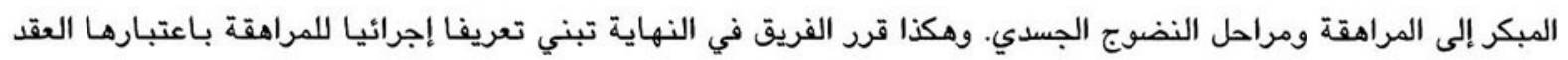


لم يرغب فريق "النشء والتغيير الاجتماعي في مصر" في إلقاء نظرة كلية على حياة النشء فحسب، وإنما سعى أيضا لفهم السياق

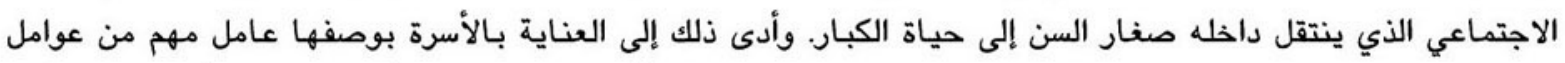

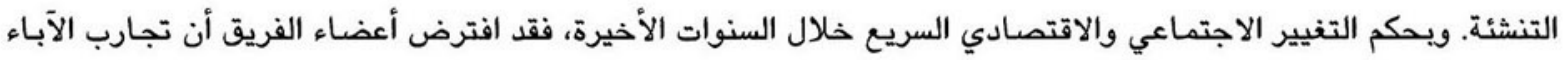

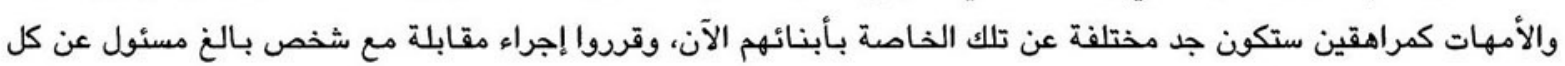

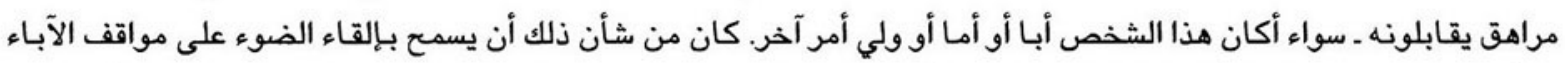

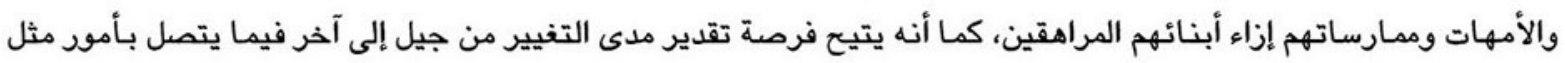

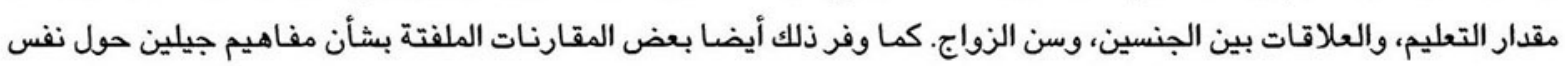

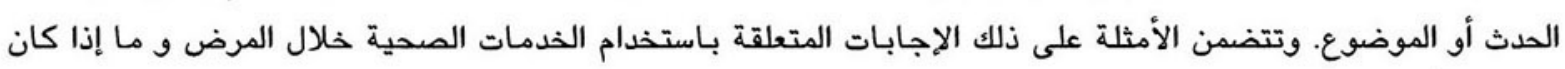

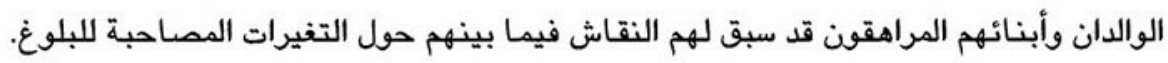

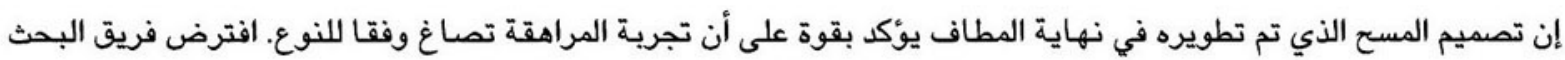

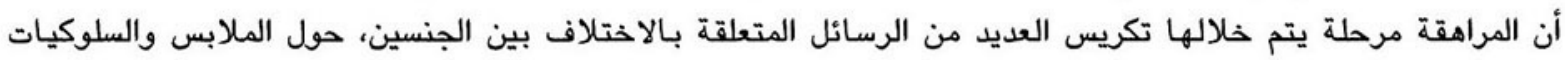

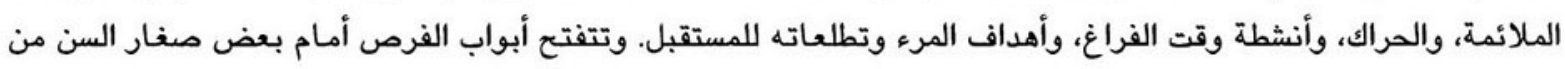

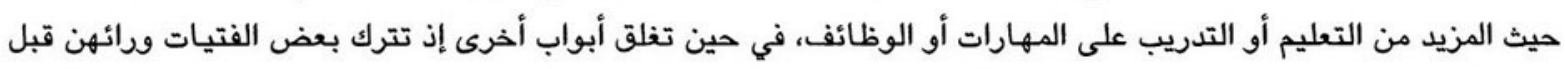

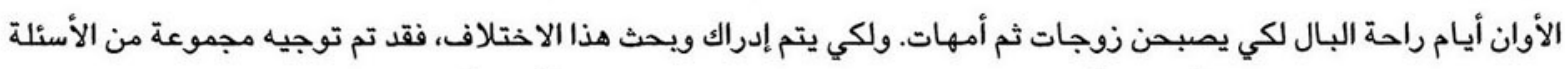

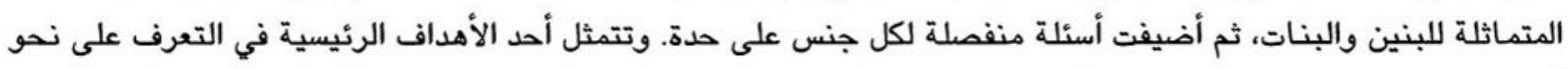

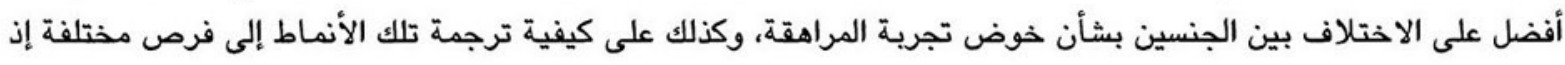
يتقدم صغار السن نحو حياة الكبار.

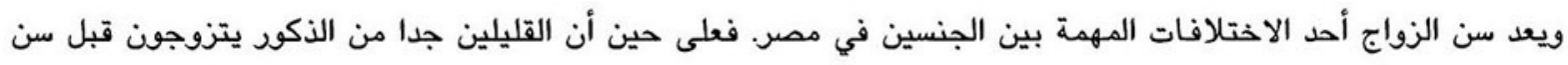

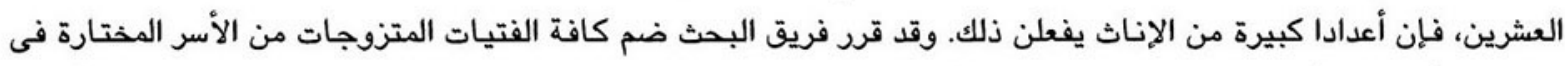

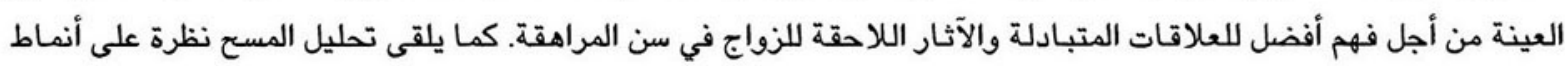

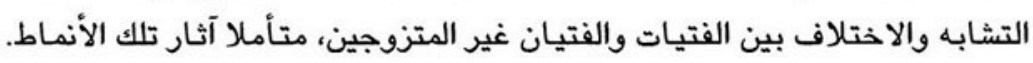

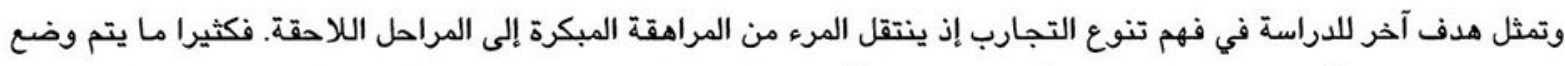

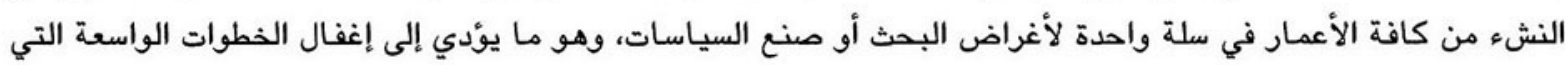

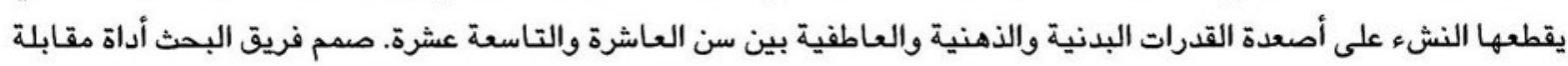

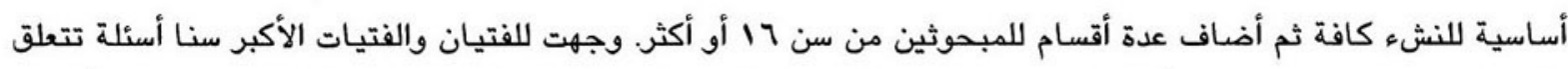

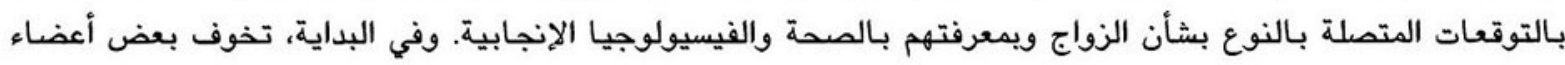

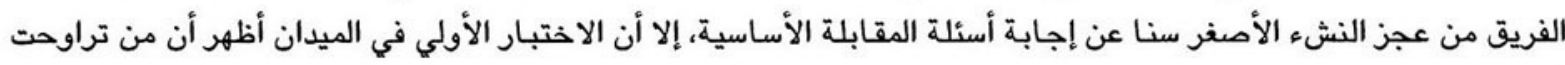

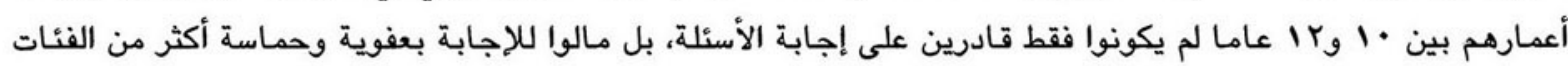

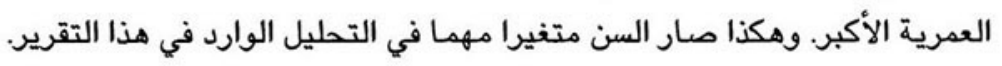

وإلى جانب النتائج التي تم التوصل إليها على مستوى الأسر، أراد فريق البحث أيضا دراسة الأماكن الأخرى المهمة التي يقضي

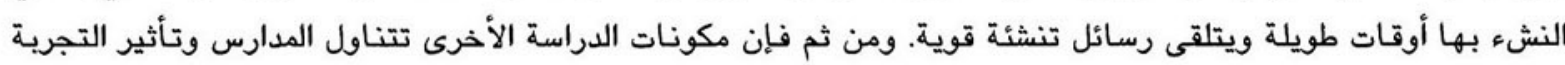

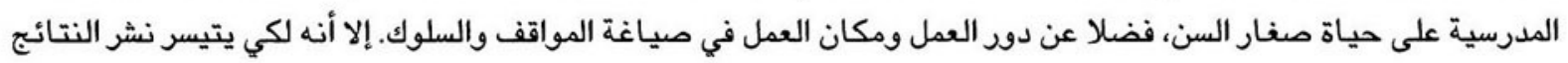




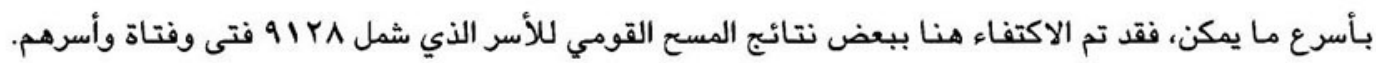

\section{ثالثا: التعاون المؤسسي/فريق البحث}

اشتمل مسح "النشء والتغيير الاجتماعي في مصر" على عدد من الإستبيانات، واختبارات طبية ومعملية، واختبار معرفي، وأداة

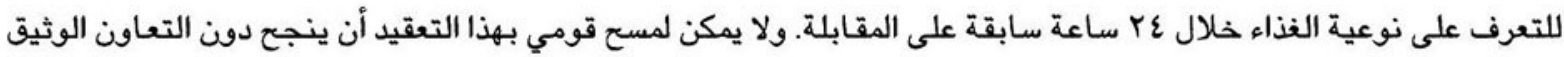

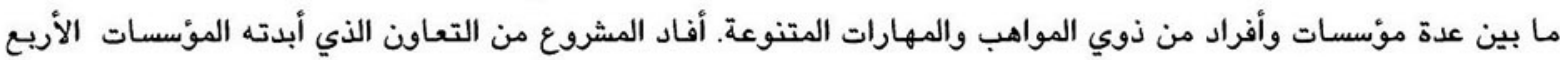

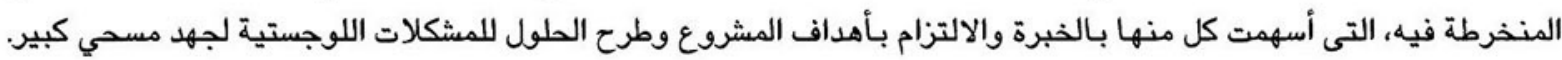

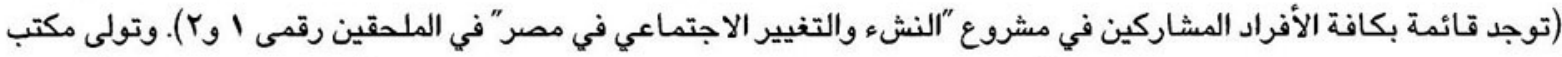

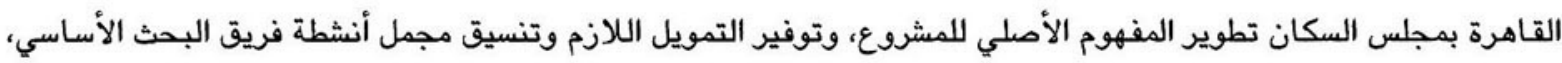

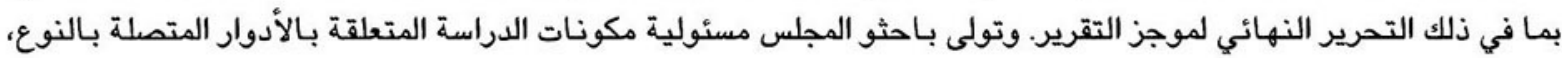
واستخدام الوقت، والتفاوض حول الزواج بين النشء.

وحيث أنه كان مقدرا أن تكون الصحة والتغذية مكونين أساسيين يبحثهما المسح، فقد سعينا للتعاون مع المعهد العالي للصحة

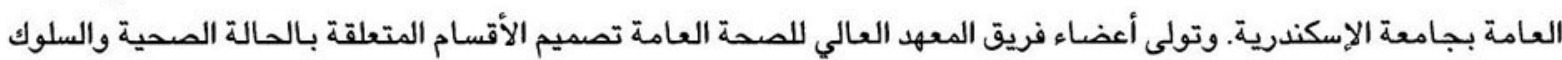

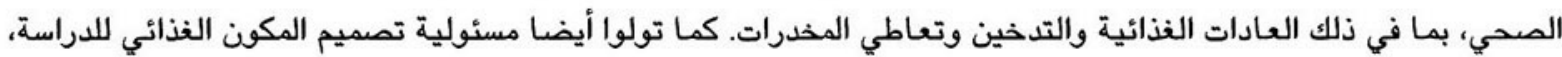
بما في ذلك تقدير معدلات النمو البدني باستخدام قياسات الوزن والطول، وتوفير وسيلة للتعرف على نوعية الطعام خلال عَ

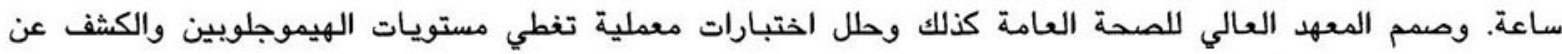

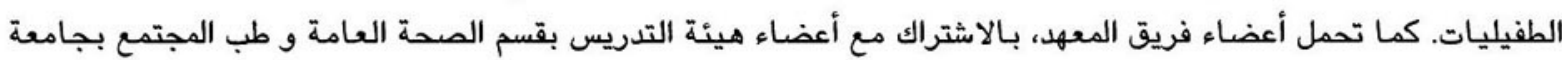

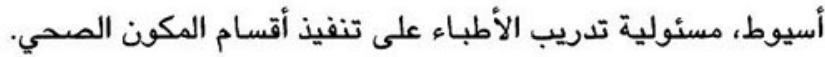

ومن أجل معالجة القضايا المهمة المتصلة ببلوغ النشء وصحته الإنجابية، وجهت الدعوة لأعضاء هيئة التدريس بكلية الطب

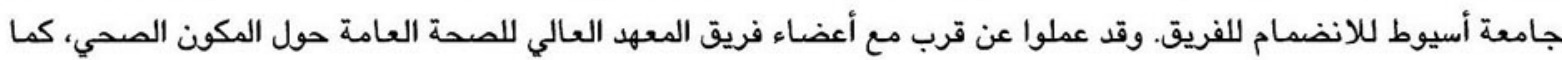
تولوا بشكل خاص مسئولية اختبارات النضوج البدني، وإعداد وابل من الأسئلة حول معارف الصحة الإنجابية وممارساتها،

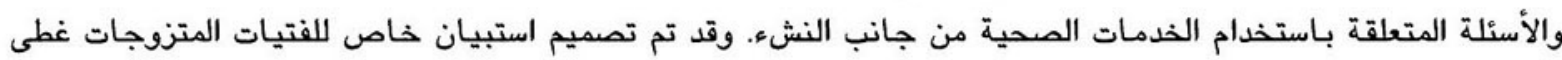
جوانب عديدة من الحياة الإنجابية والأسرية.

أصبحت آخر منظمة تنضم لفريق "النشء والتغيير الاجتماعي في مصر" الطرف الأكثر أهمية في عملية المسح من نواح عديدة.

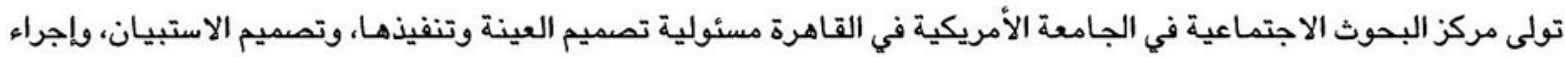

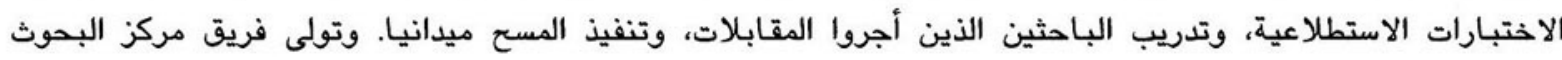

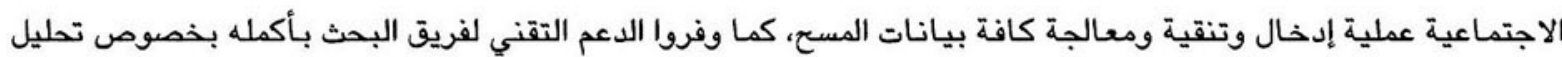
البيانات، بما في ذلك التدريب على استخدام البرامج الإحصائية. وفضلا عن ذلك تولى أعضاء فريق مركز البحوث الاجتماعية مسئولية دراسة المكونات المتعلقة بالتعليم والتشغيل والصورة النفسية العامة للنشء. 


\section{رابعا: مذا التقرير الموجز}

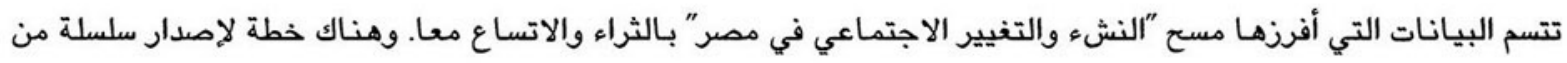

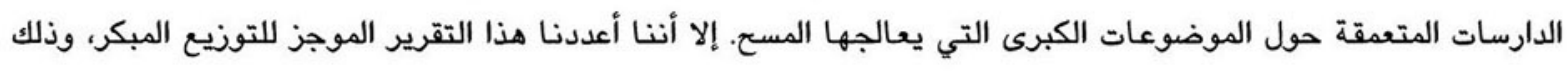

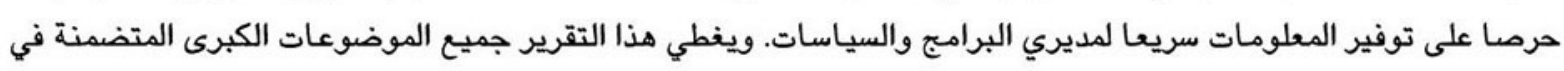

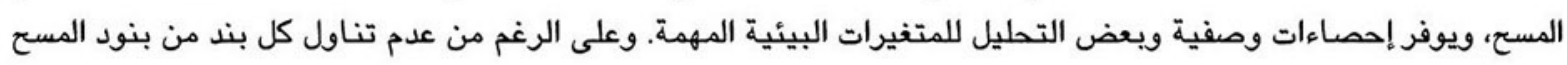

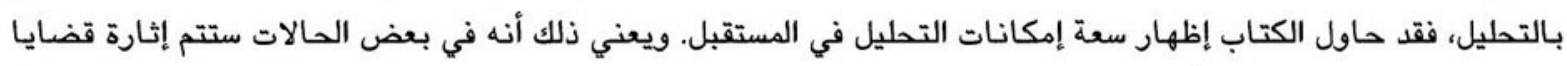

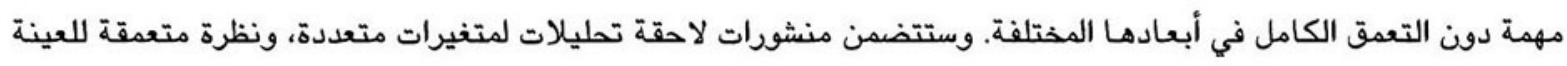

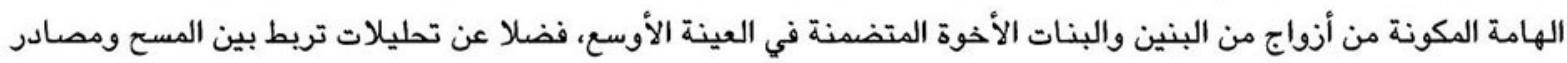
أخرى للبيانات الكيفية والكمية حول التجرية المدرسية والتفاوض حول البرات الزواج والأحوال المعيشية للشباب.

ويأمل الكتاب أن يشجع هذا التقرير على النقاش والمزيد من البحوث، وأن يشير إلى جوانب عديدة لتدخل البرامج من أجل تحسين حياة النشء في مصر. 


\section{منهج ونطاق الدراسة}

لمشروع "النشء والتغيير الاجتماعي في مصر" أهداف متعددة تتقاطع مع الأبعاد الاجتماعية الاقتصادية، والثقافية، والمحية

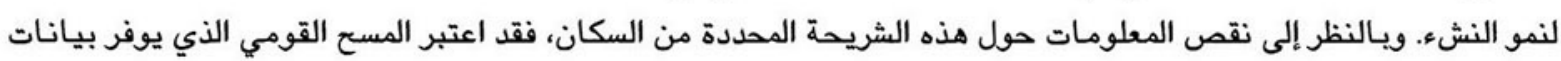

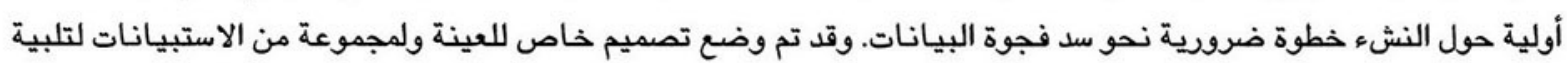
أهداف المشروع المتعددة.

\section{أولا: تمميم العينة}

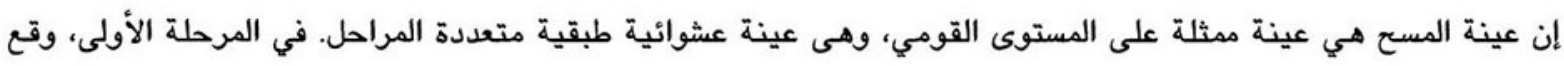

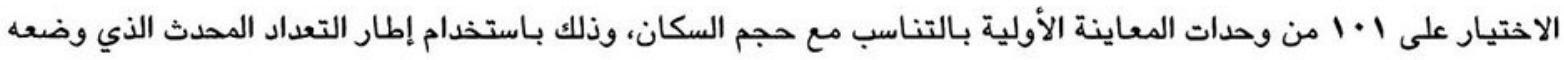

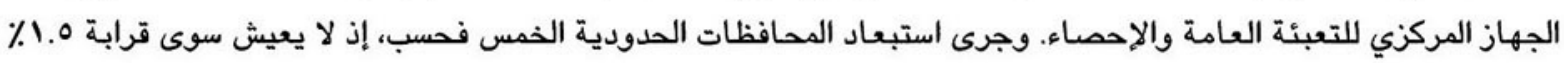

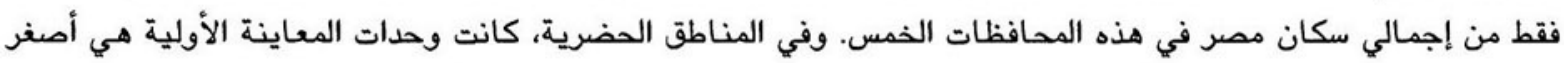

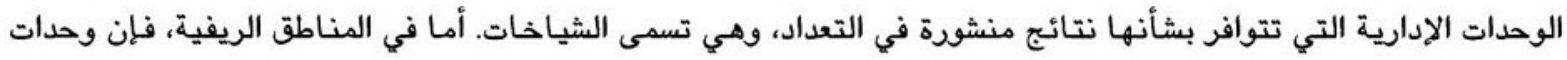
المعاينة الأولية كانت القرى فضلا عن الكفور والنجوع المرتبطة بها إداريا.

وزعت وحدات المعاينة الأولية على آ محافظة وفقا لنمط محل السكن ما بين ريفي وحضري داخل كل محافظة. وعلى أساس

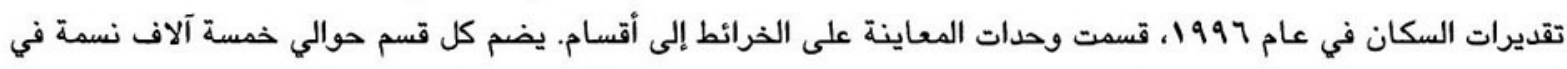

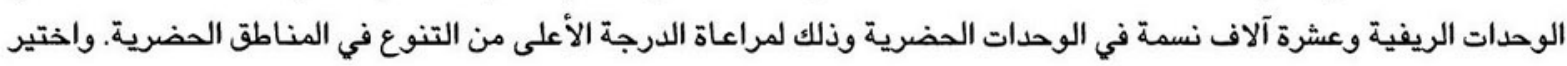

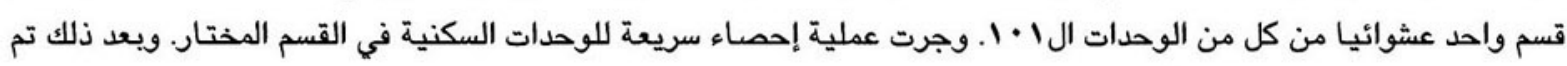

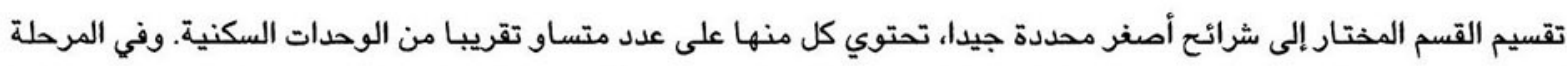

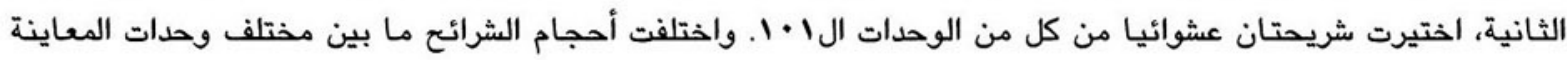

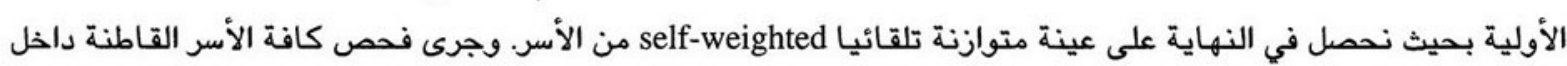

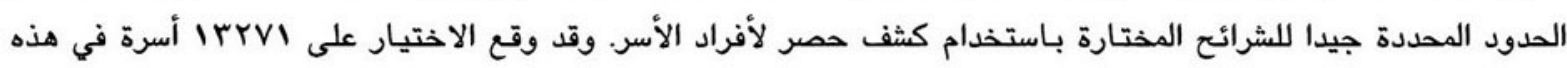
المرحلة من مراحل المسح.

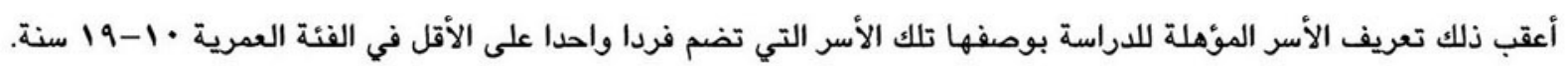

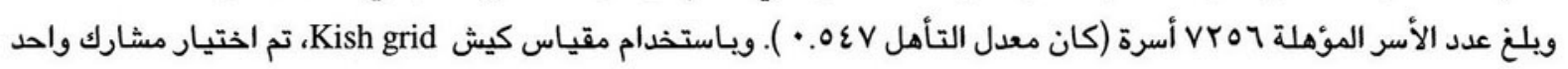

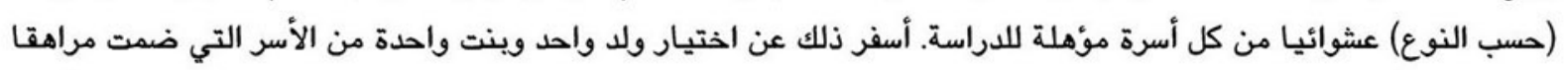

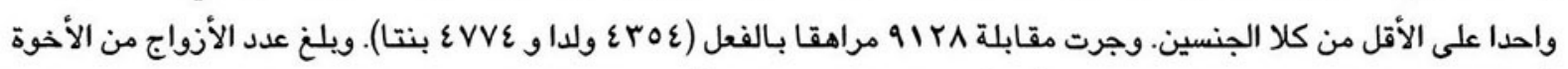

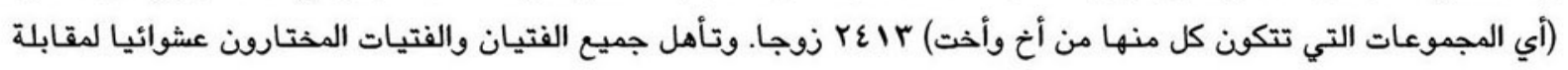

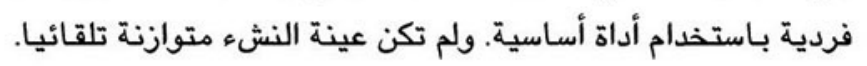


تأهل جميع الفتيان والفتيات المختارون عشوائيا المقيدون حاليا في المدارس بين الصف الخامس الابتدائي والصف الأول

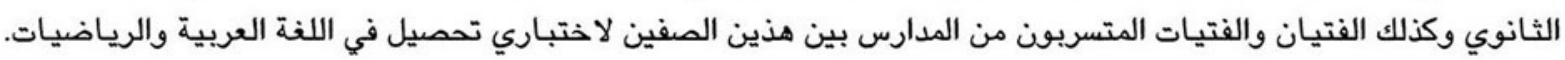

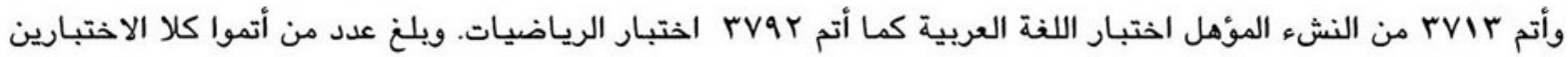

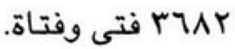

وتكونت عينة فرعية من ريع عينة النشء المختارعشوائيا؛ وسرى ذلك على نصف العينة (حسب النوع) في •ه من وحدات

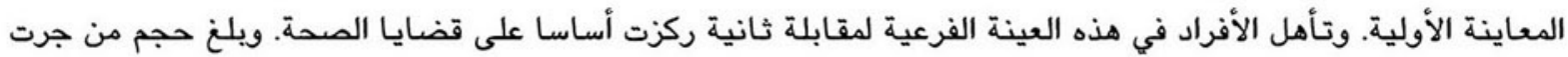

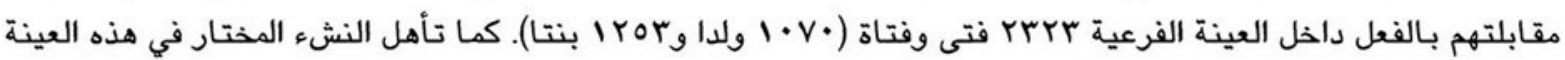

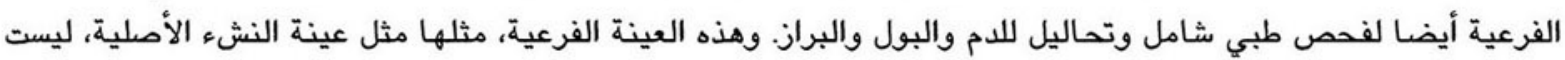

متوازنة تلقائيا.

ونظرا لاهتمام الباحثين الأساسيين بظاهرة زواج الفتيات، فقد تم توجيه أسئلة الأداة الفردية الأساسية وكذلك الأداة الصحية

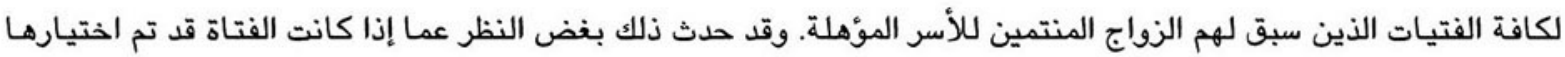

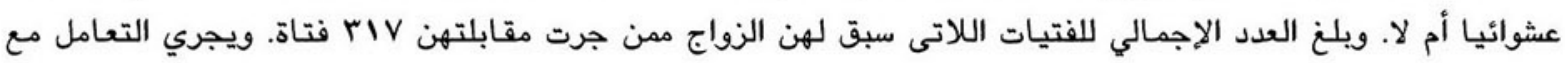
البيانات حول الفتيات اللاتي تزوجن بشكل منفصل.

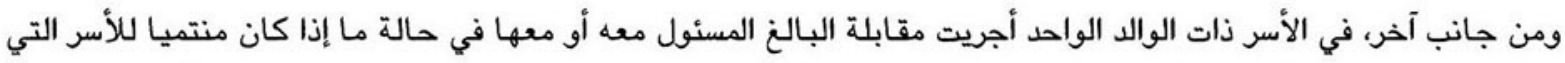

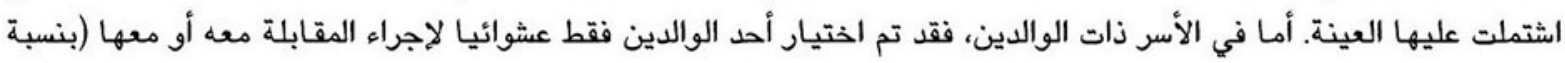

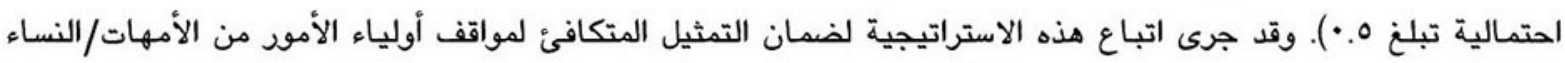

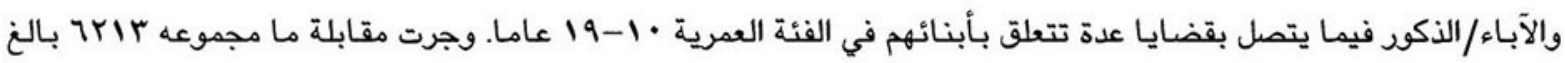

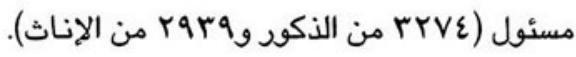

وأثمر هذا التصميم عينات ممثلة على المستوى القومي من النشء والبالغين بحيث أن كافة التقارير المستقاة منها قابلة

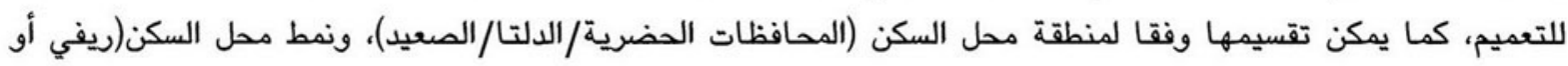
حضري)، والنوع.

\section{ثانيا: أدوات الدراسة ومنهجها}

استخدمت أدوات ومناهج عدة من أجل تدقيق أهداف الدراسة. وأجريت مقابلات وجها لوجه باستخدام عدد من استمارات

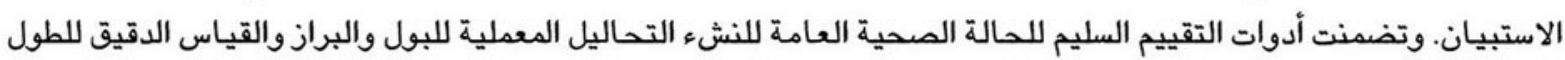

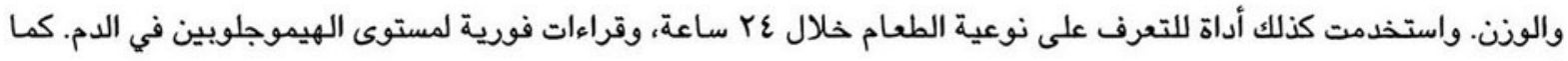

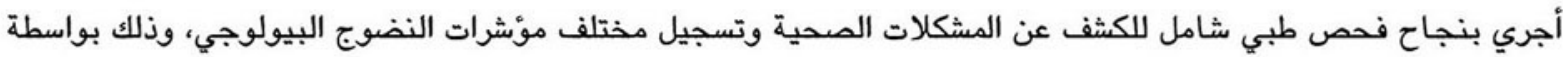
أطباء مدربين من وزارة الصحة والسكان. 


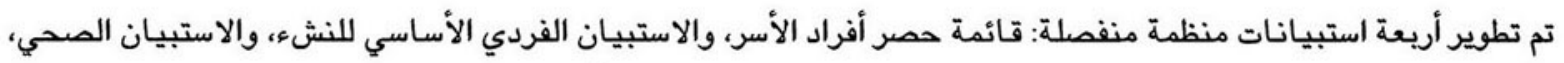
والاستبيان الموجه للبالغين المسئولين. ويلخص القسم الآتي مضمون كل من أدوات المسح.

\section{تائمة حمر أفراد الأسر}

جمعت قائمة الحصر معلومات ديموجرافية أساسية من كافة الأسر التي اشتملت عليها العينة البالغ عددهـا الإبr ا أسرة حول

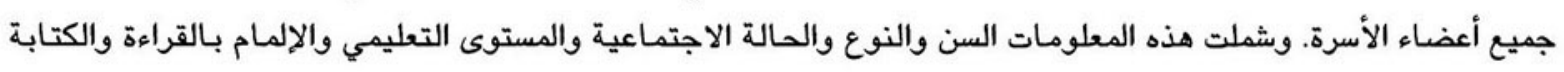
بين من لم يلتحقوا بالمدارس قط وحالة العمل.

\section{الاستبيان الغردي الأساسي للنشء في خمسة أجزاء}

جمع القسم الأول وعنوانه "التعليم" معلومات حول تاريخ الميلاد الدقيق، وما إذا كان الشخص قد سبق له الالتحاق بالددارس،

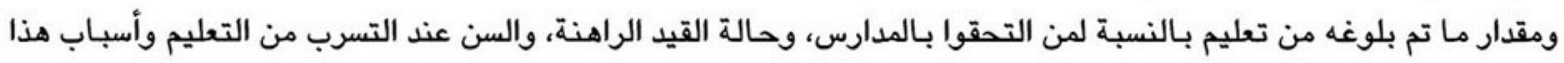

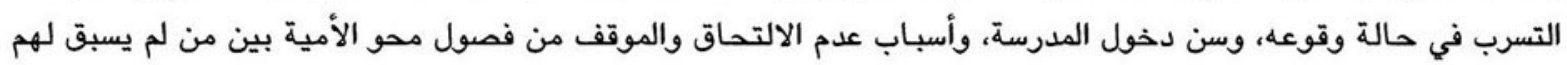

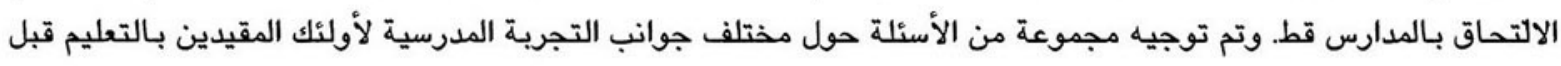

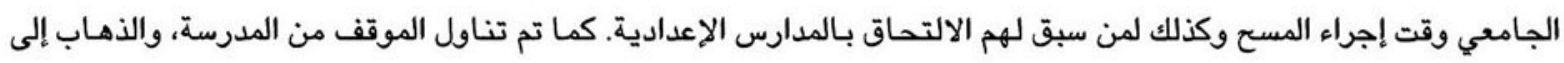

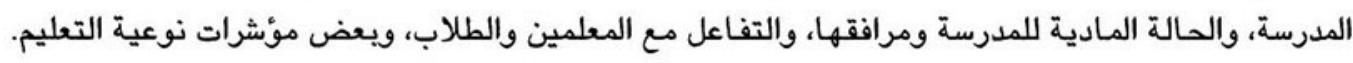

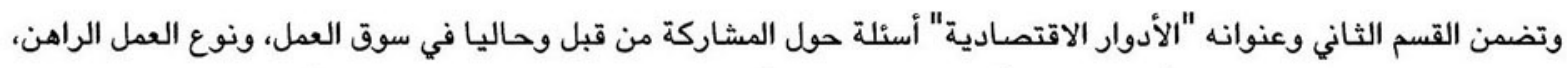

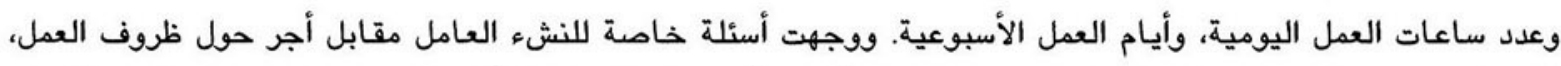

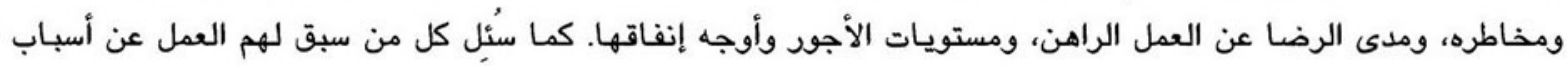
الانخراط في العمل وسن البدء فيه.

وركز القسم الثالث وعنوانه "الحالة الصحية" على استخدام الخدمات الصحية، والأدوية التي يتم تناولها بانتظام، والتمرينات الرياضية، والسلوك المتصل بالتدخين. ووجهت للبنات أسئلة حول الحيض وكيفية تعاملهن معه.

وركز القسم الرابع وعنوانه "العلاقات الاجتماعية والسمات الشخصية" على التفاعل والدعم المتبادل بين النشء وأفراد أسرهم

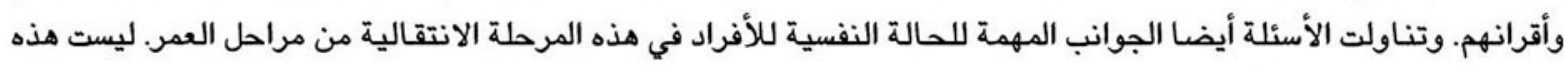

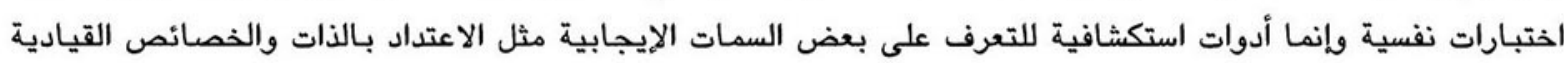

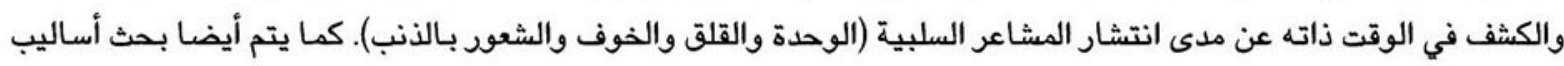

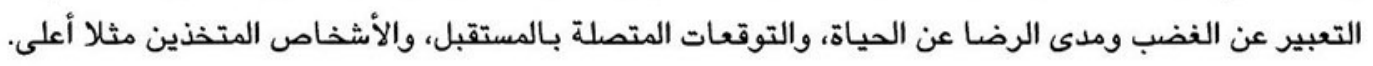

أما القسم الخامس وعنوانه "استخدام الوقت" فقد جمع معلومات حول الأنشطة التي تم القيام بها خلال الساعات الأريع

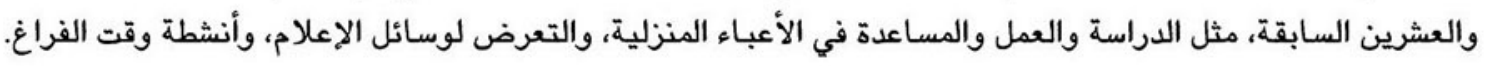


ركز القسم الأول وعنوانه "استخدام الخدمات الصحية" على عدد مرات إجراء التحاليل المعملية للبول والبراز والدم خلال الشهور

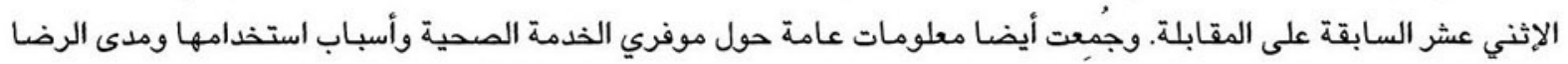
عنها أثناء المرض مؤخرا.

وجمع القسم الثاني وعنوانه "الممارسات المتصلة بالصحة" معلومات عن الحصول المنتظم على الفيتامينات وأقراص الحديد،

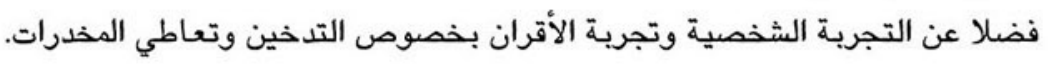

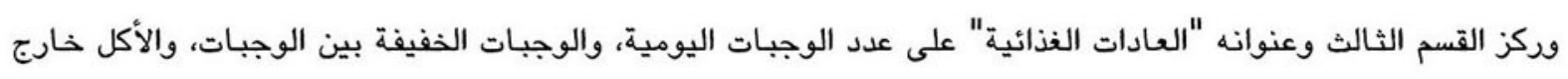
المنزل، واستهلاك الشاي والقهوة، والخضراوات، والفاكهة، والخبز، والملح، وما إلى الفي ذلك.

وجمع القسم الرابع وعنوانه "الصحة الإنجابية والأدوار المتصلة بالنوع" بيانات حول السن الملائم للزواج للبنين والبنات

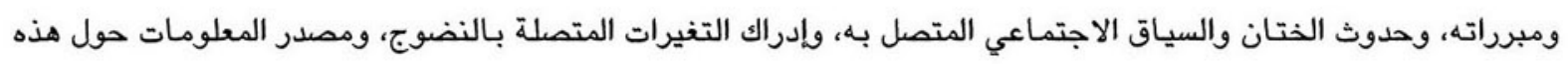
التغيرات، وتعامل الفتيات مع الحيض. وحدوث الغتان واليات الات.

ووجهت للنشء في سن 17 - 19 أسئلة حول معرفته بقضايا الصحة الإنجابية ومواقفه منها، بما في ذلك الأمراض التي تنتقل

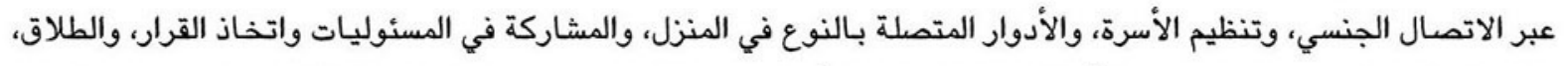

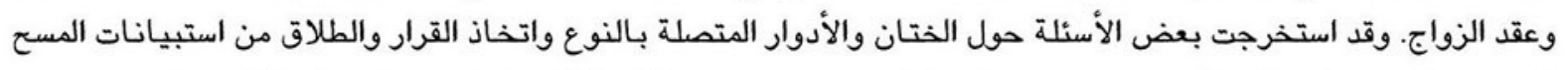

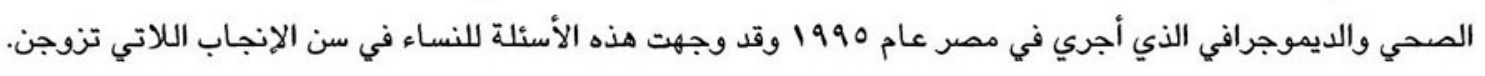

وسأل القسم الخامس وعنوانه "الزواج" النشء بين السادسة عشرة والتاسعة عشرة من العمر حول الصفات التي ينشدونها في

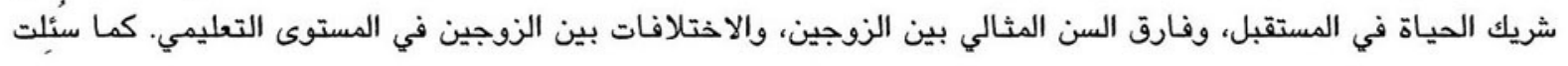

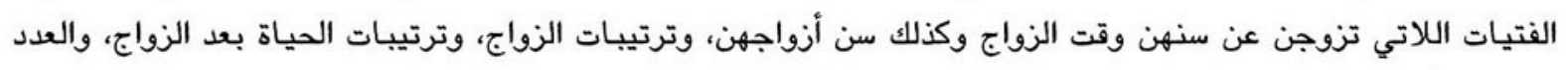

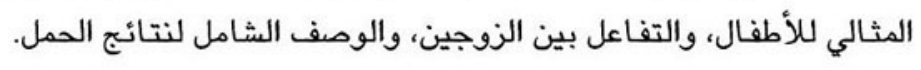

\section{استبيان البالغين المسنولين}

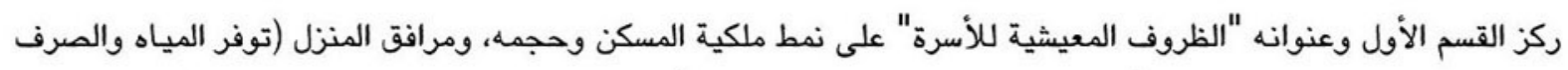

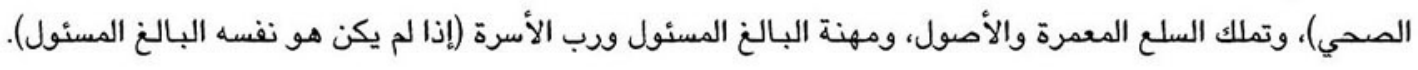

وجمع القسم الثاني وعنوانه "الموقف من التعليم" معلومات حول قيمة تعليم الأولاد والبنات وطموحات الآباء والأمهات

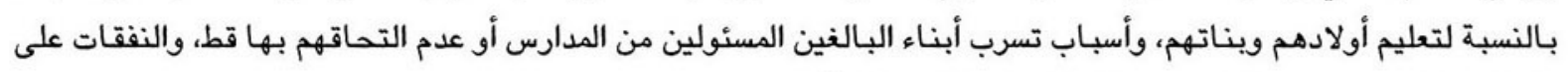
التعليم، والنفقات على الغذاء، وإجمالي النفقات الشهرية للأسرة.

وغطى القسم الثالث وعنوانه "الصحة" التقارير حول المرض والعجز بين النشء، واستخدام الخدمات الصحية، والموقف من

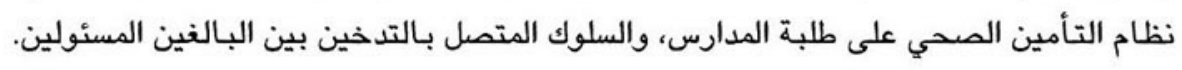




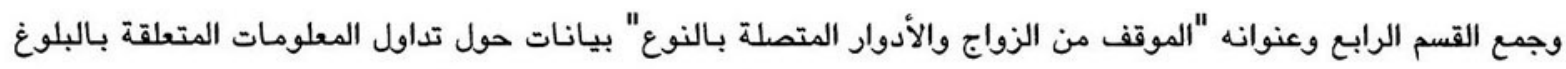

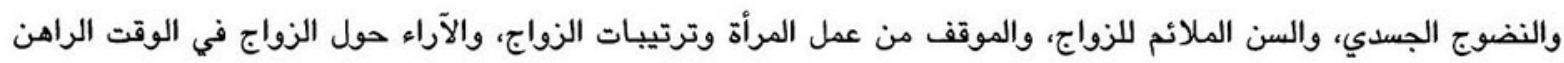
بالمقارنة بالزواج في جيلهم.

اعتبارات التحميل

اللغة العربية

جرى تطوير ثلاثة مستويات مختلفة من اختبارات اللفة العربية تناسب الصفوف الخامس الابتدائي والأول الإعدادي، والثاني

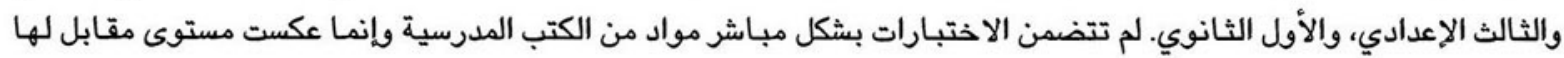
في المعلومات والأسئلة. وقصد من الاختبارات قياس مهارات محددة مثل الاستيعاب والاستدلال المنطقي والتعبير اللغوي والنحو.

الرياضيات

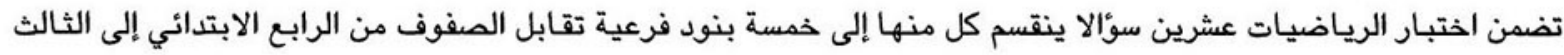

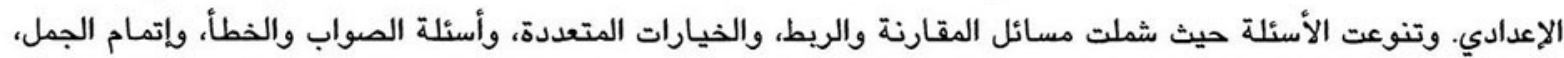

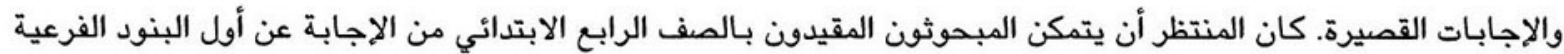

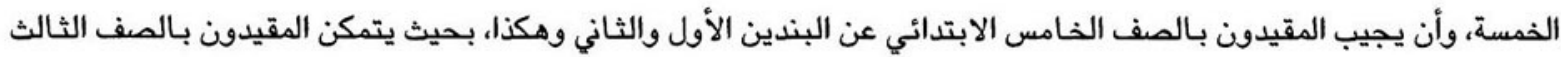

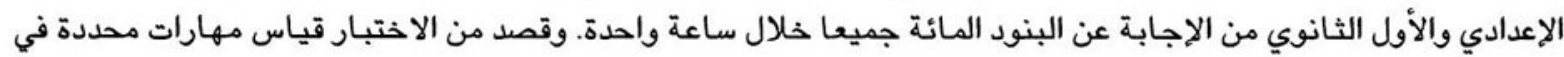

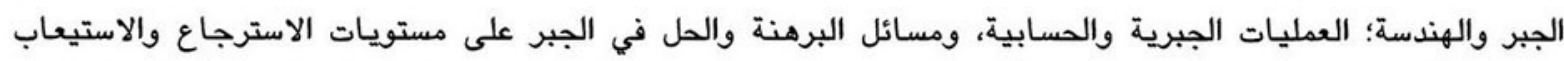
والتطبيق. أما في الهندسة فقد جرى قياس المهارات البصرية والكتابية والمنطقية ومهارة الرسم فضلا عن حل المسائل على الى والى مستويات التحديد والتنظيم والتحليل والاستدلال.

\section{تقييم الصالة الصحية العامة}

\section{النمومعات المعملية}

$$
\text { تصديد مستوى الهيموجلويين في الدم }
$$

تم الحصول على عينات الدم عن طريق وخز طرف الإصبع بمشرط معقم. ووضعت قطرة دم على شريحة مجهرية قابلة للاستخدام مرة واحدة حيث جرى تحديد مستوى الهيموجلويين باستخدام فوتومتر · (HemoCue AB, Angelholm, Sweden)

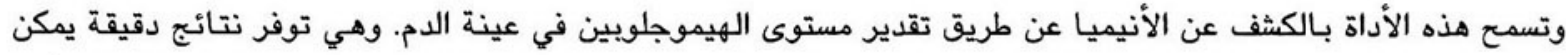

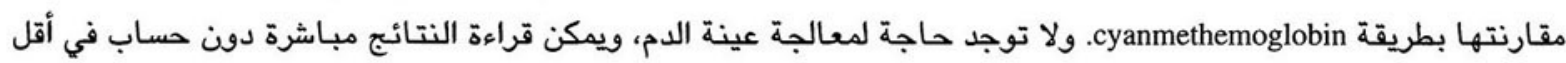

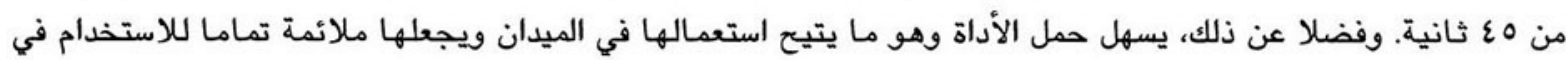

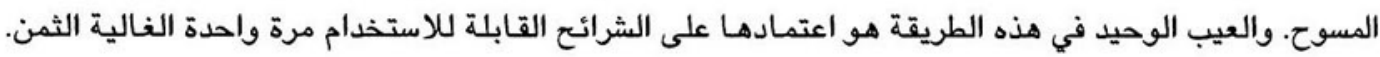

واعتبرت الأنيميا موجودة إذا كانت نسبة الهيموجلويين أقل من Y I جرام في عشر اللتر بالنسبة للفتيات والفتيان تحت سن ع ا، 
وأقل من ب ا جرام في عشر اللتر بالنسبة للفتيان فوق سن ع ا وفقا لمقترحات منظمة الصحة العالمية (منظمة الصحة العالمية،

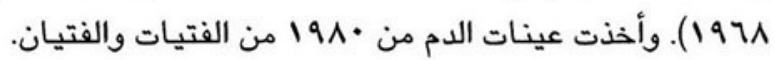

دراسة الطفيليات

أعطي كل فتى وفتاة وعاءين من البلاستيك ملصق عليهما شارة بالاسم، وطلب منه توفير عينة براز وعينة بول. ولم يستجب

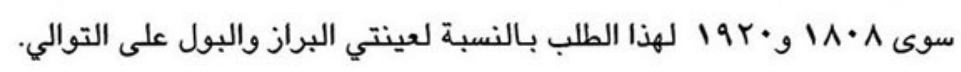

تحليل البراز: أخذت عينات البراز التي تزن حوالي · · جرام بواسطة ملعقة مصممة خصيصا ووضعت في أوعية تحتوي مسبقا

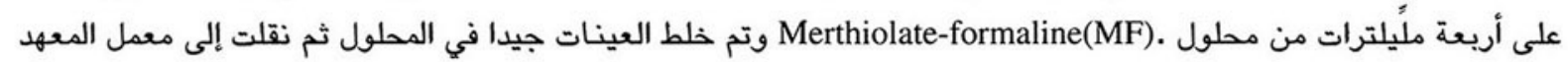

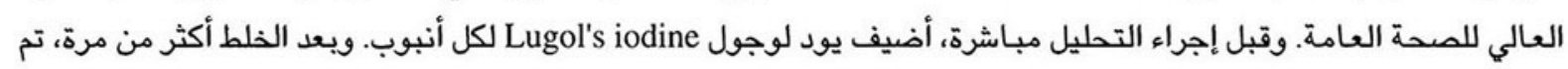

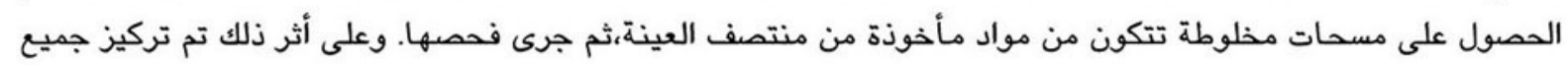

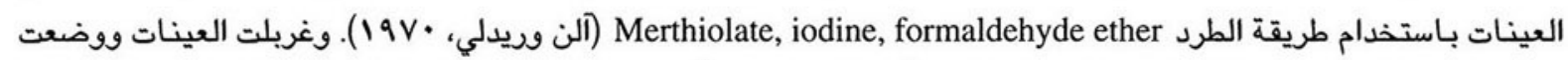

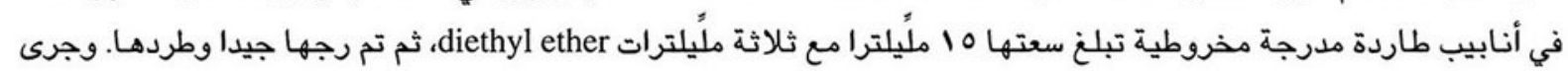
فحص المسحات المترسبة مجهريا بحثا عن الطفيليات.

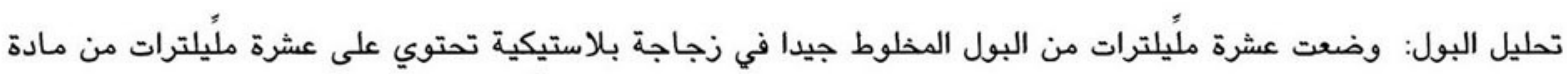
carbal fuchsin

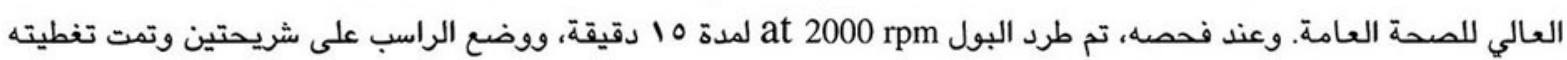
بكوب وجرى فحصه مجهريا (ريتشاردو، حسن، كلاين، والعلمى، عـ19 1).

وأعطيت نتائج تحليل عينات البول والبراز للبالغ المسئول عن كل مشارك على هيئة تقرير مكتوب. كما أبلغ أولياء أمورالمشاركين فى البحث فورا بنتائج اختبار الهيموجلويت والبين في حالة كونها مهمة طبيا.

\section{القياسات الأنثريومترية}

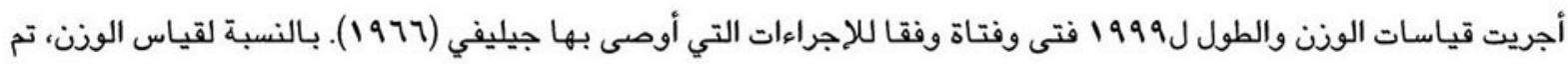

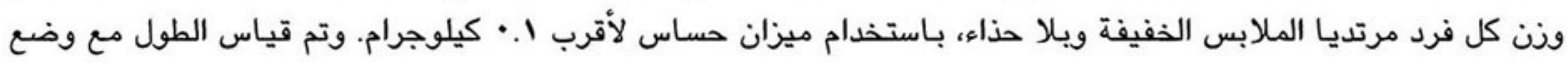

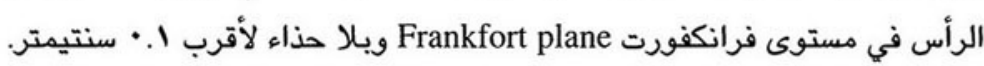

ومن أجل تقييم الحالة الغذائية للنشء، تم استخدام الدليلين الذين أوصت بهما لجنة الخبراء بمنظمة الصحة العالمية (1990)

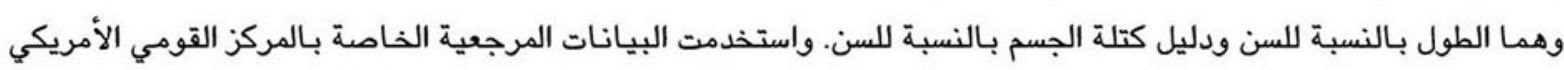

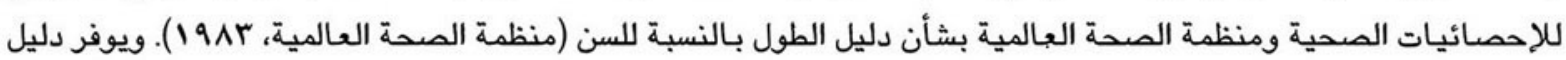

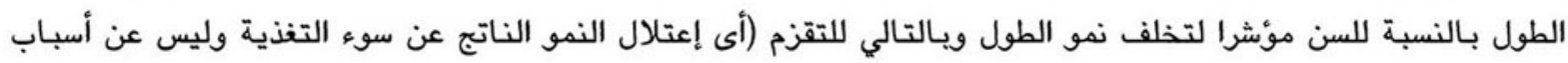
وراثية). ويبدأ المستوى الحدي لاعتلالات النمو لدى النشء عندما يصل الانحراف عن المتوسط بالنسبة للشريحة السكانية

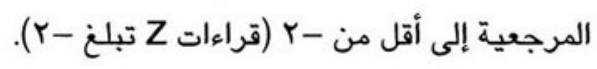

يوصى بدليل كتلة الجسم بالنسبة للسن (الوزن بالكيلوجرام/مربع الطول بالمتر) كأفضل مؤشر للنحافة وزيادة الوزن لدى 
النشء. ويقل المستوى الحدي للنحافة أو نقص كتلة الجسم بالنسبة للسن لدى النشء عن خمس نقاط مئوية من الشريحة

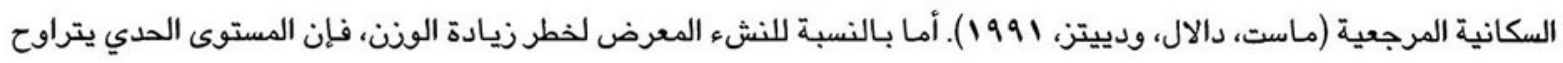
بين 10 و09 نقطة مئوية، بينما يزيد المستوى الحدي للبدانة عن 90 نقطة مئوية.

\section{مستوى التفذية}

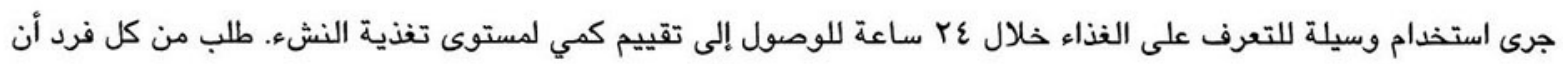

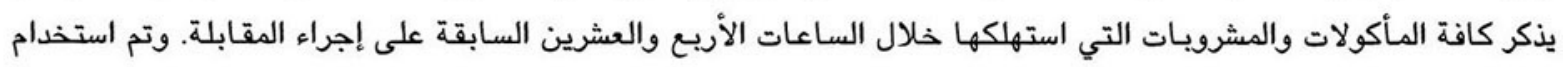

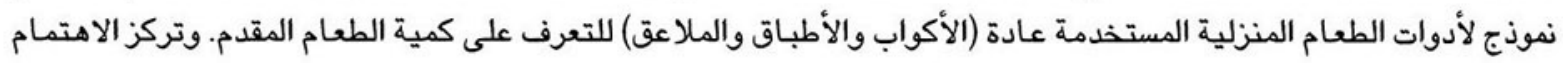

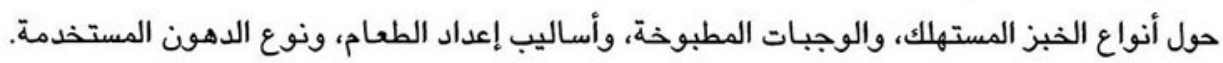

وتم تقييم الحصيلة الغذائية باستخدام تعديل لنظام تحليل الحصيلة الغذائية (جامعة تكساس ووزارة الزراعة الأمريكية، الصيغة

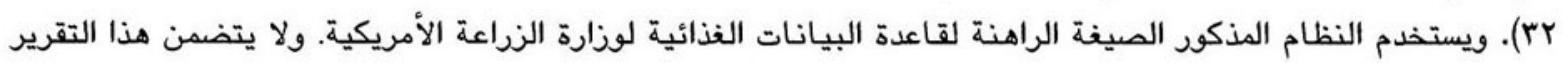

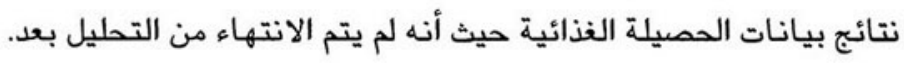

\section{تقييم النفوج الجنسي}

يعد مقياس تانر Tanner scale أداة لتقييم ظهور الخصائص الجنسية الثانوية لدى الذكور والإناث، وهي نمو شعر العانة لدى الدي

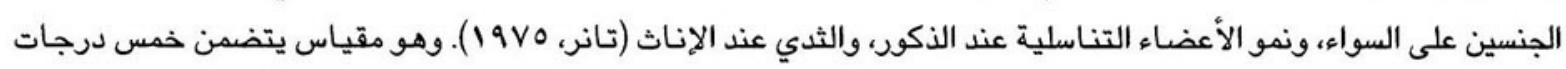

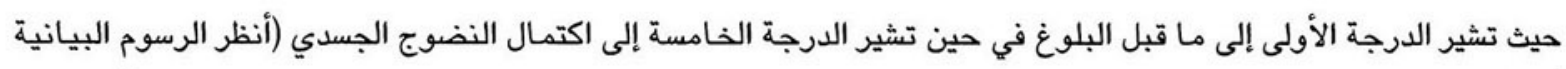

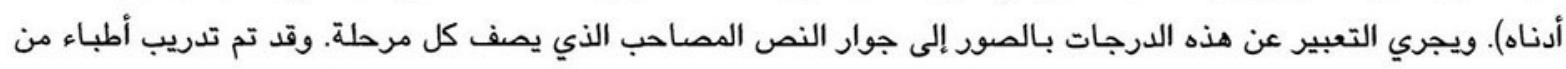

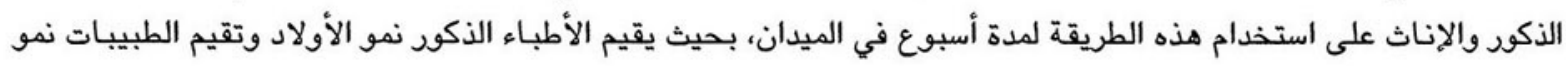

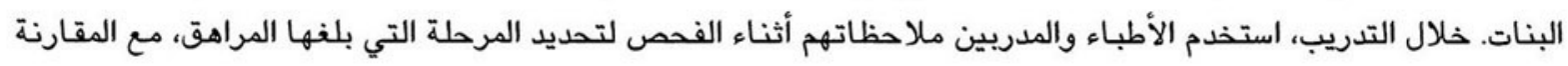

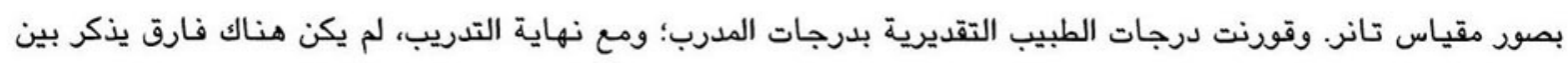

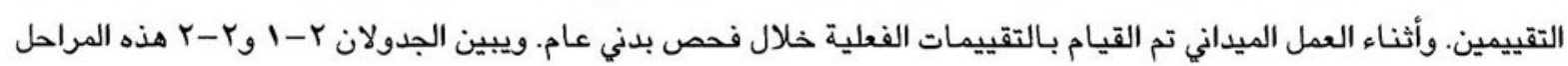
بالنسبة للأولاد والبنات. 


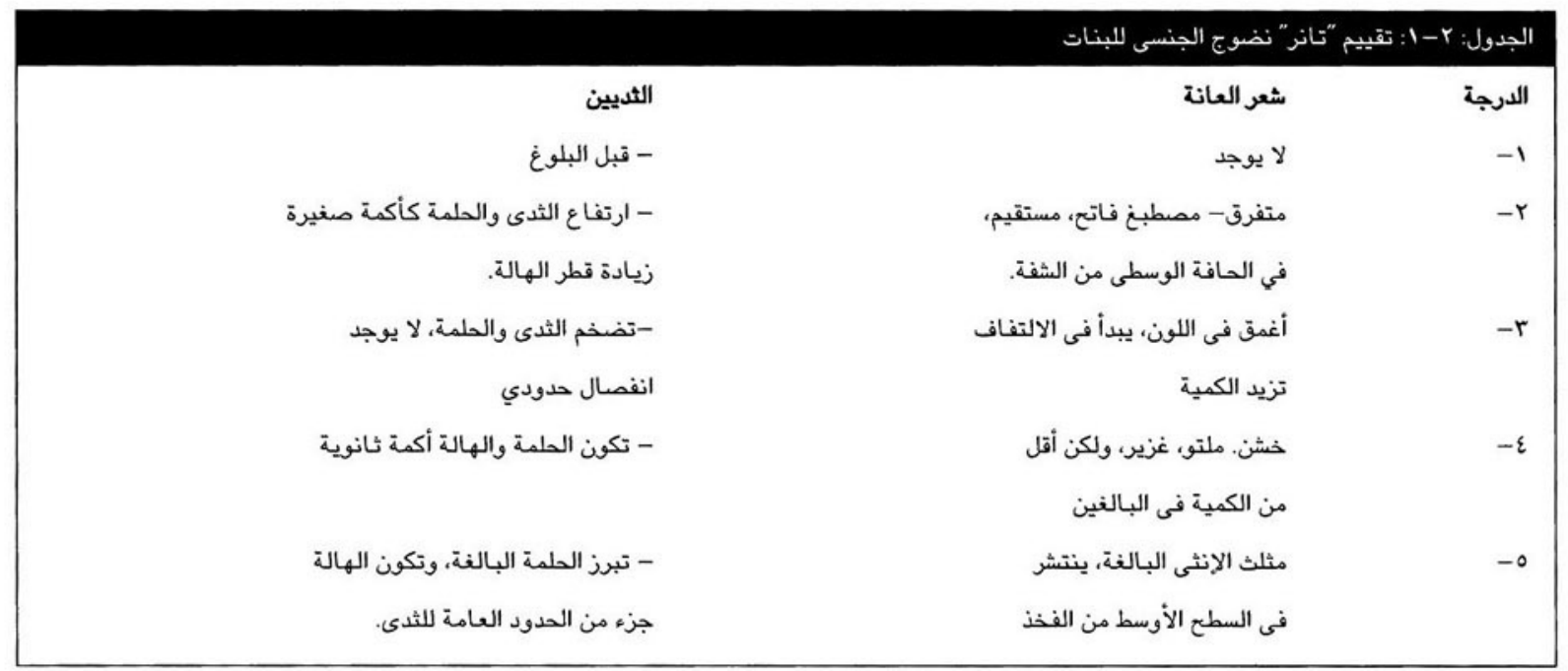

\begin{tabular}{|c|c|c|}
\hline \multicolumn{3}{|c|}{ الجدول r-r r تقييم "تانر" للنضوج الجنسى للبنين } \\
\hline عضو التناسل الذكرى & شعر العانة & الدرجة \\
\hline 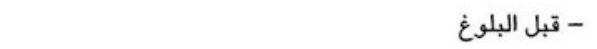 & لا يوجد & -1 \\
\hline - تضخم الخصيان، تغيير النسيج الوردى & قليل، طويل، مصطبغ فاتع & $-r$ \\
\hline - تضخم الخصيان، القضيب الذكرى أطول & أغمق فى اللون، يبدأ في الالتفاف، & $-r$ \\
\hline & كمية صغيرة & \\
\hline - تضخم الخصيان، غامق فى اللون، & يشبه نوع البالغ، والكن أقل فى الكمية، & $-\varepsilon$ \\
\hline ازدياد طول القضيب الذكرى مع الحشفة فى العرض والحجم. & والخشونة والالتفاف & \\
\hline - الحجم البالغ للقضيب الذكرى والخصيان & توزيع البالخ، ينتشر فى السطح & -0 \\
\hline & الأوسط من الفخذ & \\
\hline
\end{tabular}

\section{ثالثا: تنفيذ الدراسة وجمع البيانات}

تحقق التنفيذ الدقيق للدراسة من خلال الخطوات الثلاث الآتية:

\section{الاختبار الأولي}

عندما صارت الصيخ الأولية للاستبيان المنظم جاهزة للاختبار، خضع ستة من الباحثين ذوي الخبرة في مجال إجراء

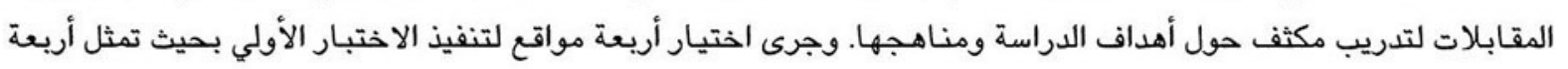

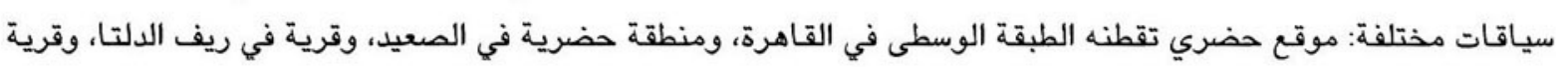
في ريف الصعيد.

وعقدت على امتداد مرحلة الاختبار الأولي جلسات مع فريق البحث لاستخلاص المعلومات. وعلى أساس نتائج الاختبار الأولي، تم تعديل شكل ومضمون الاستبيانات المنظمة وجرت مراجعة الإجراءاء مرات الميدانية. 
نُظُّت دورة تدريبية استغرقت شهرا لجامعي البيانات بمركز البحوث الاجتماعية بالجامعة الأمريكية في القاهرة، وأعقب الدورة

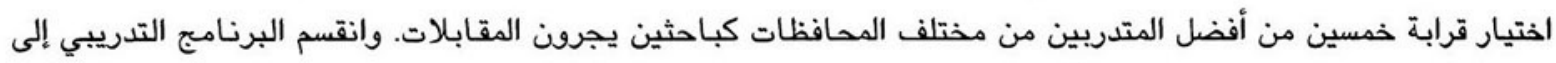

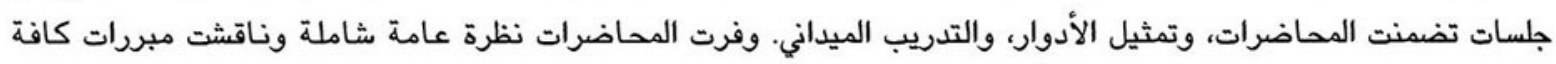

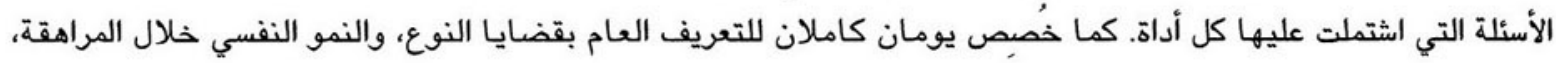

$$
\text { وتقنيات إجراء المقابلات مع صغار السن. }
$$

وتم كذلك تنظيم برنامج تدريبي لمدة أسبوع لثلاثين طبيبا بوزارة الصحة والسكان من مختلف المحافظات. وخصص البرنامج

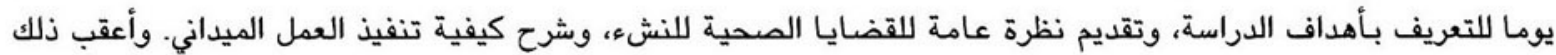
أربعة أيام من التدريب الميداني على إدارة الكشف الصحي للنشء في مركز مرئ صحي حكومي. وقد غطى البرنامج كافة الإجراءات

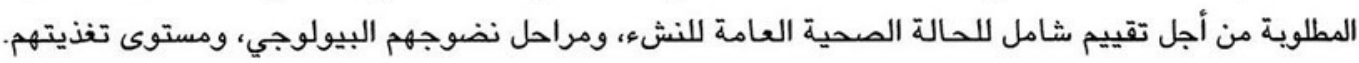

\section{التنسيق بين جمع البيانات وتنفيذ المركبة الممية}

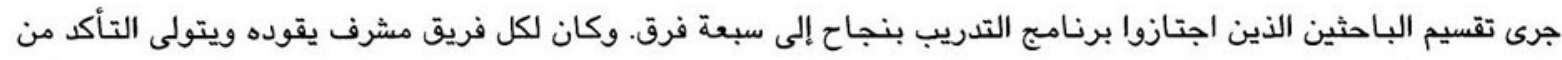

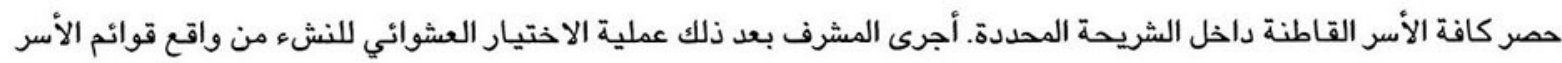

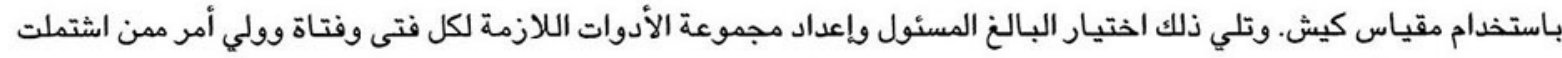

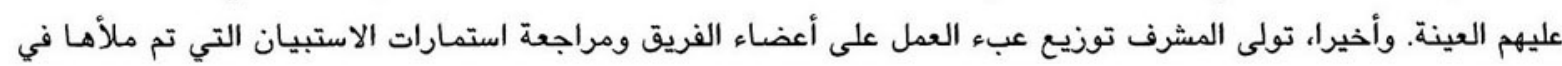

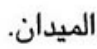

طُلب من الباحثين الذين يجرون المقابلات القيام بثلاث محاولات للقاء الفتيات والفتيان المختارين والبالغين المسئولين

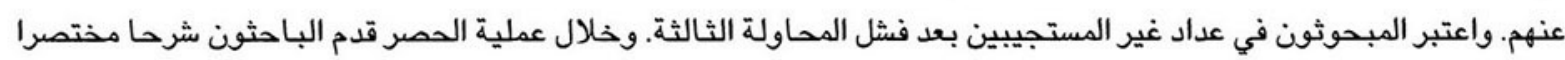

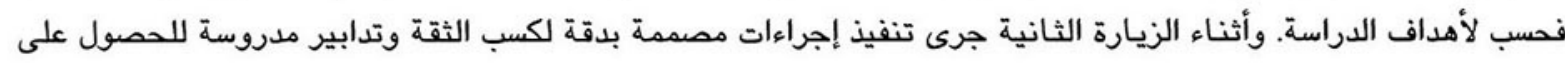

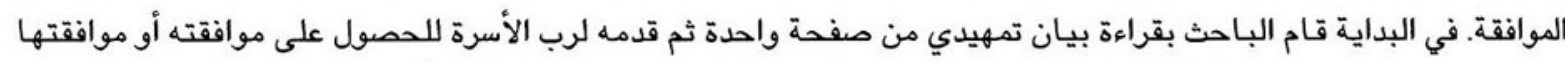

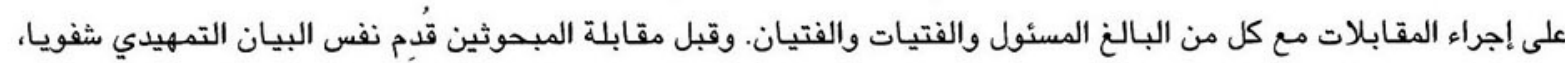

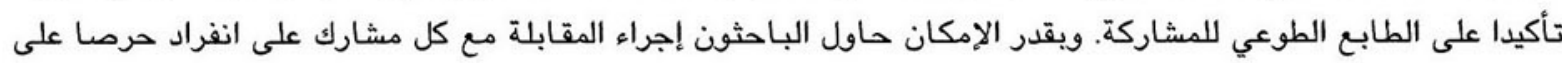

وفي حالة وقوع وحدة المعاينة الأولية داخل نطاق الوحدات الخمسين المختارة للعينة الفرعية الخاصة بالمكون الصحي، فقد الصداء

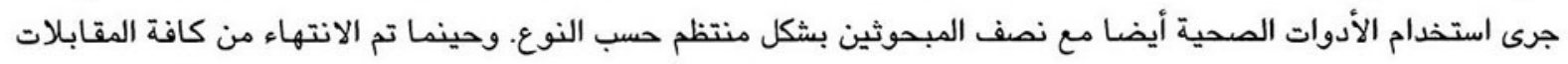

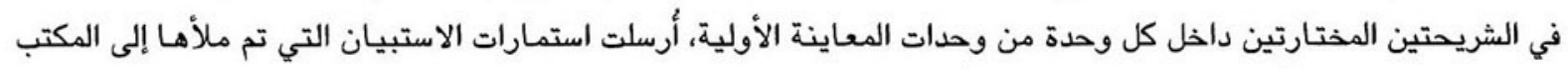
المركزي في القاهرة لأغراض التحرير وترميز الأسئلة المفتوحة.

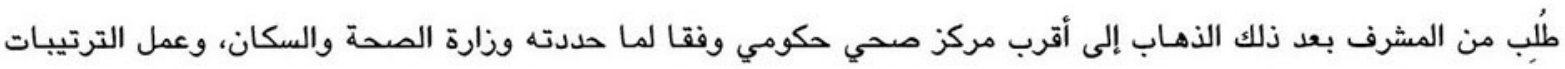

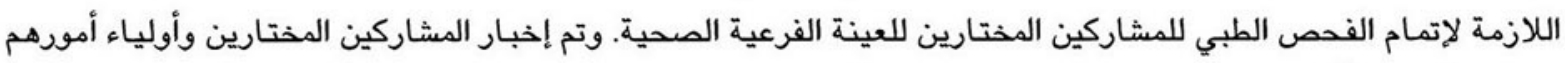

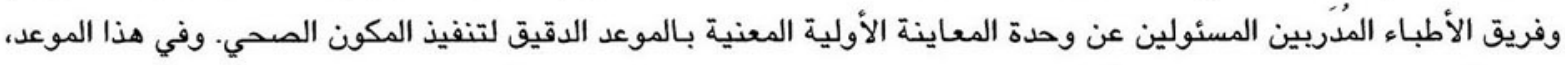

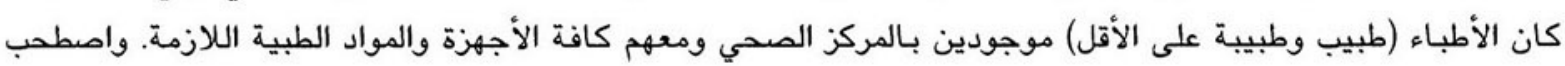


الباحثون المشاركين وأسرهم إلى المركز الصحي، وحاولوا أن يبثوا فيهم الشعور بالجدية والالتزام. وأعيد التأكيد على هذه

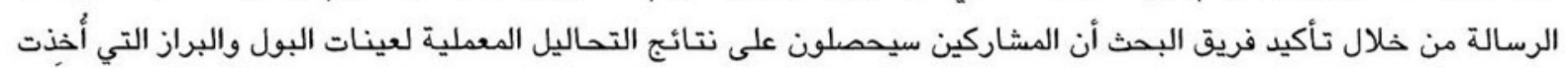
منهم. وقد تم تحليل كافة الاختبارات المعملية بالمعهد العالي للصحة العاركة العادي، جامعة الإسكندرية.

امتد جمع البيانات وتنفيذ المكون الصحي للمسح على مدى خمسة أشهر (من منتصف مارس إلى منتصف أغسطس لو 1997). وقد

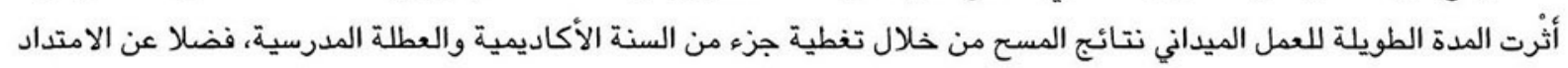

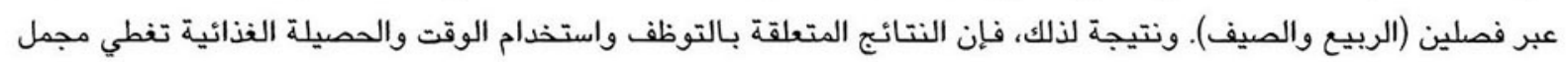

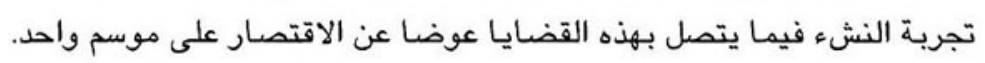

\section{رابعا: دروس العمل الميداني}

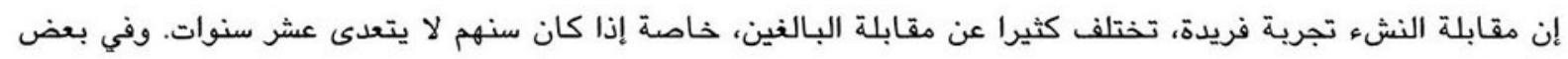

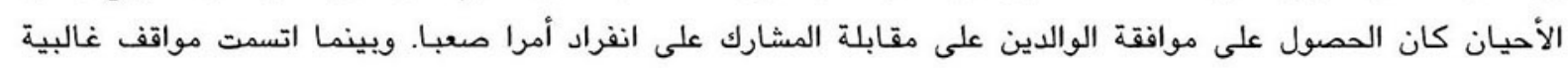

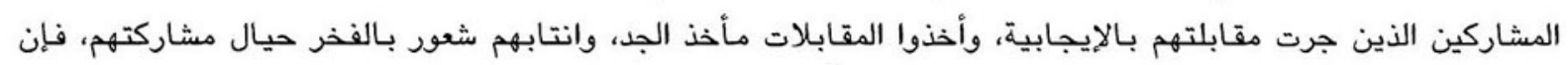

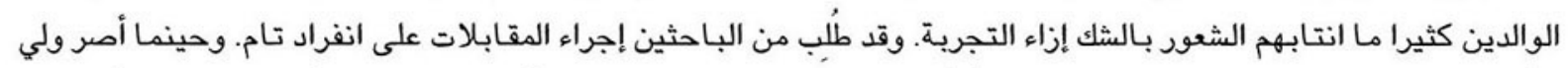

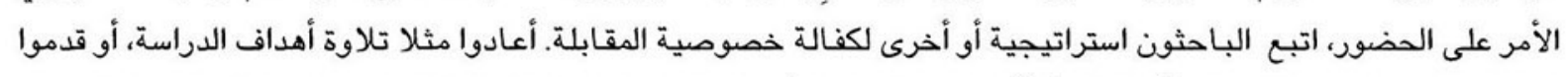

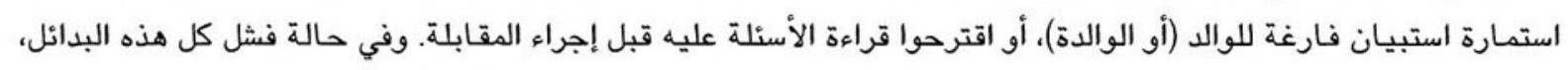

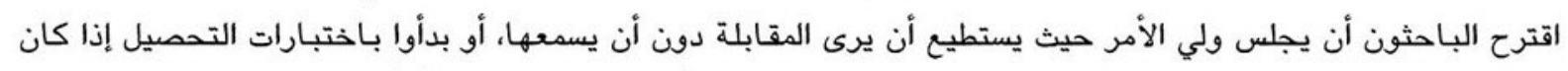

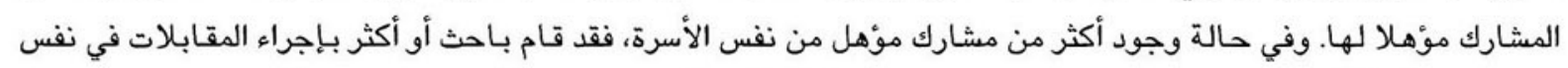

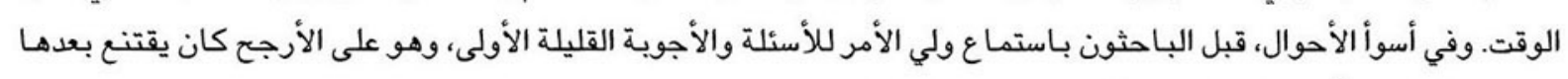

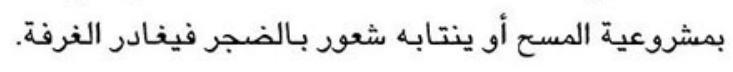

وتتمثل مشكلة فريدة تتعلق بمسح النشء في الحراك العالي نسبيا لهذه الشريحة من السكان داخل منطقة محل السكن. فالنشء

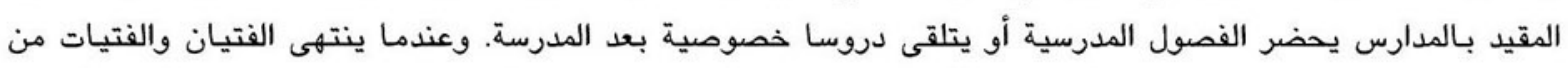

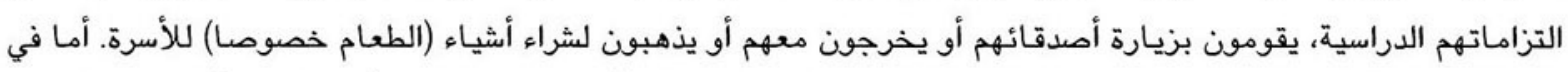

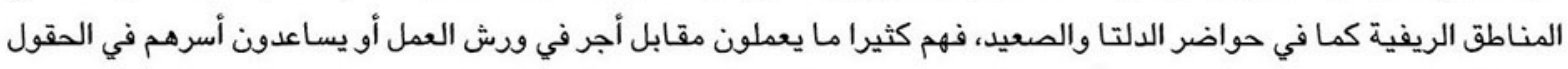

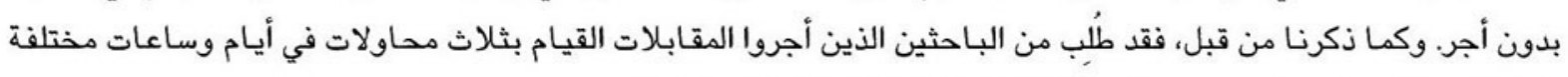

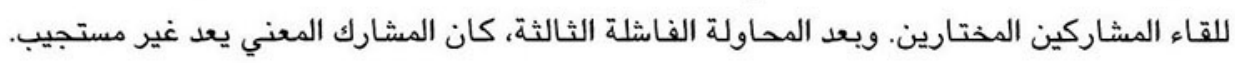

اقتضى استخدام عدة أدوات مع نفس الشخص زيارته أكثر من مرة. ويعد المشاركون المختارون الذين اشتملت عليهم العينة

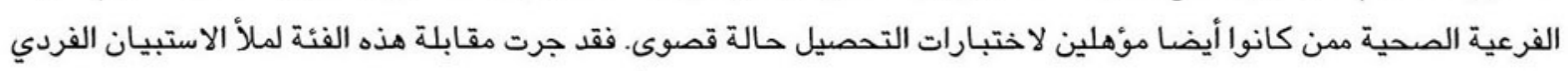

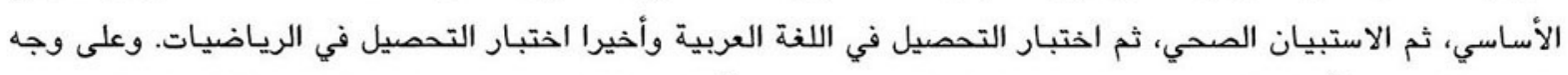

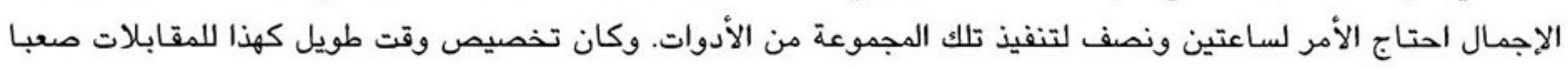
بالنسبة لبعض المشاركين بسبب الإنهاك أو الالتزامات الأخرى.

ويعد تنفيذ المكون الصحي المعقد للمسح قصة نجاح كبرى ينبغي توثيقها. وهي نتاج لمستوى عال من التنسيق بين أربع

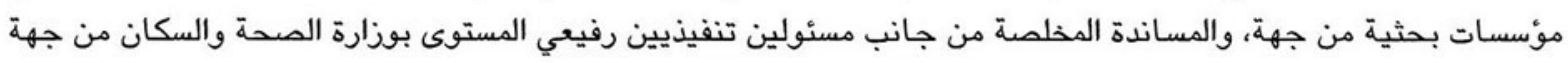
أخرى. كما أن جدية والتزام الأطباء المختارين لتنفيذ هذا المكون فضلا عن حساسيتهم إزاء المبحوثين كانت بلا شك مزائ منايا 
مُلّل شعور الوالدين بالشك (واللامبالاة أحيانا) عقبة كبرى أمام الباحثين الميدانيين. وكان إقناع الوالدين والفتيان والفتيات

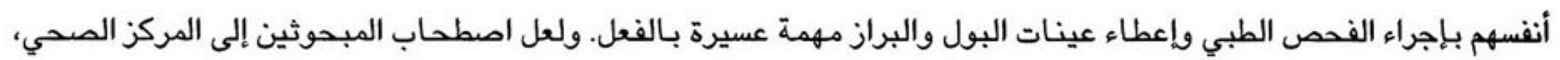

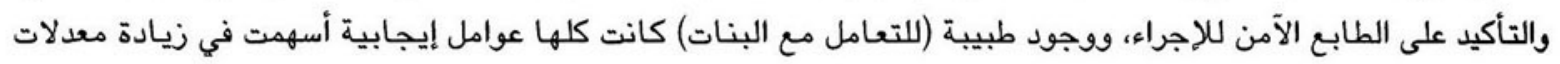

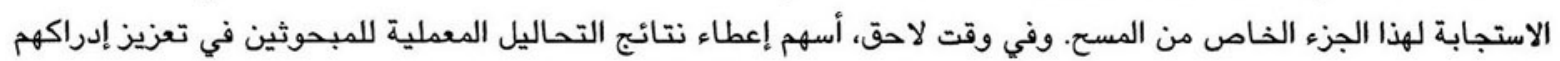
لمزايا المشاركة وشعورهم بالتزام الباحثين إزاءهم.

وفي بعض وحدات العينة الأولية، لم يكن أقرب مركز طبي حددته وزارة الصحة والسكان قريبا بما يكفي من الشريحة التي

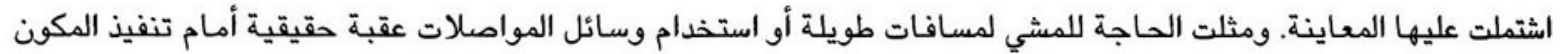

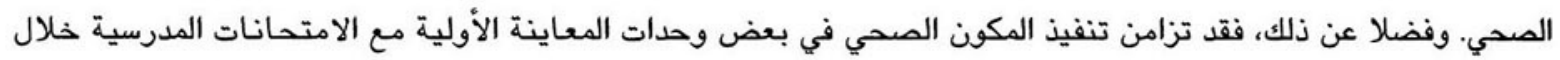

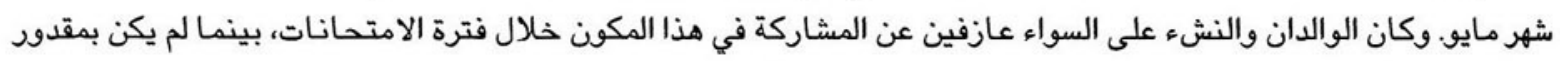
فريق المسح تأجيله بسبب النفقات المحتملة التي يجلبها هذاء والت التأخير.

وتتصل المشكلة الأخيرة المتعلقة بتنفيذ المكون الصحي بغياب أفراد التمريض عن الفريق الطبي. فعلى الرغم من كل الجهود

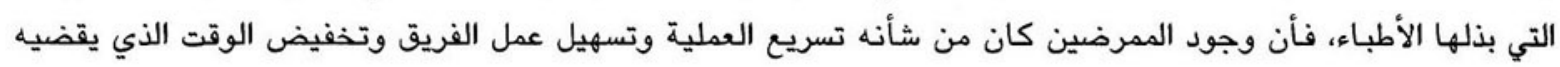
المبحوثون في الانتظار.

\section{خامسا: السمات الفريدة للدراسة}

هناك عدد من السمات الفريدة للبيانات المستقاة من "مسح النشء والتغيير الاجتماعي في مصر".

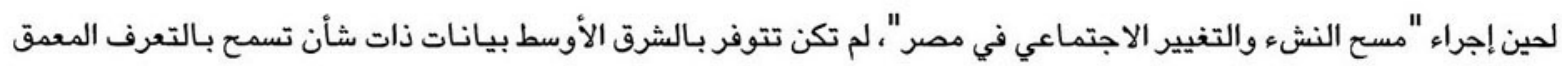

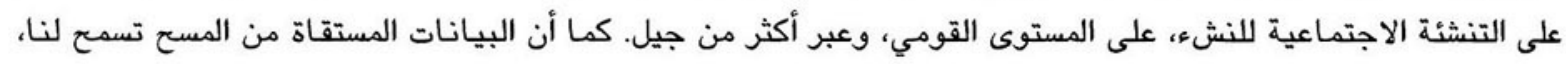

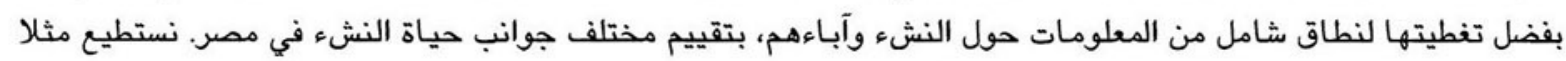

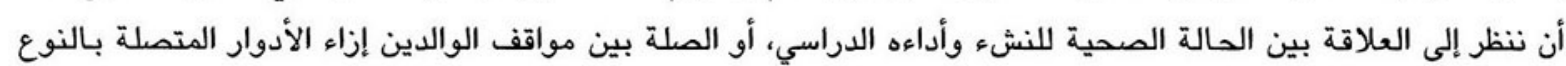
ومواقف أبنائهم.

وتوفر بيانات "مسح النشء والتغيير الاجتماعي في مصر" أيضا فرصة نادرة لمقارنة إجابات الأولاد والبنات المنتمين للأسرة

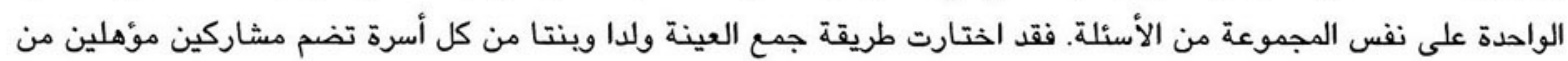

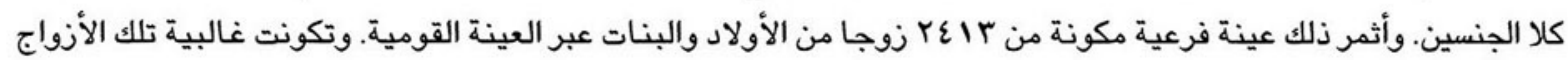

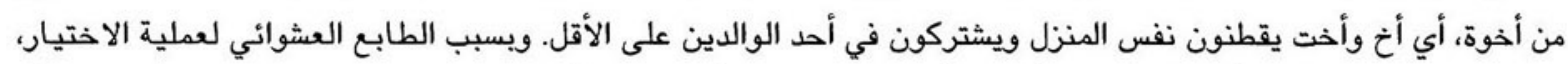

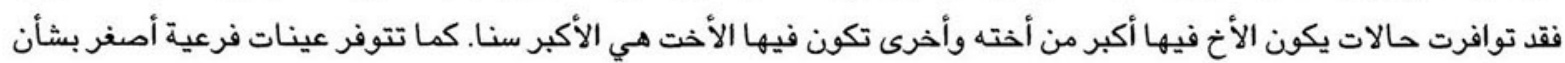

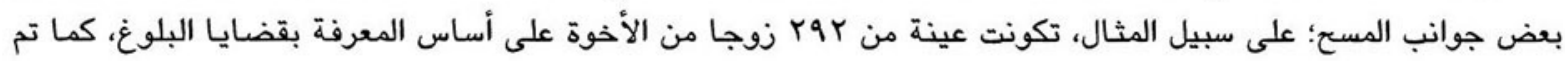

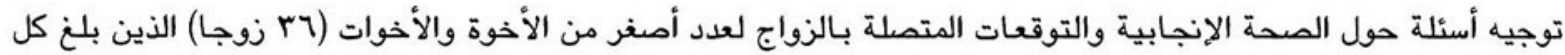




\section{سادساً: بعض الملاحظات الفنية}

تم إستخدام تحليلات الإنددار الثنائية فقط في تناول موضوعات هذا التقرير. وعلى هذا الأساس لم يؤخذ في الإعتبار العلاقات

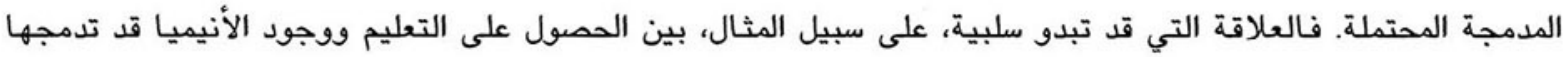

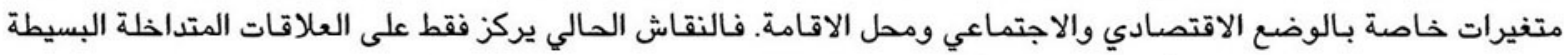

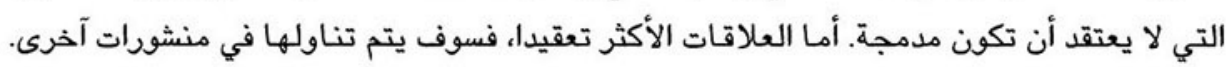

بالاضافة الى ذلك، نتيجة لتصميم العينة، استخدمت البيانات بالأوزان الترجيحية للحصول على النسب المئوية المذكورة فى الحي

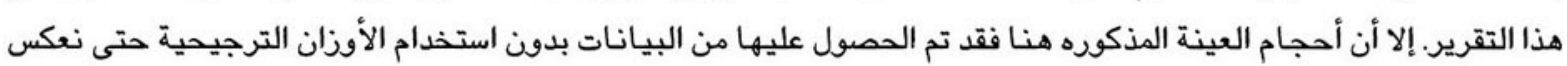
العدد الدقيق للاستجابات التي تم التوصل اليها في مرحلة جمع البيانات. 


\section{خصانص العينة}

\section{أولاً: مدى تمثيل مجتمع النشء في مصر}

يبين الجدول r-1 توزيع الأفراد في كافة الأسر المعيشية التي شملتها العينة حسب النوع والسن ونمط ومنطقة محل الإقامة،

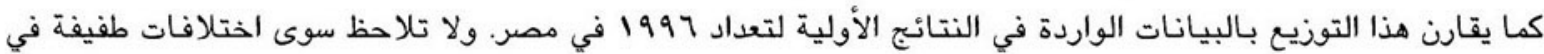

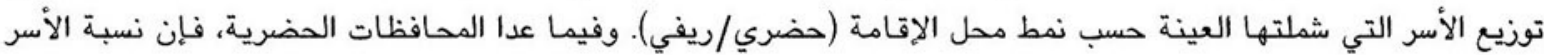

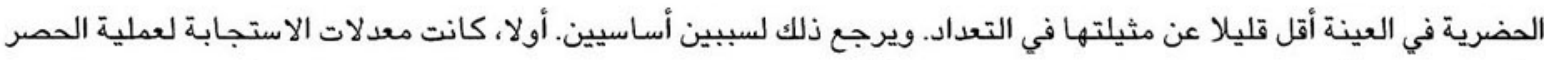

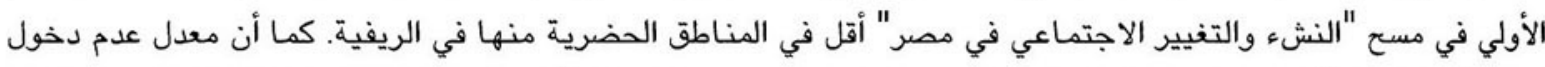

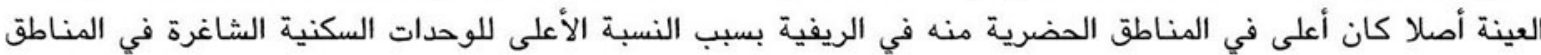

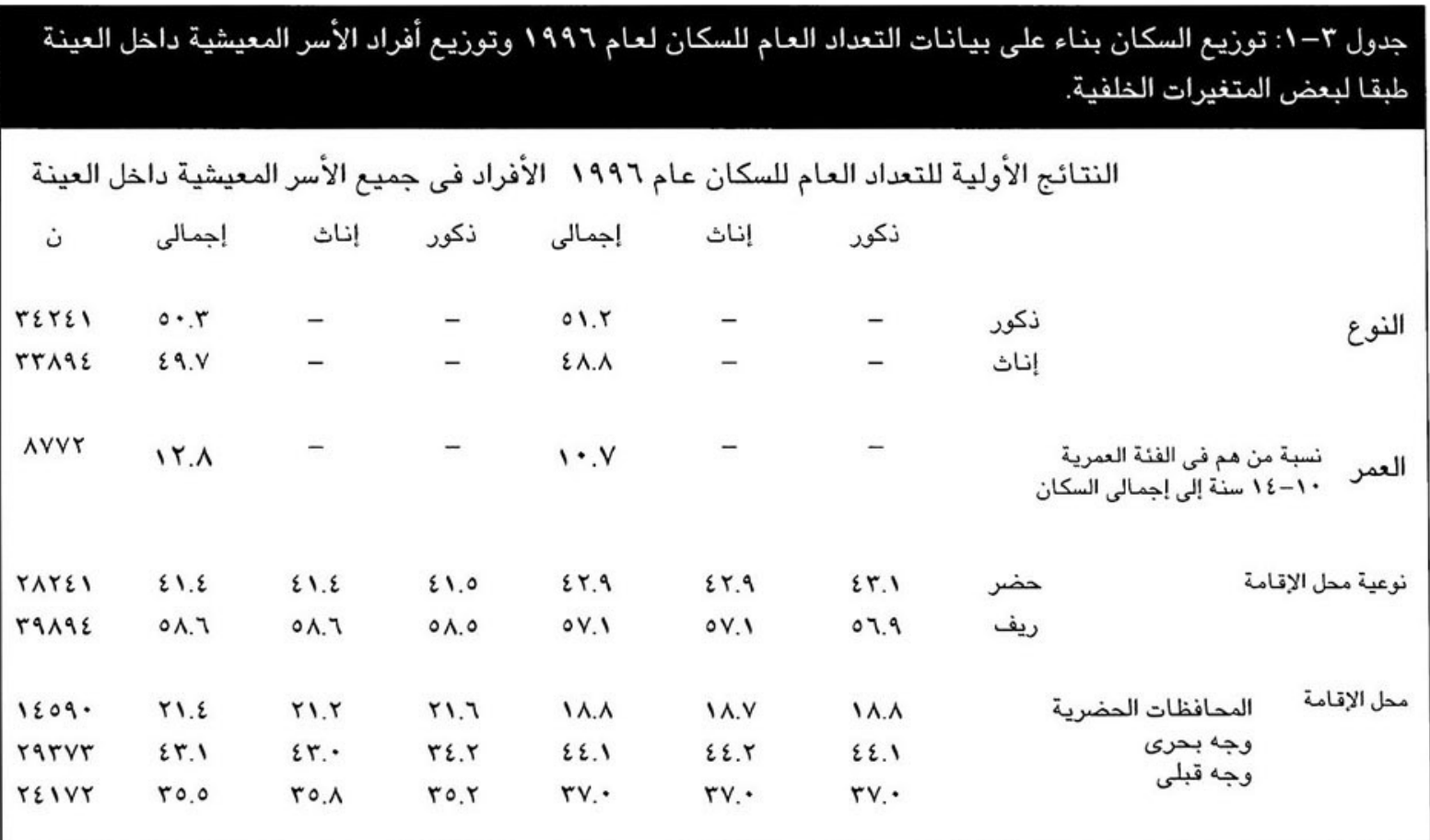

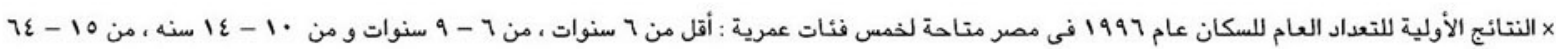

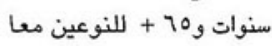

ويحاول الجدول r-r أن يسجل أي نقص في تمثيل جموع النشء في مصر، إذ ننتقل من فئة كافة النشء في الأسر التي شملتها

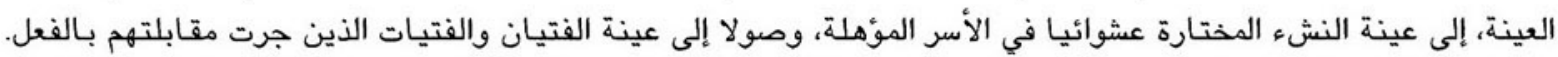

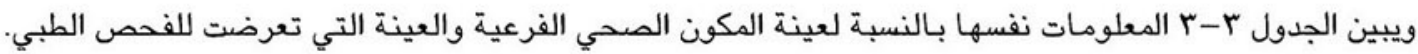


جدول r-r : توزيع الفتيات والفتيان الذين تم حصرهم و الذين وقع عليهم الإختيار العشوائى و الذين تمت مقابلتهم

فعلا طبقا لبعض الخصائص الديموجرافية

الفتيات والفتيان الذين

تم مقابلتهم

ذكور إناث

$1 \cdot 1 \cdot 1$

I..V Ir.

Ir.Y Ir.A

$1.0 \quad 1.7$

$11.0 \quad 1.0$

$11.1 \quad 11$.

1.1 A.A

q.ह 9.

V.T V.A

$0.1 \quad 0.1$

$77.7 \quad$ Vา.

$18.9 \quad 11.9$

$10.0 \quad \varepsilon . \varepsilon$

E.r I9.r

$90.1 \quad \Lambda \cdot . \Lambda$

Ir.9 YA.A

AV.I VI.Y

rA.t rV.I

II.A Ir.9

IN.E $\quad 11.0$

$\varepsilon \varepsilon .0$ \&r.V

rv.l ry.s

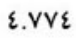

\&.ro\&
الفتيات والفتيان الذين تم

اختيارهم

زكور إناث

$9.0 \quad 9.0$

$1.1 \quad 1 \% .1$

Ir.E Ir.O

$1 \cdot \varepsilon \quad 1 \cdot . r$

$1 \cdot 9 \quad 1 \%$

$1.9 \quad 11$.

$1 \cdot . \varepsilon \quad 9 . \varepsilon$

$9.9 \quad 9.8$

1.0 9.

I.A V.

רe.v $\operatorname{vr} . \varepsilon$

19.1 rI.A

IT.Y

$\varepsilon . \varepsilon \quad 19.1$

$90.7 \quad A \cdot . r$

ir.r r.

AV.A Vr.q

rq. rq.1

71. $\quad 7 \cdot .9$

IN.V r.riq.A

$\varepsilon \varepsilon . \quad \varepsilon$

rv.r rv.q

o.rrr $\quad 0 . r \cdot r$
الفتيات والفتيان الذين تم

حصرهم

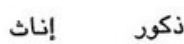

$1 \cdot .19 .8$

$1 \cdot . r \quad 11 . \varepsilon$

11.9 ir.r

$1.0 \quad 1 \%$

$1.9 \quad 1 \%$

$1.7 \quad 1.9$

$1.7 \quad 1.1$

$9.1 \quad 9.0$

1.1 9.1

1.0 V.

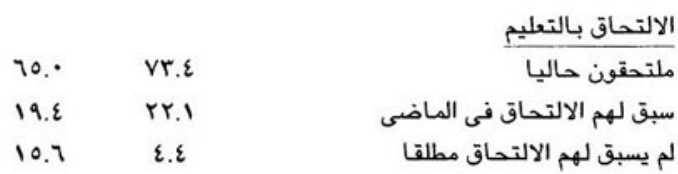

لعم

$97 \varepsilon \quad A r$

نعم العمل بدون أجر

1.. rr.

१..

نوعية محل الإقامة

rq. rq.

$7.7 \quad 71$.

محل الآقامة

19. $\quad 19.5$

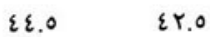

المحافظات الحضرية

وجه بحرى

rา. rv.A

A. 71 A.rr.
ريف

العمر

وجه قبلى

الإجمالى

ويوضح الجدول r-r أن عملية الاختيار العشوائي للنشء حسب النوع باستخدام أسلوب كيش Kish grid نفتت بشكل سليم

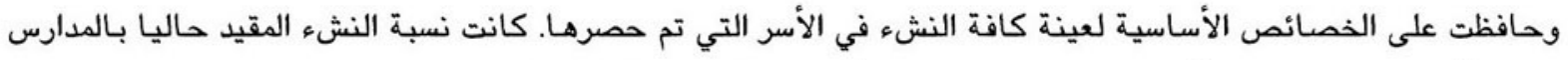

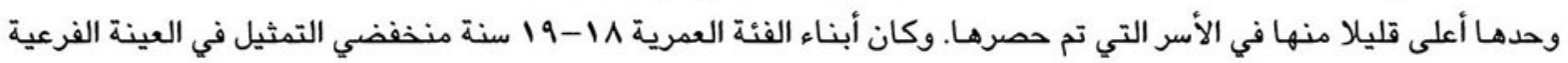

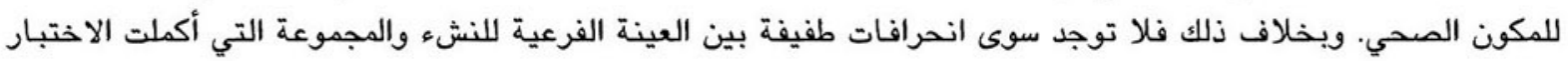

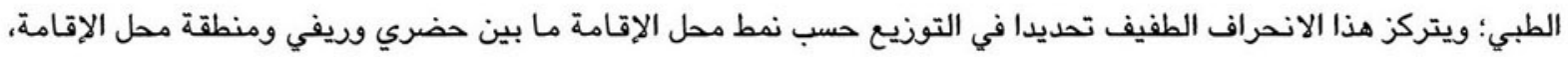




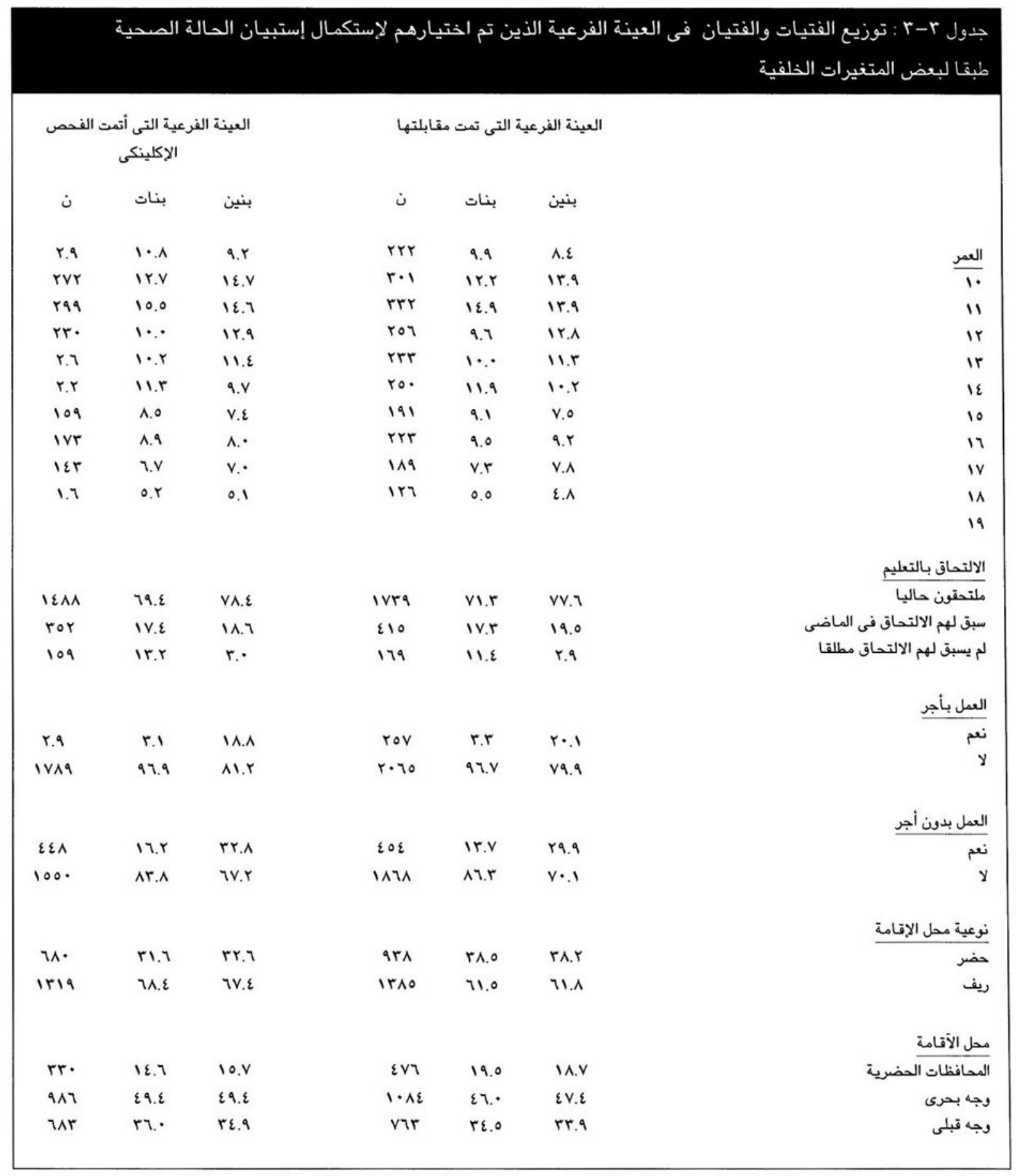

\section{ثانياً: خصانص عينة البالغين المسنولين}

إن اختيار البالغ المسئول قد تلى اختيار المراهق (أو المراهقين) في الأسر المختارة. وفي حالة وقوع الاختيار على مشارك واحد

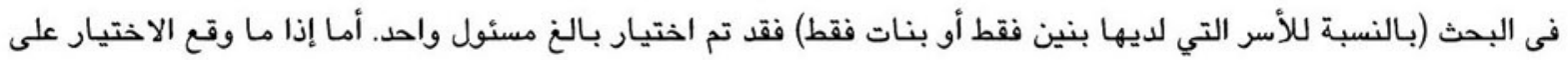

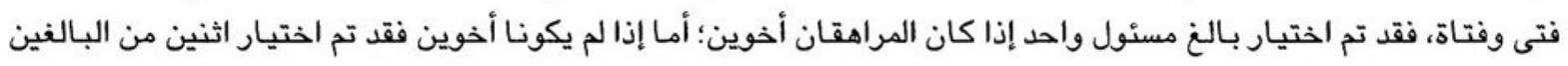
المسئولين إلا إذا كان الشخص البتار بالغ مفئز نفسه مسئولا عن الاثنين. 
وتكشف نتائج المسح أن \9٪ من البالغين المسئولين الذين جرت مقابلتهم كانوا آباء أو أمهات للنشء المبحوثين. ومن ثم

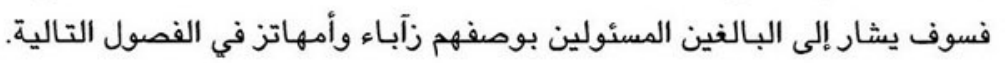

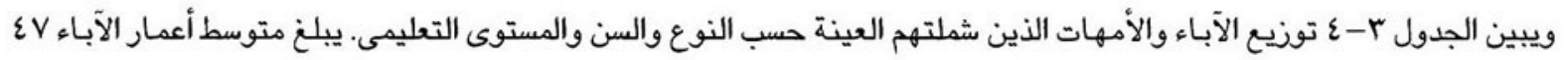

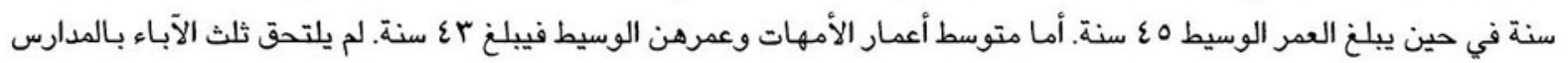

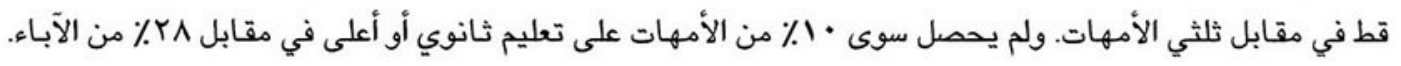

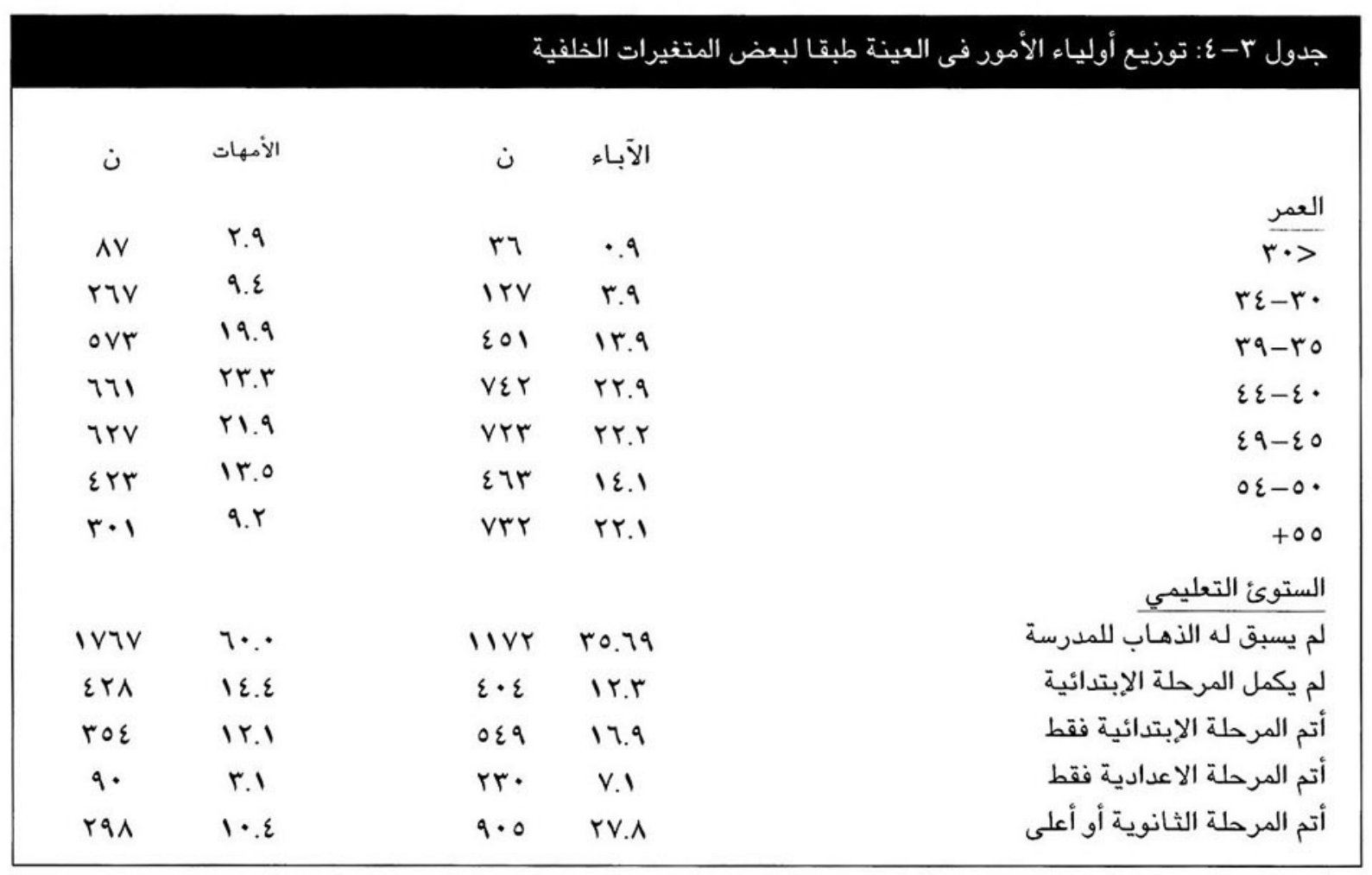

\section{ثالثاً: تكوين دليل الحالة الاجتماعية الاقتصادية للأسر المختارة}

يعد بحث التفاوتات في تجرية النشء من مختلف المستويات الاجتماعية الاقتصادية وكذلك التأثير المحتمل لتلك التفاوتات

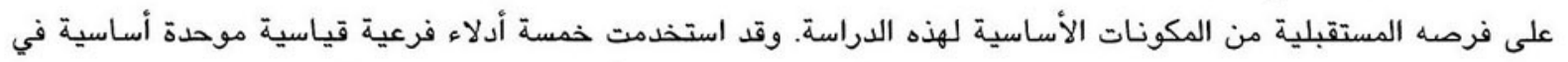

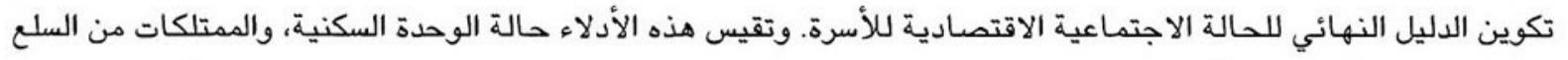

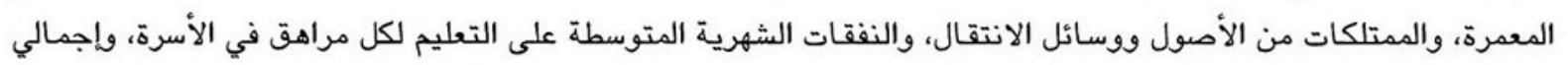

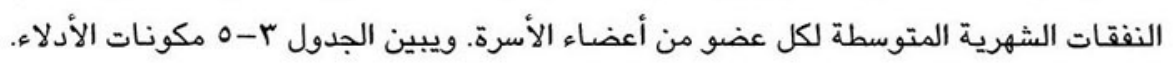

وقد تم جمع القيم المدرجة لمكونات كل من الأدلاء الثلاثة الأولى لكل أسرة ثم توحيدها قياسيا ما بين كافة الأسر (تعتمد

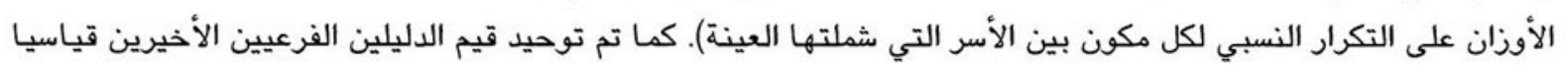

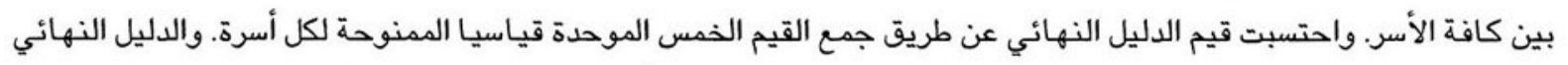

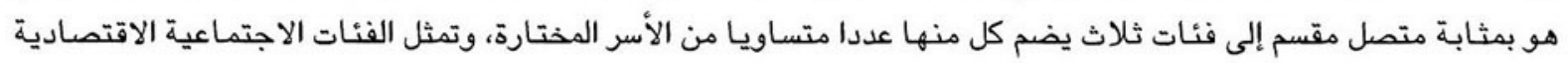

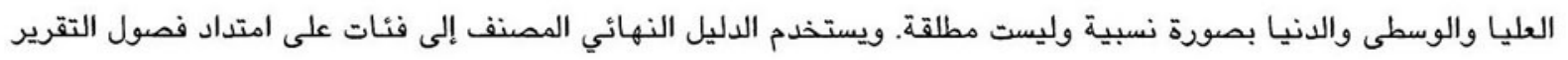

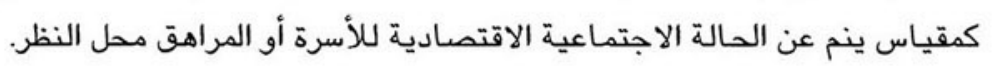


جدول r-0 : توزيع الأسر المؤهلة حسب مكونات دليل الحالة الاجتماعية الاقتصادية الذى تم تصميمه للدراسة

.17
.$r v$

- हv

. vi

- ra

.70

. ro

$\cdot .11$

.rr

$\cdot .17$

$.1 \varepsilon$

$\cdot .17$

$\cdot 1 \varepsilon$

.07

$\cdot \varepsilon \varepsilon$

$\cdot r$

$\cdot$.va

$\because \cdot 1$

$.9 \varepsilon$

. .19

.11

$\because r$

$\cdot 9 \Lambda$

$\because \cdot v$

$\cdot .9 r$

$\because \cdot 1$

$\cdot .99$

$\because \cdot r$

$\cdot .91$

$\because \circ$

.90

. vo

r. ro

$\cdot r \varepsilon$

$\cdot . \mathrm{v}$

$\because \cdot 1$

.99

$\because \bullet$

.90

Y P.1.19

ع 97.1
1- حالة الوحدة السكنية

أ- عدد غرف السكن- عدد الغرف المخصصة للنوم

ب- اتصال المسكن بشبكة المياه العمومية ج- وجود مكان مخصص لاعداد الطعام (مطبخ) r- ملكية السلع المعرة

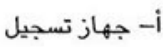
تليفزيون

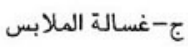
د- م- ملاجة

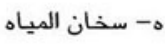

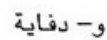
ز - مليفون ح- جهاز تكييف

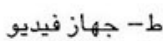
r- ملكية الأصول ووسائل الانتقال أ- دراجة بخارية

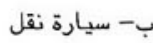

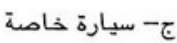

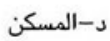
- م- (أرض زراعية و- أرض فضاء للبناء

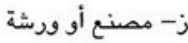
ع- متوسط الإنفاق الشهرى على تعليم افرد الواحد في الفنة.

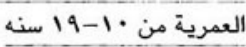
0- متوسط الإنفاق الشهرى للفرد في الأسرة المعيشية

× النسب المرجحة بإستخدام أوزان العينة 


\section{المصرة المصية العامة للنشء المصرى}

وفقا لتعداد السكان المصري لعام 1997، يمثل النشء في الفئة العمرية ـ 1-19 عامـا ب ب\% من سكان مصر. إلا أنه على الرغم

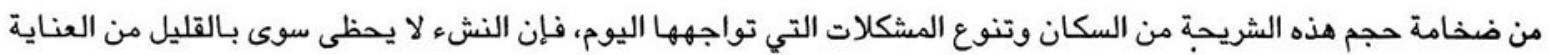

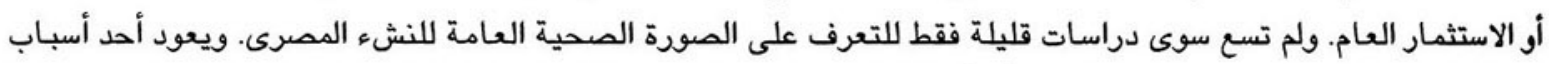

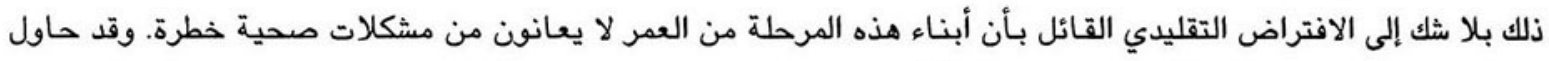

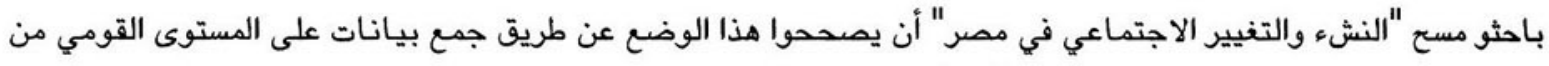

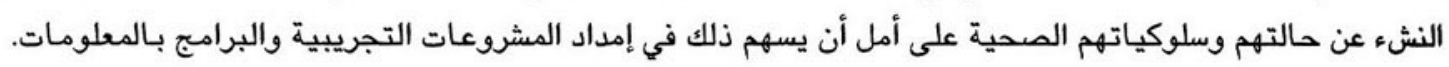

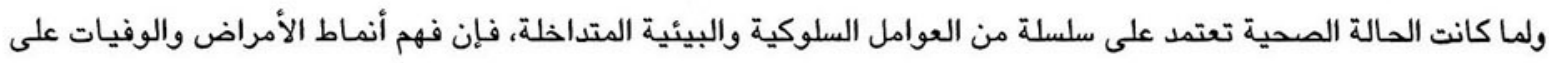

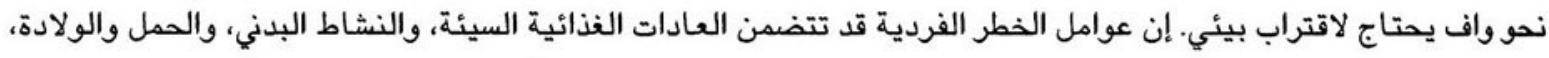

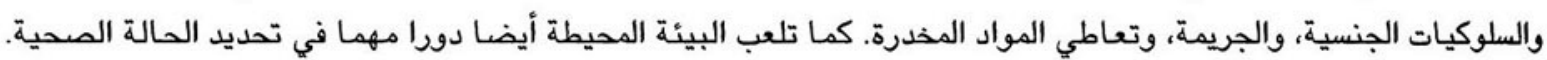

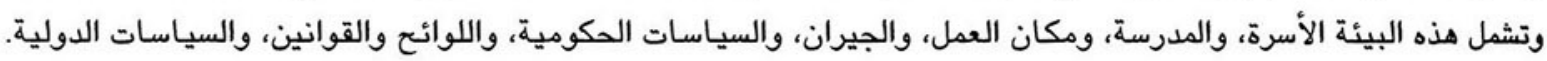

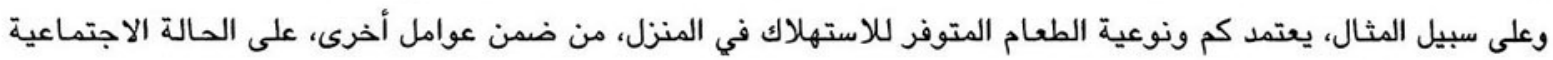

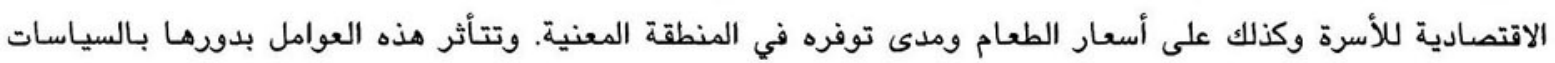

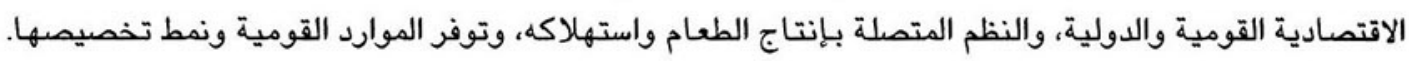

يصف هذا الفصل بعض جوانب الصورة الغذائية والصحية العامة للنشء في مصر ويستكشف بعض محددات صحة المراهق.

\section{أولا: الصالة الغذانية}

تعد الحالة الغذائية، في الماضي والحاضر على السواء، عاملا أساسيا يحدد صحة المراهق ورفاهيته البدنية والعاطفية وتطوره المعرفي. كما أن الحالة الغذائية تعتبر مثالا ممتازا للعامل الصحي الفي الذي الذاضي يعتمد على السلوكيات الفردية وكذا العوامل البيئية.

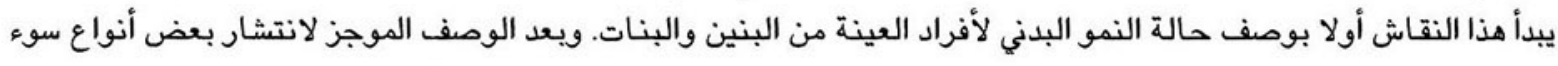

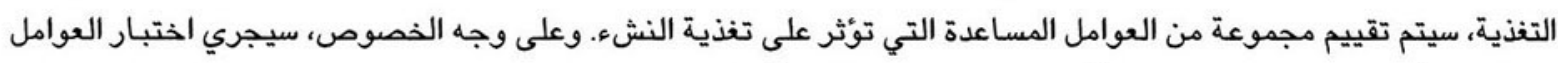

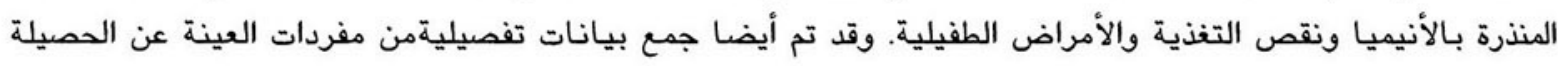
الغذائية خلال ع ساعة سابقة على المقابلة وسيجري تحليلها في مؤلفات لاحقة.

\section{تقييم النمو}

كثيرا ما تستخدم القياسات الأنثرويومترية (قياسات الطول والوزن) خلال سنوات الطفولة المبكرة لتقييم الحالة الصحية، إذ إلـات

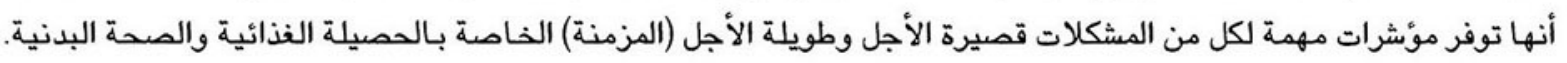

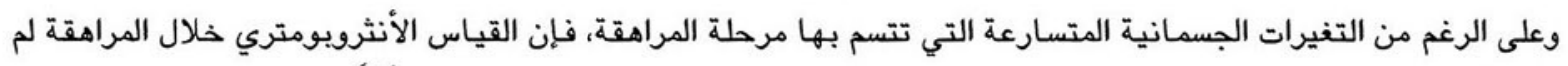

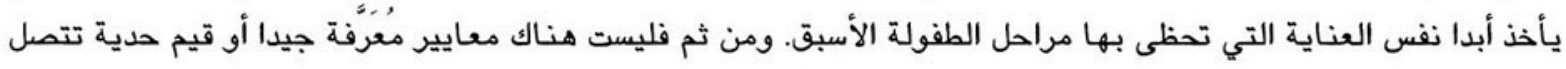
بعوامل محددة من عوامل الخطر. ومع ذلك فإن المؤشرات التي يوصى بها لتهات التييم النشء، والمستقاة من القياسات 
الأنثرويومترية، هي: اعتلال النمو (التقزم)، والنحافة، وخطر السمنة، والسمنة (منظمة الصحة العالمية، 1990). ويجري شرح هذه المؤشرات بتفصيل أكثر أدناه.

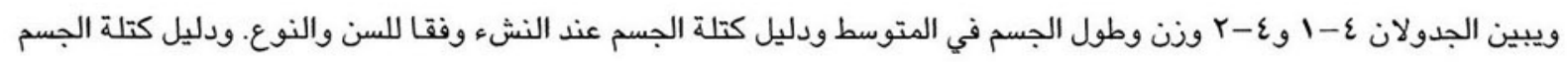

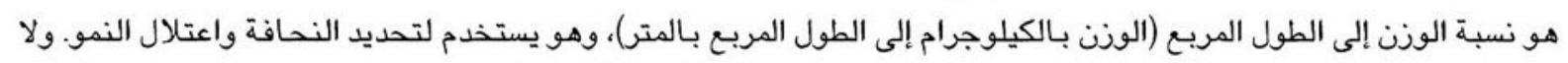

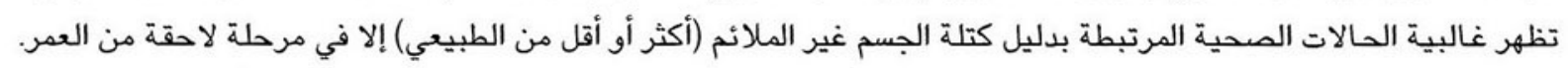

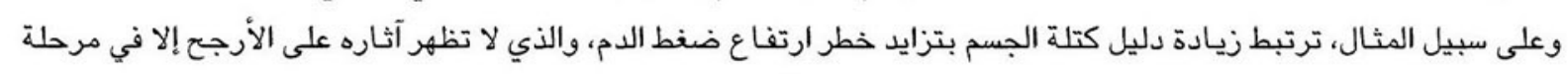

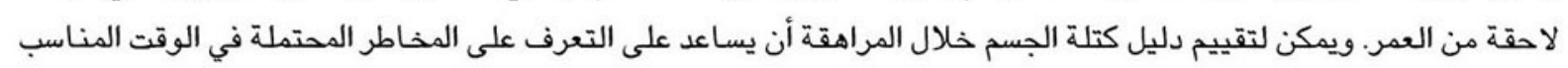

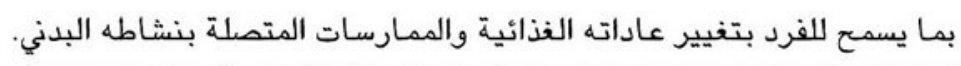

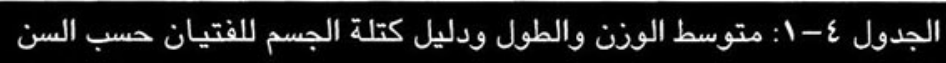

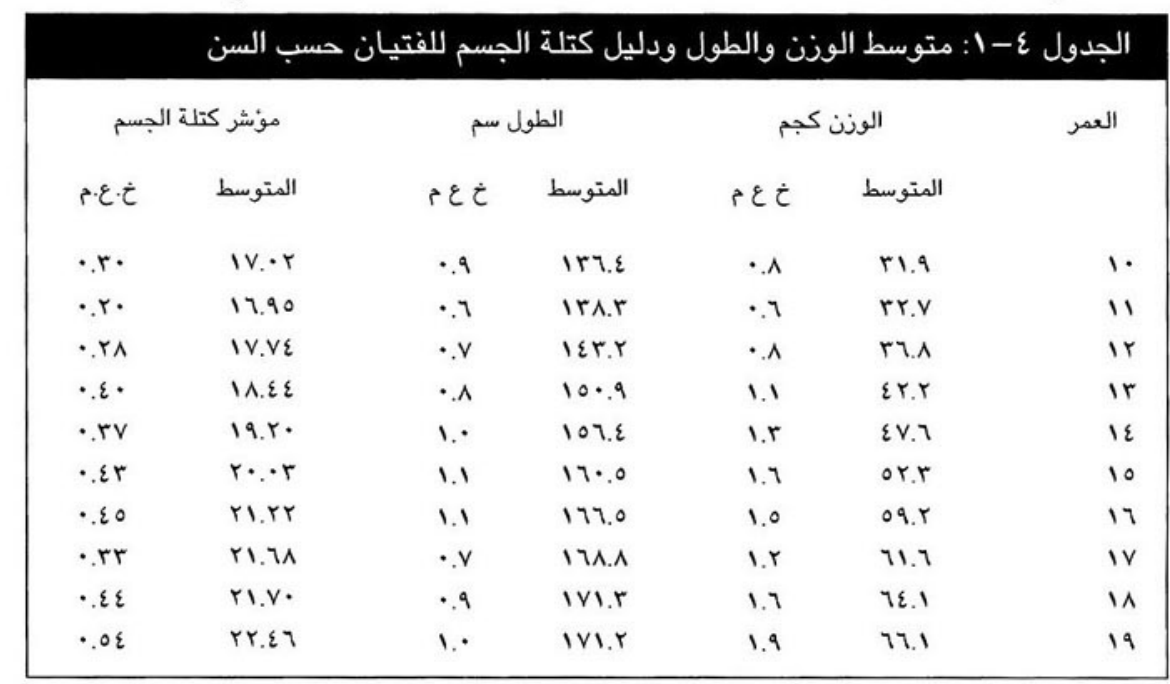

-

\begin{tabular}{|c|c|c|c|c|c|c|}
\hline \multicolumn{2}{|c|}{ مؤشر كتلة الجسم } & \multicolumn{2}{|c|}{ الطول سم } & \multicolumn{2}{|c|}{ الوزن كجم } & \multirow[t]{2}{*}{ العمر } \\
\hline م.ع.خ & المتوسط & مع & المتوسط & م ع & المتوسط & \\
\hline • & 17.87 & .7 & Ir\&.o & .0 & $r \cdot .0$ & 1. \\
\hline$\cdot r \wedge$ & $1 \mathrm{~N} .1 \mathrm{r}$ & $\cdot .1$ & Irq.r & $\cdot .9$ & ro.z & 11 \\
\hline • ro & 11.01 & $\cdot v$ & IEA.Y & $\cdot .1$ & $\varepsilon 1 . r$ & ir \\
\hline$\cdot \varepsilon r$ & $r 1 . r$ & $\cdot v$ & lor.r & 1.1 & $\varepsilon 9.1$ & ir \\
\hline$\cdot r q$ & 51.70 & $\cdot v$ & 107. & 1.1 & or.s & $1 \varepsilon$ \\
\hline$\cdot r \varepsilon$ & YI.AV & $\cdot v$ & $107 . \varepsilon$ & $\cdot .9$ & or.t & 10 \\
\hline$\cdot \varepsilon\urcorner$ & rr.\&7 & $\cdot .7$ & $10 \mathrm{~V} . \mathrm{V}$ & I.r & 0.1 .7 & 17 \\
\hline$\cdot \varepsilon 1$ & rr.q. & $\cdot v$ & $10 \wedge . \varepsilon$ & I.r & ०v. . & iv \\
\hline$\cdot .00$ & rE.rY & $\cdot v$ & lo9.r & 1.0 & 11.7 & in \\
\hline$\cdot \varepsilon \vee$ & $r r . \varepsilon r$ & $\cdot v$ & 109.7 & $1 . \varepsilon$ & 09.1 & 19 \\
\hline
\end{tabular}

-

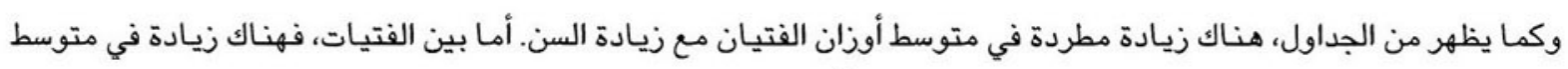

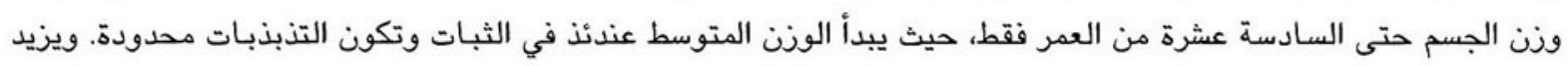

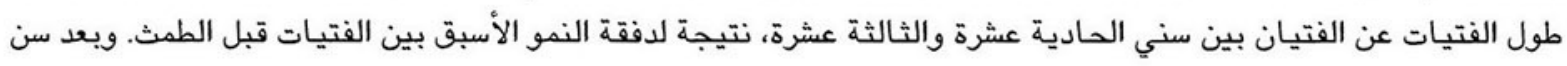

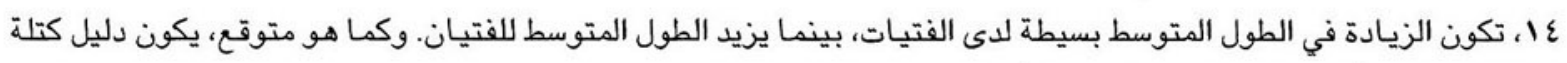
الجسم المتوسط أعلى عند الفتيات في كل الأعمار. 
جرت مقارنة الوزن والطول المتوسطين لعينة النشء المصرى بالبيانات المرجعية المستقاذّ من المركز القومي الأمريكي

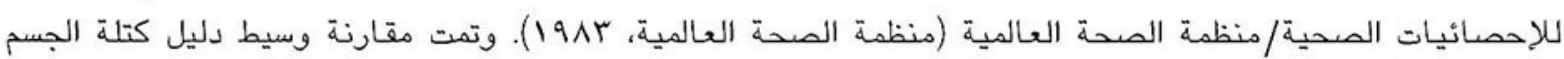
بالبيانات المصححة المستقاة من موست وآخرين (1991)'. كان وسيط الوزن والطول بالنسبة للسن عند النشء المصرى أقل

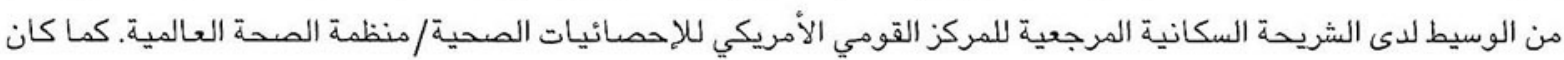

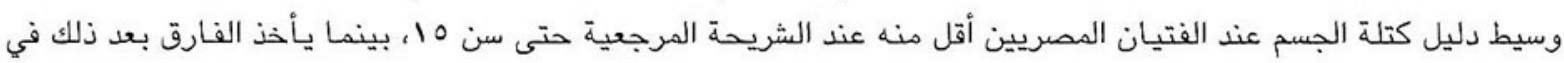

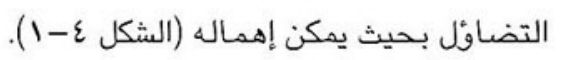

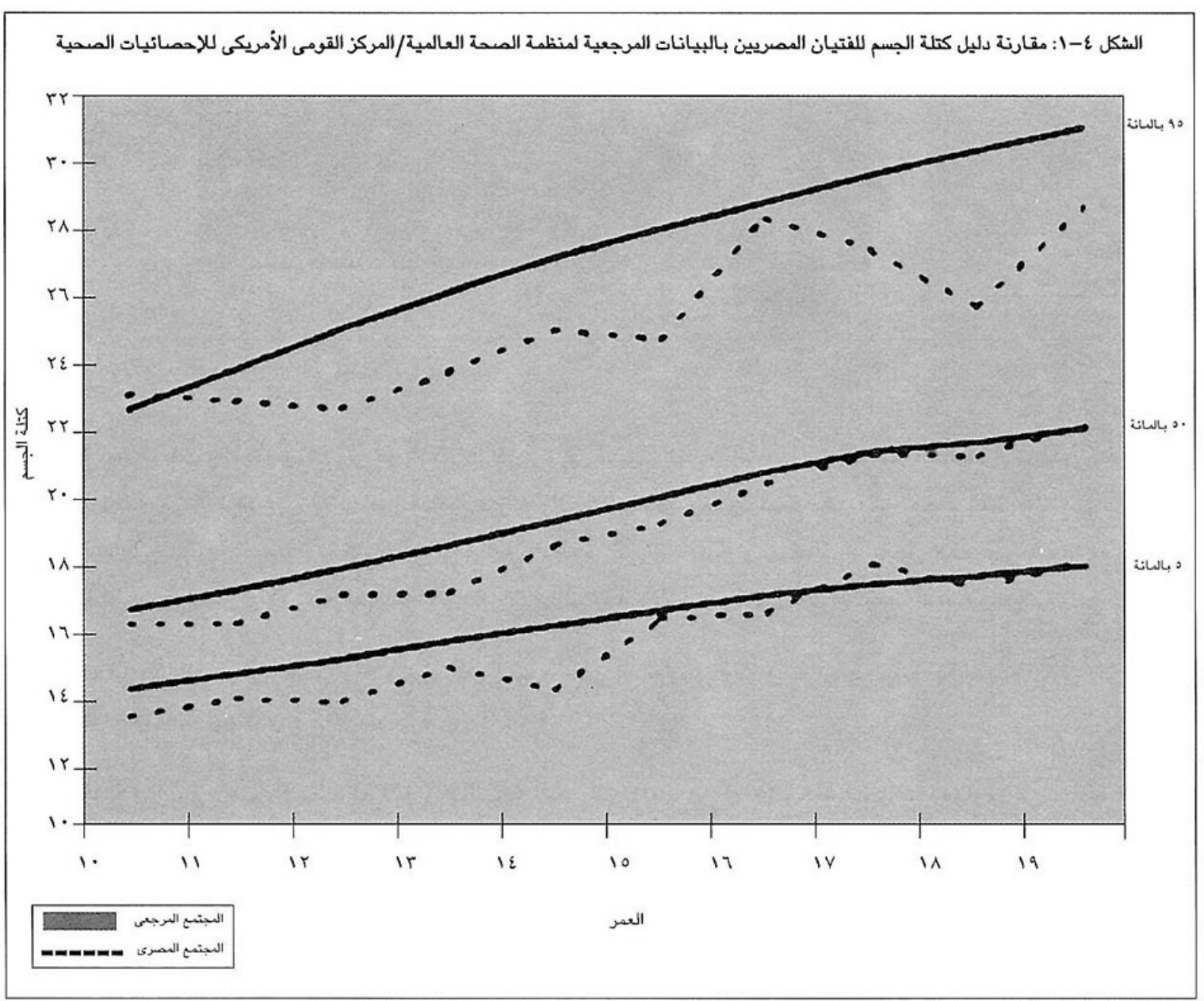

ويعد متوسط الطول بالنسبة للسن عند الفتيات المصريات أقل منه عند الشريحة المرجعية بالنسبة لكافة الفئات العمرية. ومن

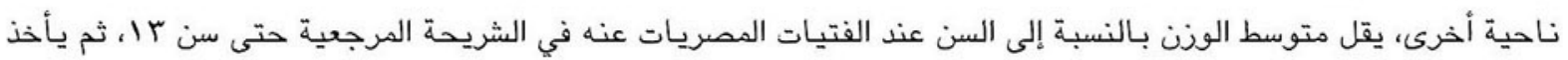

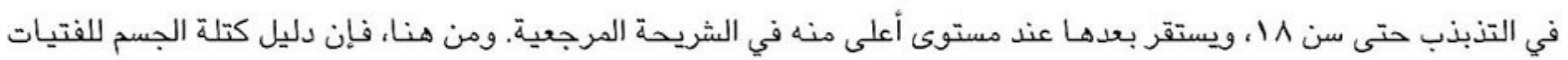

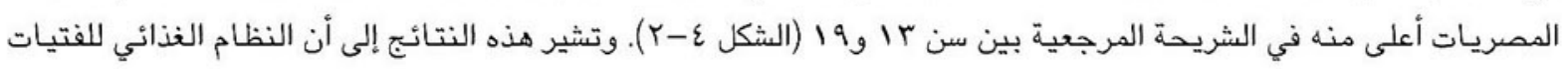
خلال سنوات المراهقة المتأخرة ريما كان يسهم في ظهور علامات البدانة المبكرة. وسنتاقش السمنة أكثر أدناه.

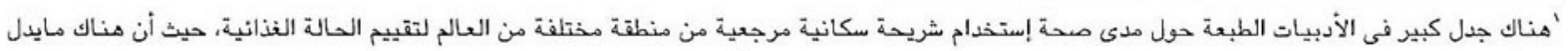

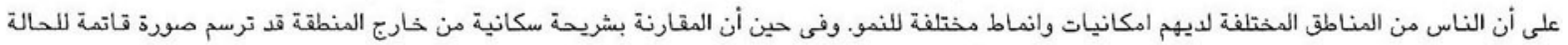
الصحية للمراهقين المصريين، فإنه لاتتوفر بيانات مرجعية أخرى بديلة. 


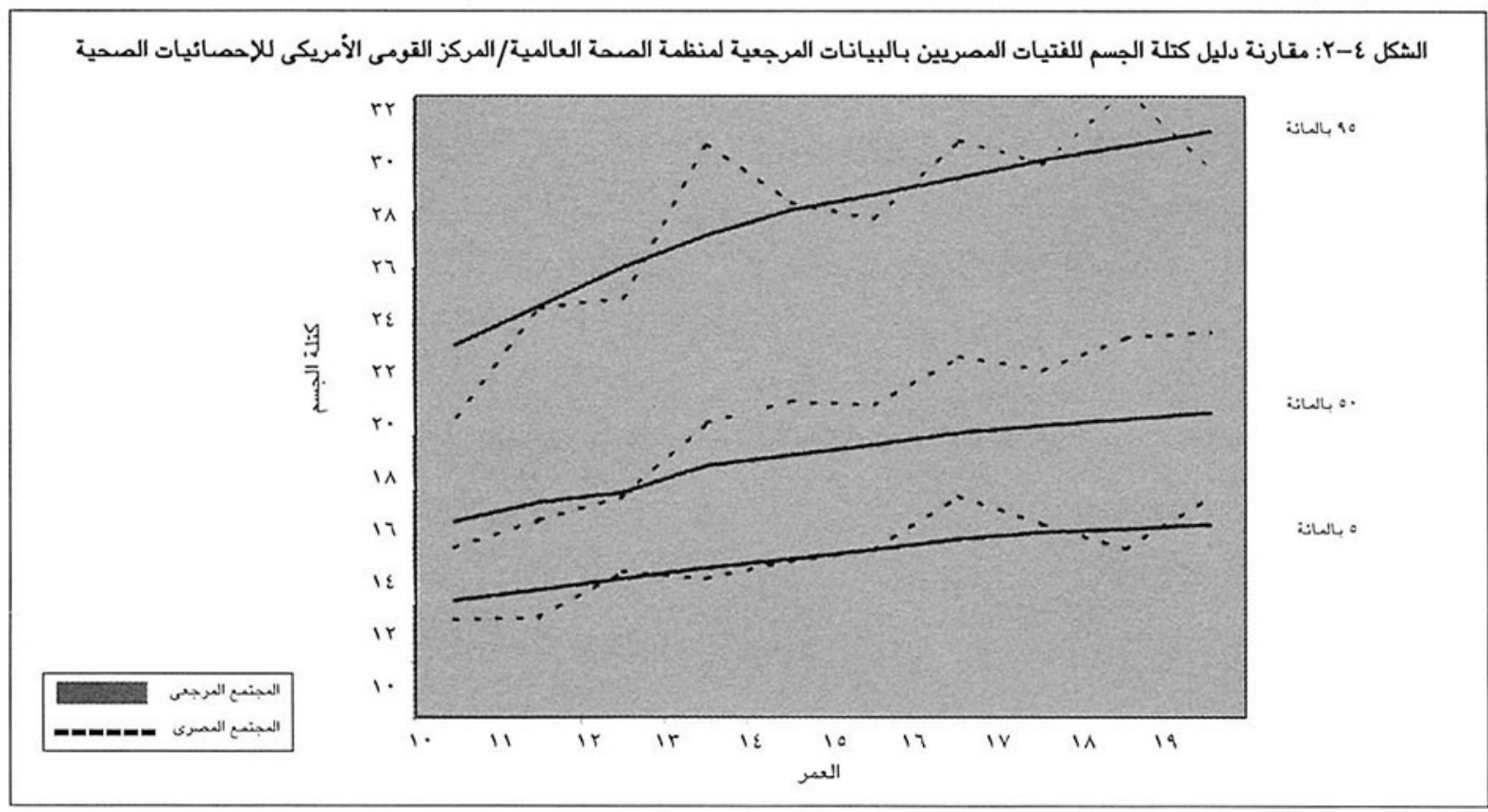

سوء التغذية

إن نقص البروتينات والفيتامينات من المشكلات المنتشرة بين سكان البلدان النامية. ويعد قصر القامة وانخفاض كتلة الجسم خلال المراهقة أثرين تراكميين للأنماط الغذائية في سنوات العمر المبكرة. ويرتبط تصر القامة عند النشء الناتج عن نقص التغذية المزمن بنحافة الجسم ونقص القوة العضلية والقدرة على العمل. وتؤثر جوانب النقص هذه على قدرة النشء على المشاركة في سوق العمل والأنشطة المنزلية، كما قد تؤدي إلى زيادة المخاطر التي ينطوي عليها الحمل والولادة.

استخدمت في هذا المسح أربعة مؤشرات لتقييم نمو النشء، على أساس المقارنة بالبيانات المرجعية المستقاة من شريحة من النشء تتمتع بتغذية جيدة. وهذه المؤشرات هي:

ا. اعتلال النمو ـ القيم المعيارية للطول بـالنسبة للسن التى تقل عن (-r) وحدة انحراف معيارى عن وسيط المجتمع

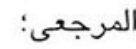
r. النحافة ـ قيم دليل كتلة الجسم بالنسبة للسن والتى تقل عن أو تساوى القيمة بـالمناظرة فى المجتمع المرجعى التى يقل عنها \% \% غقط من المفردات: r. خطر السمنة ـ قيم دليل كتلة الجسم بـالنسبة للسن والتى تنحصر بين القيمتين المناظرتين فى المجتمع المرجعى والتى يقل عنهما 110\% 90\% من المفردات على الترتيب؛ ع. السمنة ـ قيم دليل كتلة الجسم بـالنسبة للسن والتى تزيد عن القيمة المناظرة في المجتمع المرجعى التى يزيد عنها هـ ٪ فقط من المفردات.

ويبين الجدول ع-r نسبة النشء المصرى المصنف على أنه ناقص تغذية وفقا لمقارنة مؤشرات الطول بـالنسبة للسن ودليل كتلة الجسم بتلك الخاصة بـالشريحة المرجعية على النحو الموصوف أعلاه.

اعتلال النمو(التقزم أى تصر القامة الناتج عن سوء التننية وليس عن أسباب وراثية): كما هو مبين، يصنف VV من كافة الفتيان والفتيات على أنهم معتلو النمو، بينهم نحو 9 1\% من البنين وه 1\% من البنات. بالنسبة للبنات، يتضاءل مقدار الاعتلال مع التقدم في السن، بينما لا يوجد نمط واضح بـالنسبة للبنين. والنسبة الأعلى لمعتلي النمو بين البنين تتمثل في الفئة العمرية 
rا-10 سنة (19.1 1\%). وينتشر اعتلال النمو بين النشء المنتمين لأدنى الشرائح الاجتماعية الاقتصادية وقاطني المناطق

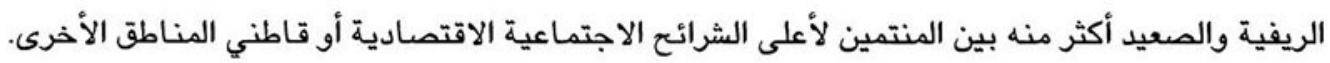

الجدول ع-r: توزيع الفتيات والفتيان المصنفين كناقصي تغذية وفقا للطول بالنسبة للسن ودليل كتلة الجسم بالنسبة

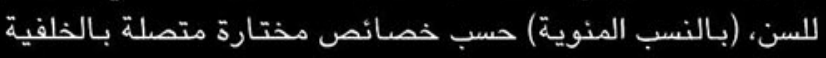

\begin{tabular}{|c|c|c|c|c|c|c|}
\hline اجمـالى العدد & بالسمابية & المعرضين & المصابين & اجمالى العدد & نسبة التفزم & 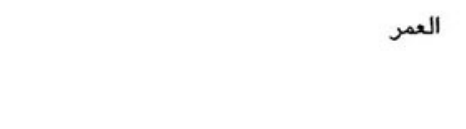 \\
\hline 1971 & $\varepsilon . r$ & $1 \cdot .1$ & $9 . r$ & 1701 & 17.7 & الاجمالى \\
\hline $90 \mathrm{~V}$ & $r . r$ & 0.9 & ir.o & $\Lambda \cdot 1$ & $1 \wedge .9$ & الفتيان \\
\hline $1 \cdot 11$ & 0.1 & $\mid \varepsilon .1$ & 7.r & 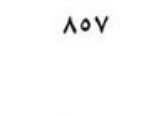 & $1 \varepsilon .0$ & الفتيات الفتيان \\
\hline rAl & Y.A & A. ${ }^{\cdot}$ & 17.1 & ryo & $19 . r$ & $\mid r-1$. \\
\hline$r \cdot o$ & $\varepsilon .1$ & r.v & Ir.7 & YAN & 19.1 & $10-1 r$ \\
\hline rVI & $r .9$ & 0.7 & 7.1 & $1 \varepsilon \Lambda$ & 10.1 & $\begin{array}{r}\text { الفتيات } \\
\text { الفتيات }\end{array}$ \\
\hline r9q & $\varepsilon$. & 7.1 & 9.1 & ra. & YI.Y & $\mid r-1$. \\
\hline rrr & $0 . r$ & $1 \wedge . \varepsilon$ & 0.1 & rig & 9.7 & 10-1r \\
\hline$r \wedge \cdot$ & 7.7 & $r \cdot .9$ & r.० & 101 & A. & +17 \\
\hline & & & & & & الوضع الاقتصادى/ الاجتماعى \\
\hline 001 & r.l & V.V & Ir.r & $\varepsilon \vee \varepsilon$ & $r \cdot r$ & منخفض \\
\hline רזr & r.A & 11. & V.1 & oor & 10.7 & متوسط \\
\hline OAr & $v . \cdot$ & $1 \cdot .1$ & V.A & $\varepsilon \wedge \uparrow$ & II.V & مرتفع \\
\hline$\varepsilon 1 v$ & r.r & $\Lambda .0$ & $\mid r .1$ & roo & IA.Y & لم يلتحقوا مطلقا/ لم يكملوا المرحلة الإبتدائية \\
\hline$\wedge \varepsilon 0$ & r.r & V.1 & 11.0 & VAI & 19.8 & إبتدانى / لم يكمل اعدادى \\
\hline$\varepsilon>$ & 7.r & Ir.A & 7.0 & $\varepsilon 川$ & ir. & إعدادى / لم يكمل ثانوى \\
\hline ivi & $0 . V$ & IV.7 & r.V & 91 & $1 \cdot . \wedge$ & ثانوى \\
\hline 79 & 0.9 & ir.9 & r.* & $r \cdot$ & $1 \cdot *$ & فوق متوسط/ جامعة \\
\hline TVV & $V .9$ & IE.V & $\varepsilon .9$ & ००V & Ir.V & حضر \\
\hline$|r q|$ & r.o & $v .9$ & $M .0$ & $11 \cdot 1$ & $1 \wedge .1$ & ريف \\
\hline rra & V.1 & IV. & r.v & ודו & 9. & المحافظـات الحضرية \\
\hline 978 & $\varepsilon . \varepsilon$ & $1 \cdot . \wedge$ & I. & 117 & ir.9 & وجه بحرى \\
\hline ivr & r.A & 7.1 & IT. & 011 & rr.t & وجه قبلى \\
\hline
\end{tabular}

ملاحظة : تم استبعاد ع ٪ من المشاهدات. أيضا تم استبعاد النشء أكبر من ^\ سنه نظرا لأن المجتمع المعيارى يتضمن فقط النشء فى الفنة العمرية من • - 1 \ سنه

النحافة: استخدم دليل كتلة الجسم أيضا كأساس لتقييم النحافة، وخطر السمنة، والسمنة. ويصنف المراهق كنديف إذا كان

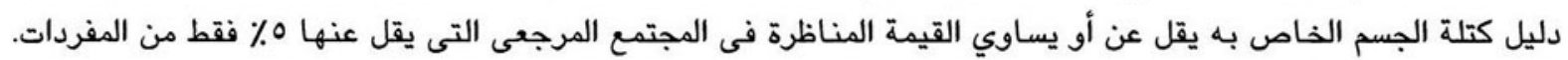

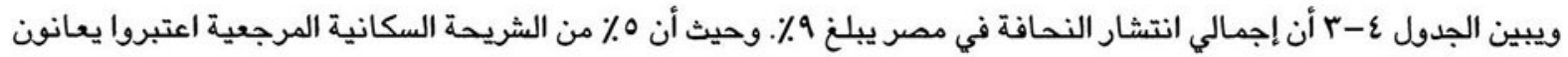

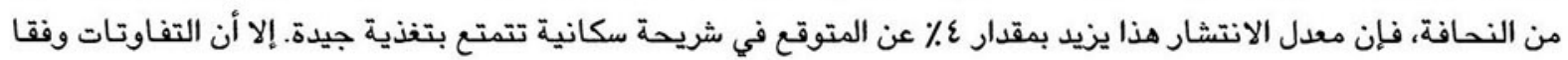

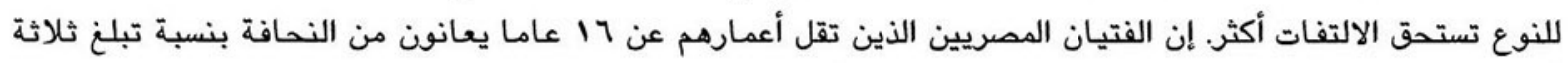

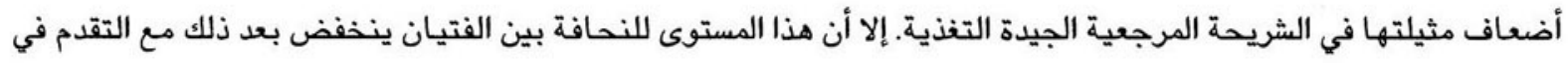

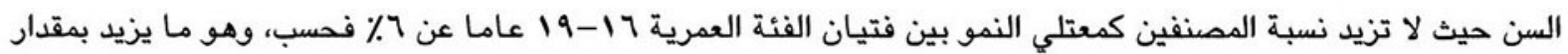


ويظهر نمط مماثل بين الفتبات مع التقدم في العمر، وإن كان هذا النمط أقل لفتا للنظر لأن مستوى النحافة بين الفتيات عموما

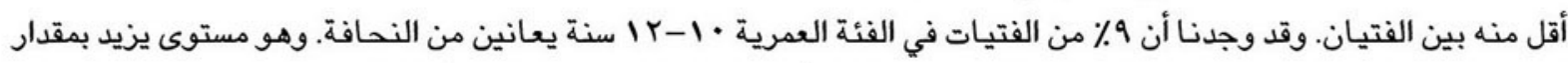

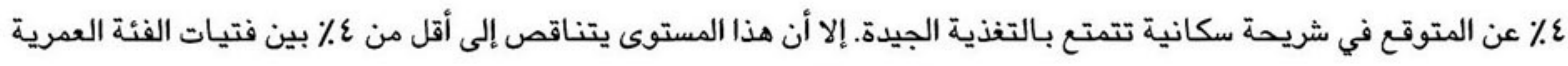
19-19 عاما، وهو مستوى يقل عن ذلك الخاص بـالشريحة المرجعية.

خطر السمنة: يبين الجدول ع-r أيضا أن · إ من النشء المصرى يعانى من خطر السمنة. ويصنف المراهق على أنه عرضة

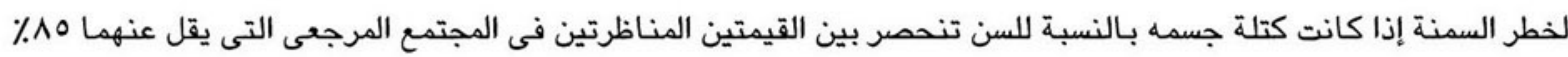

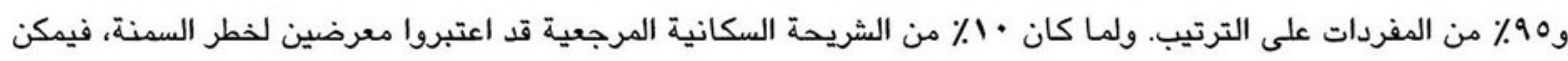
القول إذن بأن النشء المصرى ليس أكثر تعرضا لخطر السمنة من نظيره في الشريحة المرجعية.

أما بين البنات، فإن معدلات التعرض لخطر السمنة أعلى عامة من تلك الخاصة بالشريحة المرجعية، باستثناء الفئة العمرية

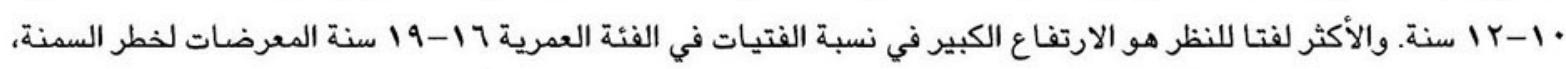

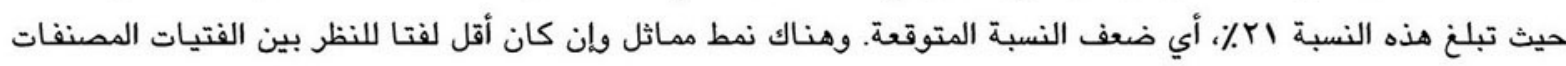

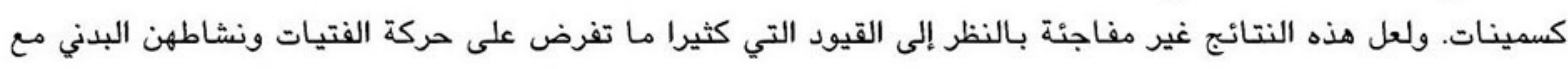

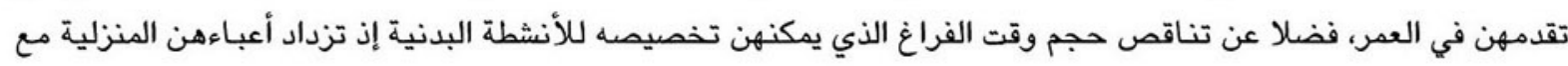
التقدم في العمر.

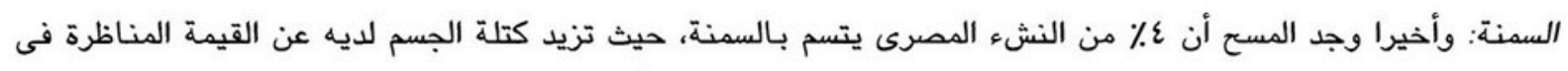

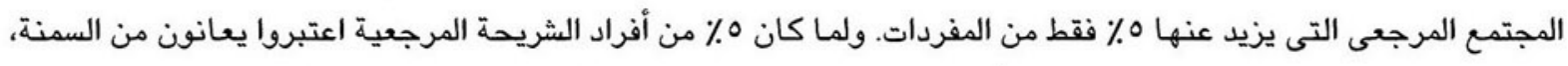
فإن معدل السمنة القائم بين النشء المصرى أقل قليلا من المتوقع في شريحة سكانية تتمتع بالتغذية الجيدة.

تخفي الأرقام الإجمالية أيضا اختلافات مهمة حسب الحالة الاجتماعية الاقتصادية ومنطقة السكن. فالنحافة أكثر انتشارا في

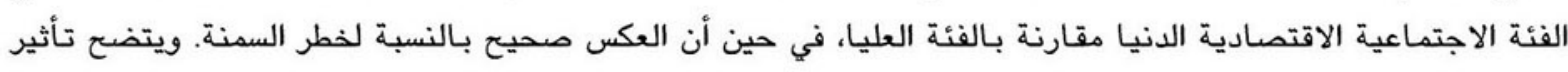

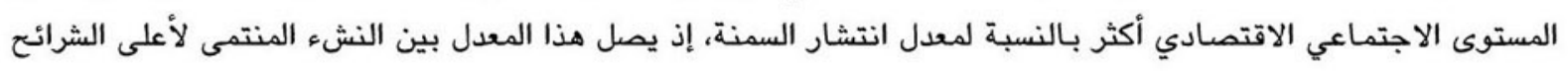
الاجتماعية الاقتصادية إلى ضعف مستواه في الشريحتين الوسطى والدنيا.

كما تبدو التفاوتات بين المناطق واضحة كذلك في مستويات تلك المؤشرات الأنثرويومترية. يزيد عدد النشء المتسم بالنحافة

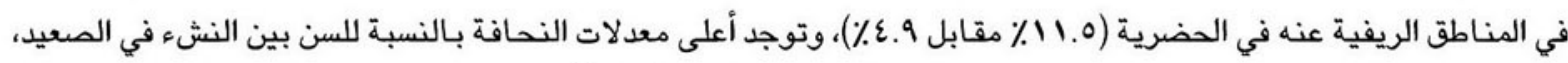

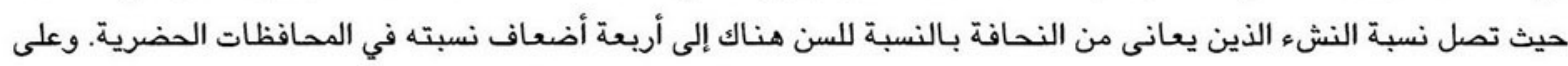
الجانب الآخر، تنتشر السمنة وخطر السمنة في المحافظات الحضرية أكثر من الدلتا أو الصعيد.

ولا شك أن تحليل بيانات التعرف على الحصيلة الغذائية على مدى عr ساعة من شأنه أن يوفر مزيدا من الإلمام بهذا الأمر، وأن

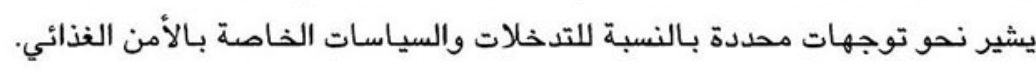

\section{تمديد مستوى الهيموجلويين}

تعد الأنيميا الغذائية أكثر المشكلات الصحية انتشارا في العالم اليوم. وهي تُعَّف بأنها نقص تركيز الهيموجلويين عن المستوى

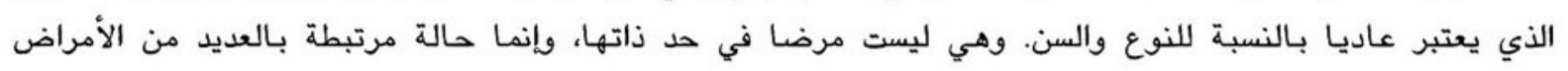


والاضطرابات، بما في ذلك بعض الأمراض والاضطرابات الوراثية. وتعتبر أنيميا نقص الحديد أكثر أنواع الأنيميا الغذائية انتشارا، ويمكن أن يكون لها تأثير ضخم على التطور النفسي والبدني، والسلوك، ومستوى الأداء في العمل. وتنتج هذه الألئ الأنيميا

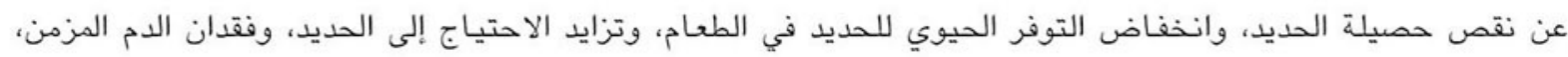

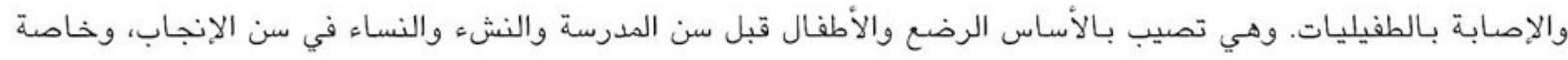

الحوامل منهن.

استخدم تحديد مستوى الهيموجلوبين في المسوح الغذائية بوصفه اختبار بسيط وموثوق به للكشف عن الأنيميا. وقد استخدمت هذه الطريقة في مسح "النشء والتغيير الاجتماعي في مصر" لتحديد مدى انتشار الأنيميا بين النشء المصرى النو (أنظر الفصل الثاني).

\section{انتشار الأنيميا وحدتها}

تصنف الأنيميا في فئات ثلاث حسب درجة حدتها: خفيفة [مستوى الهيموجلوبين فى • ل جرام في عشر اللتر والقيمة الحدية]،

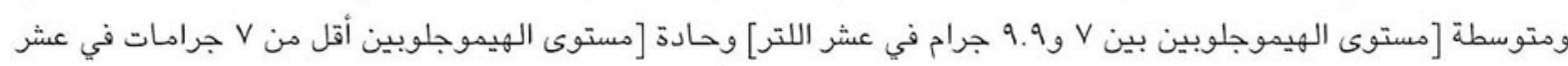

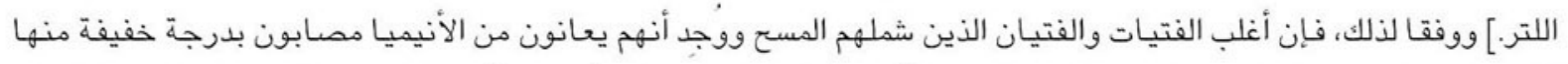

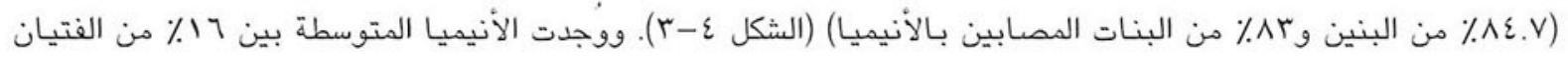

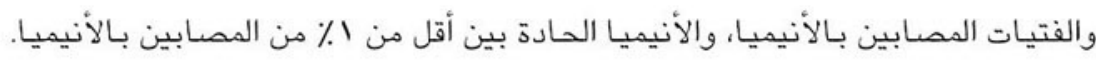

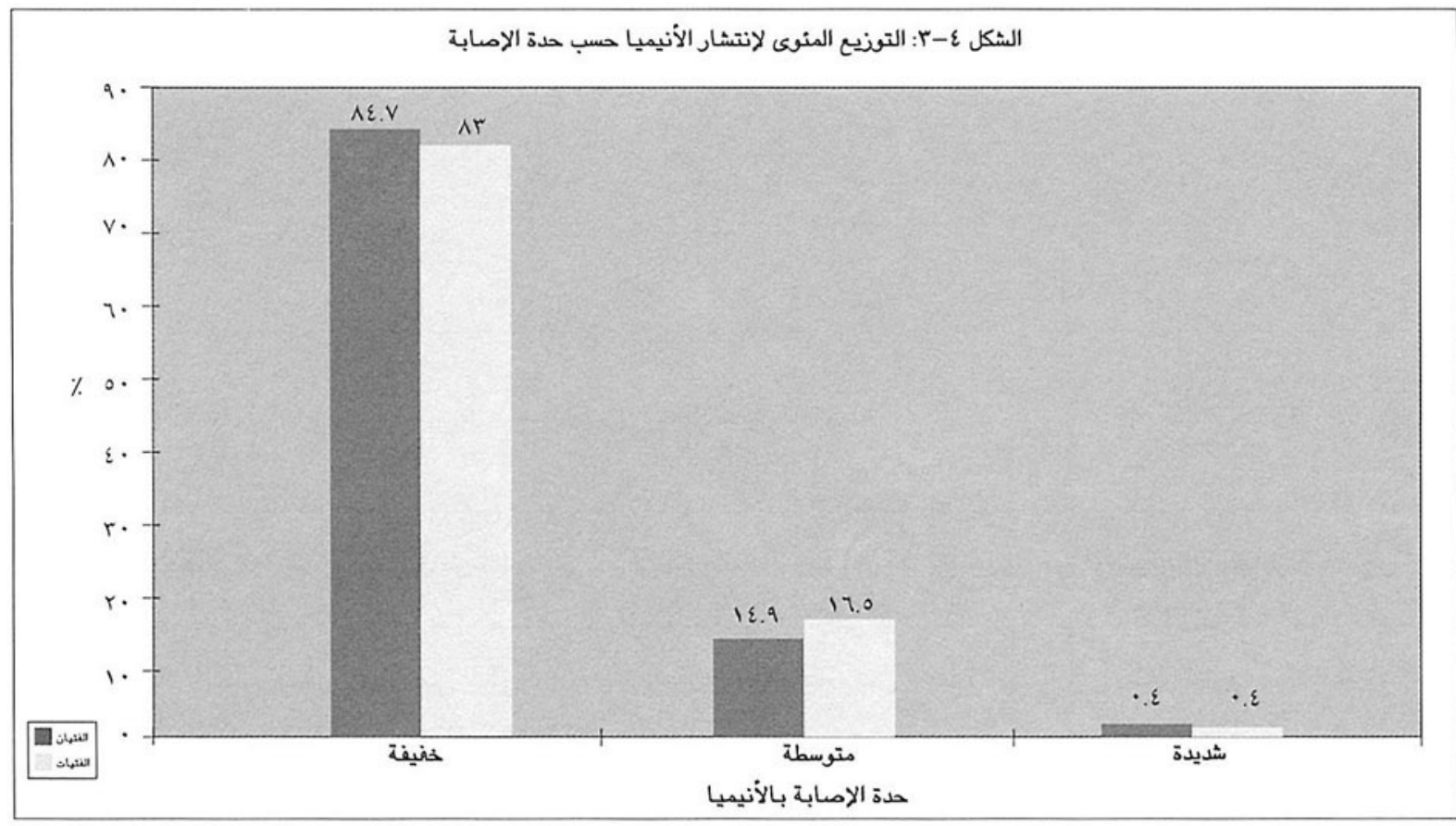

وتعد الأنيميا قائمة إذا كان مستوى الهيموجلوبين أقل من با جراما في عشر اللتر بالنسبة للفتيات والفتيان دون الرابعة عشرة

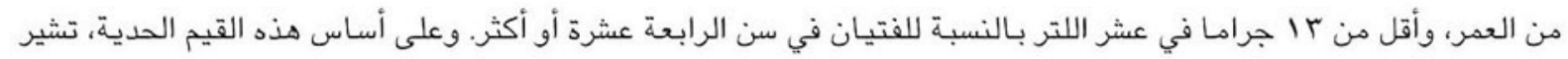

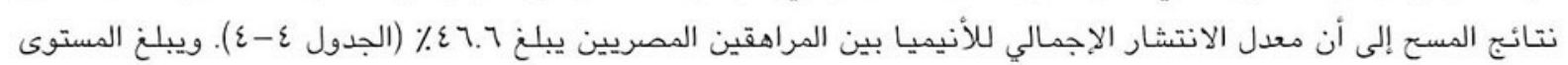

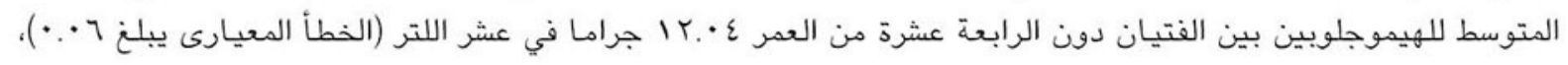

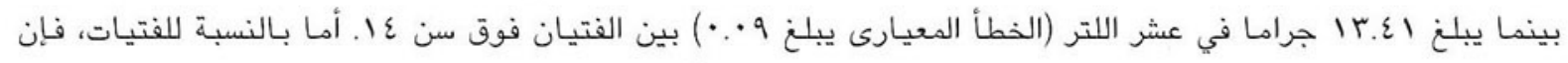

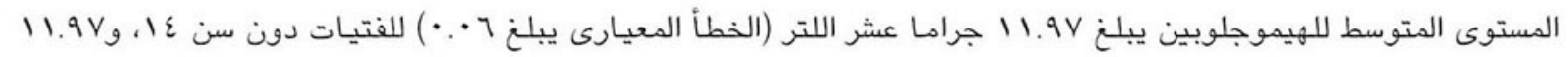

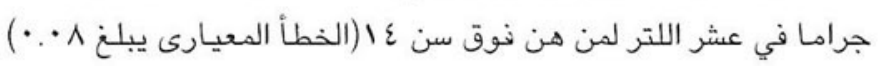




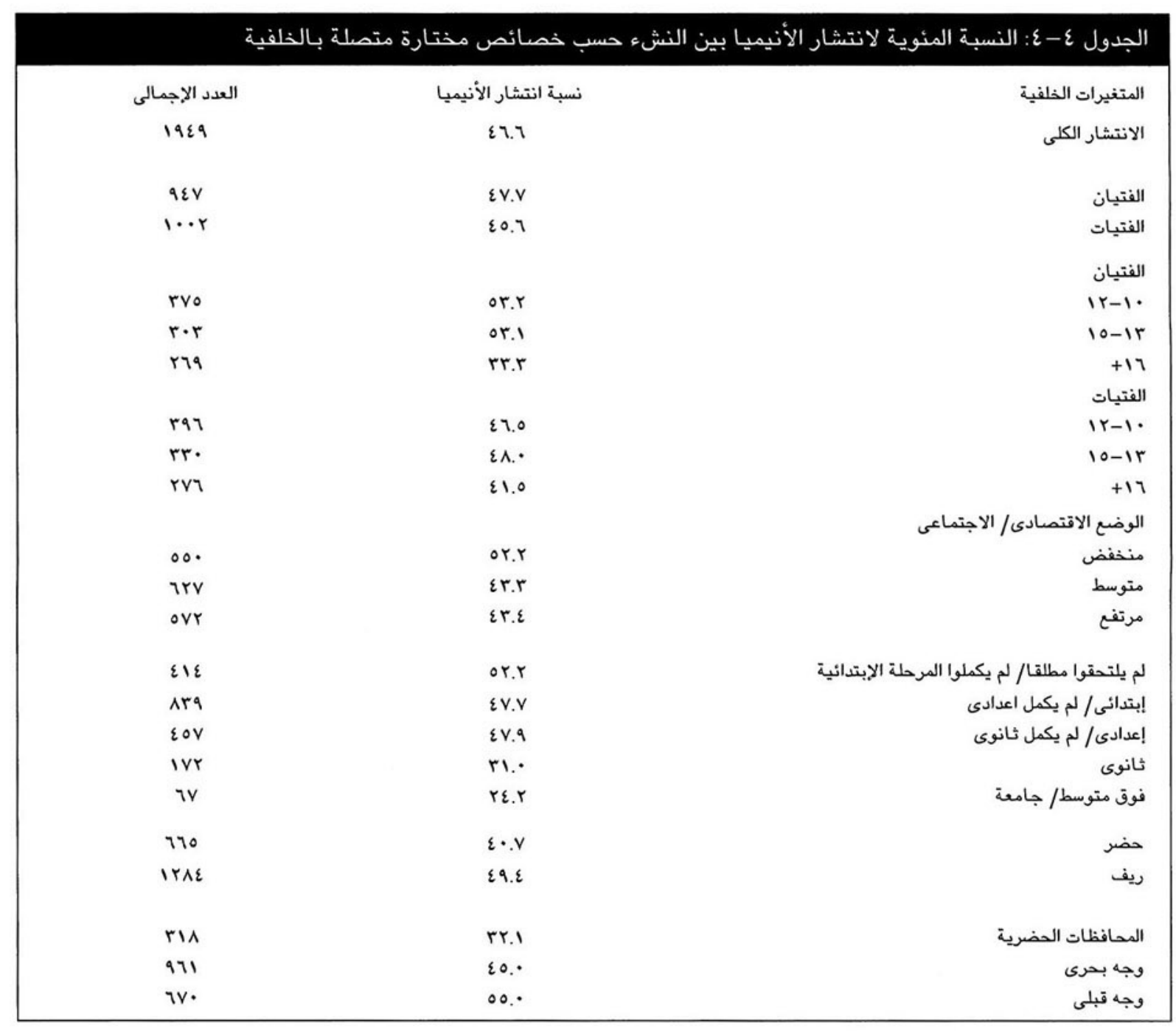

ملاحظة : السيدات الحوامل واللاتى أرضعن لمدة تقل عن ستة أشهر تم استبعادهم من هذا التحليل.

ولعل النتيجة الأكثر إثارة للدهشة هي عدم وجود اختلافات ذات شأن في مستويات الأنيميا عبر مختلف المستويات الاجتماعية

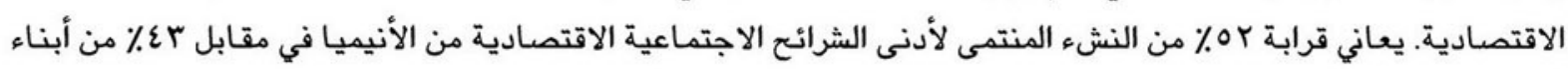

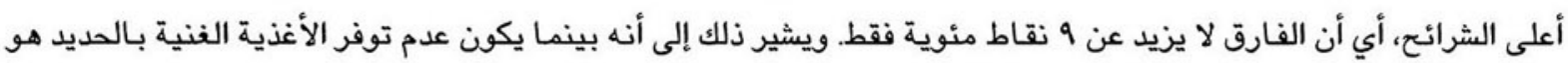

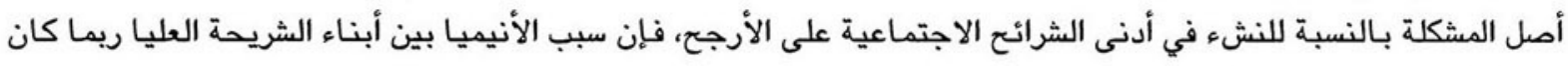
يرتبط على نحو مباشر بالعادات الغذائية السيئة.

وتكاد الاختلافات بين الجنسين فيما يتصل بمجمل انتشار الأنيميا تكون منعدمة. إلا أن الاختلافات واضحة تماما داخل كل

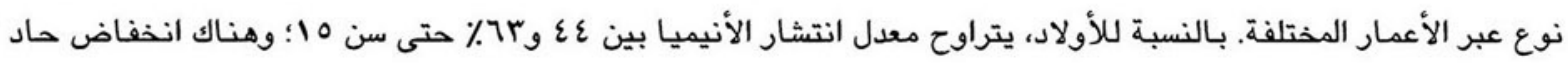

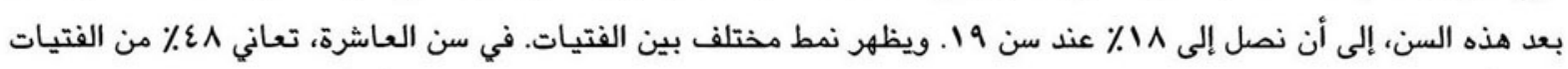

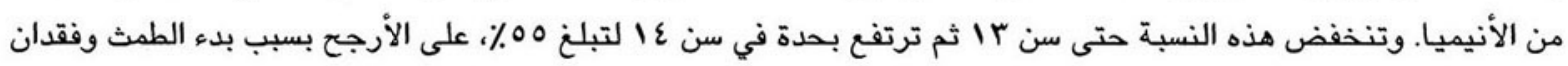

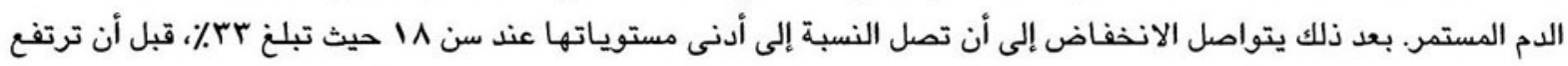

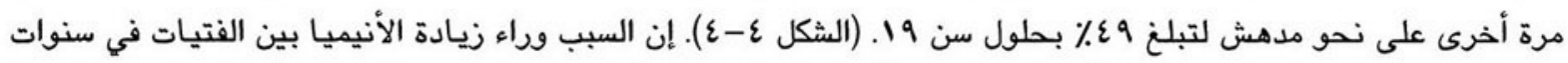

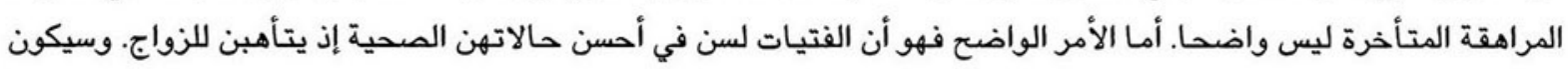
من شأن الضغوط الإضافية الناتجة عن الحمل والرضاعة أن تفاقم من مشكلاتهن الصحية. 


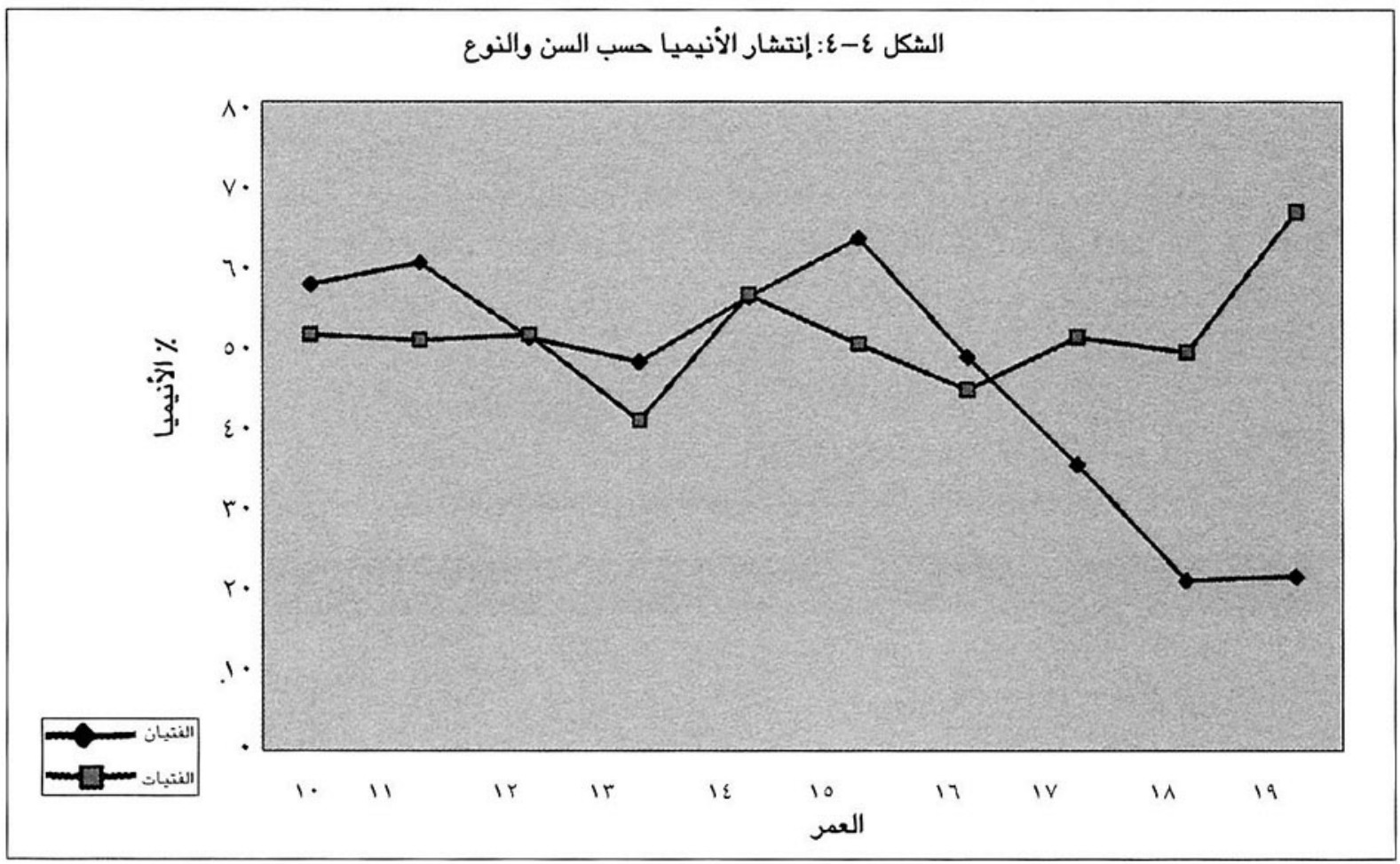

تنتشر الأنيميا بين مراهقي الهناطق الريفية أكثر من الحضرية. وتتماثل اتجاهـات انتشار الأنيميا في المناطق الحضرية

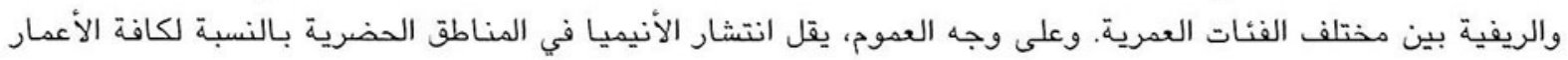

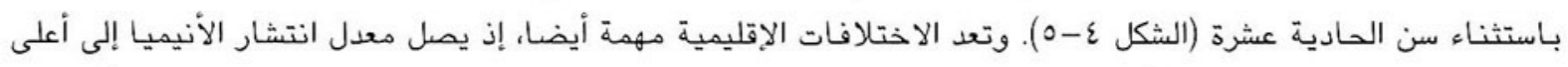

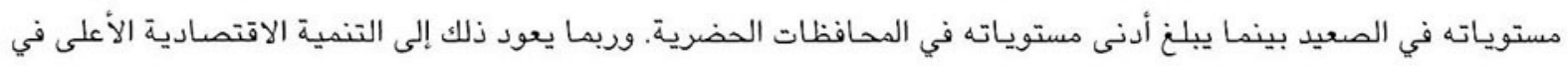
المحافظات الحضرية والدلتا والتي تنعكس في صورة تنذية أفضل.

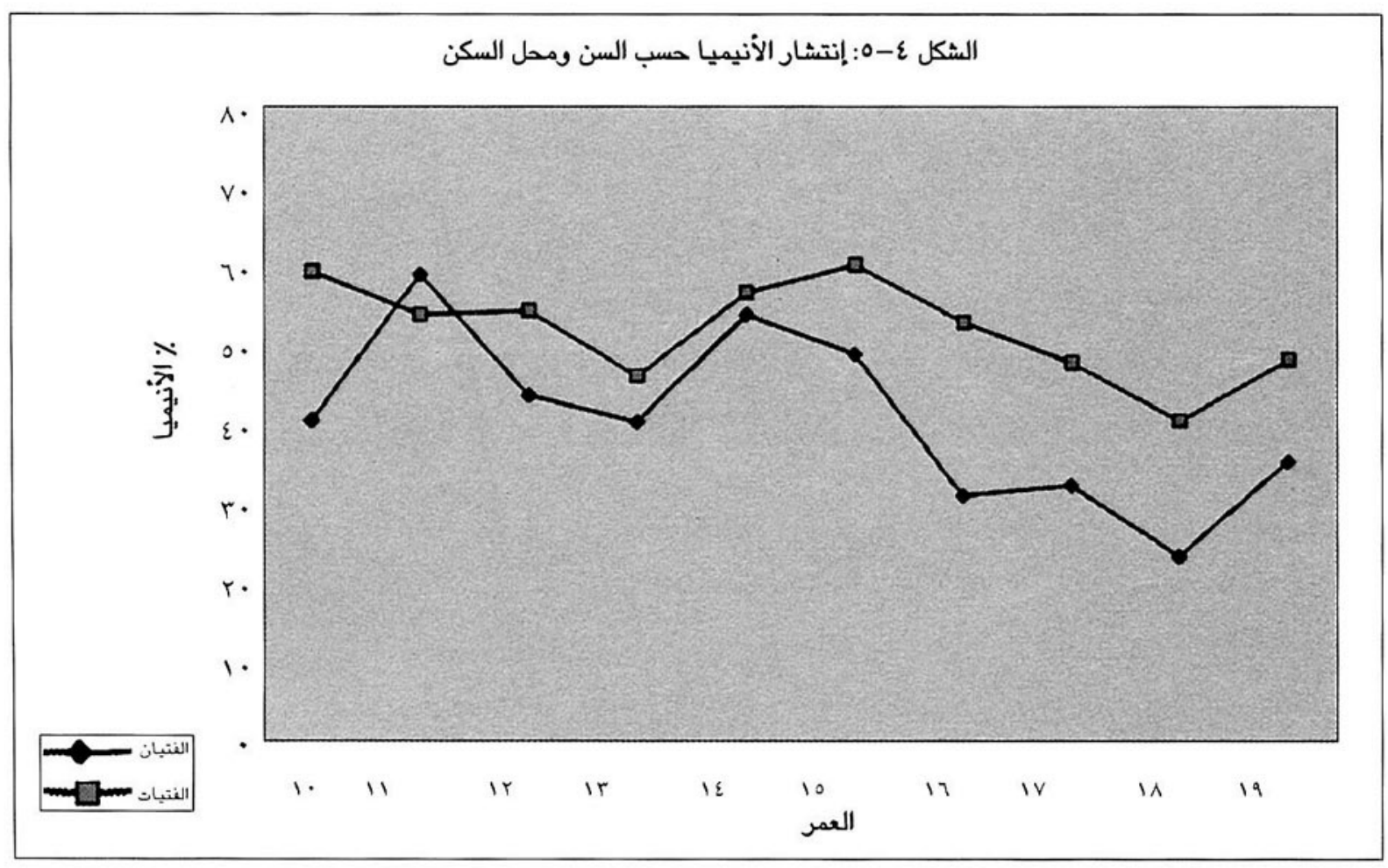




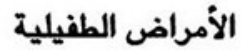

لا تزال الأمراض الطفيلية تعد من بين أكثر المشكلات الصحية انتشارا واستعصاءُ على مستوى العالم، خاصة في البلدان النامية.

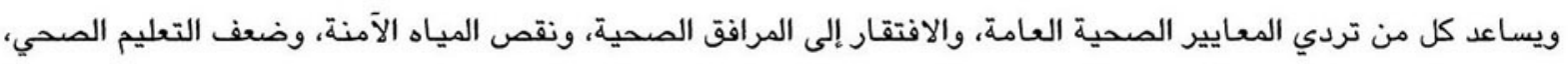

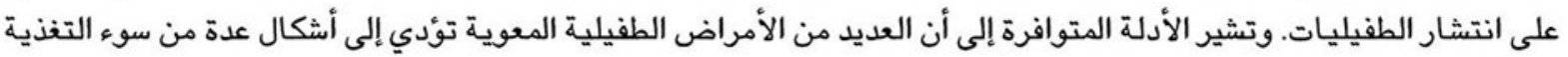

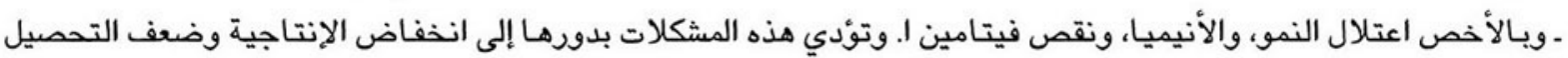

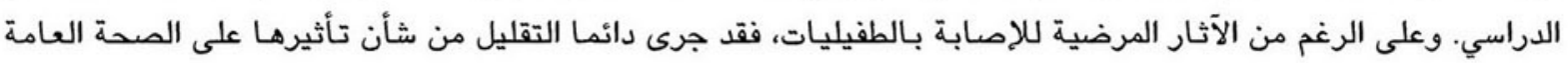
بسبب قلة الوفيات الناتجة عنها. وقد جرى قياس انتشار الطفيليات بين النشء المصرى بواسطة تحليل البول والبراز (الجدول ع-0).

\section{الجدول ع-0: النسبة المئوية لانتشار الأمراض الطفيلية حسب خصائص مختارة متصلة بالخلفية}

\begin{tabular}{|c|c|c|c|}
\hline 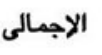 & 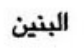 & 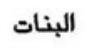 & المتغيرات الخلفية \\
\hline 07.1 & 00.0 & $\circ v . \varepsilon$ & الانتشار الكلى \\
\hline OA.r & ov. & 09.7 & $1 \varepsilon-1$. \\
\hline \multirow[t]{2}{*}{ or. $\varepsilon$} & or.q & or. 9 & $19-10$ \\
\hline & & & الوضع الاقتصادى/ الاجتماعى \\
\hline OA.r & $0 \wedge .1$ & $0 \wedge .0$ & منخفض \\
\hline $7 \because \cdot$ & $09 . r$ & $7 \cdot .7$ & متوسط \\
\hline $0 . r$ & $\varepsilon \wedge .0$ & or.r & مرتفع \\
\hline ०१.V & 07. & 71.9 & لم يلتحقوا هطلقا/ لم يكملوا المرحلة الإبتدائية \\
\hline on.r & 07.1 & 09.9 & إبتدائى/ لم يكمل اعدادى \\
\hline or.r & or.r & $01 . \varepsilon$ & إعدادى/ لم يكمل ثانوى \\
\hline or. & 07.0 & $\varepsilon v . \cdot$ & 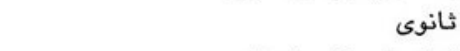 \\
\hline $0 \cdot \cdot$ & $\varepsilon \vee .0$ & or.y & فوق متوسط/ جامعة \\
\hline 0.9 & $\varepsilon\urcorner . r$ & o.r & حضر \\
\hline ०A.V & oq.r & ON.Y & ريف \\
\hline$\varepsilon \cdot .0$ & $r v . \varepsilon$ & $\varepsilon r . v$ & المحافظات الحضرية \\
\hline$\circ 9 . \varepsilon$ & ov. 9 & $7 \cdot .1$ & وجه بحرى \\
\hline \multirow[t]{2}{*}{ ov.1 } & $0 \wedge . \varepsilon$ & OV.Y & وجه قبلى \\
\hline & & & مكان إعداد الطعام \\
\hline O $\{\varepsilon$ & 01.0 & ०V.1 & مكان مخصص لإعداد الطعام \\
\hline \multirow[t]{2}{*}{$7 \cdot .1$} & $7 r .7$ & OV.A & لا يوجد مكان مخصص لإعداد الطعام \\
\hline & & & الاتصال بشبكة المياه العمومية \\
\hline or.9 & or.o & 00.1 & 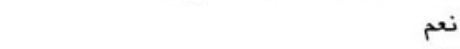 \\
\hline \multirow[t]{2}{*}{$\pi}$. & 11.0 & $7 \cdot .7$ & ע \\
\hline & & & الاتصال بشبكة الصرف الصحى \\
\hline$\varepsilon 9 . \vee$ & $\varepsilon 0.9$ & or.r & نعم \\
\hline $7 \cdot r$ & ir.r & $0 \wedge .0$ & ע \\
\hline
\end{tabular}

ملاحظة: تم تضمين ديدان في الإنتاميبا كولاي في التحليل 
قسمت الطفيليات إلى مجموعتين: الطفيليات المتحلقة بالأنيميا وتلك المتعلقة بالجهاز الهضمي. وتتضمن الطفيليات المتعلقة

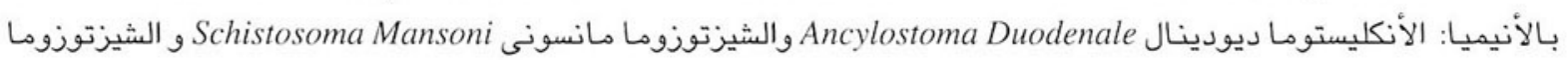
هيما توبيوم Schistosoma Haematobium وترايكو سترونيجيلس Trichostrongylus. بينما تشمل الطفيليات المتعلقة بالجهاز الهضمى: الإسكارس لامبريكويدس Ascaris Lumbricoides والتريكوريس ترايكورا Trichuris Trichura والهيمنوليبيس نانا Hymenolepis Nana والإنتاميبا هيستوليتيكا Entamoeba Histolytica والإنتاميبا كورلایى Entamoeba Coli

وتشير البيانات المستقاة من مسح "النشء والتغيير الاجتماعي في مصر" إلى أن معدل الانتشار الاجمالي للأمراض الطفيلية

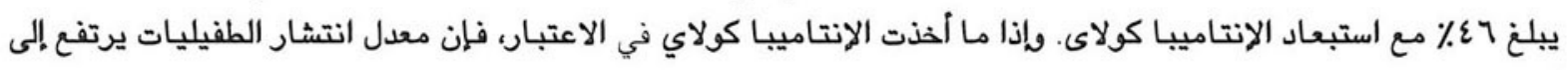

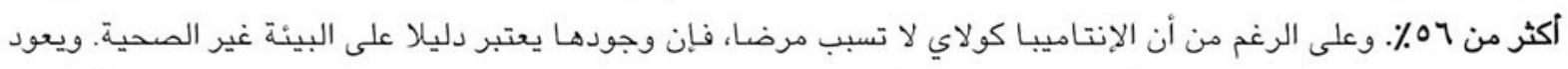

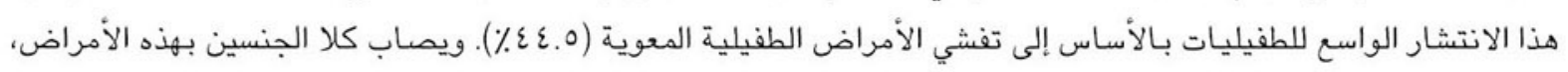

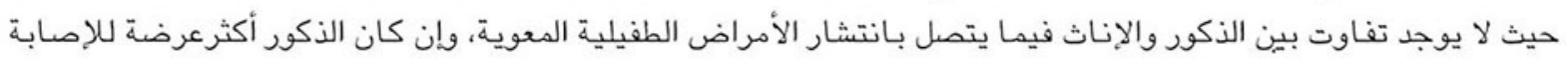
بالطفيليات البولية. (أنظر الفصل الخامس لمزيد من التفاصيل حول الصلة بين حالة العمل والإصابة بالطفيليات).

\section{أنواع الطفيليات بين النشء المصاب}

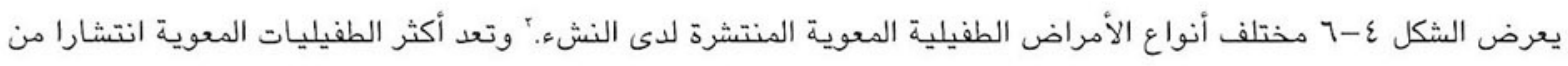

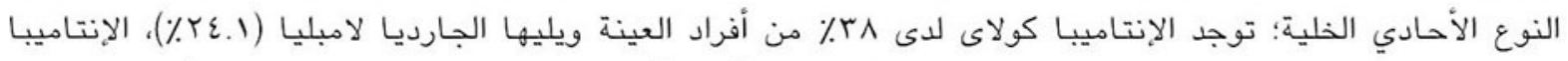

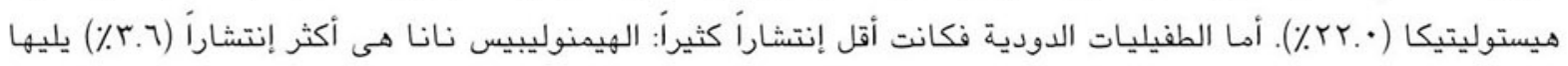

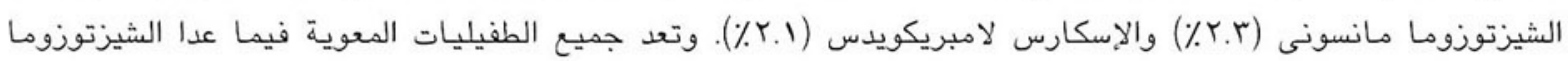

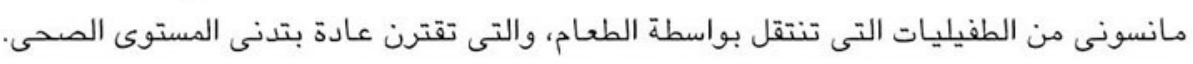

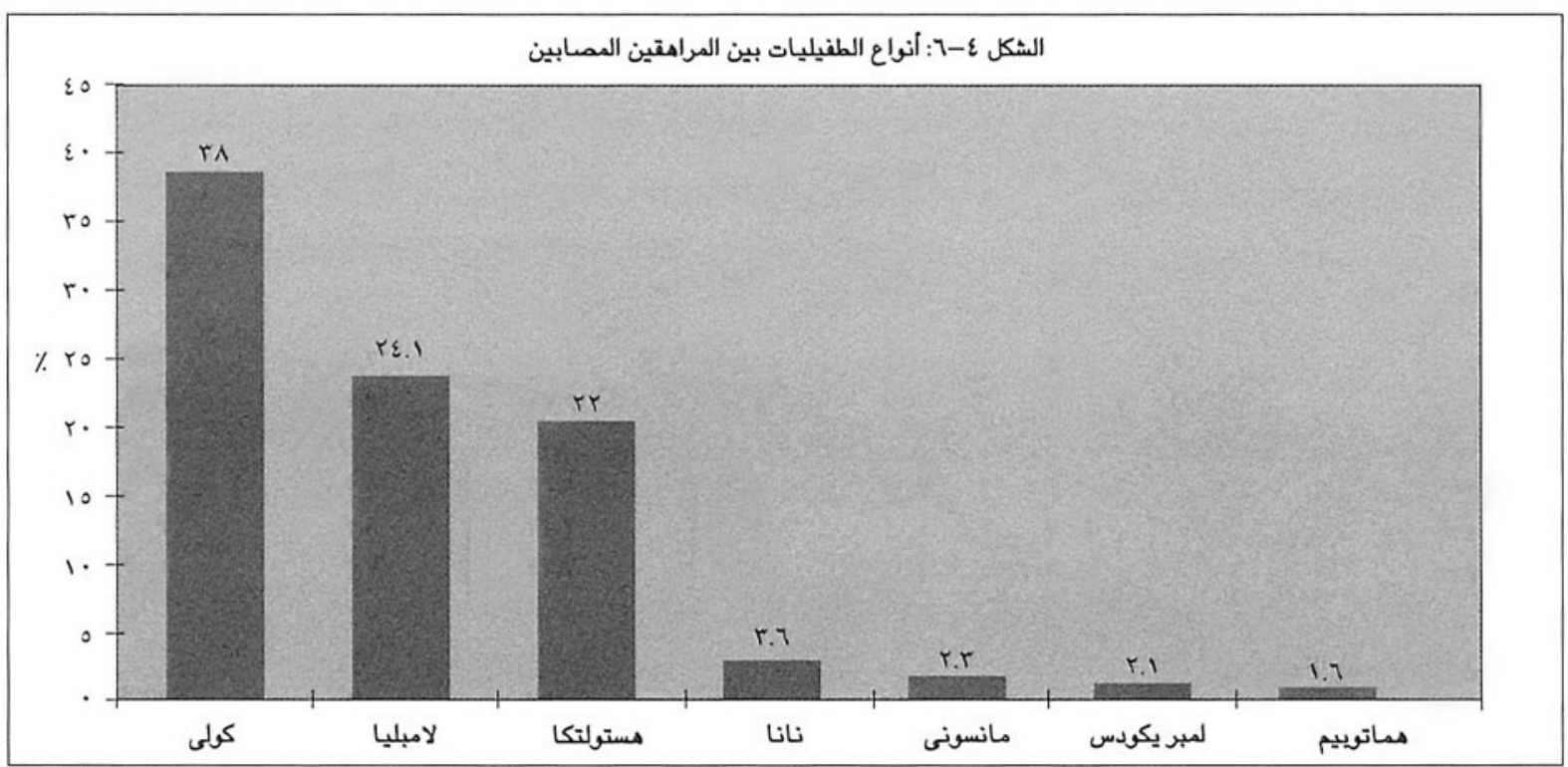

وإذا ما استبعدنا الإنتاميبا كولاى فإن نحو ثلث الفتيان والفتيات الذين جاءت نتائج اختبار الطفيليات بالنسبة لهم إيجابية

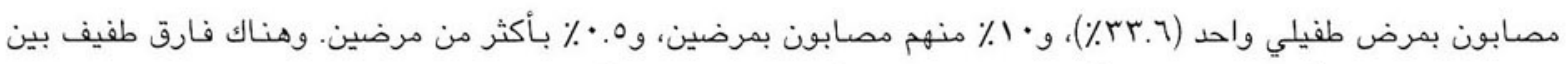

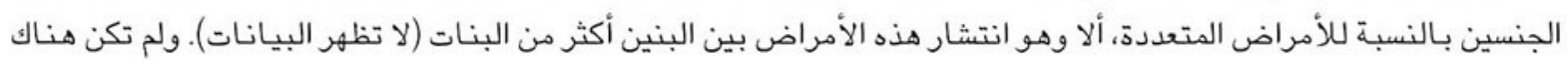

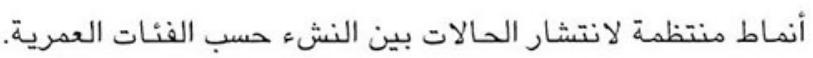

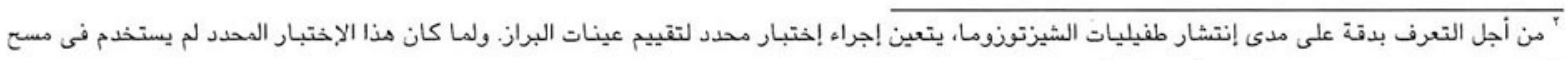
"النشء والتغيير الإجتماعى في مصر"، فنعلينا أن نعتبر معدلات الإنتشار المذكورة هنا تحت المعدلات الطبيعية. 


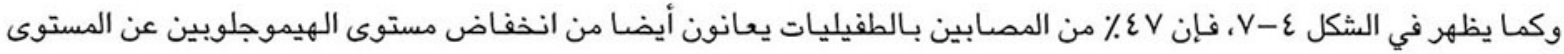

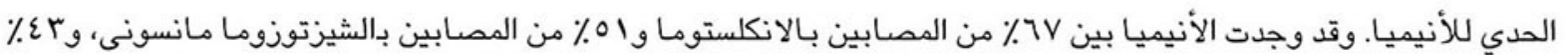

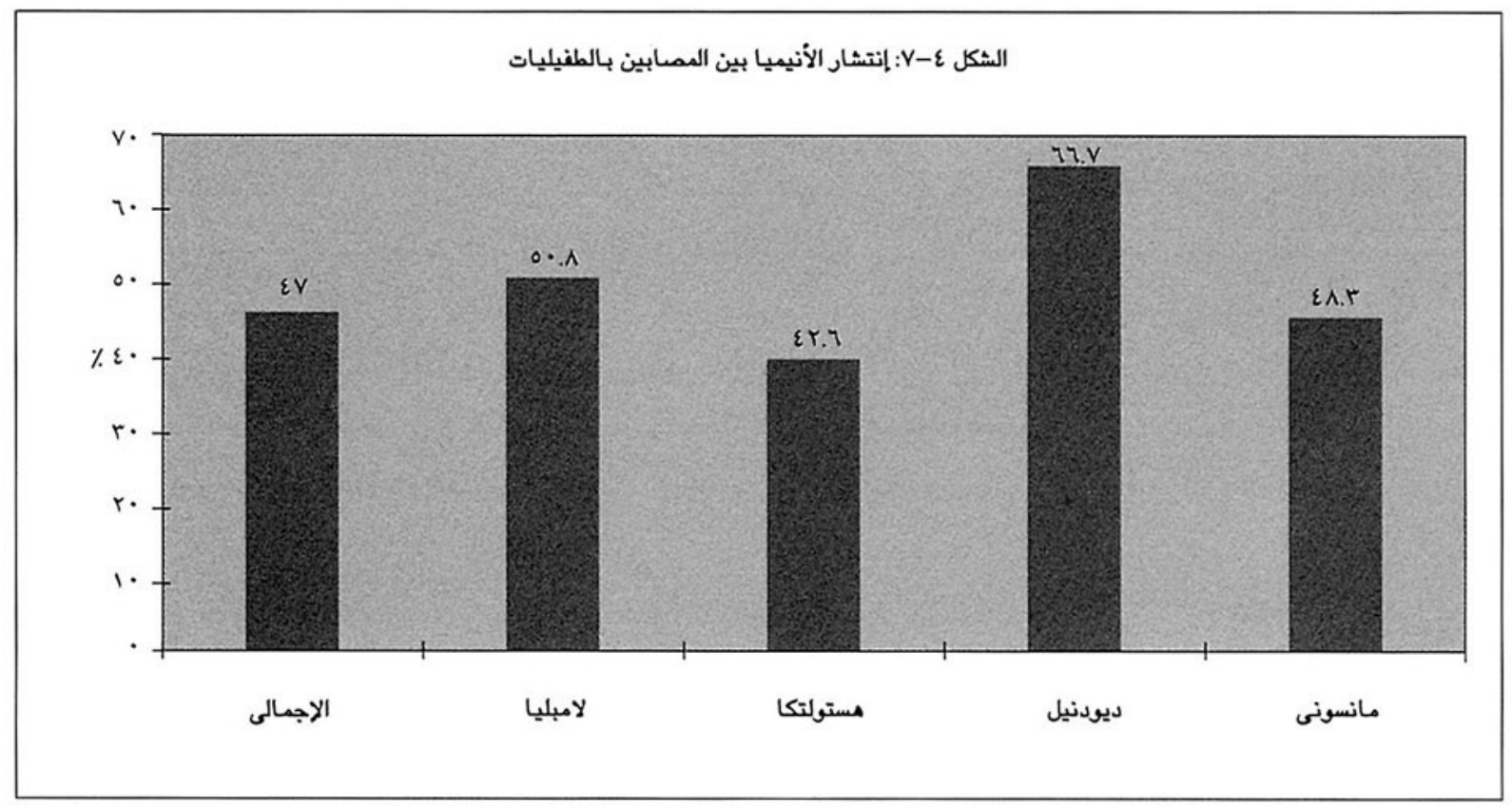

العوامل المساعدة المقترنة بالطفيليات

يقتضي التحليل الشامل لعوامل الخطر الرئيسية المرتبطة بالإصابة بالطفيليات اختبار تلك السلوكيات والمعتقدات التي تؤثر

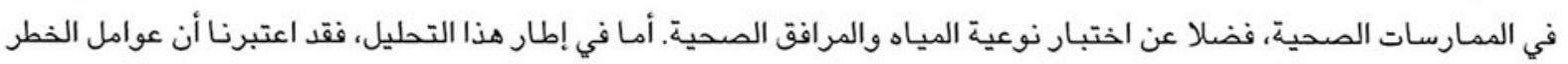

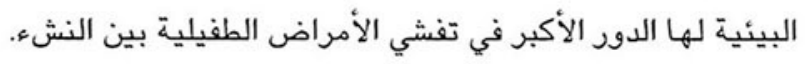

وترتبط الإصابة بالطفيليات بين النشء بسكنى المناطق الريفية، خاصة بالنسبة للفتيان؛ تبلخ نسبة الإصابة بمرض طفيلي

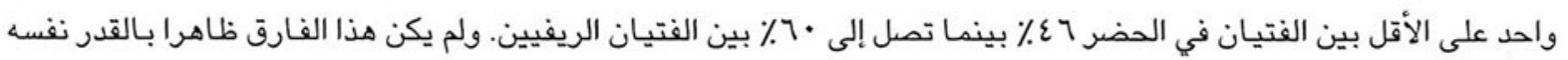

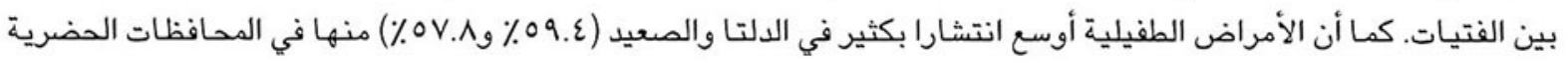

وتقترن الإصابة بالأمراض الطفيلية كذلك بالحالة الاجتماعية الاقتصادية. ويزيد احتمال الإصابة بمرض طفيلي واحد أو أكثر

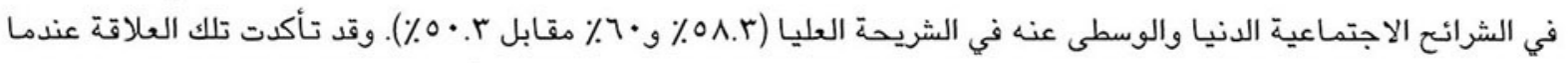

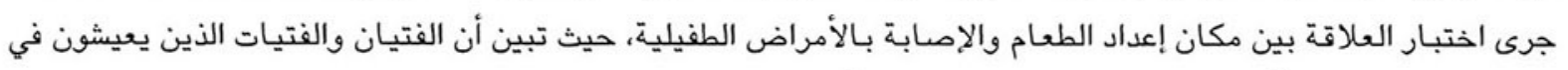
منازل ليس بها مطبخ أو حجرة مخصصة للطبيخ يكونون أكثر عرضة للإصابة بالطفيليات من نظرائهم الذين يحيون في منازل تضم تلك المرافق (1. • 7\% مقابل ع.عْ ٪). 
وريما كان التأثير السلبي لبعض عوامل الخطر البيئية على صحة النشء راجعا إلى الافتقار إلى المياه الآمنة والمرافق الصحية.

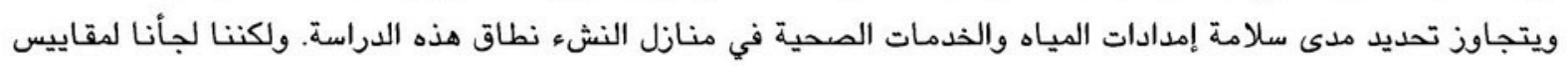

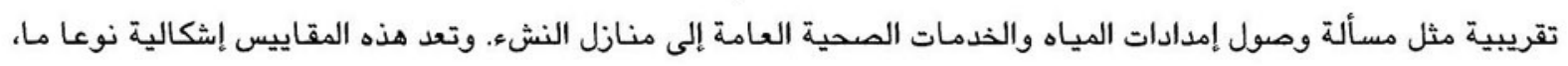

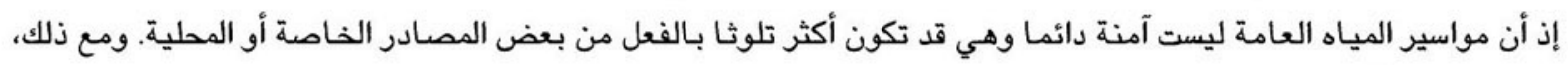

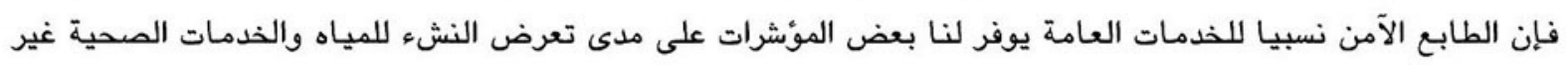

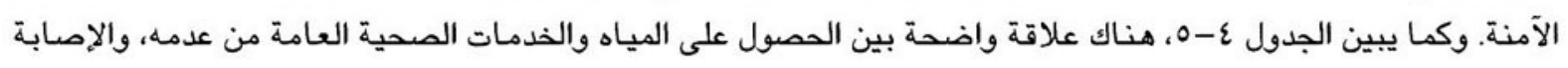

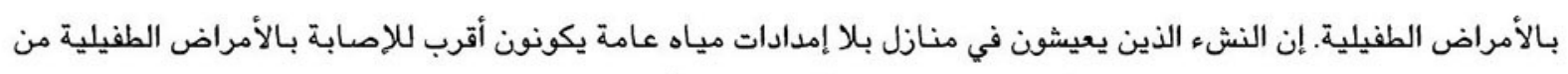

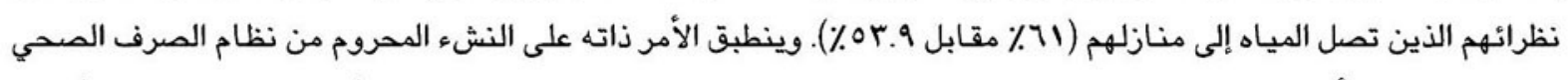

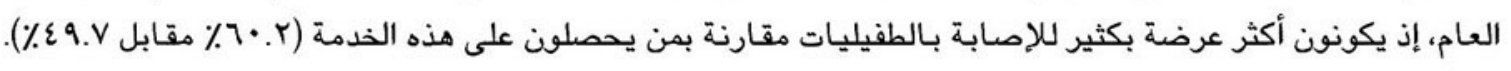

وكما هو متوقع، ترتبط الإصابة بالطفيليات بعدد من المتغيرات وليس عاملا واحدا فحسب. وتتفاعل هذه المتغيرات فيما بينها

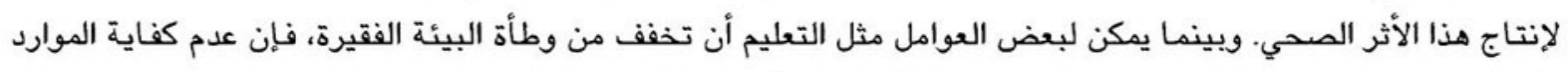

يقوض قدرة العديد من النشء المصرى على حماية نفسه من الأمراض الطفيلية.

\section{محددات الحالة الغذائية}

إن الأمراض المرتبطة بسوء التغذية مثل اعتلال النمو والأنيميا تقترن بعدد من العوامل، من بينها السكن في المناطق الريفية

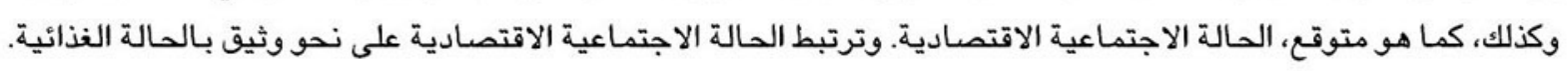

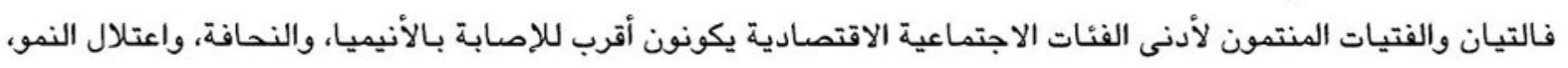

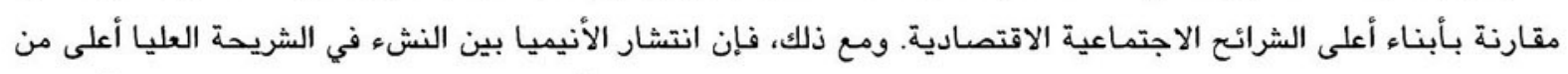

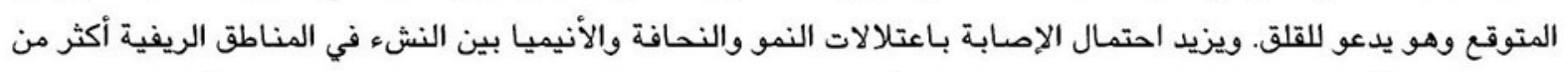

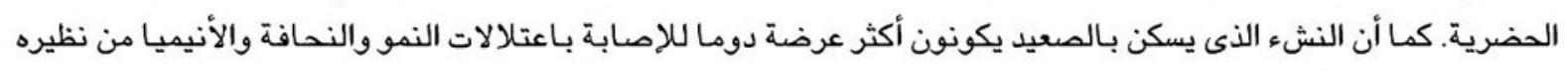

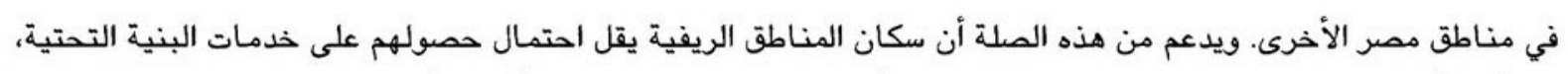

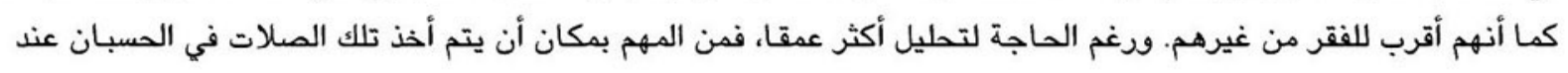

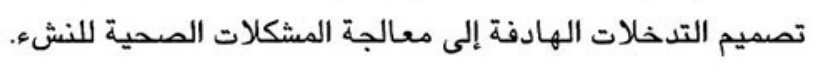

\section{ثانيا: النضوج الجنسي}

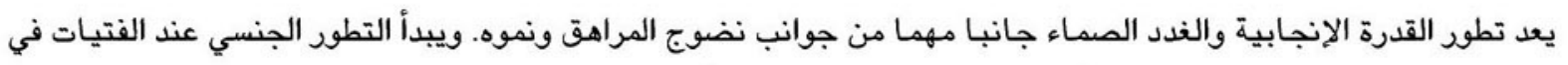

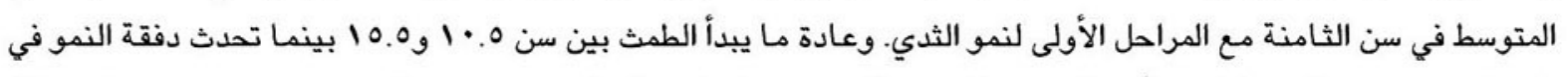

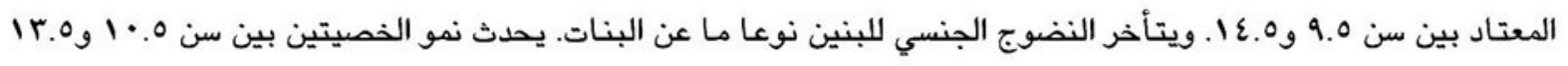

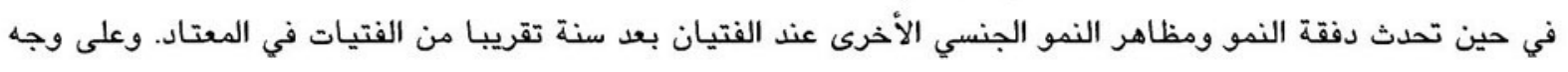

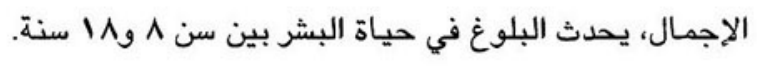


وعلى الرغم من أن النضوج الجنسي يتفاوت بين الأفراد، فإن نمو المراهق يعتمد على الصحة وكذا على حسن التغذية. وتؤخر

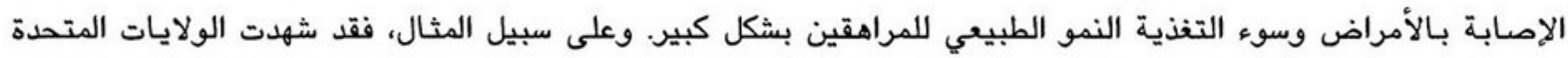

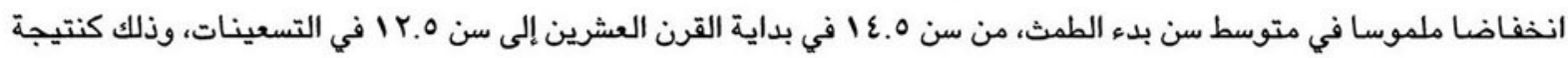

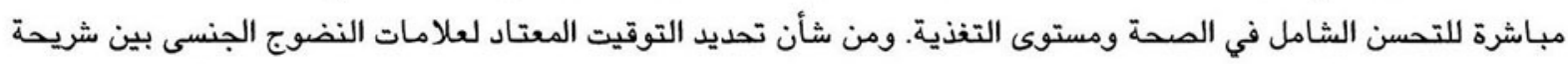

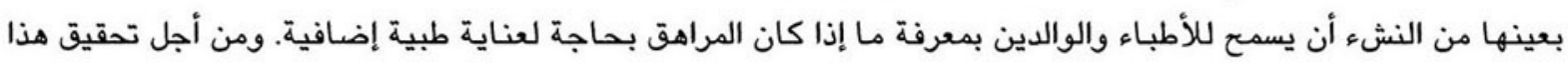

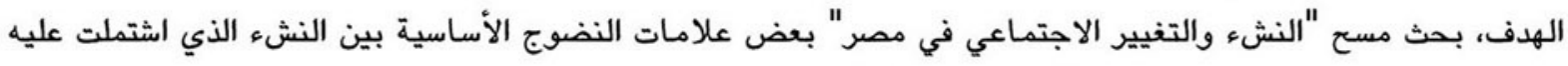

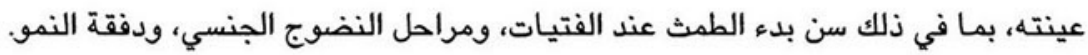

سن بدء الطمث

يستخدم وقت بدء الطمث كمؤشر على مجمل زمن المراهقة داخل المجتمعات وفيما بينها. وعلى الرغم من أن بدء إفراز السائل

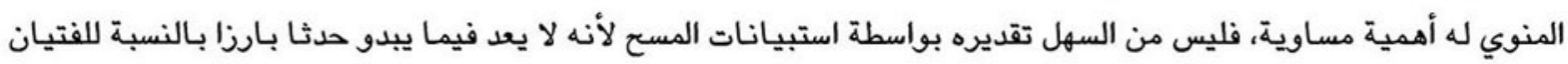
كما هو الحال مع بدء الطمث عند الفتيات. ومن ثم فسوف يتناول القسم الآتي بدء الطمث فقط.

يتفاوت متوسط سن بدء الطمث كثيرا من مجتمع إلى آخر. وقد دللت الأبحاث على أن العوامل الوراثية والبيئية على السواء

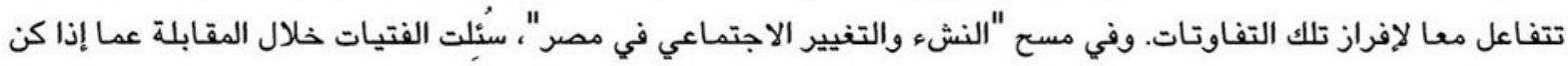

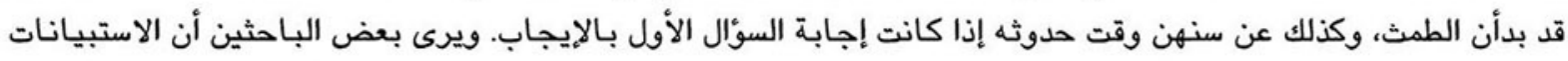

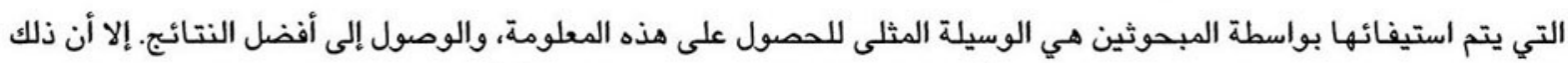

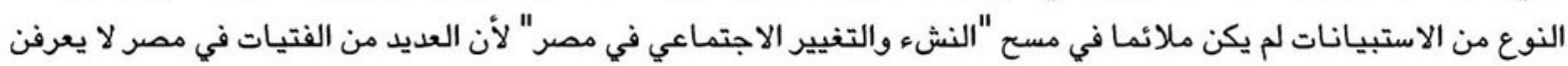

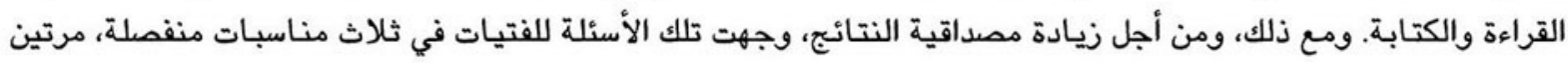

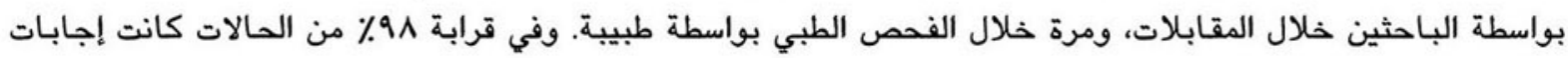

الفتيات متسقة.

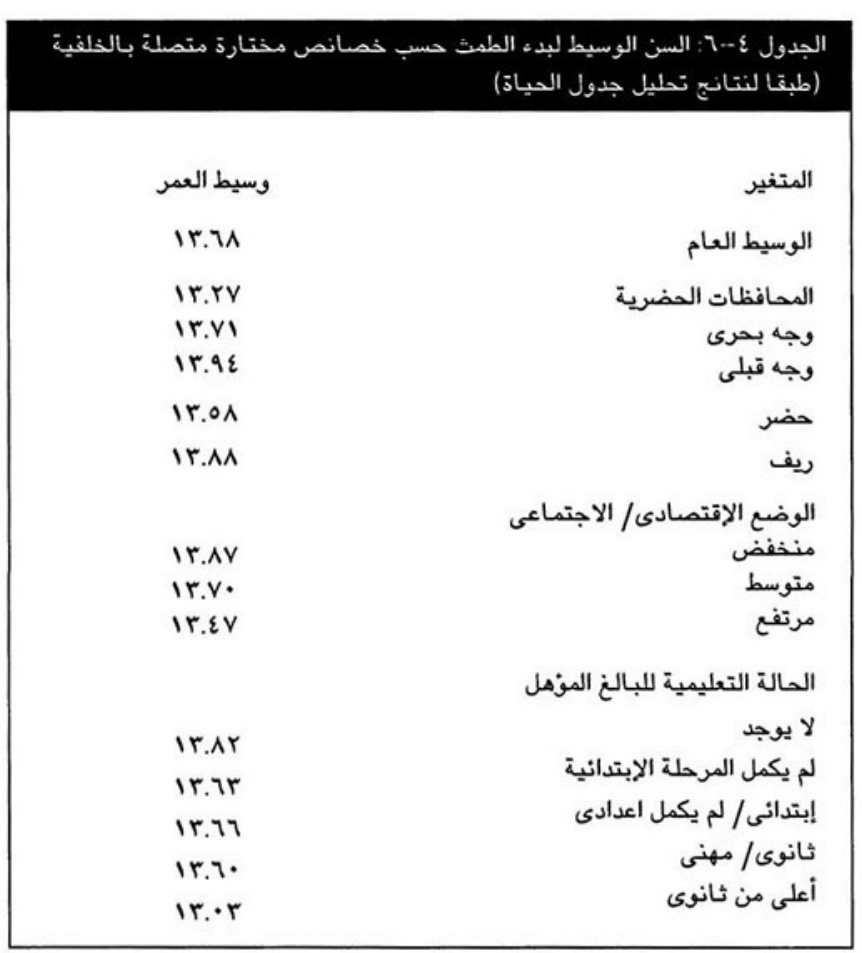

وياستخدام تمليل جدول المياة، تبين أن متوسط سن بدء الطمث للفتيات الممريات مو M.M. II سنة (الجدول ع-7) ). وقمنا بدراسة متوسط سن بدء الطمث

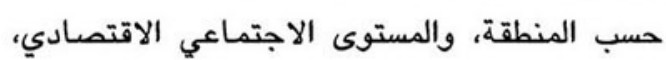
والخلفية التعليمية للفتاة ووالديها. وكان أدنى سن متوسط لبدء الطمث r.r. الفتيات اللاتي حاز والديهن تعليما ثانويـا أو أعلى. بينما بلغ أعلى الأعمار ع9. Ir سنة، وقد أفادت به الفتيات في الصعيد. كما وجدت أعلى أعمار بدء الطمث في المتوسط بين الفتيات المنتميات لأسر أدنى الطبقات الاجتماعية الاقتصادية، أو القاطنات

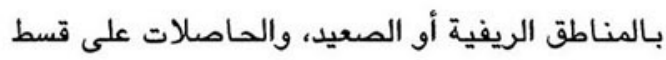
محدود من التعليم (لا تعليم على الإطلاق أو تعليم ابتدائي فقط)، أو اللاتي لم يحصل والديهن على أي الي قسط من التعليم. 


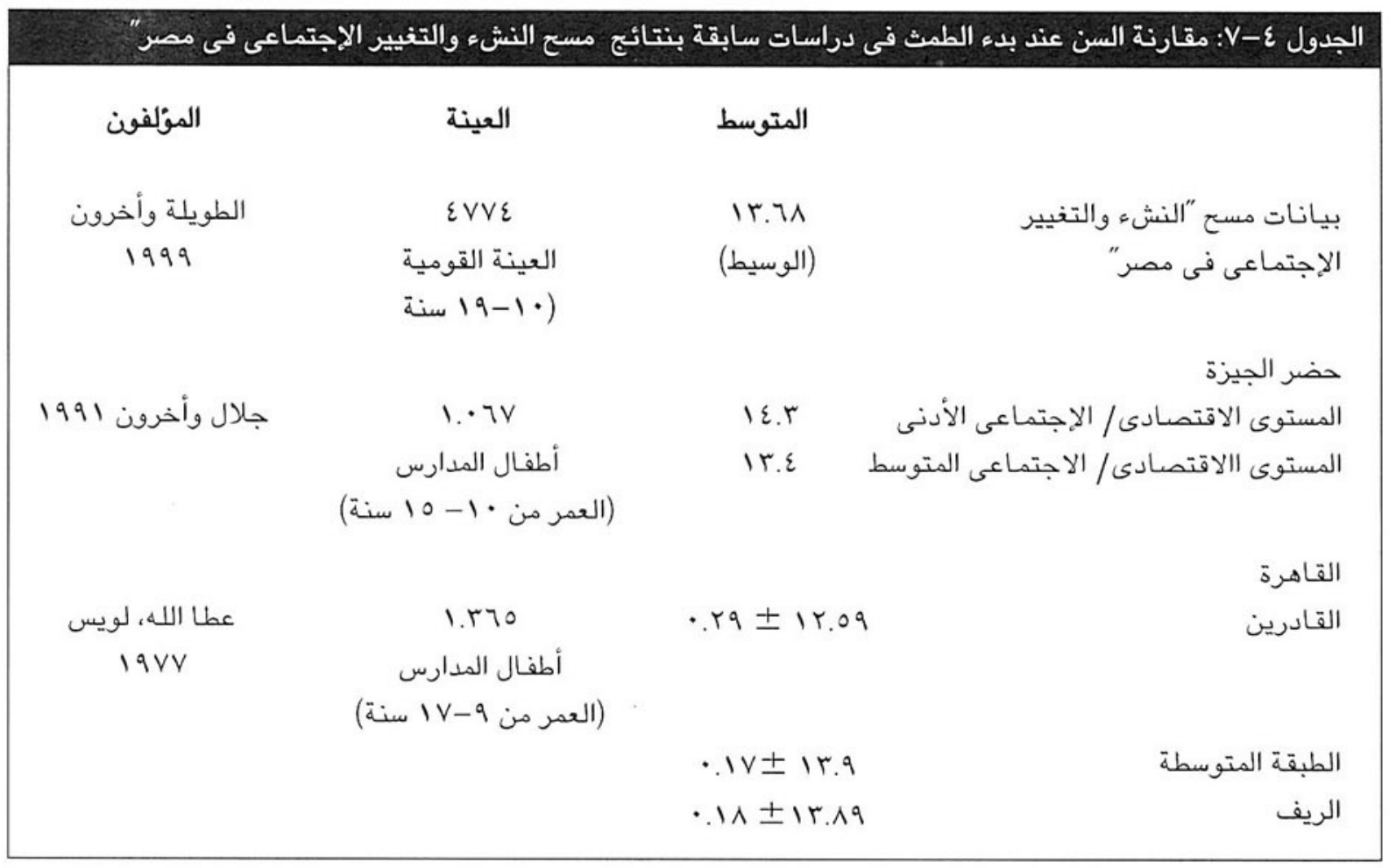

ويعرض الشكلان ع-1 وع-9 احتمال بدء الطمث بين الفتيات المصريات من الفئة العمرية • 1-19 عاما حسب محل الإقامة

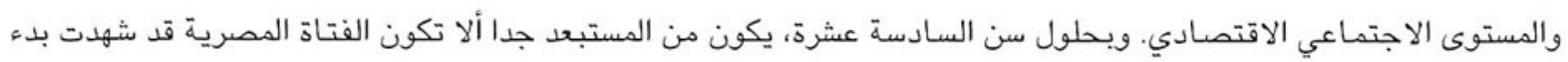
الطمث. إلا أن ثمة فروق في سن بدء الطمث بين الفتيات حسب الحالة الاجتماعية الاقتصادية للأسرة، وكذلك بين قاطنات المحافظات الحضرية والمناطق الريفية. وتتراوح هذه الفروق بين ستة شهور و لب شهرا. ويشير ذلك إلى تأثير العوامل البيئية،

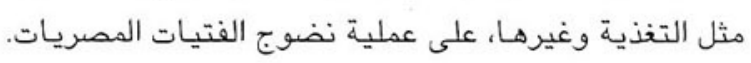

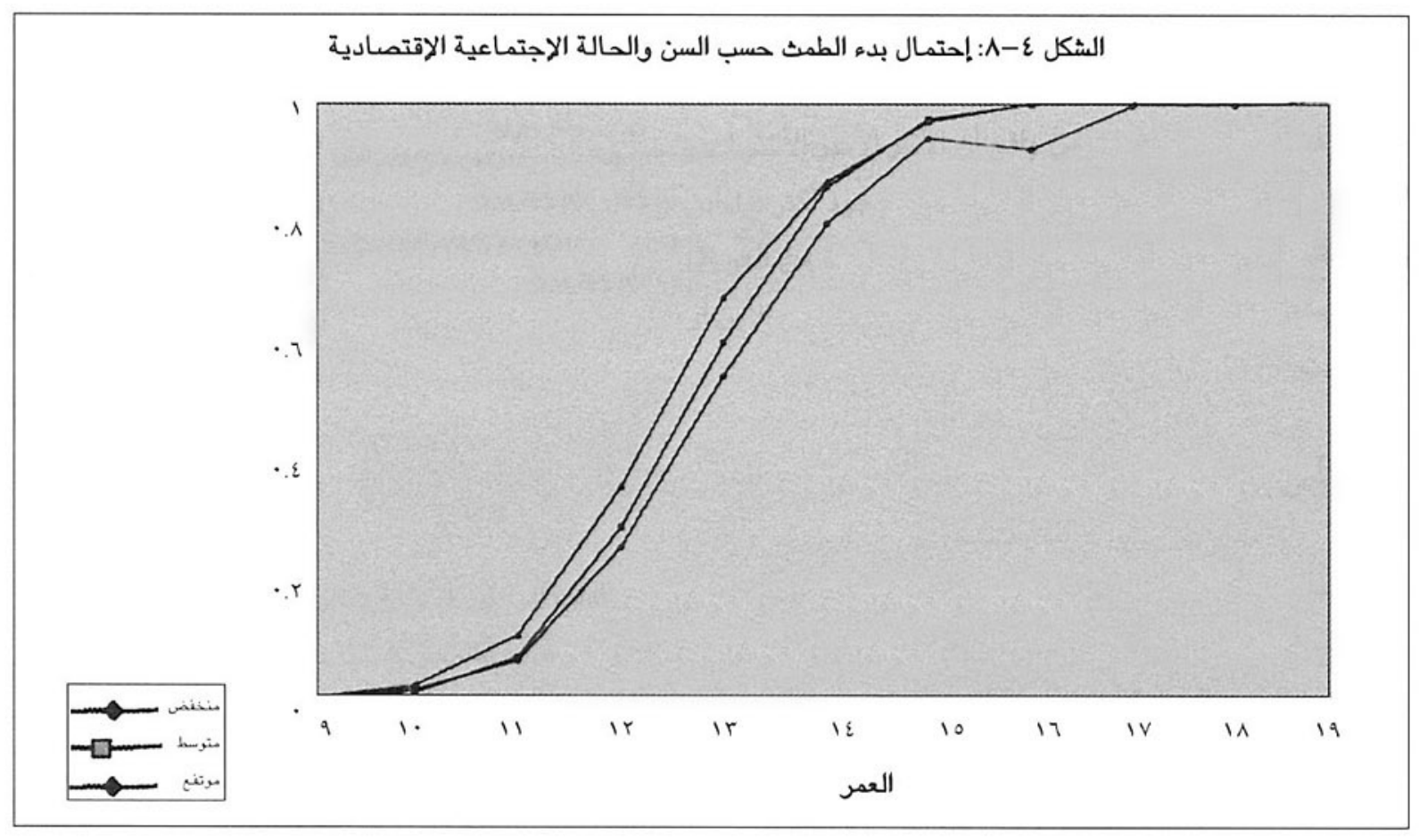




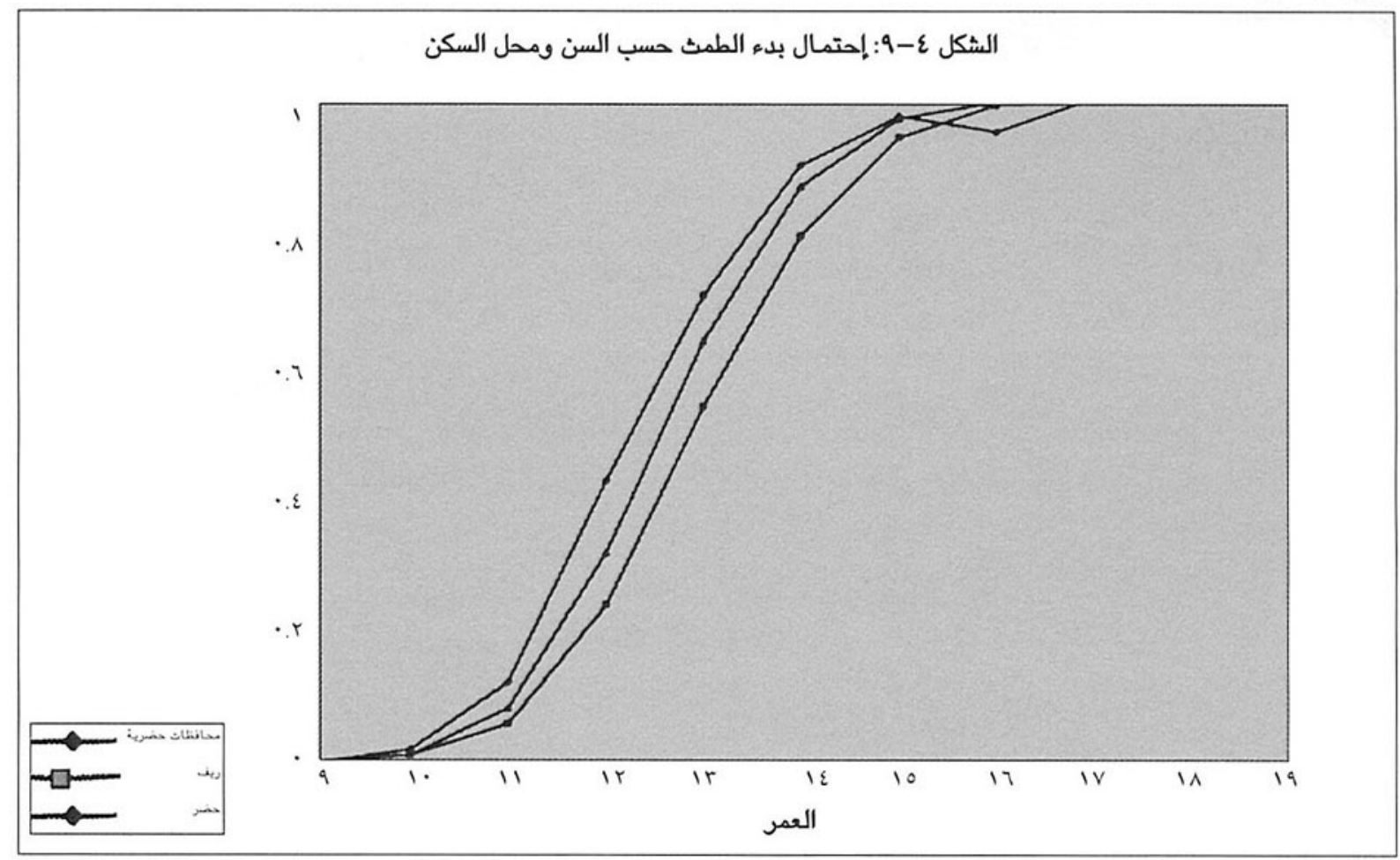

تقييم النضوج الجنسي

تم استخدام مقياس تانر للنضوج الجنسي (تانر، 19V0) من أجل تقييم عملية نضوج النشء المصرى من حيث التطور الجنسي

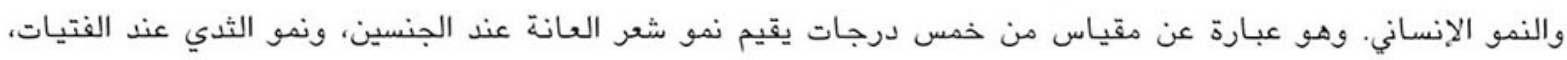
والأعضاء التناسلية عند الفتيان (أنظر الفصل عنارد الثاني لمزيد من التفاصيل).

وتعرض الجداول الأربعة التالية معلومات حول مستويات النضوج الخاصة بالبنات والبنين في مصر وفقا لمقياس تانر.

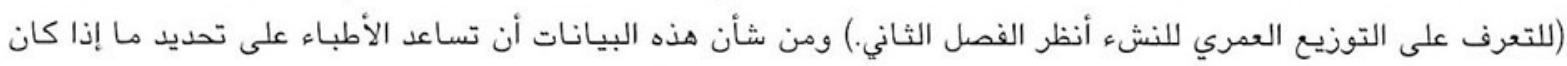

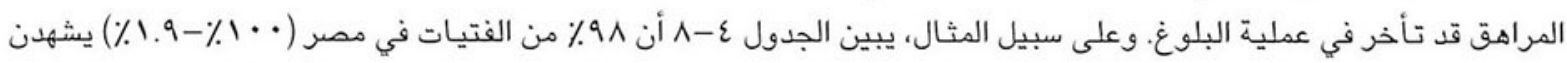

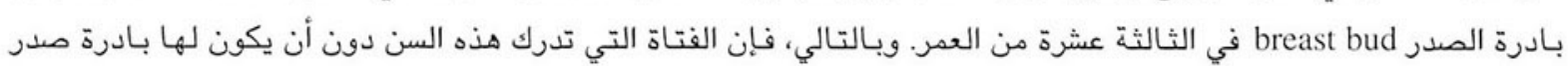

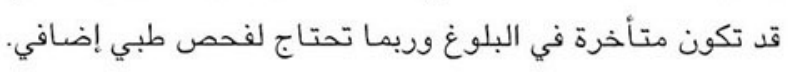

\section{جدول ع-1: التوزيع النسبى لمرظلة نمو الثدى عند الفتيات تبعا للعدر (بالنسبة المنوية)}

عمر البنات بـالسنوات

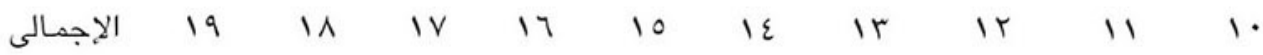

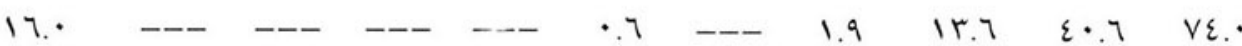

المرحلة

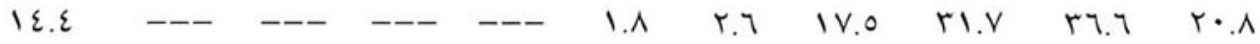

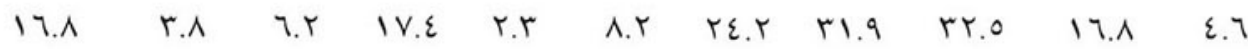

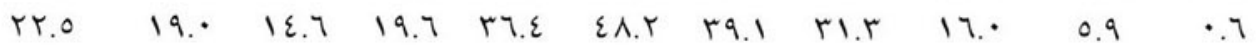

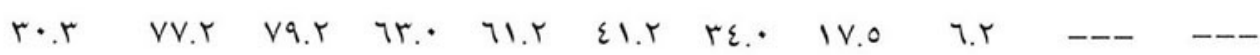

الإجمالى 


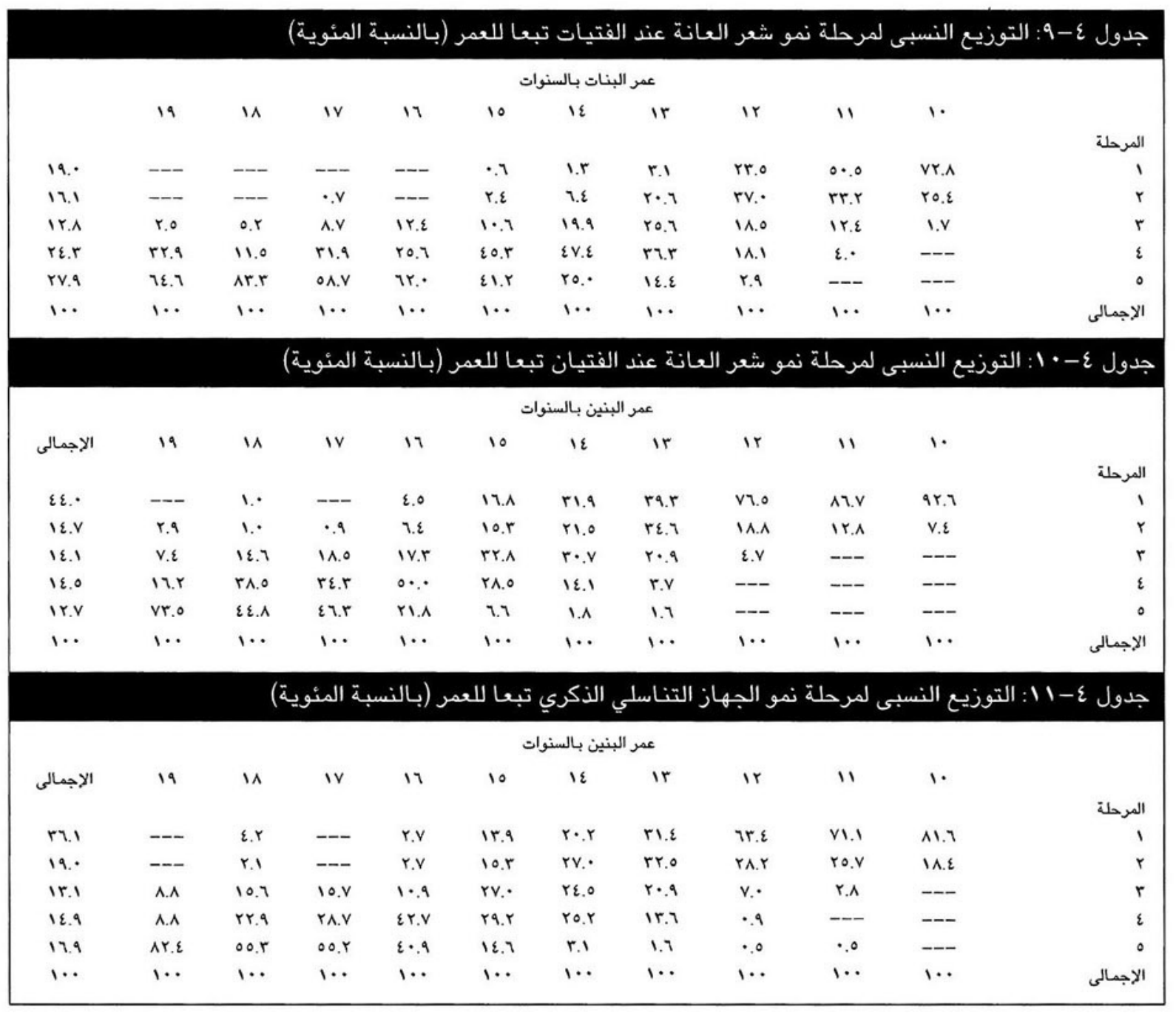

بالنسبة لبعض المراحل التي يحددهـا تانر، لا تتوافر بيانات كاملة فيما يتعلق بالتوزيع حسب السن في مسح "النشء والتغيير

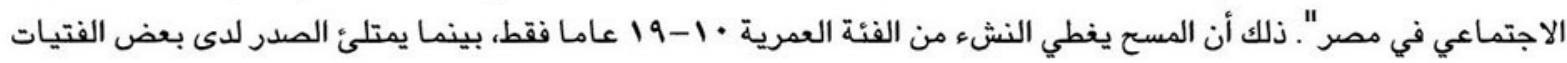

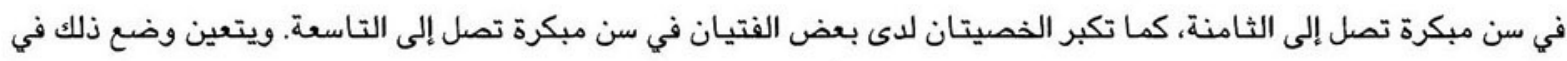
الاعتبار عند مقارنة هذه النتائج بتلك المستقاة من بحوث أخير أخرى.

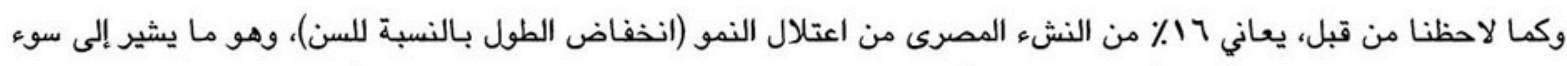

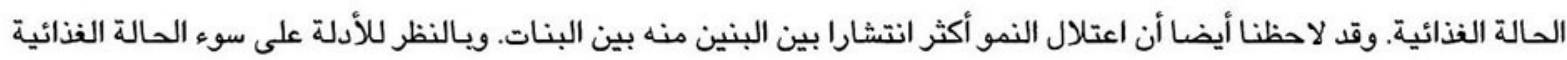

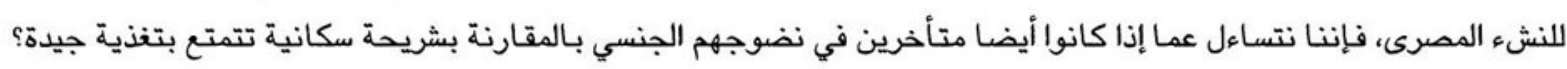

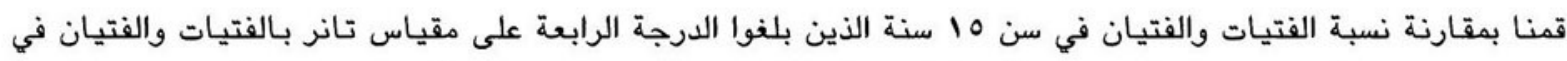

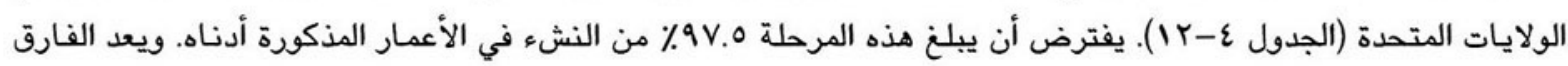

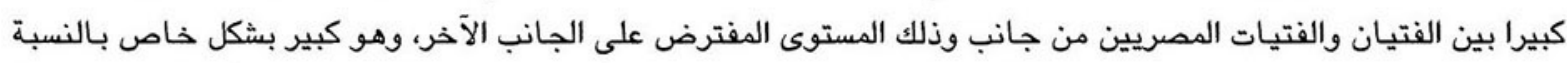

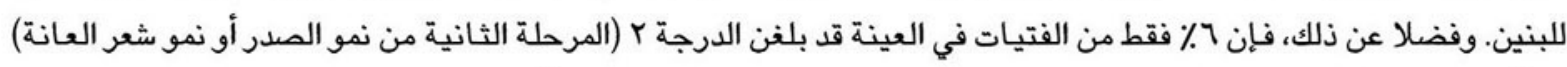

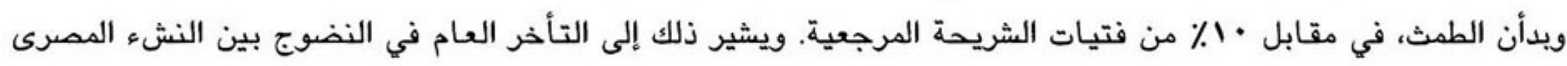

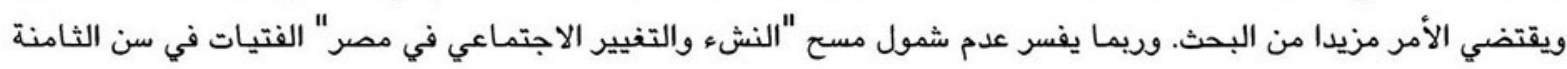
والتاسعة بعض هذه الفروق المرصودة، ولكن ليس كلها بـالتأكيد. 
جدول ع-r 1: مقارنة عينة المسح الخاصة بالنشء المصرى باستخدام مجتمع معيارى من الولايات المتحدة الأمريكية"

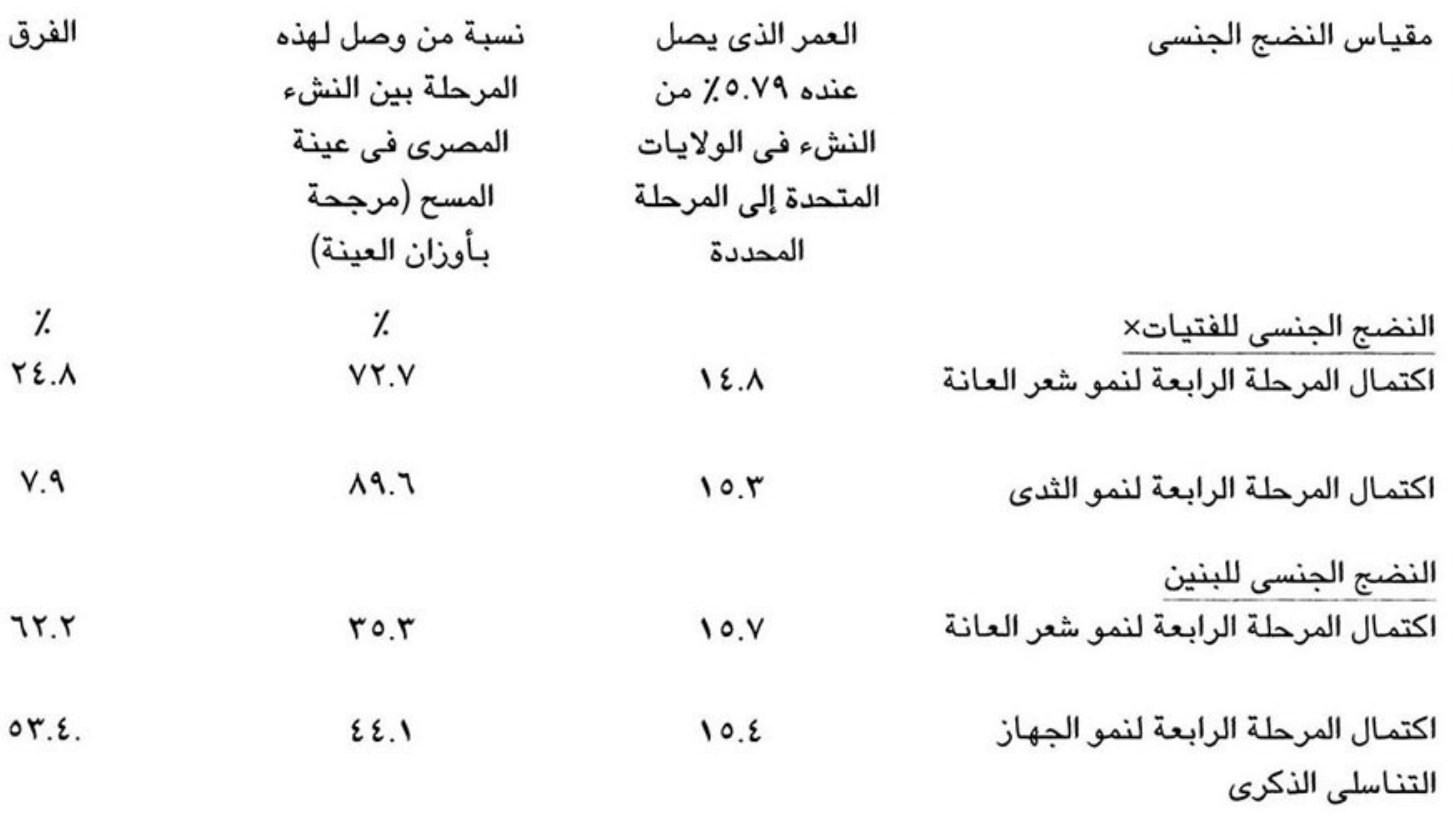

× بالنسبة للمرحلة الرابعة المرتبطة بشعر العانة، تم حساب النسبة للفتيات عند عمر عا سنة بدلأ من 10 سنة.

كما ذكرنا من قبل، تعد دفقة النمو حدثا ملفتا على صعيد النضوج خلال المراهقة. ونحن نعرف دفقة النمو بأنها الزيادة في

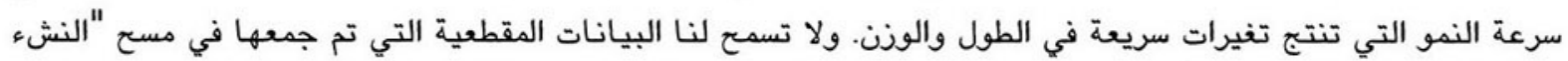

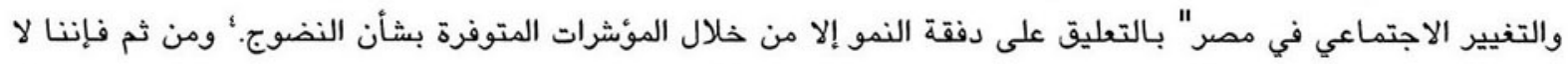

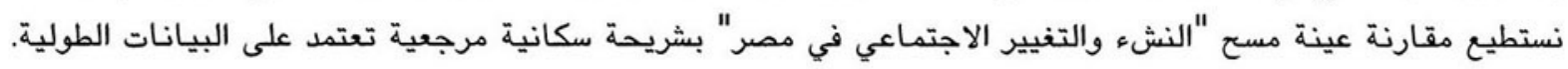
ويبحث الجدول ع-r ا حالة دفقة النمو لدى الجنسين حسب متغيرات مختارة متصلة بالخلفية الاجتماعية.

وكما هو متوقع، هناك فارق في نمط دفقة النمو بين الجنسين؛ إن 7 ا٪ من الفتيات في العينة بأسرها لم يبدأن بعد دفقة النمو

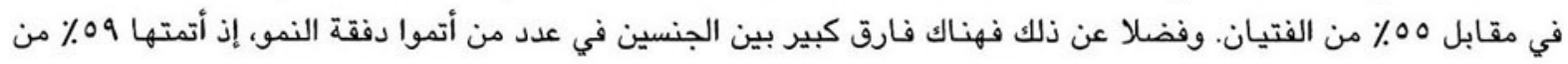

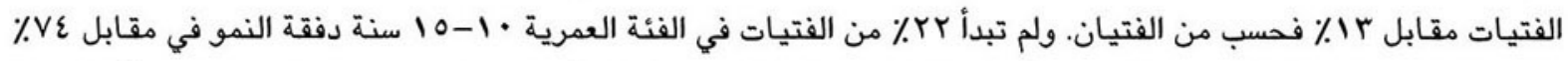

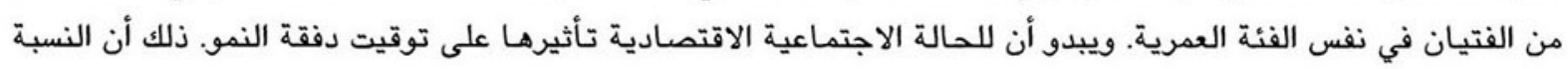

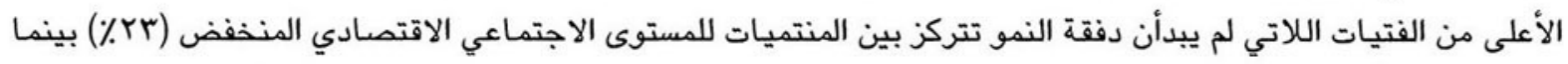

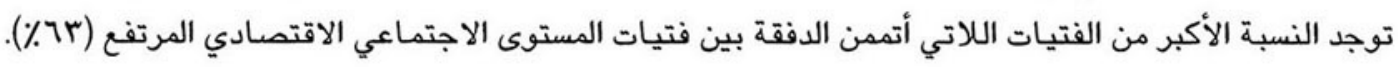

r أخذت بيانات الشريحة السكانية الأمريكية من بيانات طولية ممتدة عبر فترة زمنية طويلة، بينما بيانات مسح "النشء والتغيير الإجتماعى" مقطعية، لذلك ليس

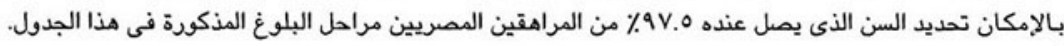

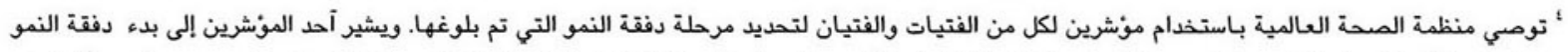

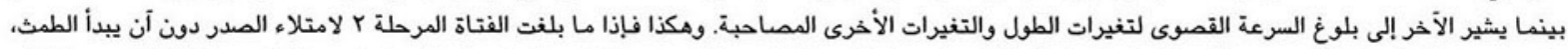

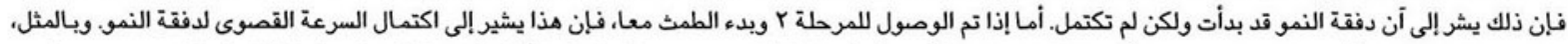

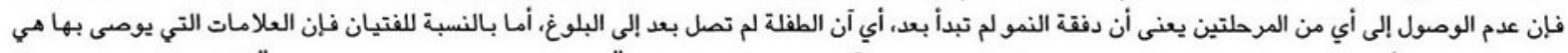

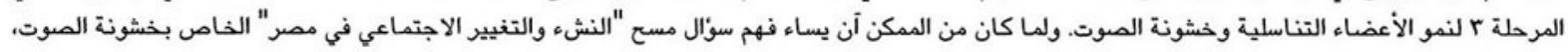
فقد استخدمنا المرحلة ه من نمو شعر العانة كعلامة ثانية بدلا منها 


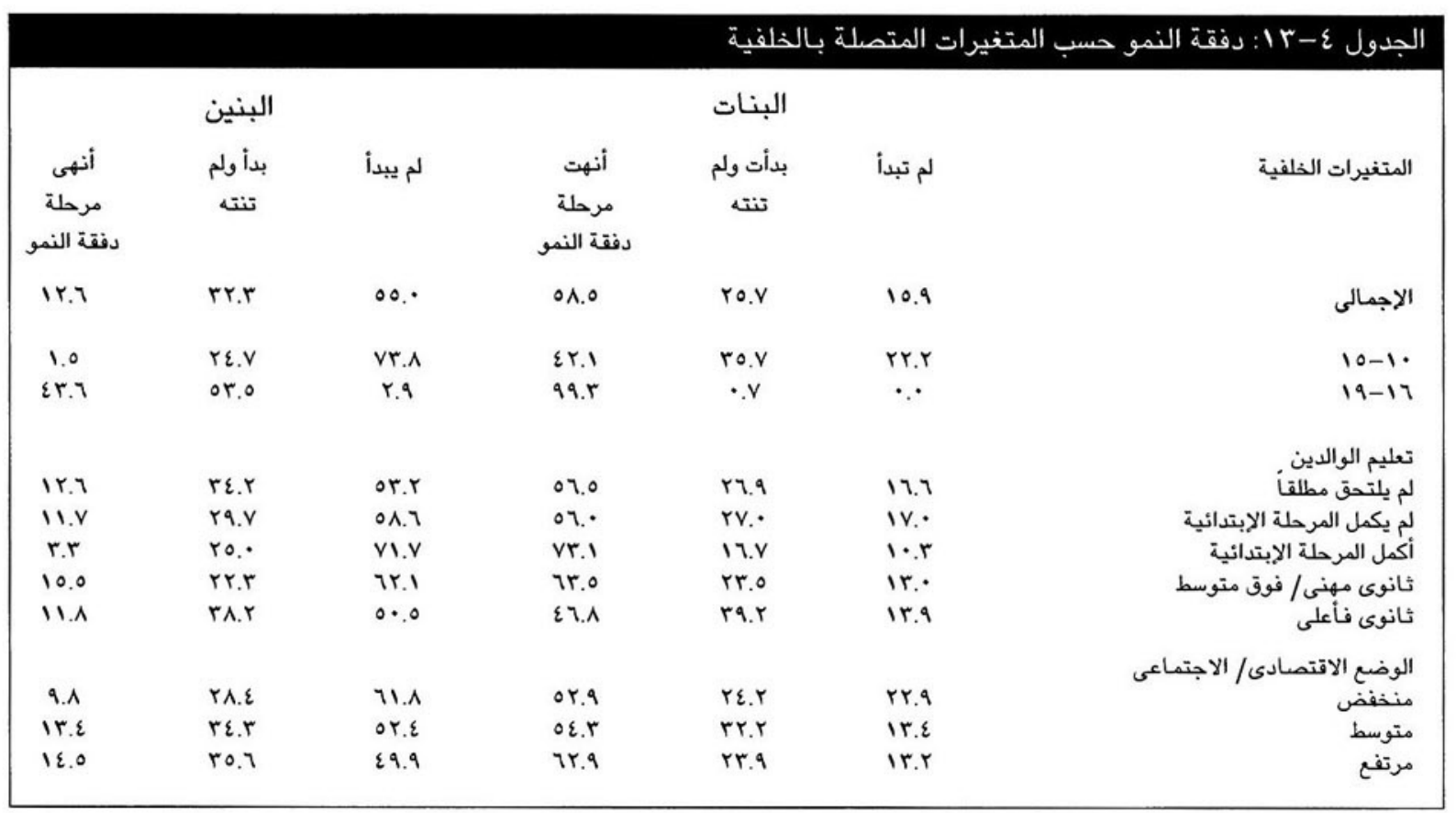

والخلاصة أن دفقة النمو تبدأ وتنتهي عند الفتيات قبل الفتيان كما هو متوقع. ولا يبدو أن الاختلافات الاجتماعية الاقتصادية

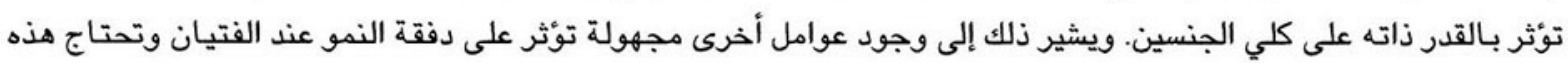

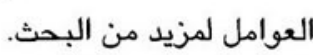

ثالثا: السلوك الصحي

العادات الغذاتية

تتسم المراهقة بقدر من النمو الجسماني والنضوج العاطفي كثيرا ما يؤدي للتوتر والقلق. ويؤثر ذلك على الحالة الفسيولوجية

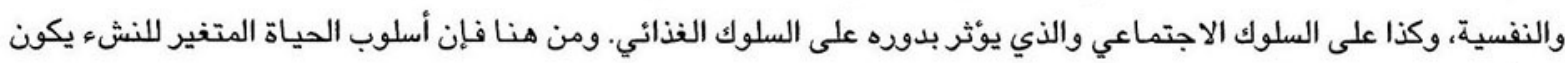
له تأثيرات ملموسة على عاداتهم الغذائية.

حصلنا في هذا المسح على معلومات حول استهلاك الأطعمة التي تمد الجسم بالألياف والفيتامينات مثل الفاكهة والخضراوات

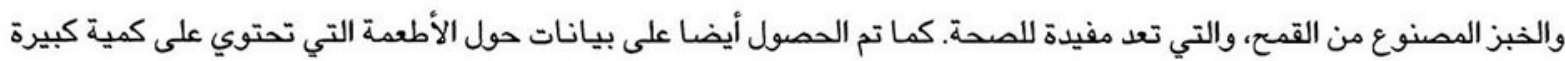

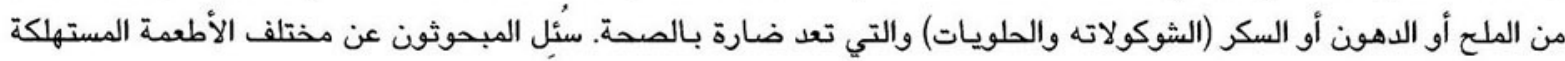

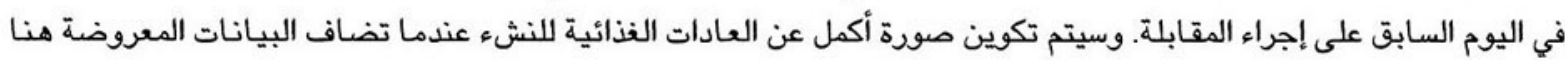

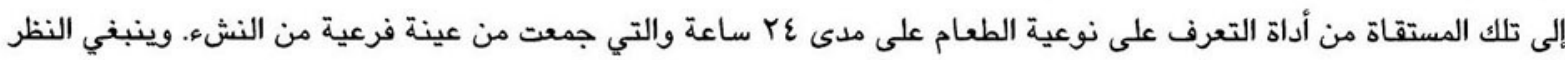

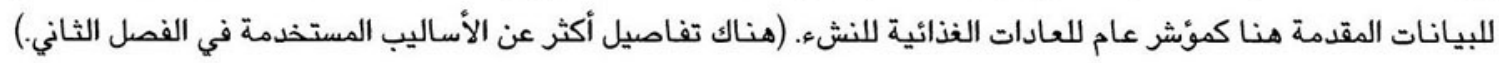

العادات الغذاية العامة

يمكن تطوير العادات الذذائية الصحية خلال المراهقة؛ إلا أن الضغوط الخارجية قد تؤثر على النشء وتدفعه لاختيار أطعمة لا تعزز النمو والتطور، ولا تساعد على الدفاظ على وزن صحي للجسم. وعادة ما يصبح النشء عامة أكثر استقلالا وحركية خلال 
تلك المرحلة من العمر؛ فالفتيان والفتيات يتناولون الطعام خارج المنزل، ويأكلون مع أقرانهم أكثر من ذي قبل، ويتعلمون

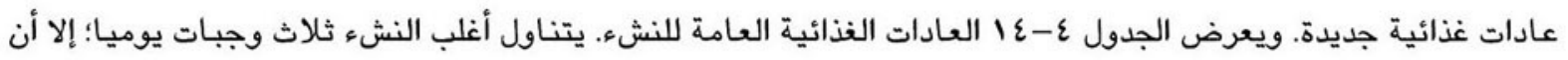

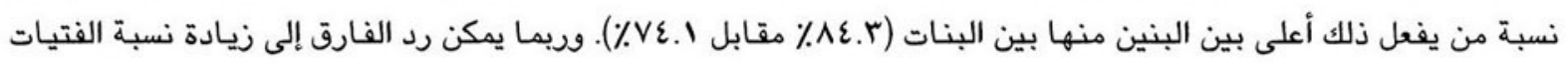

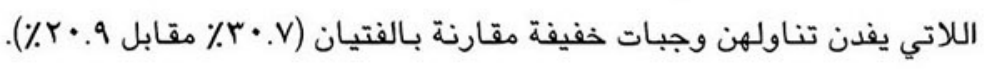

\begin{tabular}{|c|c|c|}
\hline \multicolumn{3}{|c|}{ 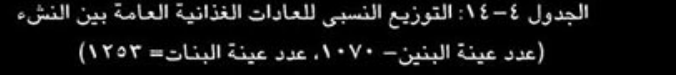 } \\
\hline الفتيات & الفتيان & العادات الغذانية \\
\hline & & الوجبات فى اليوم \\
\hline r.r & I.V & 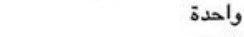 \\
\hline rr.v & Iध. & اثنين \\
\hline$v \varepsilon .1$ & $\Lambda \varepsilon, r$ & ثلاثة \\
\hline$r \cdot . v$ & $r \cdot .9$ & الأكل بين الوجبات أمس \\
\hline 9.9 & $r \cdot 0$ & تناول وجبات خارج المنزل \\
\hline
\end{tabular}

$$
\text { في هذا المسح، ذكر نحو خمس الفتيان أنهم يأكلون }
$$

الفاكهة والخضراوات: لا تذكر سوى نصف الفتيات تقريبا أنهن أكلن الفاكهة في اليوم السابق على المقابلة، وهي نسبة تزيد

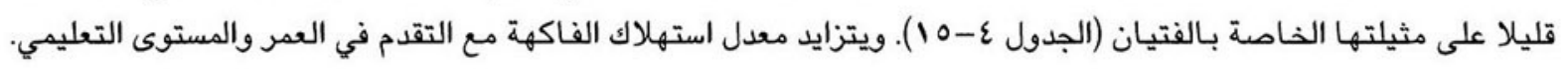

\begin{tabular}{|c|c|c|}
\hline إجمالى العدد & استهلاك الخضروات & استهلاك الفواكه \\
\hline $1 \cdot v \cdot$ & OO.r & $\varepsilon\rceil .7$ \\
\hline iror & or.y & 01.7 \\
\hline 100 & $\varepsilon q$. & $\varepsilon\rceil .1$ \\
\hline vra & 07.0 & $\{9.1$ \\
\hline vra & $0 \wedge .0$ & or.r \\
\hline$\varepsilon \circ V$ & $\varepsilon \wedge .0$ & rv. \\
\hline १ह1 & 01. & $\varepsilon \wedge . \varepsilon$ \\
\hline 070 & $0 \wedge .7$ & ૦ $\varepsilon_{. \wedge}$ \\
\hline$r \varepsilon r$ & רr. & ०\&. 9 \\
\hline IIV & 7V.0 & 77.9 \\
\hline $7 \cdot v$ & $\varepsilon 7 . r$ & $\varepsilon 1 . \varepsilon$ \\
\hline vथ। & ०..V & $\varepsilon \wedge . \varepsilon$ \\
\hline$v r \varepsilon$ & 71.1 & $0 \mathrm{~V} .1$ \\
\hline$\varepsilon า \vee$ & $0 . \varepsilon$ & 00.7 \\
\hline $1 \cdot \wedge \varepsilon$ & 0..7 & 01. \\
\hline vir & or.r & $\varepsilon r . \varepsilon$ \\
\hline 9 ara & $\varepsilon q . r$ & ov. \\
\hline irso & ०V.7 & $\varepsilon \varepsilon .0$ \\
\hline
\end{tabular}

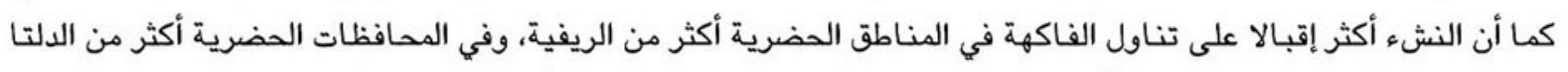

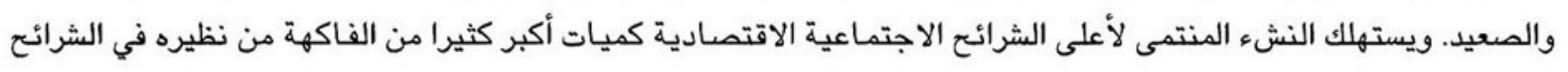

$$
\text { الوسطى والدنيا. }
$$

\section{الجدول ع-0 1: نسب التوزيع المئوية لاستهلاك النشء للفواكه والخضروات حسب خصائص مختارة متصلة بالخلفية}

المتغيرات الخلفية

الفتيان

الفتيات

$1 r-1$.

$10-14$

$19-17$

لم يلتحقوا مطلقاً لم يكملوا المرحلة الإيتدائية

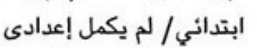
إعدادى/ لم يكمل ثانوى الثادي ثانوى

فوق متوسط/ جامعة

الوضع الاقتصادى/ الاجتماعى

منخفض الوضع الاقن

متوسط منفط

مرتفع

المحافظات الحضرية

وجه بحرى

وجه قبلى بحرى

ov.

$\varepsilon \varepsilon . \circ$

ريف 
ذكر أكثر من نصف الفتيان والفتيات وعدد من الذكور أكبر قليلا من الإناث (ro. \% مقابل 7.r\%٪) أنهم تناولوا الخضراوات

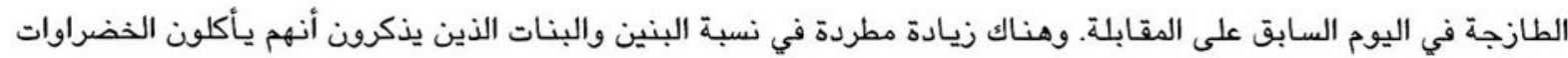

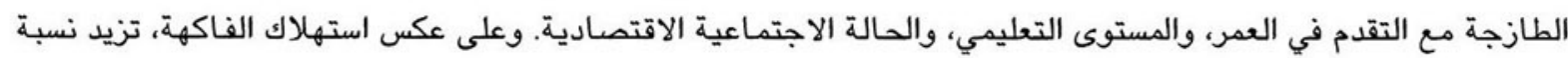

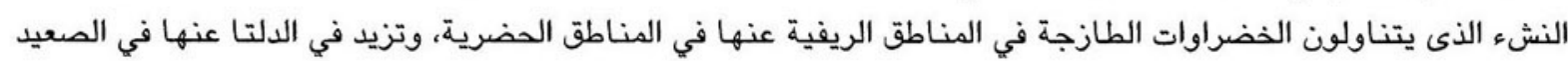

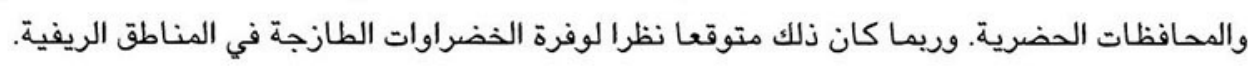

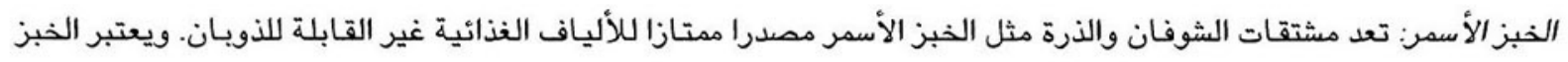

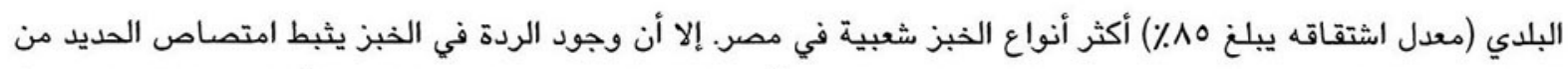

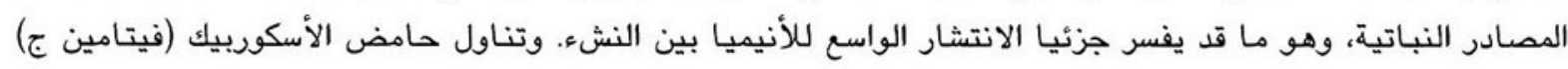

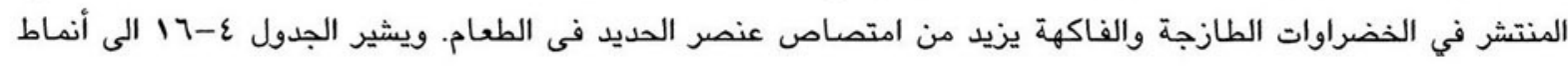

الاستهلاك بين النشء المصرى.

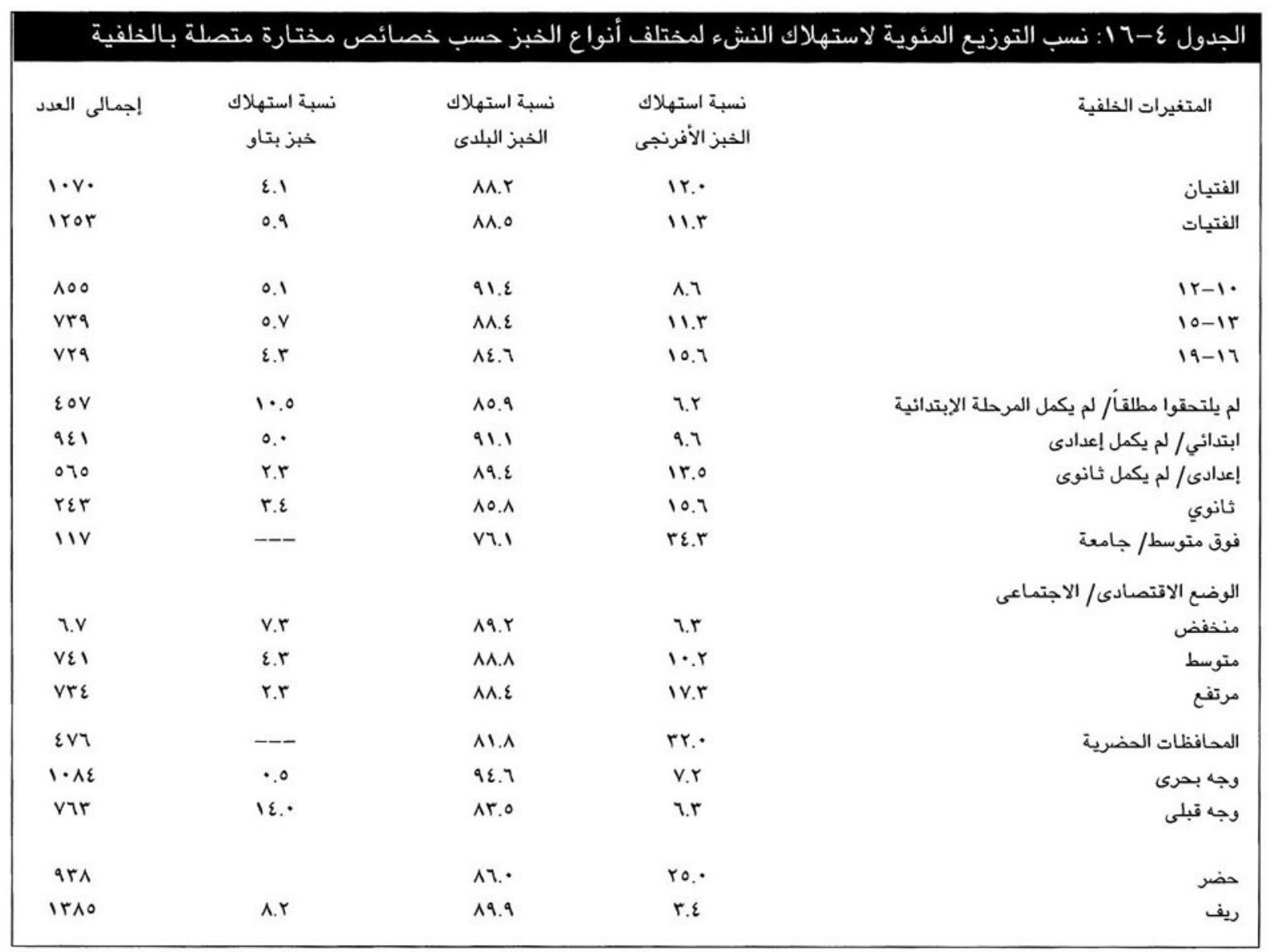

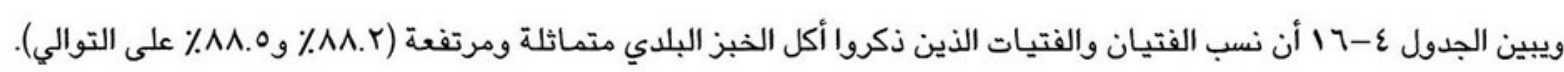

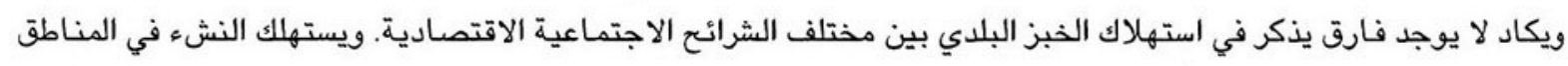

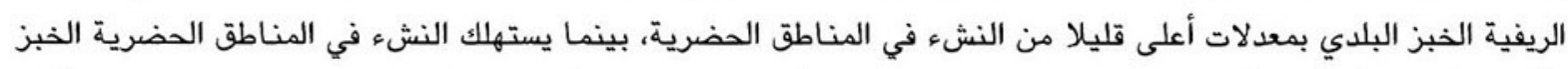

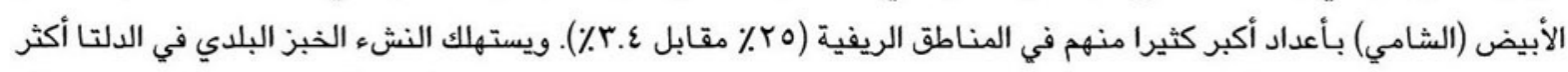

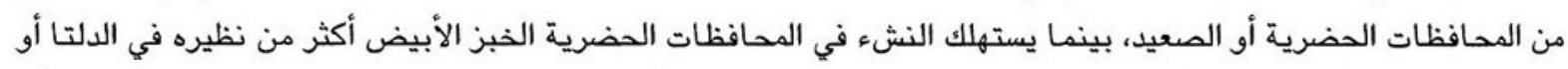

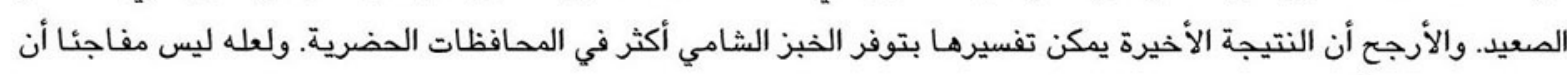
استهلاك الخبز الأبيض يتزايد مع ارتفاع المستوى الاجتماعي الاقتصادي، وكذلك مع التقدم في العمر والتعليم. 
ويستهلك نوع من الخبز المصنوع في المنزل، يسمى الخبز البتاو، في ريف الصعيد. وهو يصنع من دقيق القمح ودقيق الذرة

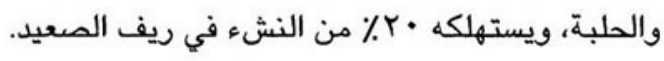

\section{الأطعمة غير المغذية}

الأطعدة المملحة: يوجد الملح بشكل طبيعي في العديد من المأكولات مثل اللحوم والأسماك والدواجن والبيض واللبن ومنتجات

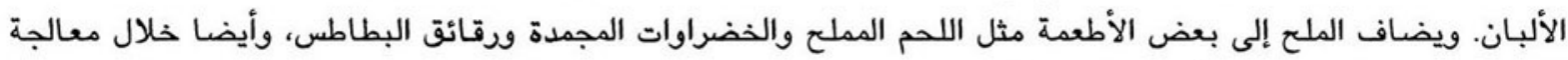

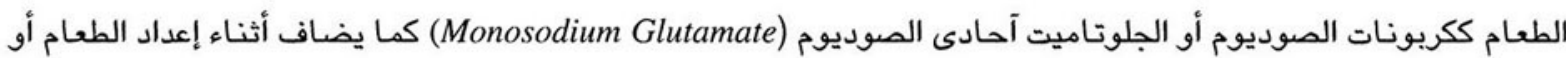

يفضل ثلثا الفتيان و •1٪ من الفتيات الطعام المملح، كما ذكر نحو نصف هؤلاء من الجنسين أنهم أكلوا الأطعمة المملحة مثل

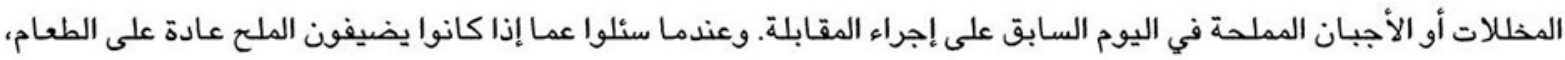

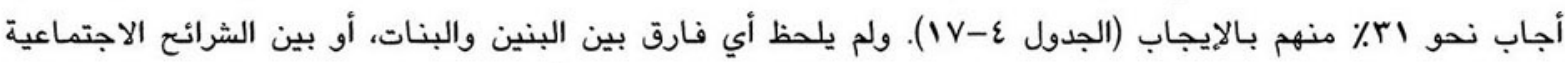

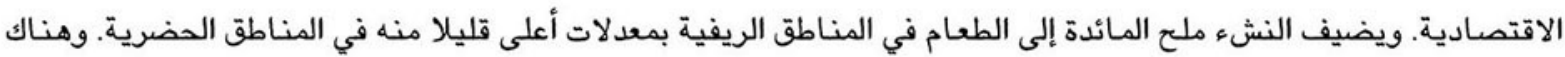

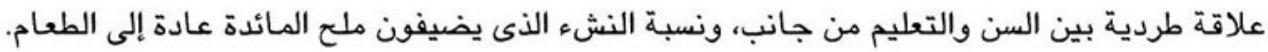

\begin{tabular}{|c|c|c|c|}
\hline إجمالى العدد & والمشرويات الغازية & إلى الطعافم الملح & المتغيرات الخلفية \\
\hline rrer & $.0 . r$ & $r \cdot .9$ & الإجمالى \\
\hline $1 \cdot \mathrm{v} \cdot$ & $\varepsilon 9 . \varepsilon$ & ri.r & الفتيان \\
\hline iror & 01. & $r \cdot . v$ & الفتيات \\
\hline 100 & £^.9 & ro.r & ir-1. \\
\hline vea & $\varepsilon \wedge . r$ & $r \cdot v$ & $10-1 r$ \\
\hline vra & o . . & rv. 9 & $19-17$ \\
\hline EOV & ro.7 & $r \cdot r$ & لم يلتحقوا مطلقاً/ لم يكمل المرحلة الإبتدائية \\
\hline वह1 & $0 . . \varepsilon$ & rv.r & ابتداني/ لم يكمل إعدادى \\
\hline 070 & ०६. & rr.q & إعدادى/ لم يكمل ثانوى \\
\hline rer & $7 \cdot r$ & rA.9 & ثانوي \\
\hline \multirow[t]{2}{*}{ wv } & vi. & ra. & فوق متوسط/ جامعة \\
\hline & & & الوضع الاقتمسادى/ الاجتماعى \\
\hline $7 \cdot v$ & $\varepsilon \cdot 9$ & ri.r & منخفض \\
\hline$v_{\varepsilon} 1$ & 0.9 & rr.t & متوسط \\
\hline$v r \varepsilon$ & $7 \because \cdot$ & rq.६ & مرتفع \\
\hline$\varepsilon \vee า$ & $7 \varepsilon . \varepsilon$ & $r \cdot 1$ & الححافظات الحضرية \\
\hline $1 \cdot \wedge \varepsilon$ & $\varepsilon 9 . \vee$ & $r \cdot .0$ & وجه بحرى \\
\hline vru & $\varepsilon r$. & $r 1.9$ & وجه قبلى \\
\hline are & ir. 1 & r..1 & حضر \\
\hline irso & $\varepsilon 1.9$ & rr. & ريف \\
\hline
\end{tabular}

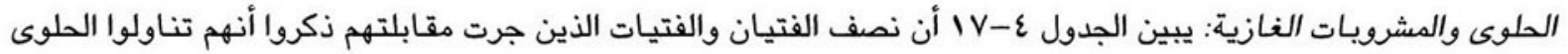

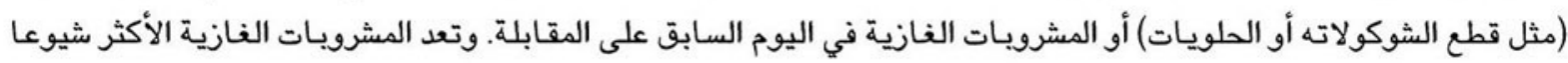

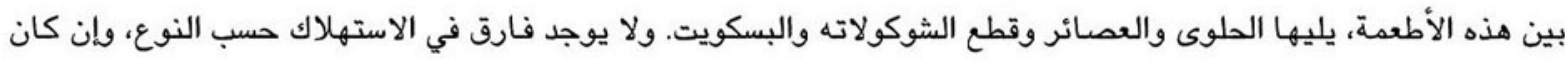


هناك فارق بين الفئات العمرية. يستهلك النشء الأكبر سنا (الفئة العمرية 17 -19 عاما) الحلوى والمشروبات الغازية أكثر من

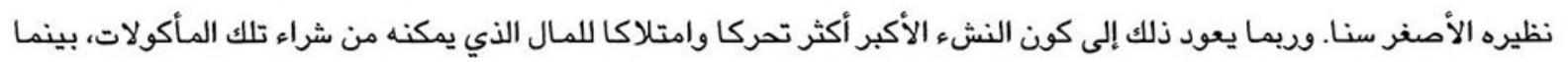

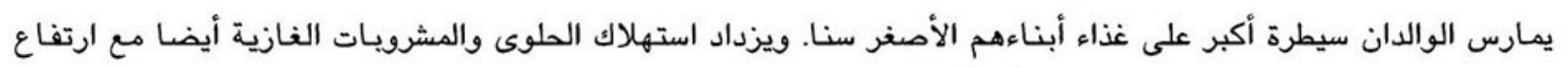

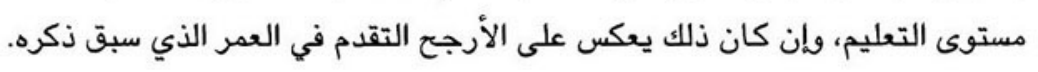

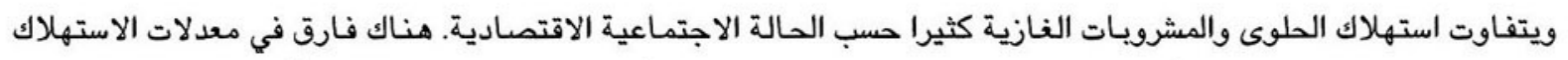

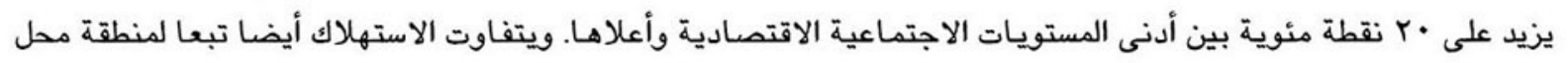

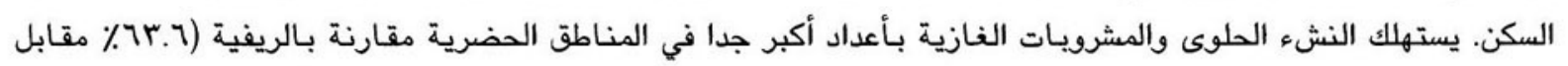

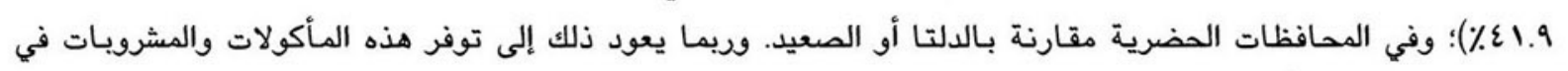
المجتمعات الحضرية أكثر من الريفية.

شرب الشاي: يعد شرب الشاي المركز عادة غذائية منتشرة بين المصريين بغض النظر عن السن أو الطبقة الاجتماعية، وخاصة

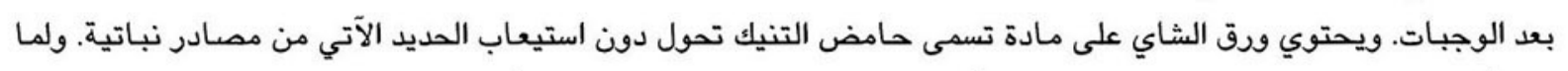

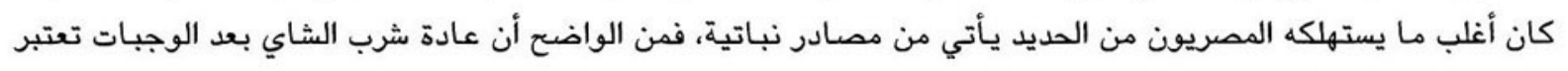
مشكلة تعرقل الحصول على الحصيلة المطلوية من الحديد.

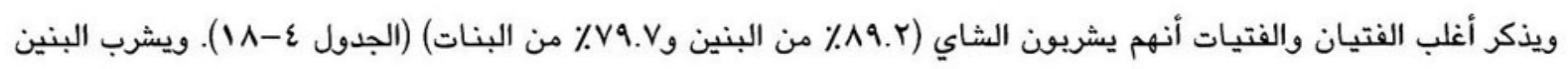

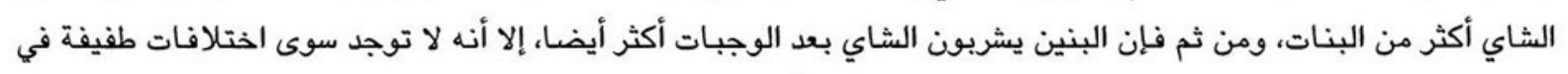

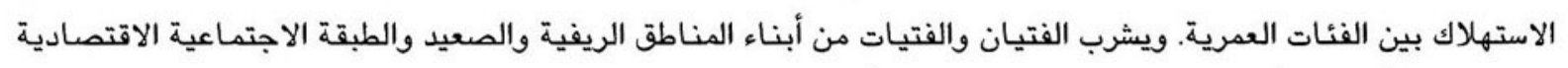

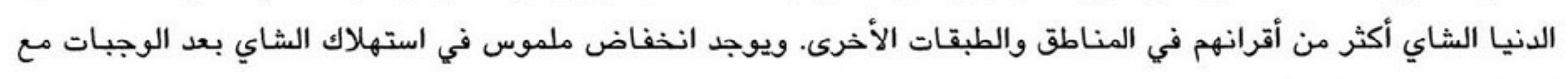
ارتفاع مستوى تعليم النشء.

\begin{tabular}{|c|c|c|c|c|}
\hline إجمالى العدد & نسبة من يشريون & نساى بالأمس شريوا & يشريون الشاى & المتغيرات الخلفية \\
\hline $1 \cdot \mathrm{v} \cdot$ & $v \cdot r$ & $\Lambda 9.8$ & ^9.Y & الفتيان \\
\hline iror & ir.o & Ar.० & จุ.v & الفتيات \\
\hline 1000 & va.r & $\wedge \varepsilon .7$ & 10.9 & ir-1. \\
\hline vra & $7 \varepsilon . \varepsilon$ & 10.r & Ar.I & $10-1 r$ \\
\hline vra & v.r. & м..r & Ar. 1 & $19-17$ \\
\hline$\varepsilon \vee า$ & $\Lambda \cdot .9$ & 1..7 & 1.7. & لم يلتحقوا مطلقاً لم يكمل المرحلة الابتدائية \\
\hline $9+1$ & 10.0 & 10.0 & A..V & ابتدائي/ لم يكمل إعدادى \\
\hline 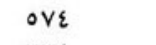 & Ir.e & 10.7 & 1.. 0 & إعدادى/ لم يكمل ثانوى \\
\hline$r \varepsilon$ & ०А. & $9 \cdot . \varepsilon$ & $9 \cdot . r$ & ثانوي \\
\hline $1 \cdot v$ & 00.1 & v9.7 & $9 \varepsilon .1$ & فوق متوسط/ جامعة \\
\hline & & & & الوضغ الاقتصادى/ الاجتماعى \\
\hline $\begin{array}{l}7 \cdot v \\
v \varepsilon 1\end{array}$ & $\begin{array}{l}v v .1 \\
v \cdot . v\end{array}$ & $\begin{array}{l}\wedge 9 .{ }^{\wedge} \\
\wedge\urcorner . \varepsilon\end{array}$ & $\begin{array}{l}\text { Av.v } \\
\text { Ar.q }\end{array}$ & متخفط \\
\hline$v r \varepsilon$ & or.1 & Al. & $\wedge \varepsilon .1$ & 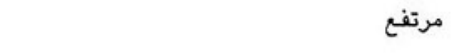 \\
\hline$\varepsilon \vee\urcorner$ & 00.1 & V^.£ & $\wedge 1.9$ & المحافظات الحضرية \\
\hline $1 \cdot \wedge \varepsilon$ & 79.5 & 17.9 & Ar.1 & وجه بحرى \\
\hline vir & 79.8 & A 1.7 & $\wedge \uparrow . \wedge$ & 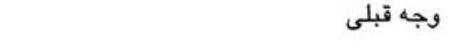 \\
\hline are & 07.9 & $\Lambda \cdot .1$ & A1.1 & حضر \\
\hline irso & vr.q & $\wedge 9 . \varepsilon$ & ^१. & ريف \\
\hline
\end{tabular}


وسيتم إجراء مزيدا من التحليل للعادات الغذائية والحالة الصحية للنشء للتوصل إلى كيفية توجيه التدخلات لتحسين الحالة الصحية للنشء.

التدخين

شجعت الآثار الضارة للتدخين عددا من البلدان على تطوير سياسات ويرامج للتقليل من الاضرار الصحية والوفيات الناتجة عن تعاطي التبخ. ويتضمن ذلك برامج البيئة الخالية من الدخان وفرض القيود على توفر ويبع السجائر والدعاية لها. إلا أن هذه البرامج والسياسات تتفاوت بوضوح بين بلد وآخر ولا تنجح دائما في إثناء صغار السن عن التدخين. وفي مصر، تضاعفت الضرائب على السجائر أكثر من مرة، وتم تقييد الدعاية لها في وسائل الإعلام. إلا أنه لا يوجد حد أدنى لسن شراء إنساء السجائر. ويبين الجدول ع-19 معدلات شيوع التدخين بين الفتيان والفتيات وأقرانهم ومقدار عرض السجائر من جانب الأقران. ويبلغ إجمالي انتشار التدخين بين النشء حوالي ح٪ كما جرَب جر٪ آخرون التدخين مرة واحدة فقط. ويذكر البنين التدخين بمعدلات

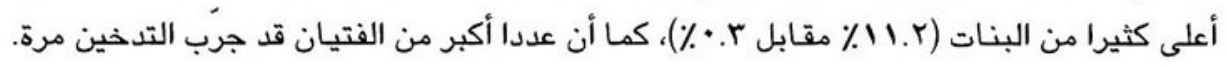

الجدول ع-19 إ: نسب التوزيع المئوية للتدخين بين الفتيان والفتيات وأقرانهم، وعرض السجائر من قبل الأقران، حسب خصائص مختارة متصلة بالخلفية التية

\begin{tabular}{|c|c|c|c|c|}
\hline إجمالى العدد & تسبة من عرض الأقران & الذين يدخنة الأقران & جربوا التدخين من & نسبة المدخنين \\
\hline 9IrA & Ir.r & rr. & 1.8 & 0.0 \\
\hline \&ror & $r \varepsilon \varepsilon$ & $\varepsilon r . r$ & r.q & $M . r$ \\
\hline EVVO & $\cdot . \Lambda$ & 0.1 & .0 & $\cdot r$ \\
\hline דורו & $r .97$ & Ir.r & 1.0 & r.r \\
\hline iros & $\backslash \wedge . \wedge$ & \&1. & Y.T & $0 . r$ \\
\hline IrAr & OO. & VV.T & $\varepsilon . q$ & rV.O \\
\hline ATr & V.r & $1 r .1$ & $\cdot 9$ & 0. \\
\hline IVIV & 0.7 & Ir.r & $1 . r$ & $r . r$ \\
\hline 11.9 & $17 . \varepsilon$ & rr.q & 1.1 & $0 . r$ \\
\hline$\varepsilon 71$ & r9.7 & Ev. & r. 1 & ir.o \\
\hline $19 \varepsilon$ & $r r . \cdot$ & OO.r & $\varepsilon . \vee$ & $M .1$ \\
\hline Irir & rr.r & rv.v & $r .9$ & 11.7 \\
\hline irs. & YO.Y & $\varepsilon Y\rceil$. & r.r & $1 \cdot . \wedge$ \\
\hline IrYY & $r \varepsilon . r$ & $\{0.0$ & r.A & $1 \cdot r$ \\
\hline $1 / 199$ & rq. & $\varepsilon V .1$ & r. & $10 . \varepsilon$ \\
\hline$r \varepsilon>\varepsilon$ & $r \cdot . r$ & rı. & $r . r$ & V. .7 \\
\hline Аᄉ. & ro. & ov.r & r.v & $10 . r$ \\
\hline 1917 & rr.t & $\varepsilon \cdot . q$ & $r . q$ & 9.8 \\
\hline $100 \mathrm{~V}$ & $r \cdot r$ & rา.\& & $r .7$ & 1.9 \\
\hline IVrr & $r \cdot r$ & 0.9 & r. & Ir.T \\
\hline • זרז & rI. & rv. & r.A & $1 \cdot r$ \\
\hline
\end{tabular}

المتغيرات الخلفية

الإجمالى

الفتيان الفتيات

الذكور فقط

$10-11$

$19-17$

لم يلتحقوا مطلقاً لم يكملوا المرحلة الإبتدائية ابتدائي/ لم يكمل إعدادى لمكادي إعدادى / لم يكمل ثانوى لماندي فوق متَوسط/ جامعة الوضع الاقتمادى/ الاجتماعى متوسل متخفظ منف مرتفع الحالة العملية يعمل لا يعمل

المحافظات الحضرية وجه بحرى وجه قبلى وجري 
ولكن بالنظر إلى أن الب٪ فقط من الذكور يقولون إنهم يدخنون في حين يذكر بع٪ أن أقرانهم يدخنون، (ويوجد نمط مشابه

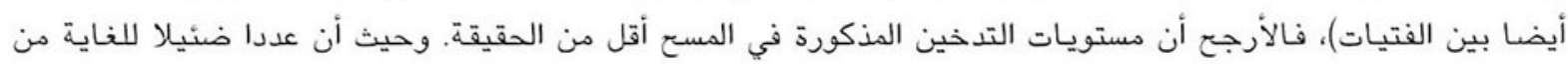

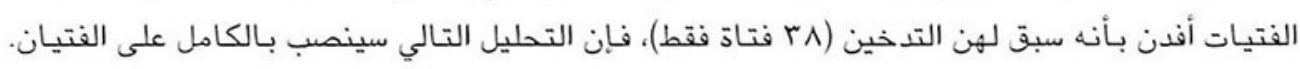

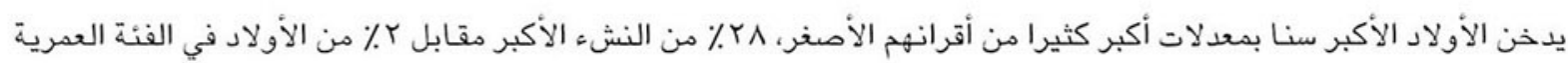

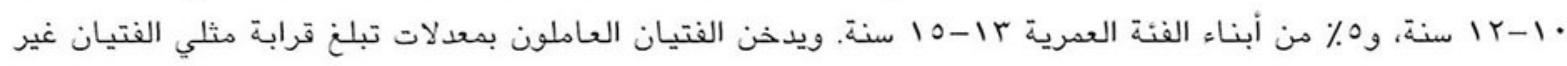

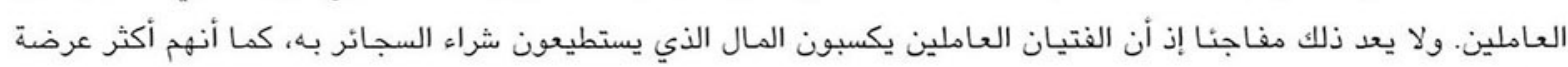
لتأثيرات الأقران ويقضون أوقاتا أكبر بمنأى عن الإشراف الأسري.

ويعد سلوك جماعة الأقران عاملا جوهريا في دفع المراهق نحو التدخين واستمرارد فيه. وتدلل البيانات المقدمة في الجدول ع- -

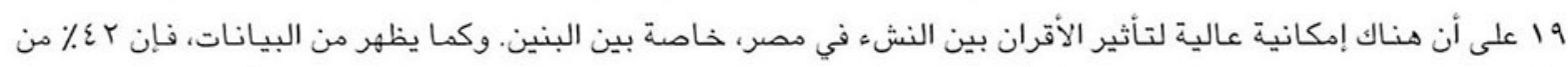

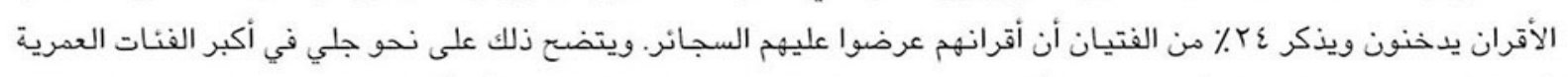

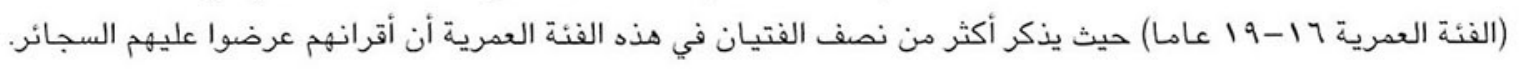

أسباب البدء في التدخين

تؤكد الأسباب التي يعطيها النشء للتدخين تأثير الأقران في مرحلة الشروع في التدخين. يبين الشكل ع- • ا أن اعـ٪ من الأولاد

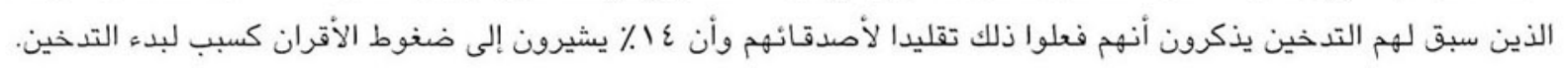

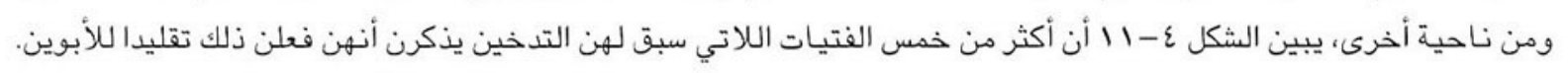

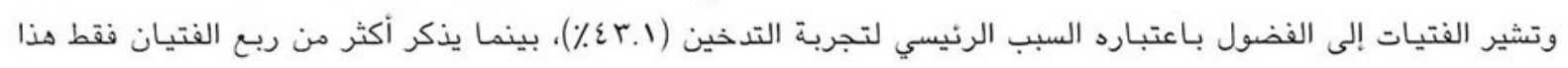

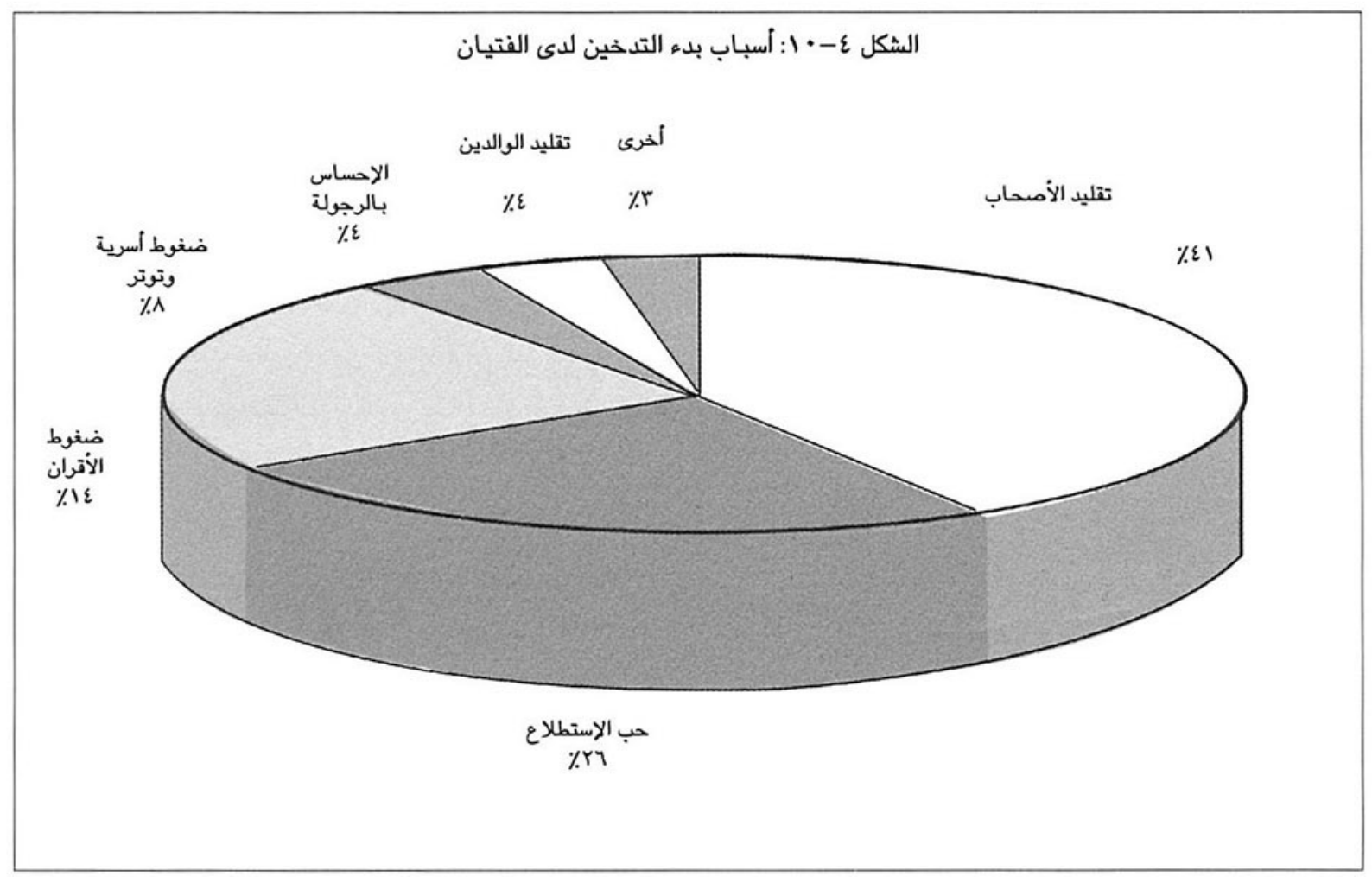




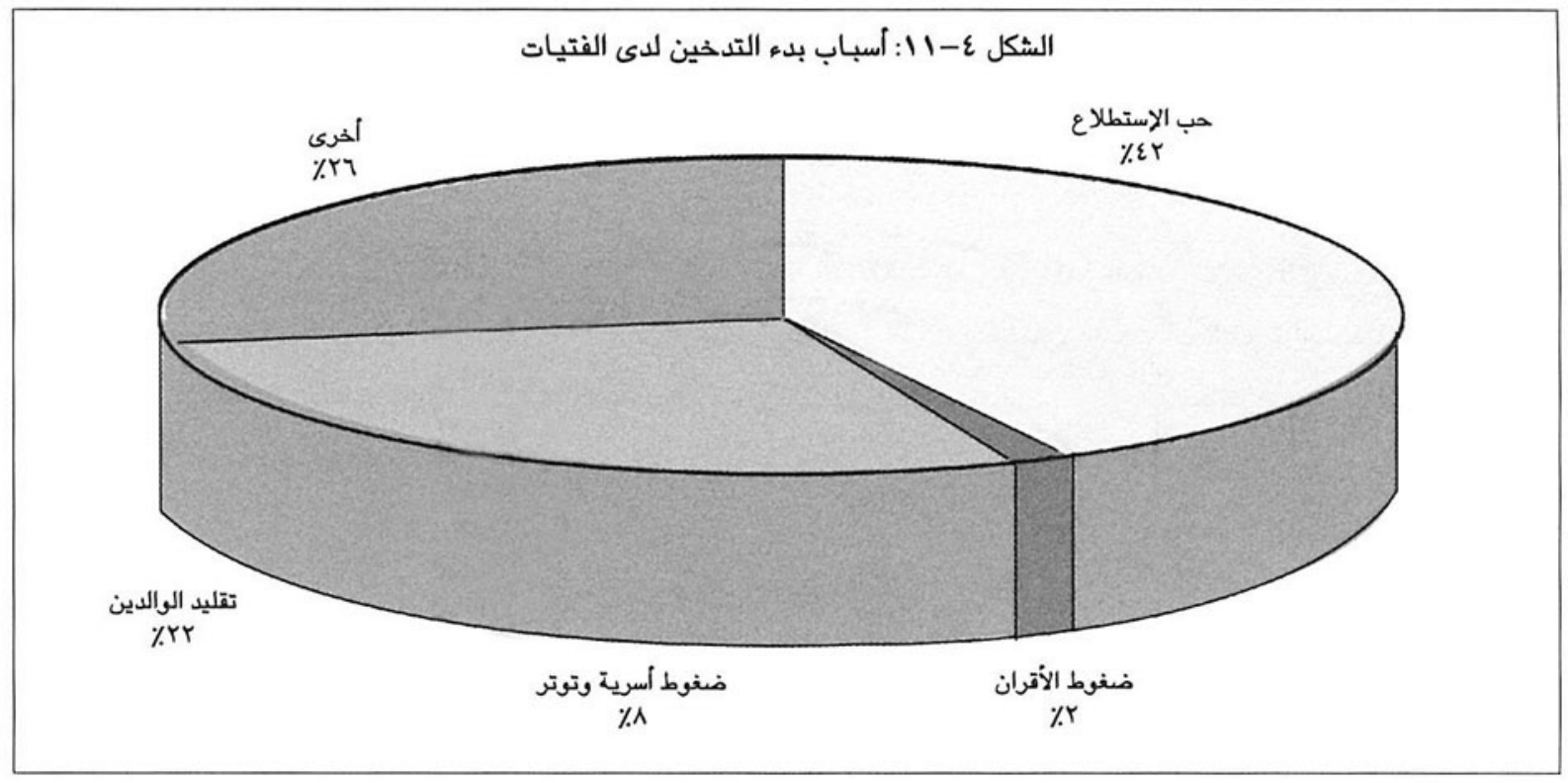

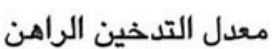

لتحديد معدل التدخين الراهن بين الفتيان الذين ذكروا أنهم يدخنون، سئل النشء السؤال التالي: "كم عدد ما دخنته من سجائر

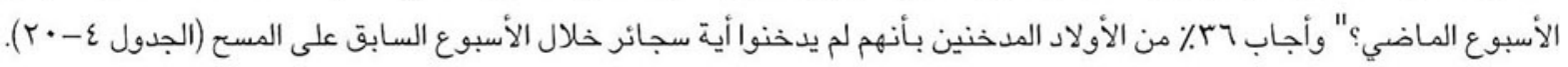

\section{الجدول ع- •r: نسب التوزيع المنوية اللتدين في الوتت الراهن بين الفتيان}

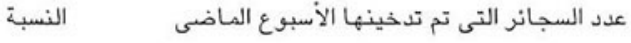

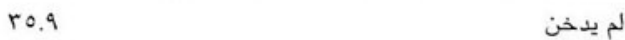

17.1

$r \cdot 1$

11.0

$10 . \mathrm{V}$

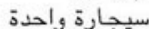

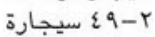

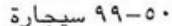

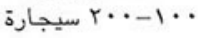

\begin{tabular}{|c|c|c|}
\hline (S) & \multicolumn{2}{|c|}{ الجدول ع- ا : تدخين الأبوين } \\
\hline إجمالى العدد & نسبة المدخنين & الانتشار الكلى \\
\hline rir & ri.v & \\
\hline & & النوع \\
\hline rTVE & $0 \wedge .9$ & ذكر \\
\hline rara & $1 . \varepsilon$ & أنثى \\
\hline $177 \varepsilon$ & & مدة التدخين \\
\hline & $r . r$ & >0 سنوات \\
\hline & $\varepsilon .7$ & ه-9 سنوات \\
\hline & $1 r .1$ & •ر-أا سنة \\
\hline & ir.r & 19-19 سنة \\
\hline & 7า. & > > $r$ سنة \\
\hline
\end{tabular}

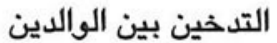

يذكر rr\% من آباء وأمهات الفتيان والفتيات الذين شملتهم

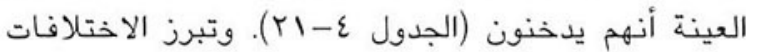

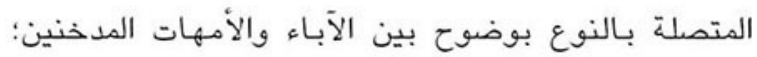

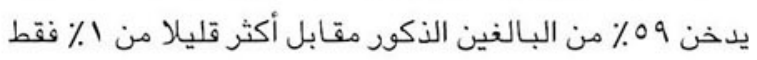

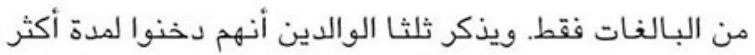

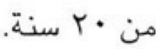

وكون أن غالبية الوالدين الذين يدخنون يذكرون أنهم فعلوا

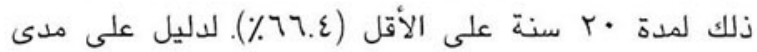

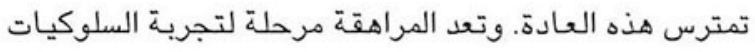

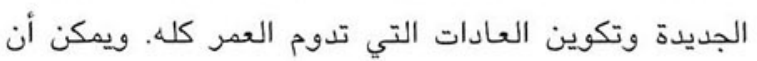

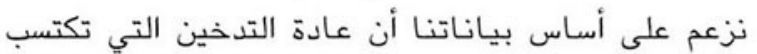

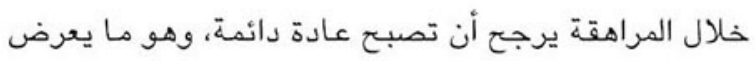

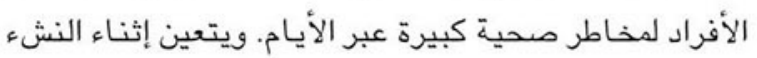
والبالغين على السواء عن التدخين من أجل تجنب التكلفة المستقبلية العالية الناتجة عنه والتي يتكبدها الأفراد والمجتمع معا. 
ويبين الجدول ع- Y Y معامل ارتباط جاماٌ بين سبّق تدخين السجائر وعدد من المتغيرات المختارة. وتؤكد النتائج على الارتباط

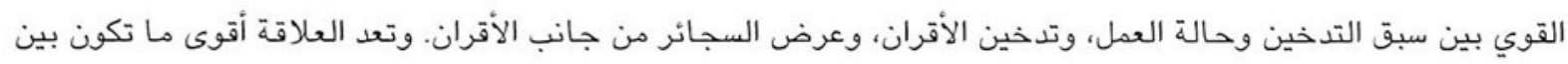

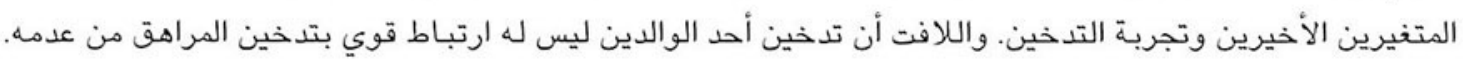

\begin{tabular}{|c|c|c|}
\hline 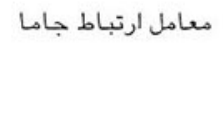 & للاستقلال أو الارتباط لاطتبار كبن & الدتغير \\
\hline - rriqu & $\because \cdots$ & الحالة العملية \\
\hline $.09 v 0 \varepsilon$ & $\because \cdots$ & ت تدخين الأقران \\
\hline$\cdot .71711$ & $\because \cdots$ & تشجيع الأقران بعضهج البعض على التدخين \\
\hline$\because \cdots 9 \leqslant q$ & $\cdot$ vo & تدخين أولياء الأمور \\
\hline
\end{tabular}

\section{رابعا: الصحة العامة}

\section{مفاهيم النشء لحالته الصحية الحالية}

خلال فترة المراهقة يمكن أن يؤدي حدوث تطور نفسي كبير والتغيرات في العلاقات الشخصية والنضج البدني إلى التأثير على

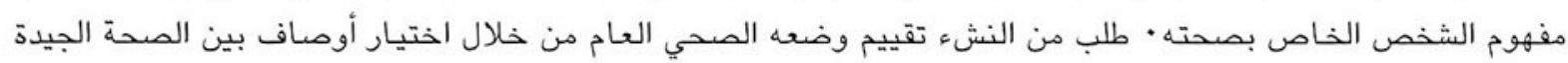

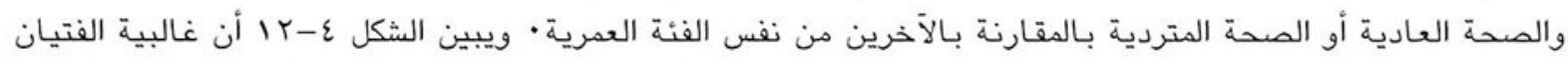

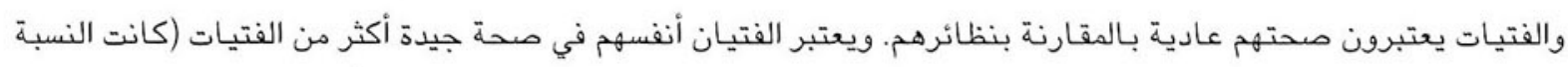

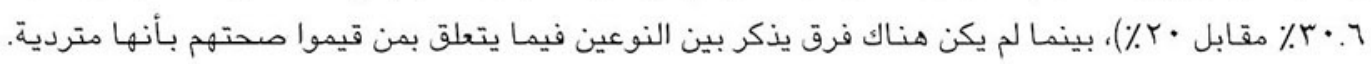

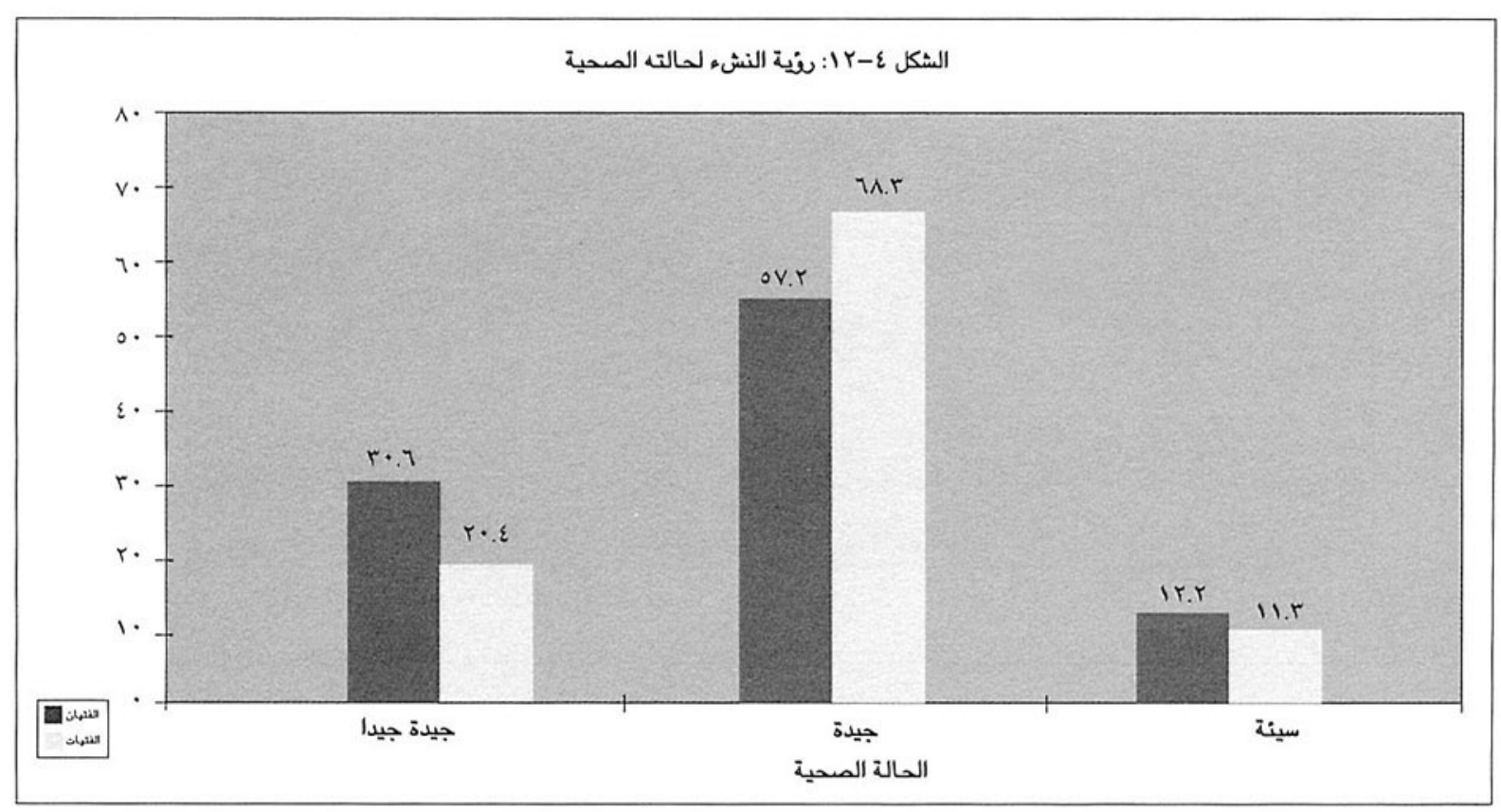

" صلة جاما هى الإدارة الاحصانية الملانمة لاختبار الارتباط بين متغييرين رمزيين، وتبين هذد الادات حجم وإتجاد العلاقة بين المتغيرين. 


\section{مفهوم النشء لمشاكله الصحية}

يمكن أن تؤثر المشاكل الصحية التي تقع خلال فترة المراهقة على التذذية والرفاهية العامة. وقد تكون بعض المشاكل الصحية

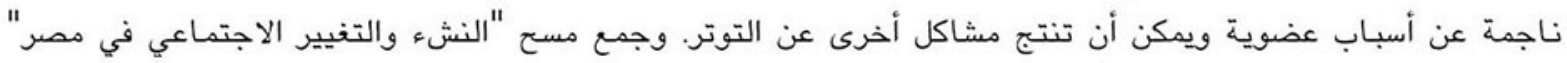

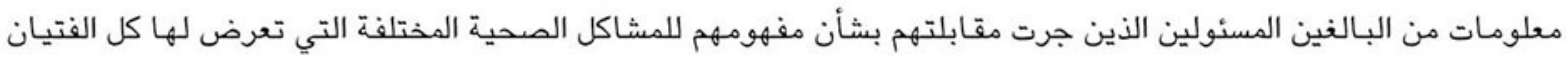

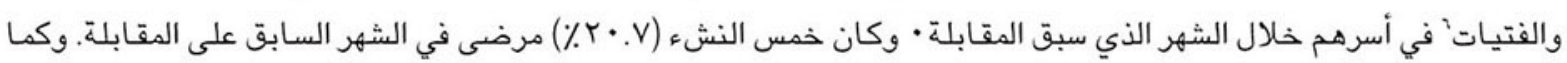

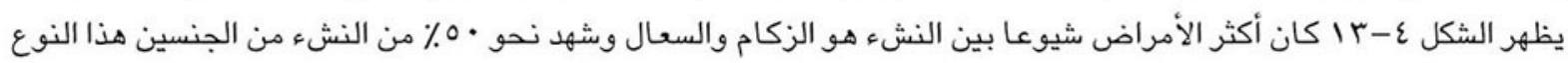
من الأمراض خلال الشهر السابق على المقابلة.

ومن الشكاوى الشائعة الأخرى أوجاع البطن والشكوى من اضطرابات المعدة والأمعاء والإبصار والسمع وألم الأسنان والآلام

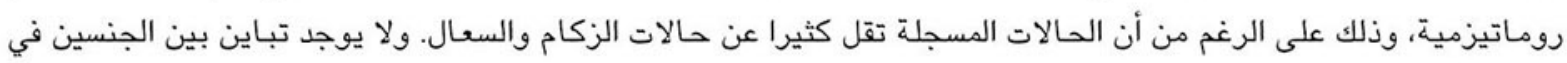

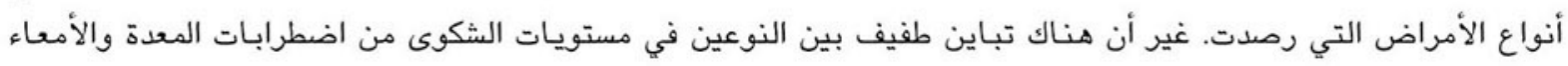

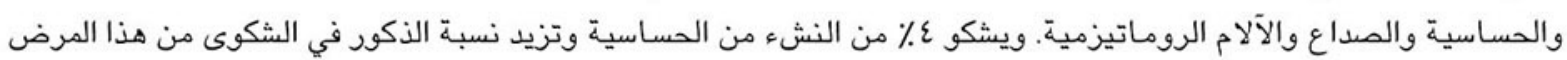

عن الإناث.

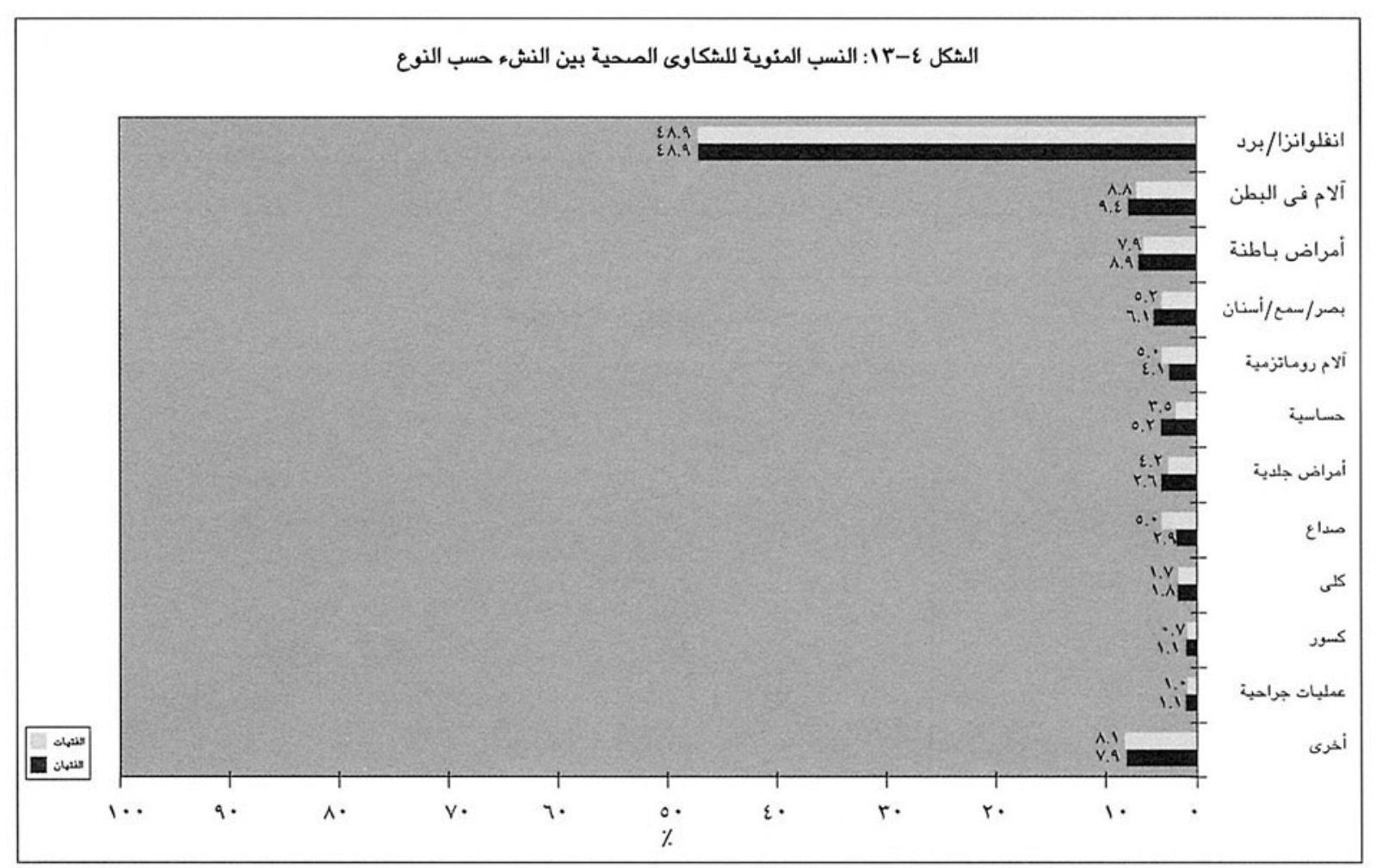

' طلب من البالغين الإفادة عن كافة المراهقين فى الأسرة لذلك فإن حجم العينة الخاصة بهذه النتانج بالتحديد تشمل كافة المراهقين فى اسر عينة المراهقين. 
تشيع الشكوى من الصداع وأوجاع البطن والآلام الروماتيزمية (آلام المفاصل) بين النشء. وريما يكون السبب في هذه الشكوى

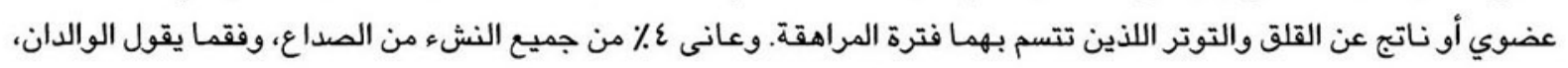

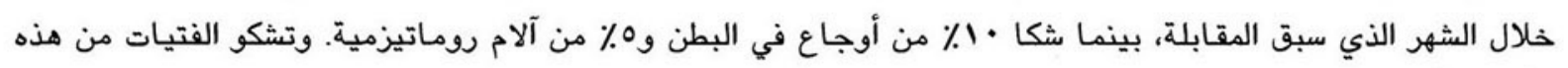

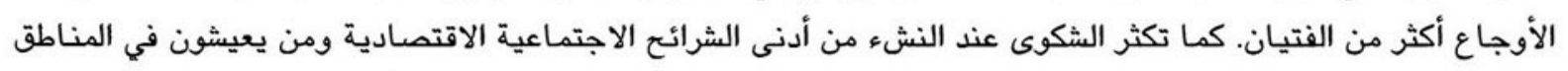

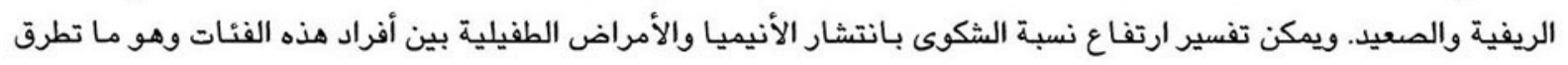
إليه هذا الفصل قبل ذلك.

\section{مفهوم الاعاقة والأمراض المزمنة}

إن الإعاقة قد تتدخل في أمور الحياة العادية. يمكن أن يتدخل ضعف الإبصار واضطرابات السمع والتخاطب والتخلف العقلي

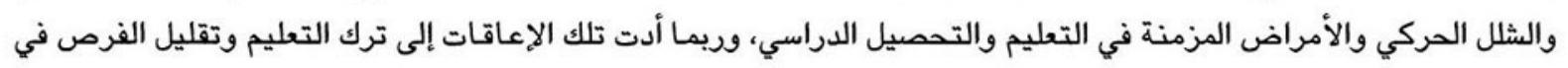

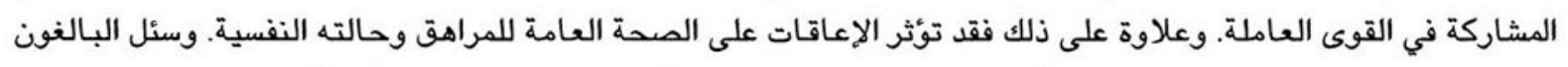

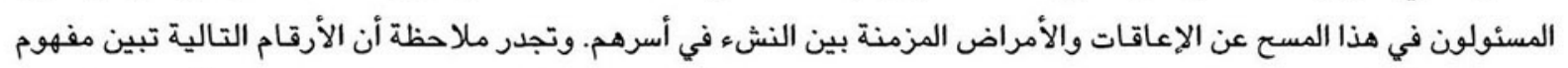

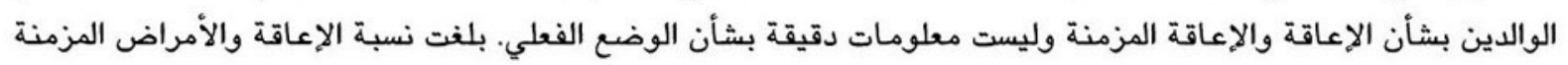

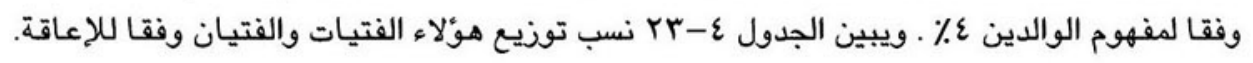

الجدول ع-rr: النسب المئوية لتوزيع الفتيات والفتيان اذين افاد أبواهم أنهم معاقون، وفقا لنوع الإعاتة أو المرض

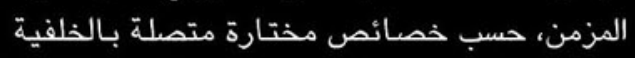

\begin{tabular}{|c|c|c|c|c|c|c|}
\hline إجمالى العدد & التخلف & الأمراضة & الأطرافة & التخاطب & الابصار & المتغيرات الخلفية \\
\hline 779 & $7 . v$ & rา.r & $r \cdot r$ & $17 . \varepsilon$ & rq.V & التوزيع المنوي \\
\hline rar & v.r & ro.r & rr.e & iv. & $r V . \varepsilon$ & الفتيان \\
\hline rAT & 0.9 & rV.T & IV.o & $10 . \mathrm{V}$ & rr.q & الفتيات \\
\hline rro & 0.1 & rr.e & $17 . \varepsilon$ & rr.V & rr.l & $1 r-1$. \\
\hline YIq & V.A & $r \varepsilon, Y$ & r.. & $1 \cdots$ & r. & $10-1 r$ \\
\hline rro & ר.V & rr.V & $r \varepsilon$. & $17 . \varepsilon$ & $r \cdot r$ & $19-17$ \\
\hline & & & & & & الوضع الاقتصادى/ الاجتماعى \\
\hline rYY & $0 . \varepsilon$ & $r r . \varepsilon$ & ra.r & 19.1 & rr.l & منخفض \\
\hline$r \varepsilon v$ & $\Lambda .1$ & rq.7 & IA.r & Iv. & rV.I & متوسط \\
\hline$r \cdot \cdot$ & 1.0 & ro. & '乏. & ir. & $\varepsilon 1.0$ & مرتفع \\
\hline irv & 0.0 & $r \cdot v$ & ro.r & A.V & $r 9.1$ & المحافظات الحضرية \\
\hline$r \cdot r$ & A. 0 & ro.V & IN.Y & 10.7 & ri.9 & وجه بحرى \\
\hline rro & 0.1 & $r \varepsilon . V$ & rI.r & ri.1 & rV.Y & وجه قبلى \\
\hline ryo & V.o & rV.o & $r \cdot \varepsilon$ & $1 \cdot .7$ & rr.y & حضر \\
\hline$\varepsilon \cdot \varepsilon$ & T.r & ro. 0 & $r \cdot . \wedge$ & $r \cdot r$ & YV.Y & ريف \\
\hline
\end{tabular}


تمثل مشاكل الإبصار نحو • ب٪ من الإعاقات عند النشء. ويعاني ثلث الفتيات وما يزيد قليلا على ريع الفتيان من هذه المشكلة.

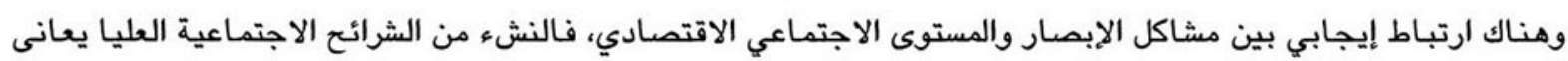

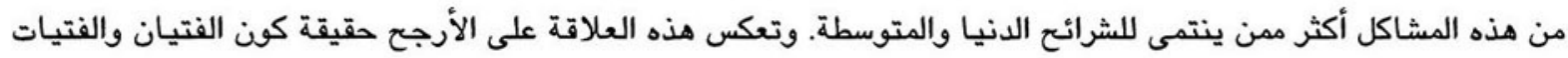

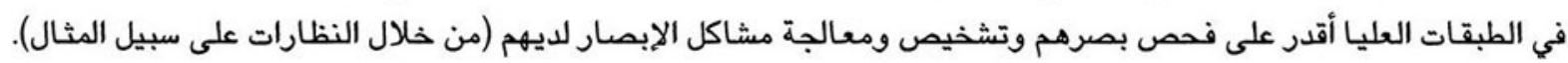

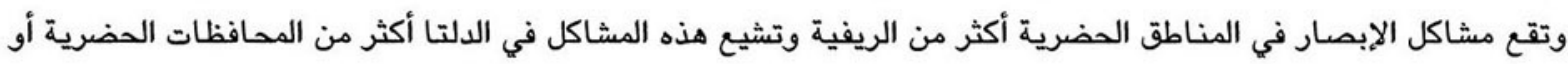

وتصل نسبة اضطرابات السمع والتخاطب التي رصدت بين النشء في مصر الذى يعانى من الاعاقة إلى 17 ٪ـ. وتوجد علاقة

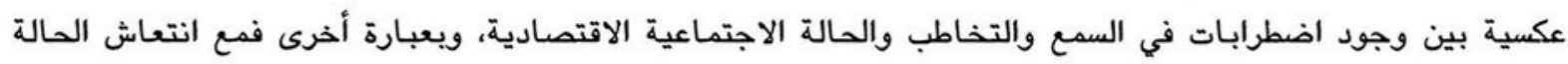

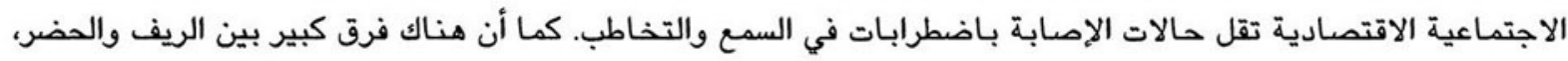

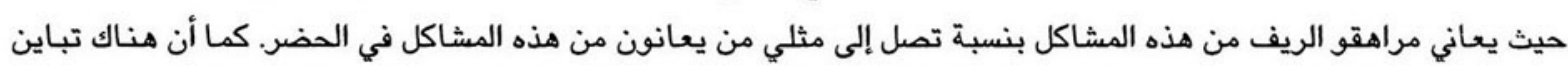

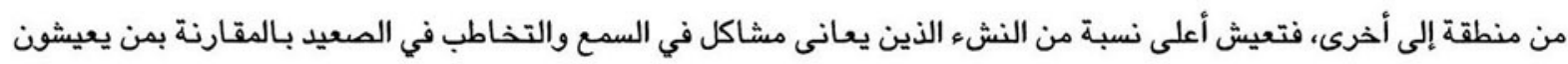

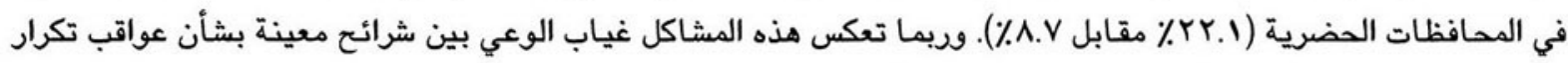

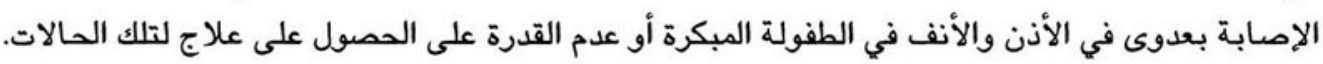

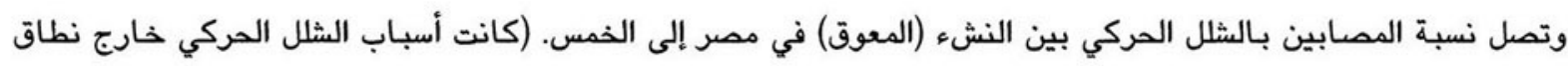

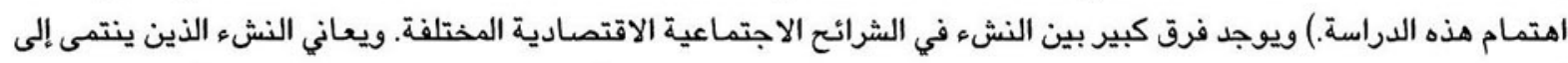

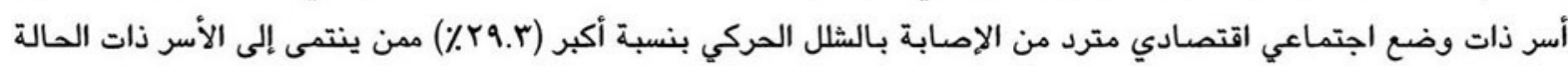

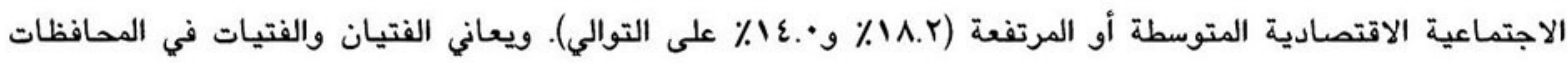

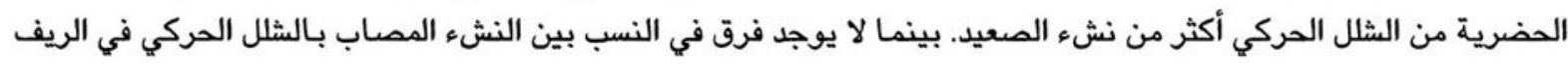
والحضر.

وتشكل نسبة الإصابة الأمراض المزمنة كالسكري وحالات الكلى والقلب المزمنة \ب٪ من الإعاقات المرصودة بين النشء. ويعاني النشء من الشريحة الاجتماعية الاقتصادية الوسطى وفي الاضكية المحافظات الحضرية أكثر من هذه الأمراض.

وتشكل نسبة التخلف العقلي \٪ فقط من إجمالي الإعاقات المرصودة. ويعاني النشء من الشريحة الاجتماعية الاقتصادية

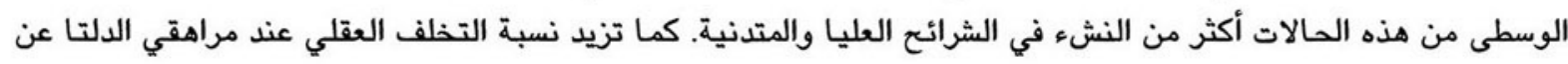
سائر النشء في المحافظات الحضرية والصعيد.

خامسا: السعي للرعاية المصية

\section{نظرة عامة على الجهات التي تقدم الرعاية المحية المتامة للنش.}

بوجه عام تقدم الرعاية الصحية في مصر من خلال أربع مؤسسات أساسية هي: منافذ وزارة الصحة؛ ونظام التأمين الصحي؛

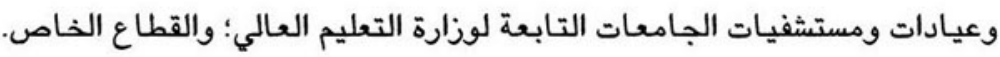

بعد صدور القانون رقم 99 لعام r99 أصبح أكثر من r ا مليون من طلاب الددارس يستظلون بمظلة التأمين الصحي وتقدم

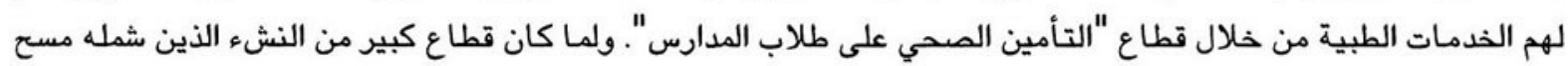


"النشء والتغيير الاجتماعي في مصر" مقيد بالمدارس حاليا فسيولي هذا الفصل اهتماما خاصا لنظام التأمين الصحي على طلاب المدارس.

ويجري ترتيب نظام التأمين الصحي على طلاب المدارس على ثلاثة مستويات هي: أطباء الرعاية الأولية والمتخصصون

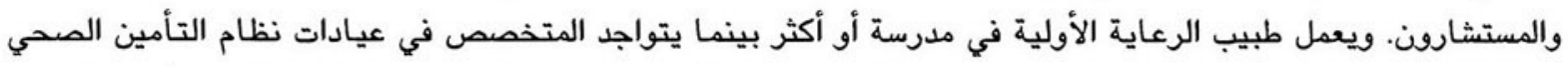

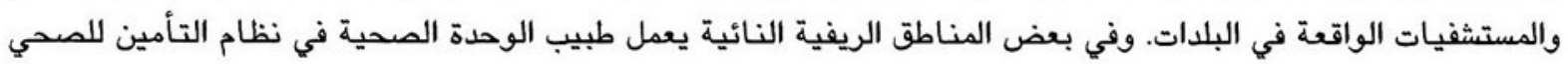

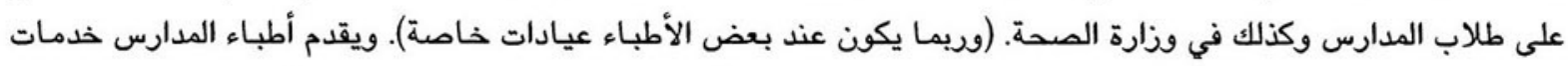

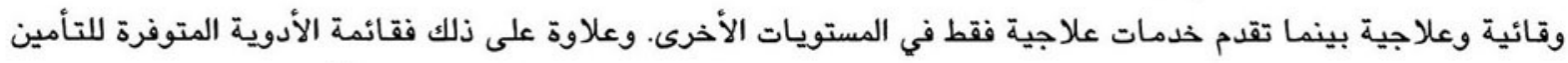

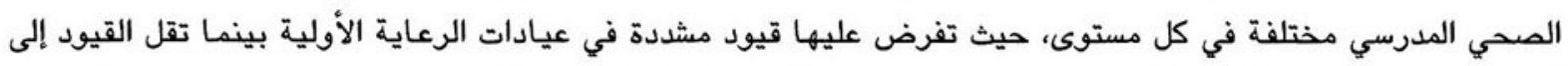

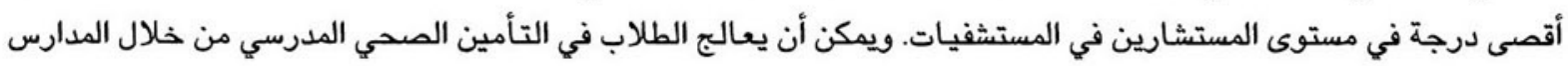

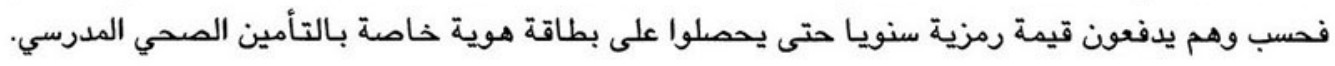

ويمكن لجميع القطاعات السكانية الحصول على الخدمات الصحية التي تقدمها وزارة الصحة من خلال مستوياتها الثلاثة.

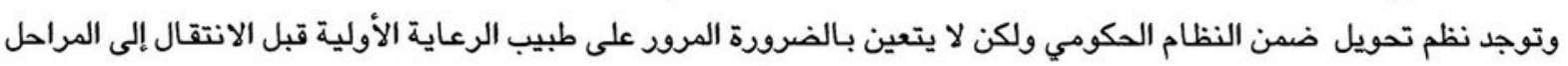

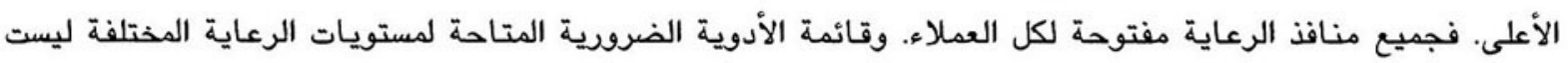

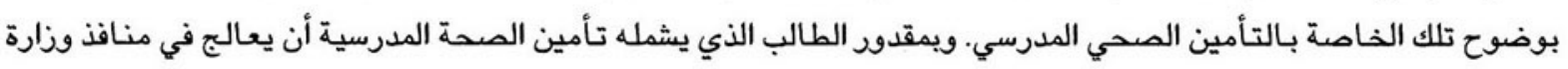
الصحة دون مقابل.

وعلاوة على ذلك فإن عيادات الجامعات والمستشفيات متاحة لجميع القطاعات السكانية. وريما يشمل التأمين الصحي

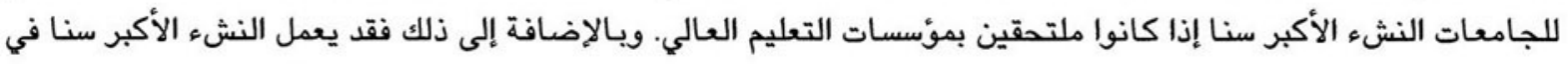
وظائف حكومية (الممرضات يعملن فور تخرجهن من معاهد التمريض الثانوية) ويذلك يشملهم التأمين الصحي للموظفين الإضين الحكوميين.

أما القطاع الخاص، فليس له بنية أو مستويات رعاية ويإمكان كل من يستطيع الدفع الاستفادة منه. ويقدم هذا الوصف المقتضب للجهات التي تقدم الرعاية الصحية في مصر إطارا لتفسير ردود الوالدين والنشء على أسئلة المسح بشأن مدى الاستفادة من الخدمات الصحية.

\section{الاستفادة من الخدمات المحية}

في الأدبيات الطبية تدرس ثلاثة جوانب للاستفادة من الخدمات الصحية هي: توفر الخدمات وإمكانية الإفادة منها والقبول

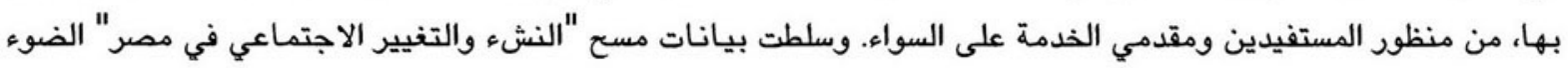
على الاستفادة من الخدمات الصحية من منظور المنتفعين من الخدمات فقط.

إن نحو ثلثي الفتيان والفتيات الذين شملهم المسح مقيدون حاليا في مدارس تقل عن المستوى الجامعي ويمقدورهم الحصول

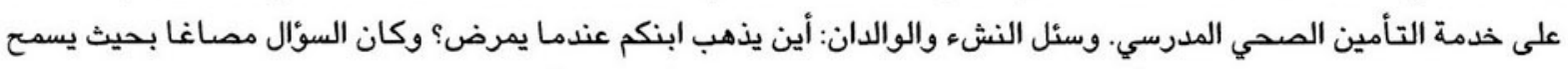

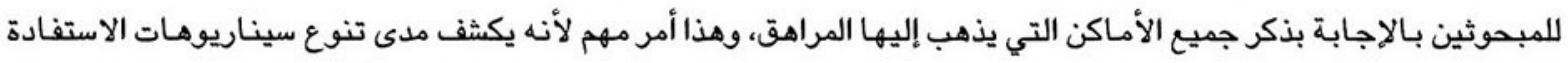
عند المنتفعين. فعلى سبيل المثال قد يذهب الطفل إلى طبيب خاص لإجية بلإكراء كشف ثم يذهب إلى التأمين الصحي المدرسي للعلاج 
أو قد يذهب إلى عيادة تابعة لوزارة الصحة ثم إلى منفذ آخر إذا لم يشف من مرضه. ويعرض الجدول ع-عن ردود الآباء بعد تصنيف كل الإجابات في أريع فئات.

\begin{tabular}{|c|c|c|}
\hline النسبة المئوية & العدد العد & \\
\hline vi.r & हाז & الخاص \\
\hline ro.r & $r \cdot 90$ & نظام التأمين المدى \\
\hline$\varepsilon 9$. . & rQAV & منافذ وزارة الصحة× \\
\hline$v$. & $\varepsilon r v$ & جمعية أهلية/ مستوصف \\
\hline
\end{tabular}

x المستشفيات الجامعية والعيادات يعتبروا ضمن منافذ وزارة الصحة

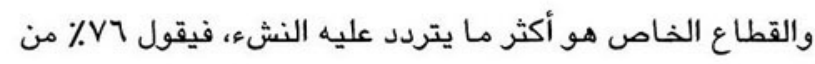

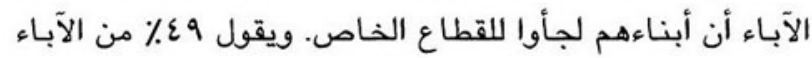

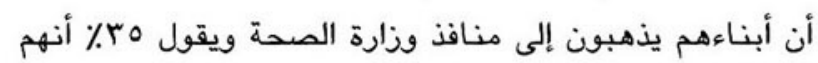

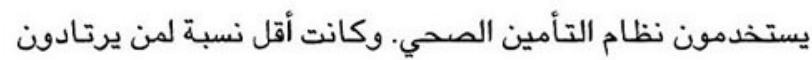

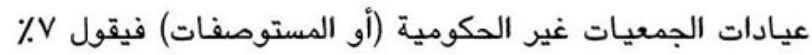
فقط من الآباء أن أبناءهم يستخدمونها.

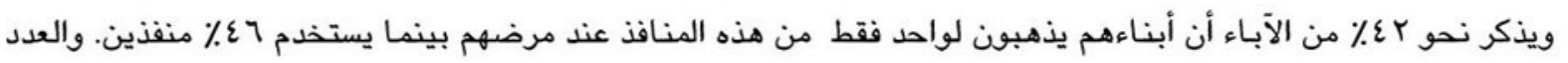

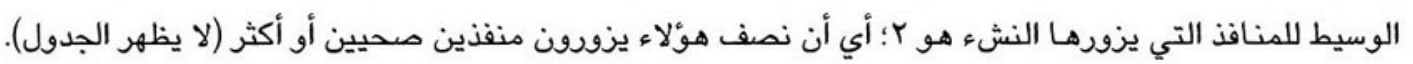

ويعرض الجدول ع-0 إن ردود الأبوين والنشء بخصوص المنافذ التي يلجأون إليها عادة طلبا للخدمة الصحية، والمنفذ الذي توجه إليه المراهق إذا كان قد أصيب بمرض في الشهر السابق على المقابلة (وهو ما يسمى الاستخدام الفعلي في هذا القسم

\begin{tabular}{|c|c|c|c|c|}
\hline \multicolumn{2}{|c|}{ 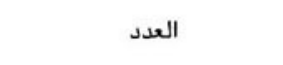 } & \multicolumn{2}{|c|}{ استجابة أولياء الأمور } & \\
\hline الأخرض & عادة & الأخرض & 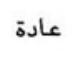 & \\
\hline & & & & إلى أين ذهبت؟ \\
\hline$r \varepsilon . r$ & T\&.o & $\varepsilon 1 . q$ & vo.r & طبيب خاص/ مستشفى \\
\hline 0.1 & $1 . v$ & r. 1 & $17 . r$ & طبيب المدرسة \\
\hline 11.r & $r r$. & Ir.A & $r \varepsilon .0$ & نظام التأمين الصحى \\
\hline 17.8 & $r v . \varepsilon$ & 1ध. & rr.q & عيادة حكومية أو مستشفى \\
\hline$\because$ & $\cdot r$ & .1 & $\cdot \varepsilon$ & مراكز رعاية الأمومة والطفولة \\
\hline v.r & 17.1 & 1.0 & IE.A & وحدة صحية ريفية \\
\hline$r .7$ & $0 . r$ & r. & 7.9 & عيادة تابعة لمنظمة أهلية \\
\hline. .0 & $r .1$ & .9 & $r . \cdot$ & عيادة بمقر عمل أولياء الأمور \\
\hline $0 . r$ & $r \cdot \cdot$ & A. 1 & 1.7 & 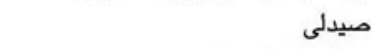 \\
\hline$\cdot . \wedge$ & $\cdot .7$ & i.r & $\cdot \varepsilon$ & معالجين شعبيين \\
\hline $19 . r$ & $\because$ & v. & $\cdot v$ & لم يذهب إلى أى مكان/ لم يستشر أحد \\
\hline
\end{tabular}

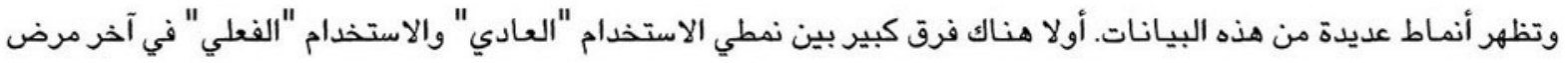

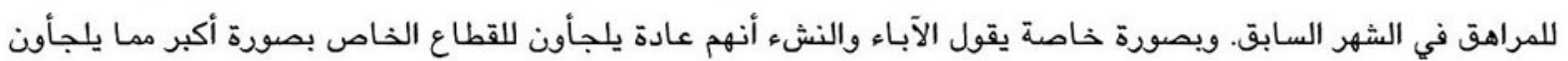

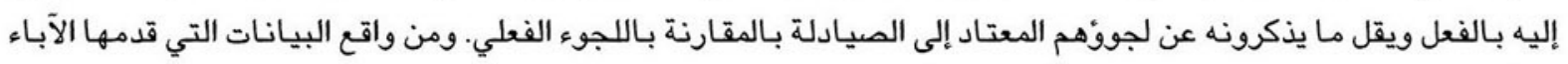

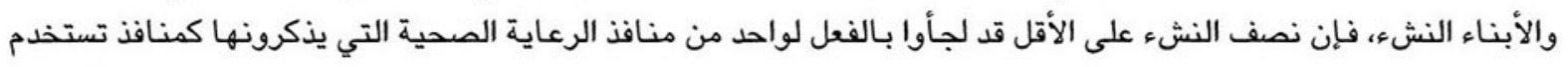

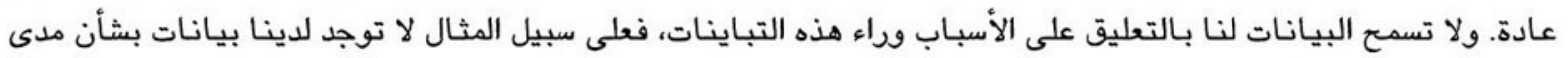

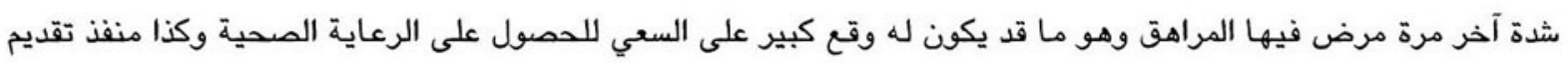

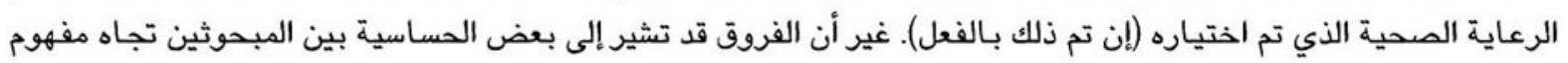

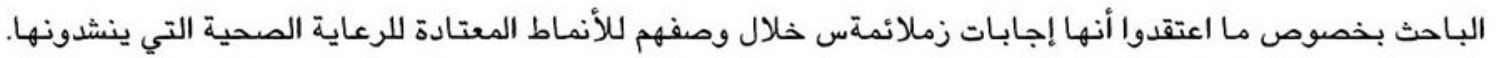


ويالنسبة للاستخدام الفعلي للخدمات فهناك اختلاف شاسع بين الأنماط المستخدمة في إجابات الآباء والأبناء. ويميل الآباء

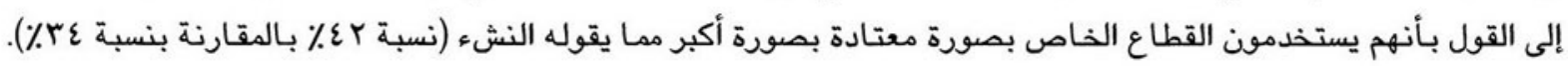

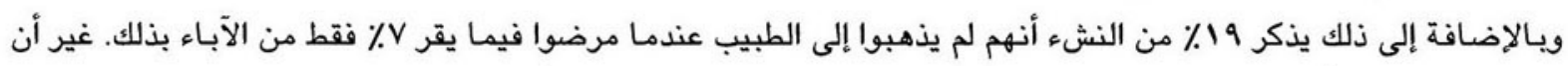

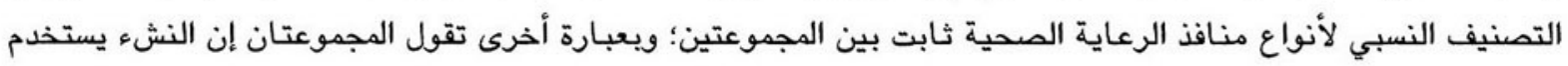

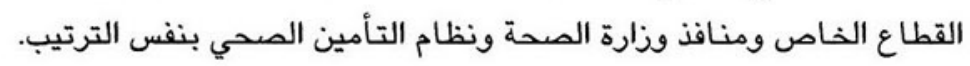

وفي الحالات التي انطبق عليها ذلك، وجه المسح أسئلة للآباء بشأن الاستفادة من الخدمات الصحية إذا كان عندهم أكثر من ابن

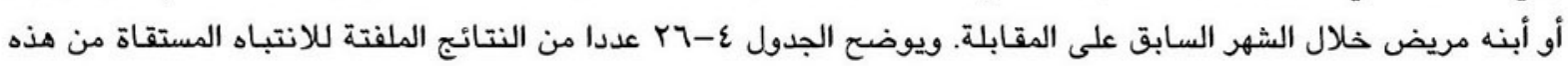

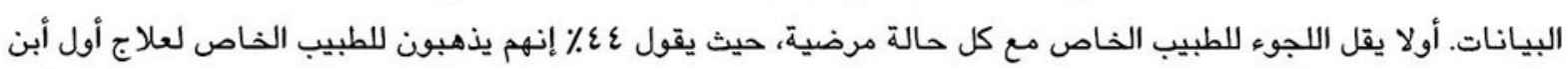

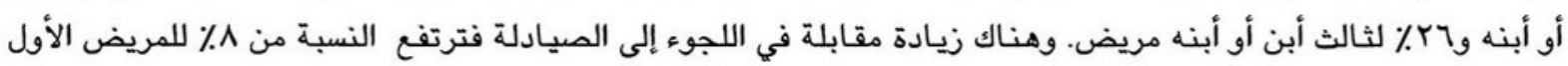

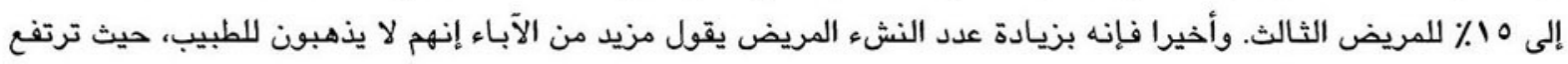

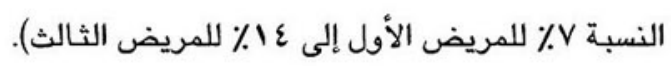

\begin{tabular}{|c|c|c|c|}
\hline \multicolumn{3}{|c|}{ الابن/الابنة } & \multirow{3}{*}{ مقدم الخذمة } \\
\hline الثالث & الثانى & الأول & \\
\hline $1 \cdot r=\dot{u}$ & $\varepsilon \vee 0=\dot{u}$ & rEro $=\dot{\dot{u}}$ & \\
\hline$r 0.1$ & rr.q & $\varepsilon \varepsilon . \varepsilon$ & طبيب خاص/ مستشفى \\
\hline$\varepsilon . \Lambda$ & ז. & r.q & طبيب المدرسة \\
\hline 10.1 & IE.Y & Ir.A & نظام التأمين الصحي \\
\hline $1 \cdot r$ & Iध.q & ir.v & عيادة حكومية أو مستشفى \\
\hline$\because$ & $\cdot r$ & $\because$ & مراكز رعاية الأمومة والطفولة \\
\hline $\mathrm{v}$. & $\pi$ & 7.7 & وحدة صحية ريفية \\
\hline r.A & r.A & r. & عبادة تابعة لمنظمة أهلية \\
\hline 1.7 & r. & $\cdot v$ & عيادة بمقر عمل أولياء الأمود \\
\hline IE.० & $1 r .1$ & V.V & صيدلى \\
\hline 1.1 & $\because$ & $\because$ & ممرضة \\
\hline r.v & $1 . \varepsilon$ & 1. & معالجين شعبيين \\
\hline IE.r & $\Lambda .9$ & 1.0 & لم يذهب إلى أى مكان/ لم يستشر أحد \\
\hline
\end{tabular}

ويمكن تفسير هذه المشاهدات من واقع أن الأسر الأكبر الأكثر احتياجا للرعاية الصحية قد لا تميل لإنفاق الهال على الخدمات

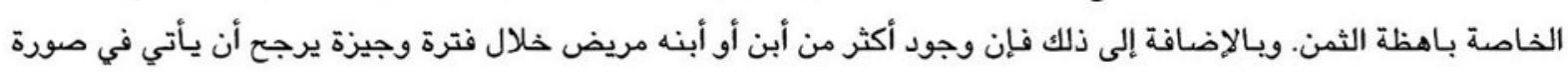

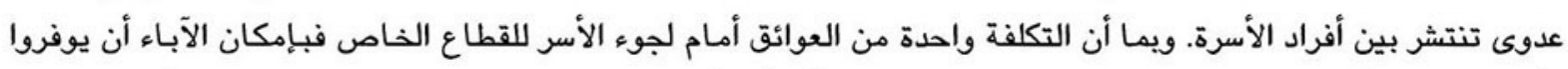

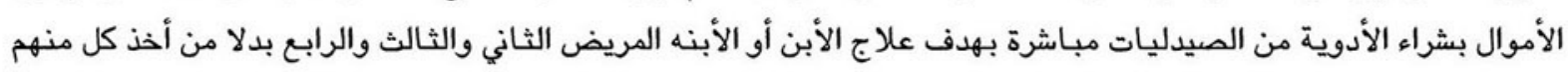
إلى الطبيب.

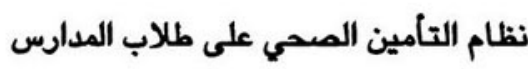

كما ذكرنا سابقا يوجد في نظام التأمين الصدي على طلاب المدارس عيادات للرعاية الأولية داخل كل مدرسة. ويتحكم عدد

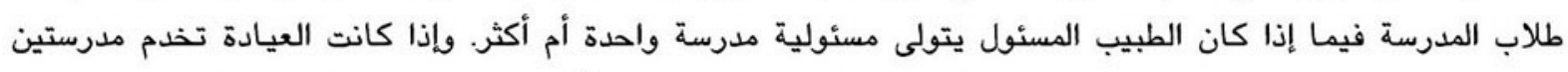

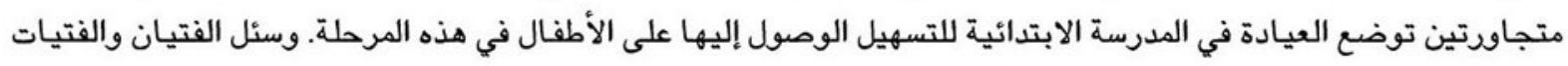

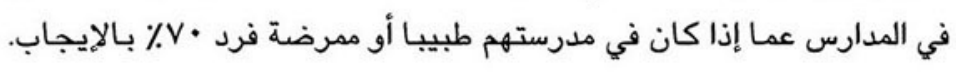




\section{كم من الفتيان والفتيات الملتحقين بالمدارس بمقدورم استخدام التامين المحي المدرسي؟}

كما ذكرنا في السابق، فإن النشء الملتحق بالمدارس يتوفر له نظام التأمين الصحي المدرسي. غير أنه حتى تتاح للطلبة

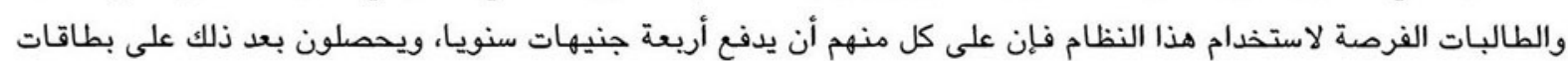

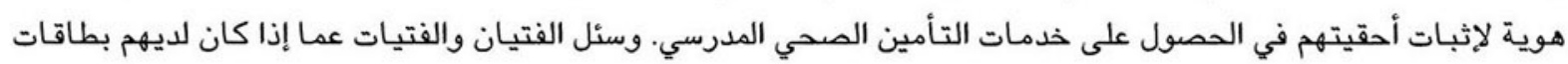

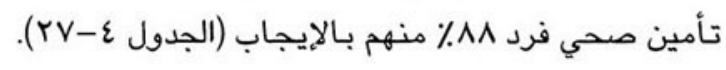

\section{الجدول ع-rv: تقارير الطلاب حول وجود طبيب أو ممرضة بالنسبة المنوية، وامتلاك بطاقة نظام التأمين الصحى على طلاب المدارس، واجراء الفحص الطبى الدورى.}

\begin{tabular}{|c|c|}
\hline الفحص الدورى المدرسى فى بداية المرحلة الاعدادية أو فى & بل تمتلك بطاقة تأمين \\
\hline بداية المرحلة الثانوية & 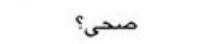 \\
\hline vo.० & $\wedge \vee . \vee$ \\
\hline re.० & ir.r \\
\hline $1 \cdots$ & $\cdots \cdot$ \\
\hline
\end{tabular}

$$
\begin{aligned}
& \text { هل يوجد طبيب أو } \\
& \text { ممرضة داخل المدرسة } \\
& v \cdot r \\
& \text { ra.A } \\
& 1 \cdots
\end{aligned}
$$$$
\text { لالإجم }
$$

وتبلغ نسبة الذين لا يحملون هذه البطاقات r ب \% وريما يعود السبب في عدم حصولهم عليها إلى عدم قدرتهم على الدفع (وهو سبب

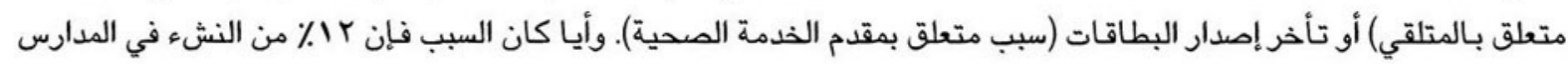
ليس بمقدوره الانتفاع من الصحة المدرسية في الوقت الذي تستهدف فيه وزارة الصحة من هذا النظام تغطية ـ . . ب٪ من الطلاب.

\section{صوايات النشء بشأن بعض الجوانب الوقاتية والعلاجية في التامين المحي المدرسي}

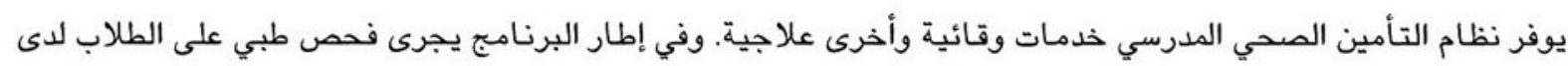

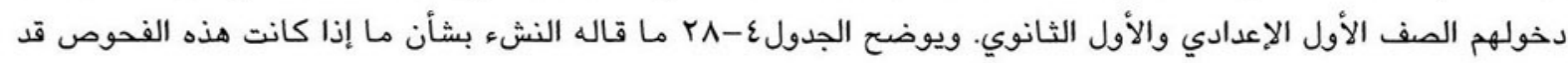

$$
\text { أجريت والإجراءات الوقائية التي جرى الاعداذي والاول الثانوي. }
$$

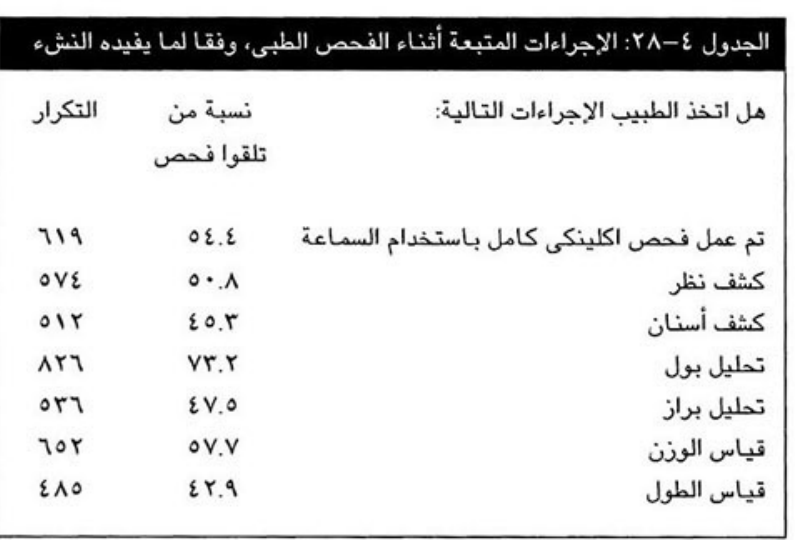

يقول ثلاثة أرياع من يحق لهم إجراء هذه الفحوص أنهم

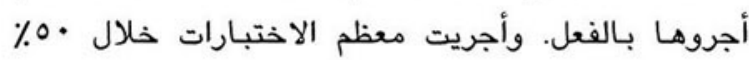

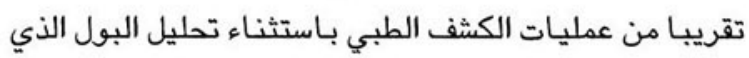

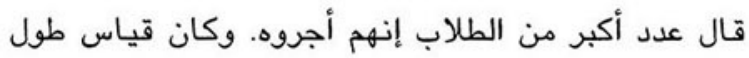

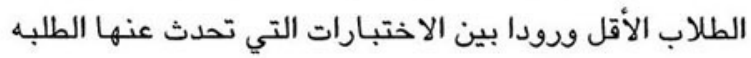
والطلبات فقال rع٪ إنه جرى قياس طولهم. وتدل هذه الأه

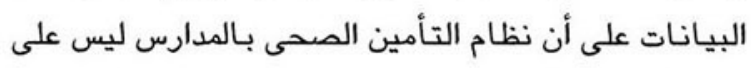

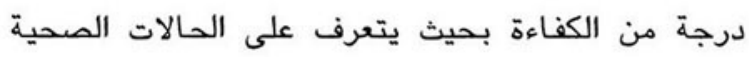

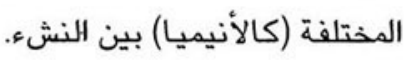

ولا تقل الخدمات العلاجية التي يقدمها التأمين الصحي المدرسي أهمية عن الخدمات الوقائية. إن تحديد مدى كثافة استخلال

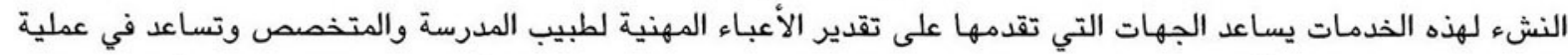

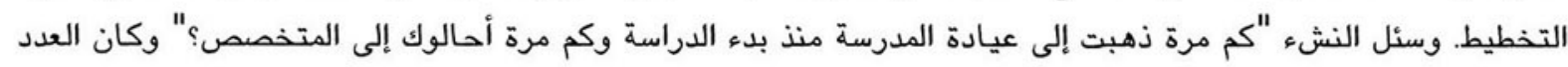

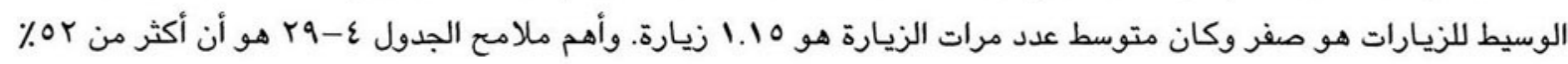

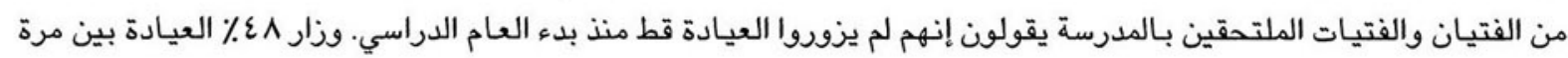
واحدة وأريع مرات منذ مستهل العام الدراسي. 
وسأل مسح "النشء والتغيير الاجتماعي في مصر" الوالدين والابناء بشأن مدى رضاهم عن الخدمات الصحية المتوفرة، كون

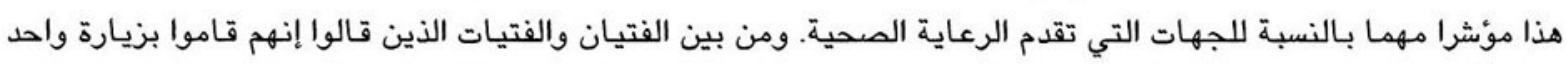

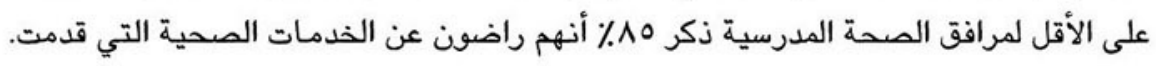

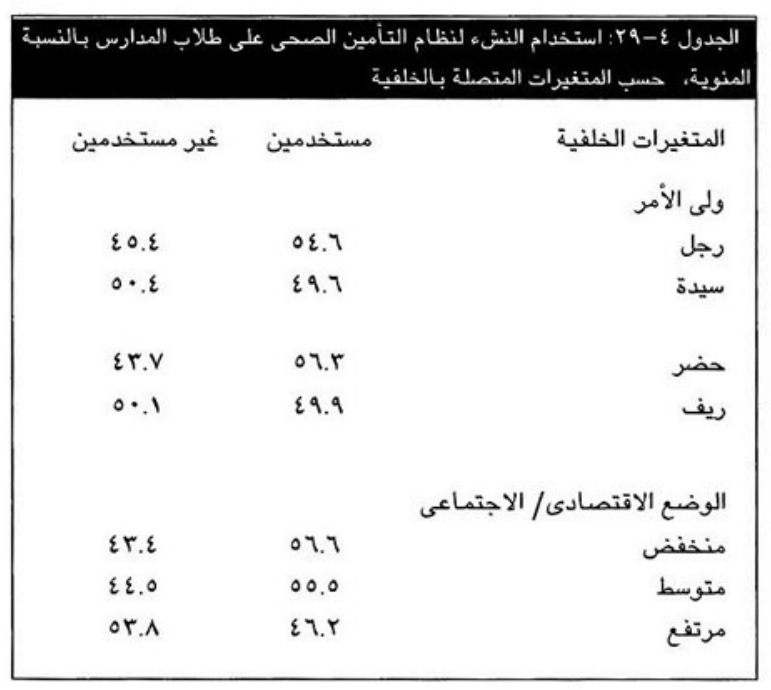

فية الوالدين للتأمين المحي المدرسي

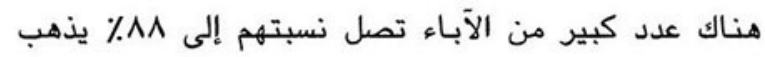

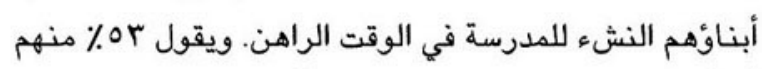
أن أبناءهم يستفيدون من نظام التأمين الصحي المدرسي.

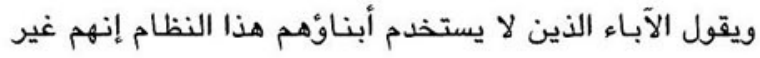

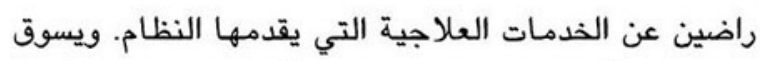

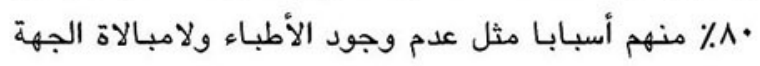

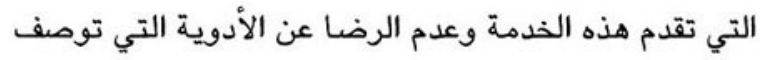
للنشء المريض وغير ذلك. ويسوق ال • ب٪ الباقون أسبابا

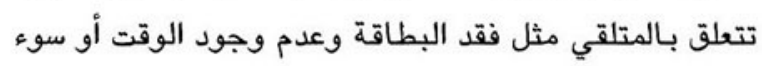
فهم الفتى أو الفتاة لحقه في استغلال النظام.

يختلف استخدام هذه النظام من عدمه تبعا لنوع ولي الأمر (ذكر أو أنثى) ونمط محل السكن والحالة الاجتماعية الاقتصادية (الجدول ع-9ج). وورد عدم استغلال النظام أكثر في ردود الأمهات وقاطني الريف والمنتمين للشريحة الاجتماعية الاقتصادية العليا.

وسئل الآباء الذين قالوا إنهم يستخدمون نظام التأمين الصحي المدرسي في علاج أبنائهم عن مدى رضاهم عن الخدمات

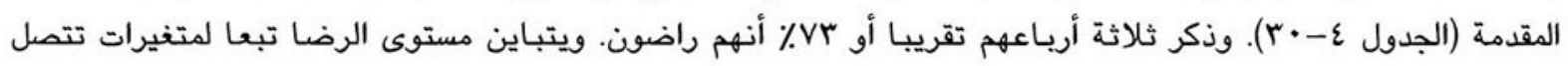

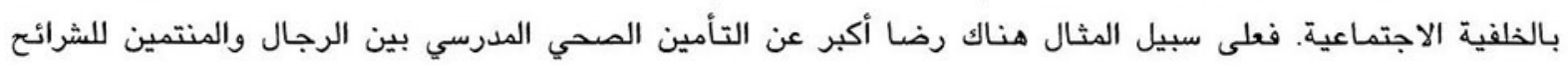

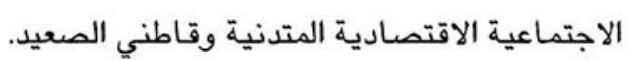

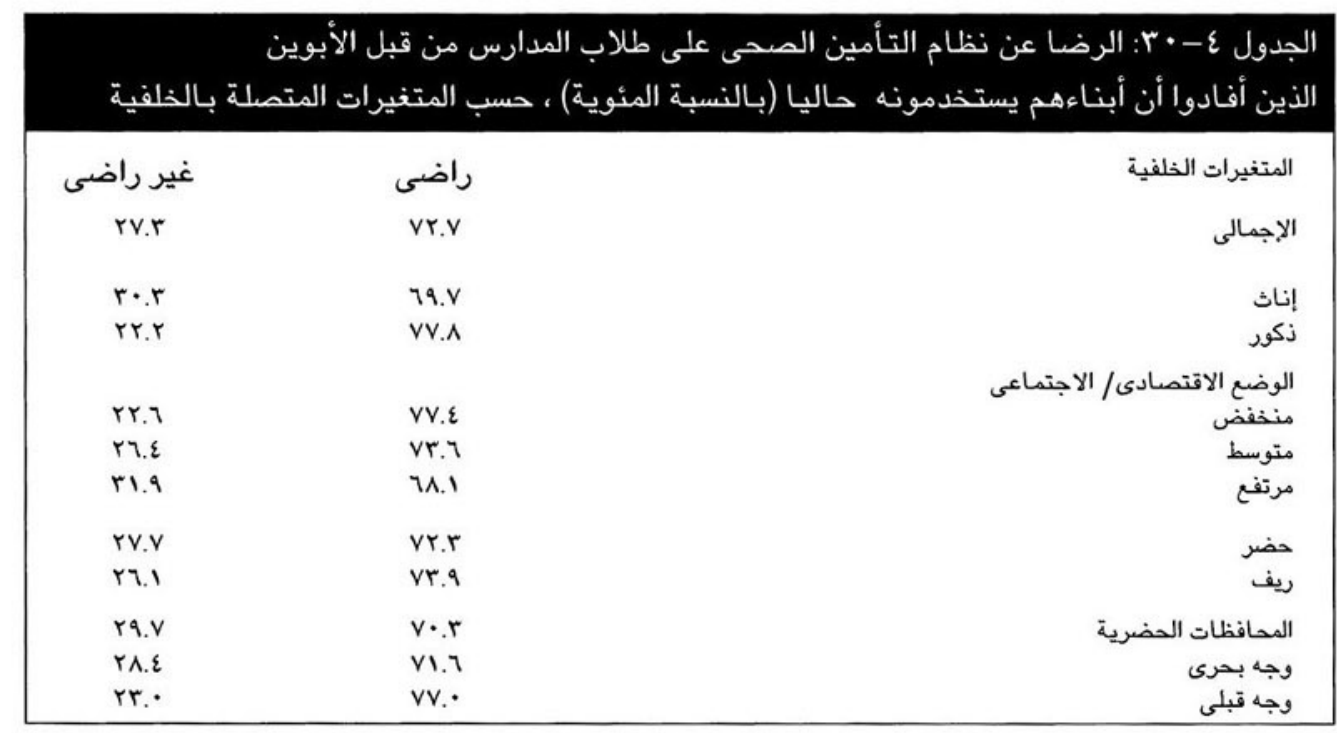


وفي المجمل فإن توافر أنواع مختلفة من الجهات التي تقدم الرعاية الصحية في السوق في غياب مظلة واحدة تضمها يؤدي إلى

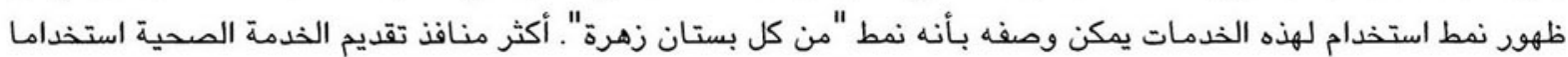

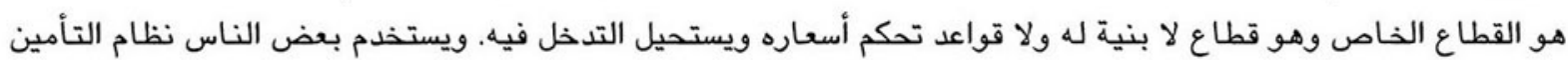

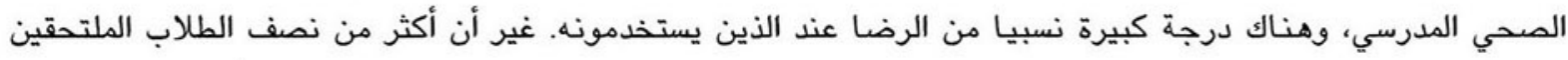

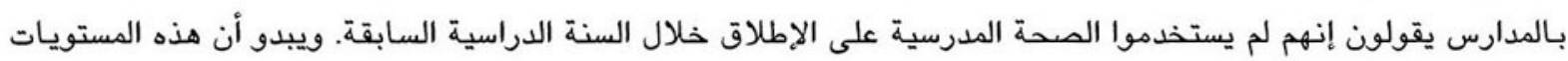

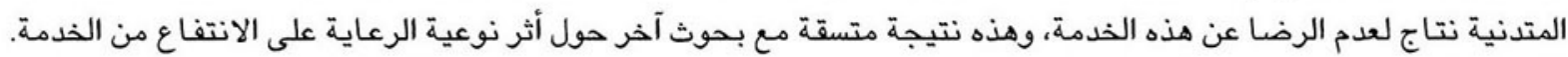

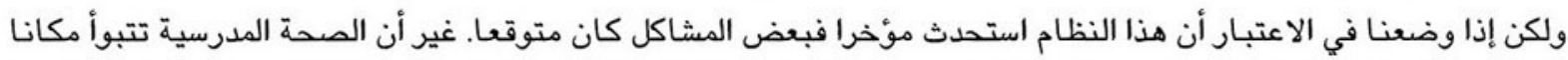

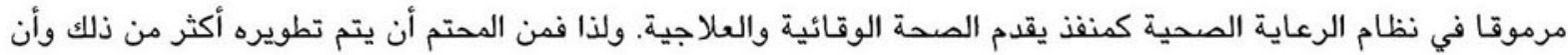

يولى مزيدا من العناية بالزيادة في نسب استخدام هذه الخدمة ورضا المنتفعين بالخدمة عنها.

\section{سادسا: الخلاصة والتوصيات}

لقد تم تجاهل النشء كفئة عمرية على نطاق واسع ويقر القليلون أن هذه المجموعة تمثل فئة عمرية لها احتياجات خاصة. وكان

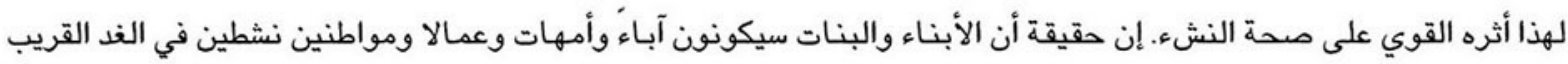

$$
\text { يجعل من سلامة صحتهم ورفاهيتهم أمرا حيويا. }
$$

تناول هذا الفصل بالتحليل بعض المحددات الرئيسية لصحة المراهق في مصر. ويشكل عام فإن جموع النشء تواجه مشاكل

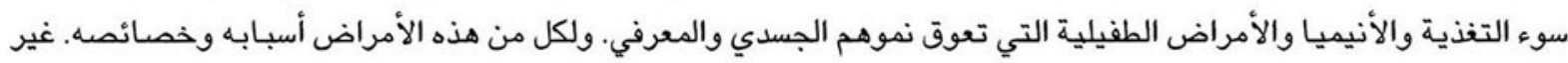

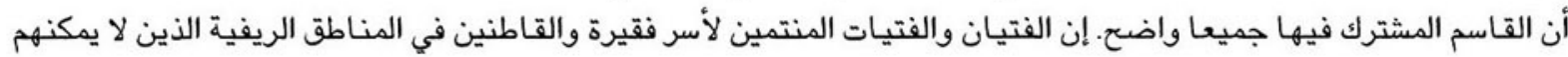

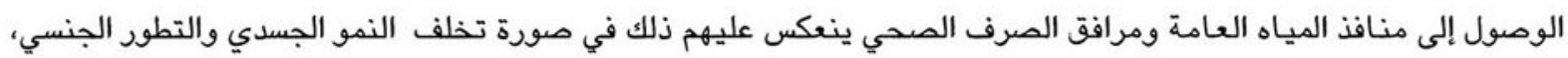

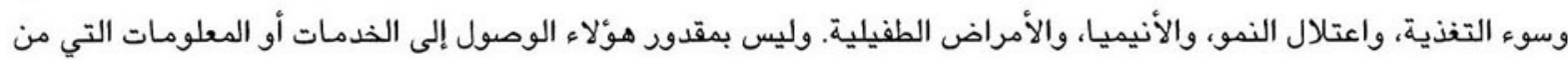

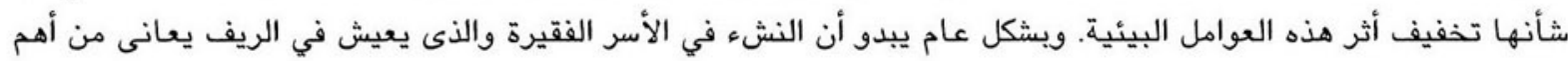
المشاكل الصحية والغذائية بين بني سنهم.

غير أن انتشار الأنيميا عبر مختلف الفئات الاجتماعية الاقتصادية يشير إلى أنه إلى جانب عدم كفاية الأغذية الغنية بالحديد

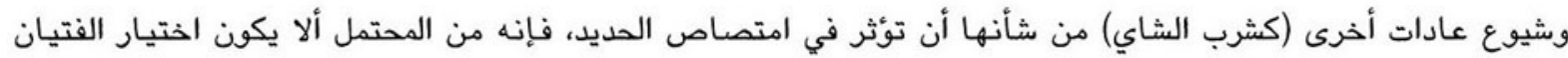

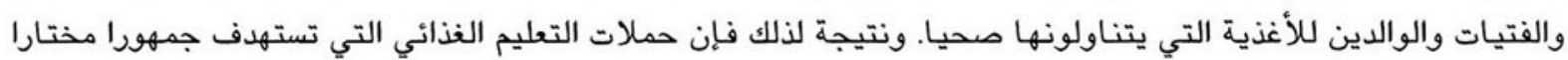

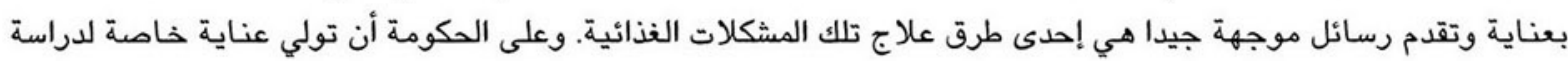

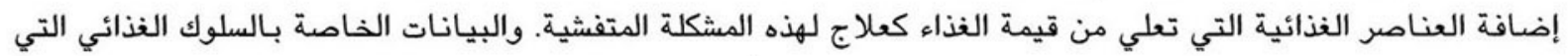

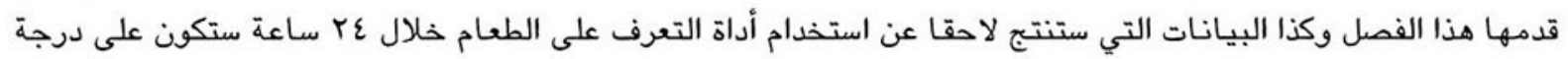
من الأهمية من أجل التعرف على الأغذية التي يمكن الإعلاء من قيمتها.

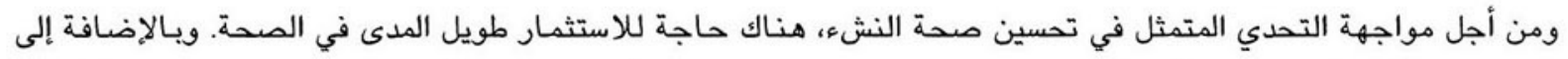
ذلك فإن الالتزام الجاد بدعم الأسر الفقيرة بهدف تحسين ظروفهم المعيشية أمر حيوي من أجل تحسين الوضع الصحي للسكان السكان. 
الفمل الخامس

\section{الصورة التعليمية العامة للنشء في مصر}

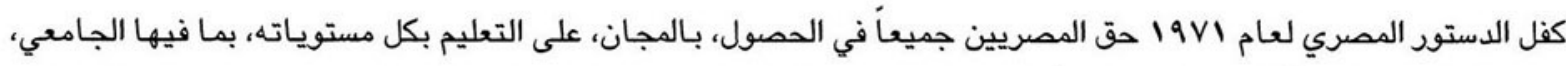

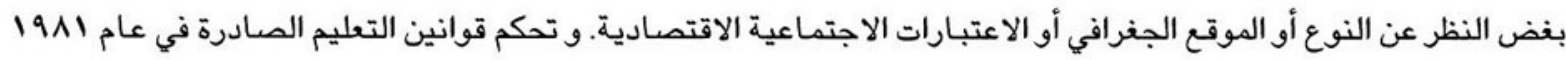

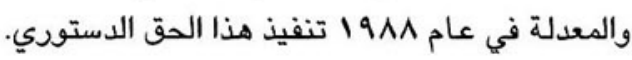

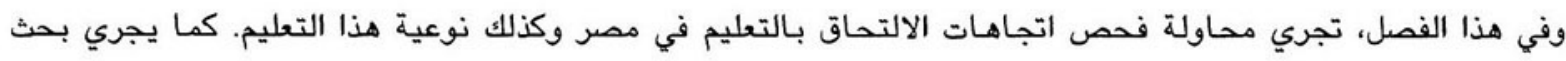

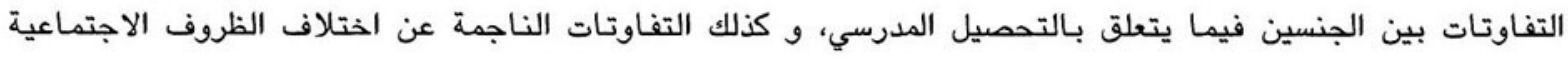

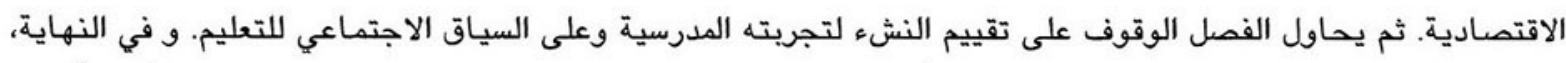

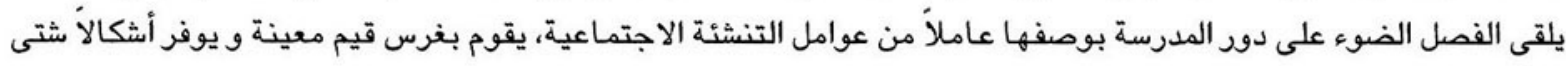
للاتصال والتفاعل.

\section{أولا: الالتحاق بالتعليم}

يتألف النظـام التعليمي قبل الجامعي في مصر من مرحلتين، مرحلة التعليم الأساسي الإلزامية (خمس سنوات للتعليم الابتدائي

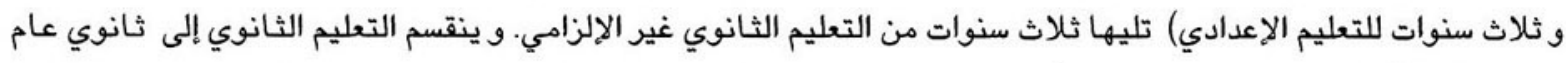

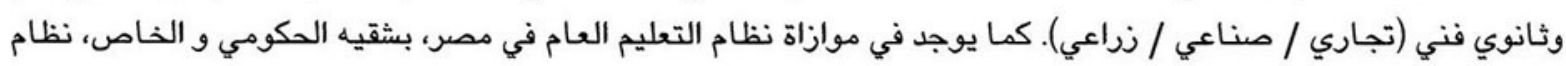

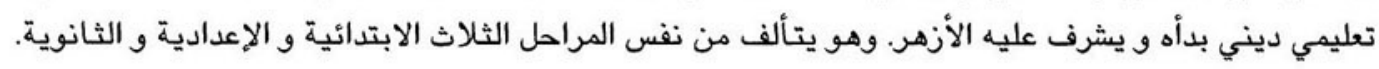

ويبين الجدول ه - 1 توزيع الأطفال والفتيات والفتيان المقيدين بالمدارس من الفئة العمرية 7 - 19 سنة في شتى مراحل

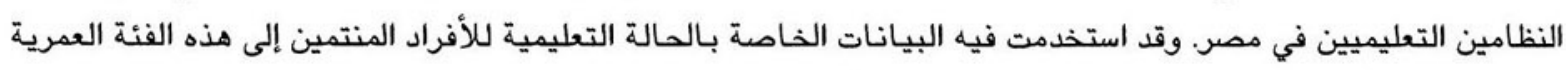

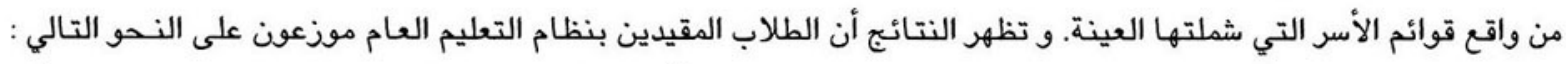

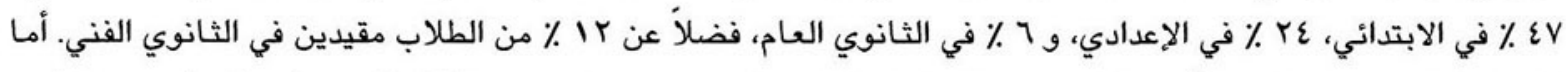

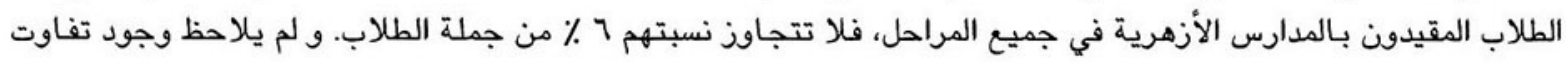
بين الذكور و الإناث. 


\begin{tabular}{|c|c|c|c|}
\hline 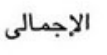 & 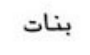 & بنين & التعليم العام \\
\hline$\varepsilon V$. & \&V.1 & $\varepsilon 7.9$ & ابتدانى \\
\hline rr.q & r६.० & rr.\& & إعدادى \\
\hline $7 . V$ & v.r & 7.1 & ثانوى \\
\hline VV.T & VA.9 & จา.ย & إجمالى التعليم العام \\
\hline$\cdots . \Lambda$ & 11.7 & ir.o & النظام التعليمي الههني الأزهرى \\
\hline$r . v$ & r. & $\varepsilon . r$ & إبتداني \\
\hline I.V & 1.0 & 1.9 & إعدادى \\
\hline$\cdot . \wedge$ & .0 & 1.1 & 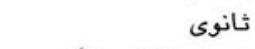 \\
\hline $7 . r$ & $\varepsilon$. & v.r & اجمالى التعليم الأزهرى \\
\hline$\varepsilon . r$ & $\varepsilon . \vee$ & r.ı & التعليم العالى \\
\hline $17 . v v \varepsilon$ & V.Vor & 9.11 & الإجمالى \\
\hline
\end{tabular}

\section{النشء المقيد بـالمدارس : القيد والاستمرار في التعليم}

تقدم لنا البيانات المستقاة من مسح "النشء والتغيير الاجتماعي في مصر" صورة مقطعية للقيد بالمدارس في العام الدراسي

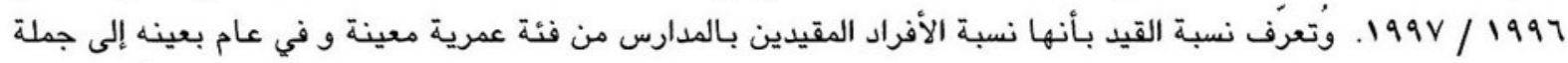

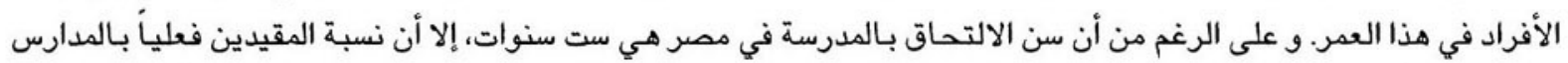

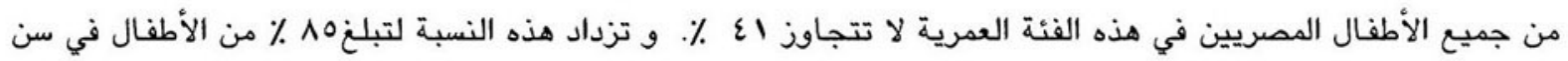

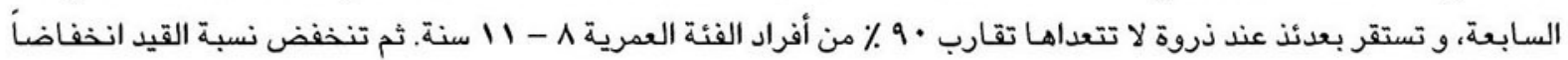

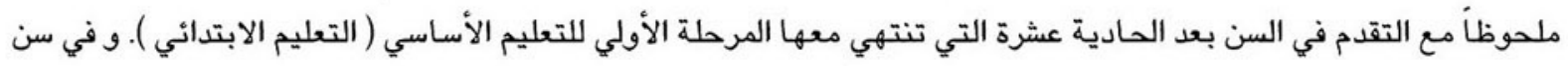
الرابعة عشرة، التي تواكب الانتقال من التعليم الإلزامي الأساسي إلى التعليم الثانوي غير الإلزامي، تبلغ نسبة المقيدين V V ٪.

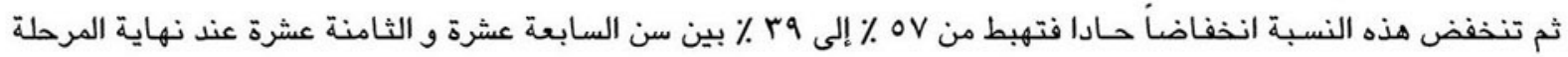
الثانوية و الانتقال إلى الجامعة.

ويسري هذا النمط للقيد بـالمدارس على كلا الجنسين في المناطق الجغرافية الرئيسية الخمس، وكذلك بين جميع الطبقات الاجتماعية الاقتصادية. لكن هناك، مع ذلك، تفاوتات واسعة في مستوى القيد. و أكثر المجموعات تضرراً هي الإناث من الفئات الاجتماعية الاقتصادية الوسطى و الدنيا، و الإنـاث في الصعيد ( في الريف والحضر على السواء ) و ريف الدلتا، و كذلك الذكور من الفئات الاجتماعية الاقتصادية الدنيا. و تؤثر الحالة الاجتماعية الاقتصادية للأسرة تأثيراً ملحوظاً على إلحاق أفرادهـا في سن المدرسة بالمدارس. إلا أن تأثير الحالة الاجتماعية الاقتصادية المتدنية للأسرة أشد وطأة بكثير على الإناث منه على الذكور.

و توضح الأشكال 0 - 1 الى 0 - ع صورة مقطعية للأفراد من الفئة العمرية 7 - 19 سنة في عام 199V. و تمثل كل نقطة على المنحنى نهاية الشوط التعليمي الذي بلغه الأفراد المنتمون لسن معينة و الذين سبق لهم الالتحاق بـالمدارس أو كانوا مستمرين في التعليم إلى وقت إجراء المسح. إن حلم الأمة في الوصول إلى تعديم التعليم قد تم تحقيقه جزئياً في المرحلة الابتدائية، حيث تفوق نسب المقيدين في المدارس الابتدائية من الذكور والإناث في المحافظات الحضرية و حواضر الدلتا وكذلك الذكور في الفئات الاجتماعية الاقتصادية العليا و الوسطى 90 \% الاعيل 

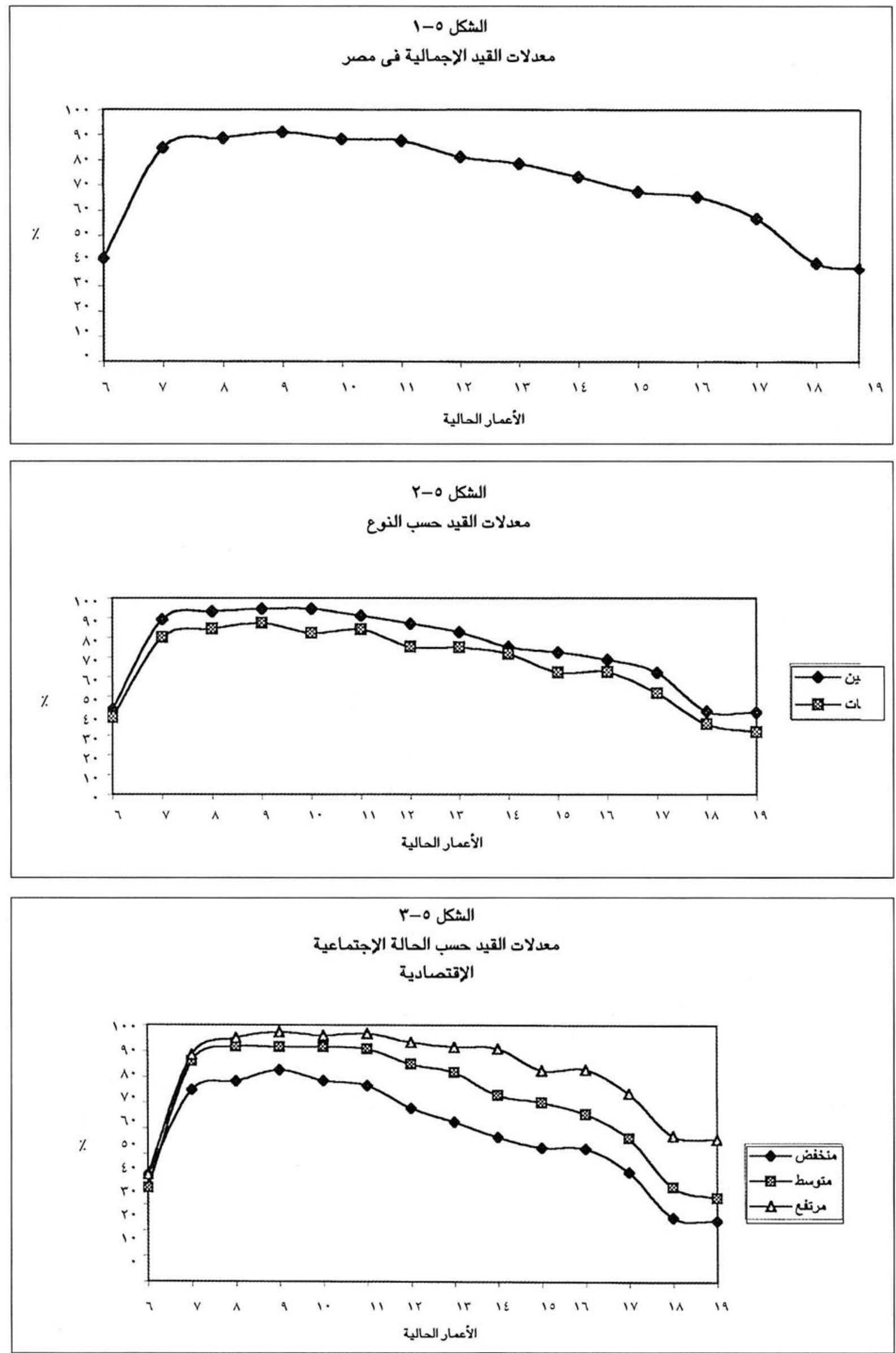


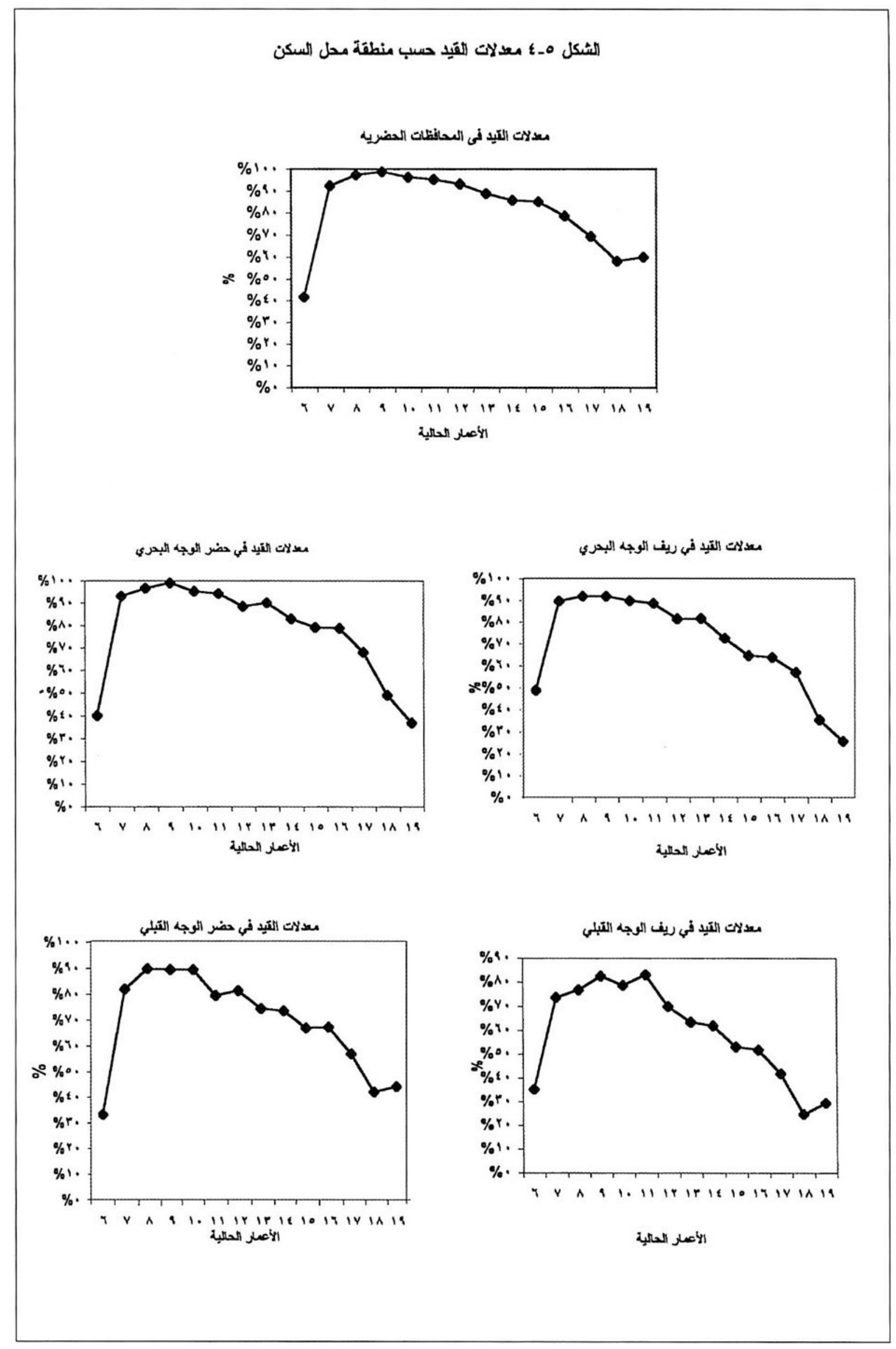


و يلقى الجدول رقم ه - r الضوء على الفجوة بين الذكور و الإناث في التعليم بمصر في السنة الدراسية 997 / 99 /

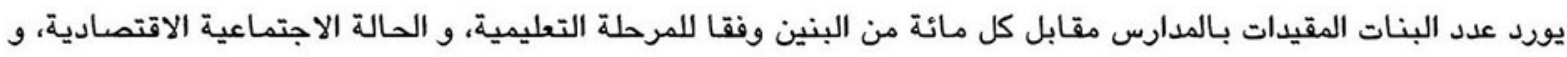

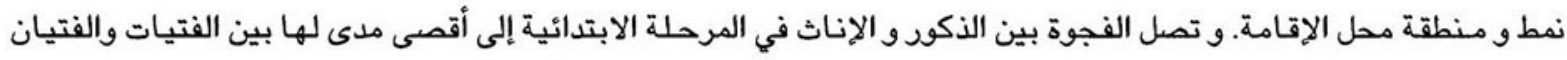

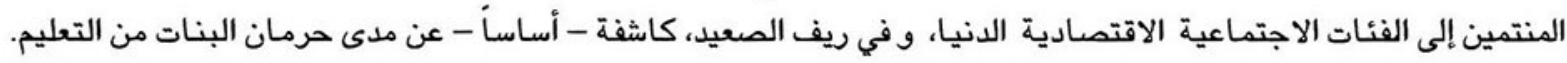

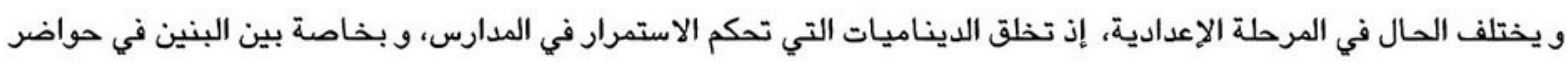

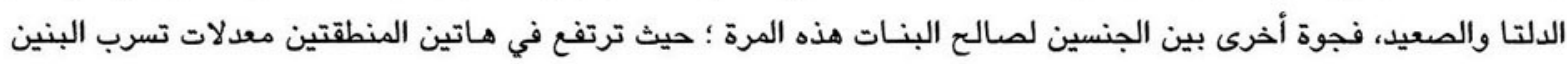

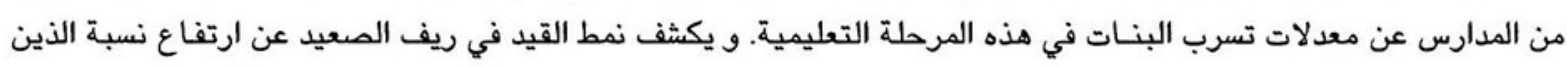

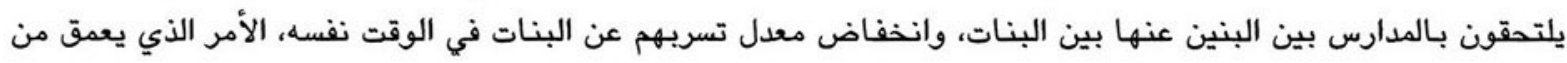
الفجوة بين الجنسين عبر مراحل التعليم المتعاقبة.

\begin{tabular}{|c|c|c|c|}
\hline الثانوى & الإعدادى & الإبتدانى & \\
\hline & & & الوضع الاقتصادى/ الاجتماعى \\
\hline 79 & vi & vi & 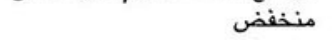 \\
\hline $\mathrm{AV}$ & qr & Ar & متوسط \\
\hline$\wedge 9$ & $9 \varepsilon$ & $9 \varepsilon$ & مرتفع \\
\hline 19 & 9 . & 90 & المحافظات الحضرية \\
\hline $1 \cdot \varepsilon$ & ir. & $9 \mathrm{~V}$ & حضر وجه بحرى \\
\hline ^^ & 91 & 17 & ريف وجه بحرى \\
\hline 1.1 & $1 \cdot 1$ & 10 & حضر وجه قبلى \\
\hline 01 & $7 \varepsilon$ & vi & ريف وجه قبلى \\
\hline Ar & $\wedge \Lambda$ & $\wedge \varepsilon$ & الإجمالى \\
\hline 1.Nor & ritir & $\varepsilon .7 \varepsilon 1$ & إجمالى عدد البنين \\
\hline $1.01 r$ & $r \cdot$ rrr & r.qIr & إجمالى عدد البنات \\
\hline
\end{tabular}

× تم حساب هذه النتائج باستخدام بيانات جميع الطلبة والطالبات المقيدين فى قطاع التعليم العام ، المهنى و الأزهرى فى جميع الأسر المعيشية فى العينة وسعيا إلى تعميق فهمنا للديناميات الماثلة وراء هذه التجرية التعليمية في مجملها ، جرى بحث العوامل المؤثرة في الاستمرار

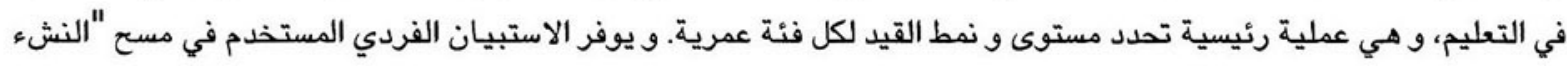

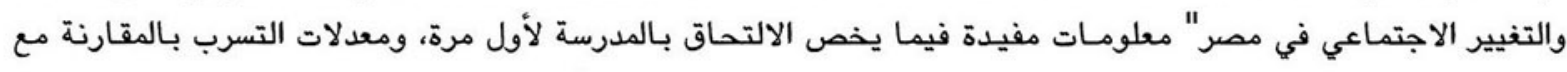

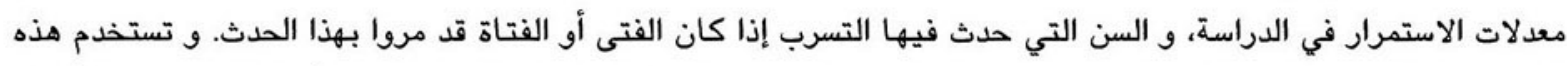

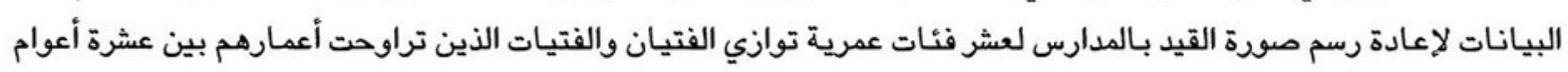
و تسعة عشر عاماً في وقت إجراء المقابلة.

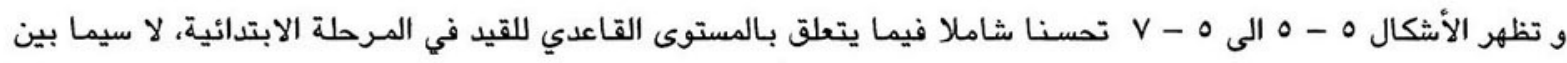

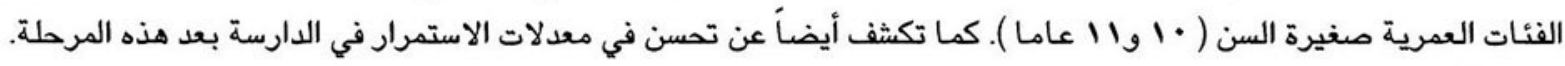

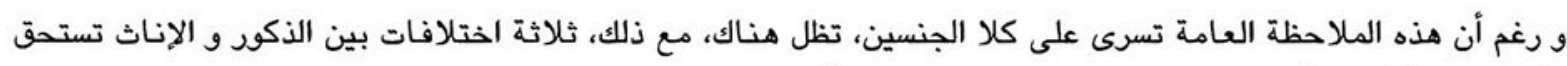

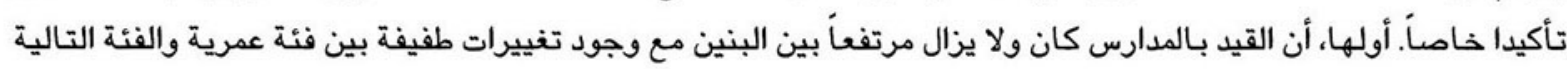
لها فيما يتعلق باحتمال الاستمرار في الدراسة.

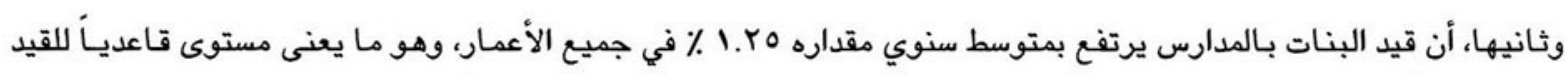

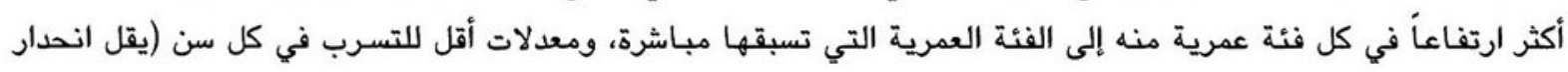

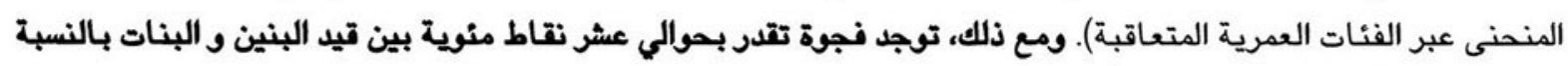


وثالثاً، يبدو أن إلحاق البنات بالمدارس يتأثر تأثرا ملحوظا بالعوامل المتملة بالسياق الاجتماعي ويالتقلبات في الحالة

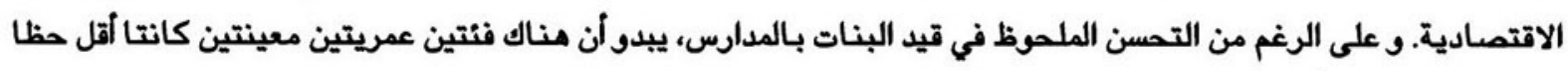

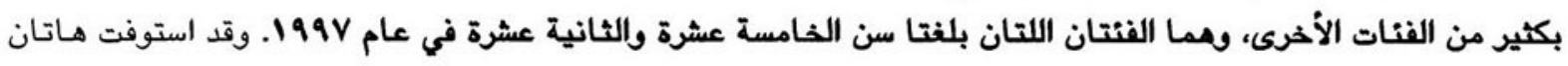

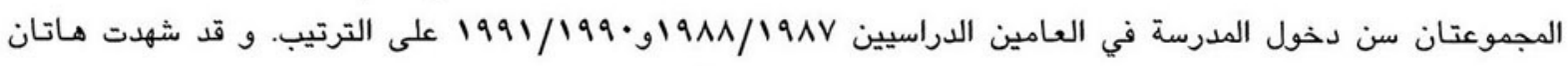

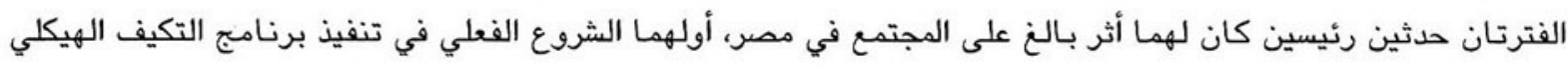

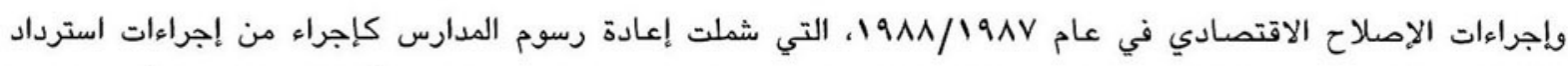

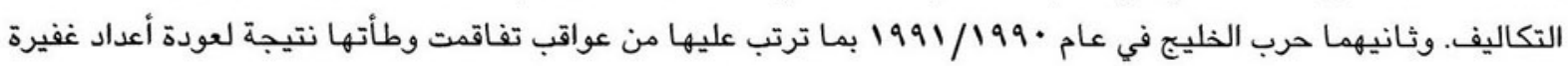

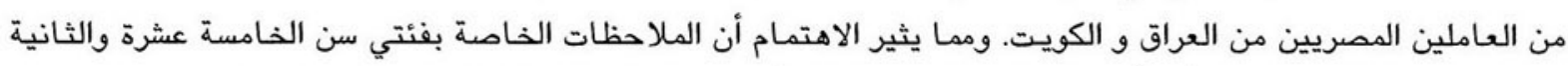
عشرة في عام 199V تصدق أيضاً على النشعين المنتمين إلى أسر من الفئة الاجتماعية الاقتصادية الدنيا.

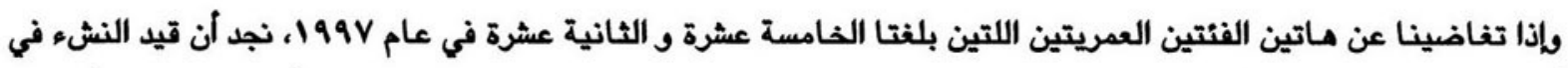

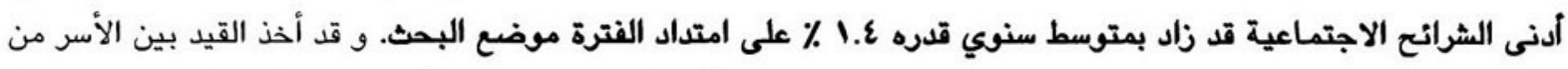

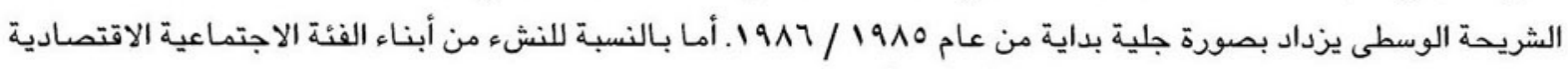
العليا، نقد كان القيد بالمدارس ولا يزال شاملأ تقريبياً حتى نهاية مرحلة التعليم الأساسي.

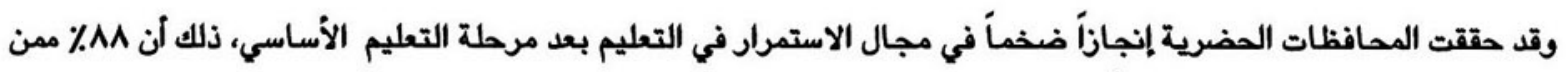

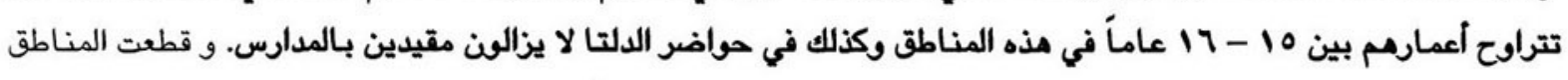

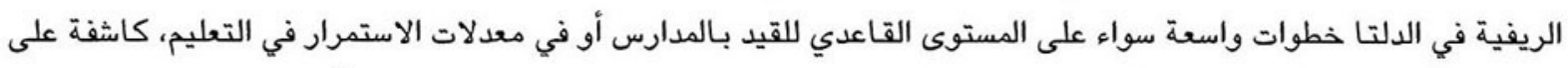

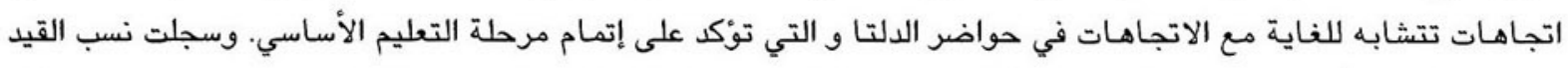

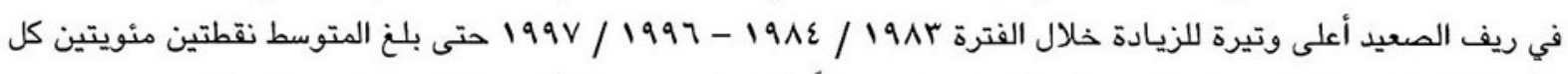
عام. إلا أن القيد بالددارس في الصعيد لا يزال يتصف عموماً بالتذبذب من سنة لأخرى، لا سيما في حواضر الصعيد. 
الشكل 0.0 : معلات القيد الفوجية ، الإجمالية وحسب النوع

معدات القيد الفوجية الإجمالية في مصر

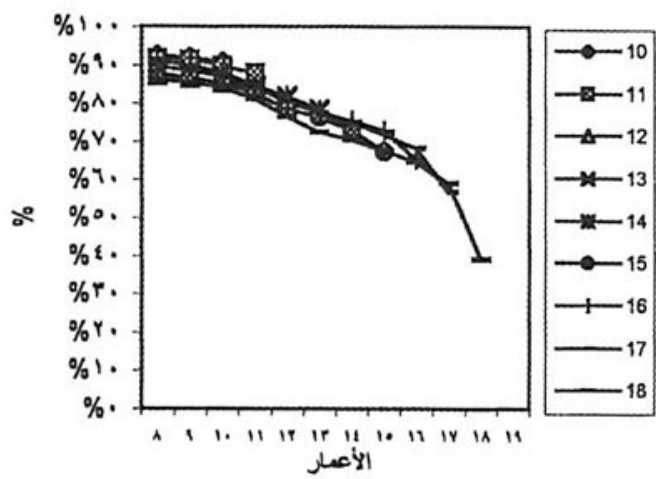

حسب النوع : البثات

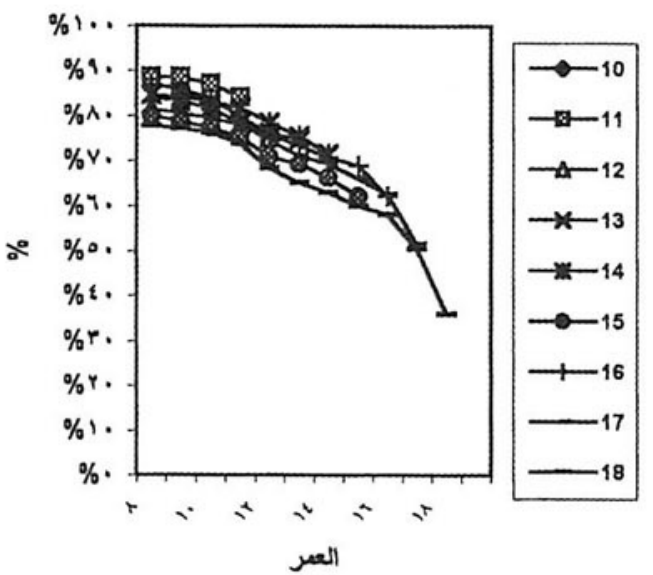

صب النوع : البنين

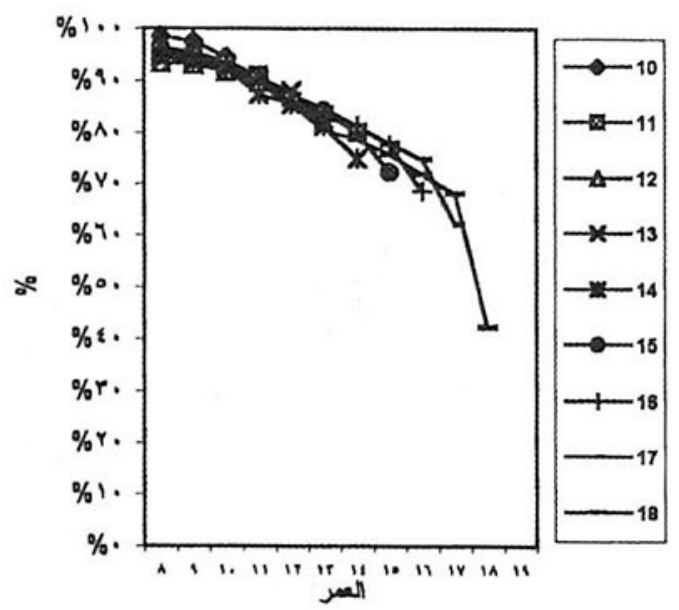

الشكل مـ ب: معدلات التيد النوجية حسب الحلة الاجتماعية الاتتصاية

$$
\text { صب المستوي الأتصادي / الاجتماعي الأنهي }
$$

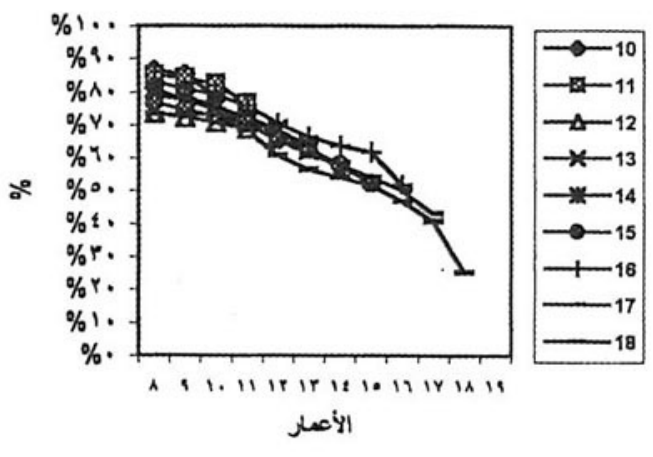

حسب المستوي الأتصادي / الاجتماعي المتوسط

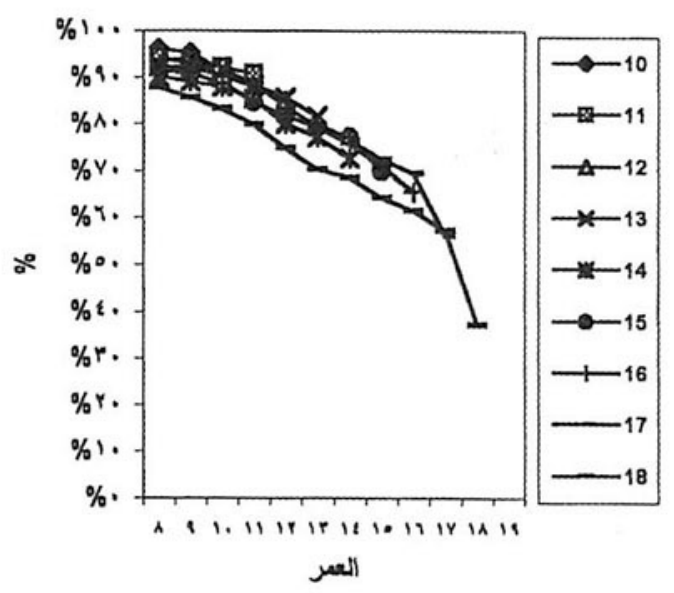

حسب المستري الاتثمادي / الاجتماعي الأعلي

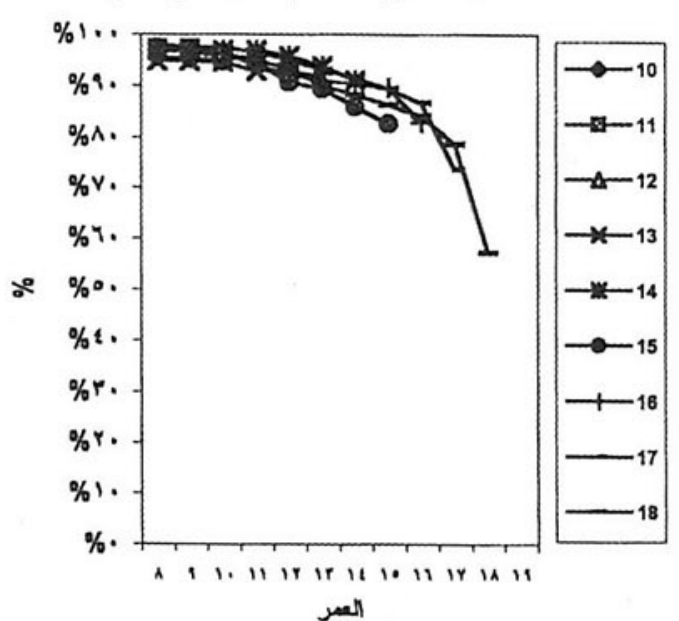




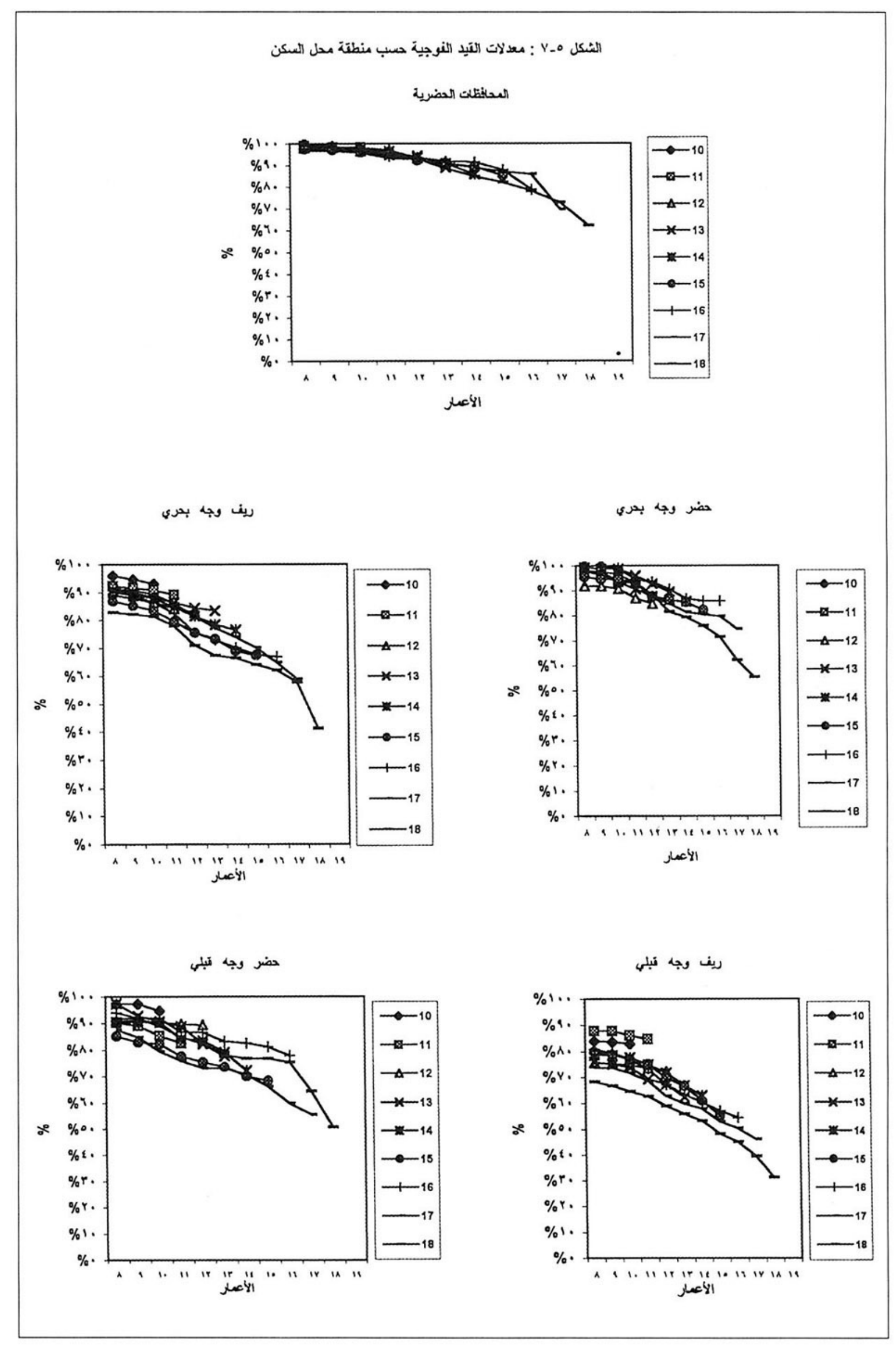


تبين الأشكال ه - 1 الى O - V V النسب المئوية للنشء الذى تسرب من المدارس في سن الحادية عشرة والرابعة عشرة والسابعة

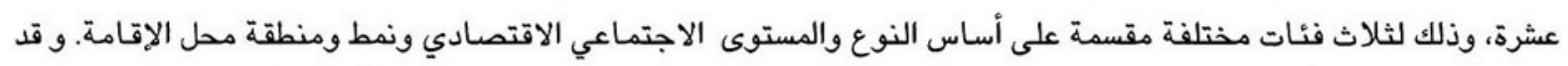

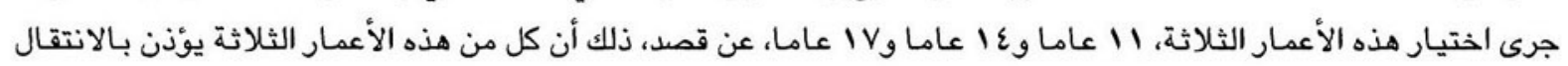
من مرحلة تعليمية إلى المرحلة الأعلى التالية لها.

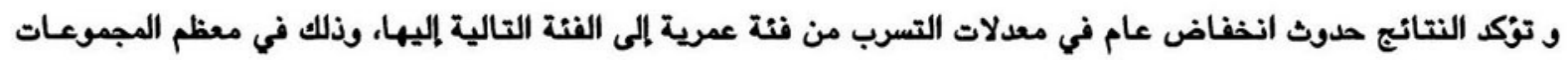

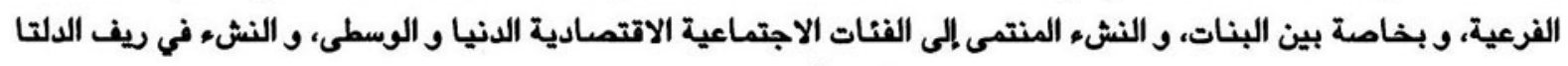

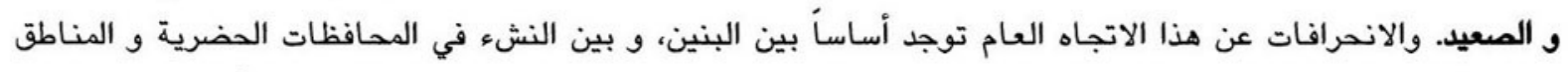

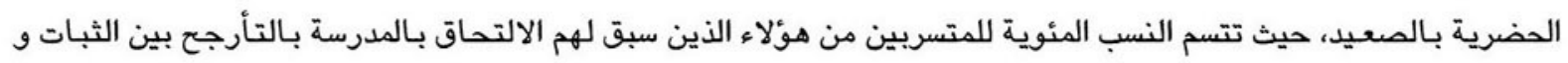

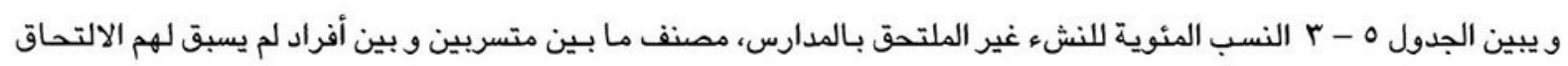

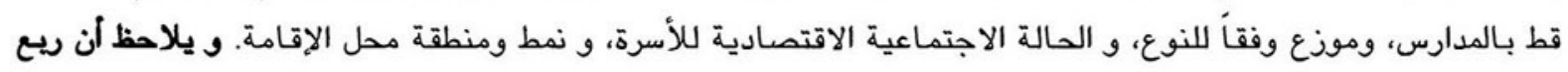

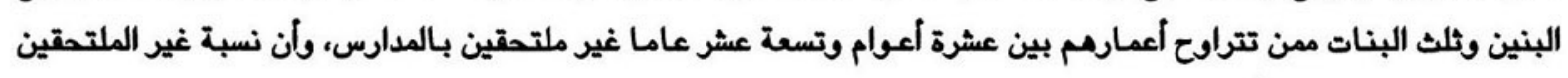

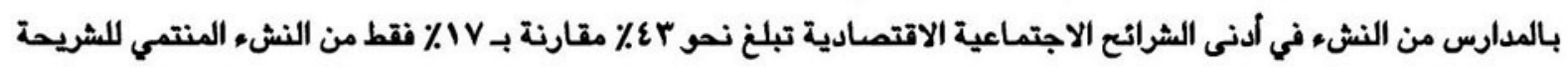

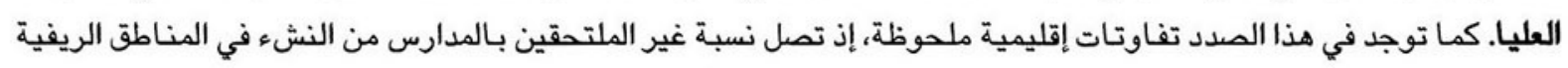

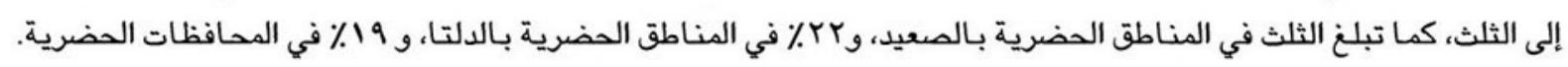

ويبين الجدول ه - r بوضوح أنه مع تناقص النسبة المئوية الكلية للنشء غير الملتحق بالمدارس نتيجة لتحسن ظروف السياق

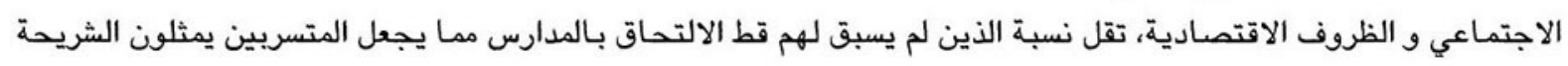
الأكبر من غير الملتحقين بالمدارس.

جدول ه-r: التوزيع النسبى للفتيات والفتيان غير الملتحقين بالمدرسة المتسربين أو الذين لم يسبق لهم الإلتحاق مطلقا طبقا لبعض المتغيرات الذلفية الملتحقية غير

\begin{tabular}{|c|c|c|c|c|c|c|}
\hline 900 & $1 \cdots \cdot$ & 11.0 & 11.0 & $\varepsilon, r \circ r$ & หา.V & بنين \\
\hline $1.0 \mathrm{Va}$ & $\cdots \cdot$ & o ०.० & $\varepsilon 0.0$ & $\varepsilon . V v_{0}$ & $r \varepsilon . \wedge$ & بنات \\
\hline & & & & & & الوضع الاقتصادى/ الاجتماعى \\
\hline $1 . \cdot v \varepsilon$ & $1 \cdots \cdot$ & 0 O . O & $\varepsilon 0.7$ & r.רv & $\varepsilon r$. & منخفض \\
\hline vro & $1 \cdots \cdot$ & Vo.V & $r \varepsilon . r$ & r.ArI & r9.0 & متوسط \\
\hline rve & $1 \cdots \cdot$ & ห৭. & ri. & $r, v \cdot \varepsilon$ & 17.7 & 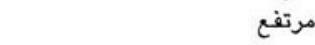 \\
\hline rq. & $\cdots \cdot$ & $9 \cdot .1$ & 9.r & $1, \wedge \varepsilon \cdot$ & 19.5 & المحافظات الحضرية \\
\hline 179 & $\cdots \cdot$ & $9 \cdot \cdot$ & $1 \cdot *$ & $\wedge \wedge 0$ & rr.1 & حضر وجه بحرى \\
\hline $9 r \varepsilon$ & $1 \cdots \cdot$ & $v \cdot r$ & rq.V & r.IrA & rr.r & ريف وجه بحرى \\
\hline$r \varepsilon$ & $1 \cdots \cdot$ & Vr.r & rV.A & $9 r \varepsilon$ & หq. & حضر وجه قبلى \\
\hline $9 \cdots$ & $1 \cdots$ & $\varepsilon \vee .0$ & or.o & r.rel & rA.V & ريف وجه قبلى \\
\hline r.ore & $\cdots \cdot$ & $77 . \varepsilon$ & rr.t & $9,1 \times \wedge$ & $r \cdot . v$ & الإجمالى \\
\hline
\end{tabular}




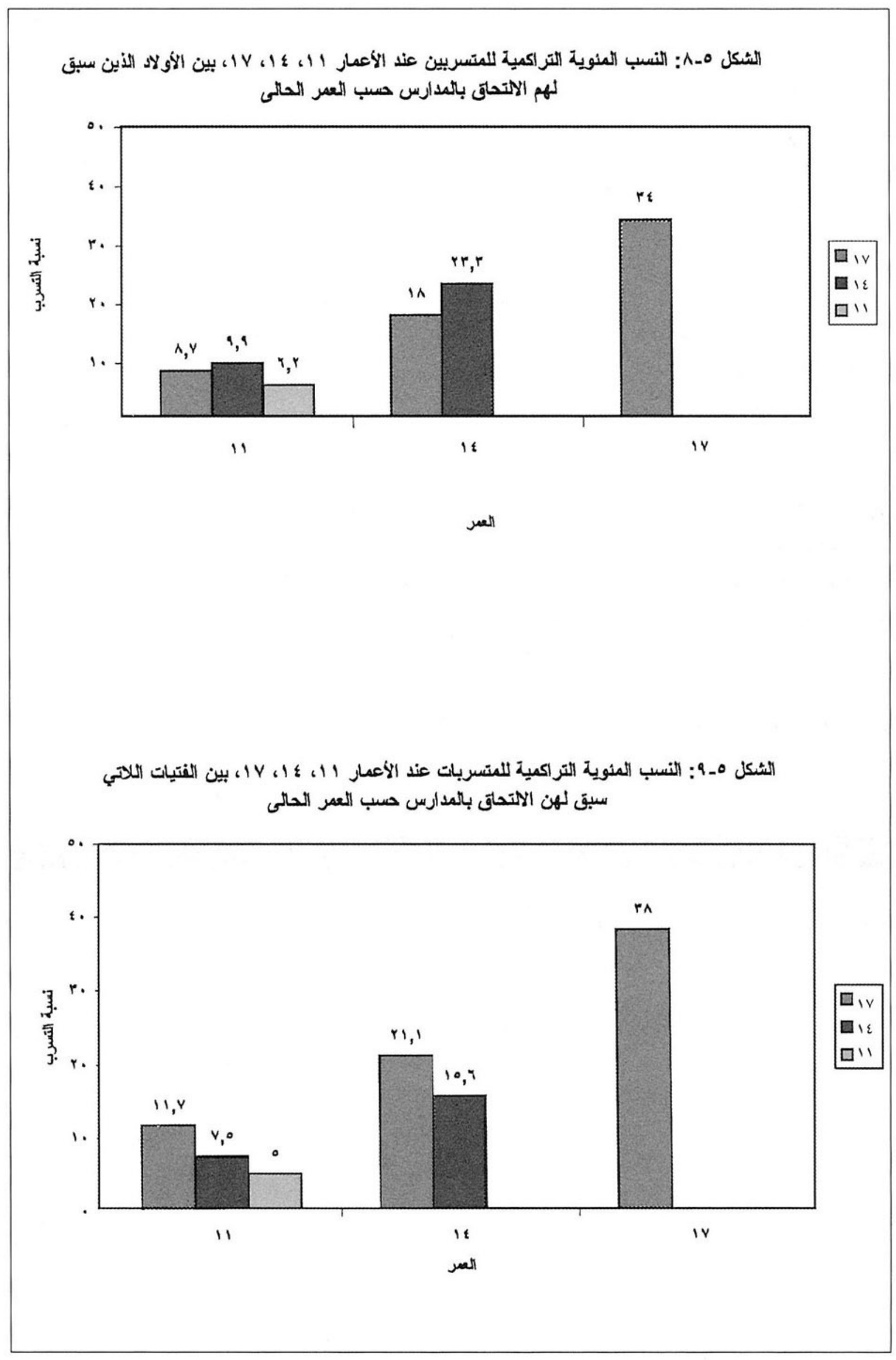




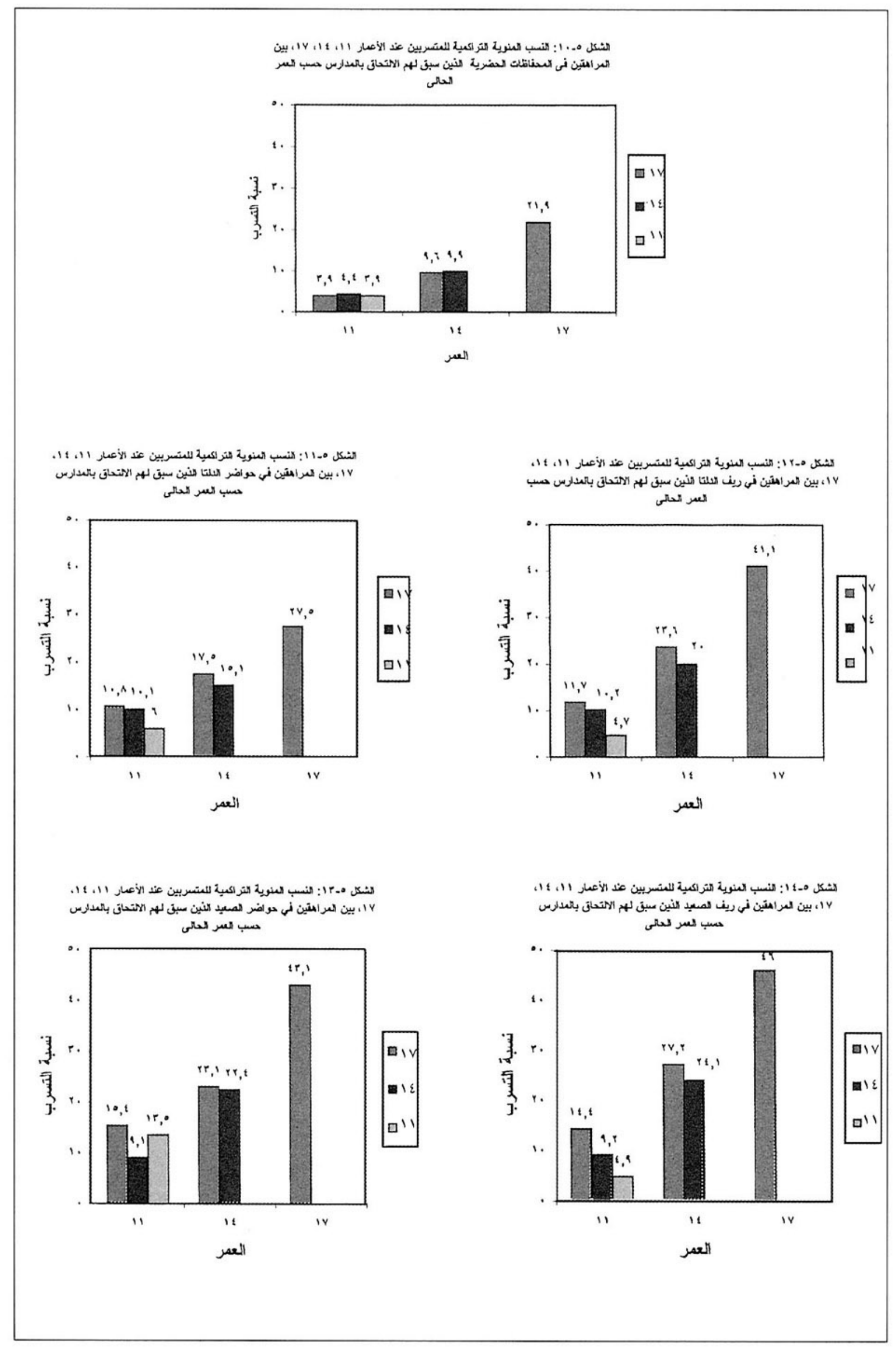




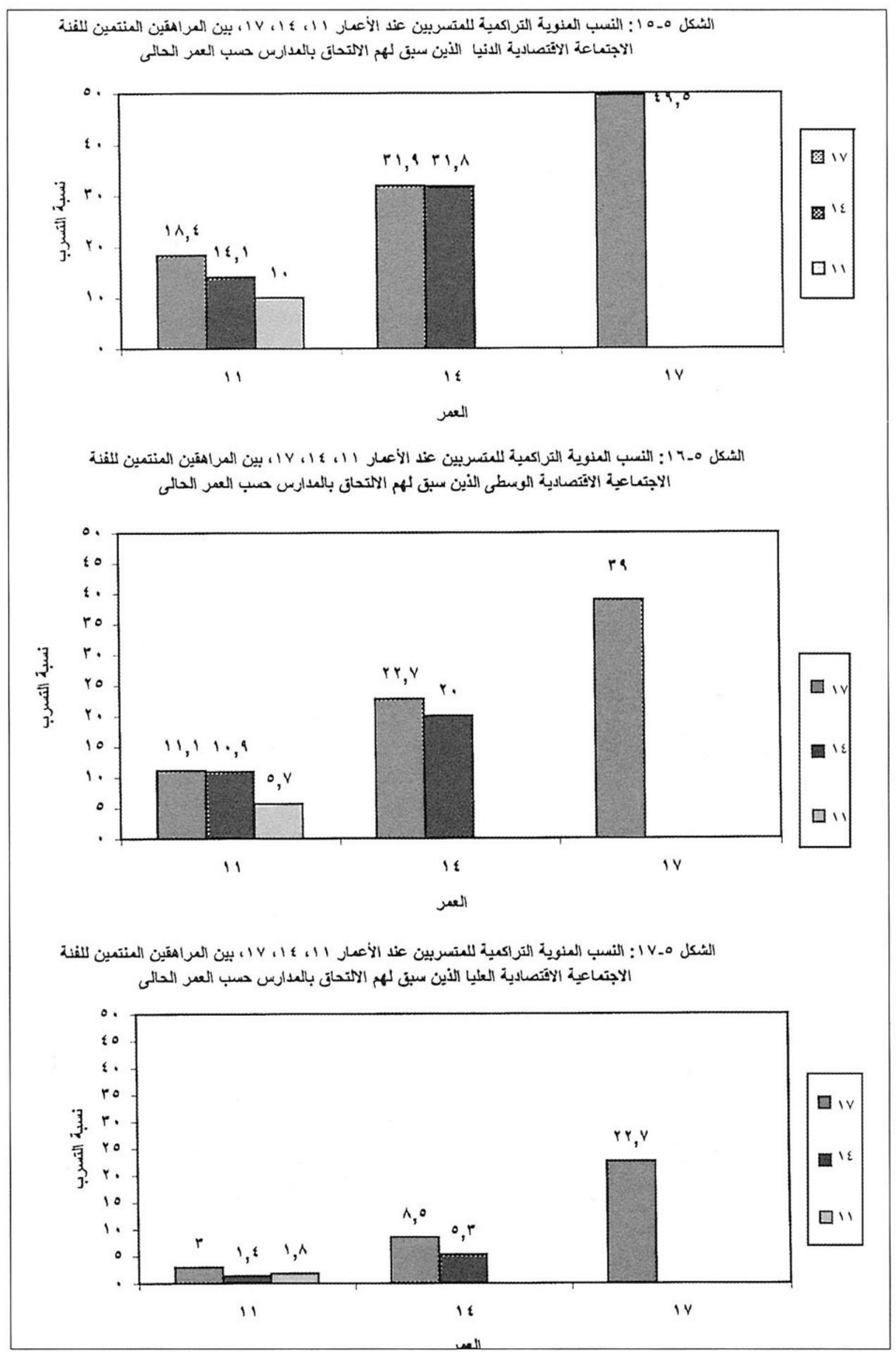




$$
\text { أسباب التسرب المدرسي }
$$

تلقى الأشكال ه - 1 1الى ه - - r الضوء على الأسباب الرئيسية لتسرب النشء في مصر موزعة حسب النوع، و نمط و منطقة

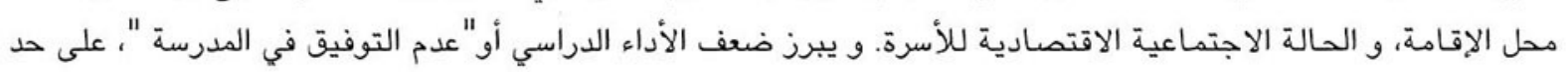

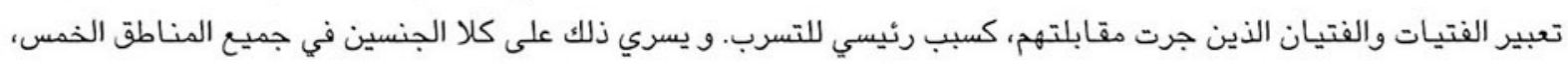

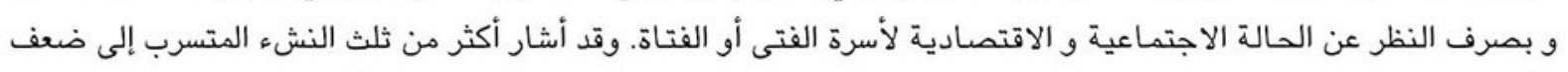

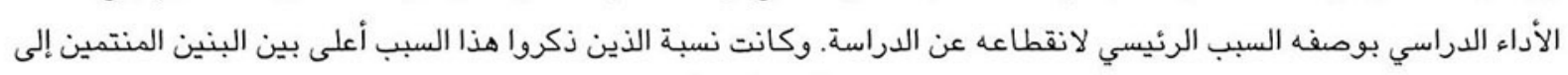

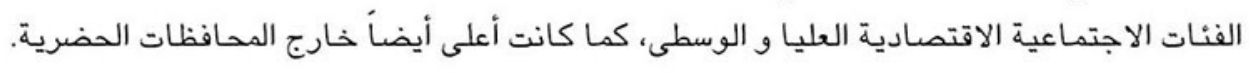

و ثاني هذه الأسباب من حيث القدر هو الاستهانة بقيمة التعليم أو ضعف الاهتمام به من جانب الفتى أو الفتاد أو آبائهم

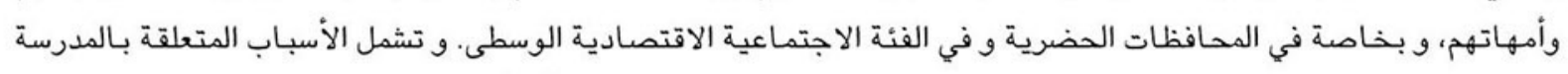

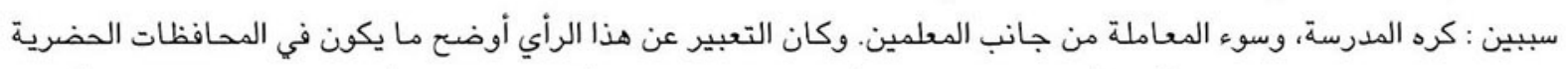

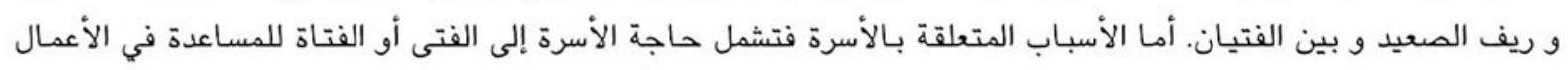

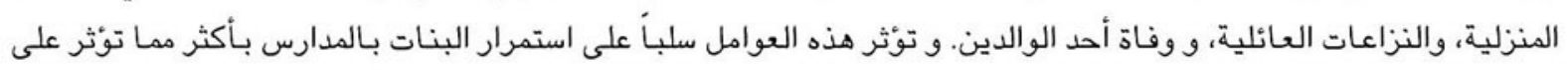

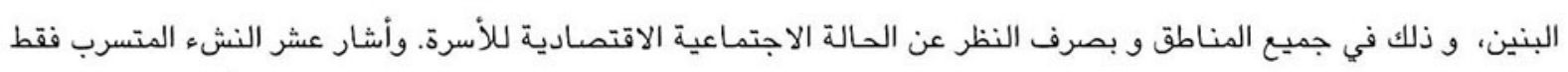

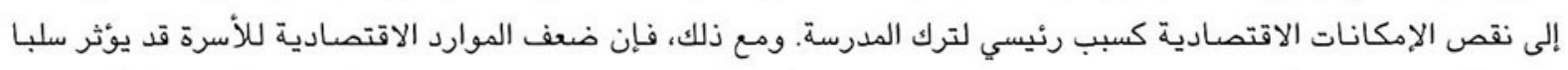

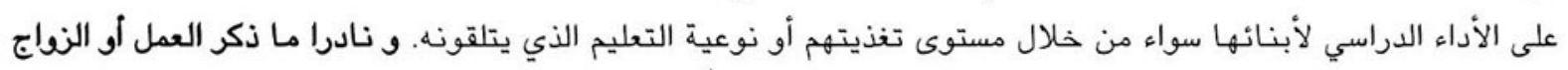

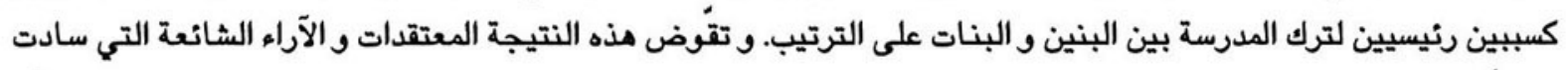

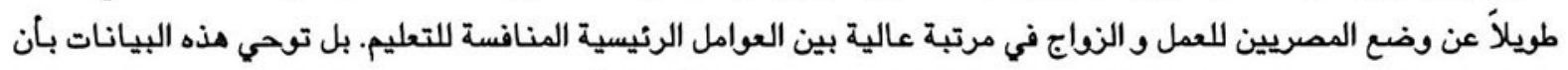
العمل و النواج ريما كانا خيارين لهوّلاء الذين تركوا المدرسة بالفعل لأسباب أخرى.

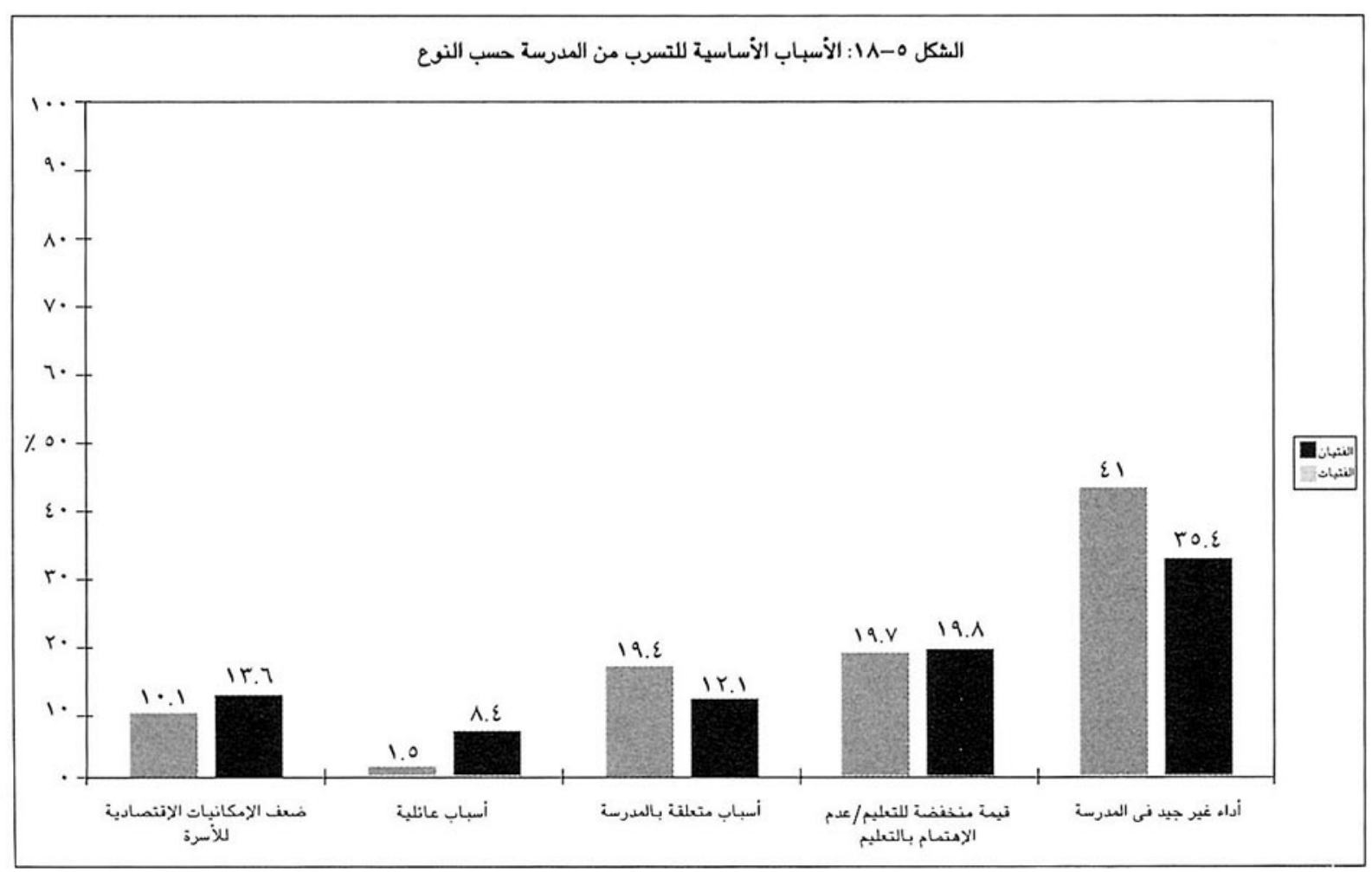


الشكل 0ـ 19 : الأمباب الأسامية للتسرب من المدزمة حسب الحالة الاجتماعية / الاقتصادية
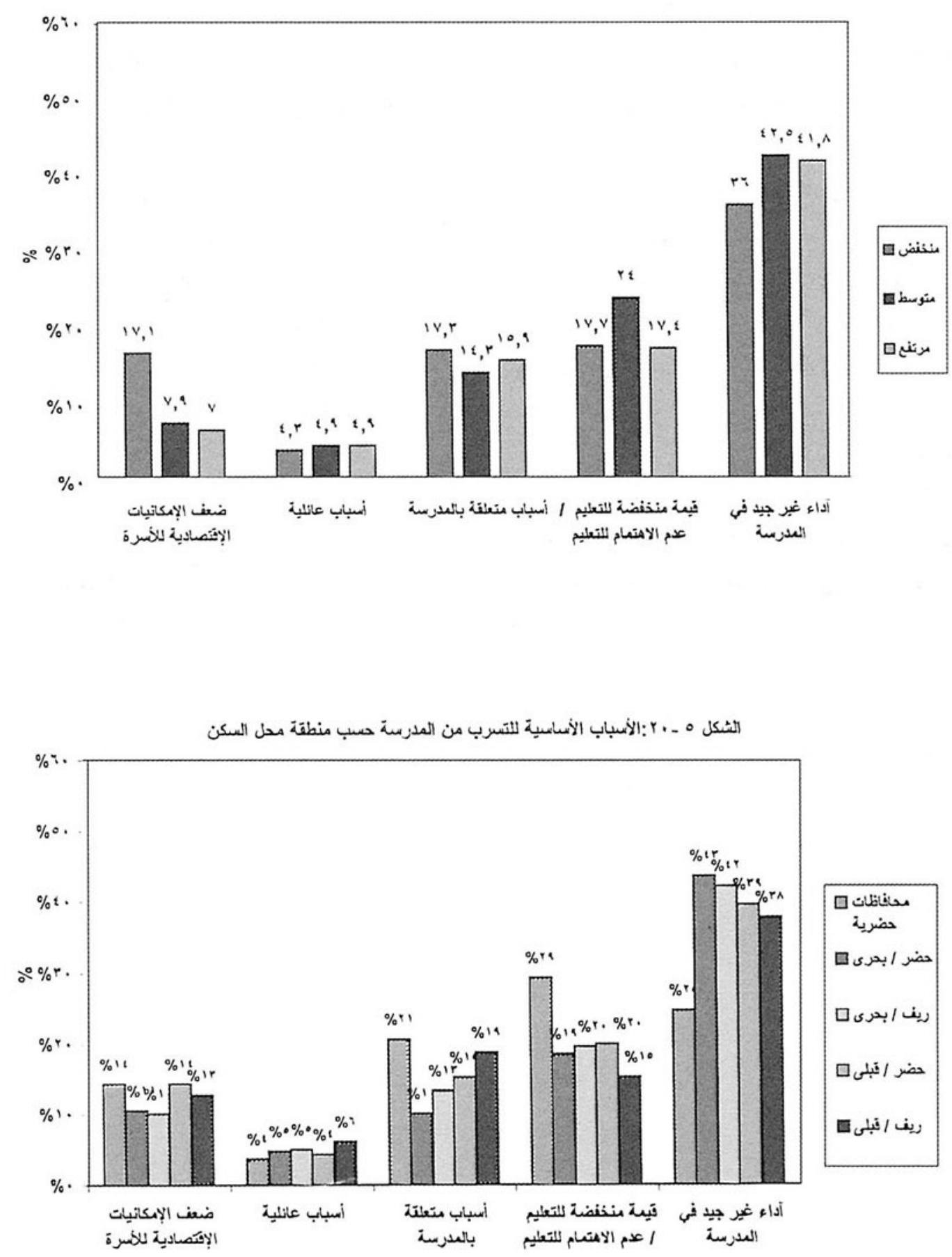


\section{اتجامات عدم الالتحاق مطلقاً بالمدرسة}

تعد النسبة المئوية للذين لم يلتحقوا بالددارس قط في أي فئة عمريه مقياساً رئيسياً في تحديد المستوى القاعدي للقيد بهذه

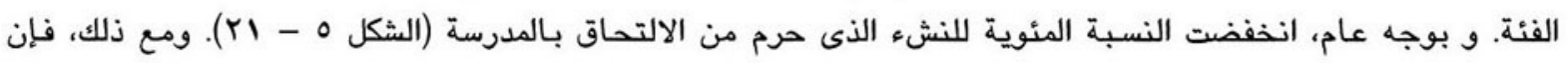
الانخفاض لم يكن سلسا أو منتظما.

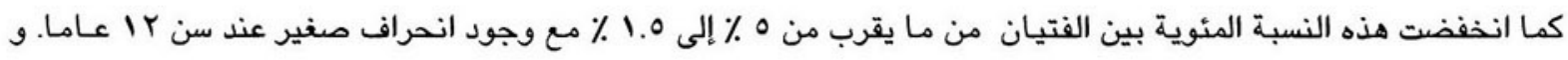

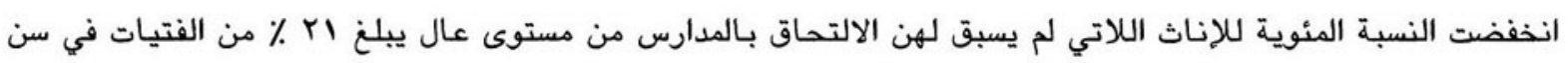

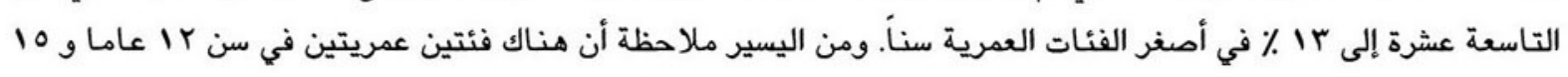

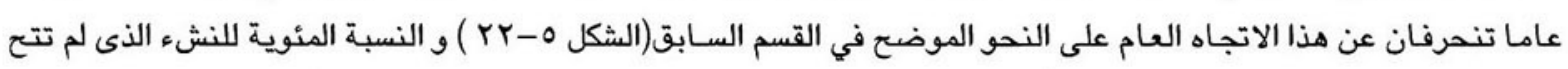

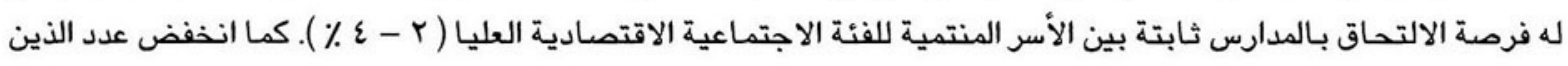

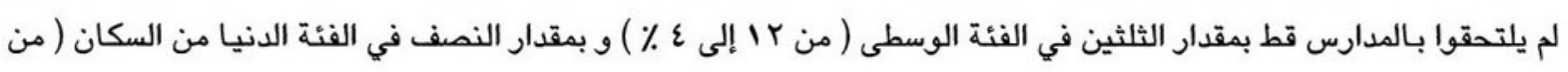

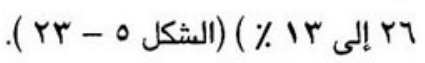

و قد أخذ الحرمان من التعليم يصبح ظاهرة نادرة على نحو متزايد في المحافظات الحضرية ( الح ٪ تقريباً بين الفئات العمرية

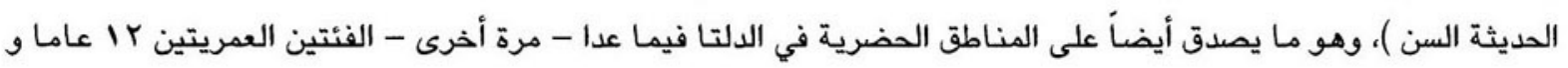

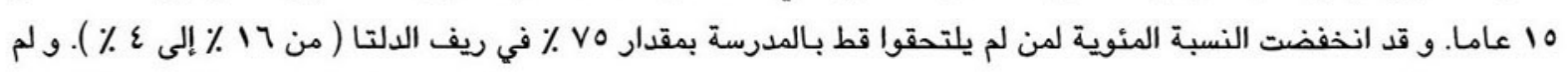

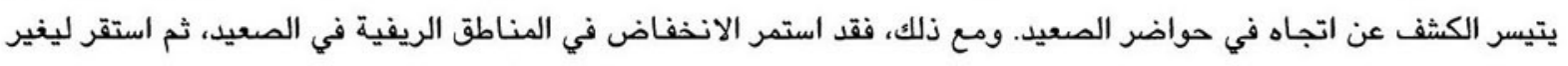

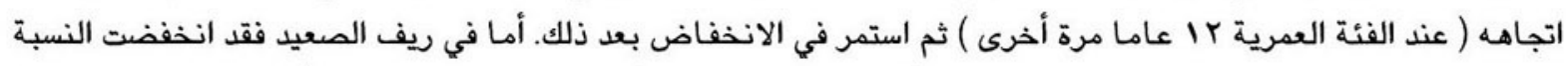

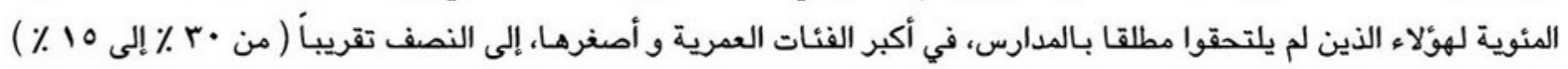

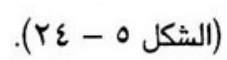

وعلى الرغم من التحسن الملحوظ في ناسب القيد، فما يزال حرمان الفتيات من التعليم في ريف الصعيد مثيراً للقلق. إذ تقدر

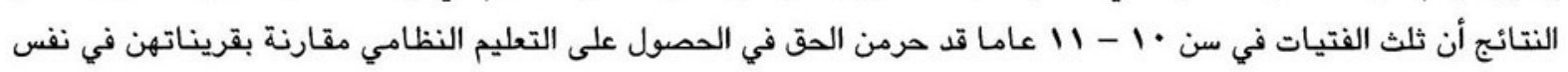
السن بباقي أجزاء البلاد. 


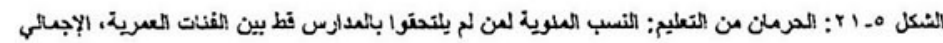

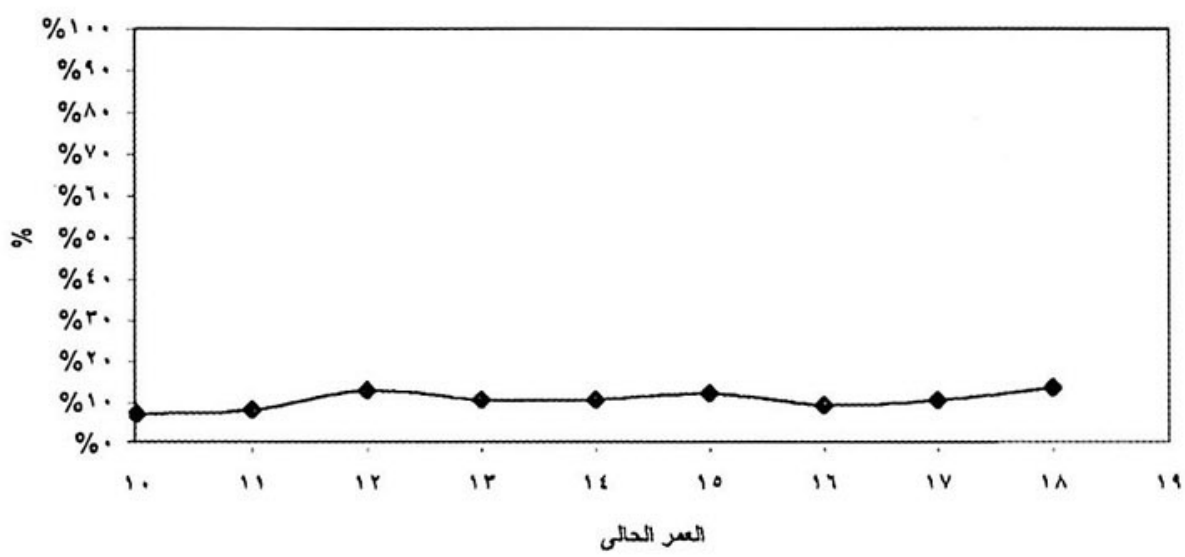

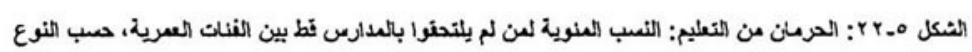

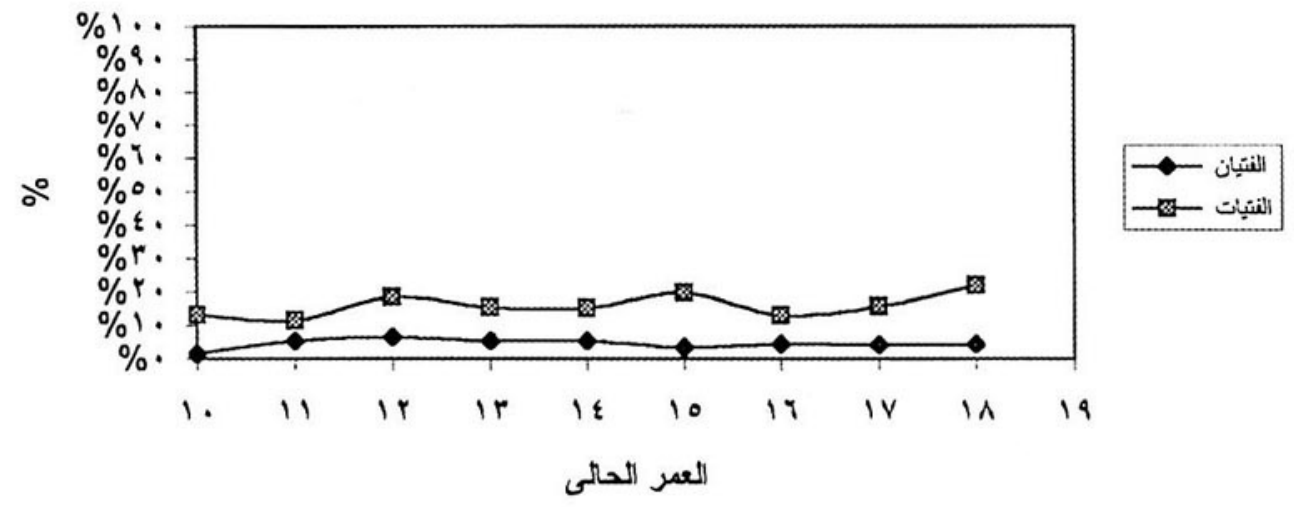

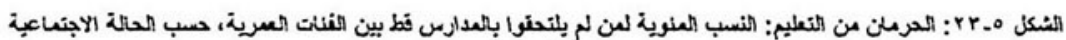
الأتصلاية

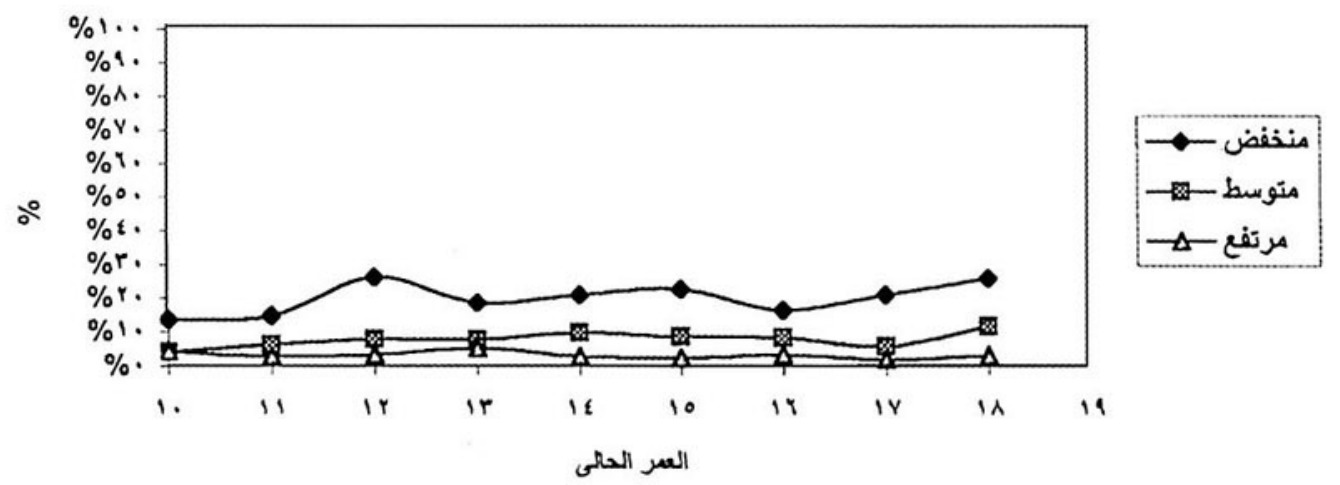


الثشكل هـ ـ צ : الحرمان من التعليم: النسب المنوية لمن لم يلتحتوا بالمدارس قط بين الفنات العمرية حسب منطقة مدل السكن.
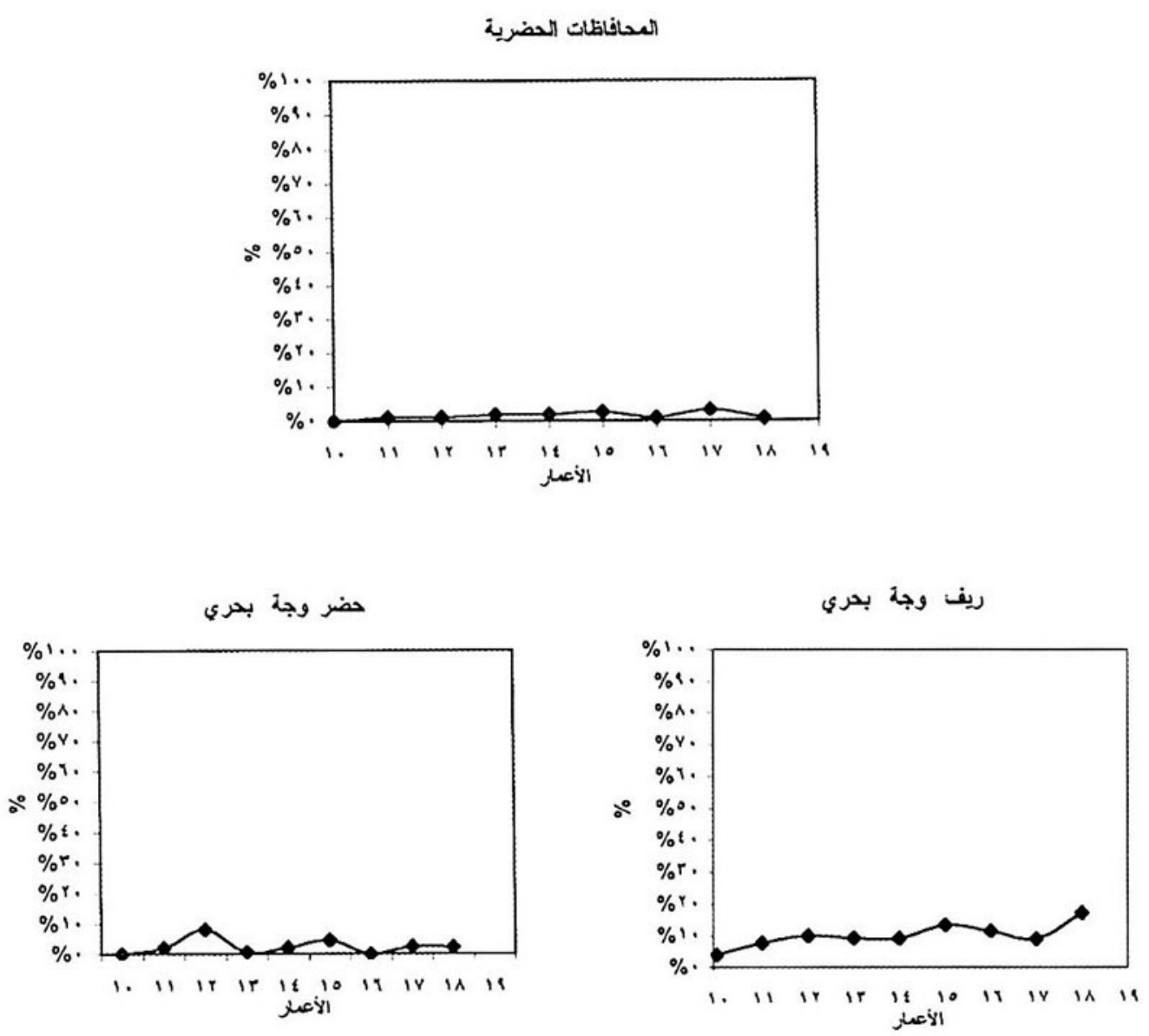

حضر وجة قبلي

ريف وجة تبلي
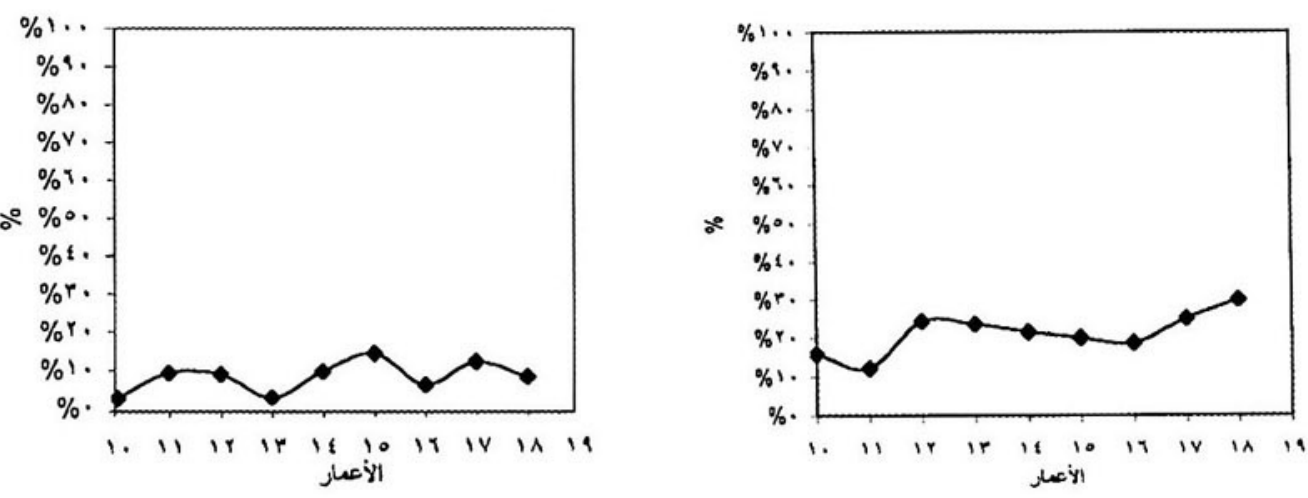


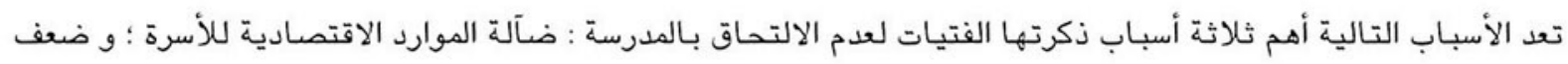

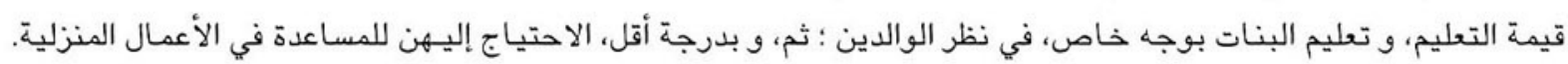

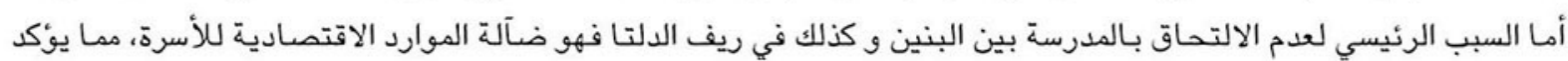

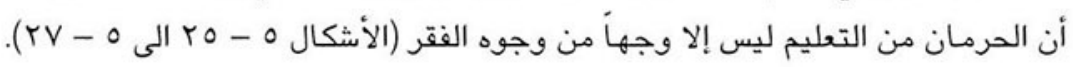
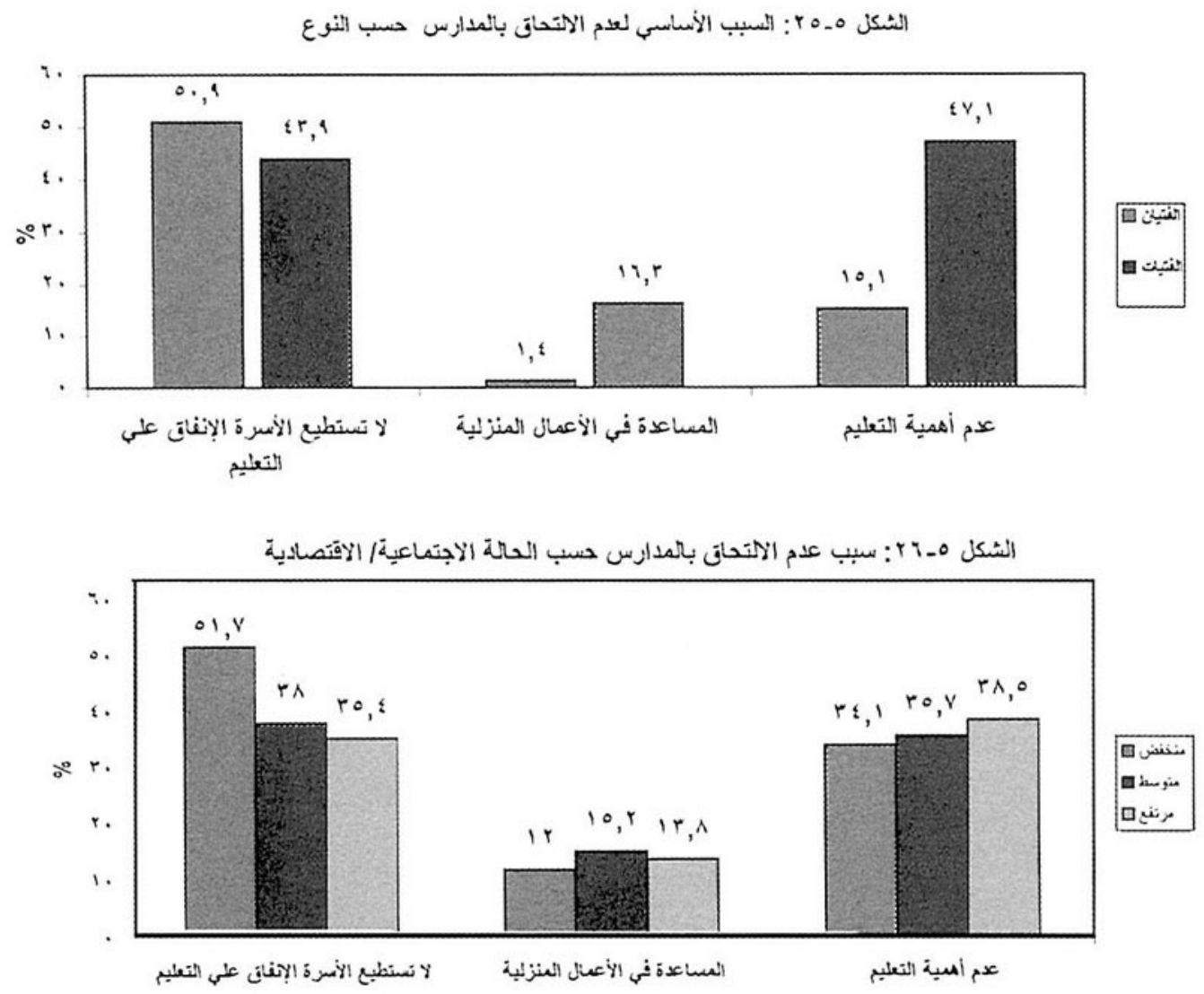

الشكل rV_o : سبب عدم الاكتحات بامدارس حسب منطقة هدل السكن

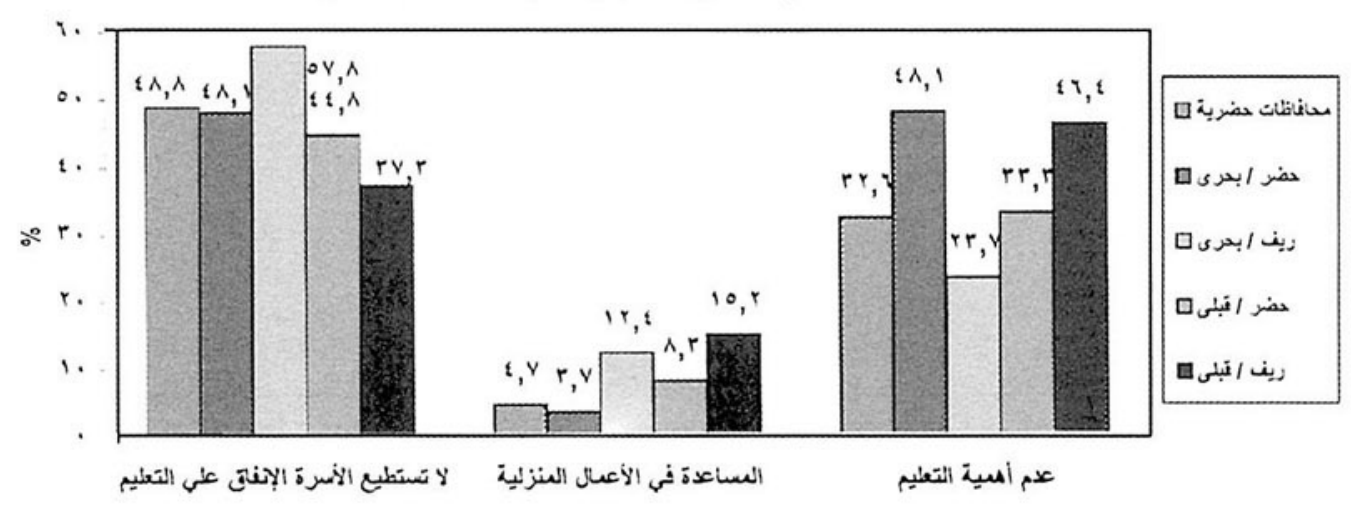




\section{نمول محو الأمية}

نادراً ما يستطيع المرء التغلب على العواقب الناجمة عن حرمانه من التعليم في الطفولة، بما يترتب على هذا الحرمان من آثار

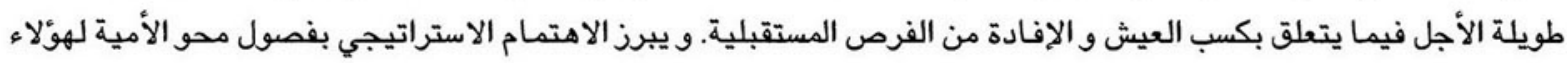

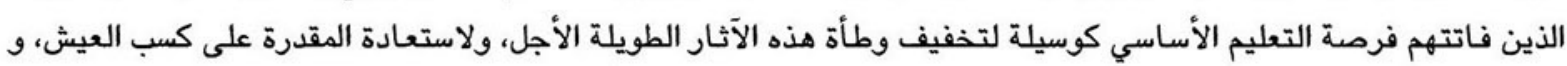

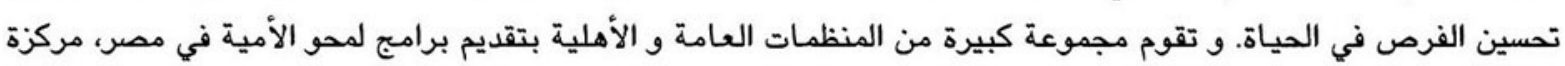

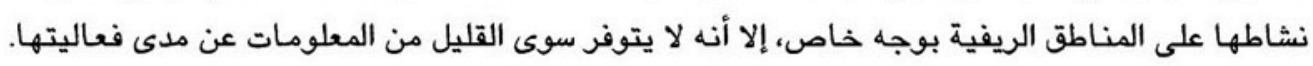

وقد أعرب ثلاثة أرباع الفتيات اللاتي لم يسبق لهن الالتحاق بالمدارس قط، و ك^ ٪ من البنين عن رغبة في التعليم إذا مـا أتيحت

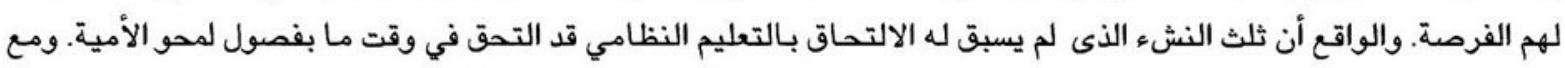

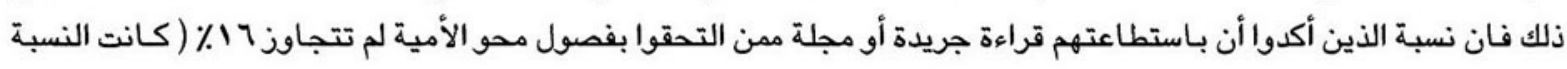

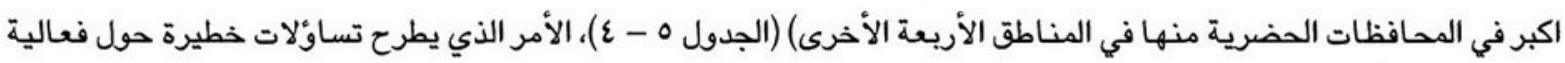

فصول محو الأمية القائمة.

جدول ه- ع: المو اتف والذبرات السابقة للنشء الذى لم يلتحق بالددرسة من قبل بخصوص فصول محو الأمية طبقا لبعض المتغيرات الخلفية

\begin{tabular}{|c|c|c|c|c|}
\hline 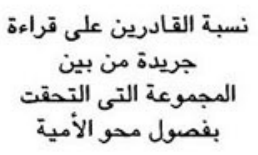 & بفصولة محنو الأمقية & التعليم إذن يترغبحت لهى & 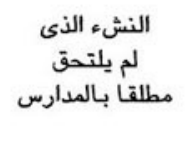 & \\
\hline $17 . r$ & rr. & vi.r & $\% \cdot r$ & الإجمالى \\
\hline ro. & $r \Lambda . \varepsilon$ & 11.9 & 109 & بنين \\
\hline Ir.A & rr.v & VE.A & vis & بنات \\
\hline IE9 & $r\{, A$ & v.. & $0 .$. & الوضفضع الاقتمادى/ الاجتماعى \\
\hline $\begin{array}{l}1.9 \\
\text { ro. }\end{array}$ & ri. & ve.r & ino & متوسفط \\
\hline$r \cdot . v$ & ri.r & $\wedge \cdot .1$ & vv & مرتفع \\
\hline$\varepsilon r . V$ & $\varepsilon\urcorner . \vee$ & $7 \cdot$. & רז & الححافظات الحضرية \\
\hline v.v & $\varepsilon \varepsilon . \varepsilon$ & 1 1.9 & $1 \varepsilon$ & حضر وجه بحرى \\
\hline $1 \varepsilon . \varepsilon$ & $r \cdot \cdot$ & v9.7 & $r V \varepsilon$ & ريف وجه بحرى \\
\hline 0.1 & rา. 9 & $V V . \varepsilon$ & $\mathrm{v} \cdot$ & حضر وجه قبلى \\
\hline IV.1 & rr.r & vย.० & $\varepsilon 9 r$ & ريف وجه قبلى \\
\hline$\varepsilon$ & rvo & T $\varepsilon r$ & $\mathrm{AVV}$ & عدد الحالات \\
\hline
\end{tabular}

ثانياً: الأداء الدراسي للفتيات والفتيان

من بين كل النتائج المحتملة للتعليم، يبرز التحصيل الدراسي بوصفه أكثر المقاييس واقعية لنوعية التعليم. وسنقوم في هذا

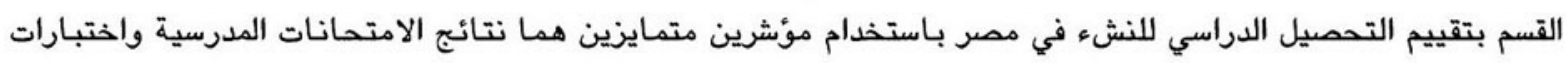
التحصيل المبنية علي قواعد قياسية موحدة.

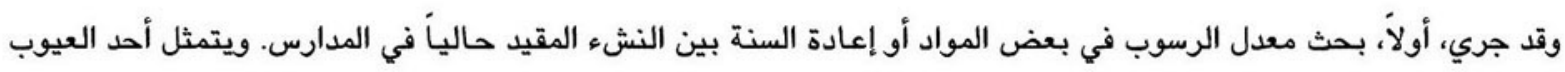

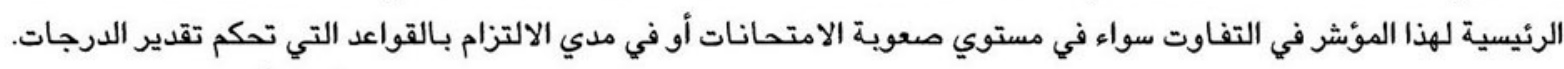

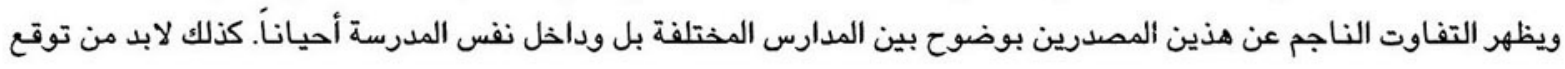


درجة ما من النقص في الإبلاغ عن حالات الرسوب وإعادة السنة نظراً للحرج الذي قد تسببه مثل هذه التقارير. ومع ذلك، وعلي

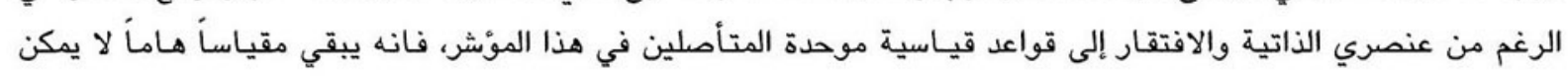

وفضلاً عن ذلك، قام "مسح النشء والتغيير الاجتماعي في مصر" بإجراء اختبارات قياسية موحدة للتحصيل في مادتي اللغة

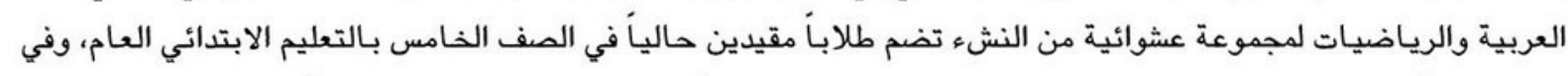

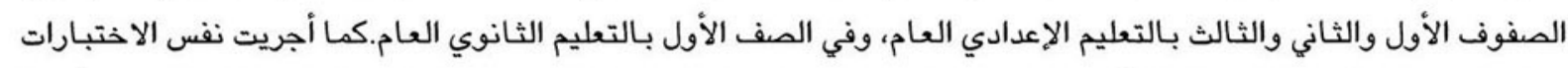

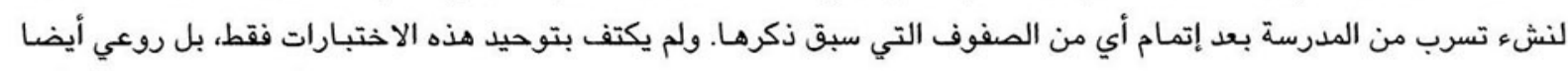

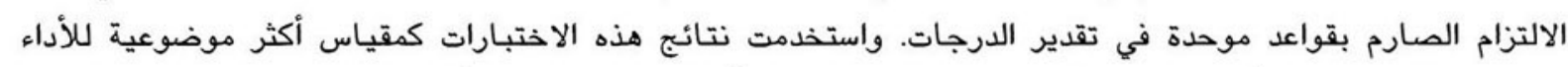

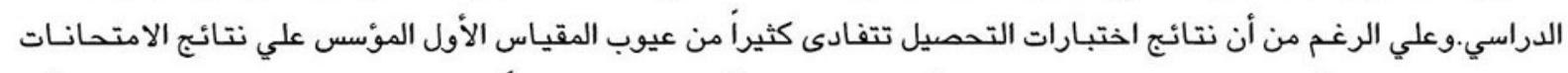

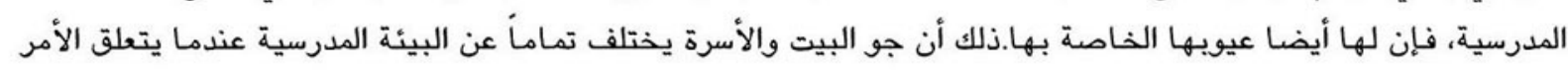

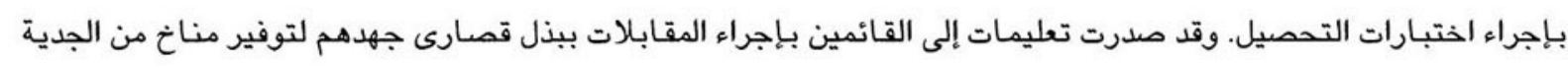

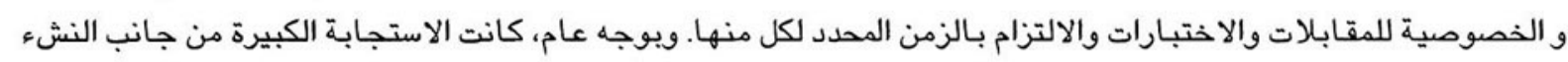
لهذه الاختبارات والدعم والتشجيع من جانب أسرهم، هما أهم عاملين ساعدا علي تحقيق نتائج طيبة.

\section{نتانج الامتحانات المدرسية}

يبين الجدول ه-ه توزيع النشء المقيد حالياً بنظام التعليم العام ابتداء من الصف الخامس الابتدائي وحتى الصف الأول الثانوي تبعاً لنتائج امتحاناتهم المدرسية ولخصائصهم الديموجرافية والاجتماعية الاقتصادية.

\section{لم يرسب ال1 ٪ من مذه المجموعة إطلاقا في أي امتحان لأي مادة دراسية، وأعاد ريع المجموعة الامتحان في بعض المواد

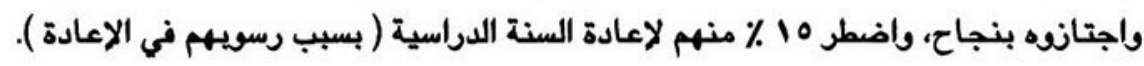

وكان الأداء الدراسي للبنين، والنشء العامل، وأفراد الأسر التي تعولها إناث، والمقيمين بالدلتا والصعيد، ضعيفاً ( أعادوا

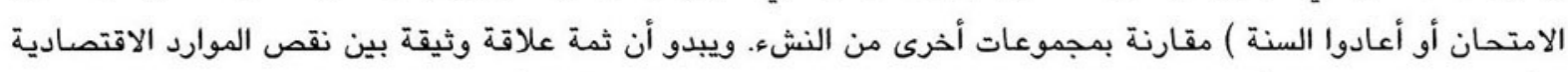

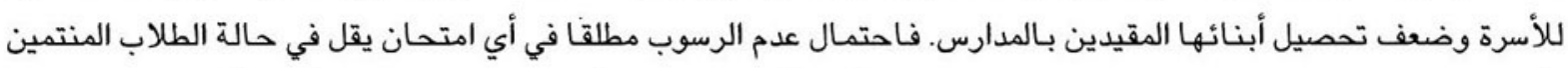

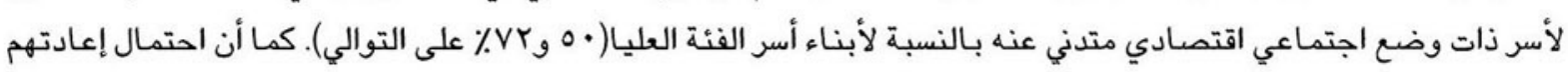

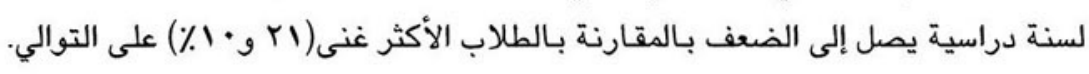

اختبارات التحميل

تعطي نتائج الامتحانات المدرسية مؤشرات للتفاوت في التحصيل الدراسي، ولكن في اتجاه التحصيل الضعيف فقط. بينما تلقي

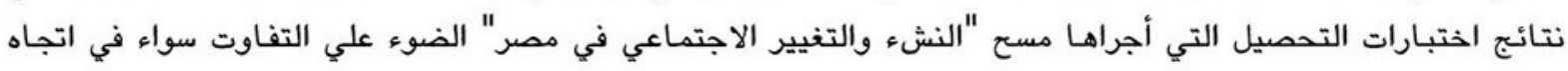

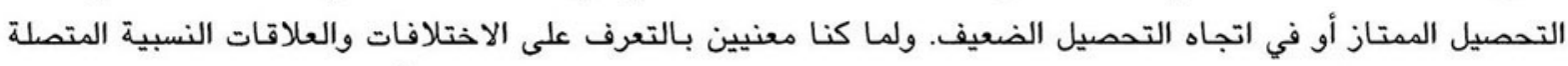

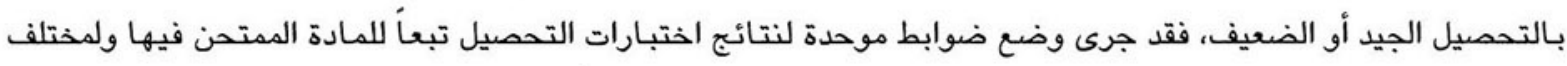

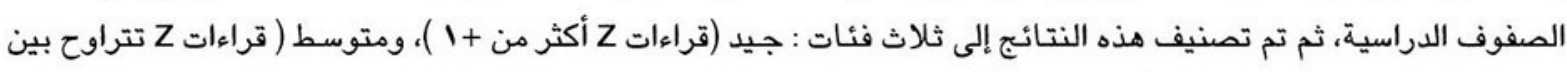
- او+1 ) ، وضعيف ( قراءات Z)، أقل من - 1) ). ولم تجر هنا محاولة لتقييم المستوى المطلق للتحصيل الدراسي. 
وفي ضوء مستوى الأداء الاجمالي للنشء الذى شملته العينة فقد حصل •7 ٪ من الذين أدوا اختبار اللغة العربية علي تقدير

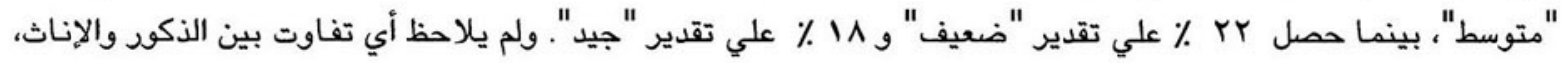

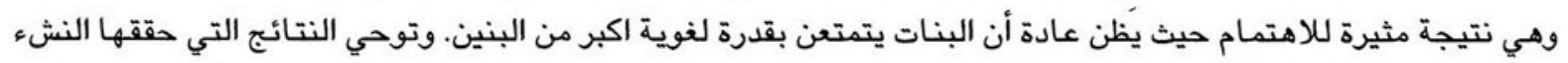

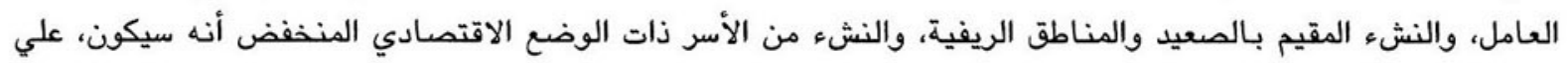

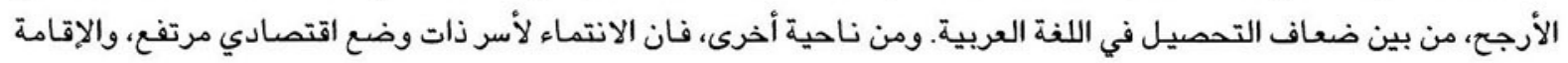
بالمحافظات الحضرية كان لهما اثر إيجابي علي التحصيل الدراسي في اللغة التهبة العربية.

\begin{tabular}{|c|c|c|c|c|c|c|c|}
\hline \multicolumn{8}{|c|}{ جدول ه - ه: التحصيل الدراسى طبقا لنتائج امتحان المدرسة وإختبارات التحصيل فى مادة اللغة العربية ومادة } \\
\hline \multicolumn{4}{|c|}{ نتائج إختبارات التحصيل } & \multicolumn{4}{|c|}{ نتائج امتحان المدرسة } \\
\hline \multicolumn{2}{|c|}{ مادة الرياضيات } & \multicolumn{2}{|c|}{ مادة اللغة العربية } & & & & \\
\hline ضعيف & جيد & ضعيف & جيد & باستمرار & في أعادة الامتحانة & سنة دراسية إىى & \\
\hline 18.1 & IE.r & rI.T & in.r & $\dddot{11 .}$ & re.r & 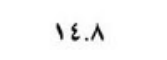 & 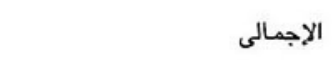 \\
\hline iv.r & 10.1 & rr.r & $1 \wedge$. & or.v & rา.० & 19.1 & بنين \\
\hline 17.9 & ir.q & ri. & $1 \wedge . \varepsilon$ & $7 \cdot .0$ & ro.r & IE.r & بنات \\
\hline $1 \cdot v$ & 17. & $\mid \varepsilon . \wedge$ & $r \cdot r$ & 11. & rE.r & $\mid \varepsilon . \wedge$ & الملتحقون بالمدرسة \\
\hline or.o & $\varepsilon . \vee$ & $r \cdot r$ & 1.9 & - & - & - & المتسريون \\
\hline$r \varepsilon . q$ & $1 \cdot . \Lambda$ & rr.o & Ir.7 & ยา. & $r \cdot .1$ & rr.o & يعملون \\
\hline IE.r & 10.7 & $1 V .7$ & $r \cdot r$ & $7 \cdot .1$ & r६.V & $10 . r$ & لا يعملون \\
\hline 17.8 & 10.r & 19.8 & 19.5 & ir. & rY.q & 10. & أسرة نووية \\
\hline 19.8 & $w . v$ & rר.A & $10 . \varepsilon$ & OV.7 & rA. $\varepsilon$ & 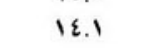 & أسرة ممتدة \\
\hline IV. & Ir.9 & ro.r & ।ध.7 & o\&.r & ro.\& & $r \cdot r$ & أسرة تعولها سيدة \\
\hline $\mid v .1$ & $1 \varepsilon . \varepsilon$ & YI.Y & $1 \times .7$ & 71.7 & $r \varepsilon .1$ & IE.r & أسرة لا تعولها سيدة \\
\hline & & & & & & & الوضع الاقتصادى/ الاجتماعى \\
\hline$r \cdot r$ & $11 . \varepsilon$ & ro. & ir.v & 0.1 & rq.r & r.A & منخفضض \\
\hline $10 . \varepsilon$ & Iध.7 & $r \cdot r$ & 19.5 & ०१.V & r.. & $\mid \varepsilon . \varepsilon$ & متوسط \\
\hline 1ध. & $1 \wedge . \varepsilon$ & IV.o & $r \varepsilon . \cdot$ & vr. & $1 \wedge .1$ & 9.9 & مرتفع \\
\hline $\mid V . \varepsilon$ & $17 . \varepsilon$ & 11.1 & rr.A & $7 \cdot . \varepsilon$ & re.r & $10 . r$ & حضر \\
\hline IV. & ir. & rr.q & 10.0 & ०\&.V & rV. & in.r & ريف \\
\hline I7. & $17 . r$ & 17.0 & rr.q & ir.v & $r r .1$ & $\mid \varepsilon .1$ & المحافظات الحضرية \\
\hline ।ध.. & $17 . \varepsilon$ & $r \cdot r$ & 18.9 & $00 . \varepsilon$ & r... & $1 \times .0$ & وجه بحرى \\
\hline rI.r & $1 \cdot .9$ & ro.o & 17.1 & $0 ., Y$ & rV.A & IV. & وجه قبلى \\
\hline irr & 070 & $\vee \varepsilon \wedge$ & 790 & r.oor & $1.07 \mathrm{~V}$ & $1 .+41$ & عدد الحالات \\
\hline
\end{tabular}

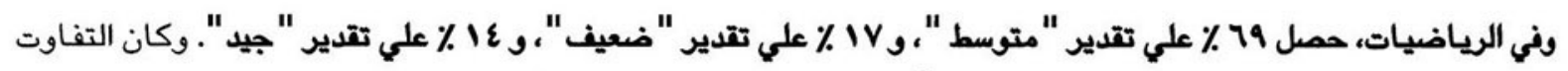

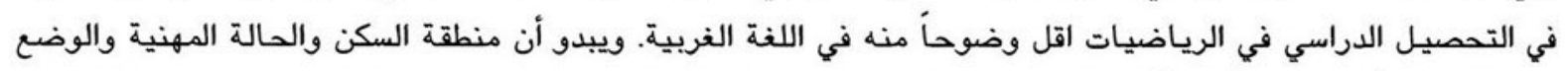
الاقتصادي للأسرة لهم الأثر الأكبر علي مستوي التحصيل في الرياضيات، علي حين كانت التفاوتات ضئيلة بين الذكور 


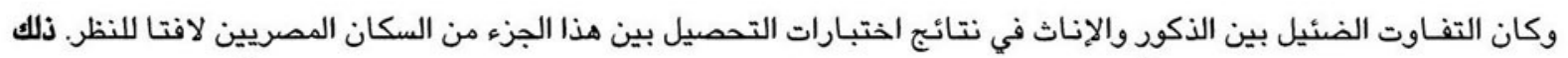

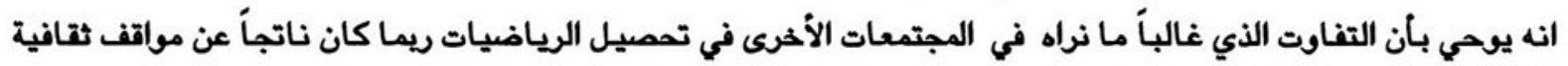
تشريها المدرسون والآباء والطلاب اكثر منه نتيجة لاستعدادات فطرية.

وتؤكد نتائج المسح الفجوة الكبيرة في التحصيل الدراسي بين الطلبة المقيدين والمتسربين. وتبين هذه الفجوة ما يحدثه

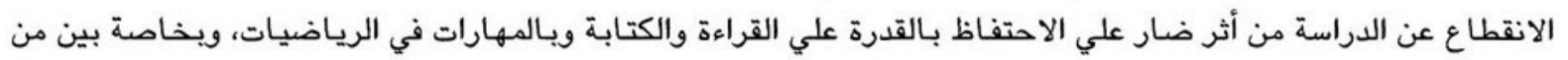

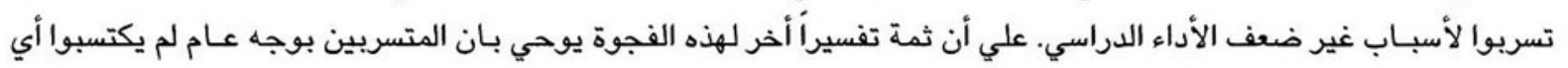

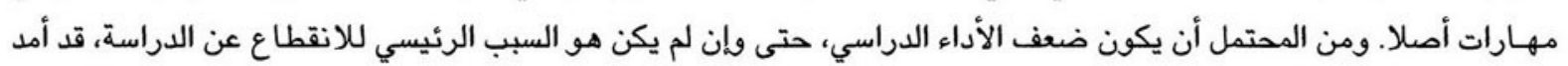
السبب الرئيسي، أيا كان، بدعم إضافي.

التحميل الدراسي والحالة المحية للنش؛

إن أحد الأهداف الرئيسية المتوخاة من الصورة العامة للنشء المقدمة في هذه الدراسة هو توضيح العلاقات المتبادلة بين

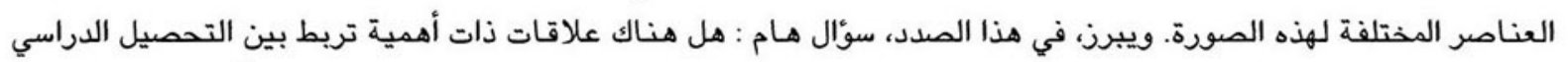

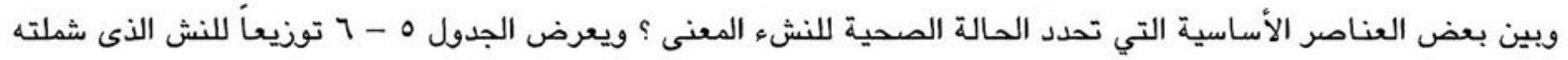

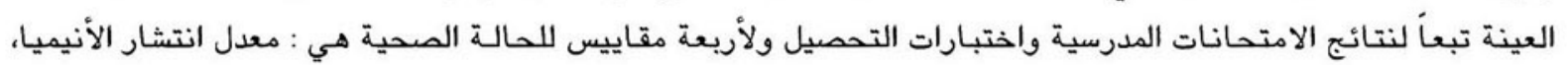

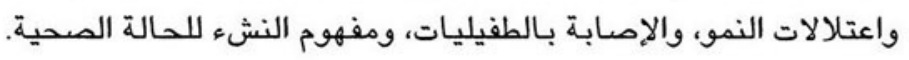

وتوكد النتائج وجود علاقة بين المحددات المحتلفة للحالة المحية للنشء ويين أداثه الدراسي بوجه عام، علي ندو ما يتبين

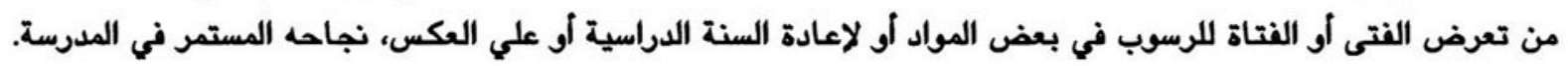

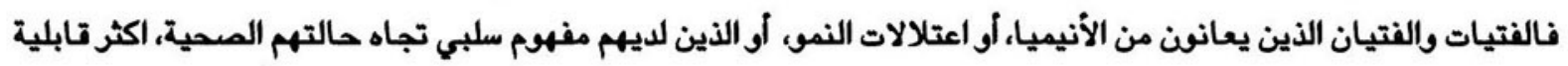
للتخلف في الدراسة.

ولم تكشف نتائج اختبارات التحصيل عن علاقة قوية بالحالة الصحية. ومن المرجح أن يكون هذا النهج لتقييم التحصيل

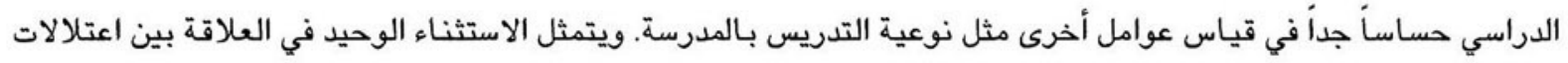
النمو والأداء الجيد في الرياضيات. ومع ذلك فإن هذاس عل النتيجة تحتاج لمزيد من البحث. 


\begin{tabular}{|c|c|c|c|c|c|c|c|c|c|}
\hline \multirow[b]{3}{*}{ 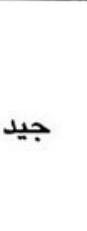 } & \multicolumn{5}{|c|}{ نتائج اختبارات التحصيل } & \multirow{2}{*}{\multicolumn{3}{|c|}{ نتائج امتحان الددرسة }} & \multirow{3}{*}{ الإصابة بالأنيميا } \\
\hline & \multicolumn{2}{|c|}{ مادة الرياضيات } & \multicolumn{3}{|c|}{ مادة اللغة العربية عال } & & & & \\
\hline & متوسط & ضعيف & جيد & متوسط & ضعيف & ستمرار & ملحق & رسوب & \\
\hline 11.1 & $v \cdot r$ & $1 \wedge$. & IV.A & 09.1 & rr.\& & ०६. . & $r \cdot .0$ & 10.0 & الإصعابة بالانيميا \\
\hline $10 . V$ & $7 v .9$ & $17 . r$ & ri.r & OA.r & $r \cdot .0$ & $7 \cdot$. & $r \varepsilon . q$ & 10.1 & $\gamma$ \\
\hline & $\cdot .1 \cdot<\tau$ & & & $\cdot 1 \cdot<\tau$ & & & $\because \cdot=\tau$ & & |الإحصائية \\
\hline V.V & vo.1 & IV.Y & IE.9 & OA.r & rา.A & $\varepsilon v . \varepsilon$ & rq. & 17.1 & |نع \\
\hline $10 . \varepsilon$ & 79.1 & 10.7 & $r \cdot .7$ & $7 \cdot . r$ & $19 . r$ & w.r & ro. & ir.A & لا \\
\hline & $\cdot .1 \cdot<\tau$ & & & $\cdot .1 \cdot<\tau$ & & & $\because \cdot=\tau$ & & |الإحصائية الدله \\
\hline & & & & & & & & & عدوى الأمراض الطفيلية \\
\hline $1 r .9$ & 79.1 & IV.r & IV.V & tr.r & $1 \wedge .7$ & 07.7 & rา. & 17.0 & |نع \\
\hline ir.A & $v \cdot r$ & IV. & $r \cdot .1$ & 00.0 & $r \varepsilon . \varepsilon$ & ०^.V & rA. & ir.r & $\gamma$ \\
\hline & $\cdot 1 \cdot<\tau$ & & & $\cdot 1 \cdot<\tau$ & & & $\cdot 1 \cdot<\tau$ & & الالإحصائية التصور للحالة الصحية \\
\hline ᄉ. $\cdot$ & $v r . \varepsilon$ & 11.7 & ri.l & 07.1 & rr.A & 07.7 & rV.A & 10.7 & |متاز \\
\hline 17.1 & TV.r & 10.9 & $1 \wedge .9$ & $7 \cdot .1$ & rI.I & $7 \cdot \cdot$ & rา.V & ir.r & عادى \\
\hline 9.5 & vi.re & rr.r & IV.r & Tr.r & $r \cdot .0$ & $\varepsilon\rceil^{\cdot}$ & ri.q & rr.l & |الدلائ \\
\hline & $\because \wedge=\tau$ & & & $\cdot 1 \cdot<\tau$ & & & $\cdot .1 \cdot=\tau$ & & |الإحصائية \\
\hline
\end{tabular}

ثالثا: التجرية المدرسية : وجهات نظر الفتيات والفتيان

تكشف البيانـات المستقاة من المسح القومي أن نسبة متزايدة من النشء تلتحق الآن بالمدارس، كمـا تستمر فيها لفترة أطول.

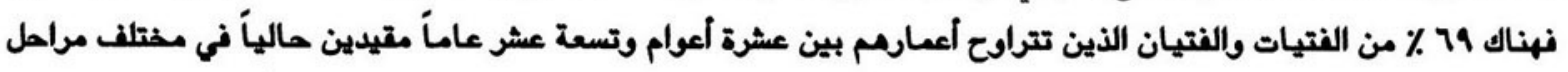

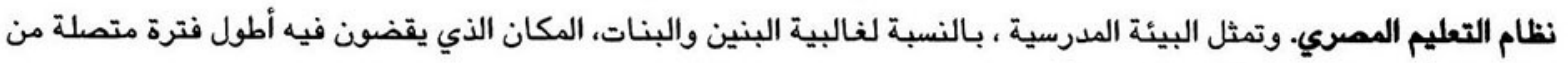
الوقت في أي نشاط من الأنشطة اليومية.

كما تناول الاستبيان الفردي مواضيع هامة تتعلق بالتجربة المدرسية من وجهات نظر الفتيات والفتيان. وتوفر الإجابات

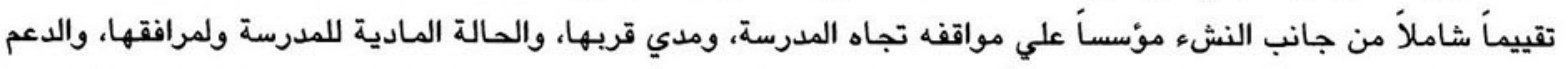

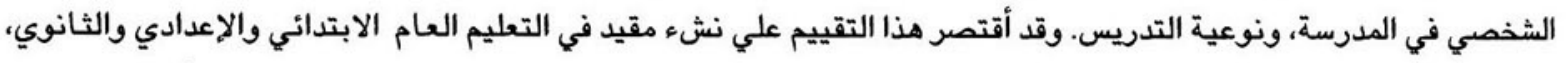

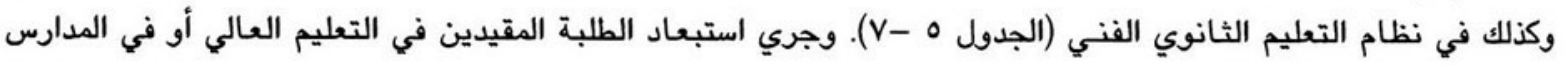
الأزهرية من هذا التحليل. 


\section{موقف النشء تجاه المدرسة}

تتضافر الإجابات علي الأسئلة الخمسة التالية في تقييم الموقف العام الذي يتخذه الفتى أو الفتاة تجاه المدرسة :

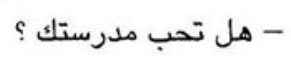

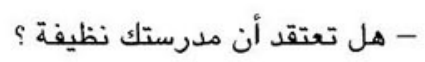

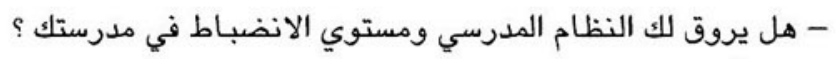

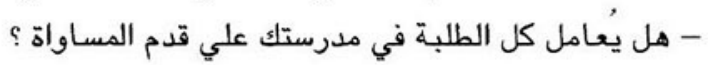
هل هناك ما يثير ضيقك في المدرسة ؟

ويعد موقف الفتى أو الفتاة إيجابياً إذا ما رد بالايجاب علي الأسئلة الأريعة الأولي بالاضافة إلى إجابته علي السؤال الأخير

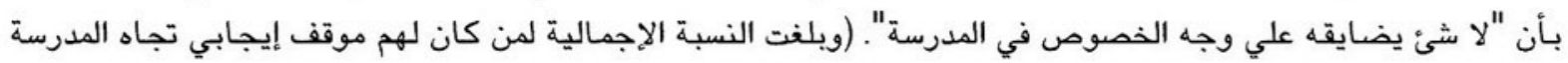

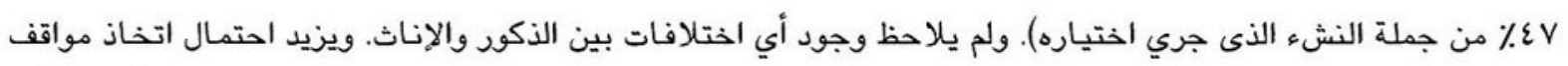

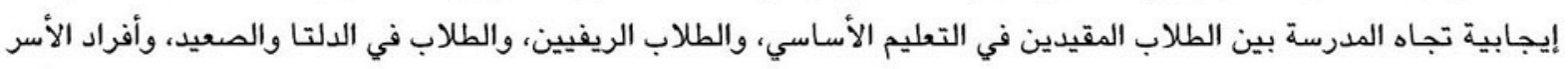

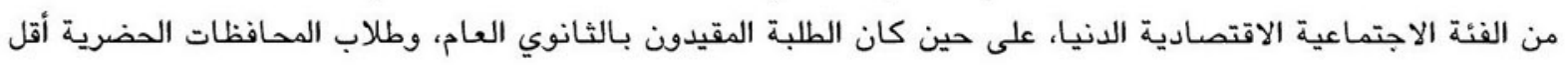
الجميع إعرابا عن موقف إيجابي تجاه مدارسهم.

الذماب إلى المدرسة

يستخدم طول الفترة الزمنية اللازمة للذهاب إلى المدرسة كمقياس ينم عن الجهد المبذول وعن مدي المشقة التي يتجشمها

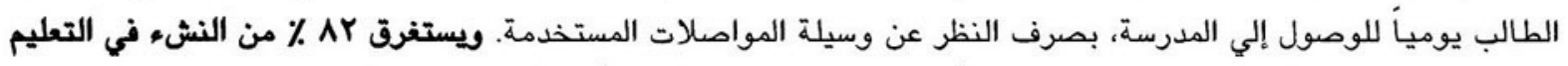

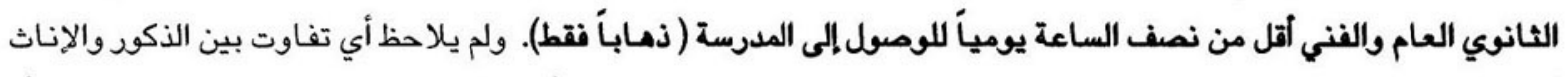

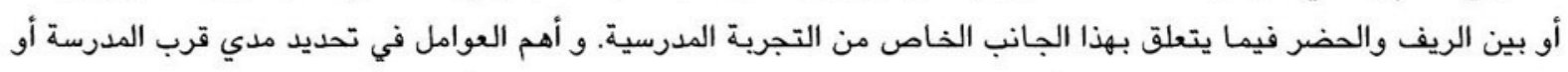

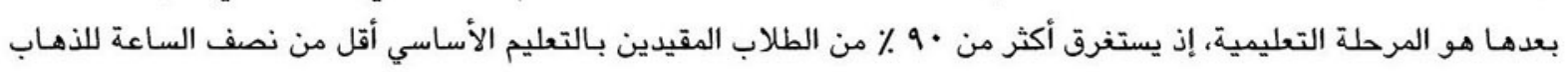

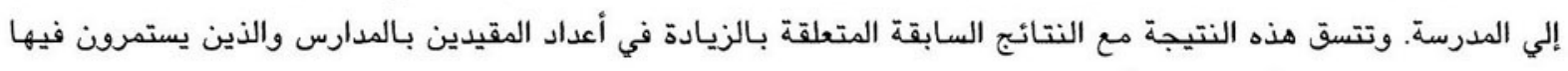

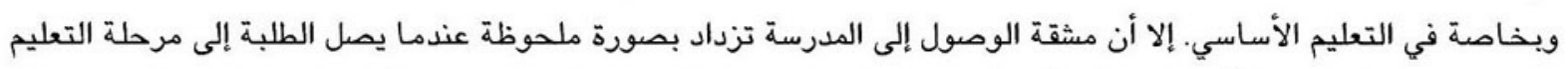

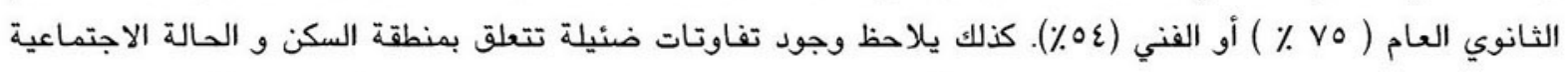

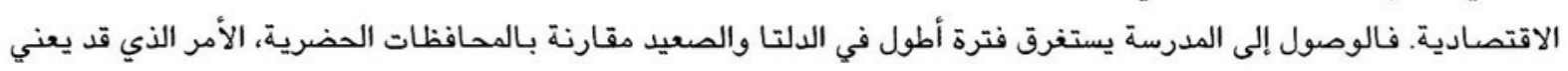
توفر الدارس علي نطاق أوسع في المحافظات الحضرية.

الظرف المادية للمدرسة ومرافقها

إن توافر مرافق معينة في المدرسة مثل أفنية اللعب ودورات المياه، والحالة المادية لهذه المرافق وكذلك للفصول، يمثلان بلا

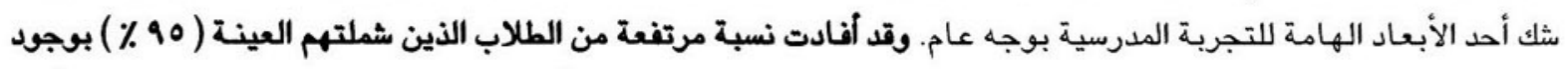

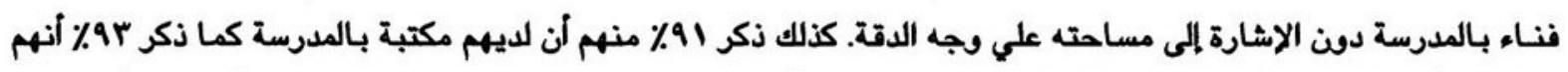

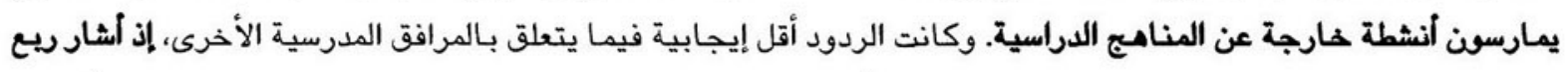

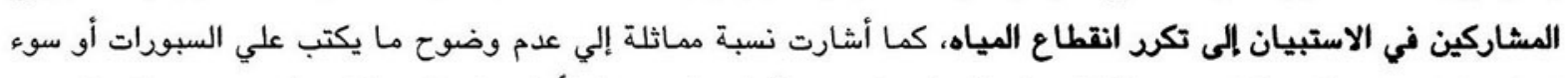

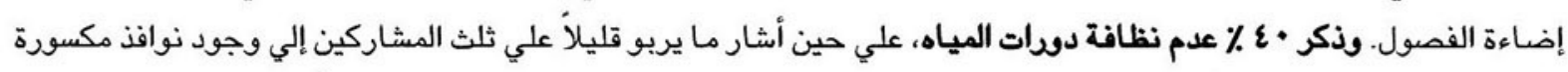

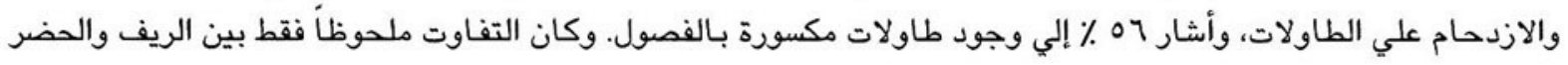


وكذلك فيما بين المناطق المختلفة. وكما يتبين من الإجابات، كانت الظروف المادية للمدارس والمرافق افضل في المناطق الريفية في الدلتا والصعيد.

\section{الخدمات غير الدراسية والتفاعل مع المعلمين والأقران}

تتاح للفتيان والفتيات الملتحقين بالمدارس فرص للتفاعل مع البـالغين والأقران من خارج نطاق الأسرة أكبر من تلك المتـاحة

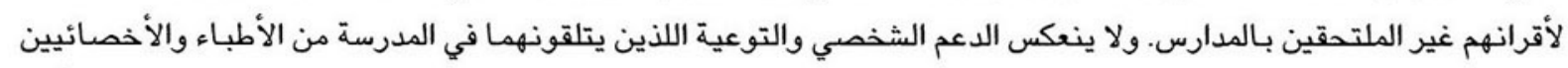

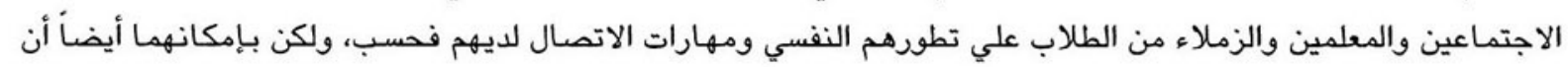

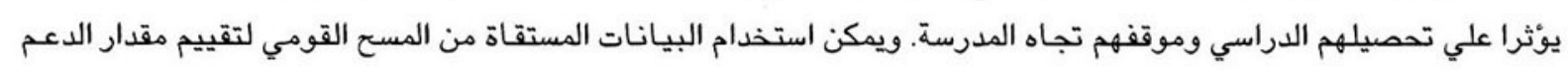
الشخصي الذي يتلقاه الطلاب في المدرسة والتفاوتات فيه.

وقد ذكر بV ٪ من المشاركين في الاستبيان وجود طبيب أو ممرضة في مدرستهم الحالية. كما لوحظ تفاوت كبير في هذا المؤشر،

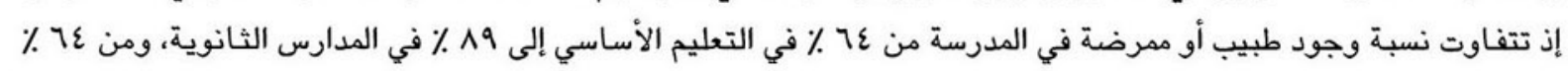

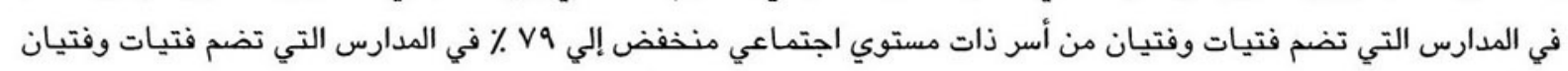

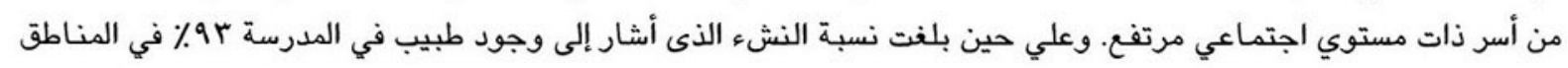

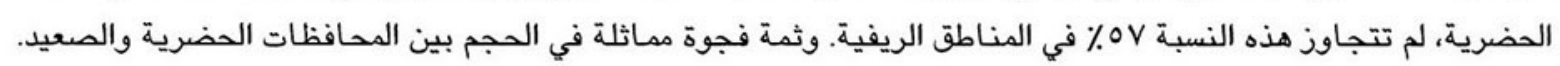

وتوجد نفس التفاوتات فيما يتعلق بوجود أخصائي اجتماعي في المدرسة، إلا أن نسبة الذين أفادوا بوجود أخماني اجتماعي

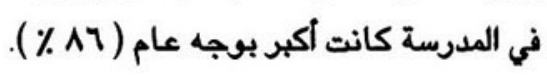

ومن بين النشء الذى شملته العينة، ذكر الثلث فقط أنهم راضون عن التجاوب والدعم الشخصي من قبل المعلمين والأقران في

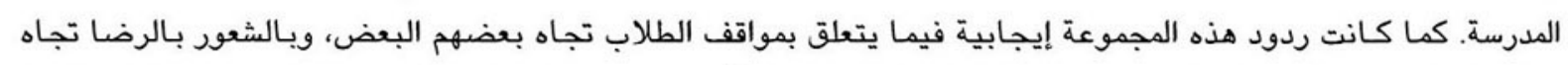

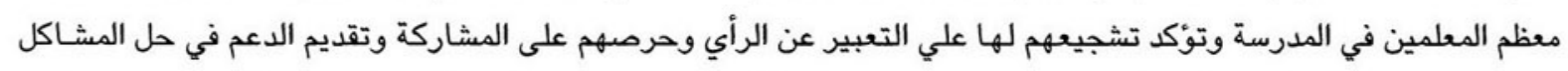

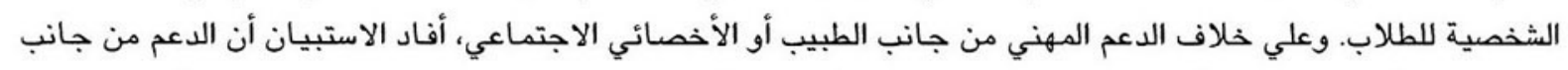

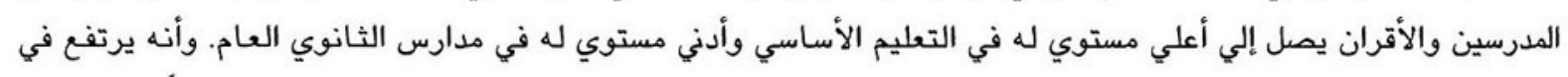

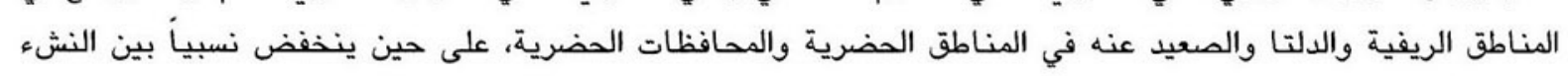

المنتمى لأسر الفئة الاجتماعية العليا.

نوعية التعليم

تقاس نوعية التعليم، عادة، بنتائجه المتمثلة في التحصيل الدراسي واكتساب المهارات المهنية والحياتية. ومن العوامل المؤثرة

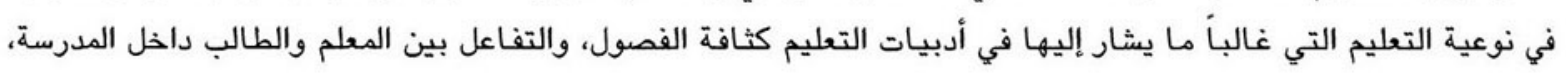
والدروس الخصوصية.

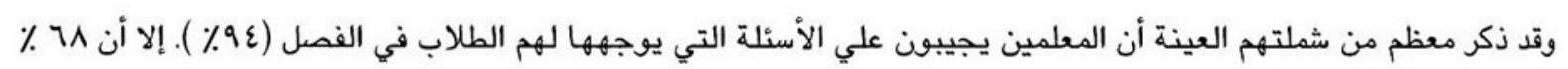

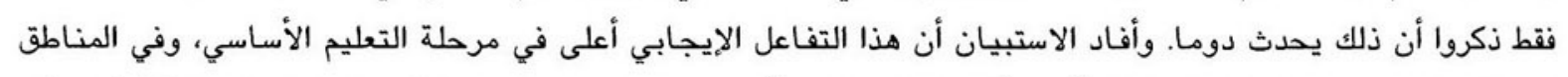

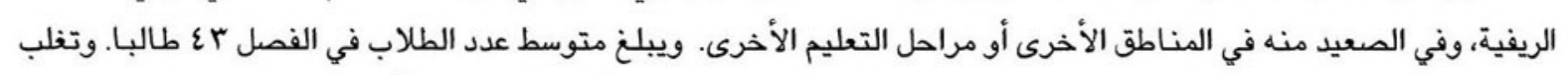

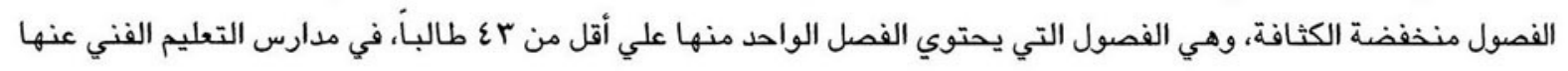




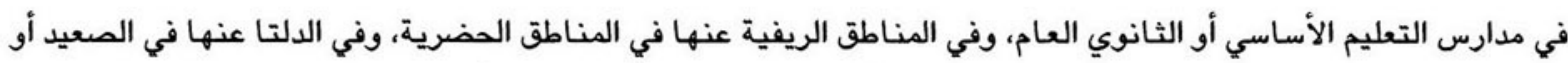

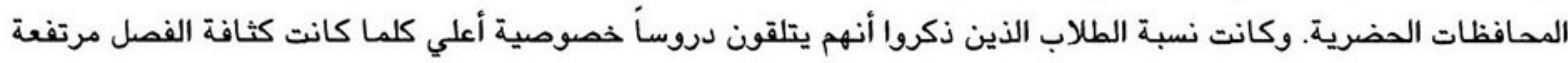

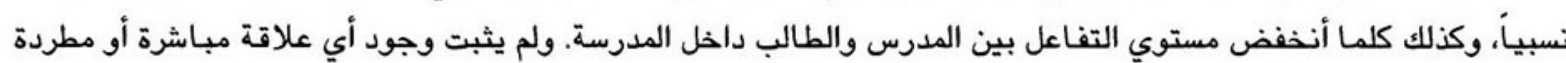
بين كثافة الفصل ويين التفاعل داخله.

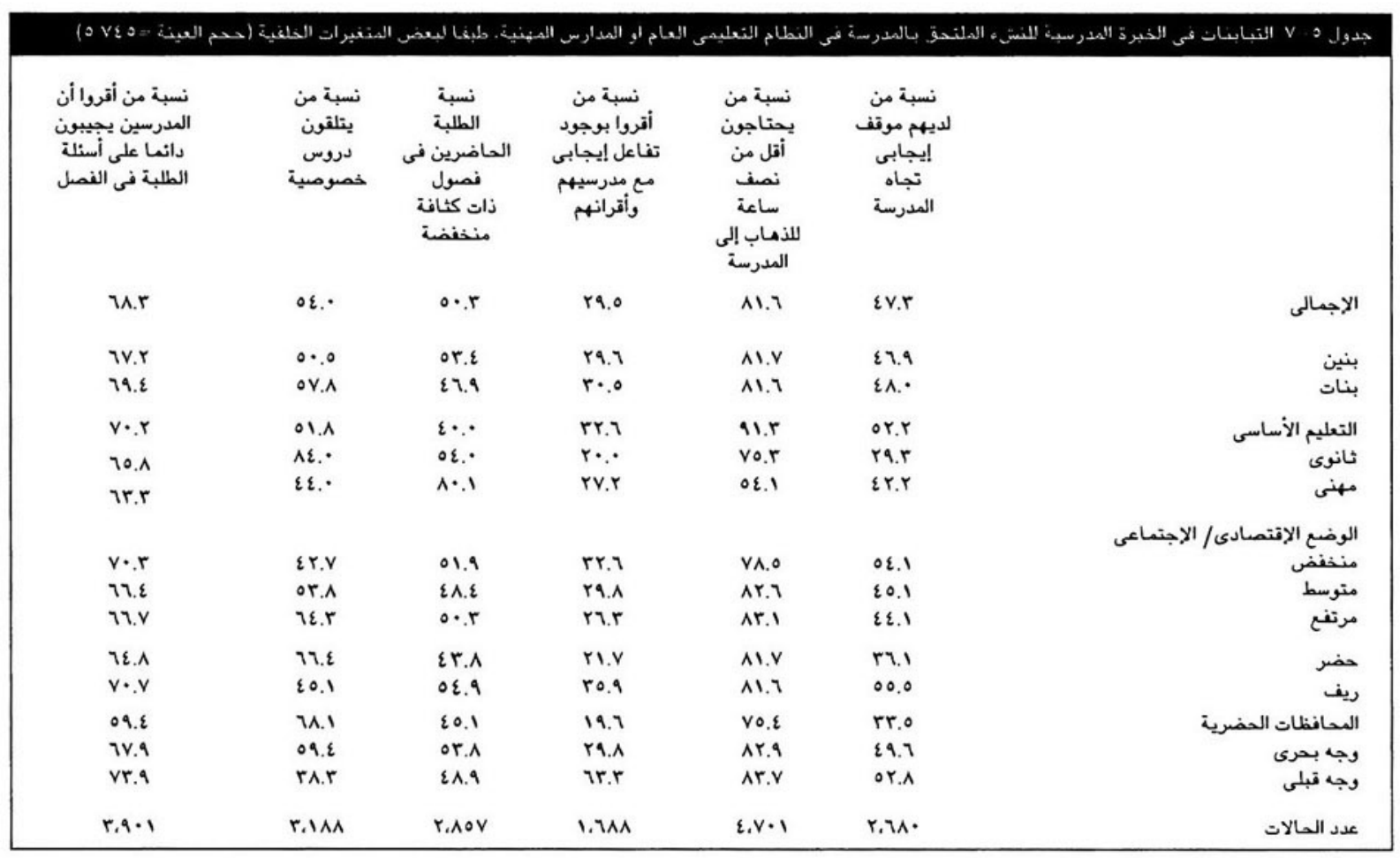

رابعاً: السياق الاجتماعي للتعليم : لغية جيلين

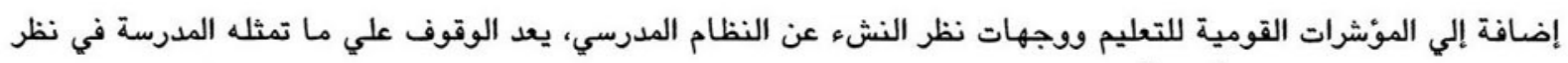

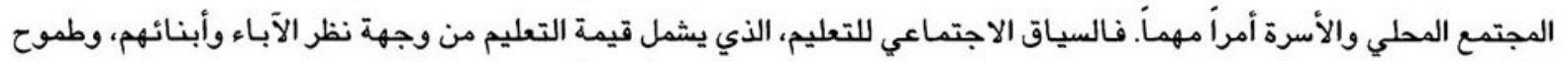

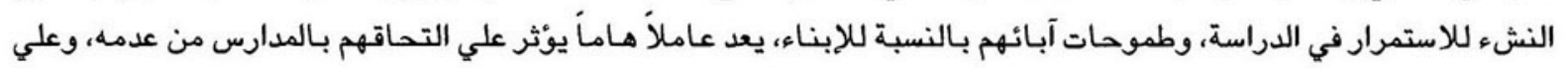

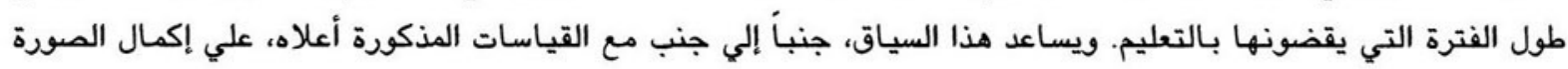

التعليمية العامة للنشء.

\section{الطموحات التعليمية}

يدرك الوالدان، سواء منهم الأمهات أو الآباء، أهمية التعليم (الجدول ه - ^)، إذ يتفق 99 ٪ من الآباء والأمهات علي ضرورة

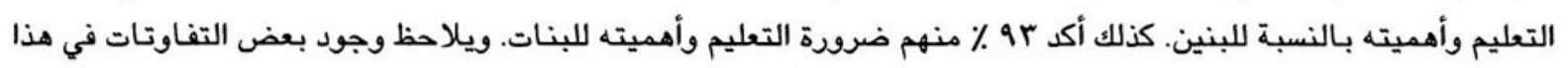

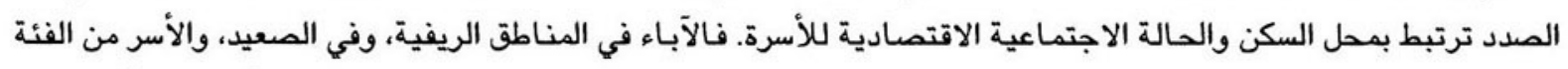

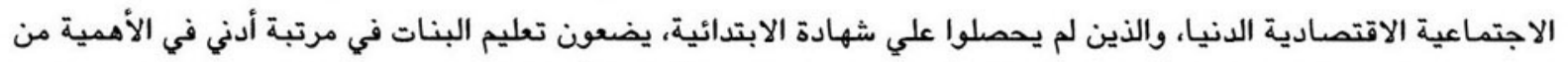

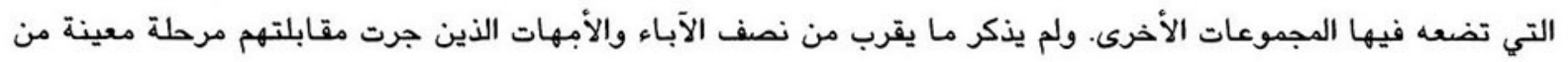

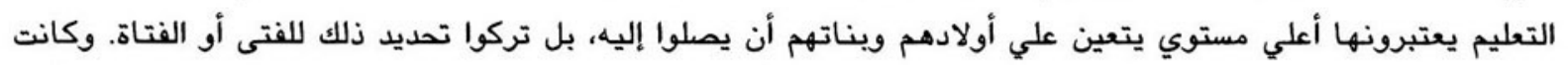

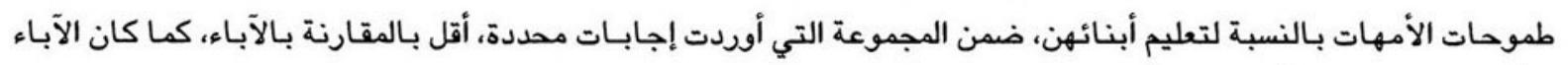
والأمهات علي السواء أقل طموحاً بالنسبة لتعليم البنات مقارنة بالبنين. 


\begin{tabular}{|c|c|c|c|c|}
\hline \multicolumn{5}{|c|}{ جدول ه - م: نسب التوزيع الهئوية للطهوحات التعليدية للنشى: والوالدين (الذين أدلوا بـاجابات محددة) } \\
\hline \multicolumn{2}{|c|}{ نسبة النشء الذي يتطلع إلى استكمال التعليم } & \multicolumn{2}{|c|}{ نسبة أولياء الأمود الذين يعتقدون أن أبناءمي } & \\
\hline بنات & بنين & بنات & بنين & \\
\hline 79.0 & vr.y & $\mathrm{v} \cdot \cdot$ & 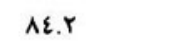 & 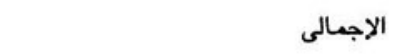 \\
\hline r9.7 & ฉ૫.1 & - & - & رسوب \\
\hline ०А. & רย.r & - & - & ملحق \\
\hline$\wedge 1 . \varepsilon$ & A.. & - & - & ناجع باستمرار \\
\hline ver.r & vา.ย & - & - & . إ-1 اسنة \\
\hline$\dddot{11 .}$ & $7 \varepsilon . \varepsilon$ & - & - & 19-19 انة \\
\hline - & - & vi.1 & 10.9 & ذكود \\
\hline - & - & 11.0 & $\wedge 1.1$ & إناث \\
\hline - & - & 0.0 & vr.v & غير متعلم/ لم يكمل المرحلة الابتداثية \\
\hline - & - & 19.1 & $\mathrm{AV}$. & حامل على الشهادة الابتدانية \\
\hline - & - & 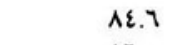 & १५. & حاصل على الشهادة الاعدادية \\
\hline- & - & 17. & 97.1 & حاصل على الشهادة الثانوية \\
\hline - & - & 90.0 & १A. & حاصل على الشهادة الجامعية \\
\hline ०А. & ०१.v & - & - & يعمل \\
\hline ro.r & vr.r & - & - & لايعمل \\
\hline & & & Yu.r & المستوى لاقتمادى/ الاجتماعى \\
\hline $\begin{array}{l}0 . r \\
u .7\end{array}$ & $\begin{array}{l}r .4 \\
v \cdot .7\end{array}$ & W.. & Ao.r & متوسط منض \\
\hline$\wedge 1 . \varepsilon$ & Ar.o & $\wedge \varepsilon \cdot \cdot$ & ar.r & مرتفع \\
\hline$v \cdot . \varepsilon$ & ve.r & vr.1 & ^я. & أسرة نورية \\
\hline 77.0 & iv. & ०А.० & vv.o & أسرة ممتدة \\
\hline TV.Y & 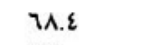 & $7 \varepsilon .1$ & va.\& & أسرة تعولها سيدة \\
\hline 19.1 & vr.e & $v \cdot .0$ & ^£.0 & أسرة لا تعولها سيدة \\
\hline VA.V & $\Lambda \cdot .1$ & Ar. $\varepsilon$ & $9 \cdot \cdot$ & حضر \\
\hline ir.o & १.. & ov.1 & VA.T & ريف \\
\hline Ar.\& & $\Lambda \varepsilon, Y$ & AM.Y & 9 9r.A & المحافظات الحضرية \\
\hline 19." & 51.7 & u.r. & ㄱ. & وجه بحرى \\
\hline 11.r & IV.A & 07.1 & vย.q & وجه قبلى \\
\hline r.AYT & $r \cdot A r$ & $r_{1} \cdots q$ & r.aiv & 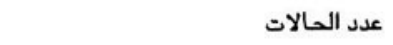 \\
\hline
\end{tabular}

وكانت آراء الآبـاء والأمهات فيما يتعلق بأعلى مستوي تعليمي يتعين علي بناتهم أولادهم بلوغه مرتبطة بدرجة كبيرة بمدي

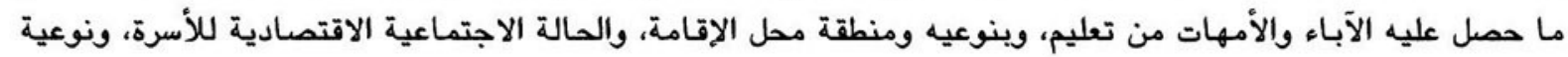

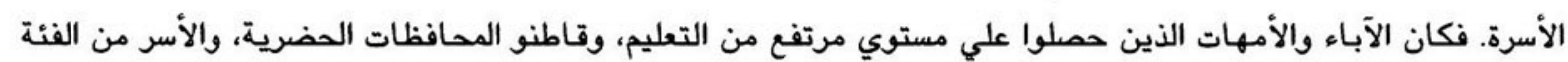

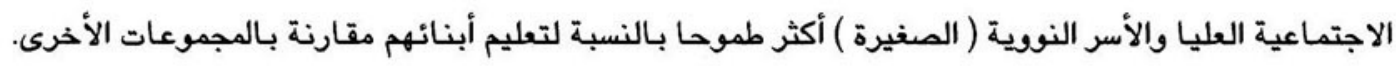


وعلي الجانب الآخر، كانت الطموحات التعليمية بين النشء المقيد حالياً بالدارس كبيرة للغاية. إذ أعريت أقلية منهم لا تتجاوز

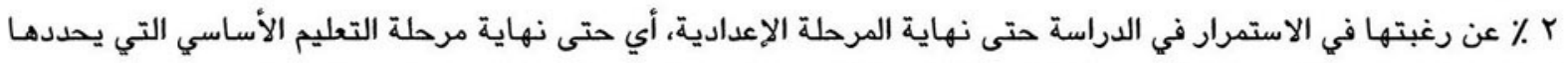

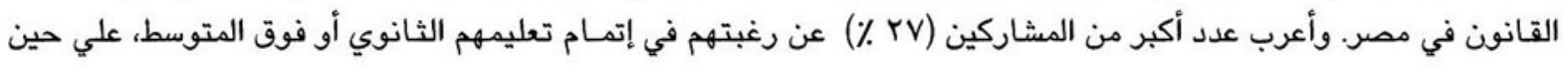

ذكر •v ٪ أنهم يريدون الاستمرار حتى نهاية المرحلة الجامعية.

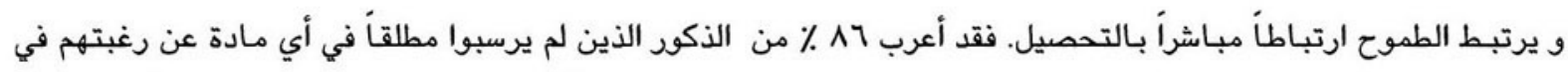

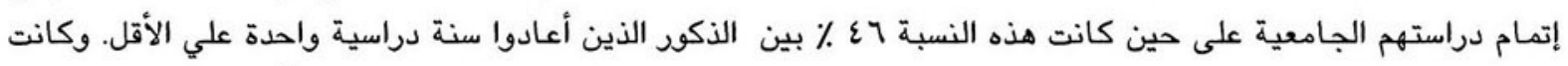

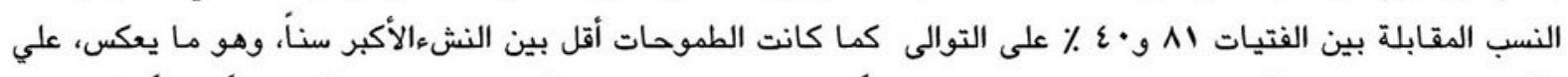

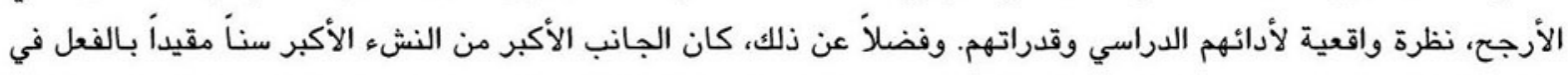

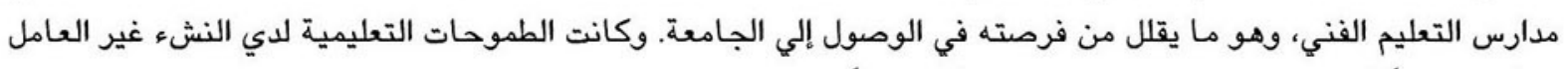

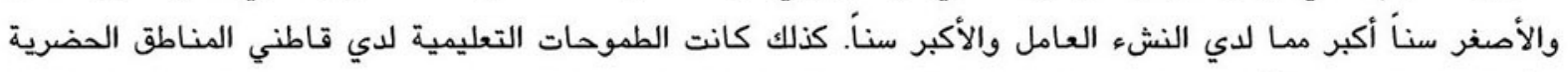

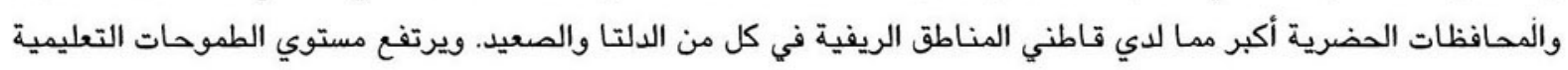
للنشء بارتفاع وضعه الاجتماعي الاقتصادي.

ويالنسبة للبالغين الذين حددوا مستوي معيناً من التعليم يعتبرونه مثالياً لأبنائهم كان هناك قدر كبير من التداخل بين طموح

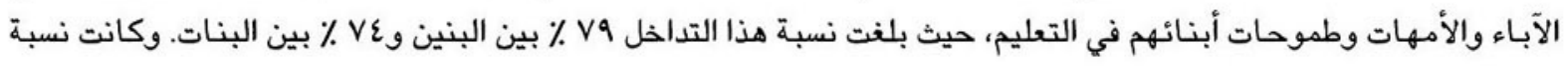

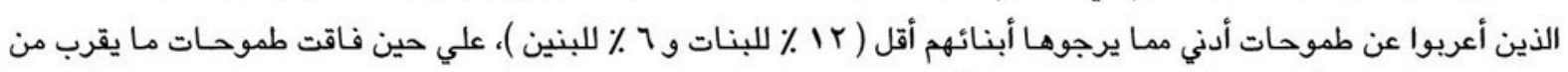

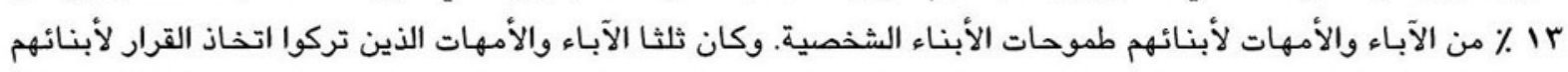

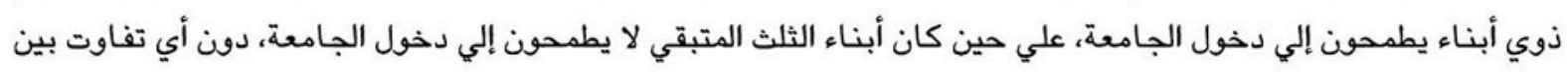
الذكور والإناث.

قيمة التعليم

يتشكل رأي الفتى أو الفتاة في قيمة التعليم عبر قنوات مختلفة، منها ما يصل إليه من مفاهيم في مجتمعه المحلي، ومن خلال

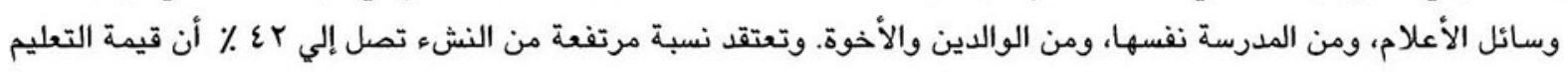

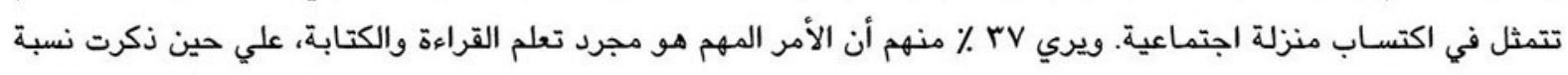

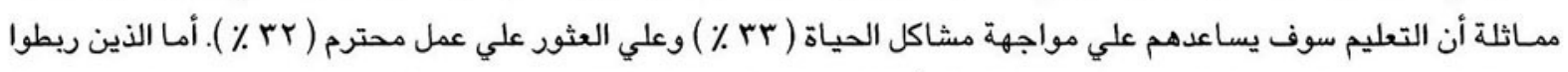
بين التعليم ويين الوصول إلي وضع مالي افضل أو الحصول علي وظيفة ذات راتب جيد فلم تتجاوز نسبتهم ح٪ (الجدول

( 9 - ०

وكانت غالبية الذين يرن أن قيمة التعليم تتمثل في اكتساب منزلة اجتماعية من الطلاب الذي يرتفع مستوى تحميلهم

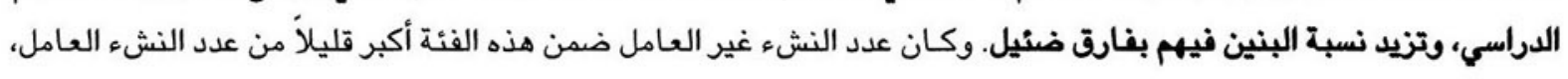

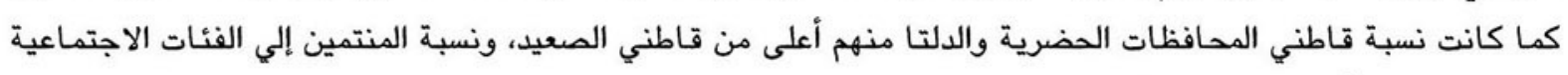

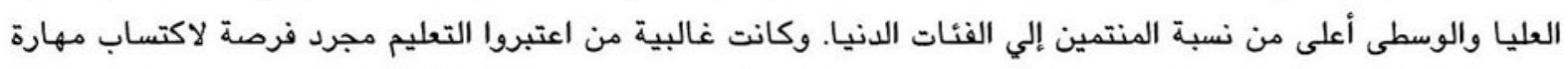

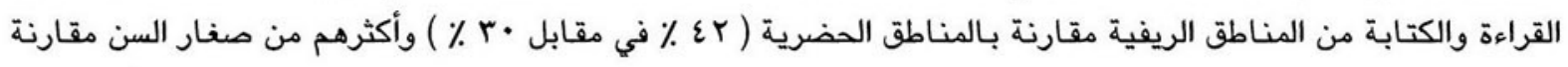

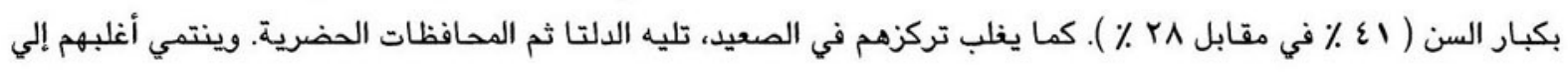
الفئات الاجتماعية الاقتصادية الوسطي والدنيا. 


\begin{tabular}{|c|c|c|c|c|c|}
\hline تحسين الوضع & مهارات القرابة & مشاكل الفضل معاة بصورة & عمل محترم على & تاجسين الوضع & \\
\hline $7 . \varepsilon$ & r... & rr.l & Mi.A & $\varepsilon r$. & 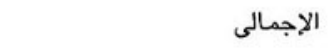 \\
\hline 0.1 & $\varepsilon r . \varepsilon$ & ru.\& & $r \cdot .9$ & rr. & رسوب \\
\hline 0.9 & rq.r & $r 1.9$ & ri.l & rA.T & ملحق \\
\hline 7.V & rr.A & re.r & rr.o & $\varepsilon$ \&า. & نجاح باستمرار \\
\hline$\varepsilon . r$ & rE.A & $r \cdot \cdot$ & rq. & $\varepsilon \varepsilon . \varepsilon$ & بنين \\
\hline A.r & rq.r & r..A & YV.r & ra.r & 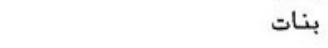 \\
\hline 0.1 & $\varepsilon 1 . r$ & r^.9 & rr.t & $\varepsilon \cdot .0$ & . \\
\hline A. 9 & YA.E & $\varepsilon 1.1$ & $r \cdot .0$ & $\varepsilon \varepsilon . \wedge$ & 19-19 سنة \\
\hline v. & $\varepsilon 1 . \varepsilon$ & $r \cdot .1$ & ro.t & rer & يعمل \\
\hline $7 . r$ & ro.o & $r \varepsilon .1$ & $r \cdot v$ & $\varepsilon r . v$ & لا يعمل \\
\hline & & & & & الوضع الاقتمادى/ الاجتماعي \\
\hline$\Lambda .9$ & $\varepsilon 1 . r$ & YA.Y & ro.7 & rา. & منخفض \\
\hline 0.7 & rv.v & 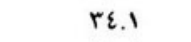 & rq.9 & $\varepsilon r . \varepsilon$ & متوسط \\
\hline 0.7 & M.r & ry.A & ri.t & $\varepsilon \vee \varepsilon$ & مرتفع \\
\hline ר.r & ro.o & $r \varepsilon . r$ & rr.l & $\varepsilon r . V$ & أسرة نورية \\
\hline 7.1 & $\varepsilon 1.1$ & rq.६ & ri.r & rq.v & أسرة ممتدة \\
\hline$\varepsilon . \varepsilon$ & $r \varepsilon .1$ & $r 0.9$ & $r \varepsilon .0$ & $\varepsilon r .1$ & أسرة تعولها سيدة \\
\hline 7.7 & rv. & rr.q & ri.t & $\varepsilon r . \cdot$ & أسرة لا تعولها سيدة \\
\hline $0 . \varepsilon$ & r৭.० & rา.o & ri.o & $\varepsilon 0 . \varepsilon$ & حضر \\
\hline v. 1 & $\varepsilon 1.9$ & $r \cdot . \Lambda$ & rr.l & rq.v & ريف \\
\hline $7 . \varepsilon$ & re.r & rn. & ri.q & $\varepsilon \wedge .0$ & المحافظات الحضرية \\
\hline V.A & ro.r & rv.A & YA.A & $\varepsilon 0.0$ & وجه بحرى \\
\hline$\varepsilon . \vee$ & $\varepsilon\urcorner$. & ro.A & $r 0.7$ & $r \varepsilon$. & وجه قبلى \\
\hline$r \varepsilon \varepsilon$ & $r_{1} \cdot 90$ & $1.9 \cdot 7$ & I.VAV & r.rAE & عدد الحالات \\
\hline
\end{tabular}

وكان أغلب من يرون التعليم سنداً لهم في مواجهة مشاكل الحياة من الإناث مقارنة بالذكور، ومن كبار السن مقارنة بصغار

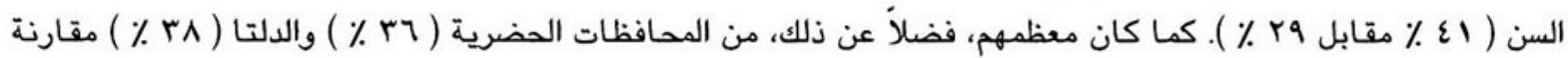

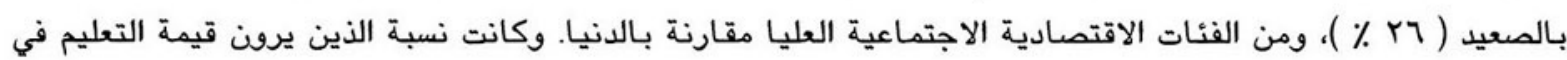

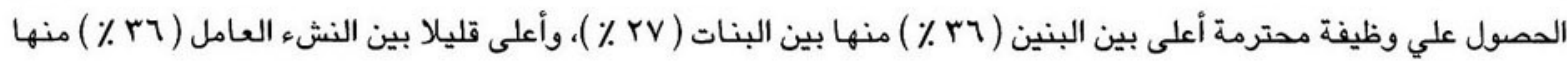
بين غير العاملين (آب\%).

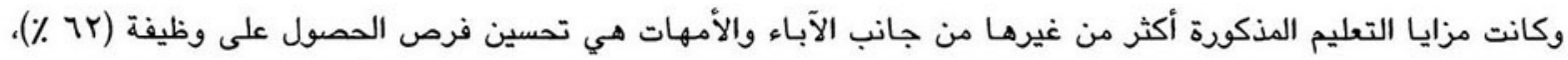

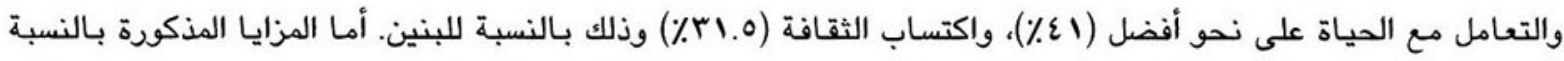

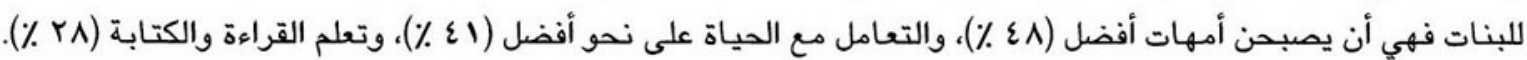

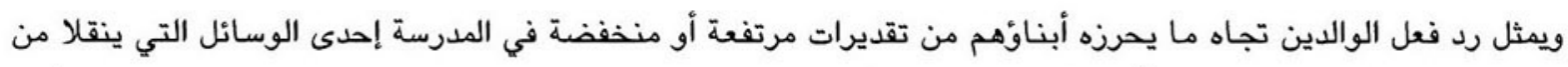

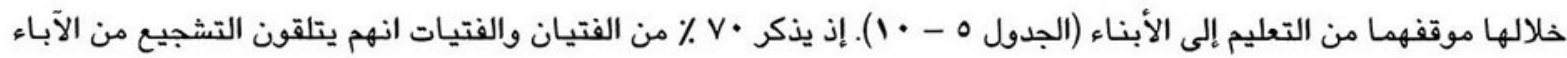

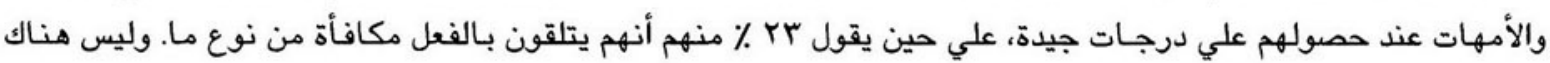


أي تفاوت بين الذكور والأثاث فيما يتعلق بهاتين الإجابتين، لكن يبدو أن التشجيع يكون هو الغالب في حالة النشء الأكبر سناً

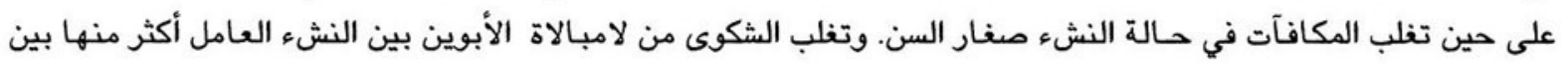

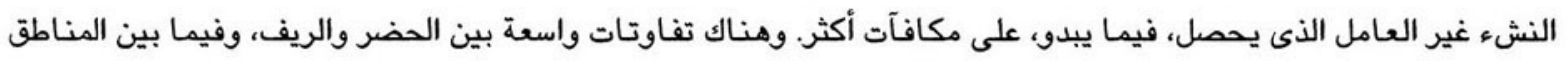

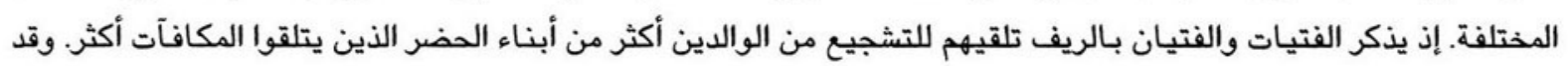

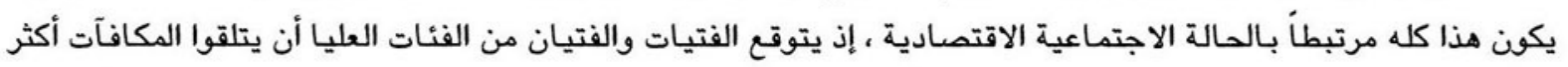

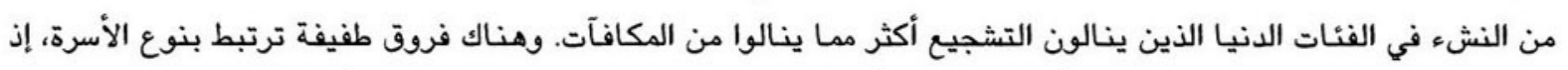

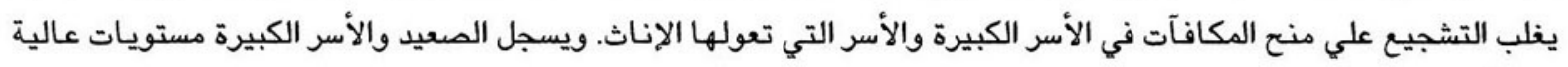
نسبياً من انعدام الاستجابة لدي الوالدين.

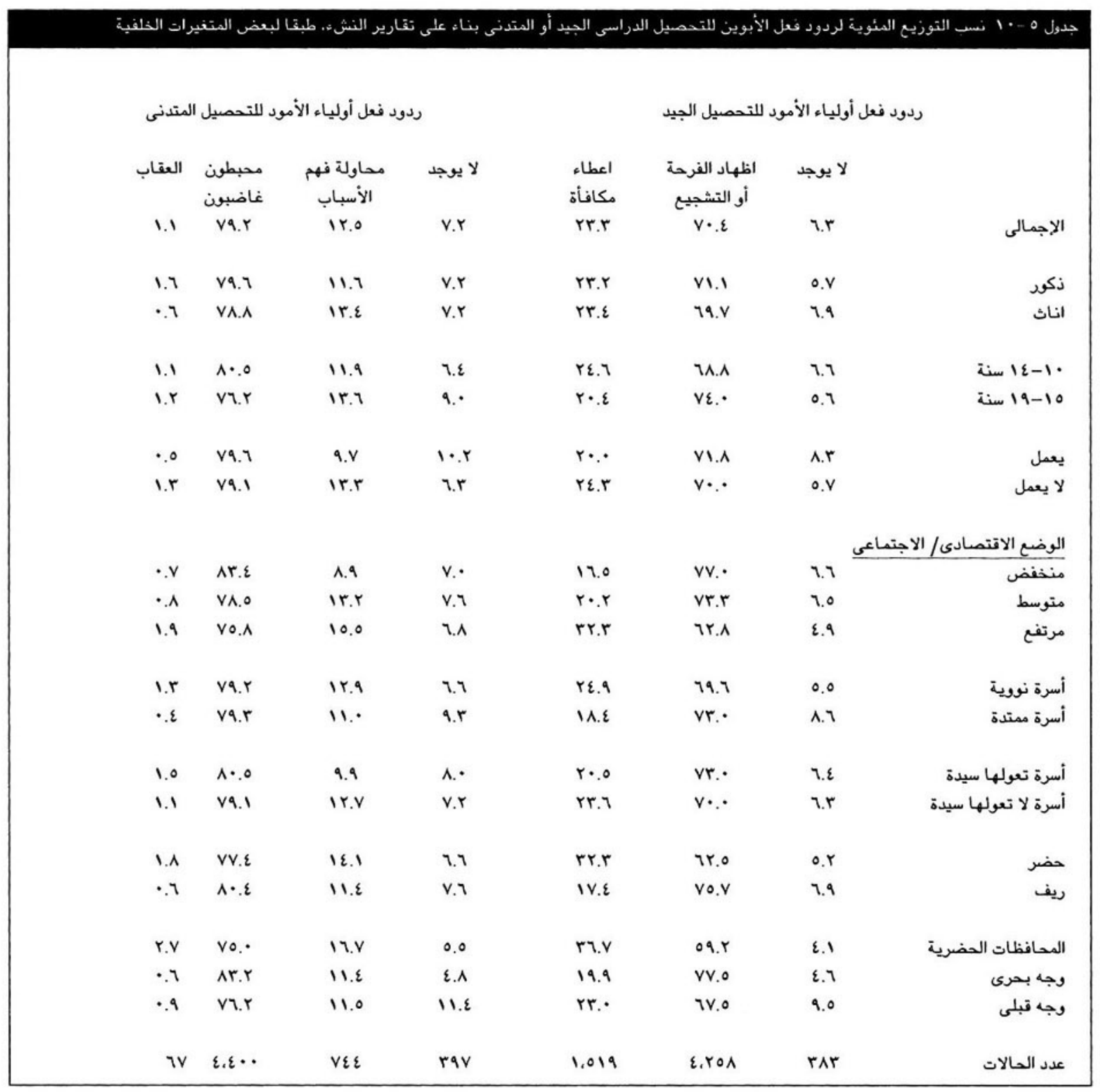

وفي حالة حصول الفتى أو الفتاة علي درجات ضعيفة، يذكر V9 ٪ أن أبويهم يصيبهم الغضب، على حين ذكر با ٪ منهم أن

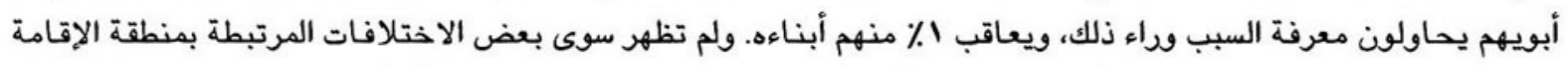

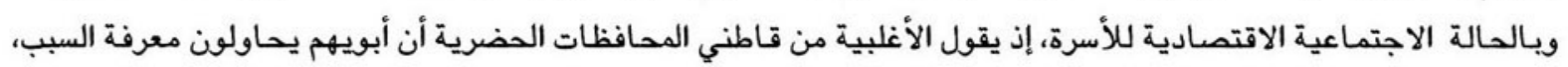


علي حين يذكر الأغلبية من قاطني الدلتا غضب أبويهم، أمـا الأغلبية من قـاطني الصعيد فيذكرون أن أبويهم لا يفعلون شيئاً. وترتبط الحالة الاجتماعية الاقتصادية المتدنية أكثر بالغضب كرد فعل، علي حين ترتبط الحالة الاجتماعية الاقتصادية العليا والوسطى بمحاولة لفهم الأسباب.

\section{المدرسة كعامل من عوامل التنشتة الاجتماعية}

تؤثر المدرسة كذلك علي المجتمع المحلي المحيط بها، وتنقل إلي طلابها قيماً معينة تعد جزءأ من عملية تنشئتهم الاجتماعية. وقد الحت

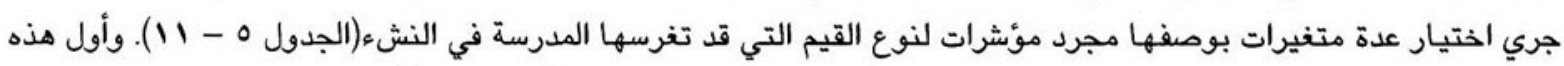

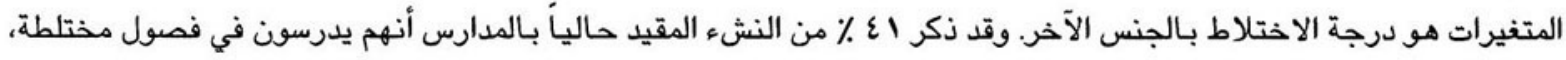

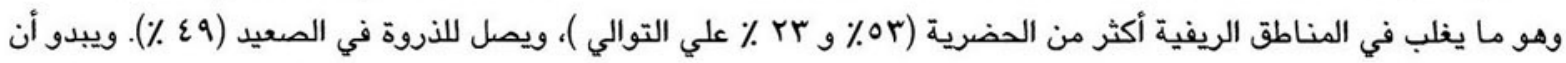

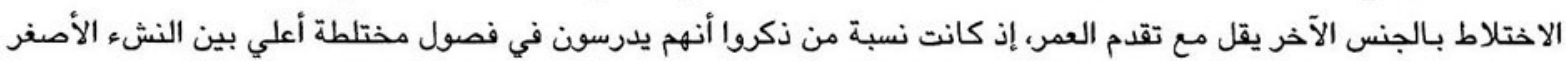

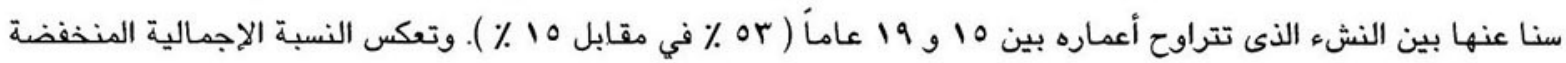
للفصول المختلطة النسبة المنخفضة نسبيا للمدارس المختلطة فضلا عن أن المدارس المختلطة لا تضم كلها فصولا مخلا مختلطة

وقد يؤدي عدم المساواة في المعاملة داخل المدرسة إلى غرس إحساس بالظلم في العالم لدى النشء صغير السن. ويمكن أن تكون

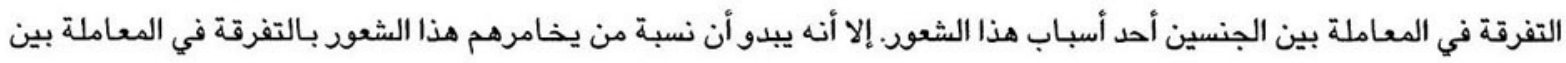

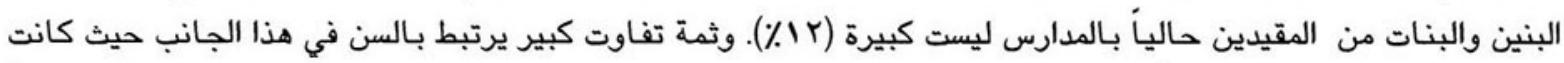

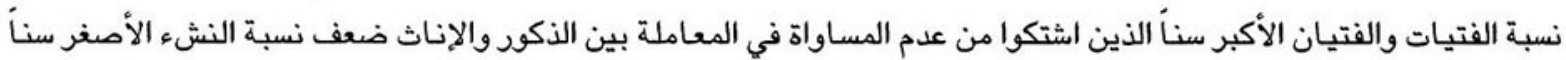

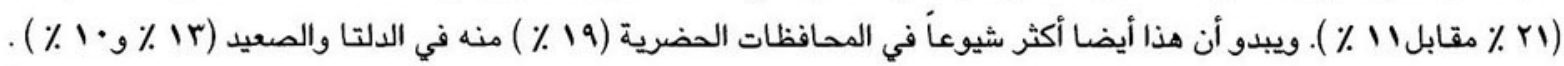

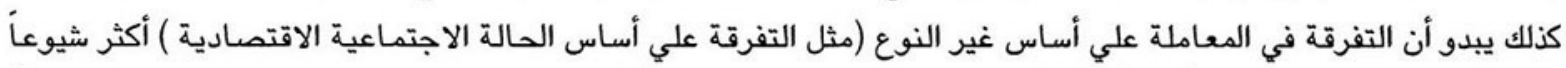

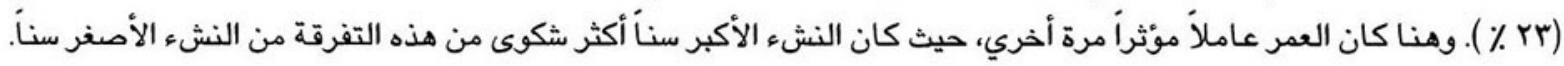

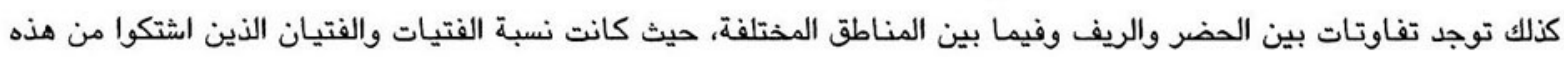

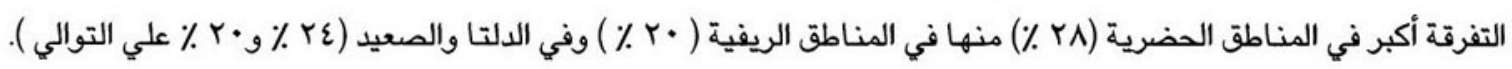

كذلك يمكن أن تؤثر ممارسات معينة داخل الفصل علي شخصية الطالب وتغرس فيه قيم معينة. ومن أمثلة ذلك، مدي تشجيع أكا

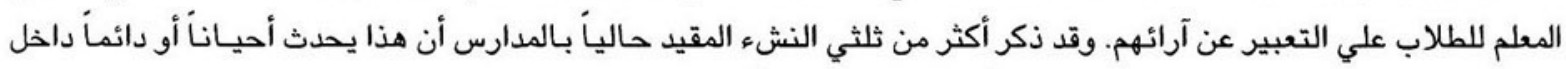

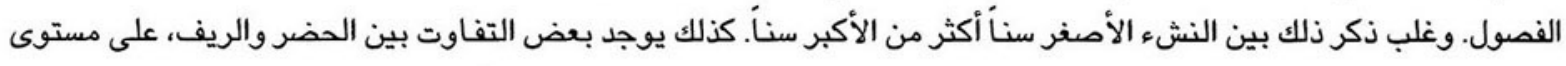

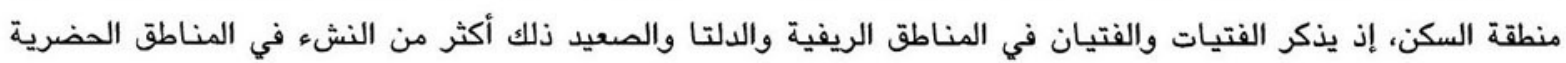
والمحافظات الحضرية. 


\begin{tabular}{|c|c|c|c|c|c|c|c|}
\hline بض أفادوا بآن & أفسادوا & 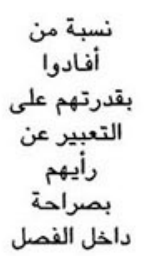 & ألمادبة من ألمدراء & 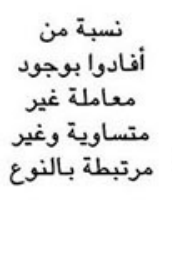 & 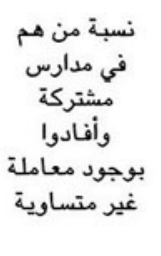 & في فصة من همل & \\
\hline ०६.1 & งา. & ०६.q & $79 . \varepsilon$ & rr.\& & Ir.\& & ६1. & 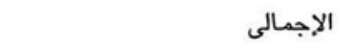 \\
\hline$¥ . \varepsilon$ & Av. 7 & $09 . \varepsilon$ & vi.o & rr.A & 11.9 & $\varepsilon 1.9$ & بنين \\
\hline$\varepsilon 7.1$ & 10.1 & $\varepsilon 9.1$ & IV.r & rध. & ir.1 & $r 9.9$ & بنات \\
\hline $7 \cdot . \mathrm{V}$ & Av. $\cdot$ & o $\varepsilon . \wedge$ & Vr.r & $r \cdot .7$ & $1 \cdot .1$ & or.r & . \\
\hline rA.9 & NT. & or.r & ir.r & rq.V & $r \cdot . V$ & $10 . r$ & 101-9-9 سنة \\
\hline 10.9 & $\wedge \mathrm{V} .0$ & $07 . r$ & vr.\& & $r \cdot . \wedge$ & 11.7 & $\varepsilon 0 . Y$ & 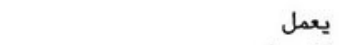 \\
\hline or.1 & 1.. & O $\{\varepsilon$ & 11.0 & $r \varepsilon .1$ & Ir.V & ra.v & لا يعمل \\
\hline Vo. $\varepsilon$ & $\Delta \mathbb{S}_{1}$ & 079 & $v r^{9}$ & r. & - & s & المستوى الاقتصادى/ الاجتماعى \\
\hline ०.. & ผา. & or. & 71.1 & rE.A & $\begin{array}{l}\text { ir. } \\
\text { int. }\end{array}$ & \&li & منخفض \\
\hline$\varepsilon \cdot\rceil$. & 10.0 & o . . & $7 V .9$ & $r \varepsilon . \varepsilon$ & IE.r & rv. & 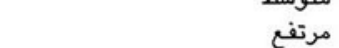 \\
\hline or. $\varepsilon$ & Aา. & o\&.r & ר.. & $r \varepsilon .0$ & ir.o & rq. & أسرة نووية \\
\hline ०1. & $\wedge \wedge . \varepsilon$ & $07 . \varepsilon$ & VI.V & 19.0 & $9 . \mathrm{V}$ & $\varepsilon 1.9$ & أسرة ممتدة \\
\hline O\&.A & $\wedge \varepsilon . r$ & or.\& & 77. & ru.r & $10 . \varepsilon$ & rv. & أسرة تعولها سيدة \\
\hline or. 9 & AV.I & 00.1 & 79.8 & rr.l & Ir.r & $\varepsilon 1 . \varepsilon$ & أسرة لا تعولها سيدة \\
\hline$\varepsilon 9.9$ & Ar.r & $01 . r$ & $7 \cdot .0$ & rA.r & $17 . r$ & rr.r & حضر \\
\hline 07.9 & ヘ१. & OV.r & vo.r & 19.7 & $\dddot{11 \varepsilon}$ & or.A & ريف \\
\hline$\varepsilon \varepsilon, Y$ & $\Lambda \cdot . \wedge$ & $\varepsilon V . V$ & $00 . \varepsilon$ & rA. & $1 \wedge .1$ & 19.0 & المحافظات الحضرية \\
\hline OA.r & $\wedge \wedge . \varepsilon$ & $00 . r$ & vo.1 & rr.q & ir.r & $\varepsilon r . v$ & وجه بحرى \\
\hline o६. & Av. 9 & ०A. & 79.9 & 19.8 & $1 \cdots$ & $\varepsilon q . r$ & وجه قبلى \\
\hline r.rra & O.rY. & r.rAT & $\varepsilon$, \&V. & l.عrr & $\varepsilon \varepsilon\rceil$ & Y.O\&A & عدد الحالات \\
\hline
\end{tabular}

إذا أحس الطالب أو الطالبة بأنه قادر علي الوقوف في الفصل والتعبير عن رأيه بحرية، قد يصلح هذا مقياساً لمعرفة هدي

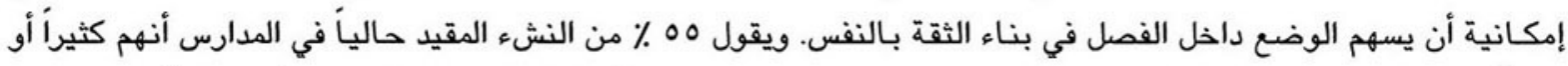

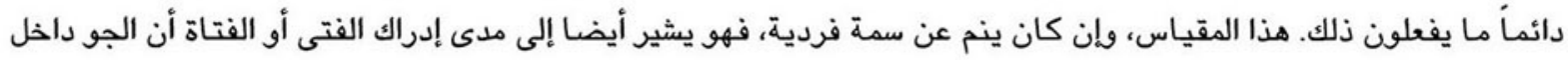
الفصل ليس معاديا ولا مثيرا للخوف.

وتري نسبة كبيرة من الفتيات والفتيان المقيدون حالياً بالمدارس ( AV ٪ ) زملاءهم في الفصل متعاونون ومحبون لبعضهم

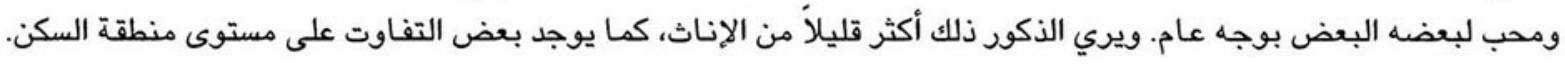

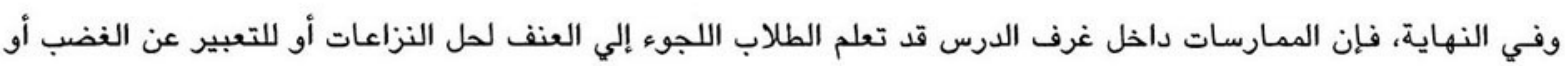

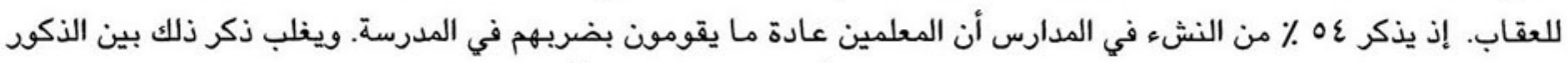

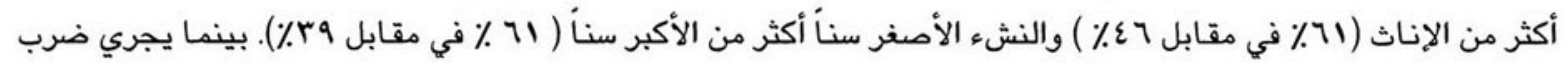




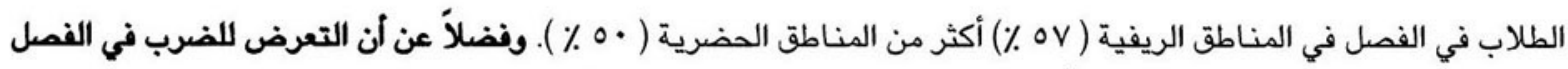

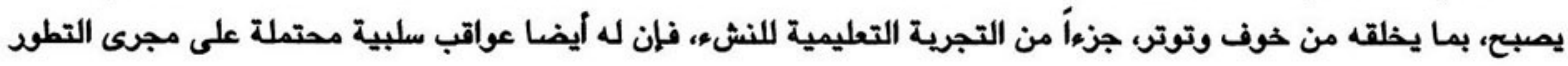
النفسي للنشء الملتحق بالمدارس.

\section{خامساً: نقاش للآثار المتصلة بالسياسات}

شهدت السنوات العشر أو الخمس عشرة الأخيرة زيادة ملحوظة في الالتحاق بنظام التعليم الأساسي في مصر. ورفقا للنتانج

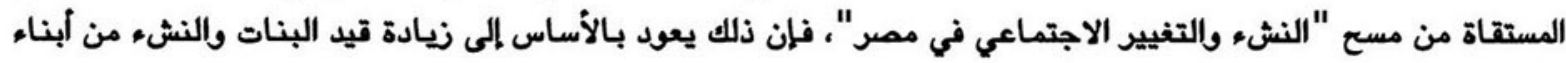

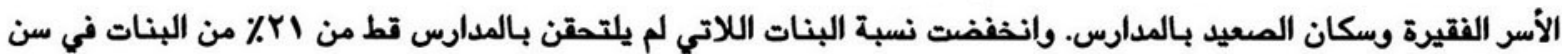

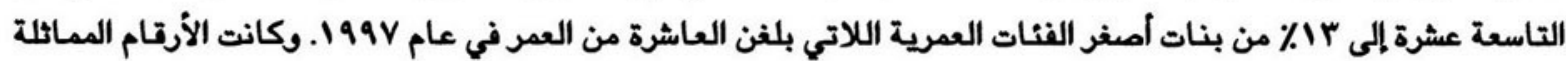

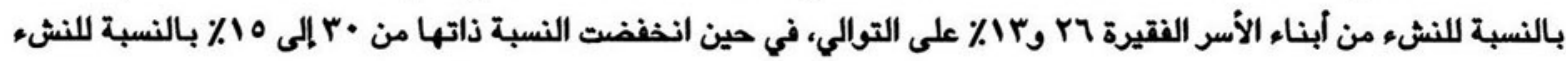

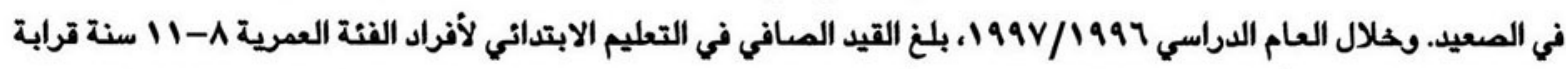

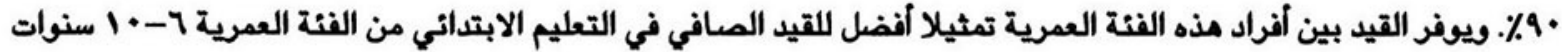

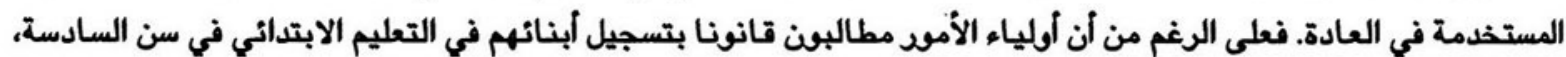

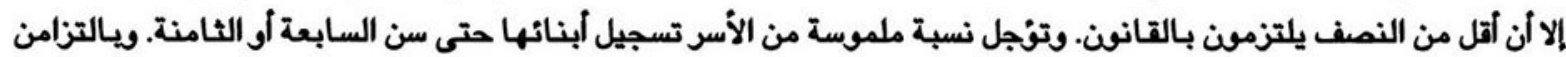

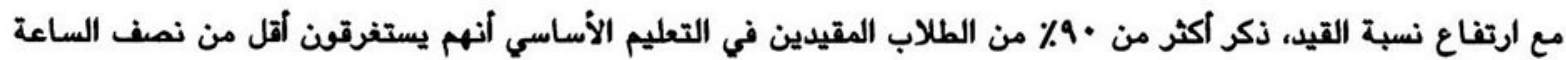

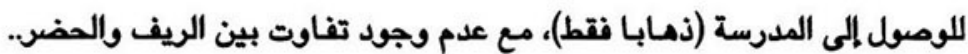

ويظل نقص الموارد الاقتصادية السبب الرئيسي وراء حرمان بعض الفئات من التعليم. وقد ذكر هذا السبب نصف من لم يلتحقوا قط بالمدارس. وعلى نحو متزايد، تميل هذه الفئة للتضاؤل إذ تشمل فقط الأطفال الأكثر تعرضا للمخاطر إزاء التقلبات في الحالة

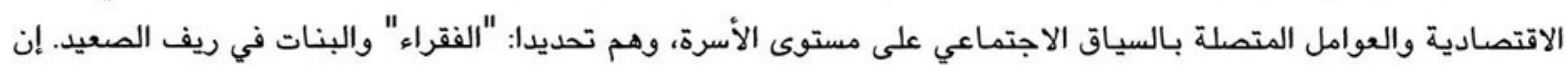

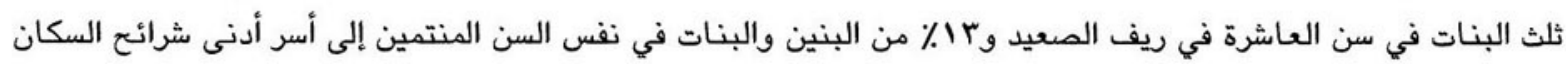

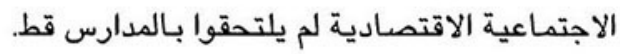

وتؤكد نتائج "مسح النشء والتغيير الاجتماعي في مصر" حدوث انخفاض عام في معدلات التسرب من فئة عمرية إلى الفئة

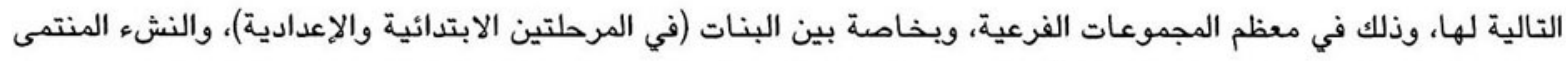

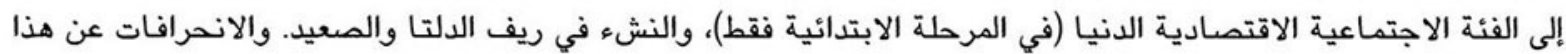

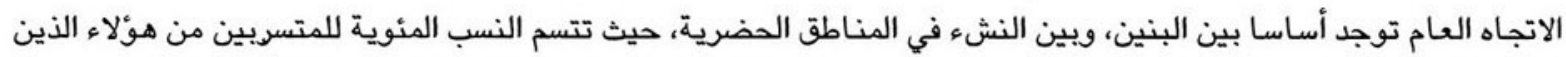

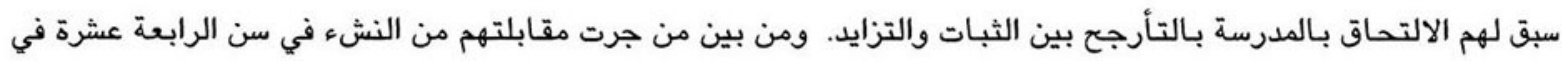

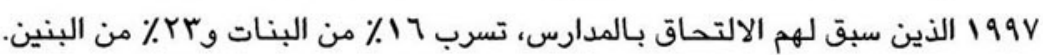

ويعتقد أن التعاون بين الأطراف الأساسية (الدولة والمدارس والمنظمات غير الحكومية والآباء والأمهات) ضروري من أجل

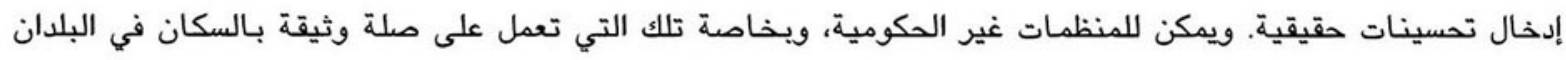

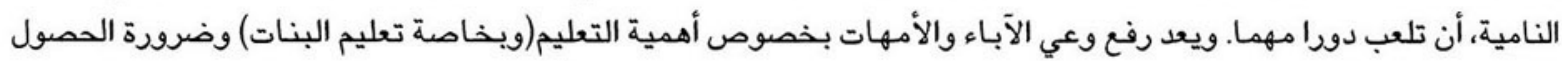

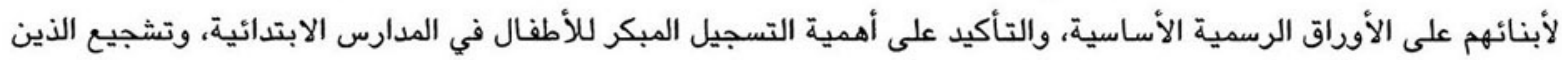

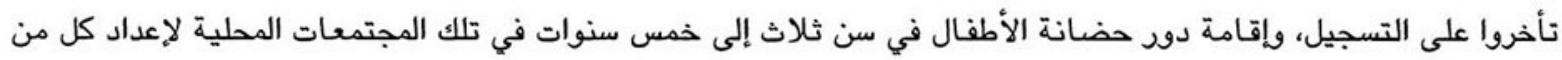

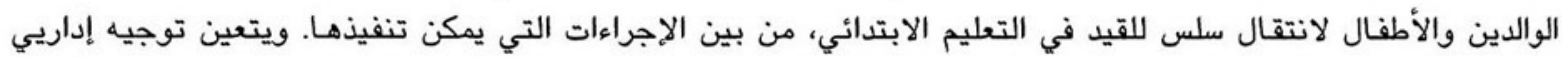

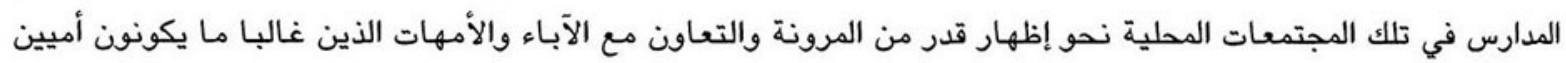


ومع ذلك، تبقى الدولة وسياسات وزارة التعليم الطرف الفاعل الأساسي. ويعد رفع الحد الأقصى لسن للقيد في المدارس الابتدائية

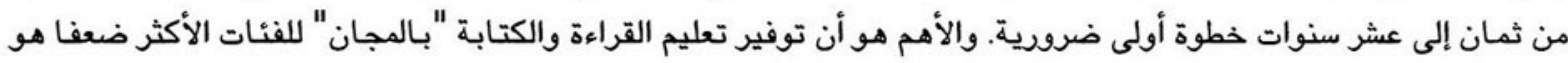
شرط ضروري لغلق ملف الحرمان من التعليم.

ولا تقتصر نفقات التعليم على الرسوم المدرسية فحسب، بل تتضمن أيضا نفقات الزي المدرسي، والأدوات المكتبية اللازمة، والمصروف اليومي(أو نفقات وجبة خفيفة) فضلا عن الدروس الخصوصية. وترتفع نسبة الطلاب الذين يذكرون أنهم تلقوا

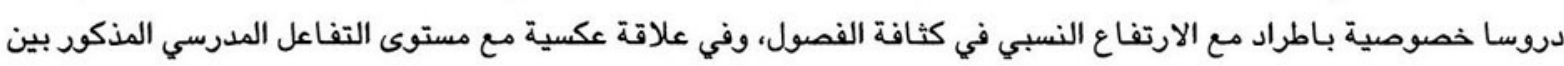

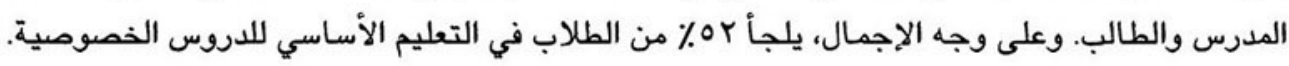

وفي حين يندرج إلغاء الرسوم المدرسية وتوفير وجبة مدرسية آمنة ومغذية للطلاب، في أماكن مختارة، في نطاق سياسات

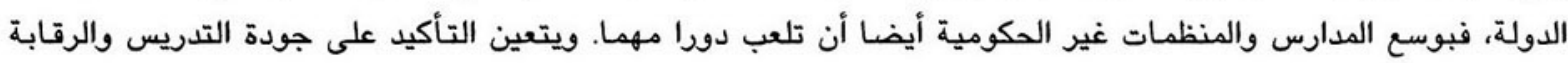

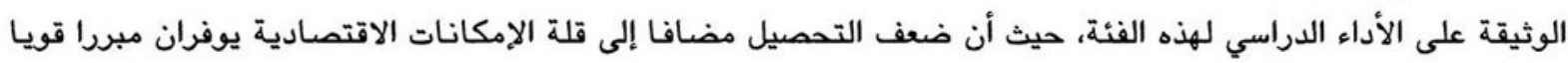

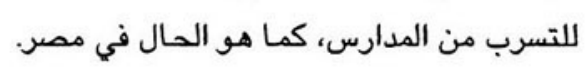

وفقا للفتيات والفتيان الذين جرت مقابلتهم، يبرز ضعف الأداء الدراسي كسبب رئيسي للتسرب. ويسري ذلك على كلا الجنسين

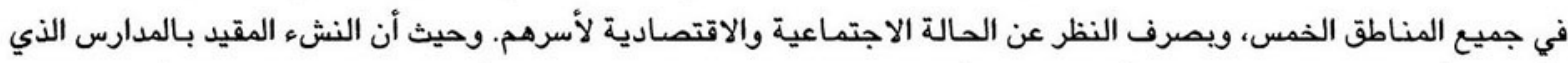

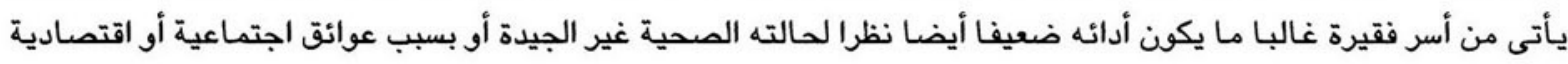

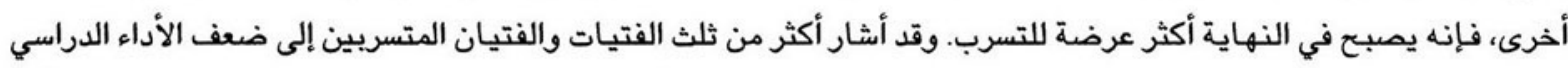

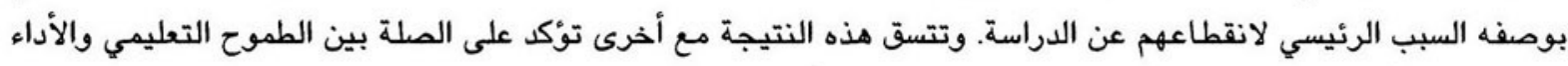

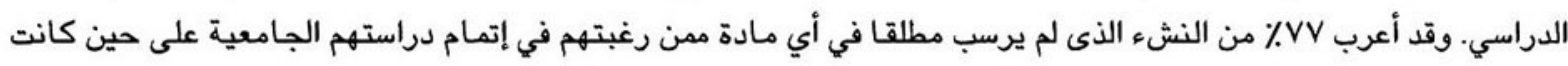

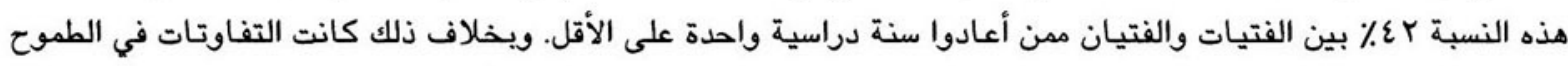

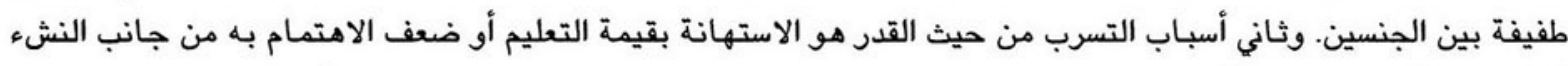

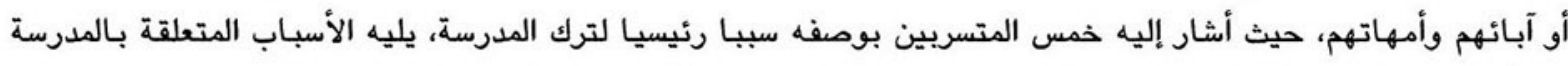

وضآلة الموارد الاقتصادية، خاصة بين المبحوثين من الفئة الاجتماعية الاقتصادية الدنيا.

وتشمل الأسباب المتعلقة بالمدرسة بالأساس كره المدرسة وسوء المعاملة من جانب المعلمين. وعلى وجه الإجمال، أعرب نصف

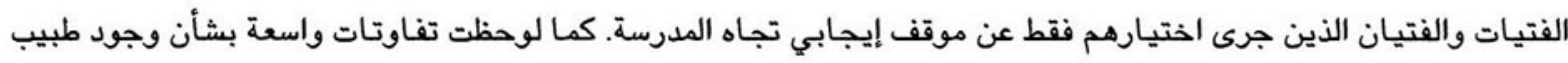

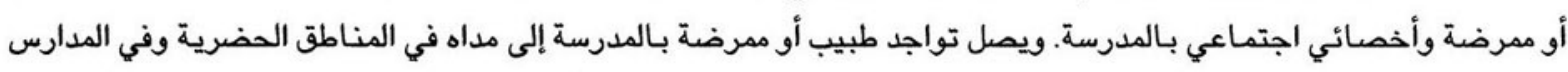

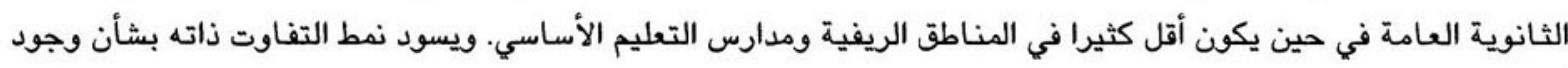
أخصائي اجتماعي بالمدرسة.

ومن بين الفتيات والفتيان الذين شملتهم العينة، ذكر الثلث فقط أنهم راضون عن التجاوب والدعم الشخصي من قبل المعلمين

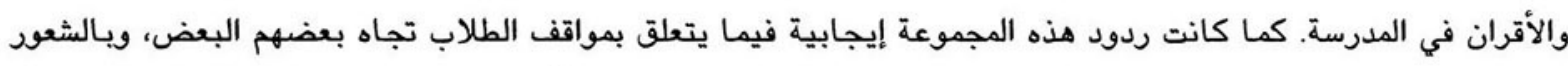

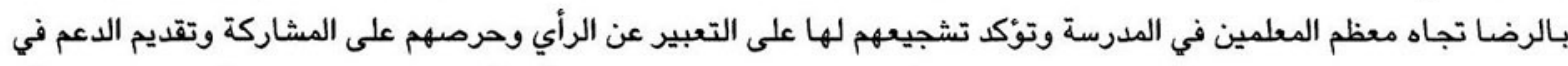

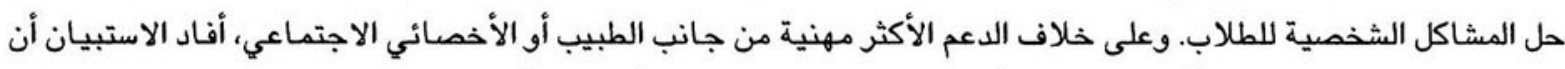

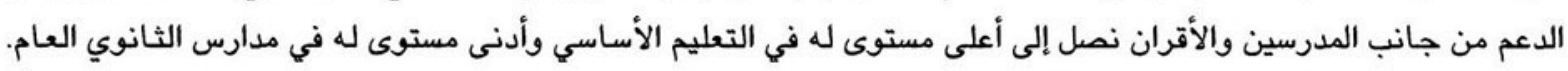


وأنه يرتفع في المناطق الريفية والدلتا والصعيد عنه في المناطق الحضرية والمحافظات الحضرية، على حين ينخفض نسبيا بين النشء المنتمى لأسر الفئة الاجتماعية العليا.

أما الأسباب المتعلقة بالأسرة، فتشمل حاجة الأسرة إلى النشء للمساعدة في الأعمال المنزلية، والنزاعات العائلية، ووفاة أحد

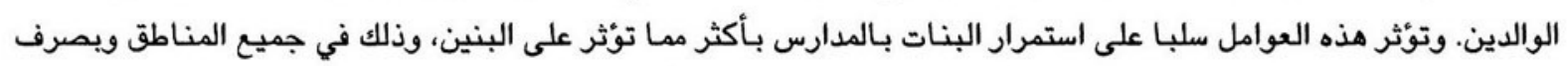

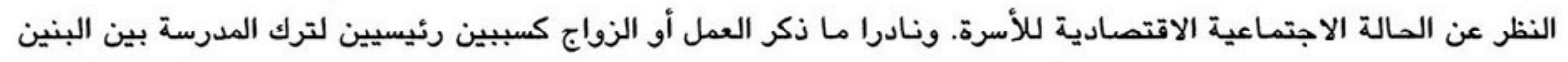

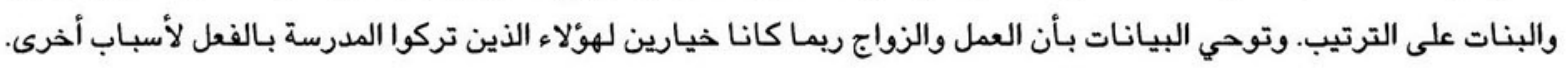

وتؤكد النتائج وجود علاقة بين المحددات المختلفة للحالة الصحية للفتيات والفتيان ويين أدائهم الدراسي بوجه عام، على نحو

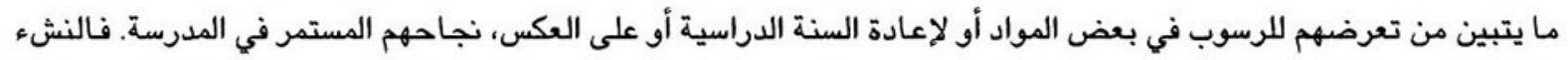
الذى يعانى من الأنيميا، أو اعتلالات النمو، أو الذى لديهم مفهوم سلبي تجاه حالتهم التهاد الصحية، أكثر قابلية للتخلف في الدراسة.

وتعتقد نسبة مرتفعة من الفتيات والفتيان تصل إلى rع ٪ أن قيمة التعليم تتمثل في اكتساب منزلة اجتماعية. أما الذين ربطوا

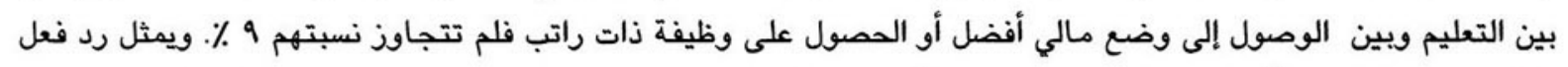

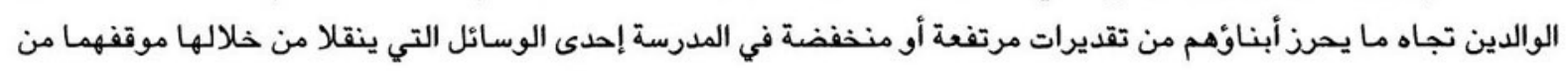

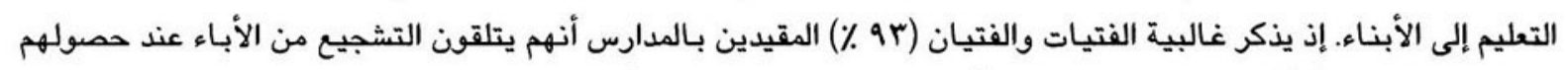

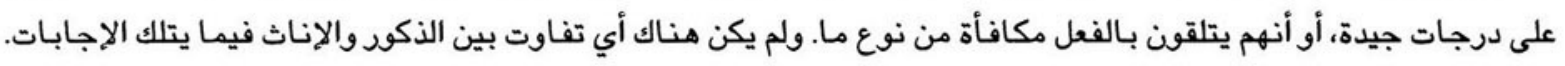

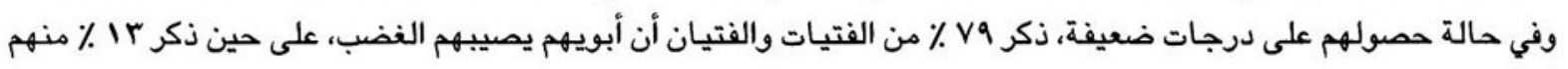
أن أبويهم يحاولون معرفة السبب وراء ذلك، ويعاقب 1 \% منهم أبناءه.

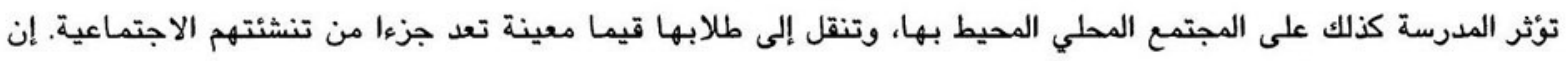

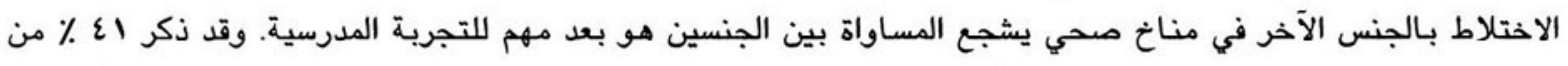

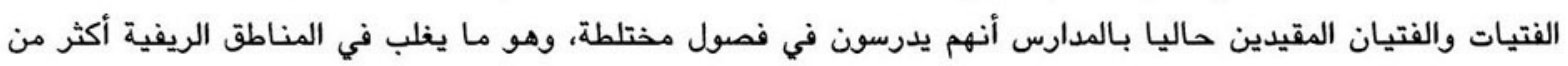

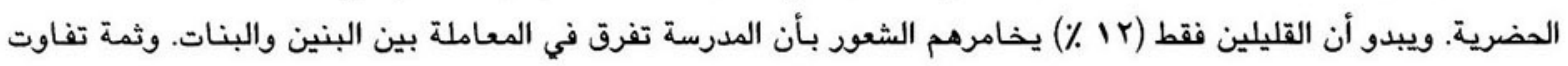

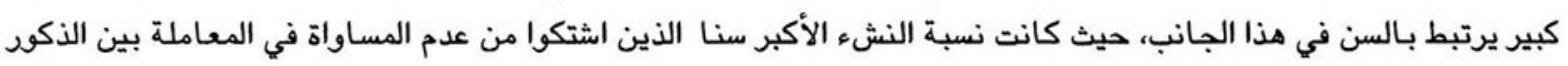

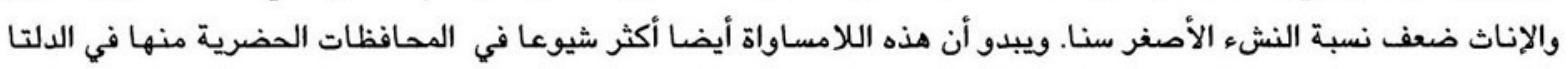
والصعيد وهي لصالح البنات في كل الأحوال.

ويبدو أن التفرقة في المعاملة على أساس غير النوع أكثر شيوعا (r \% ٪) وهو ما قد يخلق شعورا بغياب العدالة عن عالم الفتيات

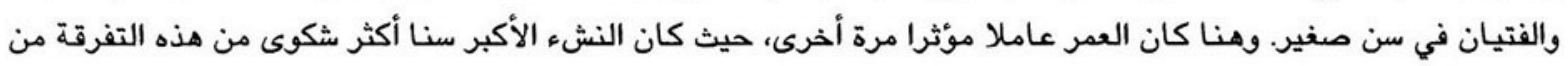

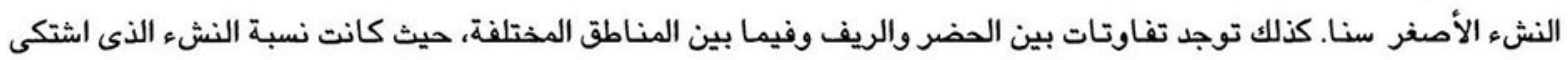
من هذه التفرقة أكبر في المناطق الحضرية منها في المناطق الريفية وفي الدلتا والصعيد.

كذلك يمكن أن تؤثر ممارسات معينة داخل الفصل على شخصية الطالب وتغرس فيه قيم معينة. ومن أمثلة ذلك، مدى تشجيع ألما

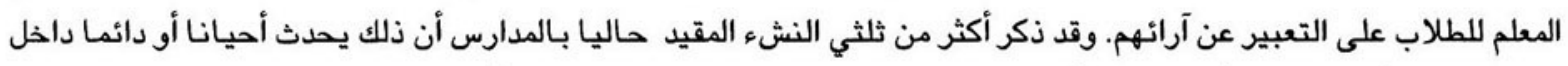

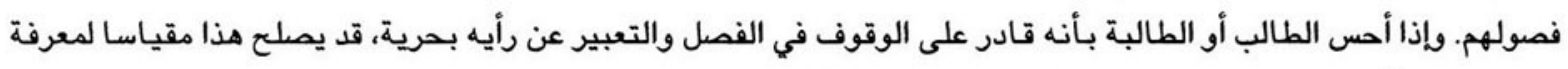

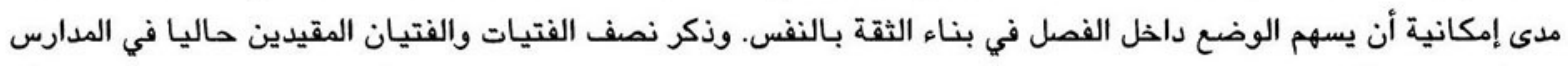

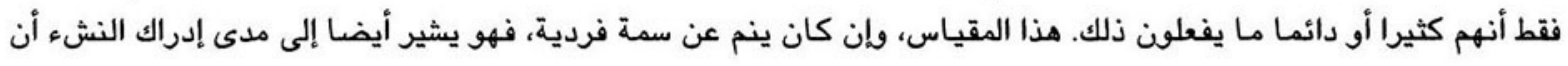




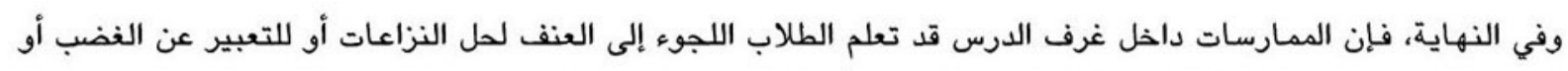

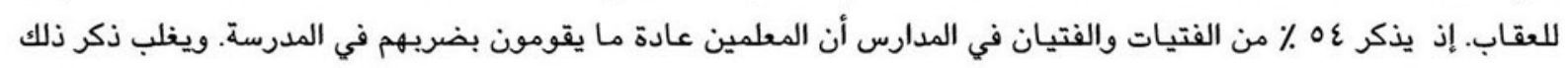

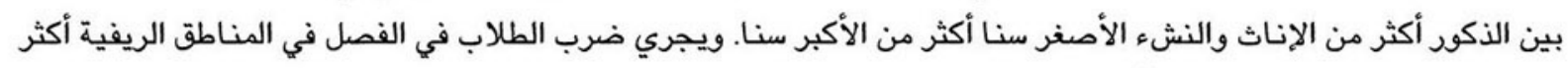

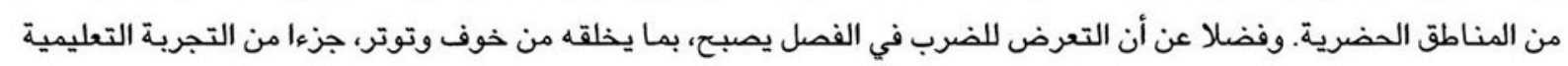

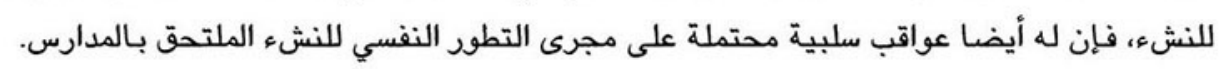

ويينما تتضافر جهود كافة الأطراف الأساسية للوصول إلى تعميم القيد بالمدارس وإتمام التعليم الأساسي على الأقل من قبل

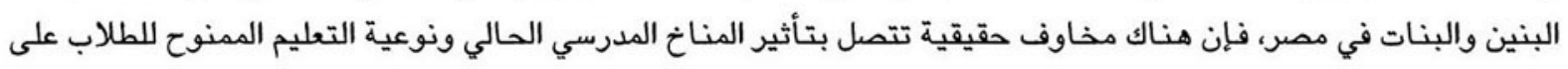

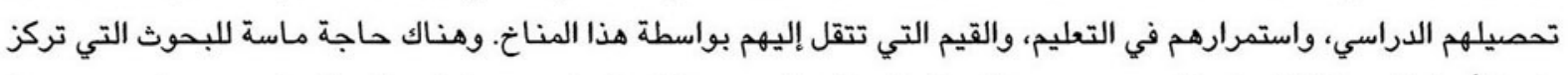

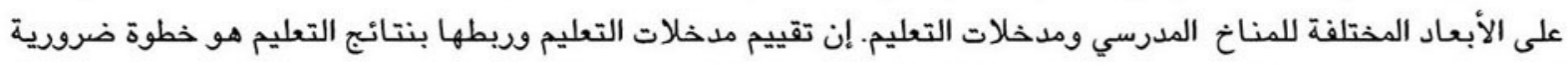

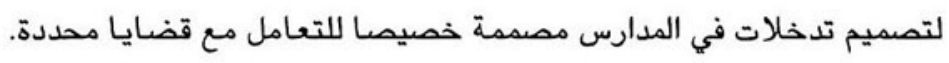


إذا كانت مرحلة الطفولة تتسم بالاعتماد على الآخرين على حين أن الاعتماد على الذات هو أحد سمات مرحلة البلوغ، فإن

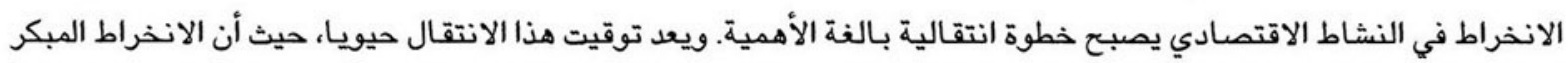

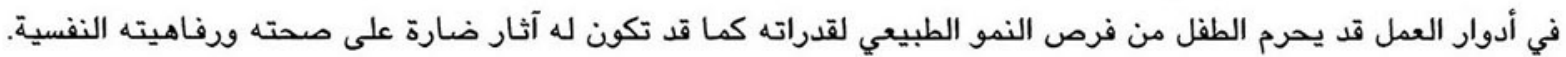

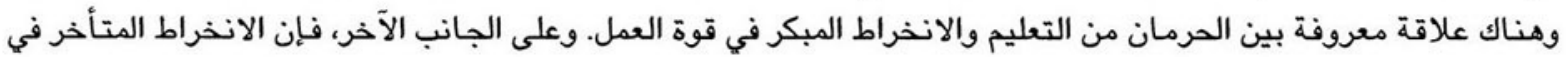

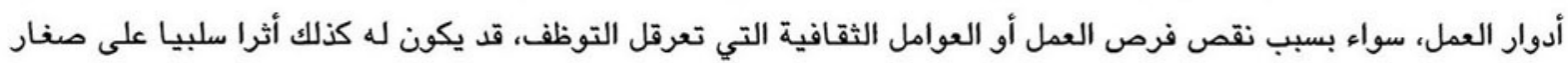

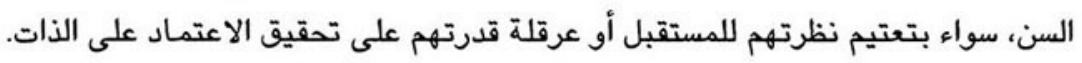

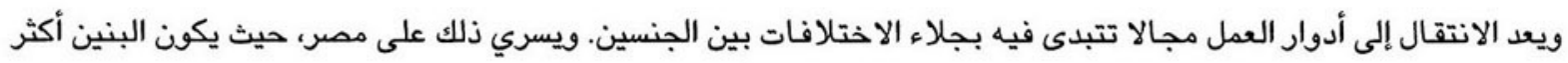

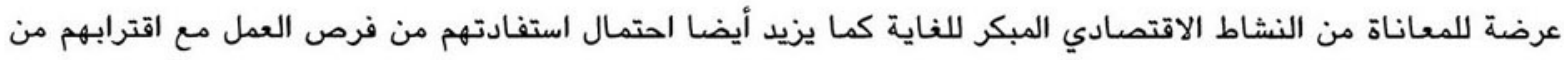

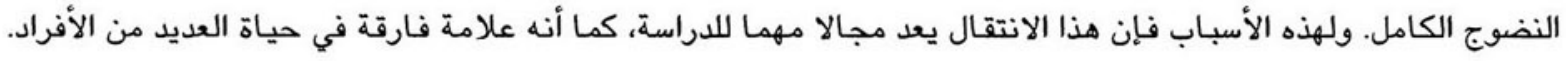

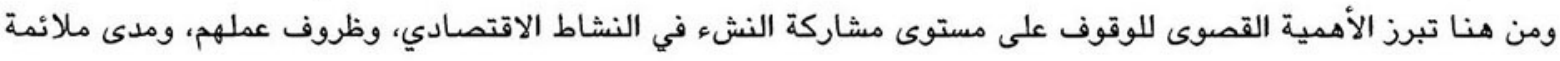

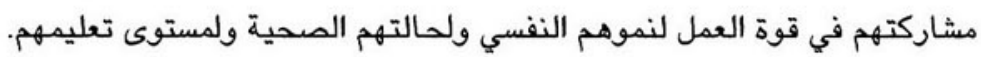

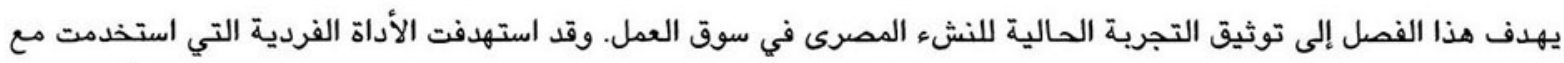

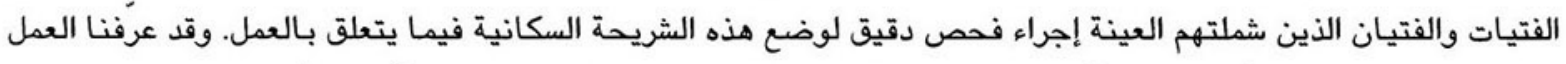

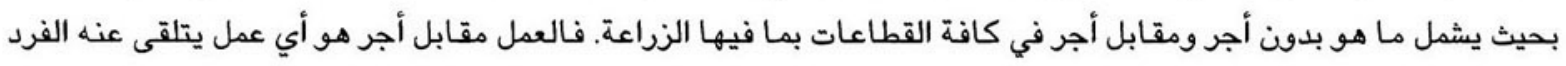

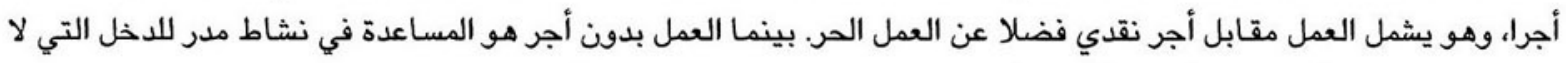

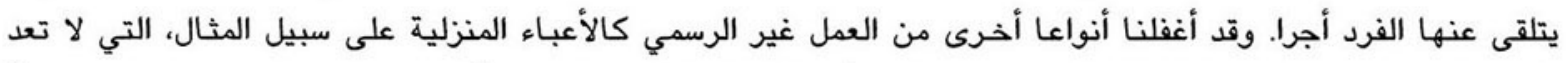

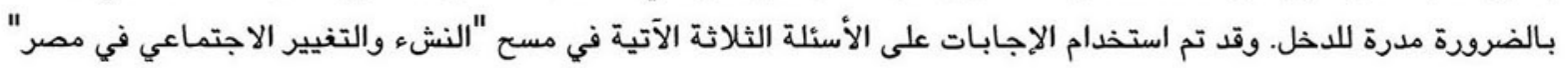

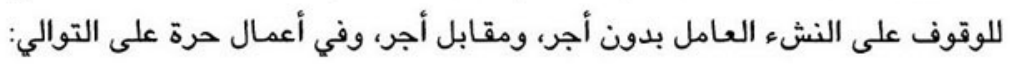

ا. هل تقوم حاليا (خلال الأسبوع السابق على إجراء المسح) بمساعدة أحد بانتظام في عمله دون أن تحصل على أجر، في أرض أو مشروع مثلا؟

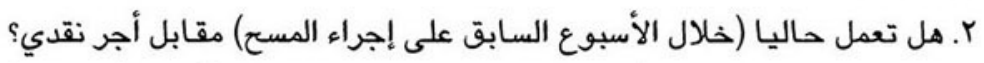

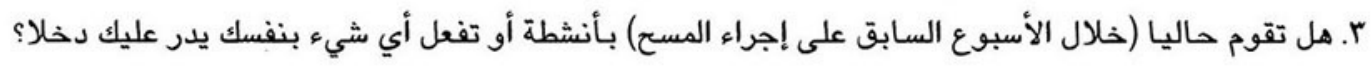

\section{أولا: مشاركة النشء في الأنشطة الاقتمادية: التجرية الحالية}

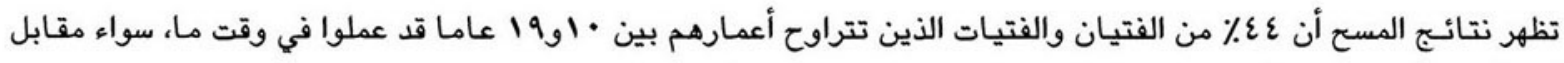

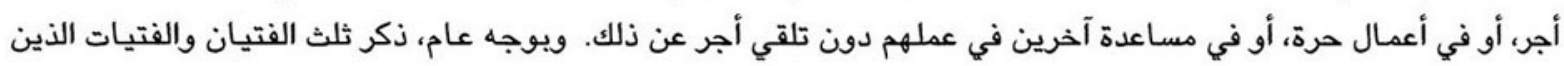

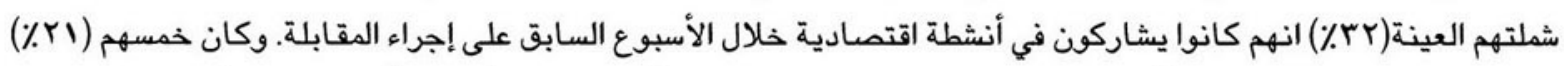

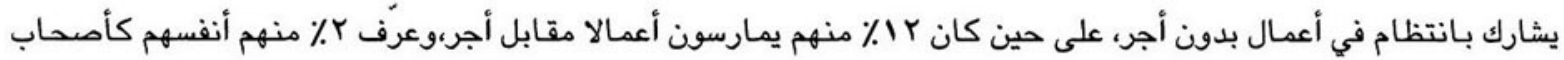

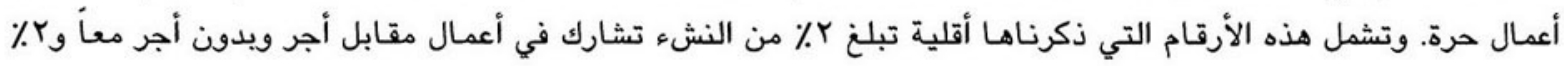


تمارس أعمالا حرة وتشارك في الوقت نفسه في أنواع أخرى من الأنشطة الاقتصادية. وجدير بالذكر أن آخر قانونين ينظمان

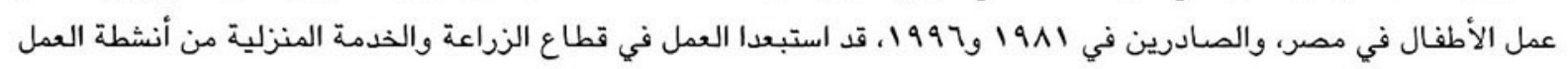

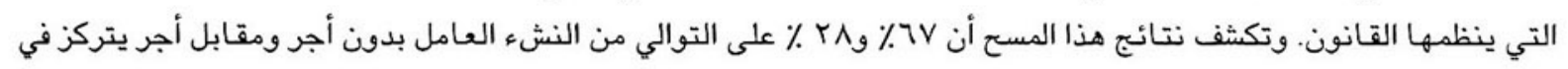

أنشطة ذات صلة بالزراعة (الشكل 7-1).

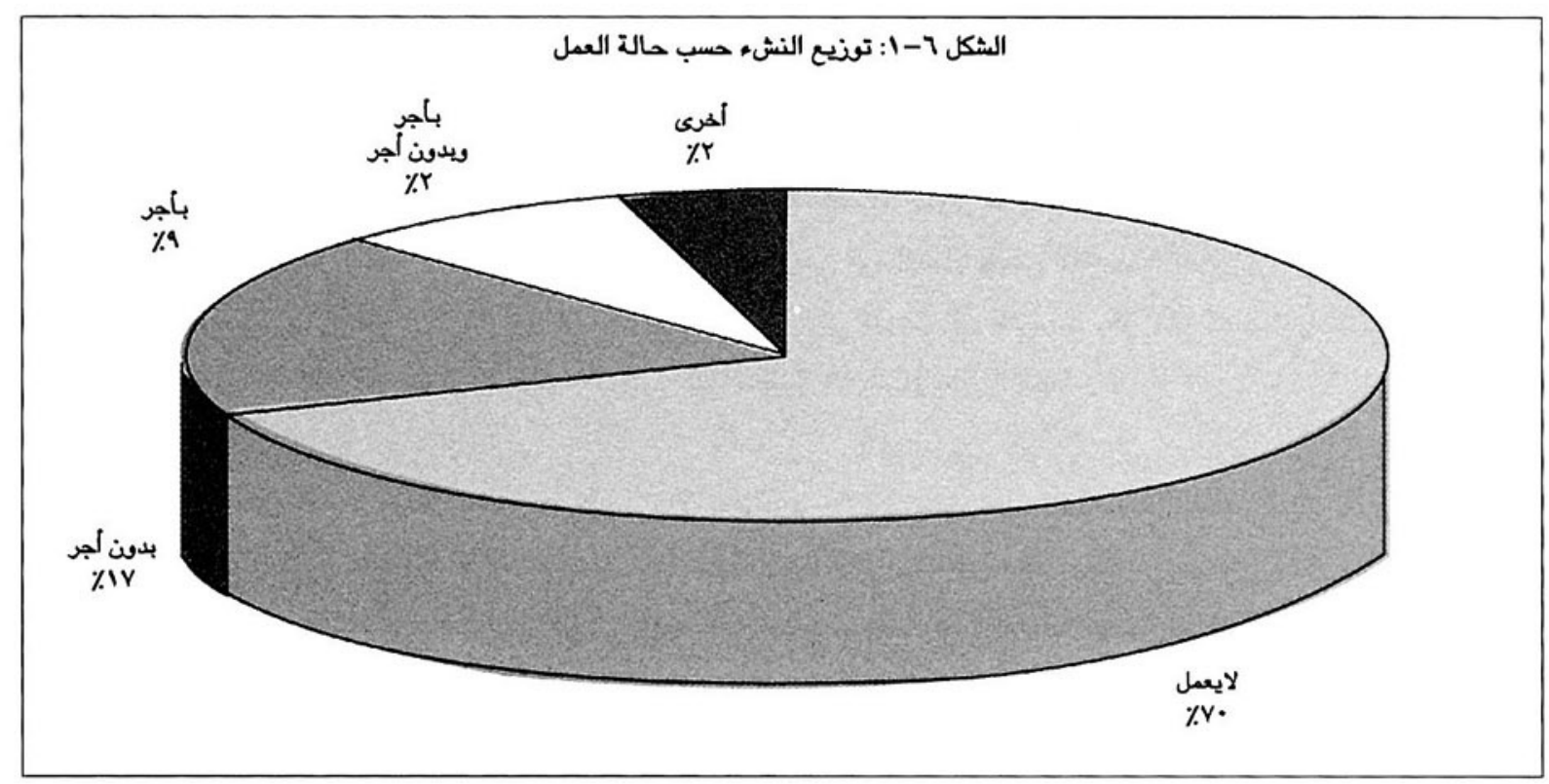

\section{ثانيا: الصورة العامة للنشء العامل}

يحاول هذا القسم رسم صورة ديموجرافية عامة للنشء العامل تأخذ بعين الاعتبار التفاوتات المتعلقة بالسن والنوع،ويين

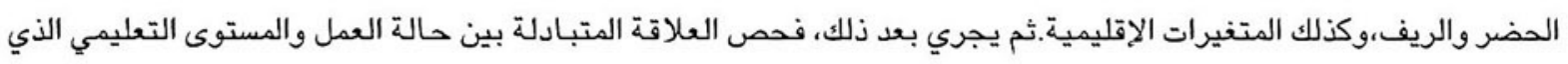

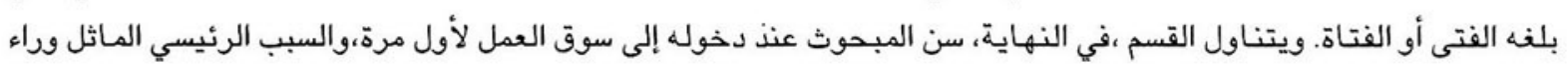
اتخاذه لهذا القرار الهام.

\section{التفاوتات المتعلقة بالسن والنوع}

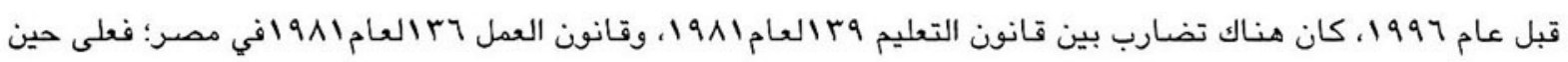

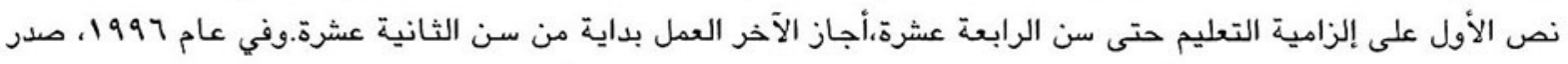

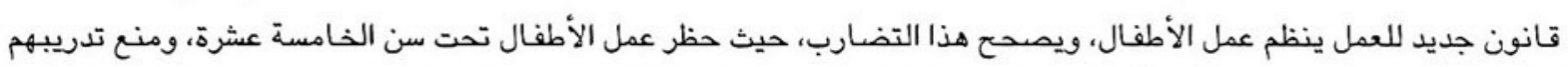

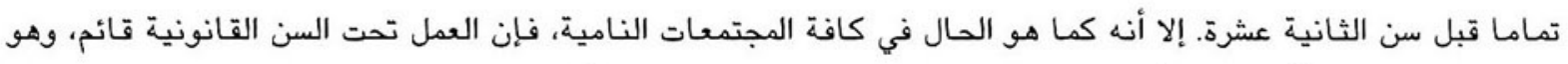

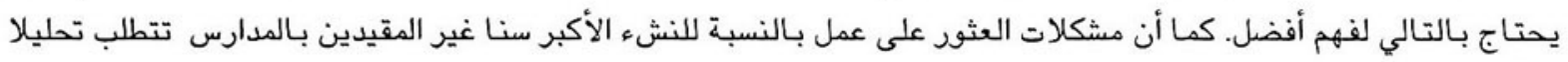
متأنيا.

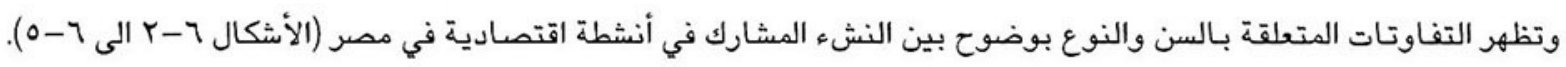

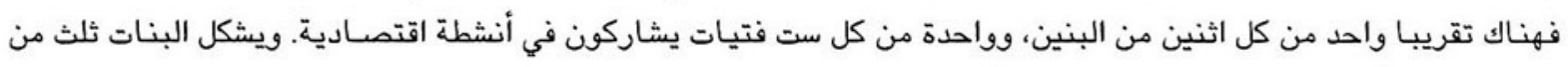

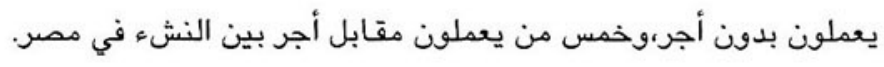



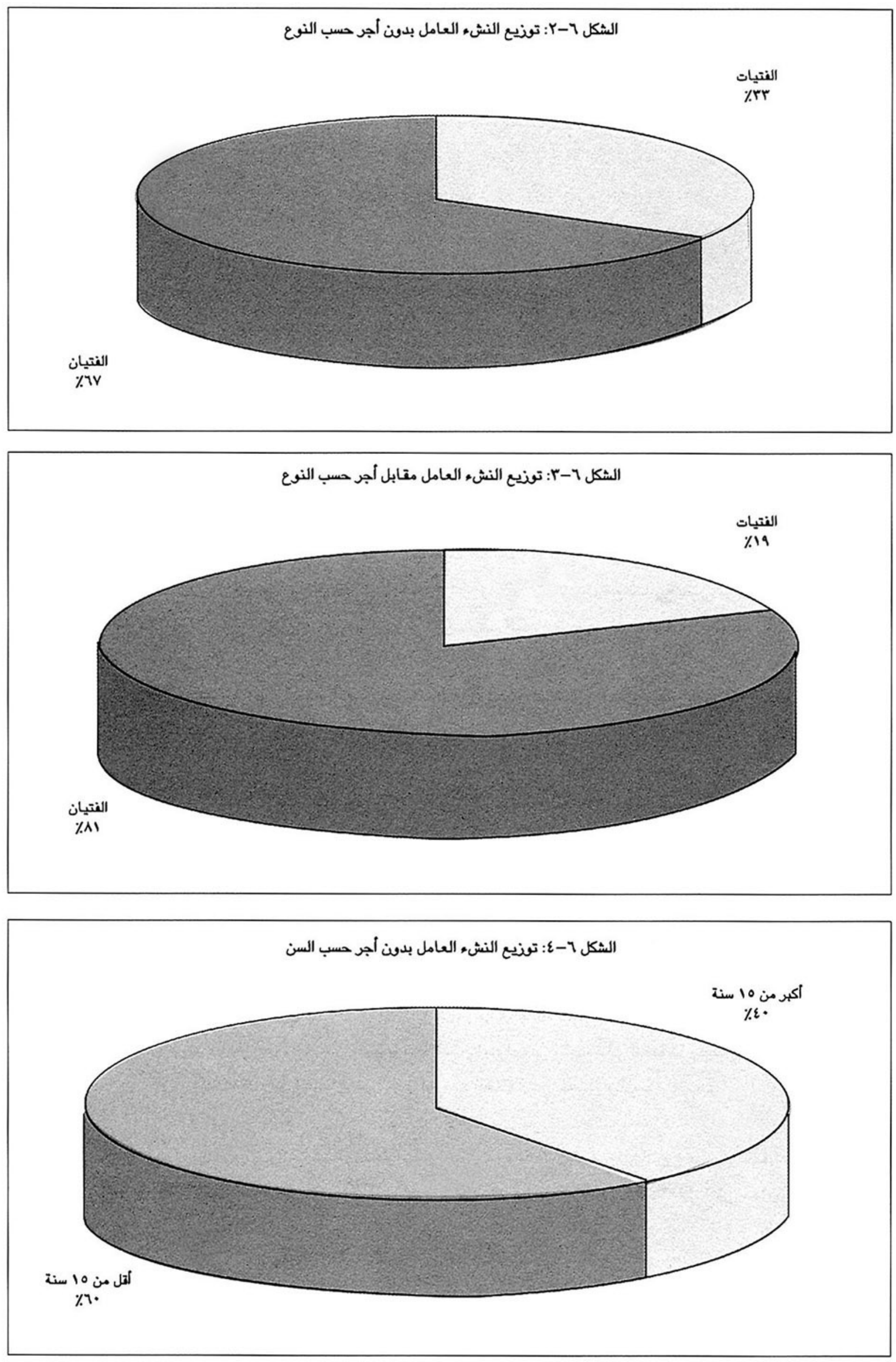


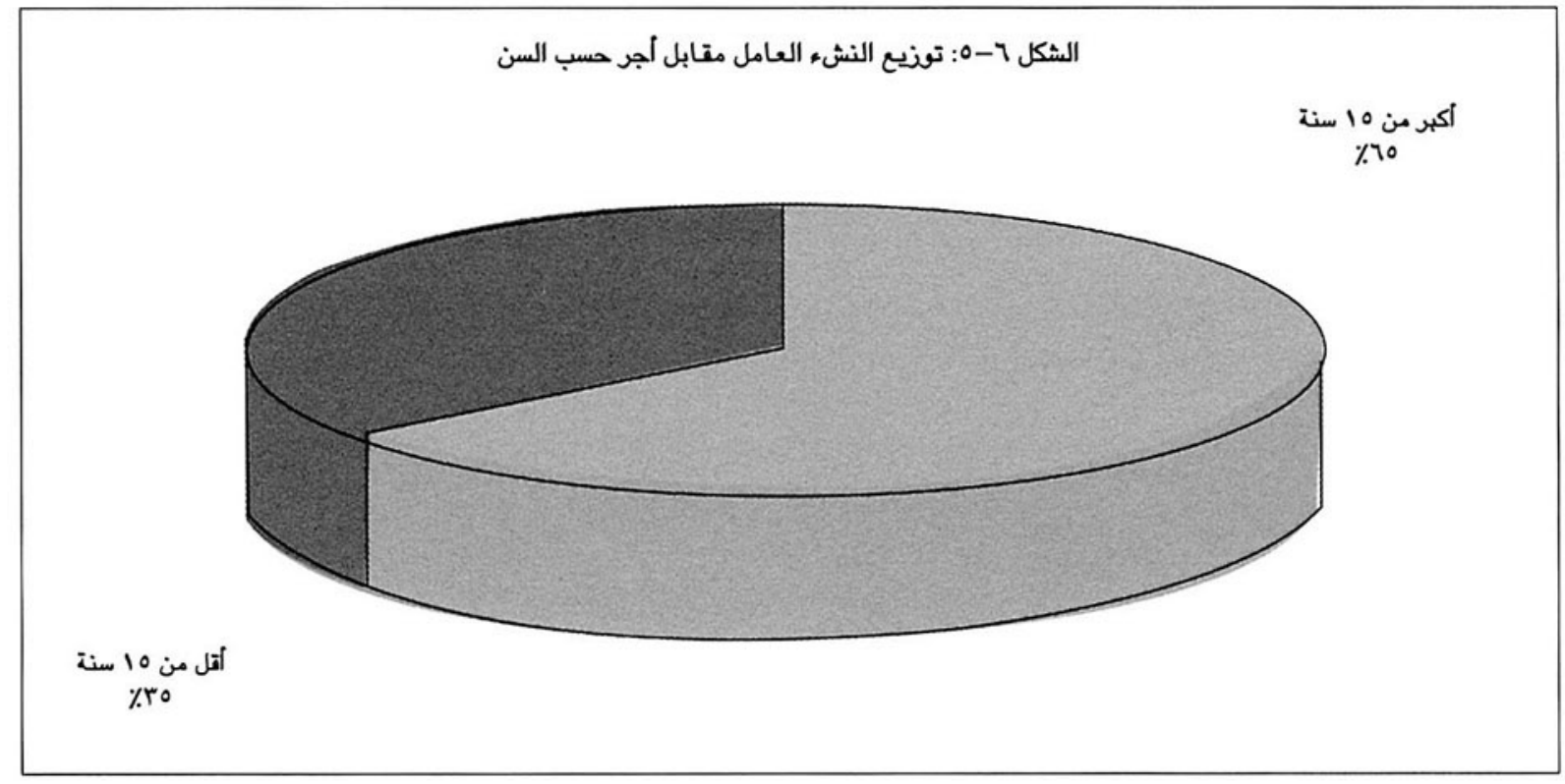

وتشير الأشكال ح-7 الى ح-^ بوضوح الى تباعد أنماط التوظيف الرسمى مدفوع الأجر لكل من الفتيات والفتيان مع تقدههم

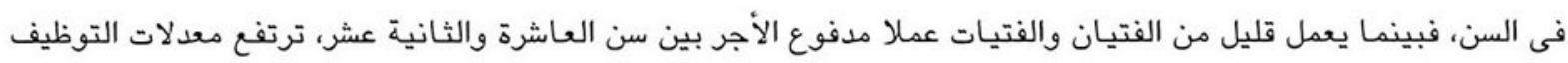

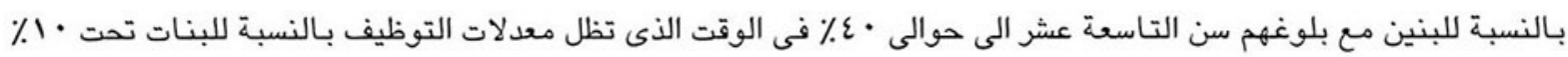

ولم يبلغ به ٪ من النشء المشارك في أنشطة اقتصادية الحد الأدنى للسن القانونية للعمل. وعلى نحو أكثر تحديدا، تبلغ نسبة

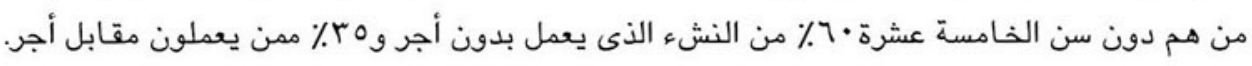

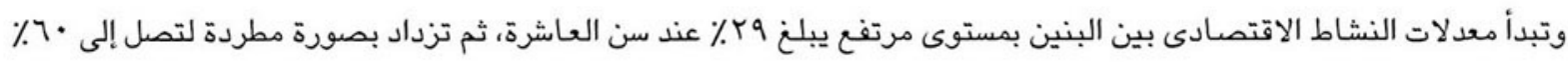

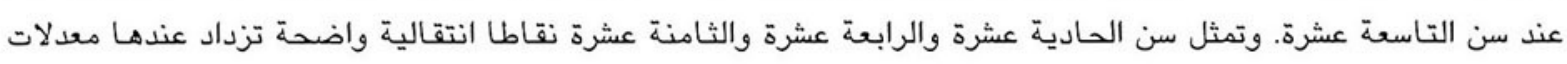

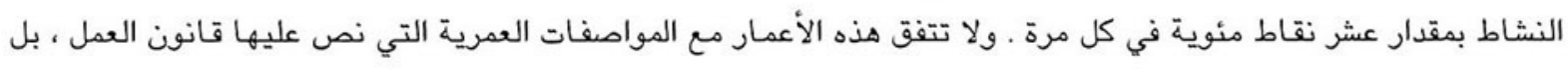

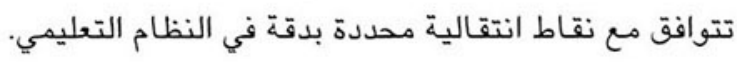

وعلى الجانب الأخر، فإن الصورة العامة لمعدلات النشاط لدى البنات تختلف تماما. تقل احتمالات النشاط الاقتصادي بين

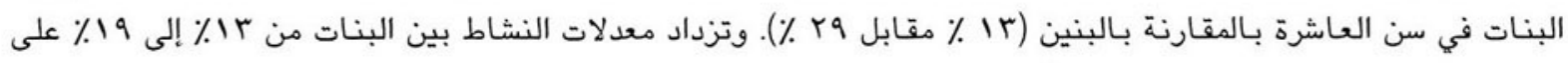

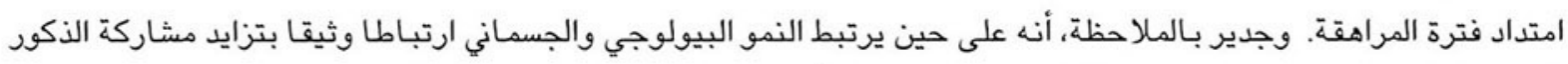
في سوق العمل، حيث تزيد هذه المشاركة بتقدم العمر، يبدو أن هذه العلاقة غير الدير قائمة بالنسبة للإناث.

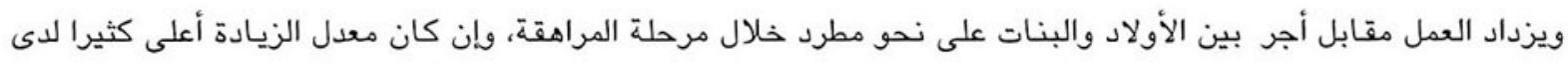

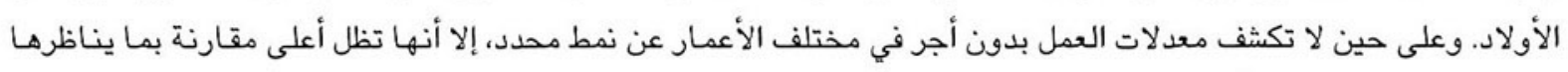
من معدلات للعمل مقابل أجر. 

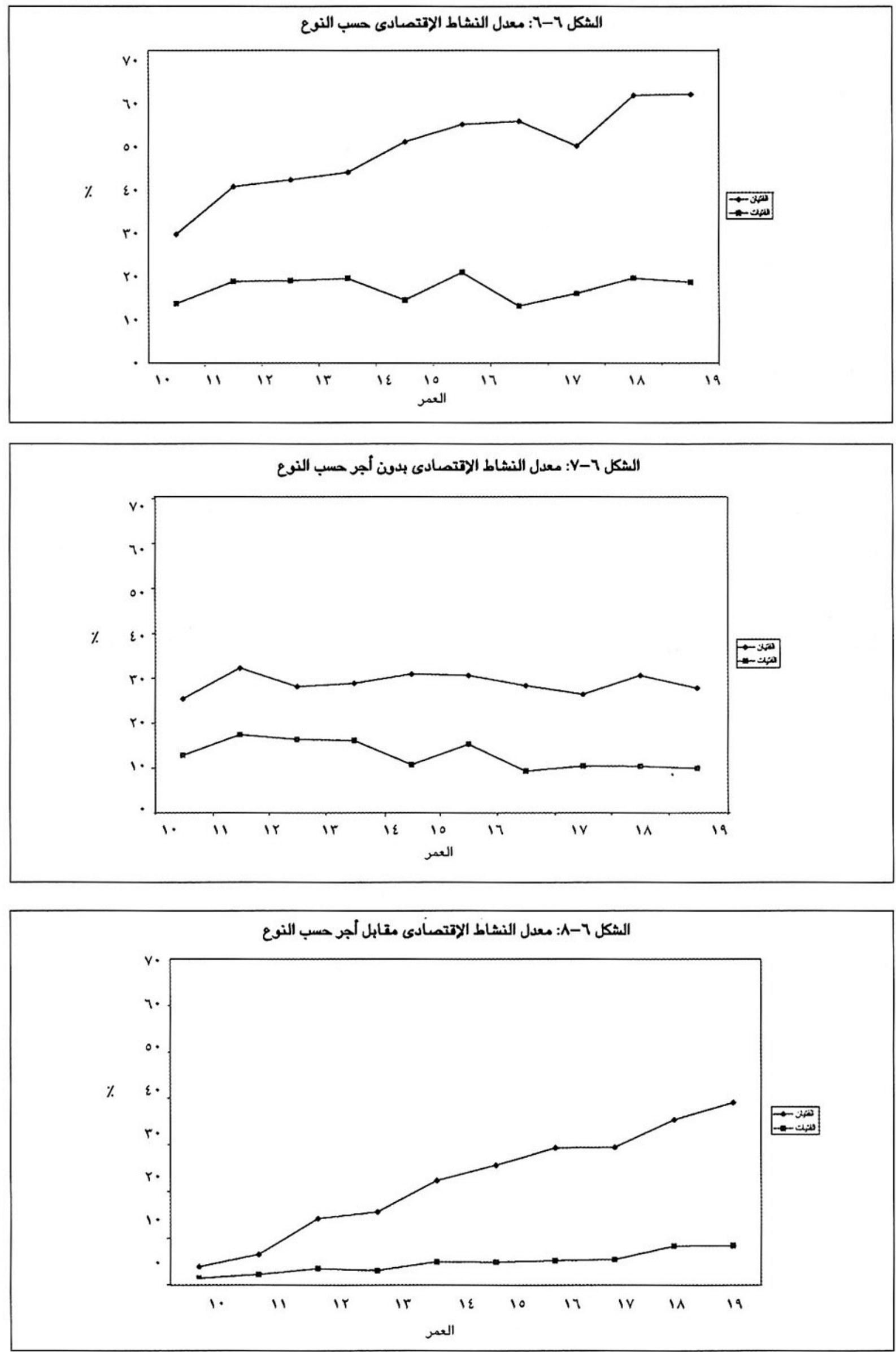
يلقي الجدول 1 - الضوء على أهمية التفاوتات الحضرية/الريفية وكذلك التفاوتات الإقليمية فيما يتعلق بمشاركة النشء في

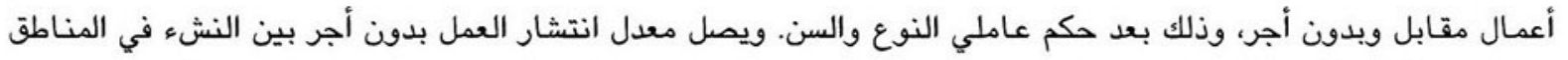

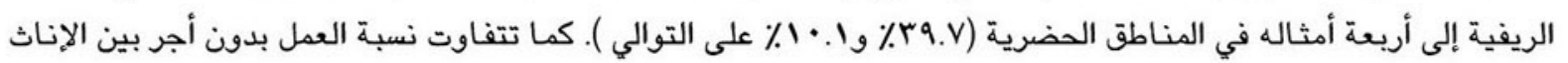

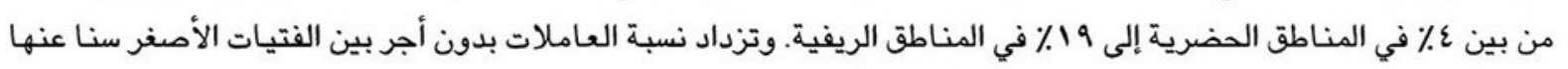

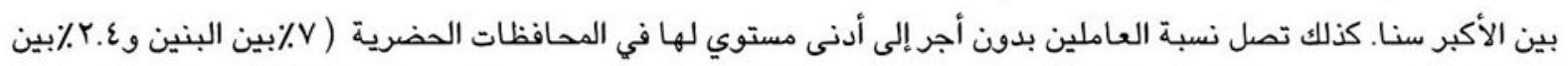

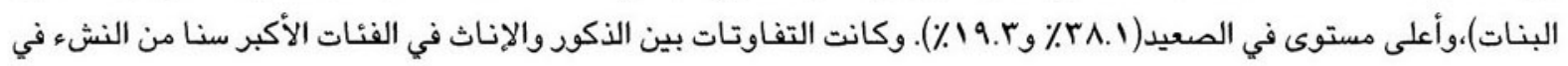

ويختلف الأمر بعض الشيء فيما يتعلق بالعمل مقابل أجر. حيث تكاد تنعدم التفاوتات بين الحضر والريف باستثناء فئة

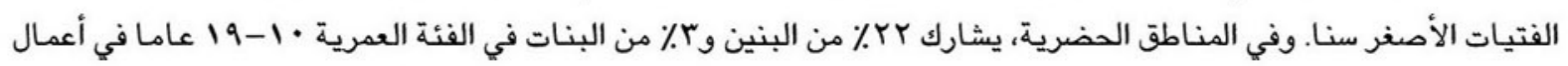

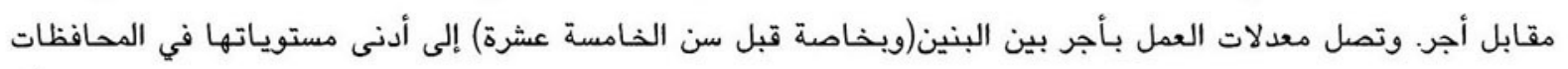

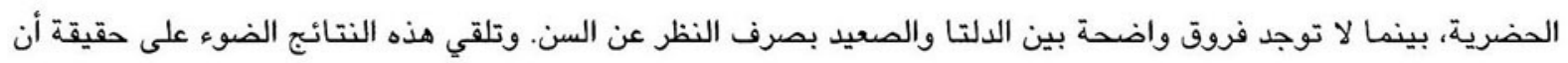

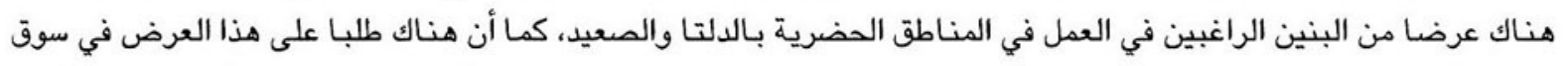

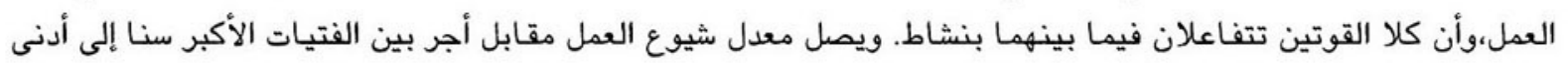

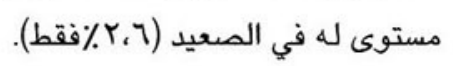

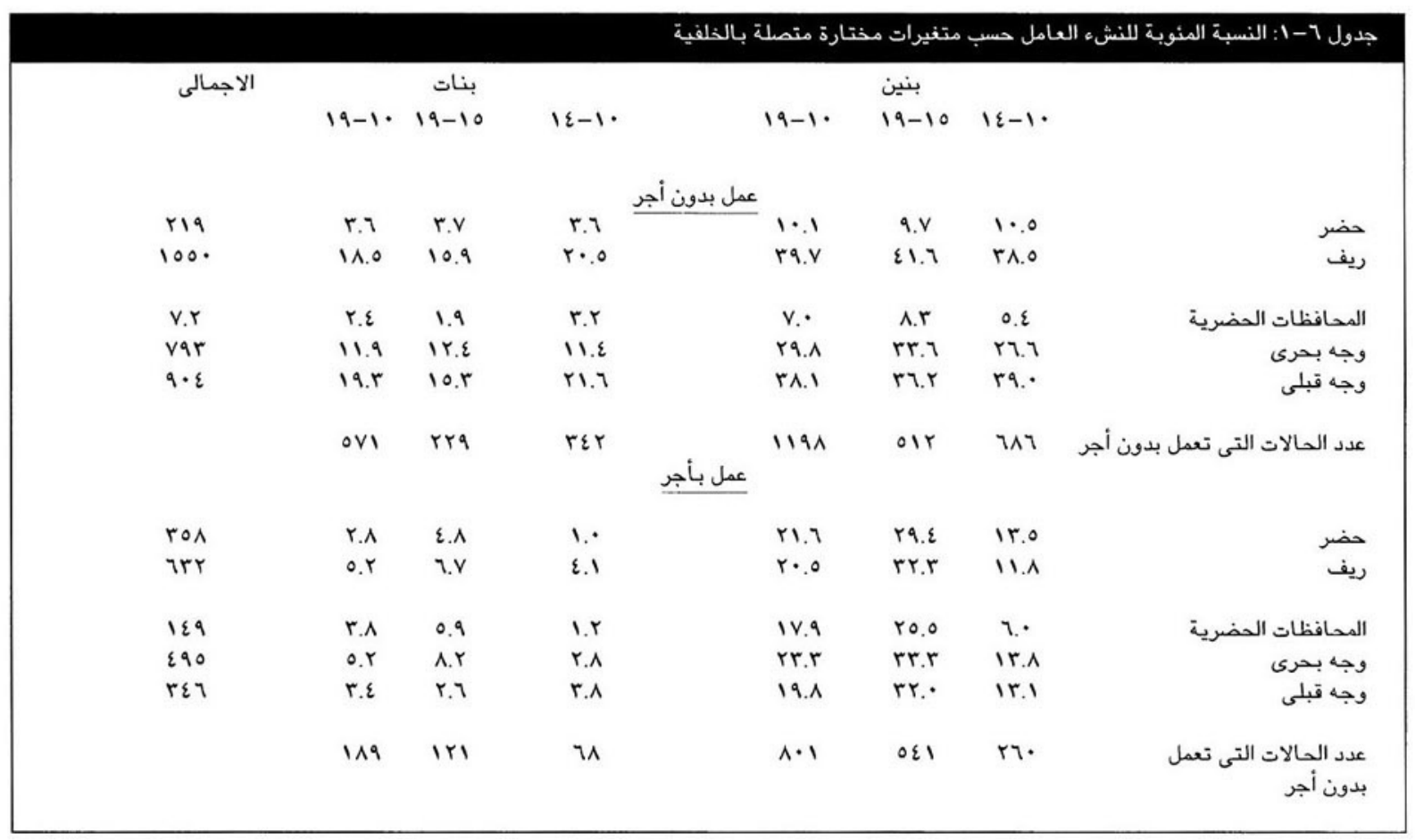

المستوى التعليمي للنشء العامل

أحد الأسئلة التي يجب طرحها في هذا السياق هو مدى ارتباط الانخراط في النشاط الاقتصادي بالقيد المدرسي؟ وفي هذا

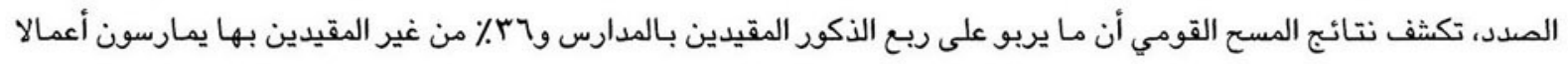

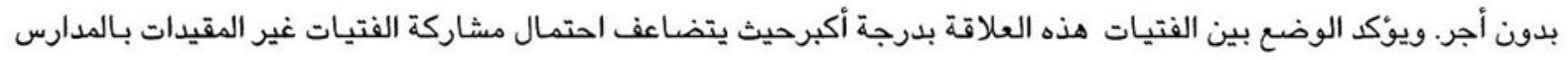




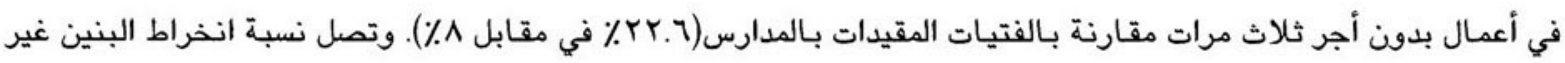

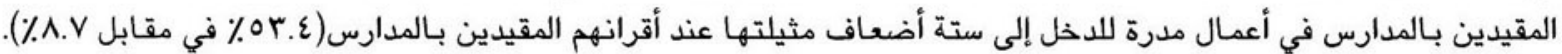

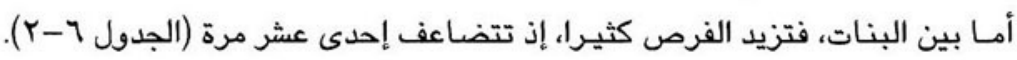

الجدول 1-Y: النسبة المئوية للنشء العامل بدون أجر أو مقابل أجر حسب متغيرات مختارة متصلة بالخلفية

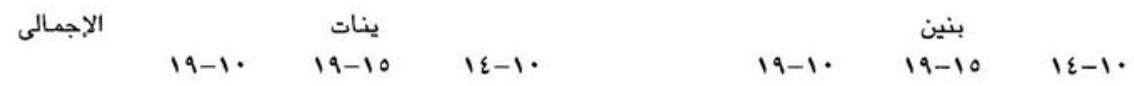

عمل بدون أجر

\begin{tabular}{|c|c|c|c|c|c|c|c|}
\hline $1 \cdot 17$ & $\Lambda \cdot$ & $\varepsilon . \vee$ & 9.1 & r7.0 & rr.r & rA.r & ملتحقون بالمدرسة \\
\hline \multirow[t]{3}{*}{ ver } & rY.T & IV.V & $r \cdot v$ & $r 0.9$ & rา. & rr.q & غير ملتحقون بالمدرسة \\
\hline & ori & rrq & $r \varepsilon r$ & 1.191 & OIr & 717 & عدد الحالات \\
\hline & & & & & & & \\
\hline$r r \varepsilon$ & 1. & 1.0 & $\cdot v$ & A.V & ir.o & $7 . Y$ & ملتحقون بالمدرسة \\
\hline רדר & $1 \cdot .9$ & $1 \cdots$ & 11.1 & or.o & $0 \wedge .7$ & $\varepsilon 0 .{ }^{\circ}$ & غير ملتحقون بـالمدرسة \\
\hline & 119 & $|r|$ & 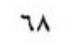 & $\lambda \cdot 1$ & O\& & ri. & عدد الحالات \\
\hline
\end{tabular}

ويعد فحص العلاقة التبادلية بين الانخراط في العمل والمستوى التعليمي بين الفتيان والفتيات ضروريا لتصميم برامج خاصة

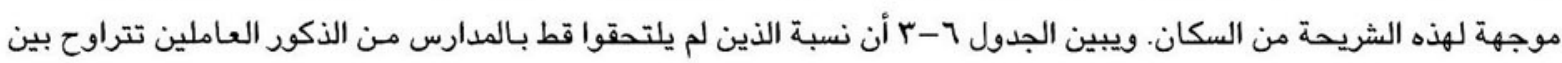

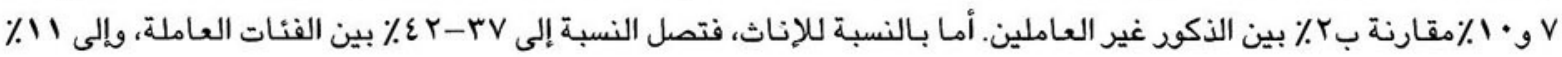

بين الفئات غير العاملة.

وعلى حين لا يهدد العمل بدون أجر المستوى التعليمي للذكور صغار السن مقارنة بأقرانهم غير العاملين، يؤثر عمل الفتيات

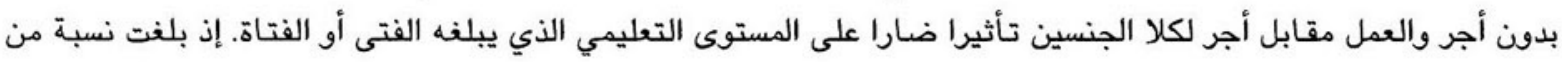

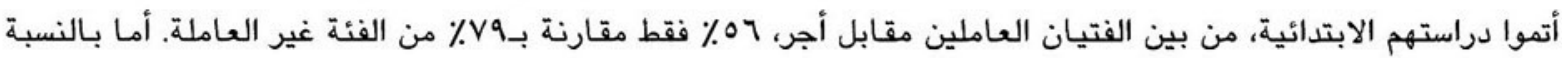

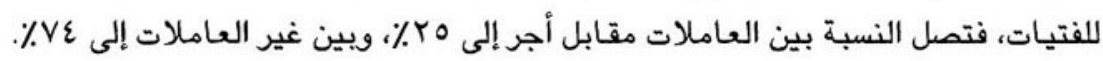

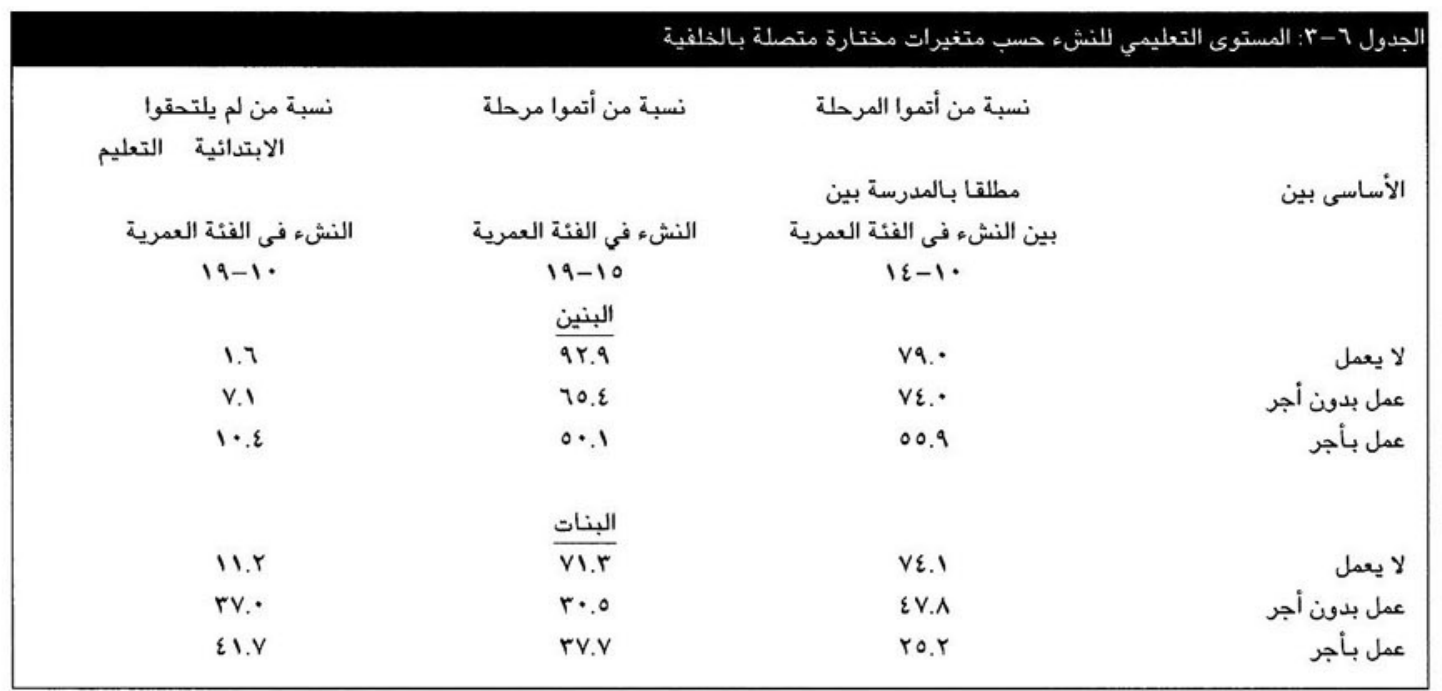




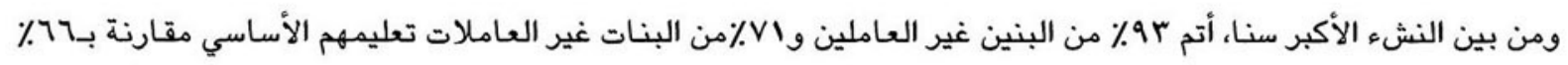

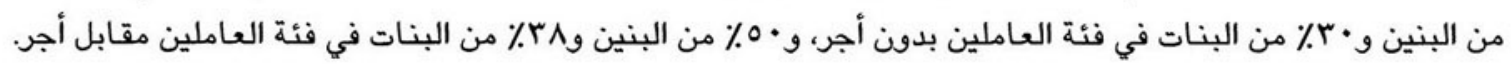

\section{سن الانضمام إلى قوة العمل}

وفقا للنتائج المبينة في الجدول 7-ع، فإن وسيط سن بدء العمل لأول مرة بين كافة النشء في سن 10-19 يبلغ 1V.7 عاما.

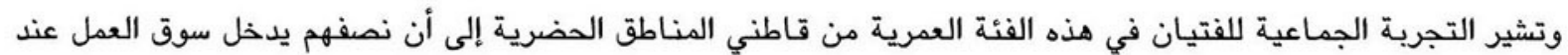

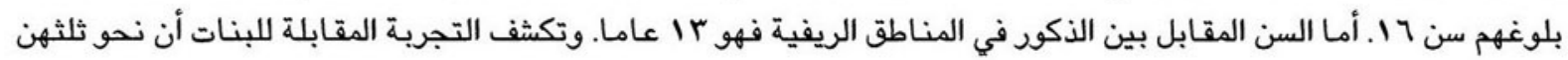

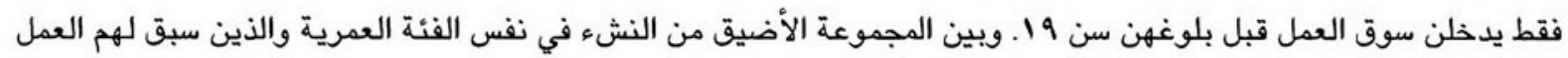

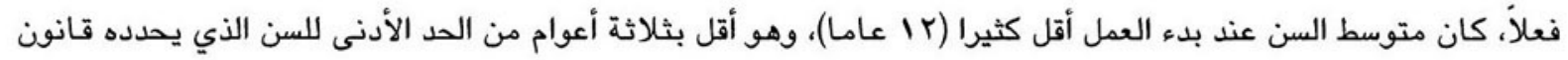
العمل. ويمكن تفسير هذا الفارق جزئيا بالدخول المبكر إلى سوق العمل لهذه المجموعة الأضيق في المناطق الرئا الريفية.

\begin{tabular}{|c|c|c|c|c|c|c|c|c|}
\hline \multirow[t]{2}{*}{$\dot{u}$} & \multirow[t]{2}{*}{ الإجمالى } & \multicolumn{3}{|c|}{ البنات } & \multicolumn{3}{|c|}{ البنين } & \\
\hline & & ريف & & حضر & ريف & & حضر & \\
\hline \multirow[t]{5}{*}{ ra79 } & $\mid v .71$ & +19 & & +19 & Ir.Ao & & 11.0 & الوسيط بالنسبة لجميع \\
\hline & & & & & & & & النشء من 10-19 \\
\hline & & & & & & & & \\
\hline & & & +19 & & & $|\varepsilon . r|$ & & إجمالى النشء من \\
\hline & & & & & & & & 19-19 سنة \\
\hline \multirow[t]{5}{*}{ IAv. } & $|r . \varepsilon|$ & II.ro & & IE.9Y & $11.9 \varepsilon$ & & Ir.or & النشء في الفنة \\
\hline & & & & & & & & العمرية من 10-19 \\
\hline & & & & & & & & سنة الذين سبق لهم \\
\hline & & & & & & & & العمل ل \\
\hline & & & $1 Y .17$ & & & Ir.\&A & & الإجمالي \\
\hline
\end{tabular}

\section{الأسباب وداء بدء العمل}

يعد الوقوف على أسباب بدء العمل بين النشء العامل حاليا أو الذين سبق لهم ممارسة العمل أمرا ضروريا لتقييم هذه التجرية

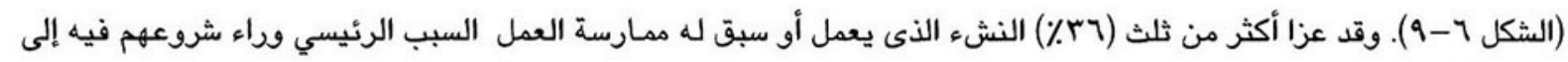

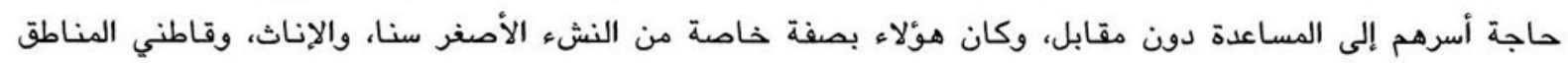

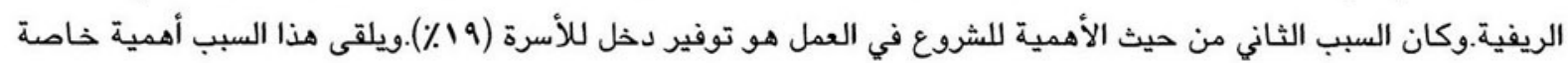

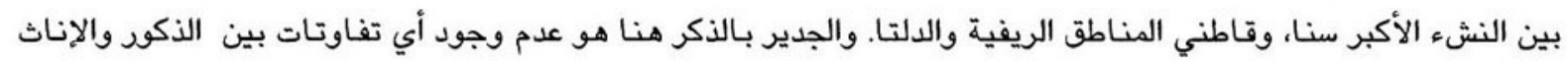

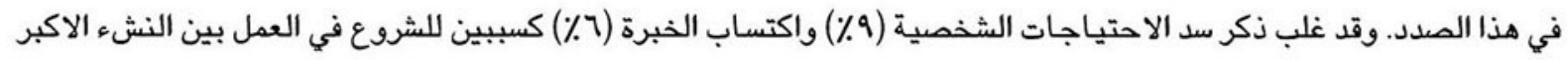
سنا، والذكور، وقاطني المناطق الحضرية.

وقد ذكره ٪ و ا ٪ على الترتيب سببين للبدء في العمل، ريما كانا يمثلان وجهين لعملة واحدة، وهما ضعف الأداء الدراسي،

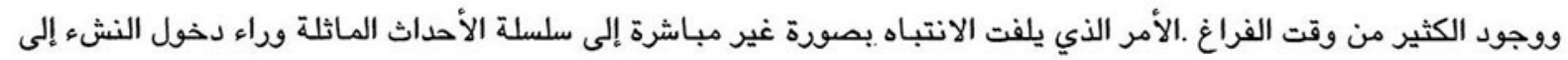
سوق العمل بتأكيده أن قرار بدء العمل يأتي كنتيجة منطقية في هذه السلسلة أكثر منه كقرار حتمي . 


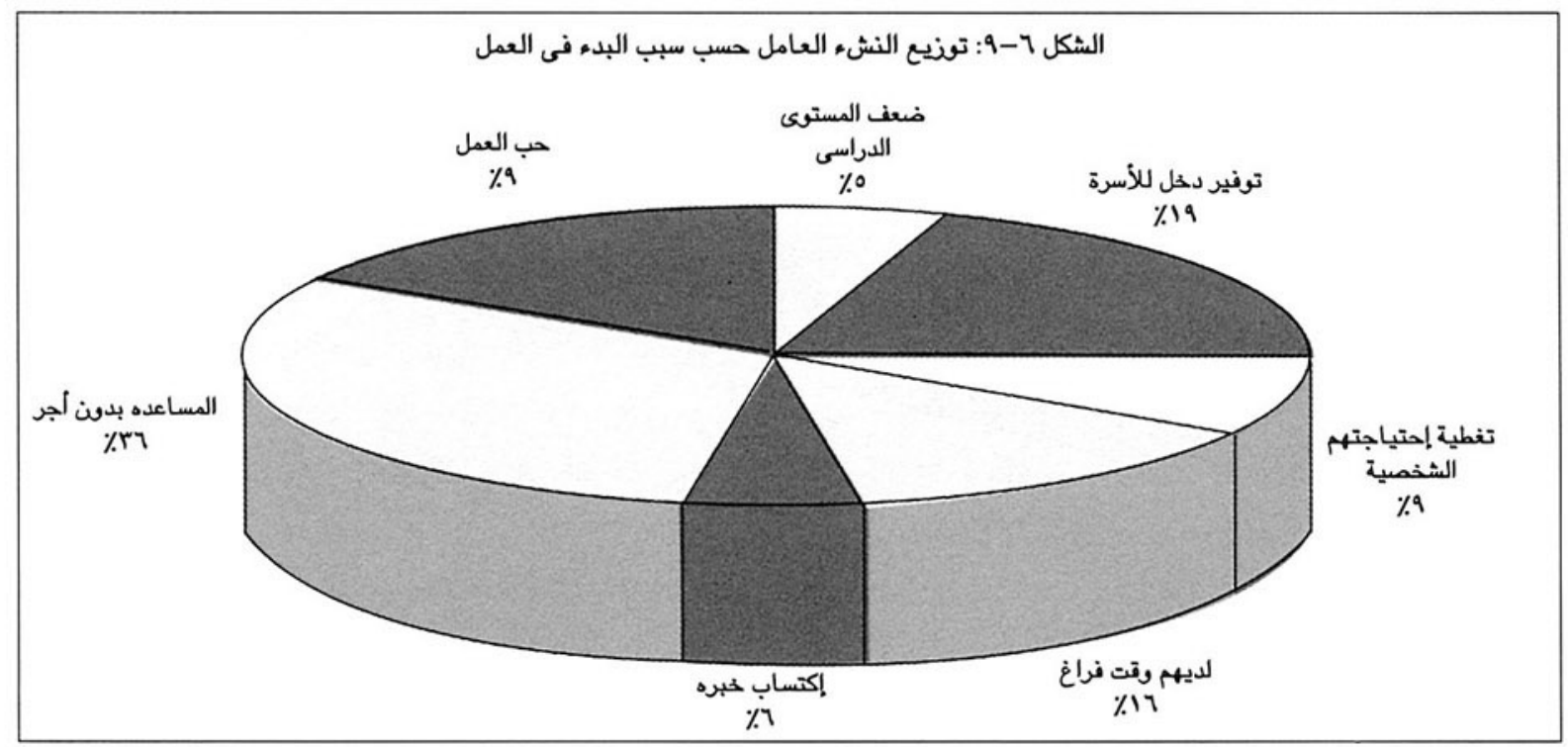

ثالثا: ظروف عمل النشء

إن ارتفاع نسبة العاملين بين النشء في مصر ودخولهم المبكر إلى سوق العمل يستوجبان إجراء فحص دقيق لبيئة العمل وكذلك لاستجابة النشء العامل لهذه البيئة.

\section{عدد أيام العمل الأسبوعية وعدد ساعات العمل اليومية}

تشير البيانات المستقاة من النشء الذى مارس أعمالا مقابل أجر أو بدون أجر خلال الأسبوع السابق على إجراء المقابلة أن

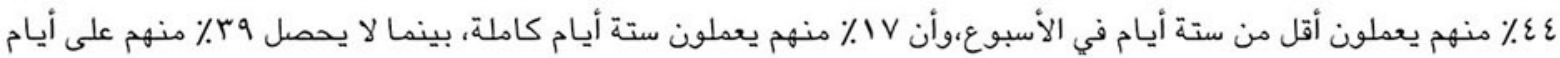

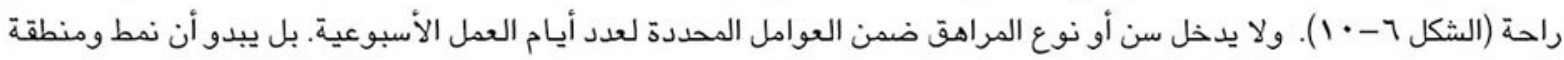

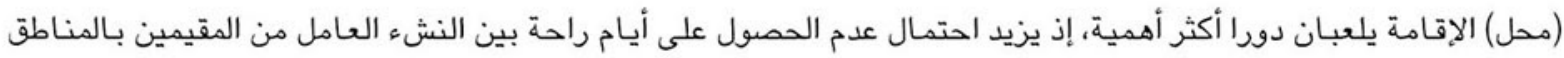
الريفية أو في الصعيد عنه بين النشء العامل في المناطق الحضرية أو في الدلتا.

ويالنسبة للنشء العامل، ينص قانون العمل على ألا يتجاوز الحد الأقصى لعدد ساعات العمل اليومية ست ساعات تتخللها فترة

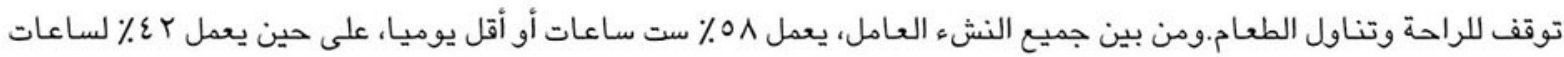

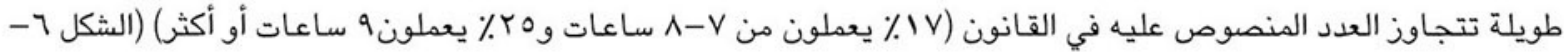

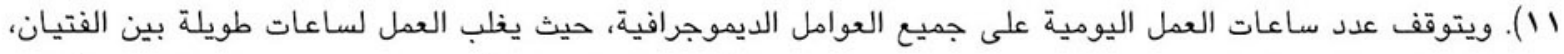

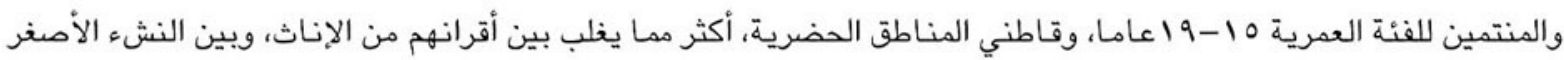

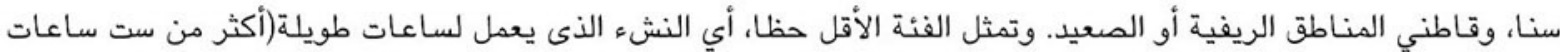

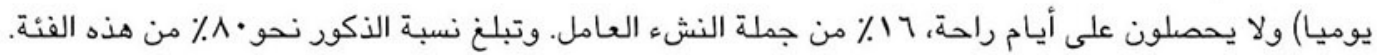



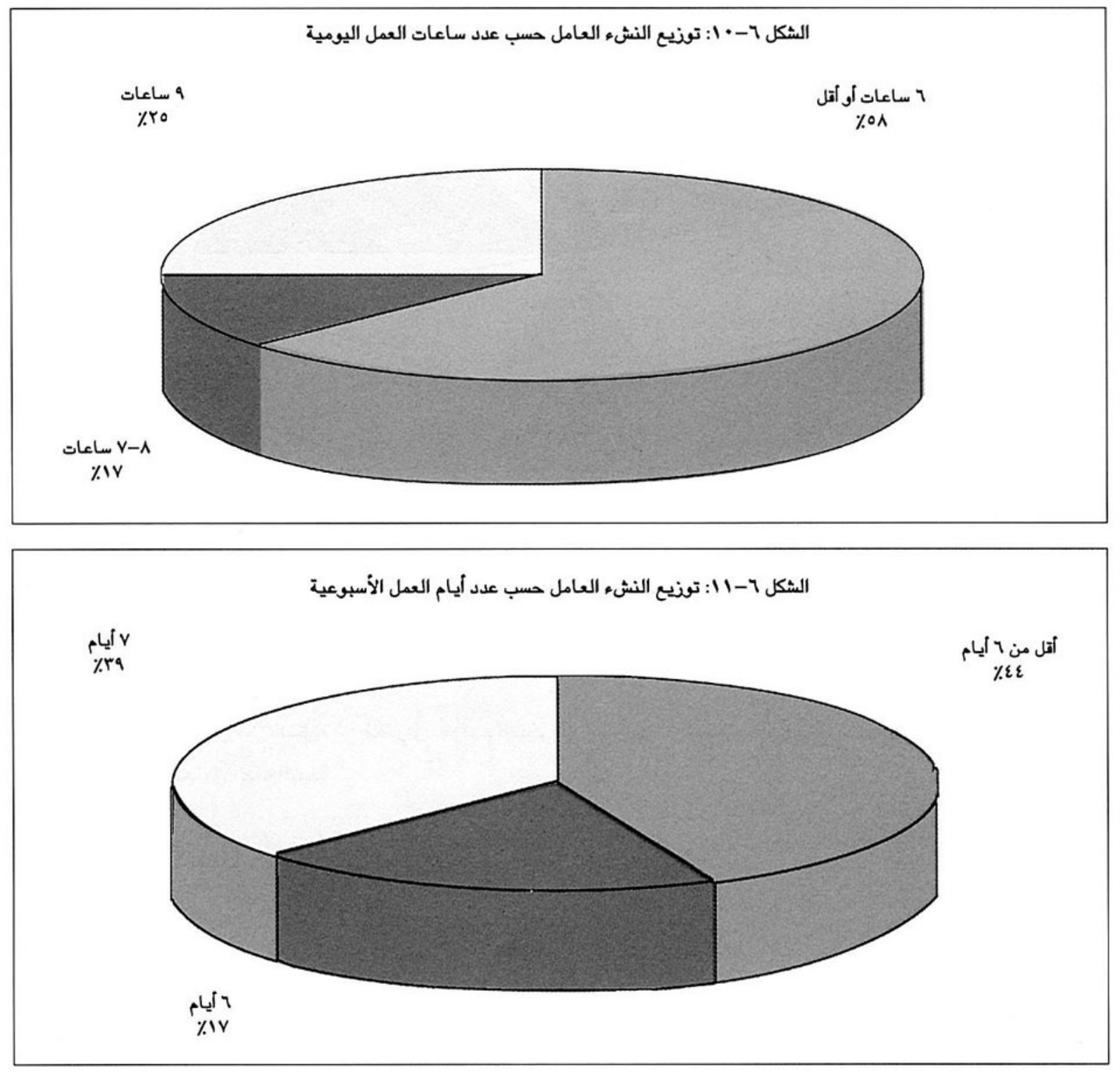

الاستقرار في العمل

ذكر ثلث الفتيان والفتيات ممن كانوا مستمرين في العمل وقت إجراء المقابلة أنهم قد عملوا لفترة تقل عن أربعة شهور خلال

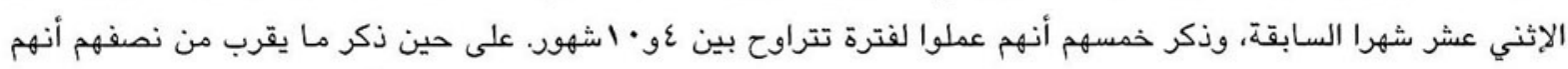

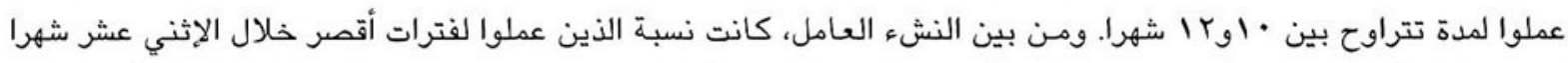

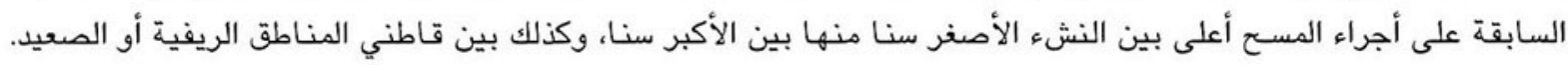

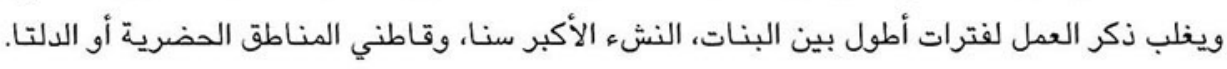

وذكر •0٪ من النشء العامل مقابل أجر أنهم يمارسون عملا ثابتا(طوال العام)، وذكر ريعهم أنهم يمارسون أعمالا موسمية،

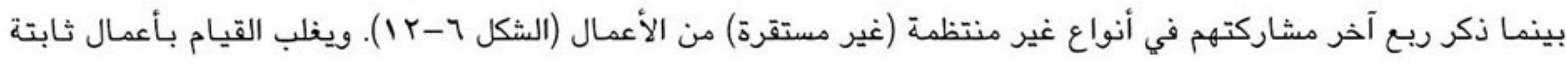

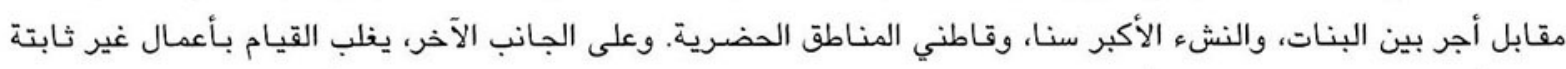

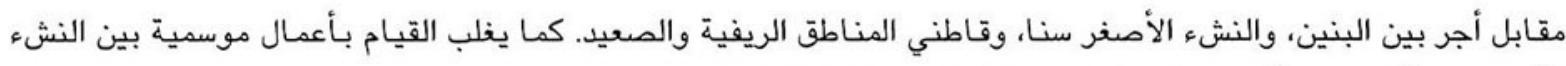

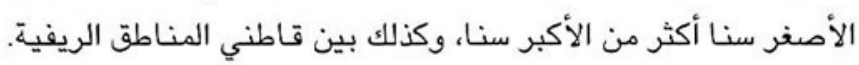




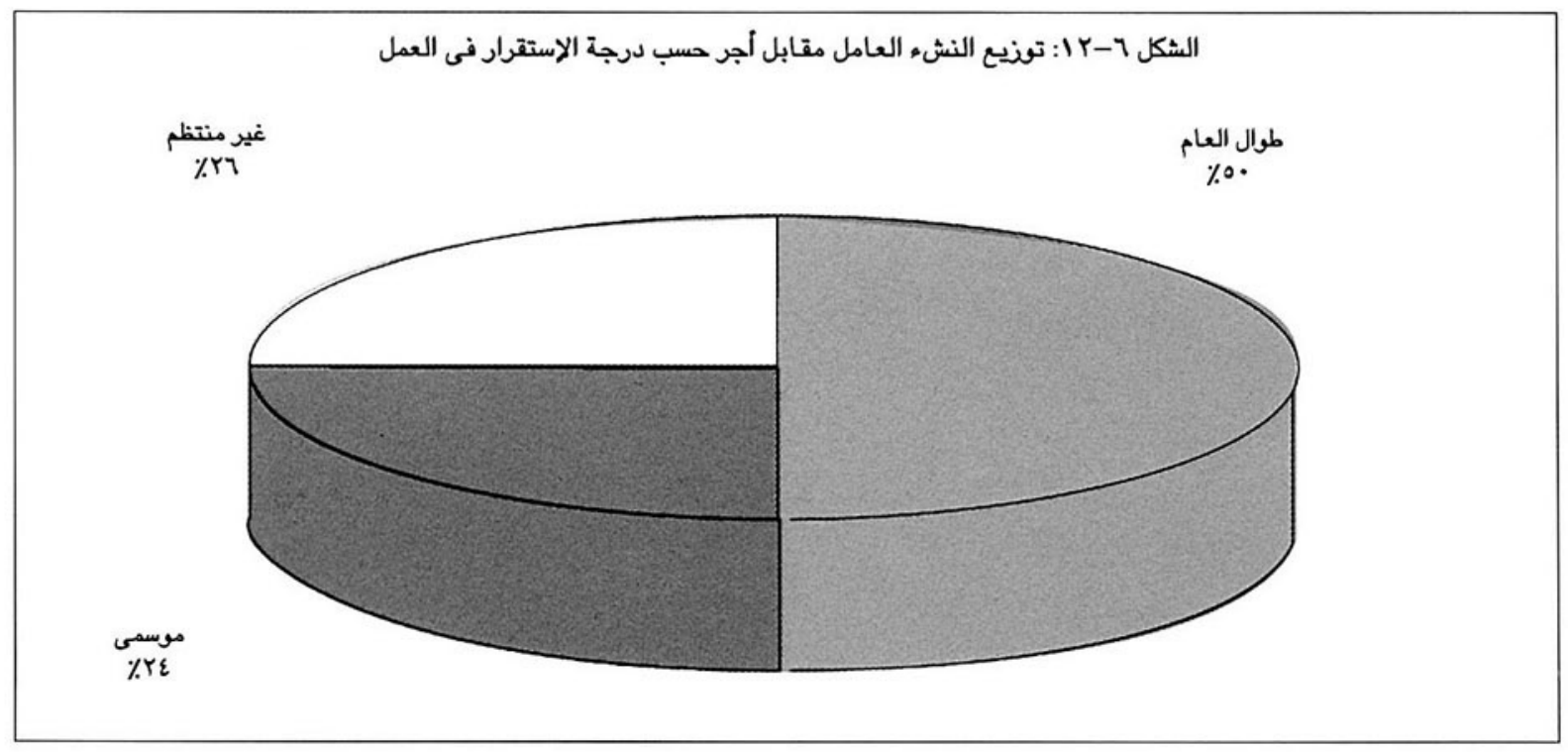

مخاطر العمل

يصبح عمل الفتى أو الفتاة مصدرا حقيقيا للقلق إذا صاحبته مخاطر قد تؤدي إلى عواقب مادية ونفسية خطيرة. وقد أكد قانون

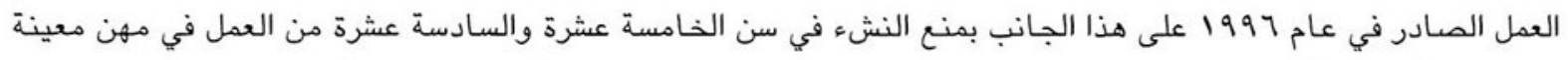

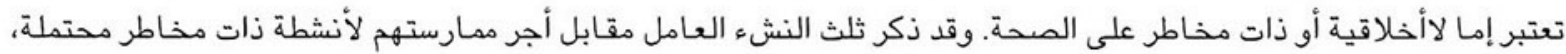

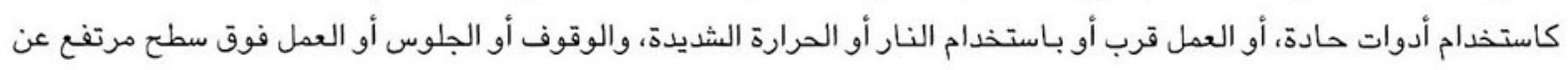

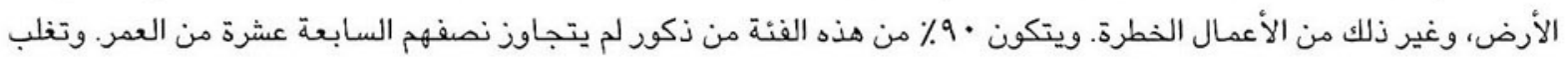
المشاركة في أعمال خطرة مقابل أجر في المناطق الحضرية أكثر من الريفية.

\section{مدى الرضا عن العمل الحالي المدفوع الأجر}

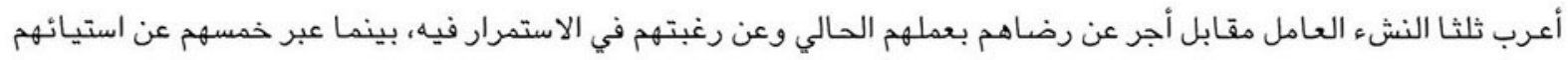

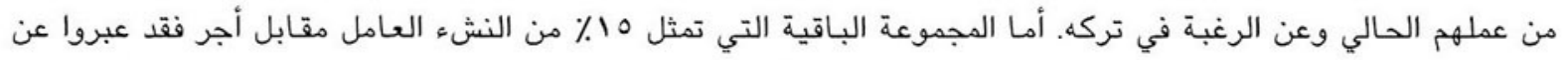

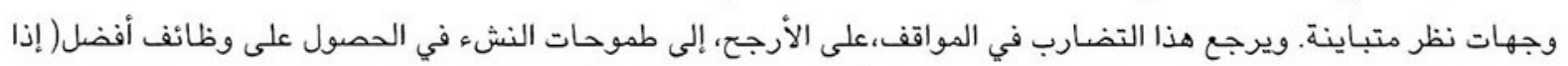

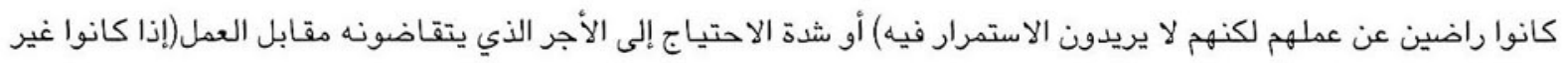
راضين عن عملهم ولكنهم ما زالوا يرغبون في الاستمرار فيه).

يبين الجدول1 -ه النسبة المئوية للنشء غير الراضى عن وظائفه الحالية موزعة تبعا لأسباب عدم الرضا عن العمل وتبعا

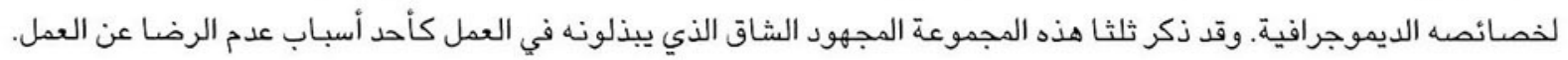

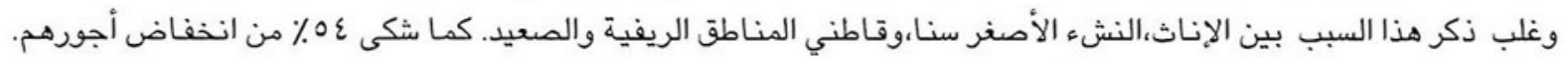

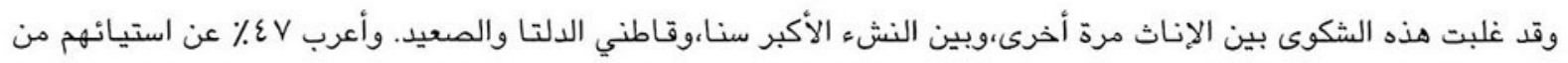

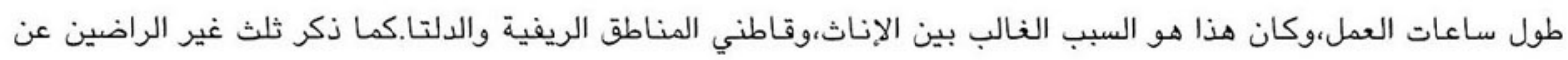

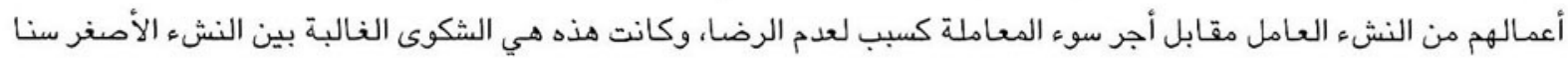
العاملين مقابل أجر،وقاطني المناطق الحضرية والصعيد. ولم يلاحظ وجود تفاوتات بين الذكور والإناث في هذا الجانب. 


\begin{tabular}{|c|c|c|c|c|}
\hline المعاملة السئة من قبل & طول عدد ساعات العمل & الأجر المنخفض & العمل يتطلب مجهود كبير & \\
\hline$r \cdot v$ & $\varepsilon า . \vee$ & ه & TV.1 & الإجمالى \\
\hline$r \cdot \varepsilon$ & $\varepsilon r . q$ & or. & ไย. & بنين \\
\hline ri.q & ir.o & OA.r & vา. & بنات \\
\hline$\varepsilon า . \vee$ & $\varepsilon 0 .{ }^{\circ}$ & $\varepsilon V .0$ & $v \cdot . \Lambda$ & من · ا-ع| سنة \\
\hline rr. & $\varepsilon \vee\rceil$. & ov.r & $70 . r$ & من 10-19 سنة \\
\hline$\varepsilon 1\rceil$. & rr.v & $\varepsilon r\rceil$. & $\varepsilon 1.7$ & حضر \\
\hline r.. & $01 . V$ & $\circ \wedge . \varepsilon$ & vา.A & ريف \\
\hline r..1 & rn.1 & YV.A & $\varepsilon \varepsilon . \varepsilon$ & المحافظات الحضرية \\
\hline rA. & $\varepsilon 9 . \wedge$ & OV.I & 77.1 & وجه بحري \\
\hline rr.q & $\varepsilon \varepsilon, r$ & 07.0 & 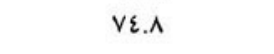 & وجه قبلي \\
\hline$r \cdot v$ & $\varepsilon า . \vee$ & o . 1 & IV.1 & الإجمالي \\
\hline IV & $1 \cdot v$ & $M r$ & 100 & عدد الحالات \\
\hline
\end{tabular}

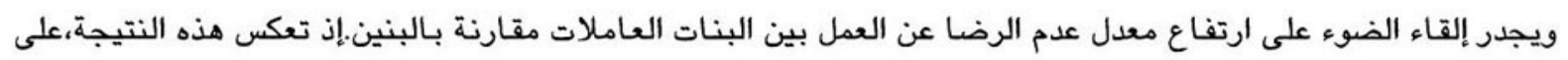

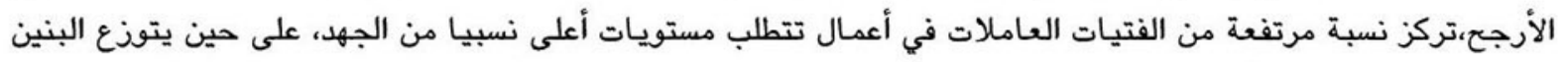

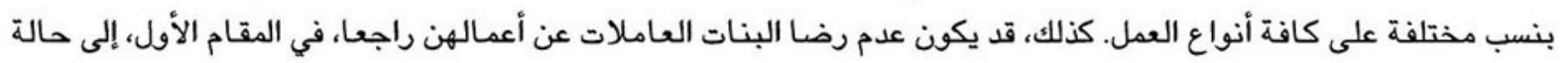

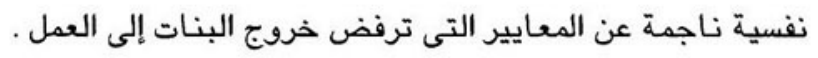

رابعا: الأجود

مستويات الدحل

تكشف بيانـات مسح "النشء والتغيير الاجتماعي في مصر" أن متوسط الدخل الشهري من العمل المدر للدخل بين من تتراوح

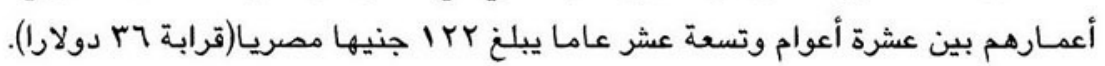

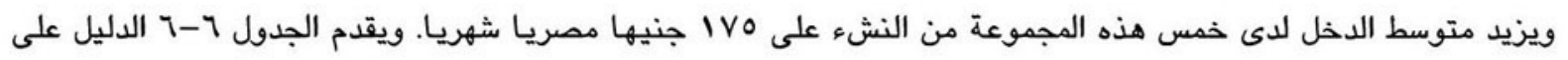

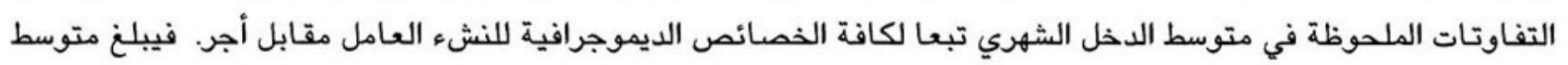

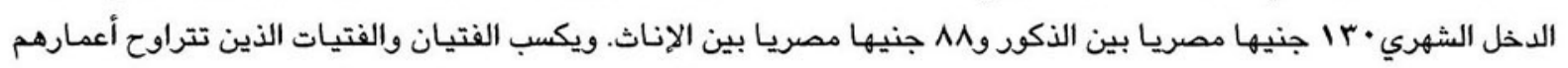

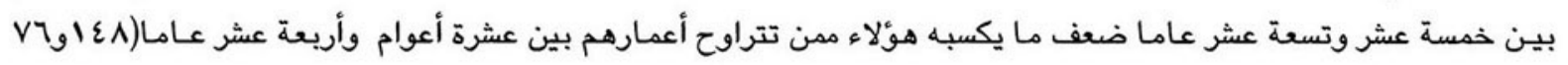

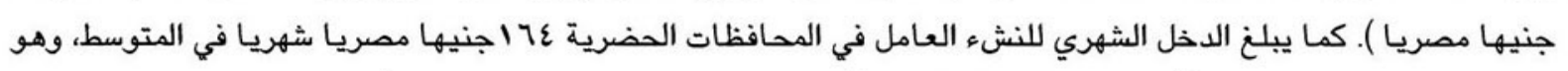

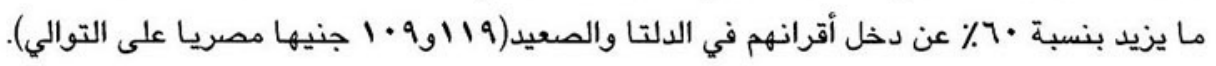




\section{أوجه إنفاق الأجود}

يمثل النهج الذي يتبعه النشء الذى يمارس أعمالا مدرة للدخل في إنفاق ما يكسبه جانبا هـاما من تجريته في العمل (الشكل

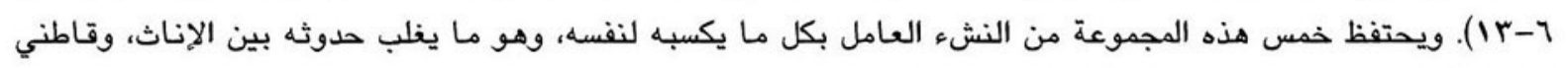
المناطق الحضرية،ويخاصة في المحافظات الحضرية.

ويعطي ما يقرب من • ع٪ من النشء كل ما يحصلون عليه من دخل لأسرهم،على حين يقتسم •ع٪ منهم دخولهم مع أسرهم.

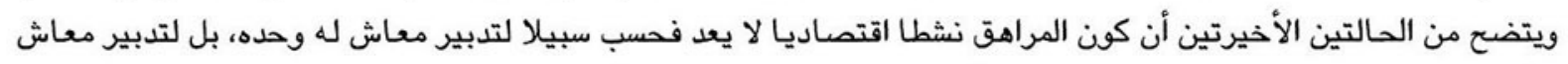

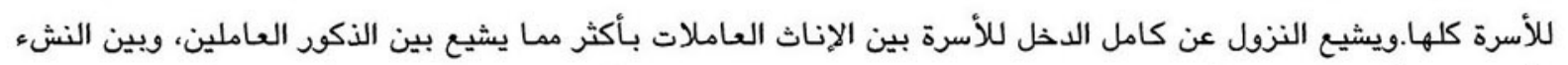

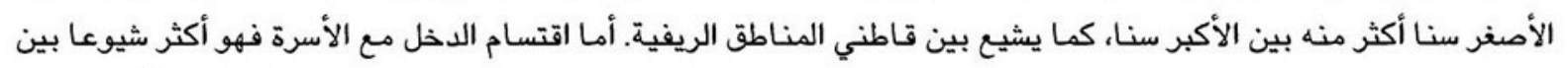
الذكور العاملين منه بين الإناث العاملات،كما يشيع في المناطق الحضرية عنه في المناطق الريفية، ويين النشء الأكبر سنا.

ويصل احتمـال أن تعطي الفتاة العاملة التي تساهم في نفقات الأسرة بدخلها كله أو جزء منه هذا الدخل إلى أمها إلى ضعف إلى إلى إنها

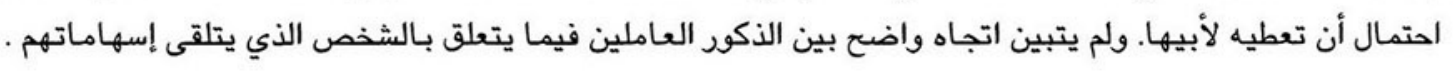

وتعكس طريقة إنفاق الدخل بين النشء إلى حد كبير الأسباب الماثلة وراء انخراطه في أعمال مدرة للدخل. فالنشء العامل الذي

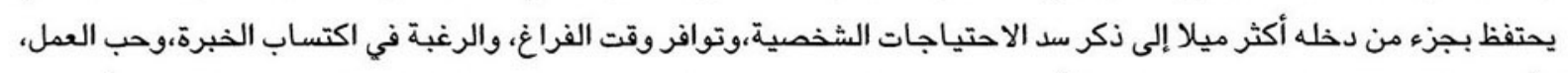

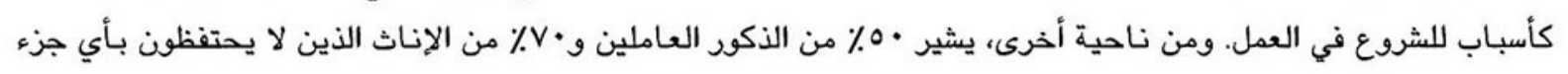

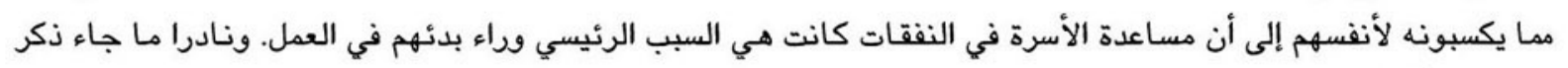
حب العمل أو اكتساب الخبرة بين هذه الفئة. 


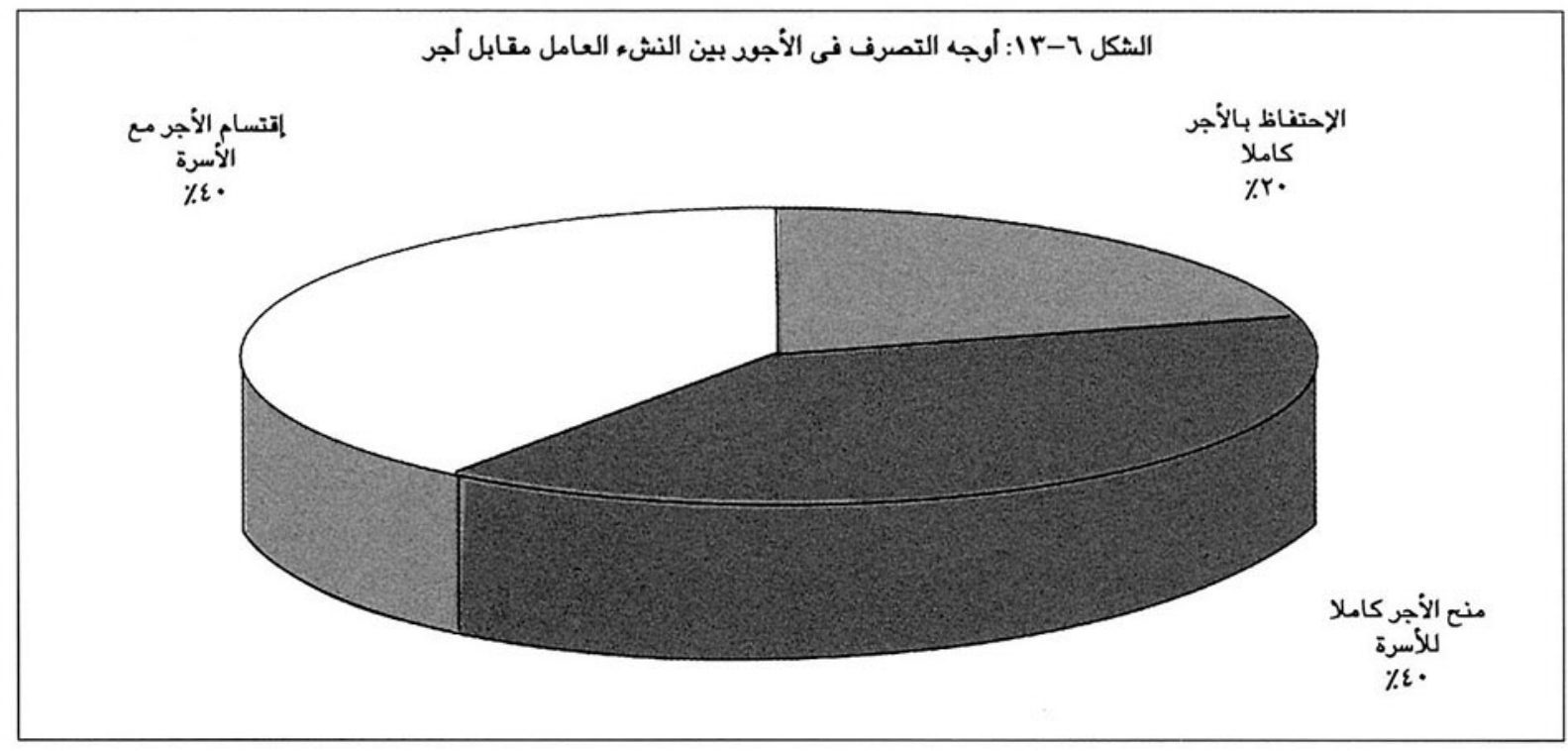

\section{خامسا: الصورة العامة لأسر النشء العامل}

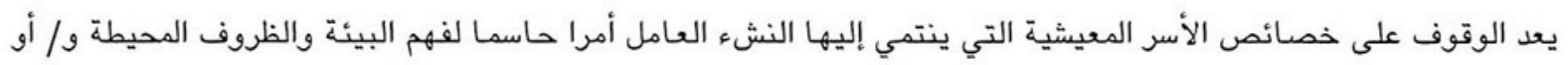

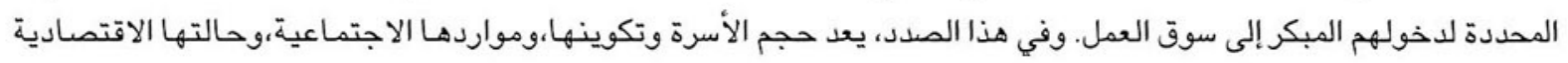

قضايا رئيسية.

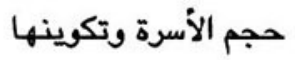

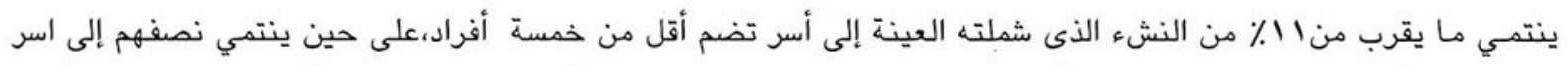

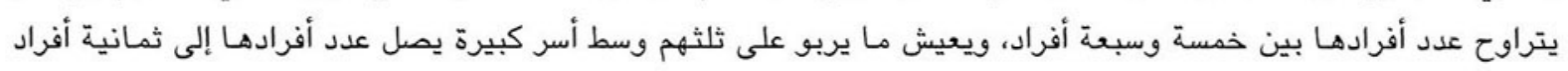
على الأقل.

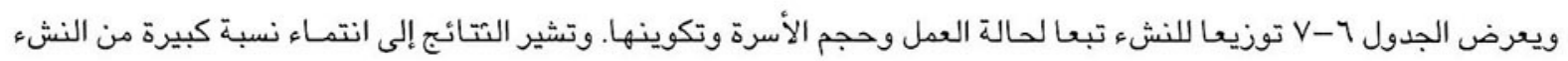

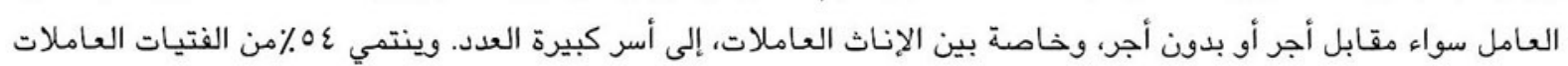

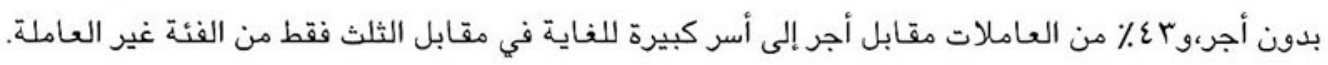

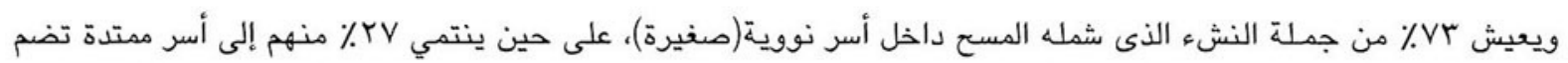

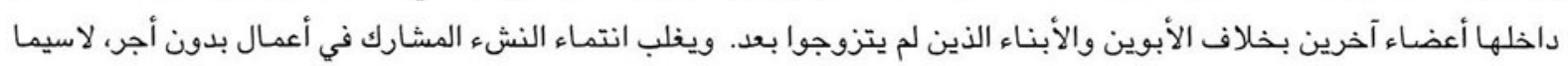

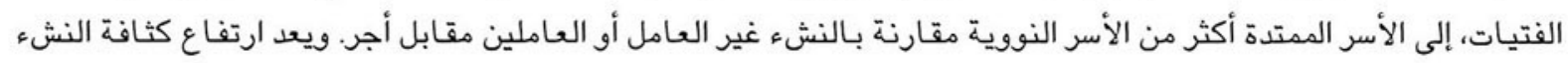

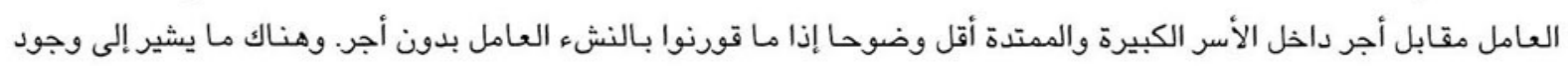

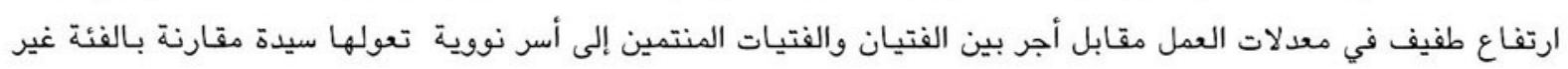




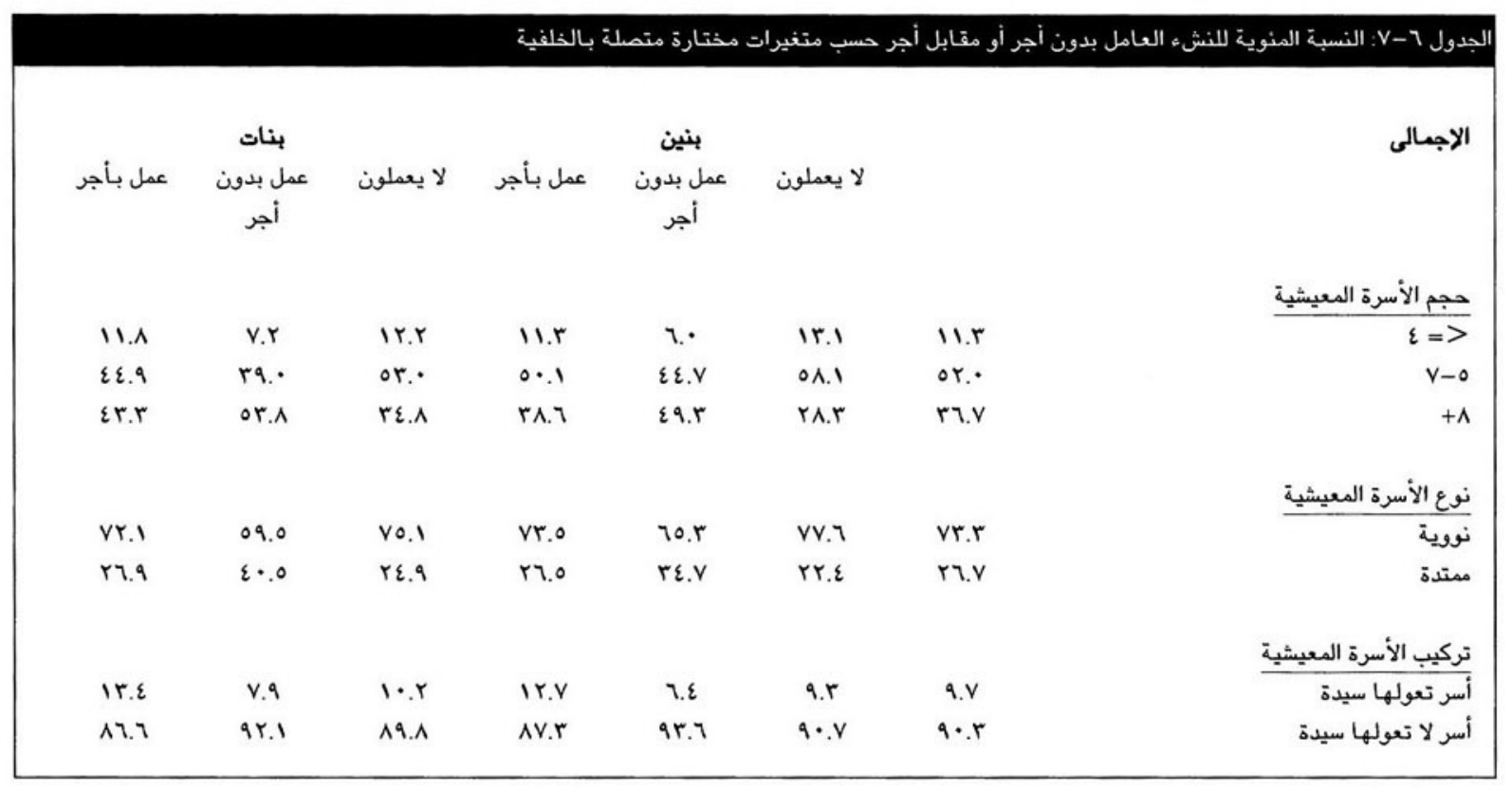

\section{الحالة الاجتماعية الاقتمادية للأسرة}

عادة ما يكون دخول النشء المبكر إلى سوق العمل هو الاستثناء وليس القاعدة، إذ يتوقع أن تؤثر الموارد الاقتصادية المتوفرة

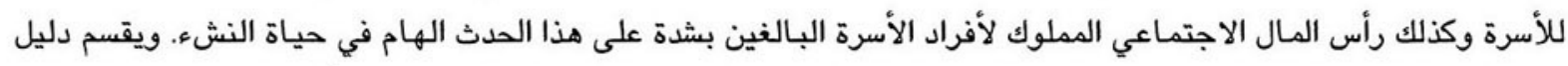

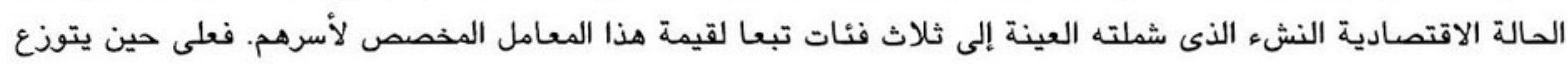
النشء غير العامل بقدر متساوي على جميع الفئات الأسرية، يغلب تركز المجموعات العاملة داخل الأسر الأكثر فقرا.

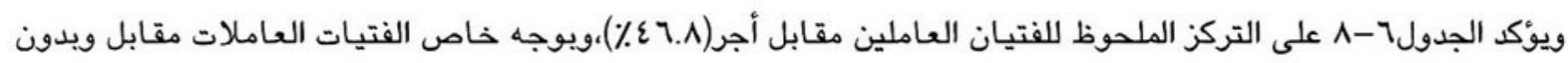

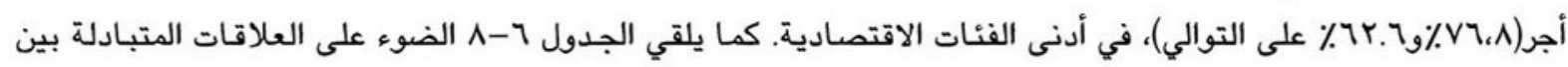

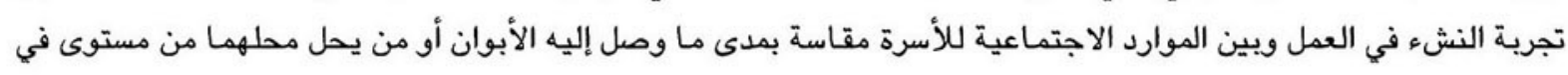
التعليم.

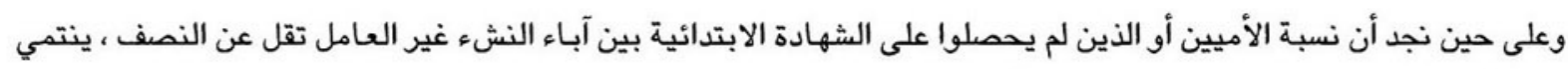

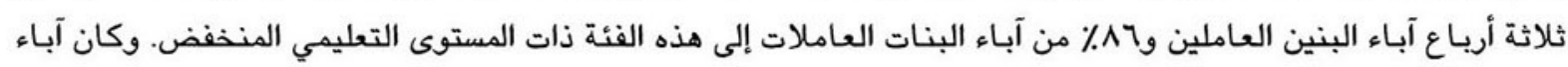

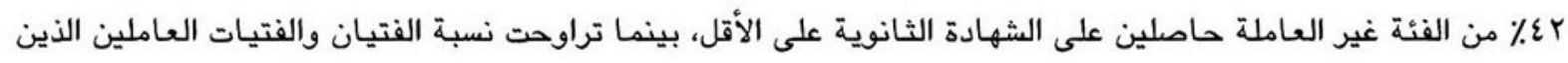

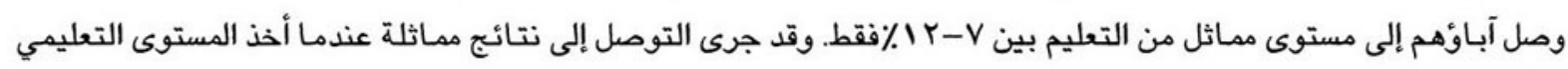
للأمهات في الحسبان.

وكان ثلاثة أرياع أمهات النشء غير العامل من الأميات أو ممن لم يحملن على الشهادة الابتدائية. أما بين البنين العاملين

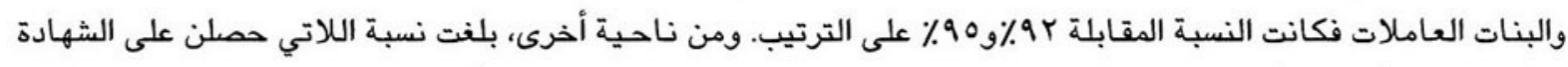

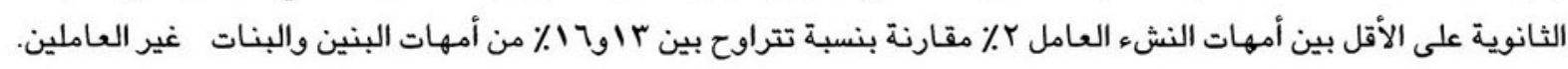

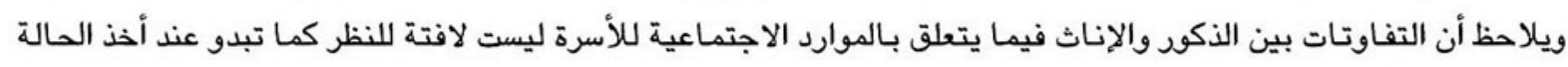


وتؤكد هذه النتائج ما سبق أن أوضحته الدراسات من قبل عن الفقر وأستراتيجيات التخفيف من نتائجه السلبية. إذ يؤثر

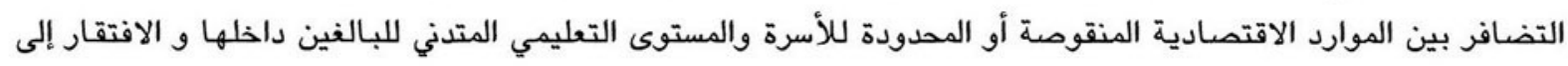

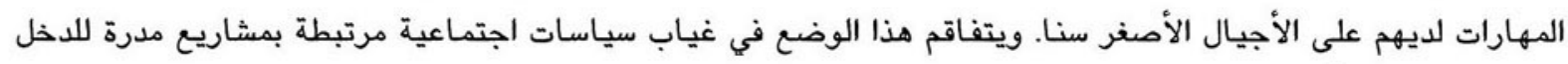
وبرامج لاععادة التأهيل /التدريب موجهة إلى المعوزين من البالغين.

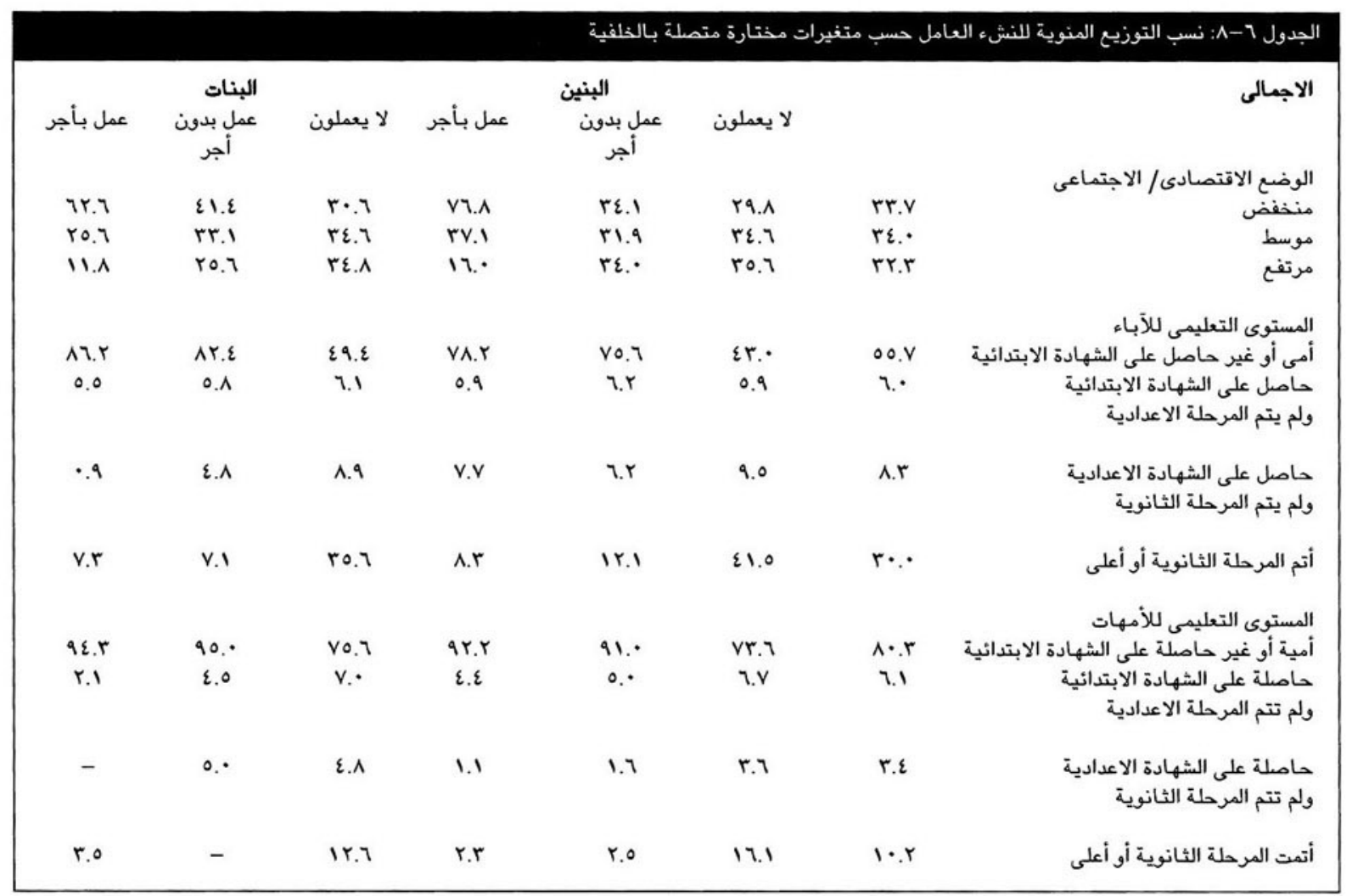

\section{سادسا: تمديد المجتمع المستهدف من النشء للبرامج التدريبية}

وفقا للتعريف الرسمي للبطالة، يُعد عاطلا كل فتى أو فتاة تعدى الخامسة عشرة لديه القدرة والرغبة في العمل، ولا يستطيع

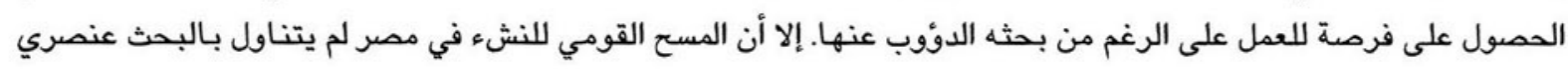

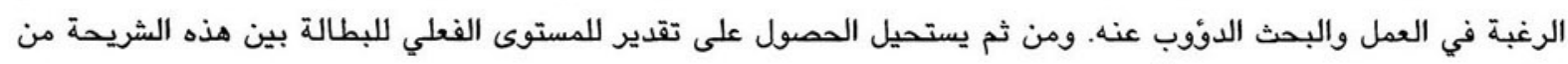

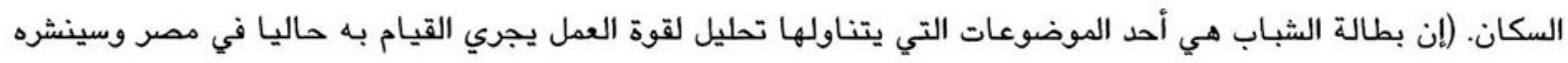

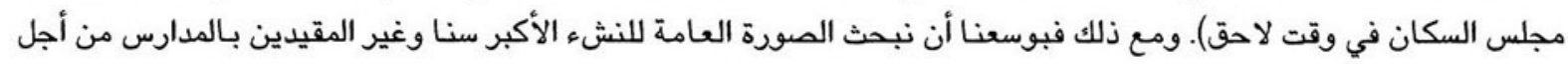
فهم أفضل لأحوالهم.

ومن أجل تحديد شريحة السكان المستهدفة من جانب التدخلات التي تركز على تعليم النشء وتدريبه، فقد تم تضمين المعايير الثلاثة الآتية: كل من بلغ الخامسة عشرة أو تعداها، وغير مقيد في التعليم النظامي، ولاني يعمل. 


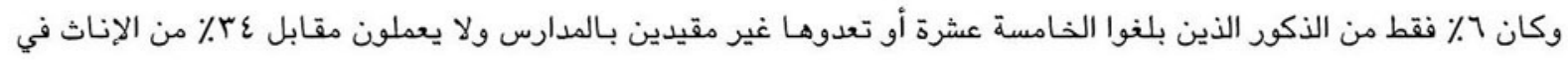

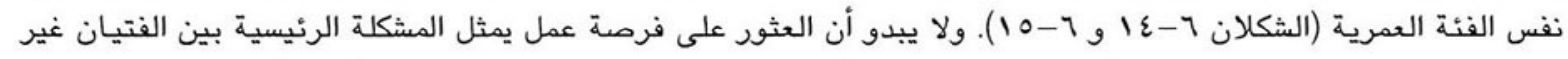

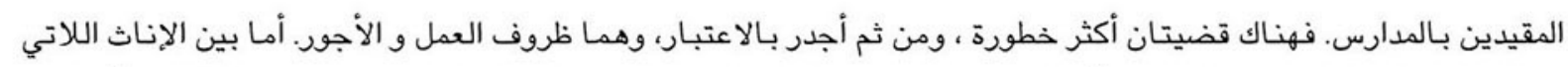

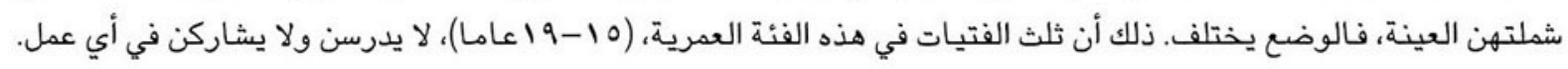

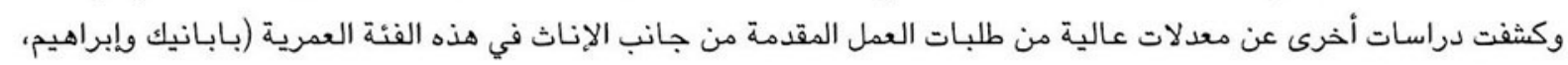

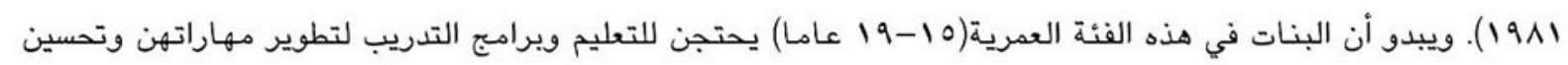

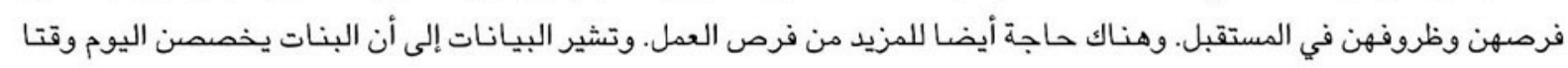
طويلا للأعباء المنزلية.
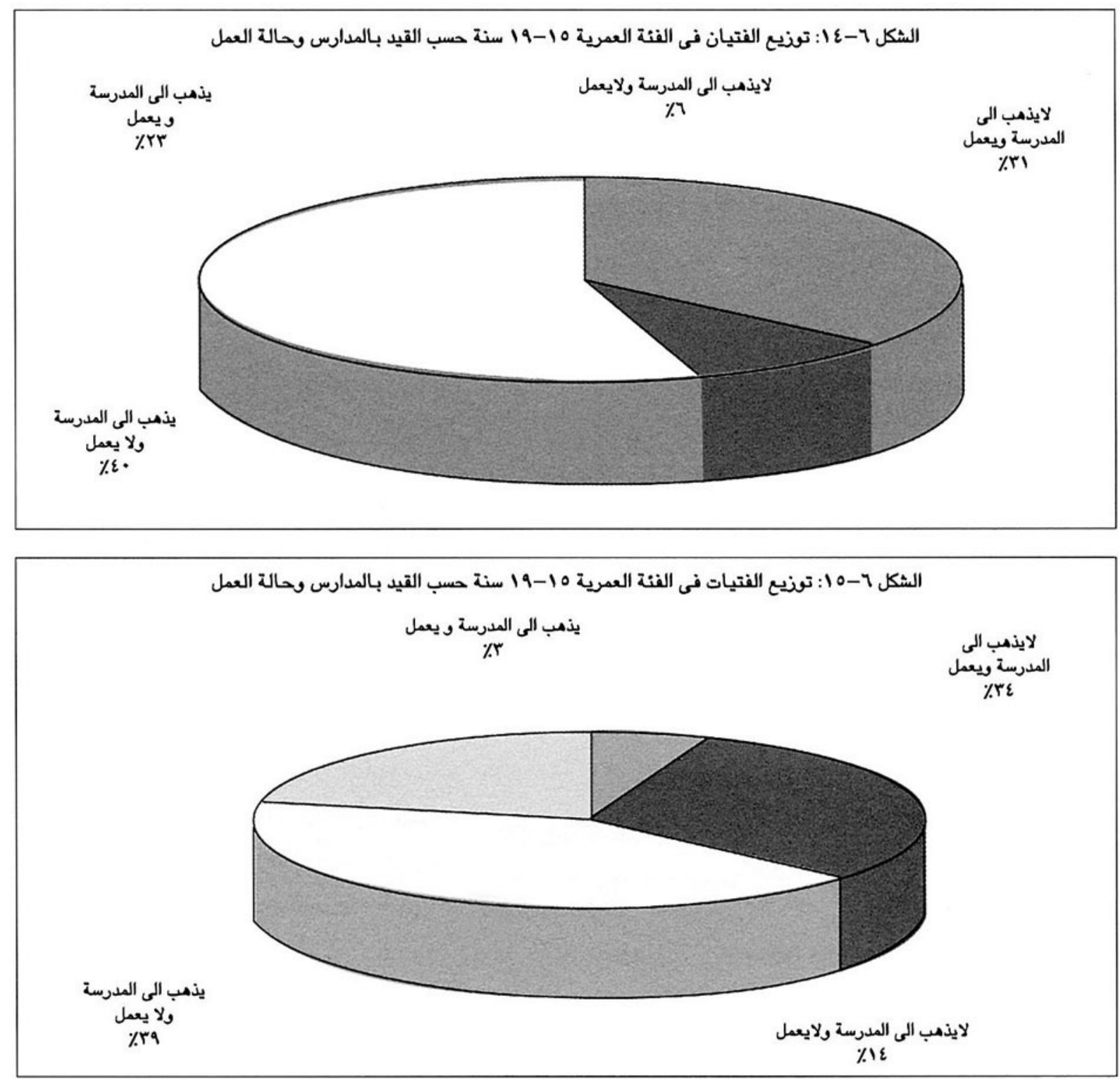

سابعا: الحالة الصحية للنشء العامل

أن الوقوف على الحالة الصحية للنشء العامل هو أمر ضروري لتصميم برامج تستهدف هذه الفئة الخاصة من السكان. ويعد

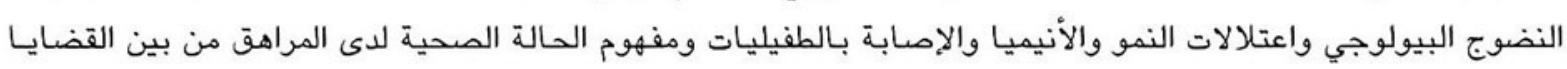
المثيرة للقلق بوجه خاص. ويعرض الجدول 1 -9 توزيعا للنشء العامل وغير العامل حسب مؤشرات مختارة للحالة الصحية. 
ويتقدم البنين العاملين على الفئة غير العاملة فيما يتصل بالنضوج البيولوجي. كما تصل نسبة البنين العاملين في مرحلتي

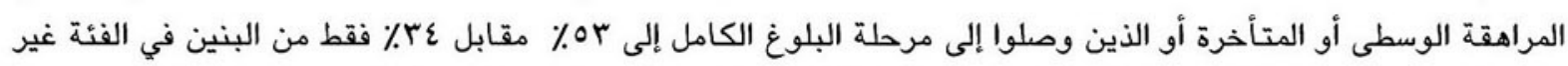

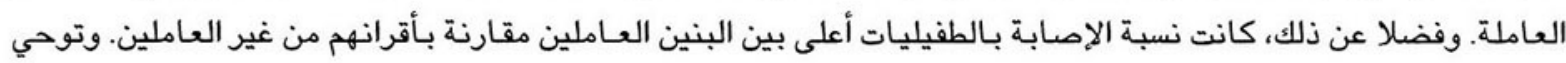

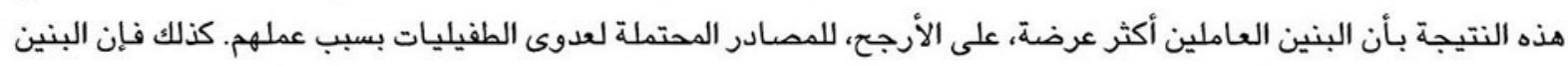

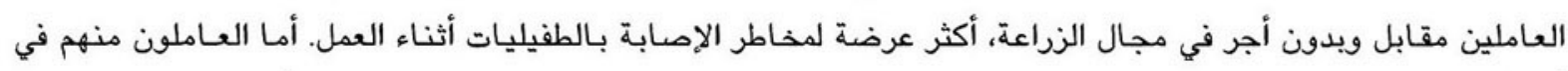
أنشطة اقتصادية خارج مجال الزراعة فيعتمدون بدرجة كبيرة على تناول وجبات رخيصة غير صحية ألمرية أثناء العمل.

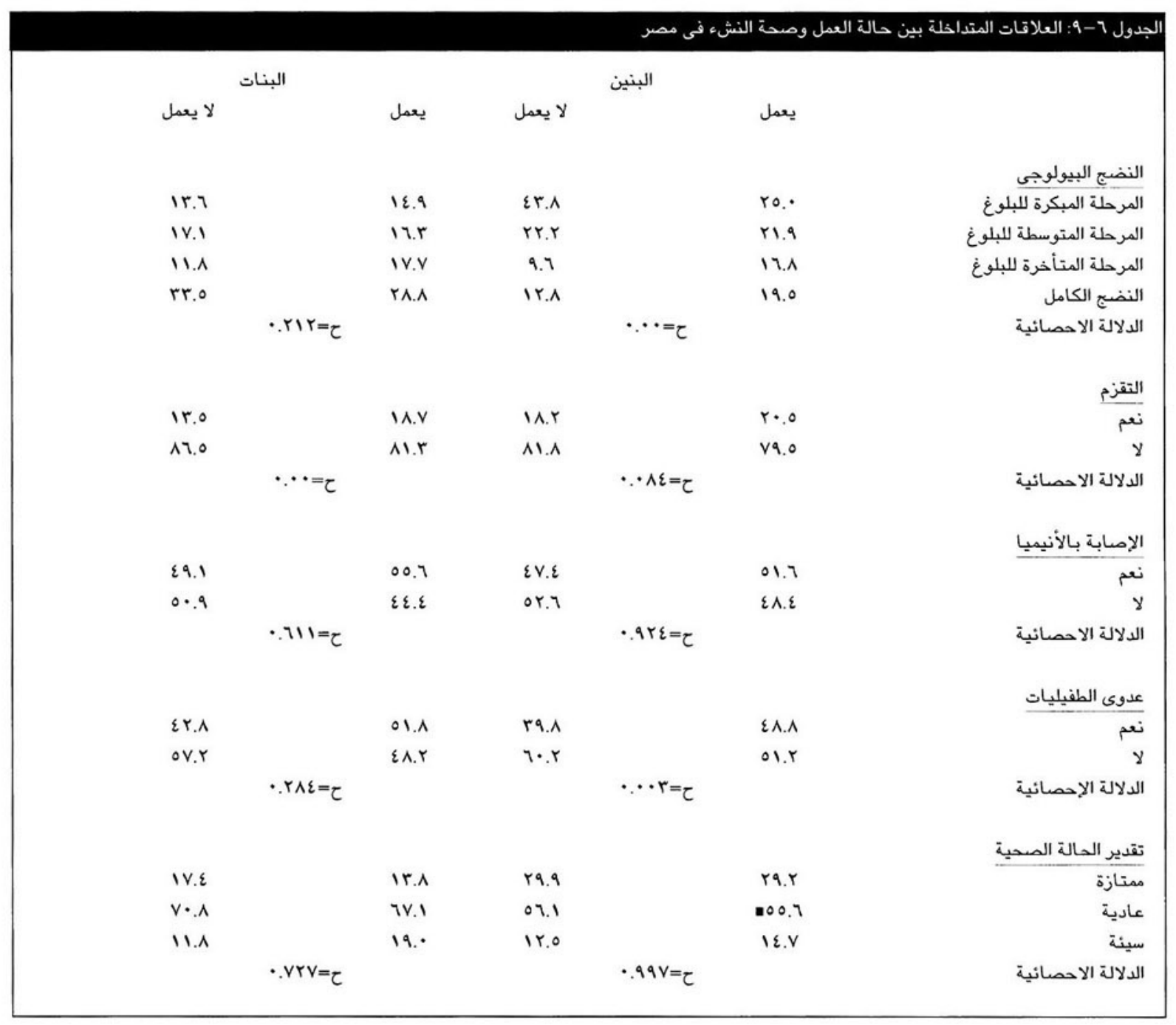

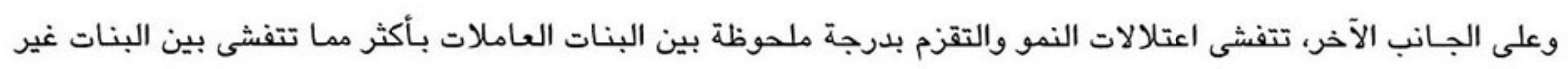

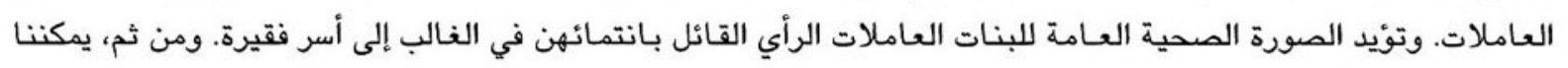

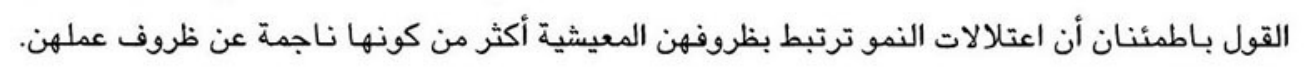


ذكر قرابة ثلث النشء، واحد من كل اثنين من الذكور وواحدة من كل ست من الإناث، أنهم يشاركون حاليا في أنشطة اقتصادية،

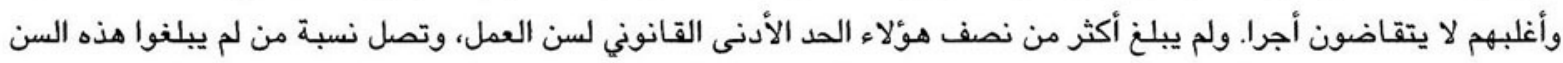

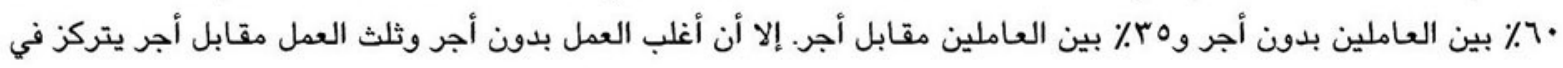

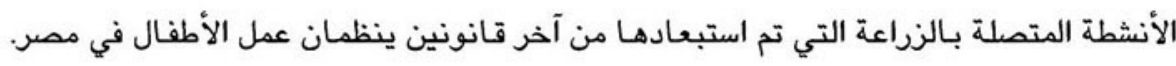

وظروف عمل النشء النشط اقتصاديا ليست نموذجية. يعمل نحو نصف النشء العامل لسبع ساعات يوميا أو أكثر، وهو ما

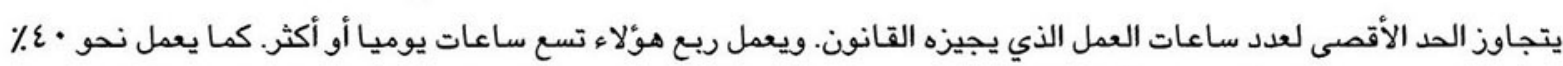

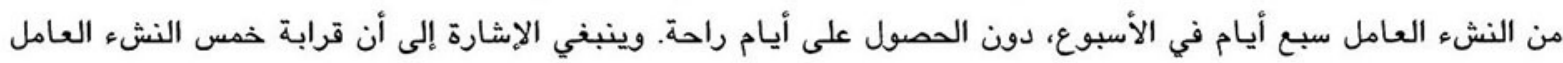
يعملون لساعات طويلة ولا يحصلون على أيام راحة.

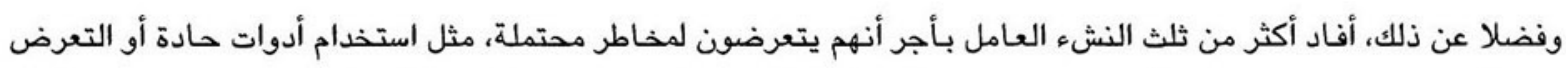

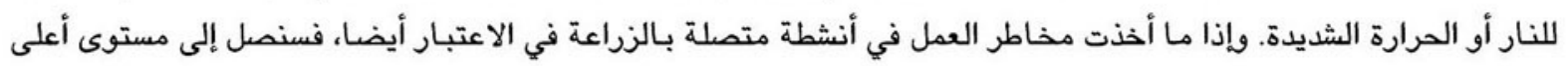
كثيرا من الانخراط في أعمال غير آمنة.

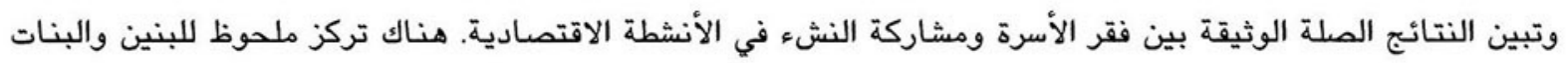

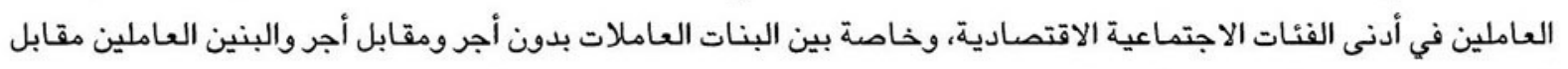

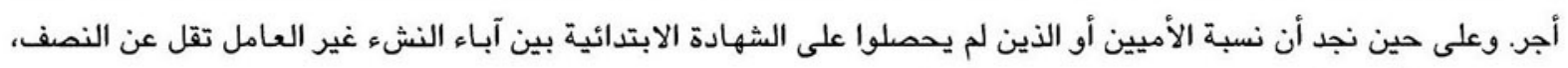

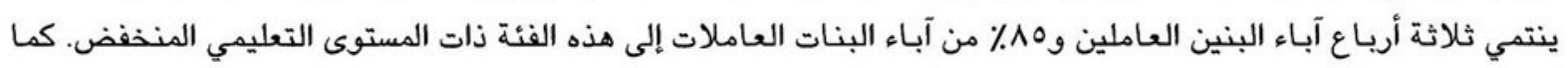

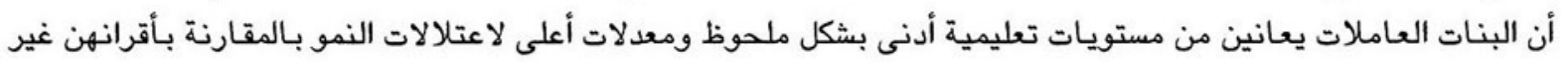

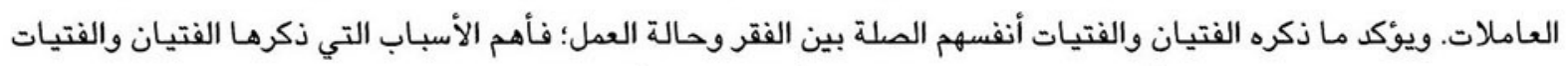
لشروعهم في العمل كانت حاجة أسرهم لمساعدتهم لهم بدون أجر وحاجة أسرهم لدخلهم.

ويبين هذا التحليل بوضوح أن المساوئ الناتجة عن تضافر نقص الموارد الاقتصادية للأسرة والمستوى التعليمي المتدني

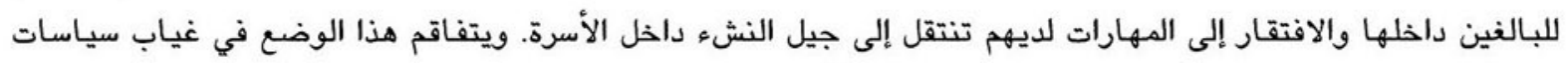

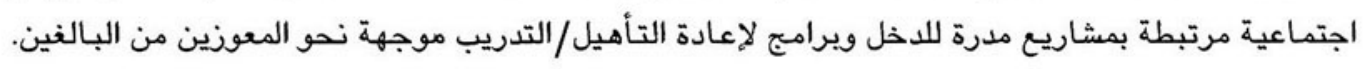

وتساعد هذه النتائج أيضا على تحديد شريحة السكان المستهدفة من جانب البرامج التي تركز على التعليم والتدريب والتلمذة.

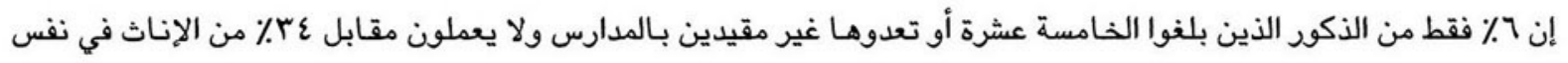

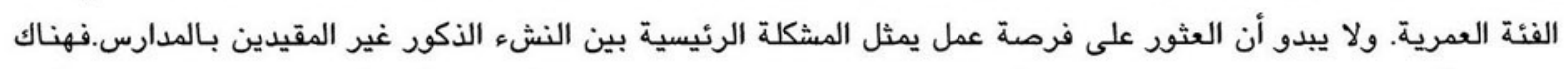

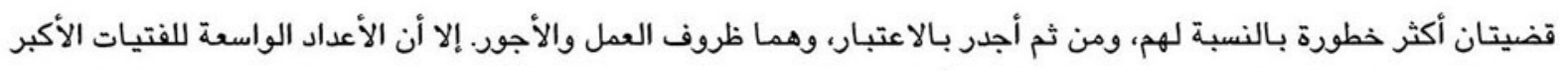

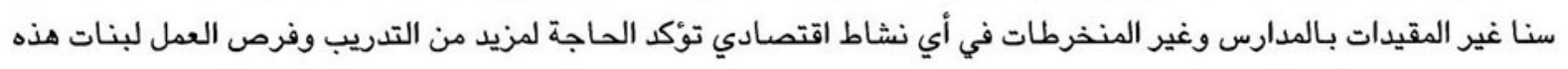

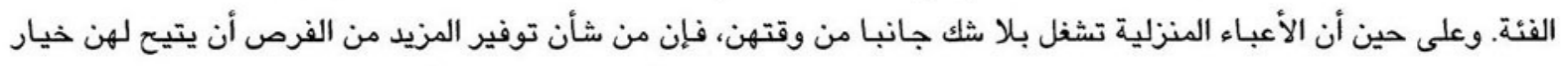

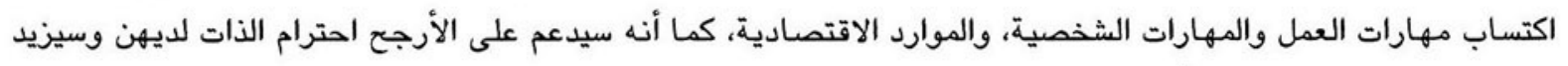
قدراتهن على التفاوض داخل أسرهن.

وأخيرا، فإنه يتعين على أية سياسات أو برامج تستهدف الأنشطة الاقتصادية للنشء أن تأخذ في الاعتبار الاختلافات الملحوظة 
في الصورة العامة للعمل وفقا للسن والنوع. ومن ثم فإن تقسيم النشء وفقا للسن والنوع هو أمر حيوي من أجل إيجاد

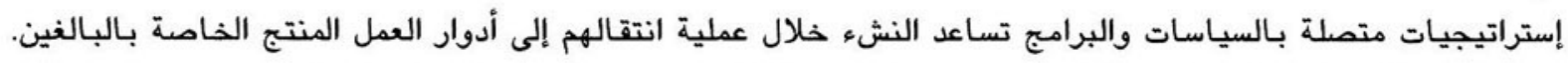
ويبحث الفصل التالي عوامل التنشئة التي تسهم في تشكيل موقف البرامع تشاء من النشاء العالم ورفاهيته النفسية. 


\section{عوامل التنشئة الاجتماعية}

عندما يصل الطفل للعقد الثاني من العمر، تتسع دائرة الأشخاص المؤثرين المحيطين به. وبينما يكون التأثير الأكبر أثناء

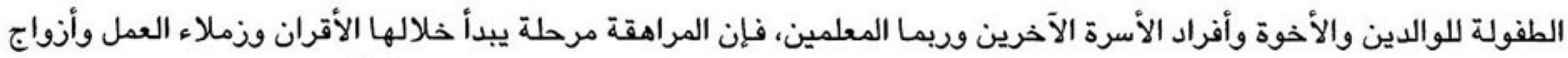

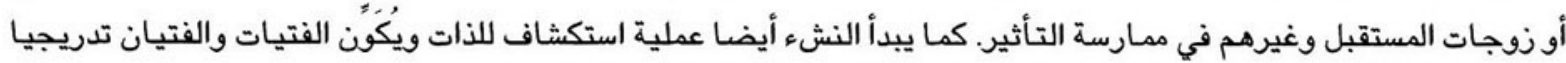

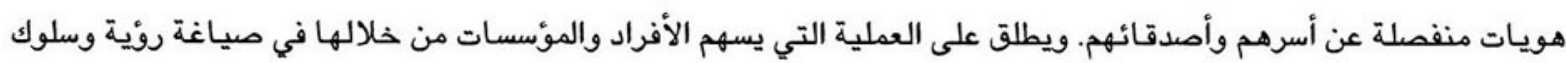

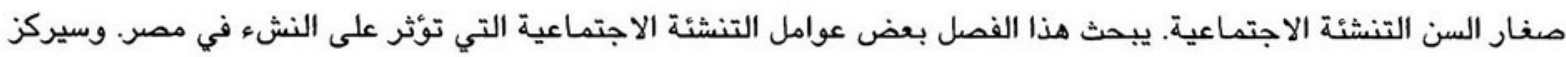

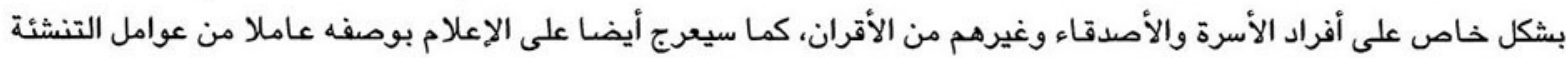

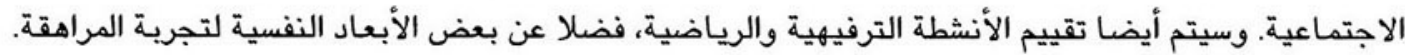

\section{أولا: الأسرة: التفاعل مع الوالدين والأخوة}

خلال فترة المراهقة، يقيم الوالدان وأبناؤهم علاقات من نوع جديد فيما بينهم. يبدأ الفتيان والفتيات فى التعبير عن أنفسهم

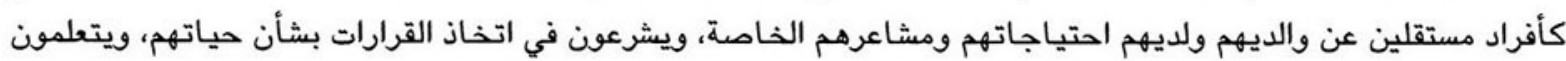

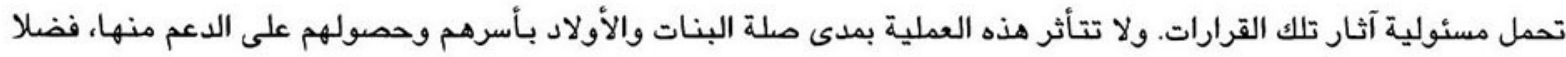

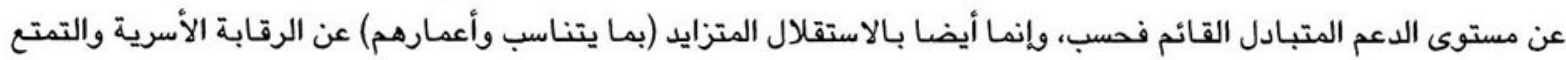
بقدر ملائم من الحرية.

بحث مسح "النشء والتغيير الاجتماعي في مص" هذه القضايا، مركزا على التعبير عن الذات ورد فعل الوالدين على ذلك، والدعم

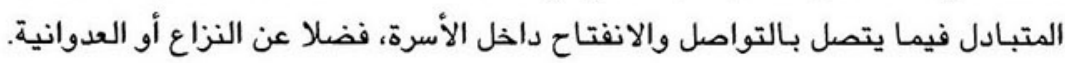

التعبير عن الذات قرد فعل الوالدين

ينمو النشء في إطار أسري يتبنى داخله القيم والتوقعات الاجتماعية والأعراف الخاصة بالسلوك المقبول. وتمثل التفاعلات

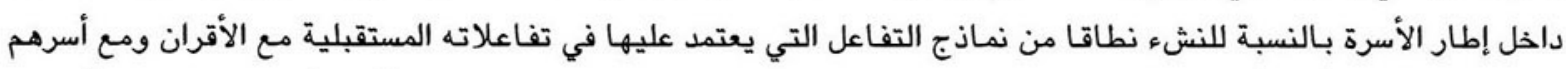

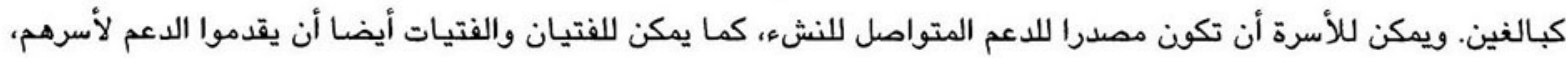

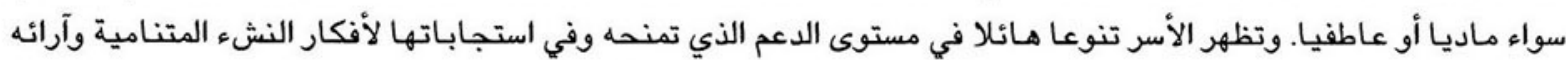

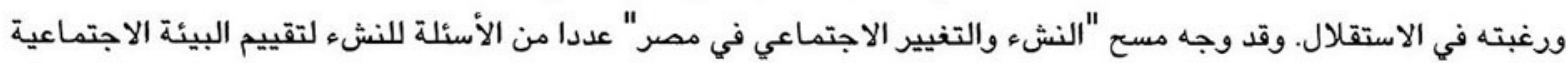
للأسرة إذ تشكل حياته.

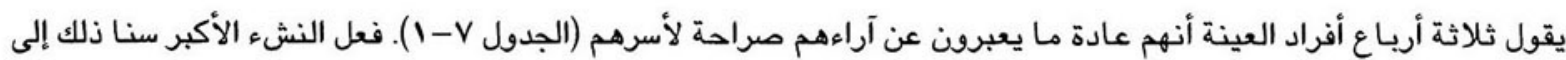

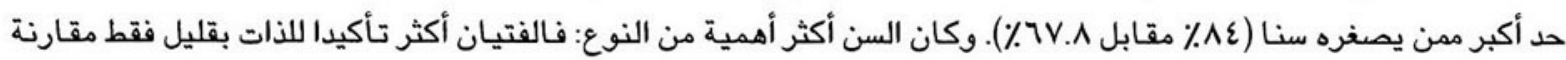

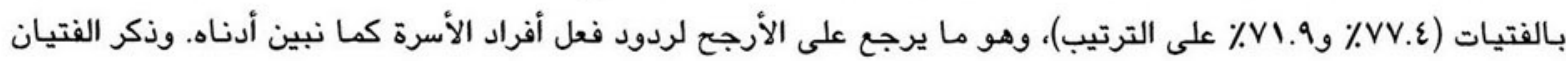

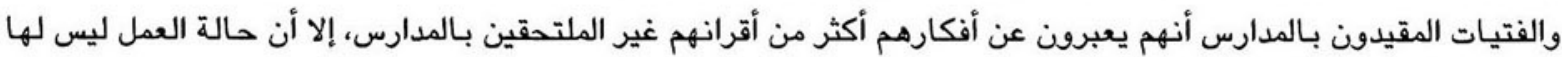

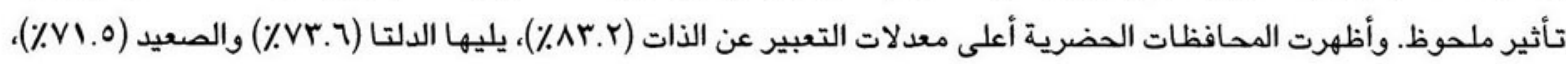


كما كانت المعدلات أعلى عموما في المناطق الحضرية منها في الريفية. ويبدو أيضا أن النشء أكثر ميلا للجهر بآرائه في الأسر

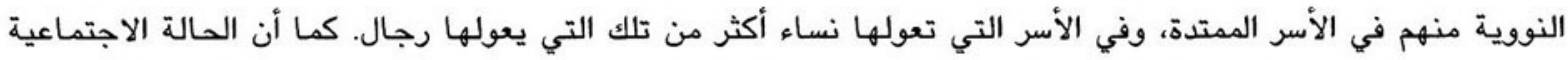

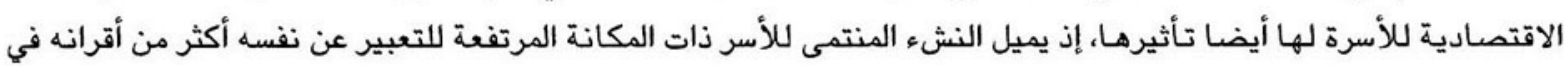

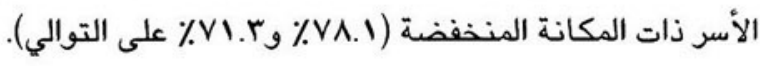

\begin{tabular}{|c|c|c|c|}
\hline الاستهانة بها & رد فترام الأَّراء & يعبرون عن رأيهم & \\
\hline $17 . \varepsilon$ & Ar.r & VV.q & بنين \\
\hline Y.. & vv.r & v1.9 & بنات \\
\hline ro. & $v r .7$ & TV.A & . \\
\hline$\cdots .1$ & Av. 9 & $\wedge \varepsilon \cdot \cdot$ & 10-19-10 سنة \\
\hline 19. & $A \cdot .0$ & var & ملتحقون بالمدرسة \\
\hline $19 . r$ & $\wedge \cdot \cdot$ & $v \cdot r$ & غير ملتحقون بالمدرسة \\
\hline 19.1 & $\Lambda \cdot . \varepsilon$ & $v \varepsilon .1$ & يعمل \\
\hline 11.9 & $\Lambda \cdot r$ & 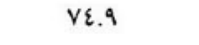 & لا يعمل \\
\hline M. & Ai.r & vา.r & أسرة نووية \\
\hline rr.r & $\mathrm{vv} . \varepsilon$ & 79.1 & أسرة معتدة \\
\hline 19. & $\Lambda \cdot \varepsilon$ & Al. $\varepsilon$ & أسر تعولها سيدة \\
\hline 19. & $\Lambda \cdot \varepsilon$ & vr.a & أسر لا تعولها سيدة \\
\hline YI.T & Vv. & vi.r & الوضفضع الاقتمادى/ الاجتماعى \\
\hline 11.0 & $\Lambda \cdot . \wedge$ & vย. & متوسط مس \\
\hline 17.1 & $\wedge r .0$ & VA.1 & 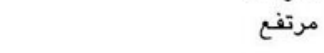 \\
\hline $17 . \varepsilon$ & Ar.v & v৭.० & حضر \\
\hline$r \cdot .1$ & VA.A & vi.q & ريف \\
\hline Ir.V & A.. & Ar.r & المحافظات الحضرية \\
\hline ।ย.7 & $\Lambda \varepsilon . \vee$ & vr.t & وجه بحرى \\
\hline rA.1 & vi.v & $\checkmark 1.0$ & وجه قبلى \\
\hline 19. & $\Lambda \cdot . \varepsilon$ & vย.า & 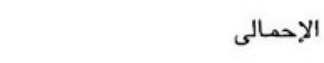 \\
\hline$M M$ & orra & 1789 & عدد الحالات \\
\hline
\end{tabular}

وذكرت نسبة أعلى تبلغ •^٪ من الفتيان والفتيات الذين يعبرون عن آراءهم أن الوالدين ينصتون لآراءهم ويحترمونها. كان

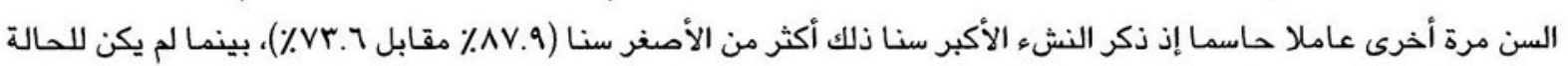

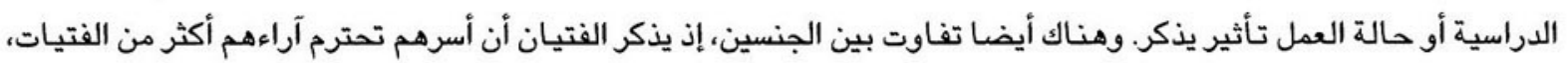

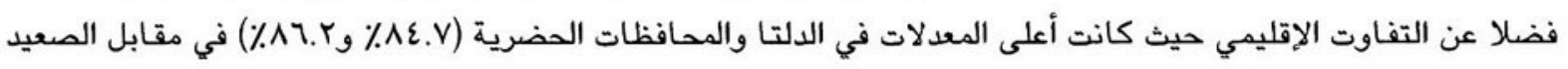

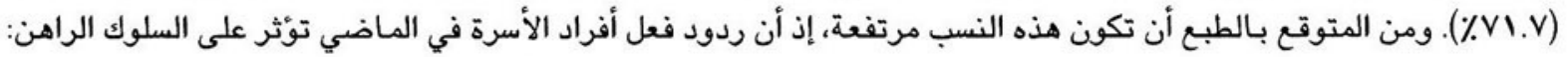

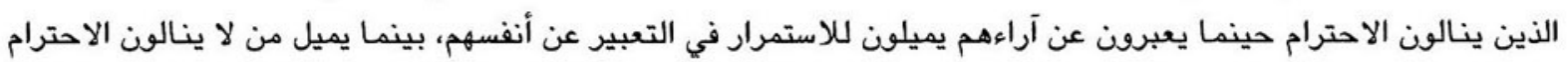
للكف عن الجهر بآراءهم في إطار الأسرة. 
ومن ناحية أخرى، فإن الاستهتار بآراء النشء أو استبعاده عن نقاشات البالغين يؤدي للإحباط ويبعث برسالة سلبية. ويمكن

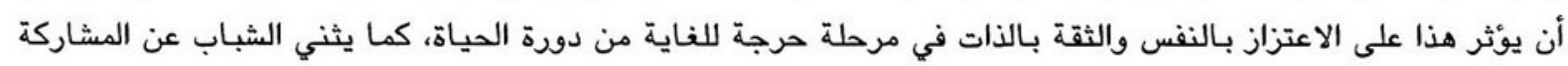

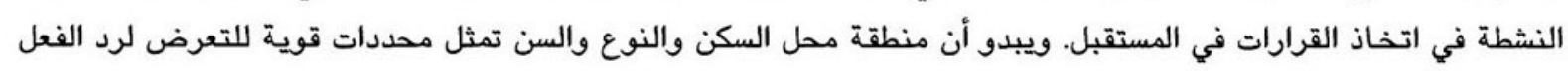

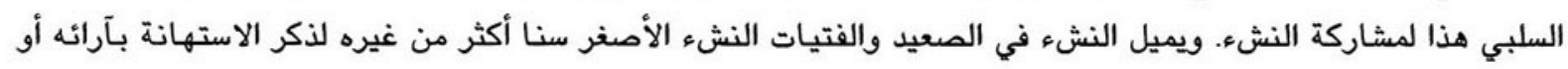

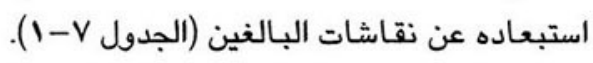

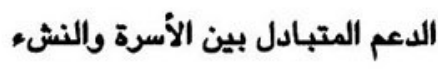

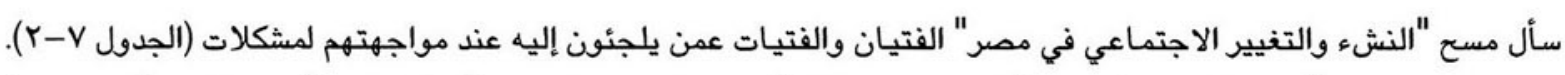

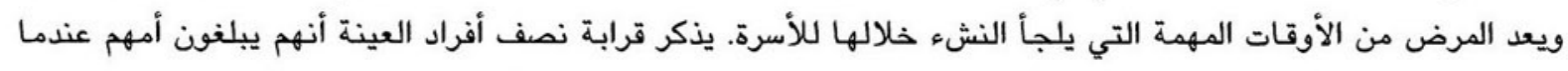

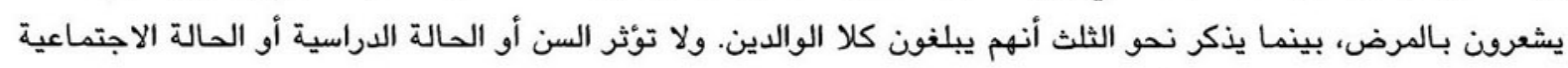

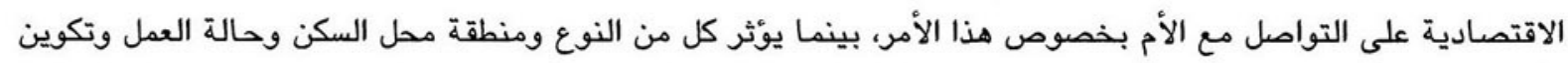

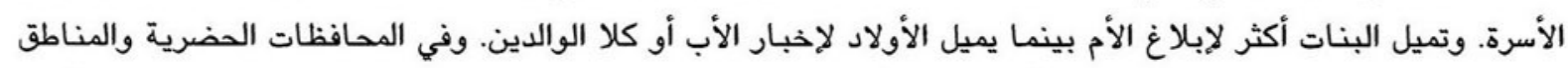

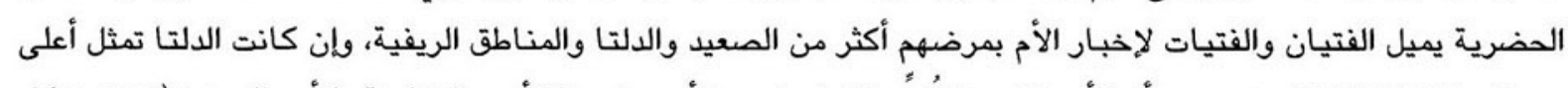

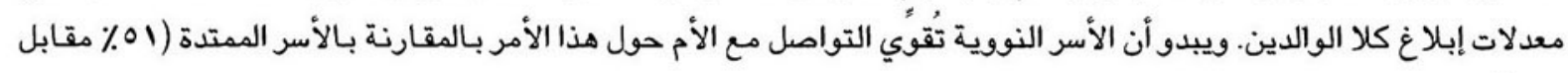

. (\%

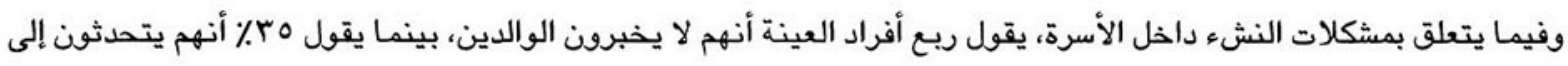

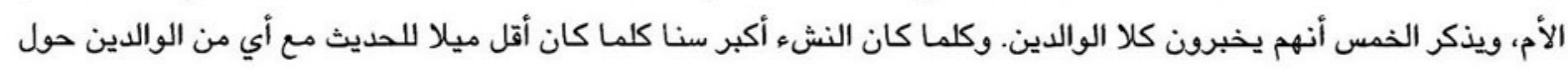

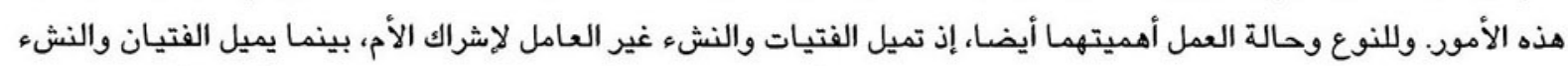

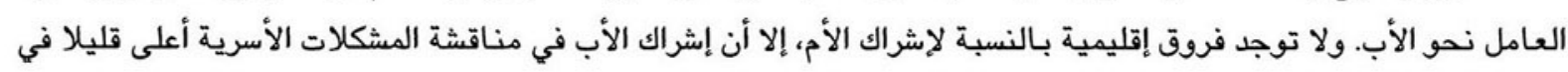

الصعيد والمناطق الريفية.

يميل النشء لتجنب الآباء والأمهات عندما تكون لديهم مشكلات مع الأصدقاء. ذكر قرابة نصف أفراد العينة أنهم لا يخبرون

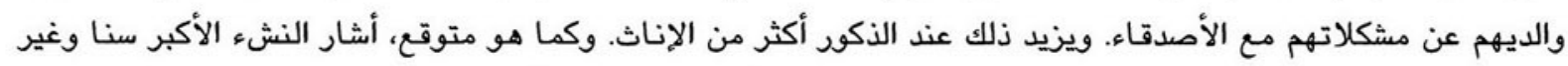

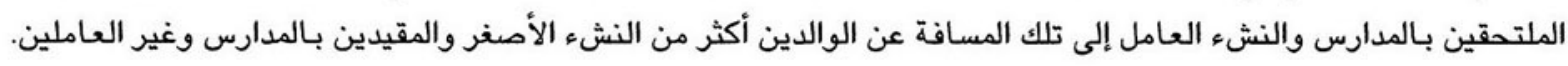

يتحدث الفتيان والفتيات إلى الوالدين أيضا حول بعض المشكلات التي يقابلونها في المدرسة أو العمل. يقول الريع تقريبا أنهم

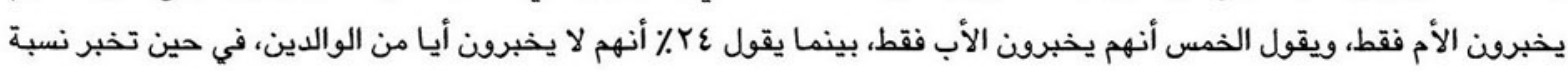

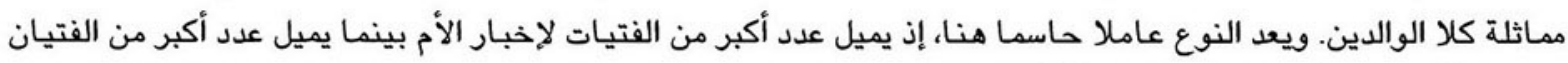

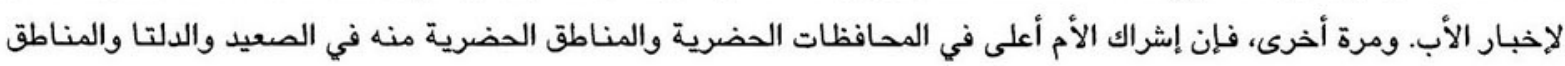


والمجال الآخر الذى ريما يلجأ النشء فيه إلى الوالدين هو مجال الصحة الإنجابية. ويناقش الفصل الثامن هذا الموضوع الهام في سياق الانتقال إلى حياة البالغين.

\begin{tabular}{|c|c|c|c|c|c|}
\hline & & & & & 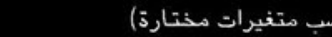 \\
\hline & ن أو كلاهما بخص & 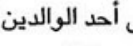 & 'بن من & & \\
\hline اعتماد الأسرة & مشاكل فى & مشاكل مع & مشاكل & مشاكل & \\
\hline عليهم & المدرسة/ العمل & 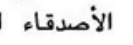 & محية & عائلية & \\
\hline AV.r. & vย.V & $\varepsilon\rceil .1$ & 91.r & 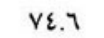 & بنين \\
\hline Al. & VA. $\varepsilon$ & ०१.Y & $\wedge 9 . \mathrm{V}$ & vo.r & بنات \\
\hline$\Delta r . \varepsilon$ & A1.9 & 09.7 & १६.า & $\Lambda \cdot \varepsilon$ & . \\
\hline ヘ $1 . \mathrm{V}$ & $7 v .1$ & $\varepsilon r . r$ & 10.7 & $\mathrm{TV} . \varepsilon$ & 19-19 19نة \\
\hline Ar.o & VA.1 & $00 . \varepsilon$ & ar.v & vv.o & ملتحقون بالددرسة \\
\hline 14.r & 17.0 & $\varepsilon 0.1$ & $\Lambda r . \varepsilon$ & $7 v .9$ & غير ملتحققن بالمدرسة \\
\hline $91 . r$ & vi.\& & $\varepsilon 0.9$ & $\wedge \wedge . \wedge$ & vi.9 & يعمل \\
\hline 11.1 & VA. 9 & 00.1 & $91 . r$ & vา.r & لا يعمل \\
\hline$\Lambda \varepsilon .1$ & VA.1 & or.v & ar.V & vo. 9 & أسرة نورية \\
\hline$\Lambda \varepsilon .0$ & vi.r & $0 \cdots$ & $\Lambda \varepsilon . r$ & vr. & أسرة ممتدة \\
\hline$\Delta r$. . & vr.v & or.1 & $9 \cdot . r$ & vi.v & أسر تعولها سيدة \\
\hline$\wedge \varepsilon .0$ & v1.7 & Or.A & 91.0 & vo.r & أسر لا تعولها سيدة \\
\hline & & or.o & 91.9 & vol & الوضفع الاقتمادى/ الاجتماعى \\
\hline $\begin{array}{ll}\varepsilon \varepsilon .7 \\
\wedge \varepsilon .\end{array}$ & vi.r & $\begin{array}{l}0.1 .0 \\
01.5\end{array}$ & 91.1 & vo.r & متوسط \\
\hline$\wedge \varepsilon, Y$ & vv.r & oo.r & Qr. & vo. & مرتفع \\
\hline$\Lambda \cdot .0$ & vv.o & ه & $9 \cdot .9$ & 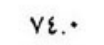 & حضر ( ل حضر \\
\hline 14.0 & vo.v & or. & $a \cdot . r$ & vo.o & ريف \\
\hline v9.9 & $\wedge \Lambda$. & $\infty .0$. & $9 \cdot . r$ & vr.q & المحافظات الحضرية \\
\hline 10.1 & vi.r & 0.9 & 91.7 & vv. & وجه بحرى \\
\hline 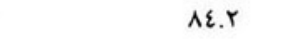 & vo.o & or. 9 & 19.1 & vr.q & وجه قبلى \\
\hline$\Lambda \varepsilon . r$ & Vฯ.ย & or.v & $q \cdot . \varepsilon$ & vย.q & 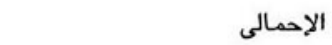 \\
\hline V. $₹\urcorner v$ & $0.7 \mathrm{VV}$ & $\varepsilon .071$ & A.rTI & $7.7 \mathrm{vr}$ & عدد الحالات \\
\hline
\end{tabular}

وإذا كان من الممكن أن ننظر للأسرة كمصدر لتقديم الدعم والمساعدة للنشء، فإن أغلبه يرى نفسه أيضا كمصدر دعم للأسر.

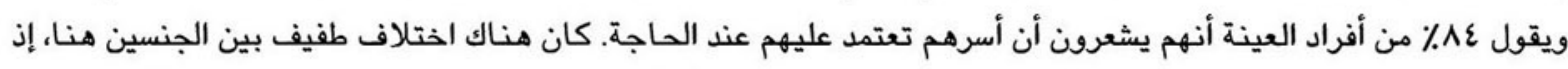

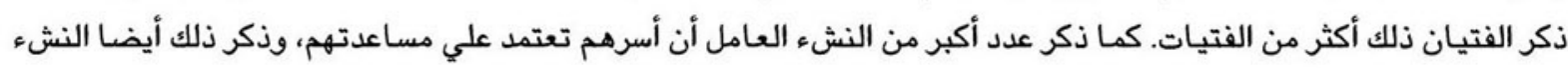
في المناطق الريفية أكثر قليلا من المناطق الحضرية.

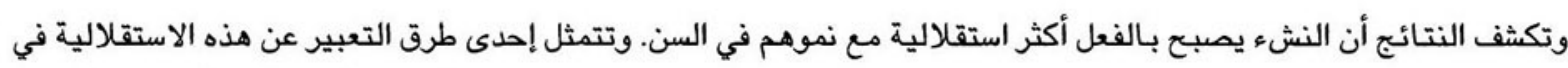

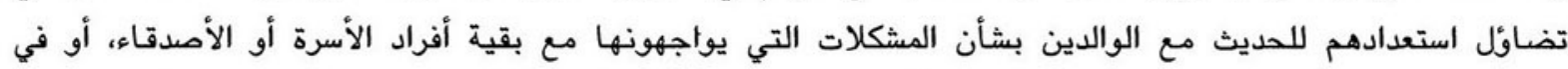

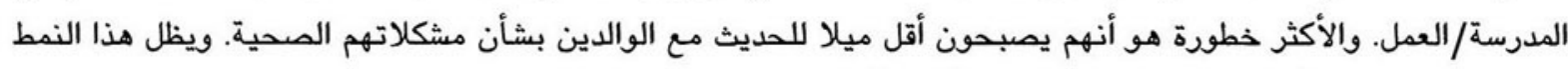

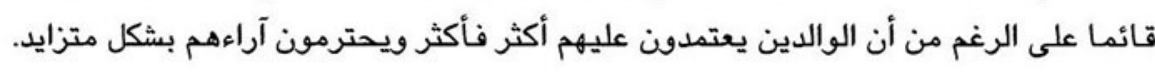




\section{العدوانية بين أفراد الأسرة}

سأل مسح "النشء والتغيير الاجتماعي في مصر" النشء حول خبرته مع العدوانية/العنف في عدد من السياقات. لم يجر التمييز

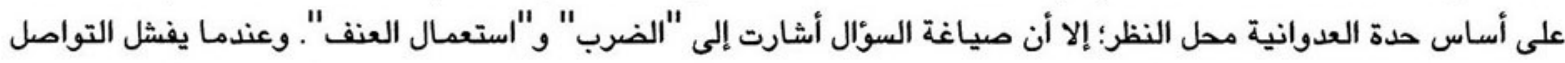

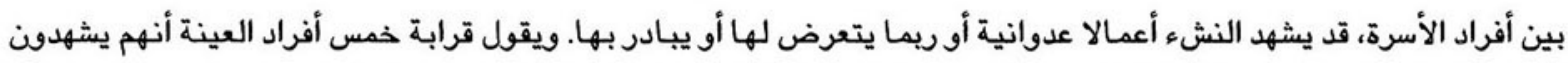

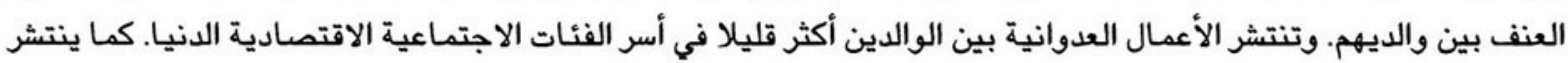

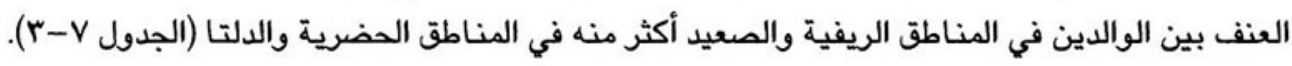

\begin{tabular}{|c|c|c|}
\hline 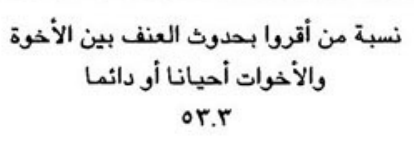 & 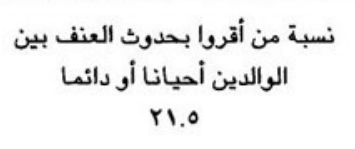 & الاجمالى \\
\hline $0 \because$. & $r \cdot . \Lambda$ & بنين \\
\hline ०..V & rr.r & بنات \\
\hline ०v. & $r r . \varepsilon$ & . \\
\hline$\varepsilon \wedge . \vee$ & 19.1 & 19-19 سنة \\
\hline or.r & $r \cdot .0$ & ملتحقون حاليا بالمدرسة \\
\hline or.r & $r \varepsilon, r$ & غير ملتدقون بالمدرسة \\
\hline ०६.१ & ru. & يعمل \\
\hline or.v & $19 . r$ & 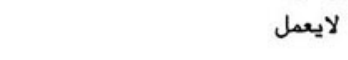 \\
\hline \multirow{3}{*}{ or.a } & r.e & أسرة نورية \\
\hline & $r r .1$ & أسرة ممتدة \\
\hline & & المستوى الاقتمادى/ الاجتماعى \\
\hline 07.1 & ro.9 & منذفض \\
\hline or.r & rI.r & متوسط \\
\hline 01.1 & $1 \times .0$ & 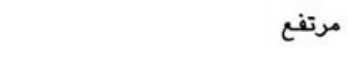 \\
\hline$\varepsilon 9.1$ & in.V & حضر \\
\hline 00.9 & rr.r & ريف \\
\hline$\varepsilon r . \varepsilon$ & ir.r & الححافظات الحضرية \\
\hline ०\&.q & rr.1 & وجه بحري \\
\hline 07.0 & ro.r & وجه قبلي \\
\hline
\end{tabular}

ويبدو أن حالات العنف بين الأخوة أ كثر شيوعا، حيث يذكر rه\% من أفراد العينة أن هذا النوع من العنف يحدث أحيانا في

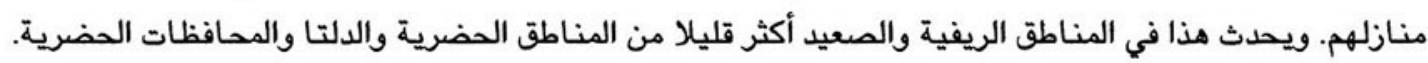

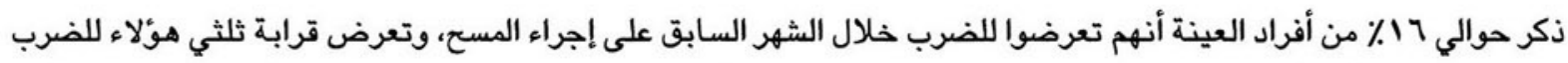

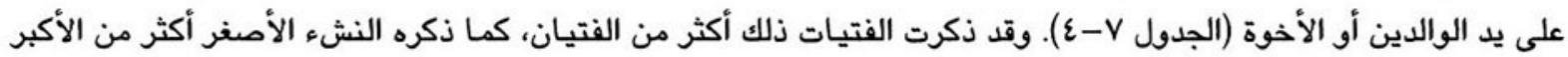

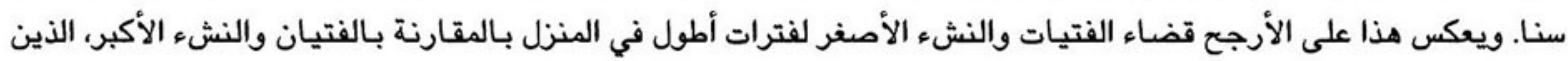




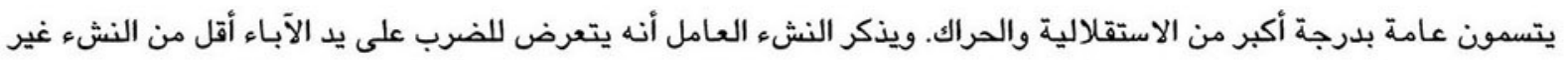

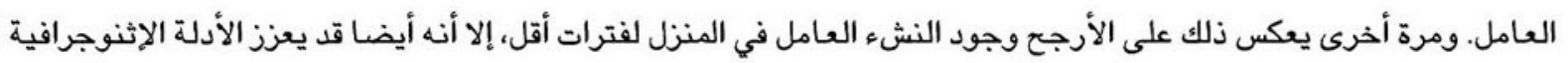

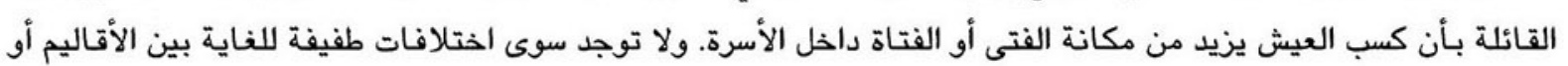

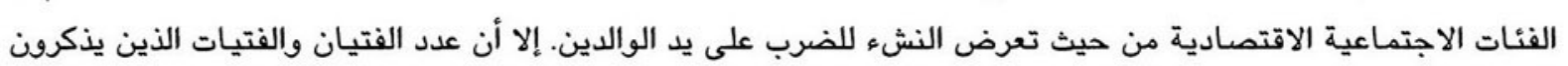

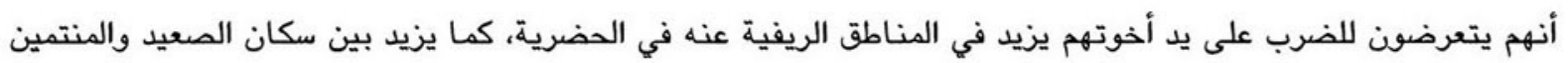
للفئات الاجتماعية الاقتصادية الوسطى والعليا.

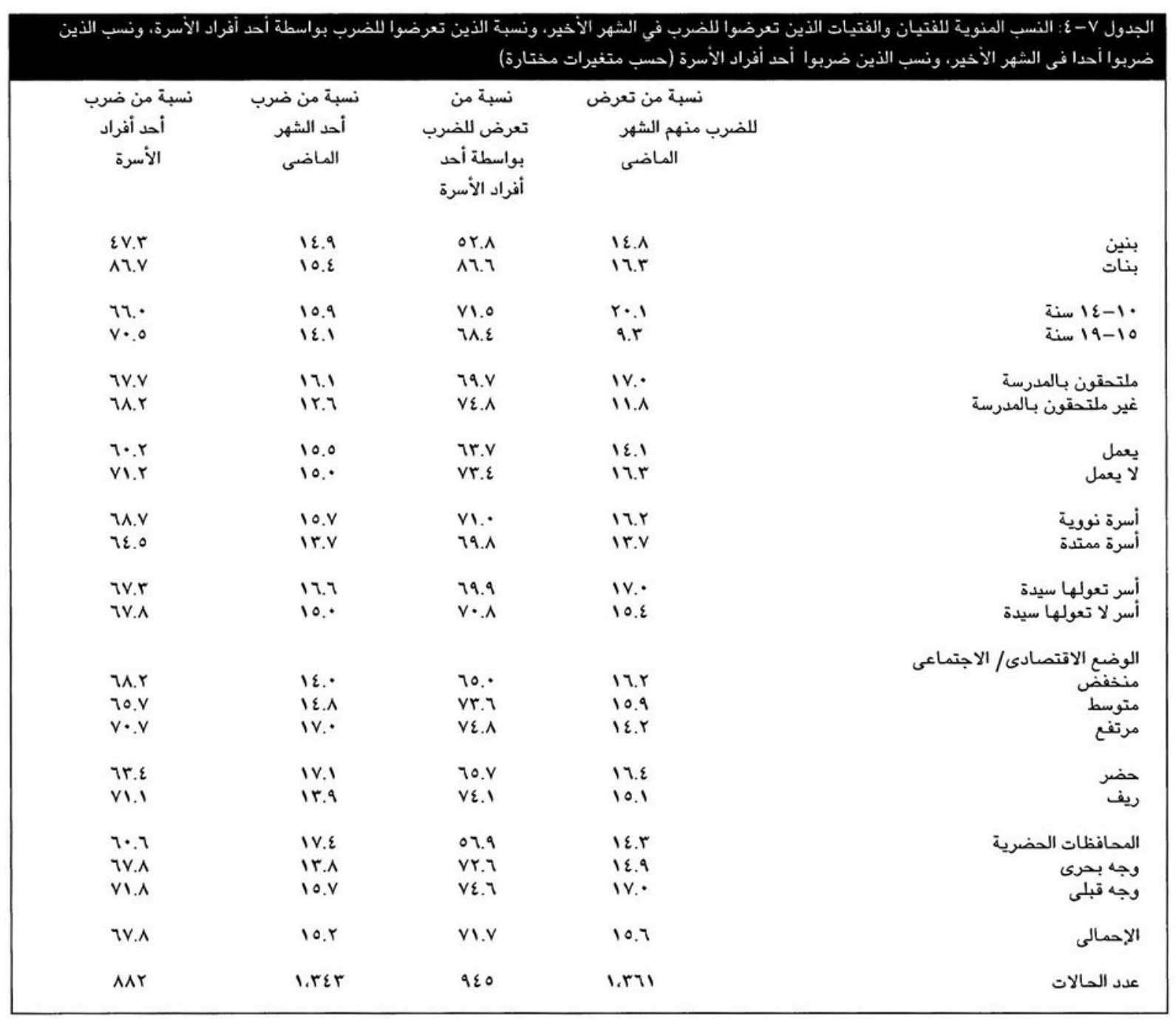

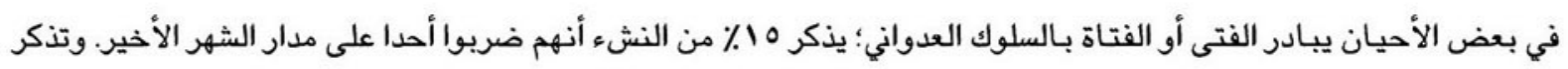

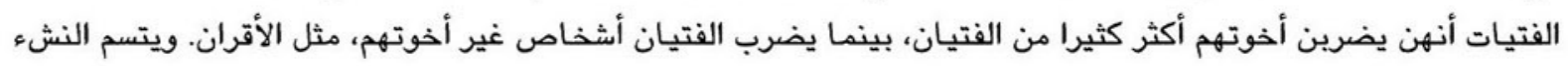

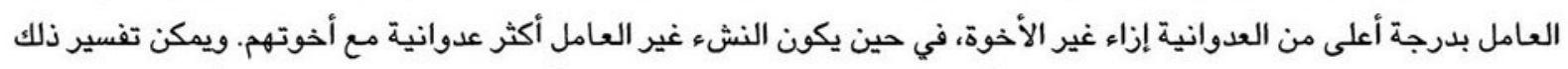

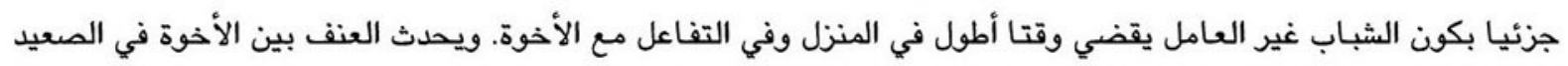
والدلتا أكثر من المحافظات الحضرية، وفي المجتمعات الريفية أكثر من الحضرية.

وتكاد نسبة النشء الذى يبادر بالضرب تتساوى مع نسبة الذين يتعرضون للضرب على يد الآخرين. وقد بحثنا ما إذا كانت

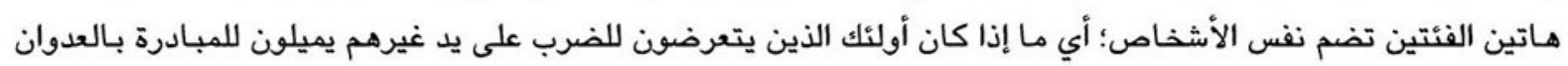


بدورهم. وتكشف البيانات أن الفئتين تكادا تكونان مختلفتين تماما: واحدة تبادر بالضرب بينما لا تتعرض للضرب الضاب على يد

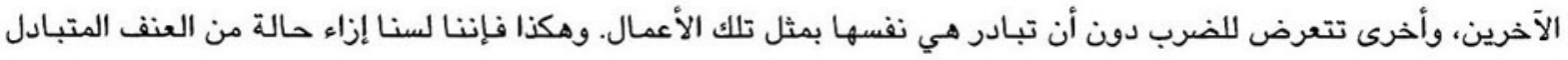

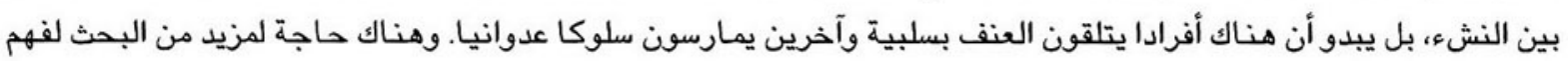
الصورة العامة لهاتين الفئتين.

\section{ثانيا: علاقات الأقران}

المداقة

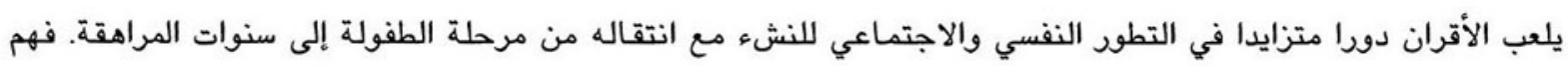

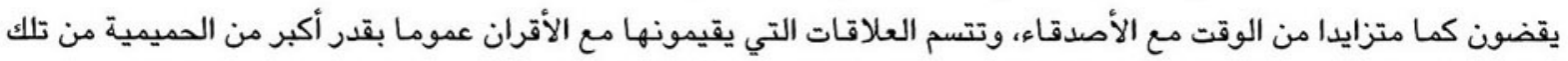

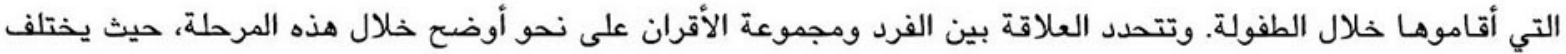

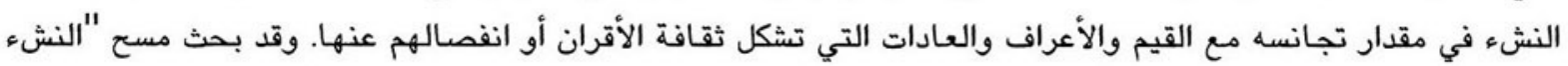
والتغيير الاجتماعي في مصر" قضيتين متصلتين بعلاقات الأقران: الصداقات وديناميات مجموعة الأقران.

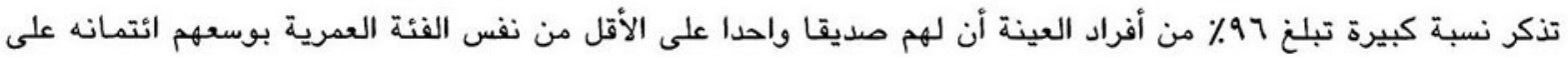

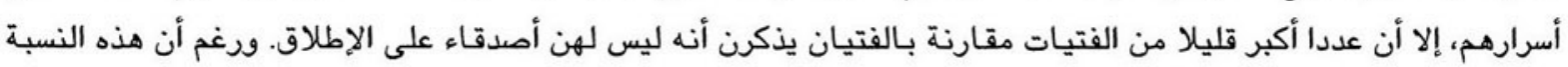

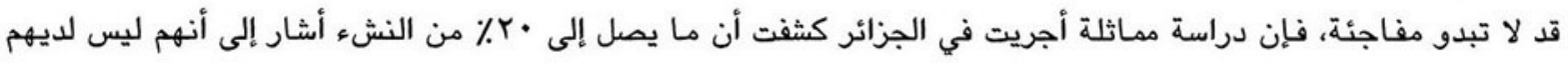

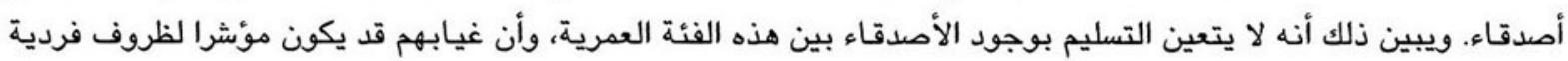
أو قومية.

وتختلف فرص رؤية الأصدقاء والتفاعل معهم وفقا للنوع والسن ومنطقة محل السكن وحالة العمل، ويعد النوع أكثر هذه

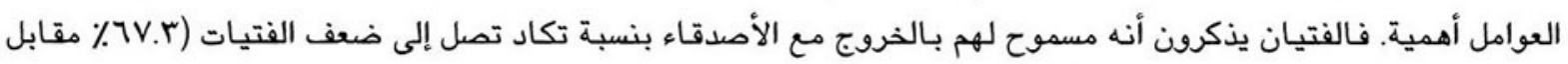

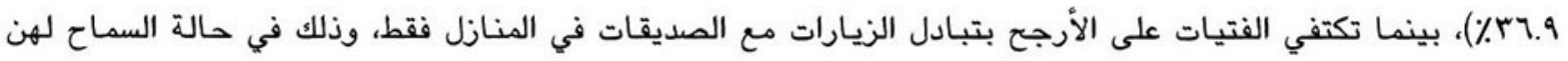
بالخروج أصلا.

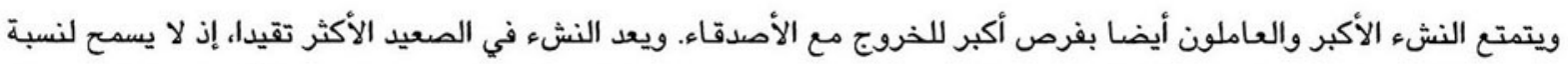

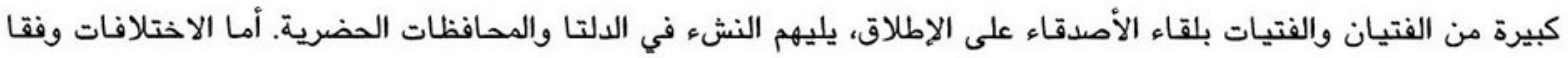

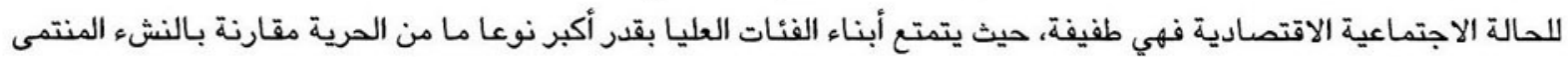
للفئات الدنيا (الجدول V-0). 


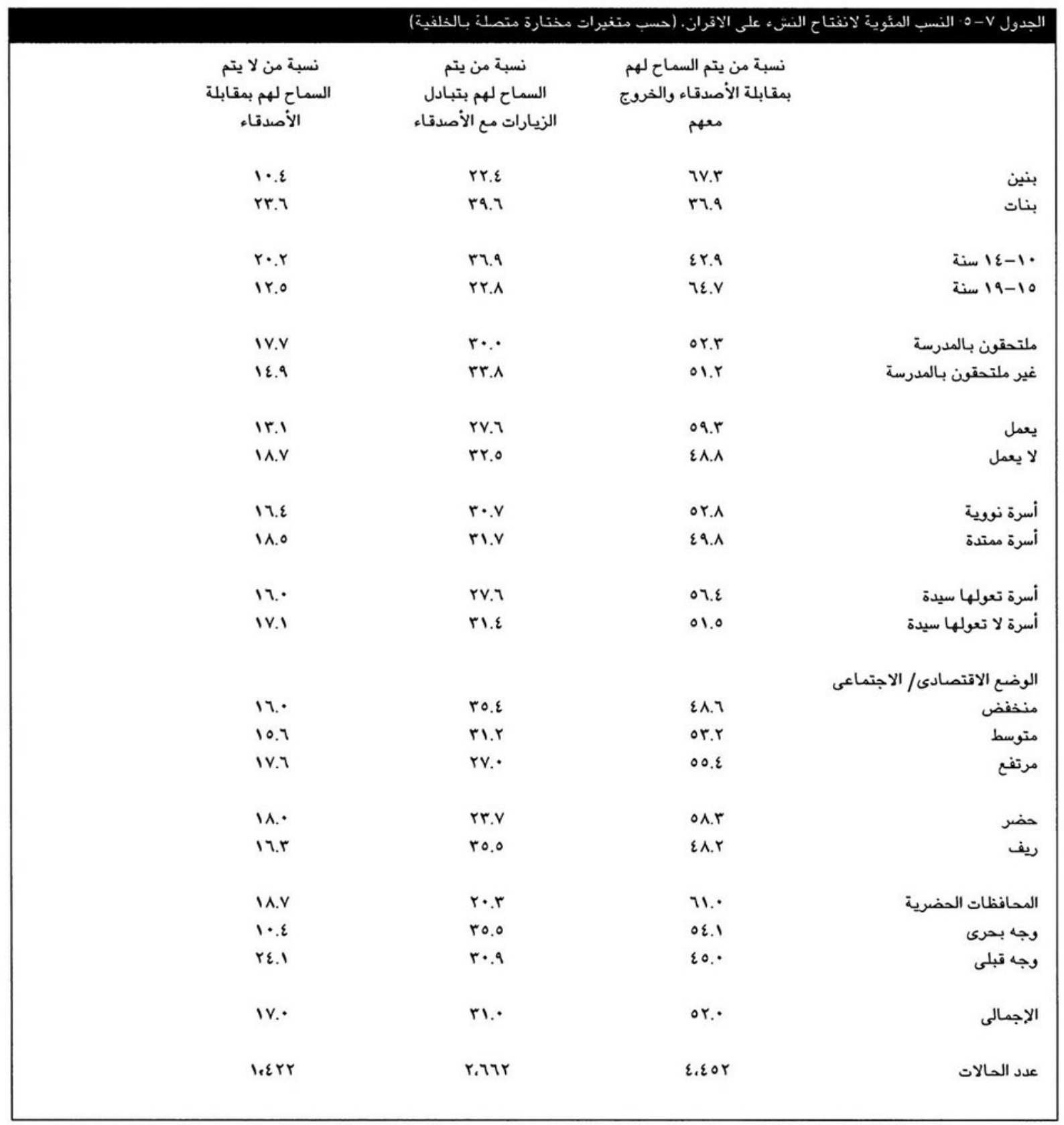

وكما هو متوقع هناك قدر كبير من الدعم المتبادل بين الفتيان والفتيات وأصدقاءهم فيما يتصل بالحديث حول المشكلات.

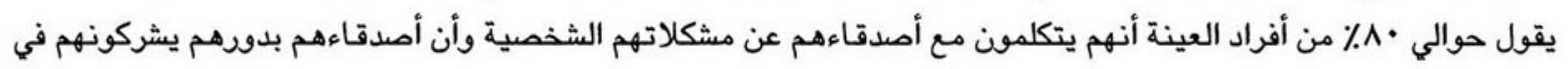

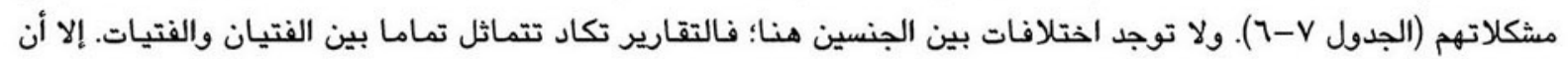

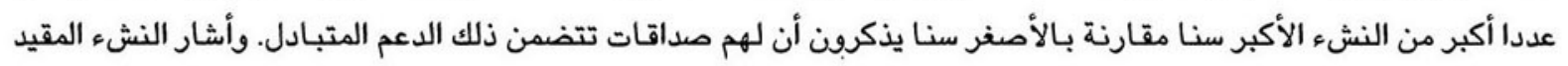

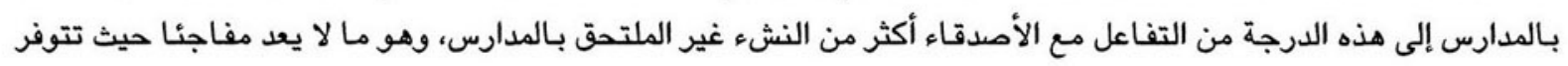

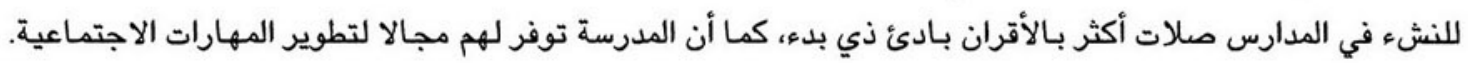

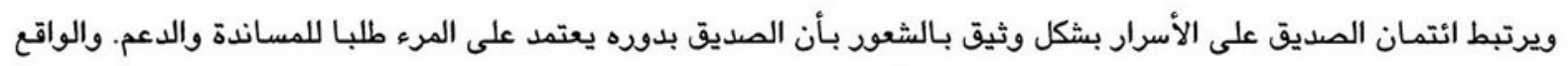

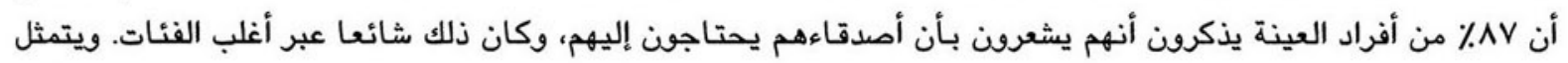

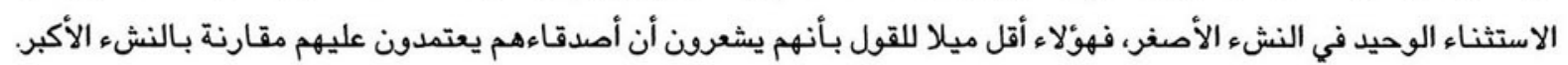




\begin{tabular}{|c|c|c|c|}
\hline نسبة من يعتمد عليهم & نسبة من يق أقرانهم & نسبة من يستشيرون & \\
\hline AN.r & $\wedge 1$. & $\Lambda \cdot . v$ & بنين \\
\hline ᄉ५. & AI.r & va.r & بنات \\
\hline$\wedge \varepsilon, r$ & $v \varepsilon .0$ & vา.า & . \\
\hline $91 . v$ & $9 \cdot .7$ & $\wedge \varepsilon . \wedge$ & 19-19 سنة \\
\hline$\wedge \wedge . \varepsilon$ & Ar.A & $\wedge 1 \varepsilon$ & ملتحقون بالمدرسة \\
\hline$\wedge \varepsilon . \varepsilon$ & vา. & vo.1 & غير ملتحقون بالمدرسة \\
\hline 19.1 & $\wedge \cdot \cdot$ & $\wedge . \wedge$ & يعمل \\
\hline 1.. & $\wedge 1 . \wedge$ & Va.r & لا يعمل \\
\hline Av.r & $\wedge r . \cdot$ & va.० & أسرة نووية \\
\hline$\wedge \vee . \varepsilon$ & va.1 & A.r & أسرة ممتدة \\
\hline 10.7 & Al. & $\Lambda \cdot r$ & أسرة تعولها سيدة \\
\hline AV.० & AI.r & $\wedge \cdot \cdot$ & أسرة لا تعولها سيدة \\
\hline & & & الوضع الاقتصادى/ الاجتماعى \\
\hline 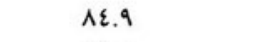 & VV.Y & va.1 & منخفض \\
\hline 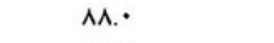 & Ar.A & $\wedge 1 . \wedge$ & متوسط \\
\hline 11. 9 & A. & $\wedge \cdot .1$ & 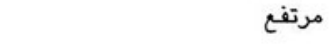 \\
\hline$\wedge \wedge . \wedge$ & $\wedge r . \varepsilon$ & $v \vee \varepsilon$ & حضر \\
\hline ᄉา. & v9.9 & A1.0 & ريف \\
\hline$q \cdot . r$ & AV.० & VV.० & الدحافظات الحضرية \\
\hline ヘา. & ^..V & Ar.r & وجه بحرى \\
\hline AV.r & VY. & จา. & وجه قبلى \\
\hline AV.r & AI. & $\wedge \cdot \cdot$ & الإجمالى \\
\hline V. $\varepsilon q$. & 7.195 & $7.1 \cdot 9$ & عدد الحالات \\
\hline
\end{tabular}

\section{ديناميات مجموعة الأقران}

عندما يكون الفرد جزءا من مجموعة، فإننا نشهد ديناميات مختلفة للتفاعل وفقا لخصائص أعضاء مجموعة الأقران. وكما هو

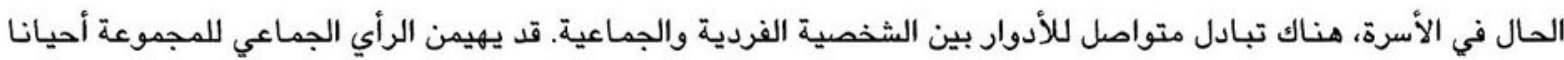

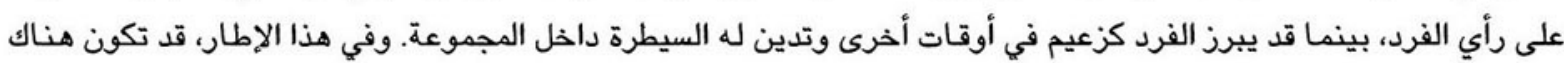

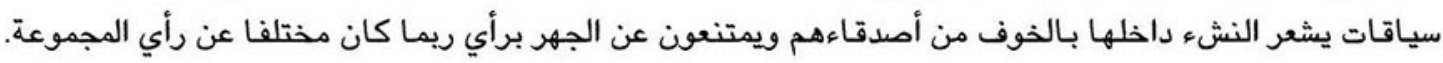

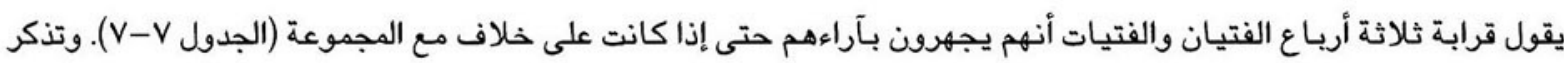

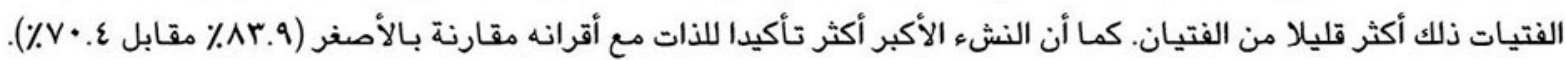

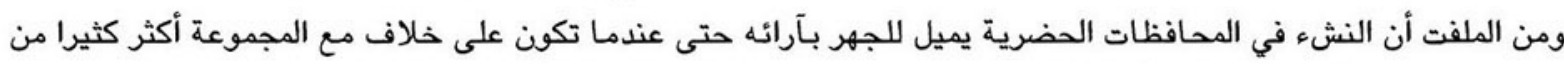

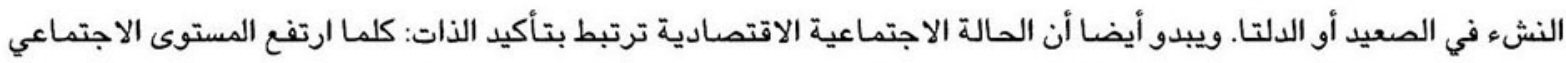

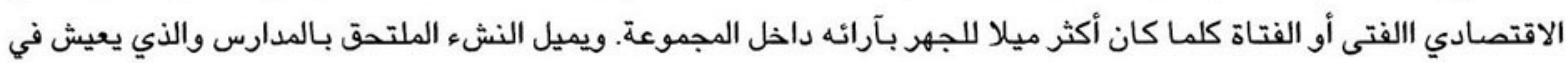

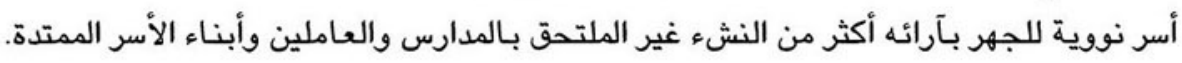




\begin{tabular}{|c|c|c|c|}
\hline نسبة من اتفقت مجموعة & تقبة من بدءوا التدخين & عنبة من يعبرون عن أنفسهم في الرأى & \\
\hline V.A & or.o & vo." & بنين \\
\hline 9.1 & $1 . \varepsilon$ & vV. & بنات \\
\hline $1 \cdot r$ & $\varepsilon \varepsilon$. & $v \cdot \varepsilon$ & . ا-1عا سنة \\
\hline 0.1 & $0 \cdot \varepsilon$ & $\wedge r . q$ & 19-19 سنة \\
\hline 1.7 & $\varepsilon \varepsilon . r$ & 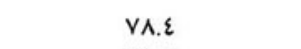 & ملتحقون بالمدرسة \\
\hline V.9 & o.$Y$ & 79.5 & غير ملتحقون بالمدرسة \\
\hline$\wedge$. & or.v & vr.v & يعمل \\
\hline A.V & $\varepsilon r . r$ & vv.o & لا يعمل \\
\hline 1.0 & $\varepsilon v .0$ & vV.o & أسرة نورية \\
\hline A.r & or.A & หi.t & أسرة ممتدة \\
\hline 9.r & $\varepsilon v$. & vo.v & أسرة تعولها سيدة \\
\hline A. $\varepsilon$ & רะ.० & vı. & أسرة لا تعولها سيدة \\
\hline & & & الوضع الاقتصادى/ الاجتماعى \\
\hline$\Lambda .9$ & 07.0 & 79.1 & منخفض م \\
\hline A.r & or.t & $v v \cdot$ & متوسط \\
\hline A. & rา.A & $\wedge 1.1$ & مرتفع \\
\hline$\wedge . \wedge$ & 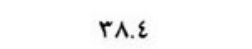 & $\wedge 1.7$ & حضر \\
\hline A.r & 07.1 & vr.o & ريف \\
\hline A. & $r \varepsilon .1$ & $\wedge$ м. & المحافظات الحضرية \\
\hline 1.0 & $\circ \mathrm{v} . \varepsilon$ & V๕. 9 & وجه بحرى \\
\hline A.7 & $0 . .0$ & vi.r & وجه قبلى \\
\hline 1.0 & $\varepsilon q$. & vา. & الإجمالى \\
\hline vrr & riq & ר.1.0. & عدد الحالات \\
\hline
\end{tabular}

إن الفرد قد يتأثر بمجموعة الأقران ويكتسب القيم والسلوكيات من خلال تقليد الأصدقاء. ولعل أحد مؤشرات هذا التأثير للأقران

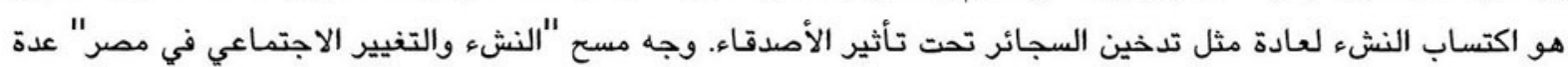

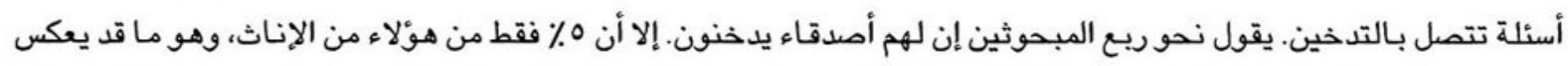

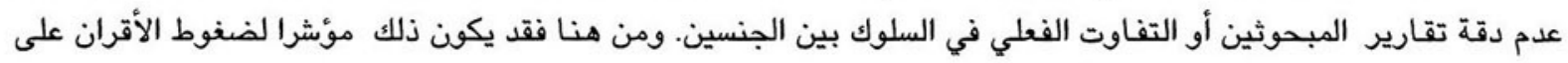

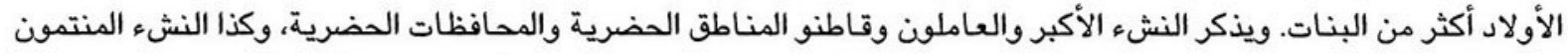
للأسر ذات المستوى الاجتماعي المرتفع نسبا أعلى لتدخين الأقران مقارنة بالفئات الأخرى.

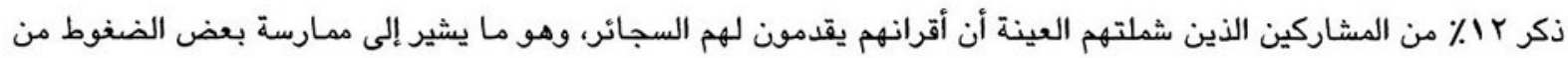

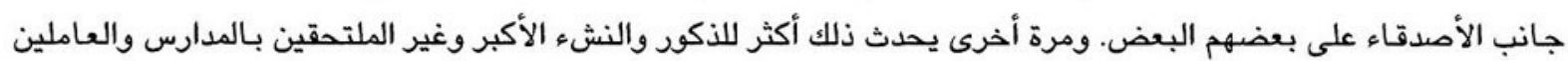

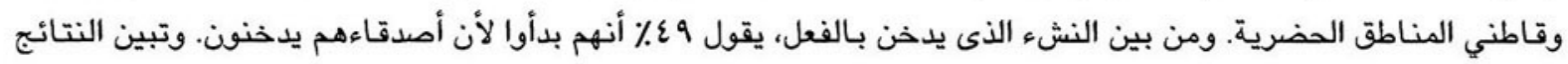

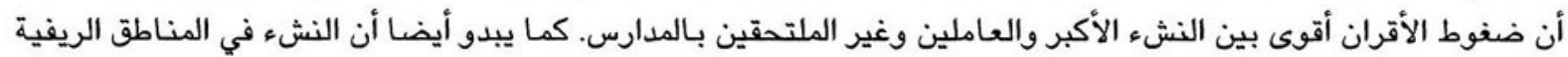

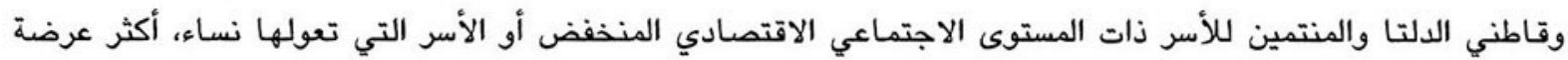

$$
\text { للضغوط. (هناك نقاش أكثر للتدخين في الفصل الرابع). }
$$


وعلى مستوى أكثر حدة، قد يتعرض الفرد للعقاب على يد مجموعة من الأصدقاء إذ تتحالف ضده المجموعة لسبب أو لآخر. وريما

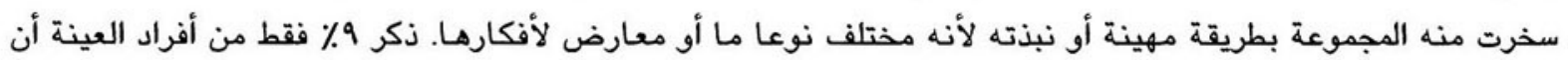

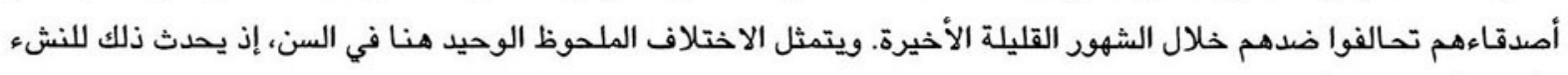

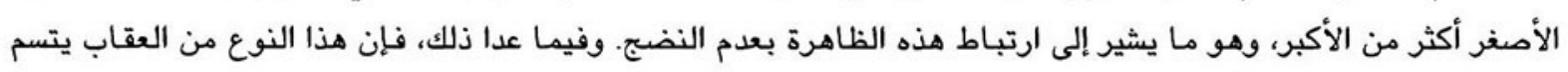
بالتماثل عبر المتغيرات الأخرى المتصلة بالخلفية الاجتماعية.

\section{ثالثا: الصورة النفسية العامة للنشء والدعم من جانب الأسرة/الأقران}

تعد الصحة النفسية وتطور الإحساس بالهوية من أهم مكونات تقييم رفاهية الأفراد، وخاصة النشء. ويتجاوز تقييم حالة

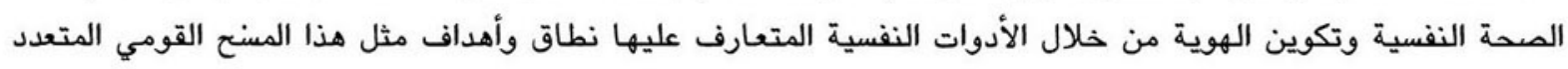

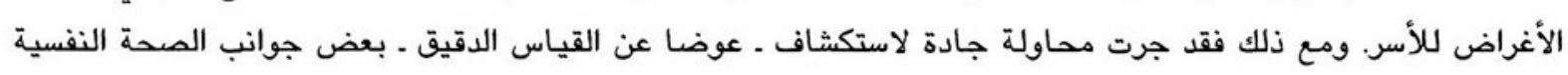
وتكوين الهوية بين النشء الذى شملته العينة.

يمكن تقييم الصحة النفسية عبر عدة أبعاد، منها مقدار الرضى عن الحياة وتقدير الدعم الذي يلقاه الفرد من الأسرة والأصدقاء

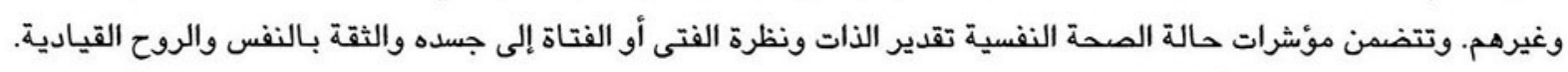

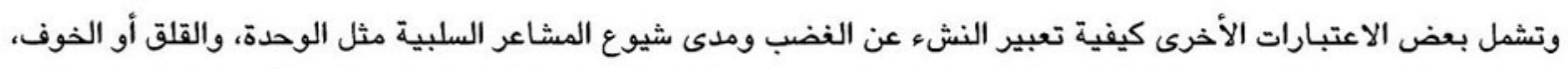

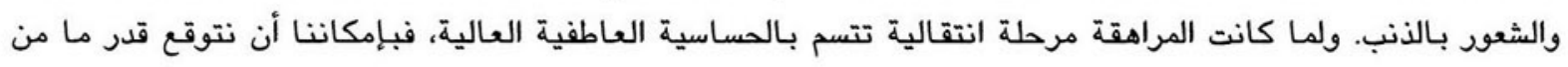

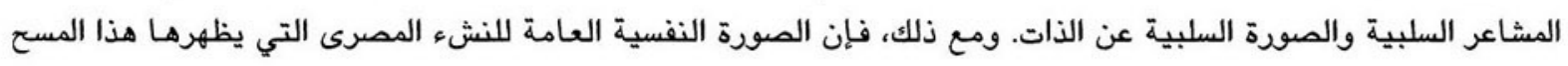
ليست معتمة على الإطلاق.

\section{المواتف الإيجابية}

تقدير الذات

كيف يرى الفتيان والفتيات أنفسهم؟ وكيف يثمنون قدراتهم وأهميتهم بالنسبة للآخرين؟ يتمثل أحد المؤشرات الجيدة فيما إذا

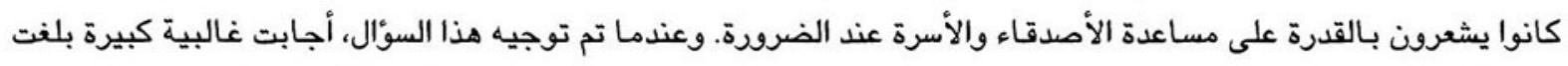

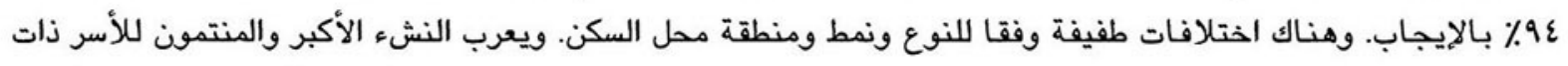

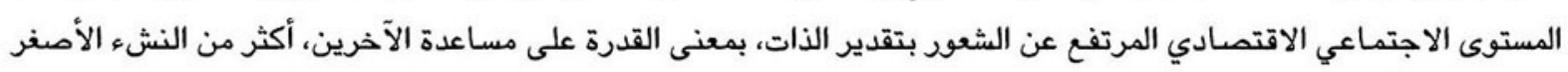

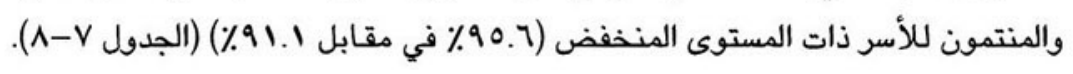




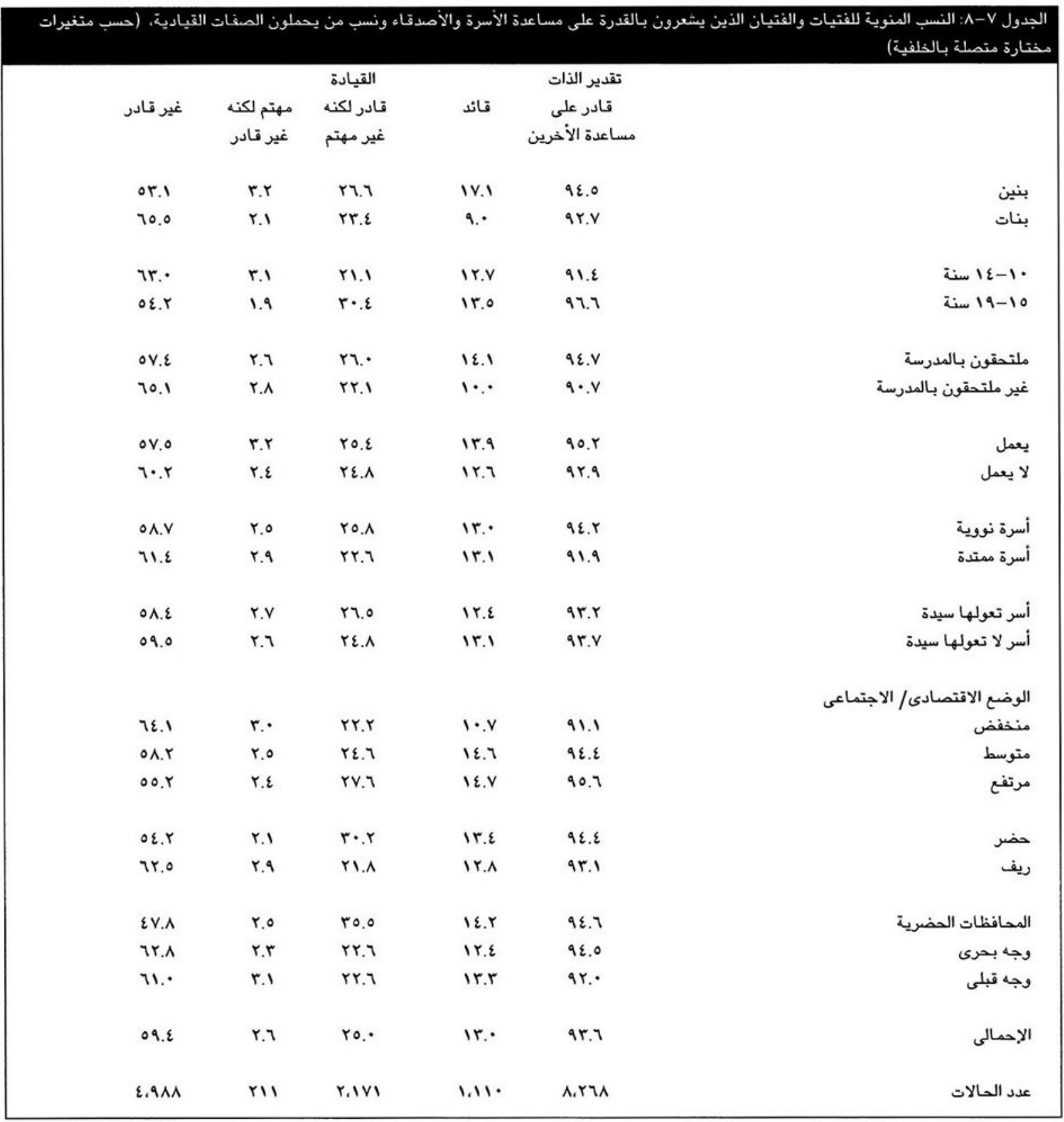

تعد الصفات القيادية التي يظهرهـا الفرد في المواقف الجماعية أحد مؤشرات الثقة بالنفس. حاول مسح "النشء والتغيير

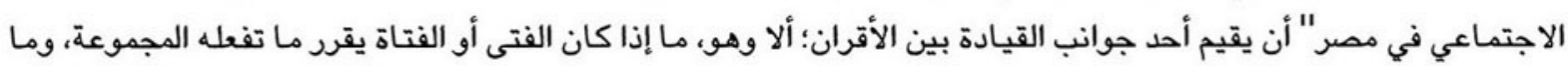

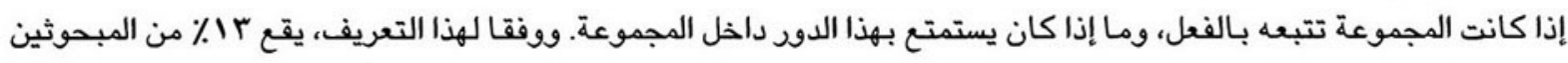

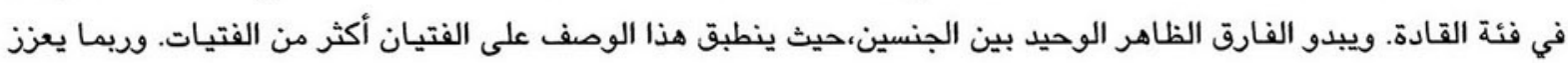

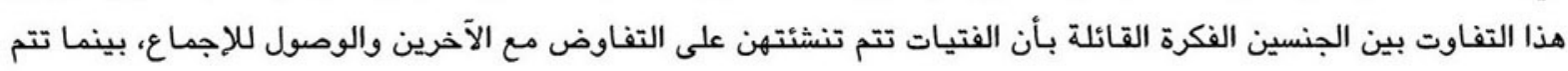
تنشئة الفتيان على تولي المسئولية واتخاذ القرارات الفردية التي يتولى تنفيذهان الفيات مجموعة من الناس.

وتتكون باقي العينة من أنواع أخرى من القادة: منهم من يتولون قيادة المجموعة بالفعل لكنهم يقولون إنهم لا يستمتعون بهذا

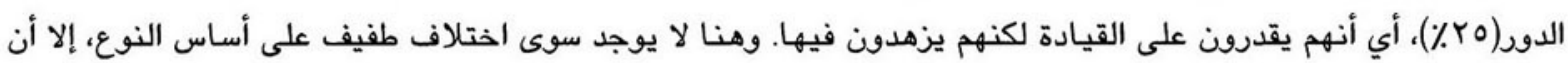

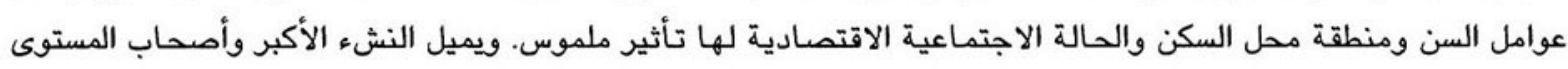




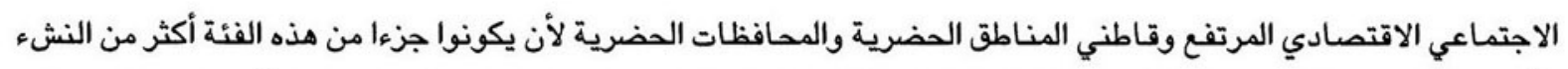

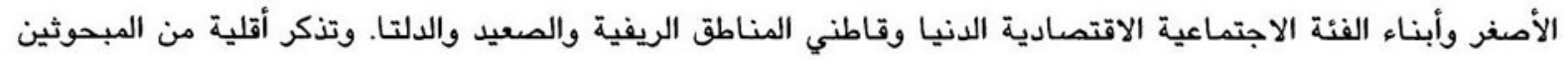

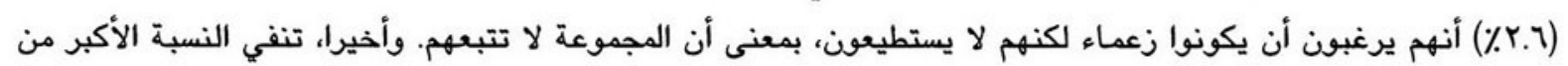

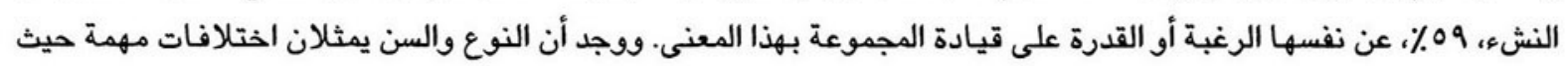

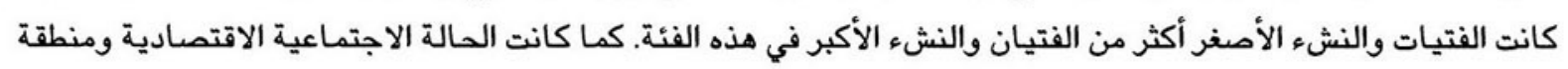

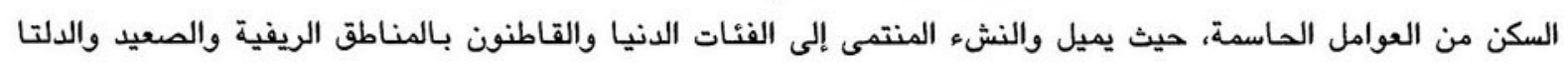

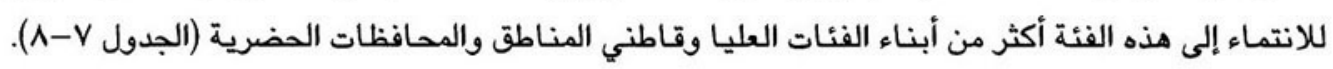

المشاعر السلبية

نظارة المرامق إلى جسده

تحدث أثناء المراهقة تغييرات جسدية عديدة قد تؤدي إلى مشاعر الارتباك أو الحرج إزاء الجسد. وفي بعض الثقافات، ينتشر

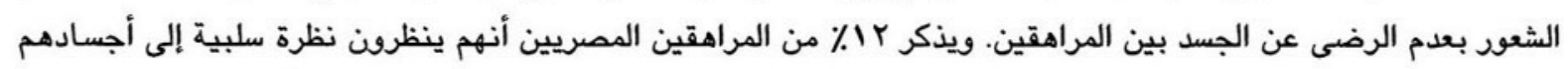

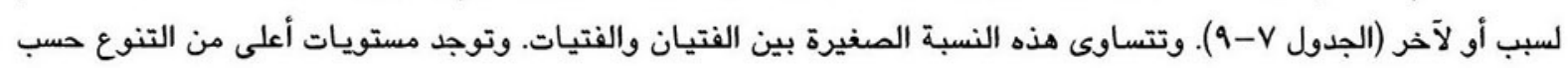

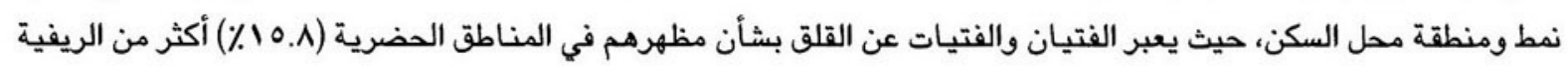

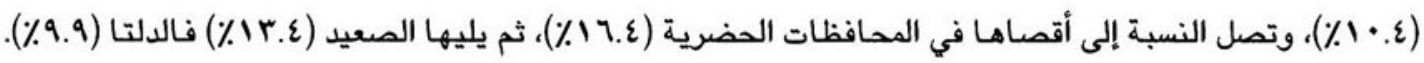

الوحدة

تشمل المشاعر الأكثر سلبية التي قد تعتري الفرد الوحدة، والذوف أو القلق، والشعور بالذنب. ويقر أكثر من نصف أفراد العينة

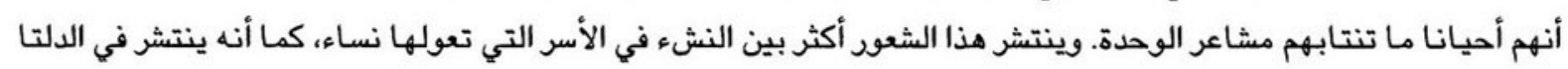

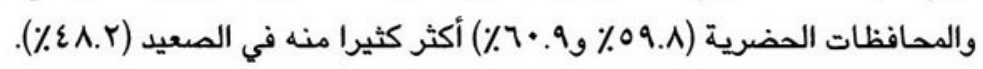

التلق والموف

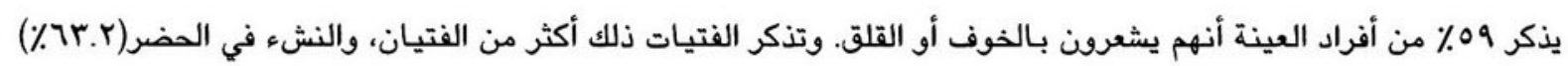

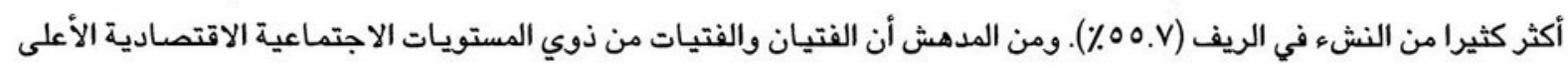

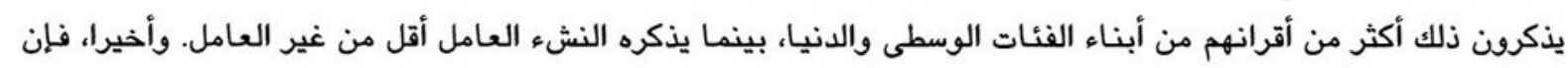

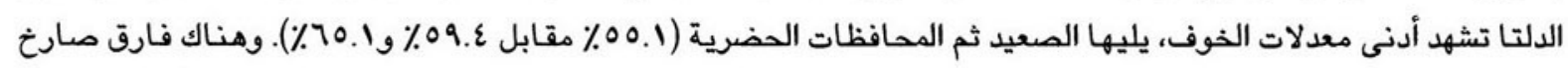

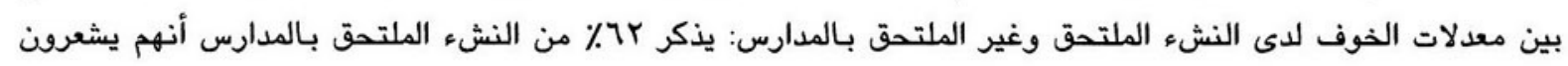

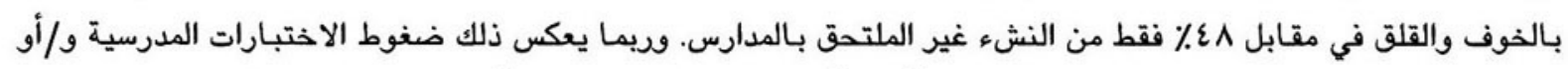

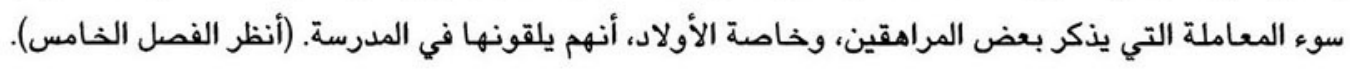


يشير الشعور بالذنب إلى مقدار توجيه الناس اللوم لأنفسهم بشأن المشكلات أو شعورهم بأنهم لا يفعلون ما يكفي لصالح

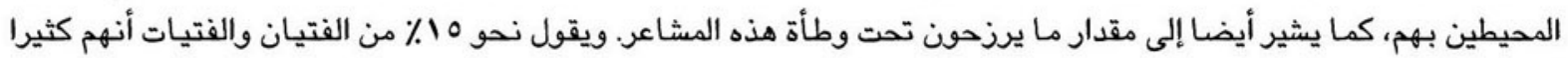

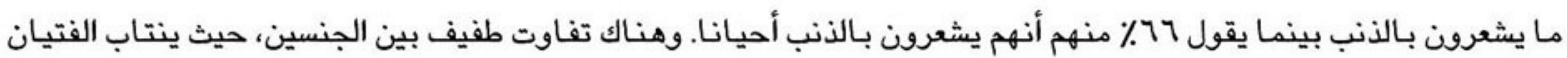

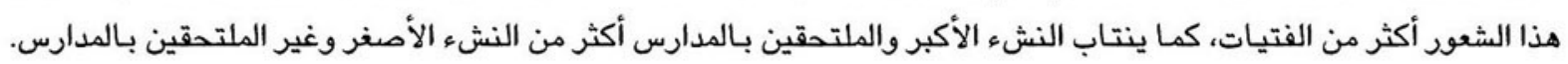

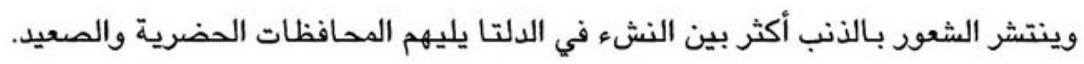

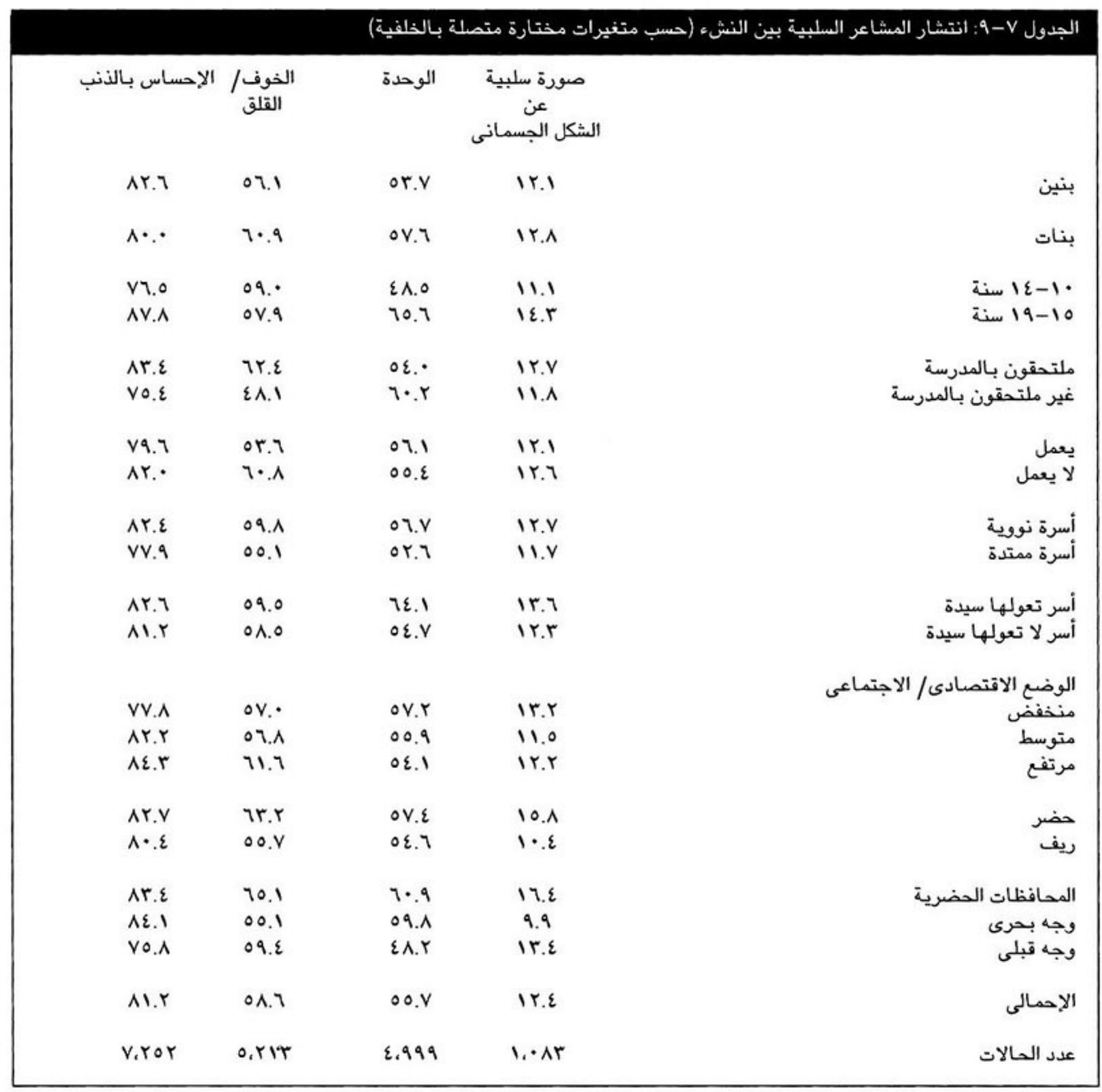

التعبير عن الغضب

قد يتخذ التعبير عن الغضب عدة أشكال تتراوح بين الكبت الكامل والاعتداء الجسدي. إن الطريقة التي يعبر بها الشخص عن

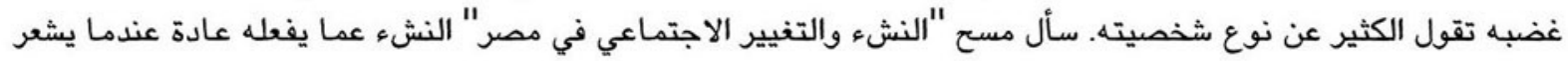

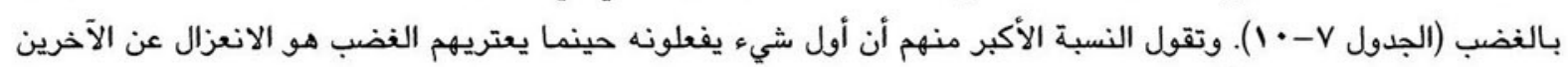

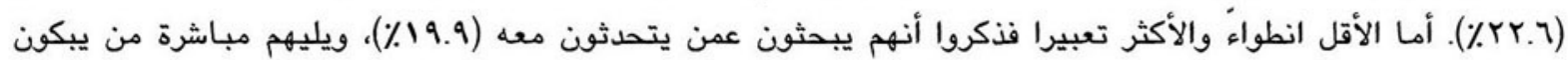

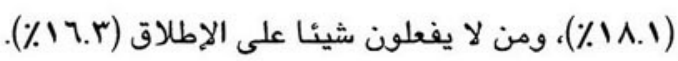




\begin{tabular}{|c|c|c|c|c|c|c|c|c|}
\hline أخرى & التدوانية & اللدين & التأنول، التوخين & المشديث & البكاء & الآنعزال & لا شين على & \\
\hline$\varepsilon . r$ & W.r & 0.9 & $\varepsilon .9$ & $r \cdot r$ & V.r & rq.r & I7.r & بنين \\
\hline r.v & V.० & $\varepsilon . r$ & r.A & 19.7 & rq.9 & ।\&.9 & $17 . \varepsilon$ & بنات \\
\hline$\varepsilon .7$ & $9 . \varepsilon$ & r.r & $\varepsilon .0$ & $r \cdot \cdot$ & $r \cdot \varepsilon$ & 18.9 & $r \cdot \because$ & . \\
\hline r.l & $9 . r$ & V.o & $\varepsilon . Y$ & 19.9 & 17.8 & rV.T & 11.9 & 19-19 سنة \\
\hline r.A & 9.5 & 0.7 & $\varepsilon . \vee$ & $r \cdot . \Lambda$ & IA.E & rr.r & $10 . r$ & ملتحققن بالمدرسة \\
\hline$\varepsilon\urcorner$. & 9.8 & $r .7$ & r.o & IV.7 & $r \cdot \cdot$ & ri.l & $r \cdot .1$ & غير ملتحقون بالمدرسة \\
\hline$r .9$ & $1 \cdot .1$ & $\varepsilon .0$ & r.q & 19.0 & Ir.7 & ro.V & 19.1 & يعمل \\
\hline$\varepsilon$. & A.V & $0 . r$ & $\varepsilon .0$ & $r \cdot .1$ & YI.T & $r \cdot r$ & $10 . \varepsilon$ & لا يعمل \\
\hline r.A & 9.0 & $0 . r$ & $\varepsilon .7$ & $r \cdot \theta$ & $1 \wedge .1$ & rr.T & $10 . r$ & أسرة نووية \\
\hline$\varepsilon\urcorner$. & $\wedge . \wedge$ & $\varepsilon . \gamma$ & r.o & 19.7 & 19.1 & $r \cdot .1$ & $r \cdot r$ & أسرة همتدة \\
\hline$\varepsilon \cdot \cdot$ & $1 \cdot .7$ & 7. & $\varepsilon . r$ & $17 . \varepsilon$ & rr.r & $r \cdot . \Lambda$ & 10.7 & أسرة تعولها سيدة \\
\hline$\varepsilon \cdot$ & $9 . r$ & $\varepsilon .9$ & $\varepsilon . \varepsilon$ & $r \cdot r$ & $1 \wedge .0$ & rr.I & $17 . V$ & أسرة لا تعولها سيدة \\
\hline & & & & & & & & الوضع الاقتصادى / الاجتماعى \\
\hline$\varepsilon . r$ & $\wedge .7$ & 0.1 & $\varepsilon .0$ & 19.1 & 19.8 & 19.1 & 19. & منخفض \\
\hline$\varepsilon \cdot \cdot$ & 9.0 & $\varepsilon . \vee$ & $\varepsilon .1$ & $r \cdot \varepsilon$ & 19.8 & ri.9 & 10.1 & متوسط \\
\hline r.v & $1 \cdot .1$ & $0 . T^{2}$ & $\varepsilon . \varepsilon$ & $r \cdot \cdot$ & IA.r & rध.q & ir.o & مرتفع \\
\hline$\varepsilon . r$ & 9.7 & 0.1 & $0 . \varepsilon$ & ri.A & $1 v .9$ & rध.r & 11.9 & حضر \\
\hline$r .9$ & $9 .{ }^{2}$ & 0. & r.v & IA.A & $19 . \varepsilon$ & $r \cdot .7$ & $19 . \varepsilon$ & ريف \\
\hline$\varepsilon .7$ & $9 . \mathrm{V}$ & 0.0 & $0 . v$ & r..1 & $1 \wedge . \varepsilon$ & หา.0 & 1.0 & امحافظات الحضرية \\
\hline r.V & 9.1 & $0 .{ }^{\circ}$ & $\varepsilon . r$ & $r \cdot .7$ & rr.q & rI.A & Ir.7 & وجه بحرى \\
\hline $0 . r^{2}$ & $9 . \varepsilon$ & $\varepsilon .9$ & r.v & $1 \wedge .7$ & $\mid r .1$ & 19.9 & ro.r & وجه قبلى \\
\hline$\varepsilon$. & $9 . \varepsilon$ & 0. & $\varepsilon . r$ & 19.9 & $\mid 1.1$ & rY.T & I7.r & الإحمـالى \\
\hline ror & V97 & $\varepsilon r r$ & rvo & 1.119 & $1.7 \mathrm{Vr}$ & $1.9 \varepsilon$. & $1 . \varepsilon \varepsilon q$ & عدد الحالات \\
\hline
\end{tabular}

ولا يوجد سوى تنوع طفيف عبر مختلف الفئات فيما يتصل بردود الفعل هذه. ومع ذلك، فإن عدد من يعزلون أنفسهم من الذكور

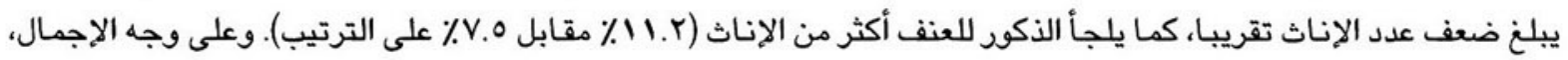

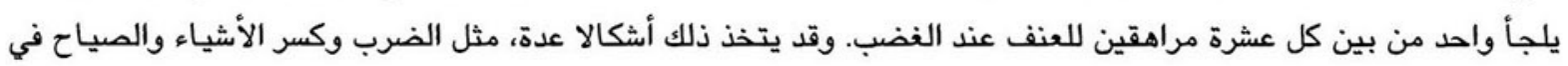

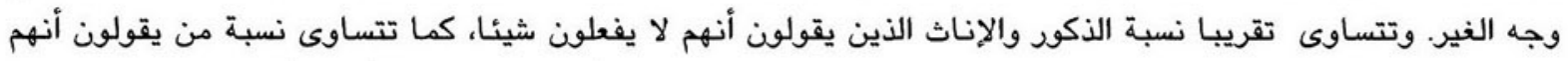

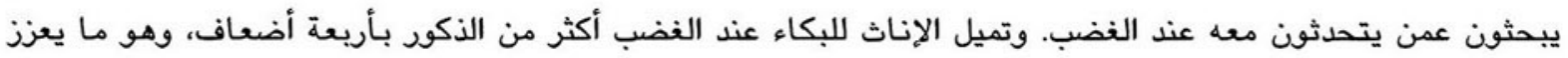

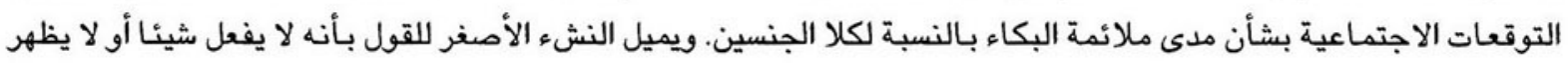

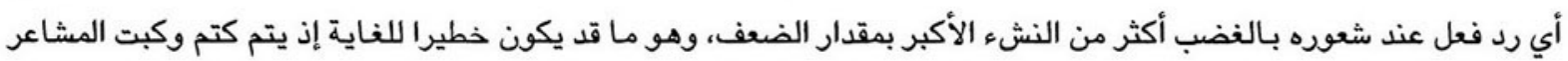
بدلا من التعبير عنها. ويذكر \%٪ فقط من النشء أنهم يلجئون للدين عند الغضب. 
بالنظر إلى المعدلات العالية إجمالا للمشاعر السلبية التي تم ذكرها، فإن مستويات الرضى عن الحياة والتفاؤل بشأن المستقبل

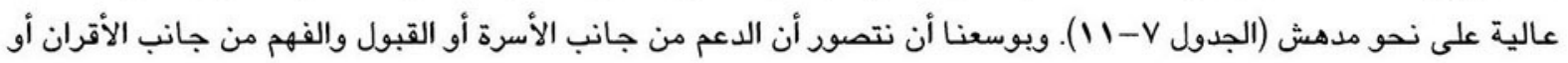

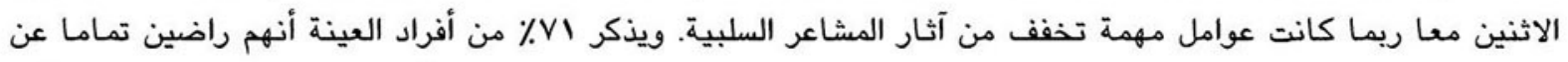

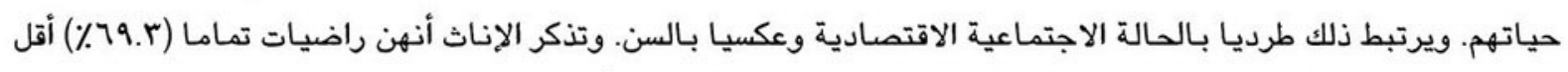

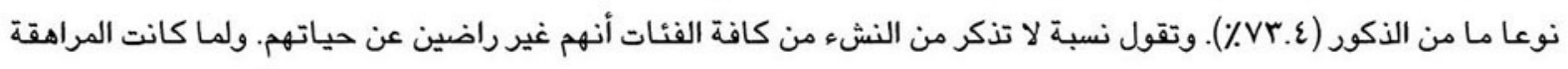

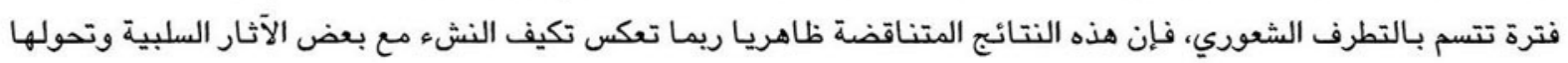

من وجهة نظرهم بالتالي إلى جزء عادي من حياتهم.

\begin{tabular}{|c|c|c|c|c|c|c|}
\hline \multicolumn{3}{|c|}{ الرضا عن الحياة } & \multicolumn{3}{|c|}{ التوقعات المستقبلية } & \\
\hline 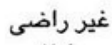 & راضى | (راضى & راضى جدا & أسوأ & كما هو & أفضل & \\
\hline$r . \varepsilon$ & $r \varepsilon, Y$ & vr. $\varepsilon$ & r. & |£.1 & Ar.q & بنين \\
\hline$r . r$ & rA.\& & 79.5 & r. & 17.7 & $\Delta \cdot r$ & بنات \\
\hline I.v & ri.r & vv.v & r. & IA.r & v9.1 & . ا-1عا سنة \\
\hline$r . r$ & rr.q & ri.o & r.v & $1 \cdot .9$ & $\wedge 0 . \varepsilon$ & 19-19-10 سنة \\
\hline 1.7 & rr.t & VE.A & r.r & $1 r .7$ & $\wedge \varepsilon, Y$ & ملتحقون بالمدرسة \\
\hline$\varepsilon . r$ & $r \varepsilon$. & T1.V & 0.0 & $r \cdot .1$ & vr.v & غير ملتحقون بالمدرسة \\
\hline r. & $r v . \varepsilon$ & 79.0 & $\varepsilon . r$ & in.r & vv.o & يعمل \\
\hline 1.9 & ro.9 & vr.1 & r.o & १ย.. & Ar.o & لا يعمل \\
\hline r.r & rา.\& & vi.\& & r.\& & IE.r & $\Delta r . \varepsilon$ & أسرة نووية \\
\hline r. .7 & re.r & vi.1 & $\varepsilon .7$ & $1 \wedge .1$ & vา. & أسرة همتدة \\
\hline r.q & $r \cdot r$ & 74.1 & r.r & 10.1 & $\Lambda \cdot .9$ & أسرة تعولها سيدة \\
\hline r.r & rq. & ท.. & $r$. & $10 . r$ & AI.V & أسرة لا تعولها سيدة \\
\hline & & & & & & الوضع الاقتصادى/ الاجتماعي \\
\hline$r . r$ & $r \cdot .7$ & 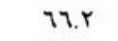 & $r .7$ & $r \cdot \cdot$ & จา. & منخفضض \\
\hline r.1 & rา. 9 & vi. & r.r & Iध.A & Ar. & متوسط \\
\hline I.V & rr.q & vo.9 & r.r & 11.1 & 17.7 & 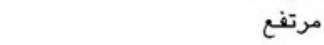 \\
\hline r.\& & rV.o & $v \cdot r$ & r.v & 11.9 & $\wedge 0 . \varepsilon$ & حضر \\
\hline r.r & ro.r & vr. & r.r & iv.o & va.r & ريف \\
\hline r.v & $r v . \varepsilon$ & 79.9 & r. & 9.7 & $A v . r$ & امحافظات الحضرية \\
\hline 1.1 & rq.V & ฟ. $\varepsilon$ & r.r & ir. & $\wedge \varepsilon . \wedge$ & وجه بحرى \\
\hline r.v & $r 1.9$ & vo.\& & r.A & r. & vo.r & وجه قبلى \\
\hline$r . r$ & หา. & vi.r & r. & $10 . \varepsilon$ & A1.7 & الإحمالى \\
\hline$r \cdot r$ & r.rAT & $7, r \varepsilon 9$ & $r \cdot v$ & l.1Er & 7.rar & عدد الحالات \\
\hline
\end{tabular}

ويكُمَّل هذا المستوى العالي من الرضى مـا تذكره نسبة عالية تبلغ ب^٪ عن التفاؤل حيال المستقبل. وهنا لا توجد تفاوتات بين

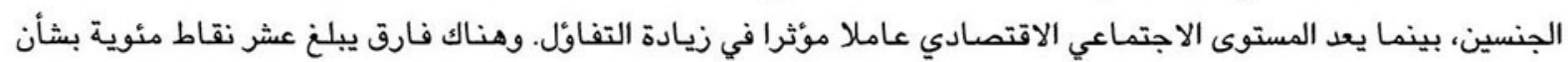

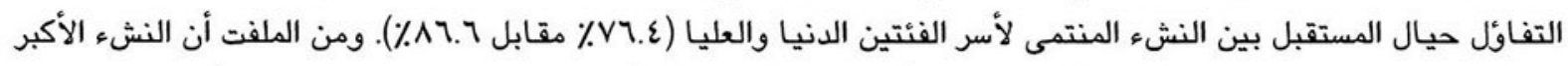

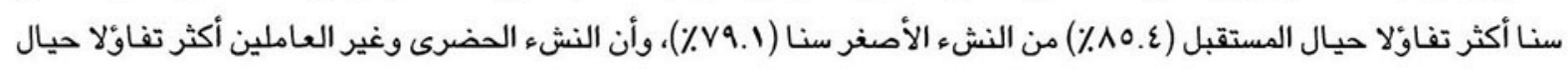

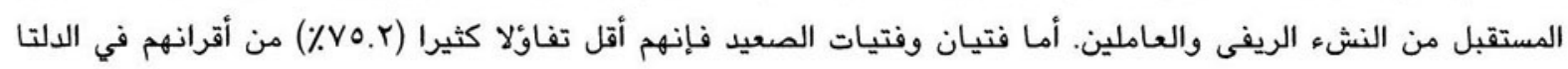

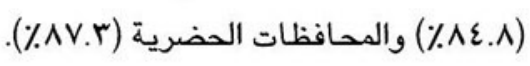




\section{رابعا: الحالة الصحية والصحة النفسية والتواصل مع الأسرة والأقران}

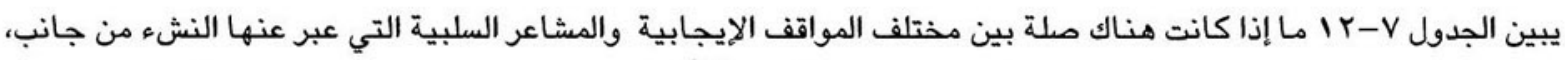

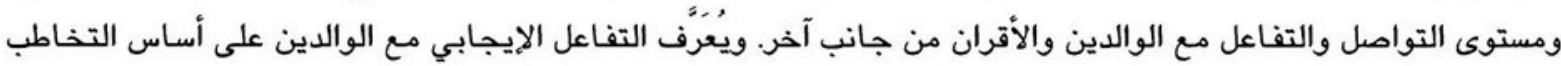

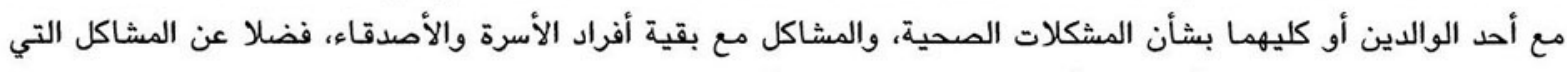

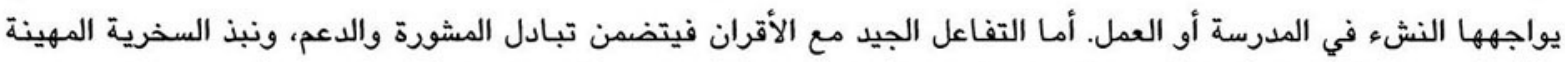

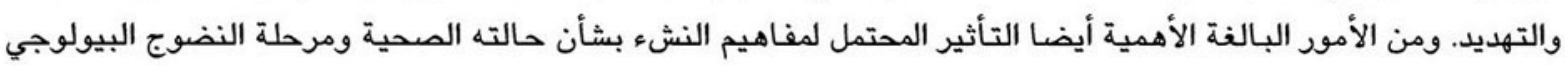
الفعلية التي يمر بها على صحته النفسية.

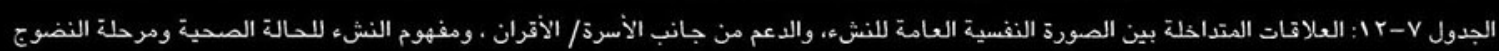 البيولوجى}

\begin{tabular}{|rrrrrrrrr|}
\hline \\
\hline
\end{tabular}

غير معنوى:

وللتفاعل الصحي مـع الأقران أكبر الأثر على صفتي تقدير الذات والروح القيادية (كما عرفناهـا من قبل) في الاتجاه المتوقع.

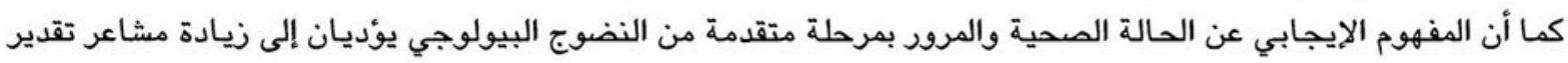

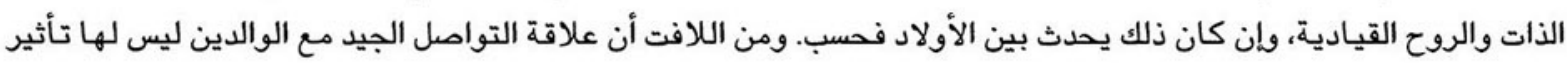

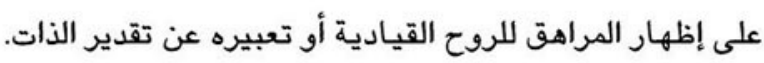

ويبدو أن نظرة الفتيات السلبية لأجسادهن ترتبط على نحو هامشي بمستوى من التواصل مع الوالدين يقل عن المنشود. أما

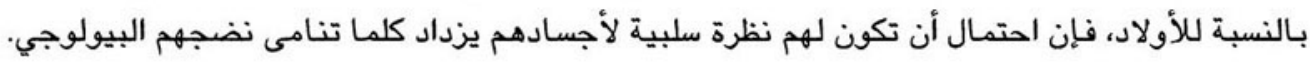




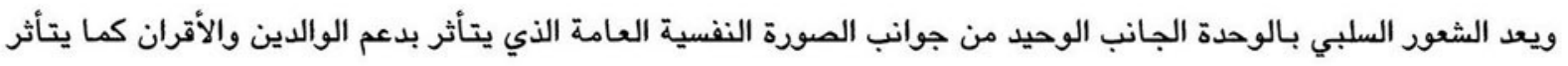

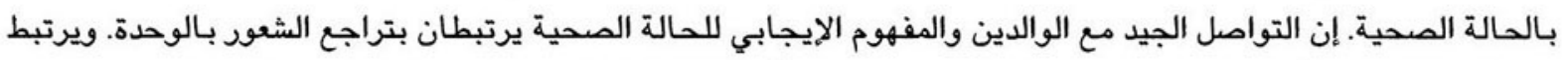

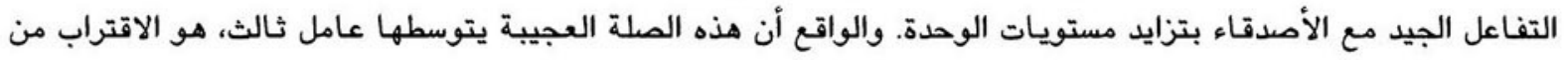

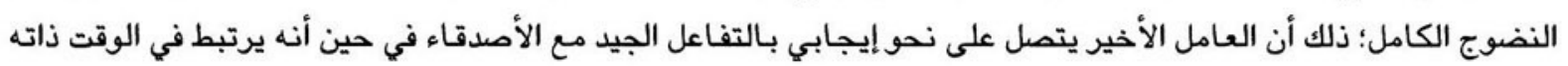

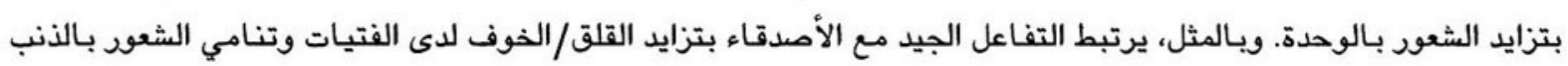

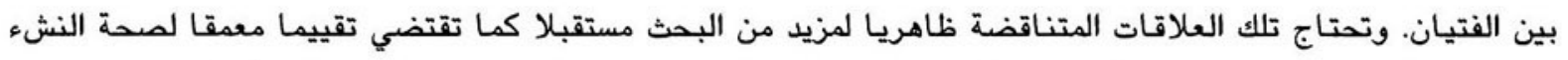

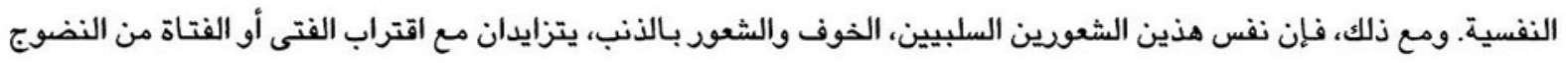

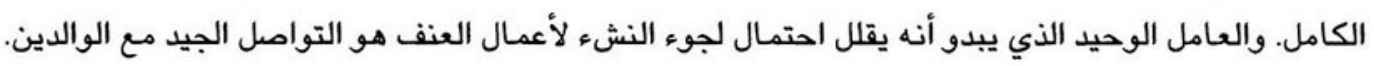

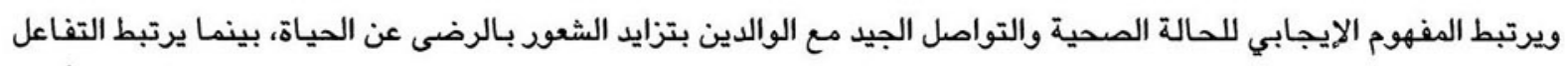

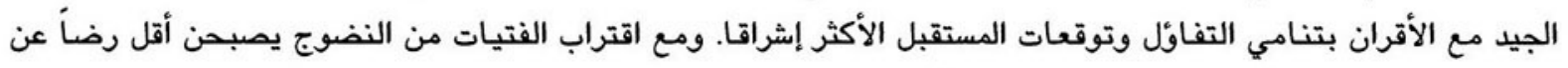

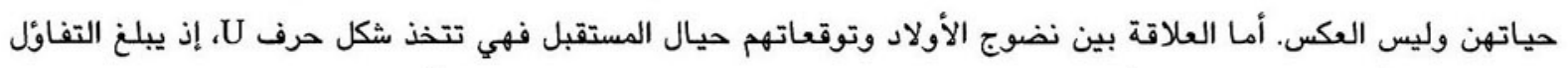

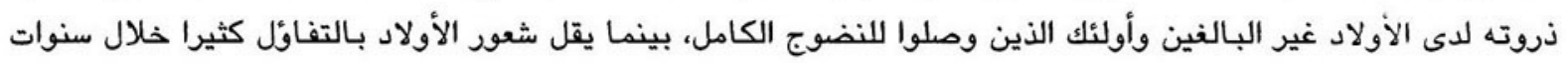

\section{حامسا: صردة النشاط اليومي للنش؟}

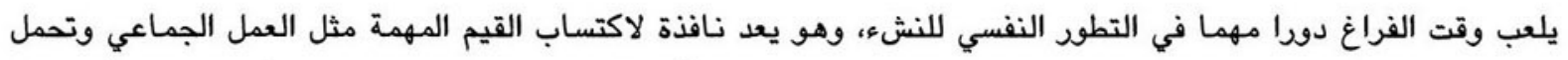

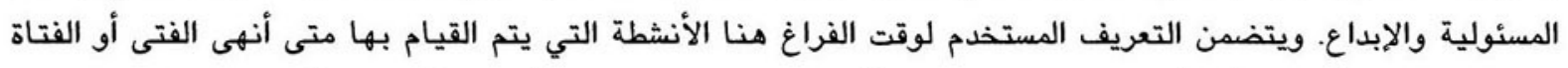

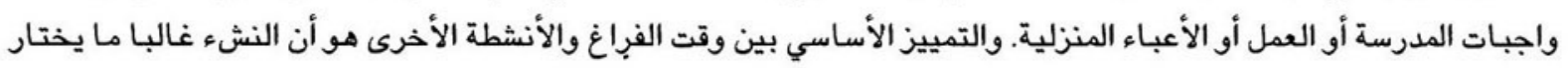

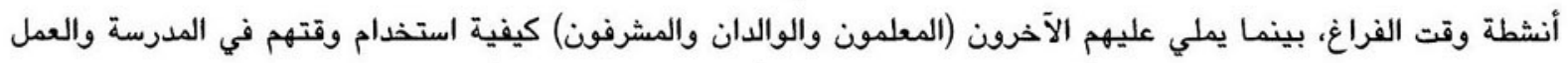

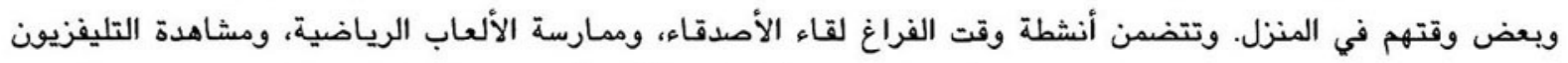

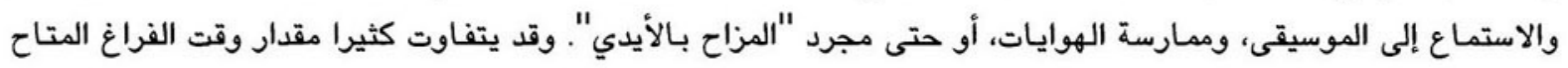

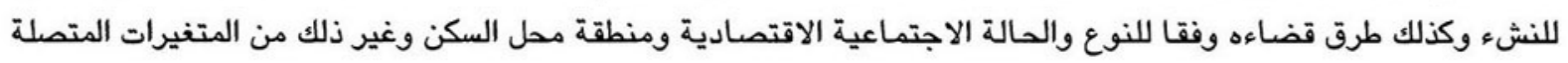
بالخلفية الاجتماعية.

ويينما توجد معلومات بشأن تعليم صغار السن من المصريين وعملهم، فإن البيانات القومية حول أنشطة وقت الفراغ كانت

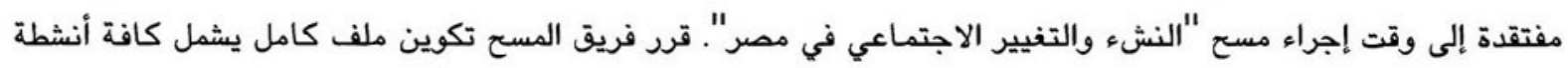

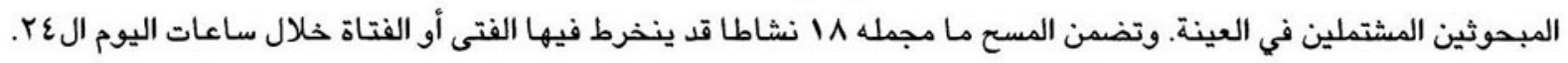

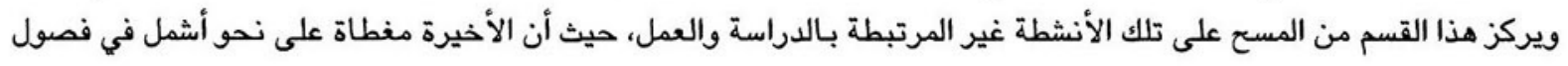

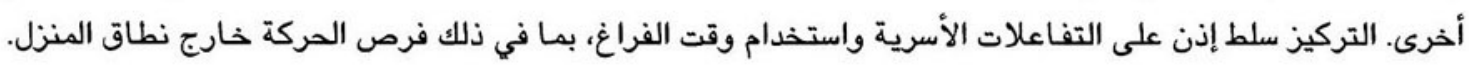




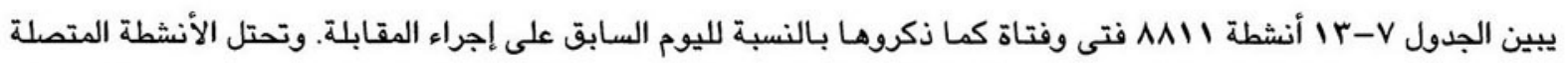

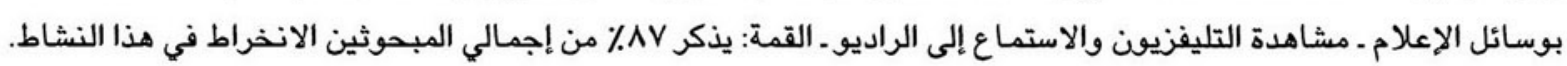

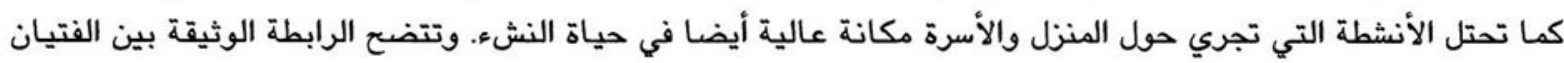
والفتيات وأسرهم بشكل خاص من نسبة من يذكرون الانخراط في أنشطة متصلة بالأسرة خلال اليوم السابق: في المحافظات التهري

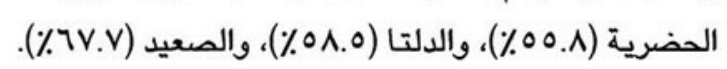

وتأتي الأنشطة الاجتماعية مثل المشي مع الأصدقاء، وممارسة الرياضة، وزيارة الأقارب والأصدقاء في المرتبة الثالثة بين

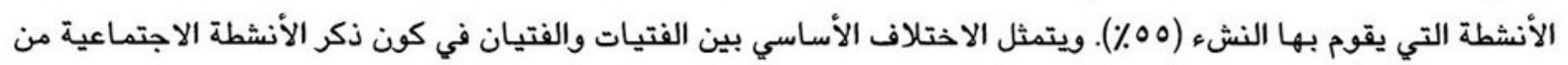

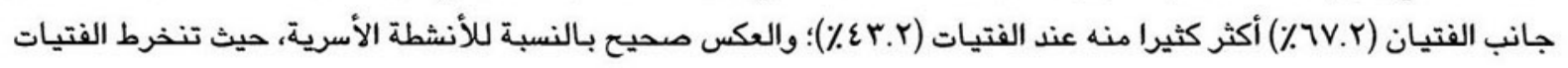

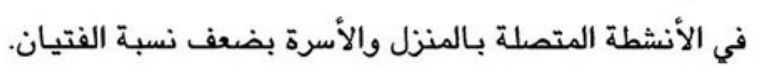

وتُذكر الأنشطة الدينية أكثر نوعا ما من جانب الفتيان، وأصحاب المستوى الاجتماعي الاقتصادي المرتفع، وقاطني المناطق

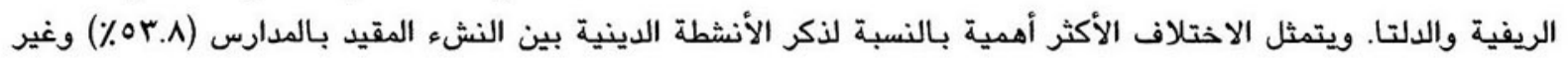

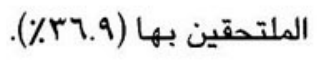

\begin{tabular}{|c|c|c|c|c|c|c|}
\hline 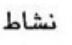 & 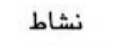 & 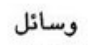 & 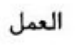 & نشاط فى المنزل & ن اط & \\
\hline دينى & اجتماعى & الاعلام & & أو مع العائلة & مدرسى & \\
\hline ६१.r & $0 . \cdot$. & $\wedge 7.9$ & rr.t & $7 . \varepsilon$ & ro.1 & الاجمالى \\
\hline \&.V & \&r.r & АТ.А & $\dddot{11 \varepsilon}$ & A1.० & rr.o & بنات \\
\hline 07.9 & TV.r & $\wedge \vee$. & ru.r & $\varepsilon \cdot . \vee$ & r... & بنين \\
\hline$\varepsilon 0 . r$ & ००. & งา.ท & ri.o & TE.r & rA.r & ا. \\
\hline ० \&.० & 00. & AV.r & rา. & ov. & $r \cdot . \wedge$ & 19-19 سنة \\
\hline or.s & $07 . \varepsilon$ & $\wedge 9 . \wedge$ & IV.r & $7 \cdot .1$ & $\varepsilon \vee .0$ & ملتحقون بالدرسة \\
\hline ry.9 & 01.5 & $9 \cdot .1$ & $\varepsilon \cdot . \vee$ & ०.. & 1.0 & غير ملتحقون بالمدرسة \\
\hline$\varepsilon$ ६. $^{\circ}$ & ०१.r & $\wedge 1.0$ & 79.9 & 01. & rr.r & 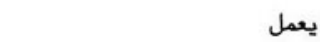 \\
\hline \multirow[t]{2}{*}{ ६9.r } & or.r & ヘ9.r & $r .1$ & 77.1 & $\varepsilon \cdot r$ & لا لا يعمل \\
\hline & & & & & & الوضع الاقتصادى/ الاجتماعي \\
\hline$\varepsilon 0 . \varepsilon$ & ०६.V & $A \cdot . r$ & YA.T & $7 \cdot . r$ & $r \varepsilon . \varepsilon$ & منخفض \\
\hline$\varepsilon 9.1$ & 07.7 & $\wedge 9.7$ & rr.r & WI.V & rr.q & متوسط \\
\hline o .r. & or. $\varepsilon$ & $9 \cdot .1$ & 19.5 & WI.r & rv.r & مرتفع \\
\hline$\varepsilon r .1$ & $01 . r$ & 91.0 & ir.t & $0 \wedge .7$ & r.. & حضر \\
\hline or. 9 & ov.r & $\wedge \varepsilon .1$ & 79.9 & tr.l & $r \varepsilon .1$ & ريف \\
\hline$\varepsilon r . \wedge$ & $\varepsilon 9.7$ & Gr.Y & $1 \cdot . v$ & 00.1 & $\varepsilon 1 . \varepsilon$ & امحافظات الحضرية \\
\hline OA.r & OA.r & $\wedge 0 . \wedge$ & rE.V & $0 \wedge .0$ & rr.e & وجه بحرى \\
\hline «.1 & or. 9 & 10.7 & rA. 9 & IV.V & ro.7 & وجه قبلى \\
\hline
\end{tabular}




\section{الأنشطة البدنية}

تناول سؤال آخر الأنشطة الرياضية التي تمت ممارستها خلال الأسبوع الأخير من حيث الكم والنوع، بما في ذلك تلك الأنشطة

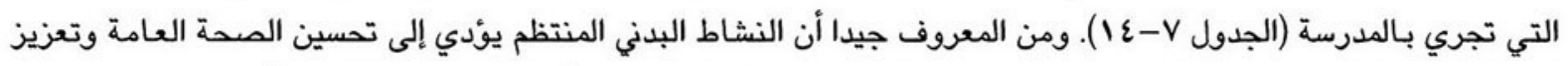

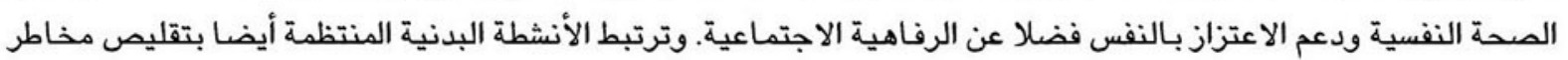

$$
\text { الأمراض القلبية والوفاة المبكرة. }
$$

ويبين مسح "النشء والتغيير الاجتماعي في مصر" أن مستوى الأنشطة الرياضية خارج المدرسة أعلى بما لا يقاس بين الذكور

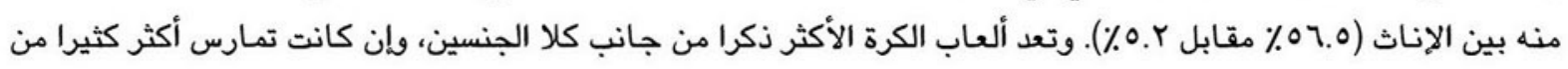

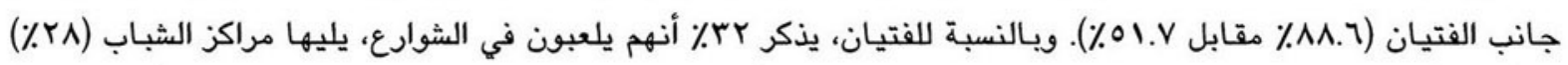

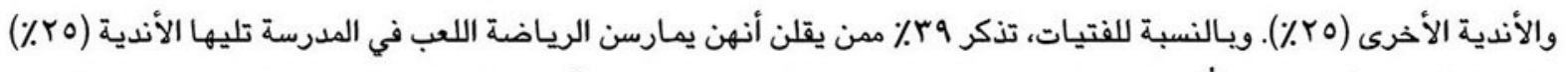

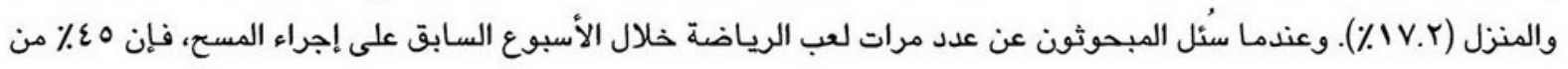
الفتيات وع \% من الفتيان ذكروا أنهم لم يلعبوا على الإطلاق.

\begin{tabular}{|c|c|c|}
\hline 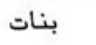 & بنين & \\
\hline \multirow[t]{2}{*}{ O.r } & 07.0 & الذين مارسو رياضة بالأمس \\
\hline & & أنواع الرياضة (إن وجدت) التي مارسوها الأسبوع الماضى \\
\hline $01 . v$ & AN.7 & ألعاب الكرة \\
\hline $1 \cdot .0$ & A.1 & كمال الأجسام \\
\hline 10. & $\cdot . \wedge$ & سباحة/ جرى \\
\hline$r \cdot \varepsilon$ & 1.0 & المشى/ ايرويكس \\
\hline \multirow[t]{2}{*}{ r.६ } & 1. & أكثر من نوع \\
\hline & & المكان \\
\hline ro.e & ro. & النادى \\
\hline$\wedge . \wedge$ & $\mathrm{rA} \cdot{ }^{*}$ & مركز الشباب \\
\hline i.r & rr.l & الشارع \\
\hline ra.1 & ir.v & 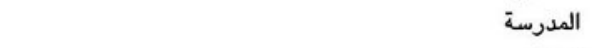 \\
\hline \multirow[t]{2}{*}{ IV.r } & I.r & 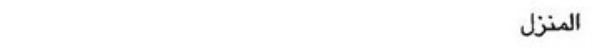 \\
\hline & & عدد مرات الممارسة الأسبوع الماضي \\
\hline$\varepsilon \varepsilon .0$ & $r \varepsilon .1$ & لم يمارس رياضة \\
\hline 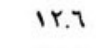 & ।ध. & مرة واحدة \\
\hline 19.4 & 19.1 & مرتين \\
\hline v.9 & 17.0 & ثلاث مرات \\
\hline 10.7 & ro.r & أريع مرات فأكثر \\
\hline$\cdot r$ & $\cdot .9$ & لا أعرف \\
\hline
\end{tabular}

يبين المسح الدور المهم للمدرسة في إتاحة الفرصة للفتيات للانخراط في أي نوع من الأنشطة والتمرينات البدنية. أما الفتيان

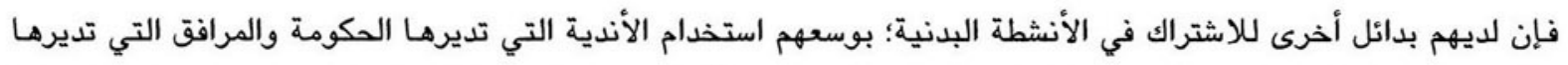

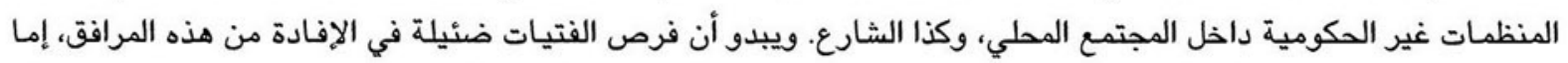

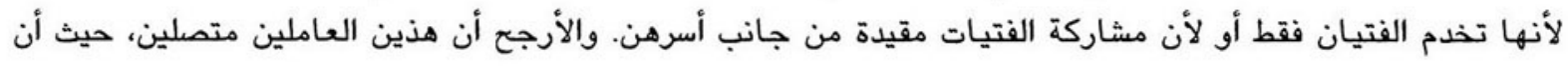

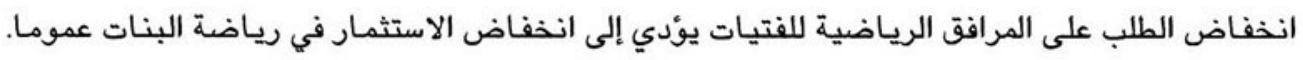


يتمثل أحد التوقعات المتصلة بالحراك في مصر في قلة فرص الحركة الحرة للفتيات مقارنة بالفتيان في السياقات الريفية

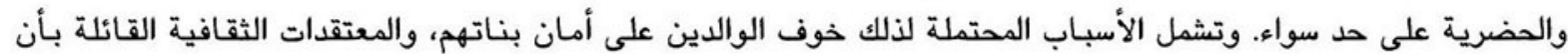
مكان البنت هو المنزل، وقلة المرافق المخصصة لاستخدام الفتيات الصغيرات. وفيما يتعلق بالحراك خارج المنزل، يؤكد هذا

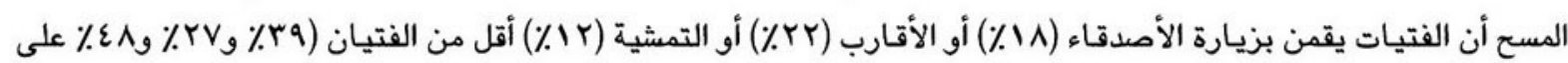

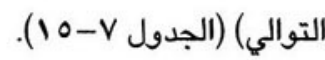

ذكر النشء في الدلتا، البنين والبنات على السواء، قيامهم بزيارة الأصدقاء أكثر منهم في المناطق الأخرى. ولا توجد اختلافات

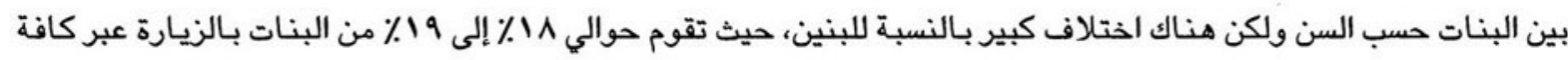

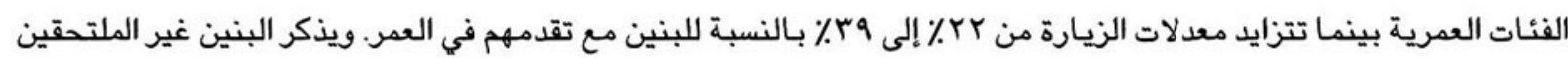

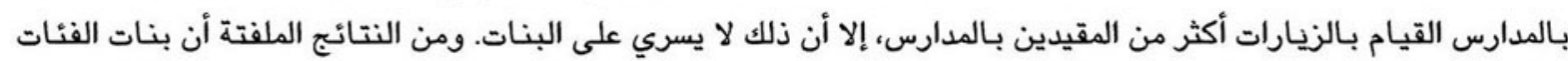

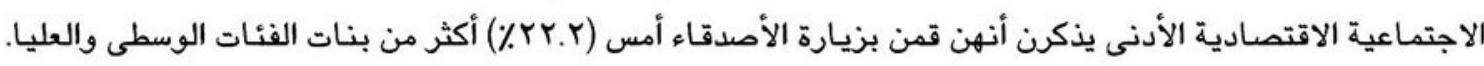

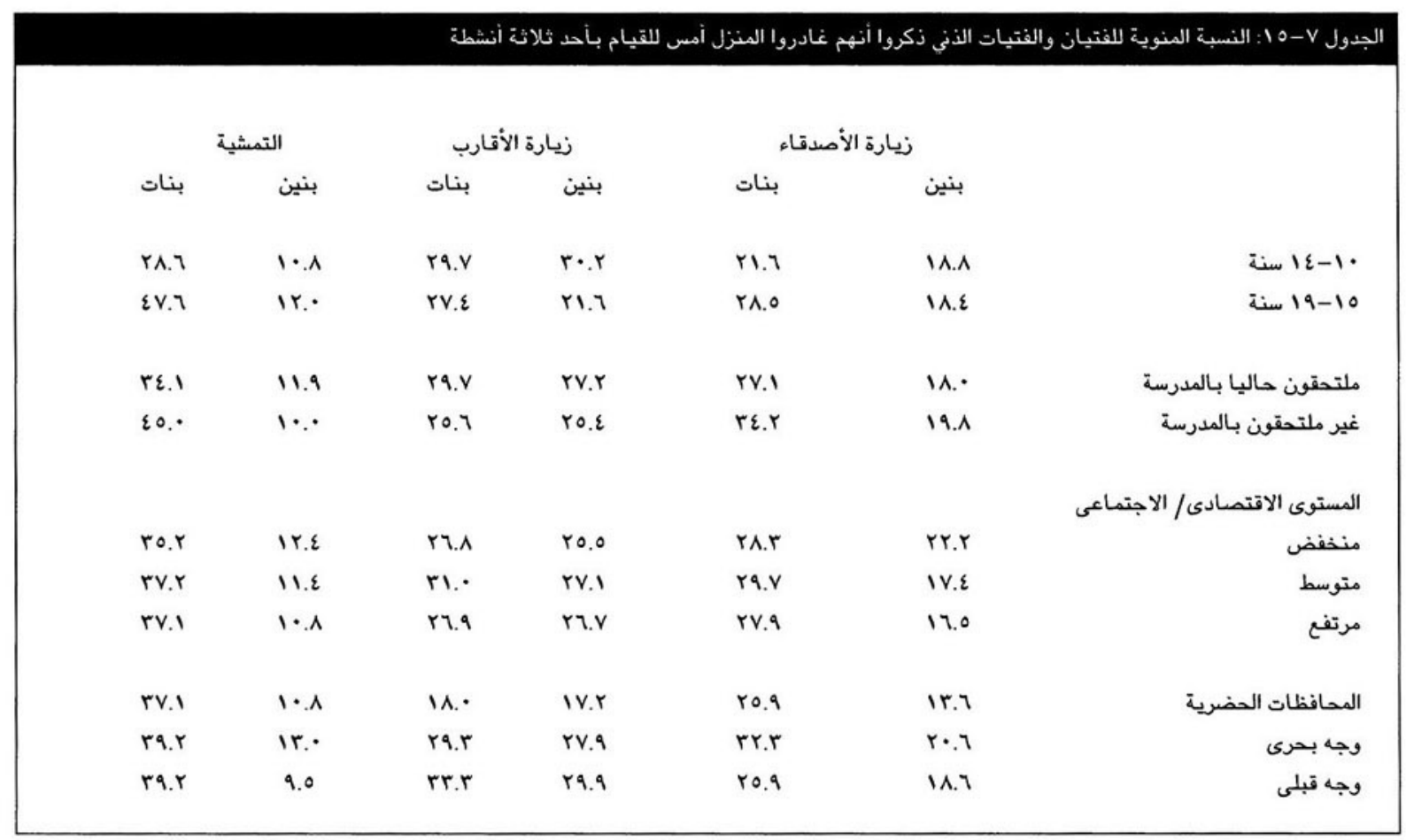

للأسر والأقارب مكانة مركزية في الحياة الاجتماعية بمصر. وقد وجه للنشء سؤالا عن زيارة الأقارب في منازلهم. ذكر النشء

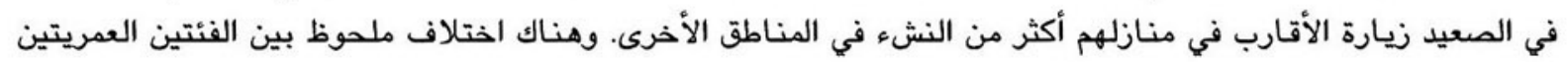

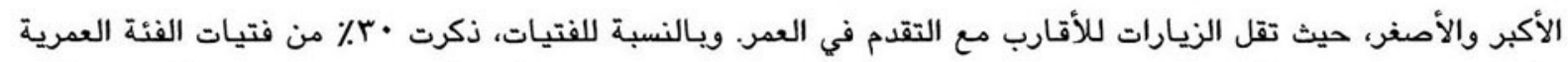

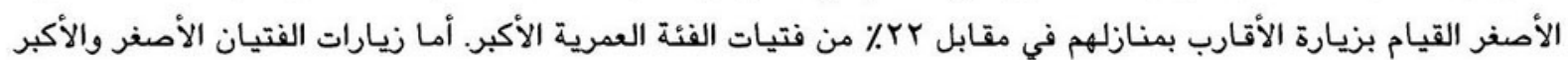

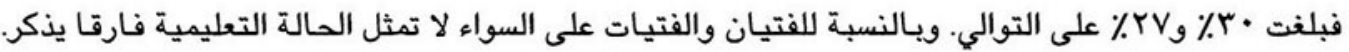

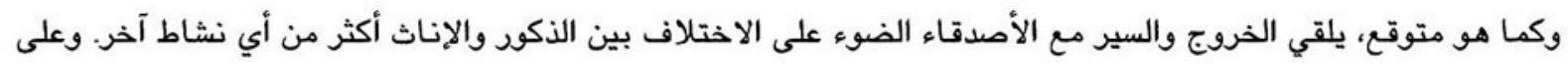

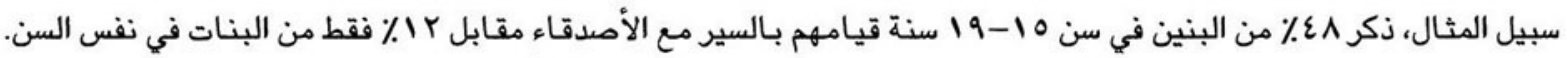

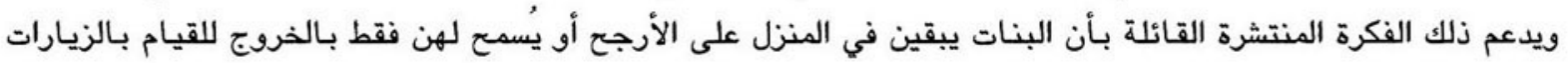


المنزلية أو في مواقف أخرى تخضع للسيطرة. وقد يكون لدى البنات أيضا وقت فراغ أقل، حيث يذكرن مستويات أعلى كثيرا من الأعباء المنزلية مقارنة بالبنين. (لا تظهر البيانات).

وعلى وجه الإجمال، يذكر البنين درجة من الحراك أعلى من البنات. ولا توجد سوى اختلافات إقليمية طفيفة بالنسبة للبنين،

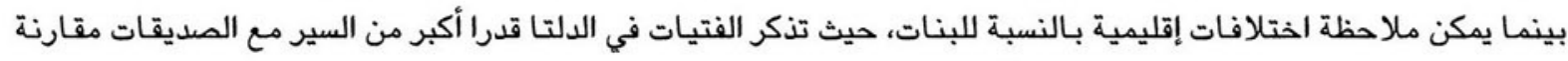

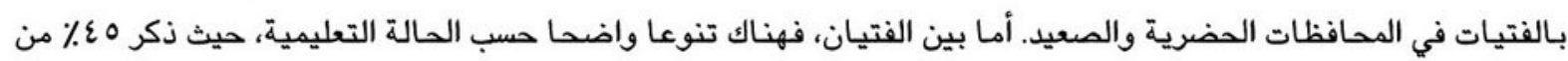

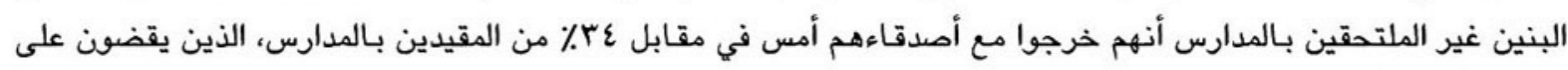
الأرجح أوقاتا أطول في المنزل للاستذكار.

الأعمال المنزلية يتولى بعض الفتيان والفتيات مسئوليات كبيرة فيما يتعلق بالأسرة المعيشية و البيئة المحيطة بها. وتتضمن هذه الأنشطة

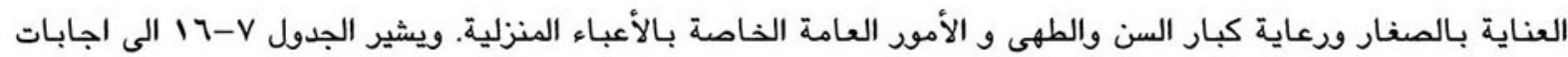
الفتيات والفتيان عند سؤالهم عن الأنشطة المنزلية التى كانوا يزاولونها في اليون اليوم السابق للمقاء العابلة.

ويشير الجدول الى اختلافات واضحة فى الأمور الخاصة بالنوع فيما يتعلق بمشاركة النشء فى الأعباء المنزلية بحيث أفادت

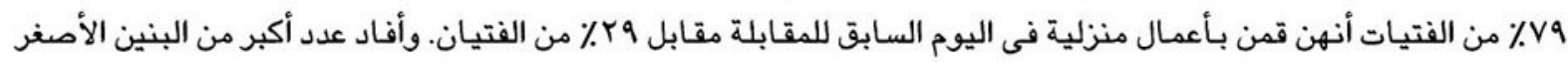

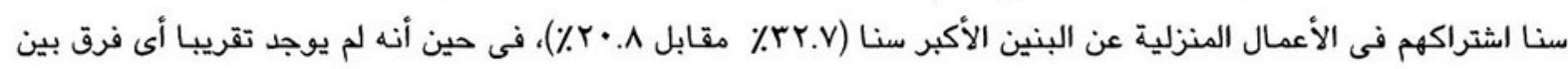

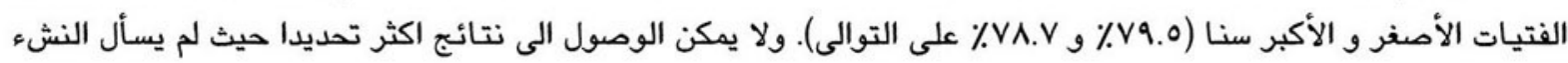

باستفاضة عن نوعية الآنشطة التى زاولوهـا.

\begin{tabular}{|c|c|c|}
\hline بنات & بنين & العمر \\
\hline r..V & v9.० & $10-1$. \\
\hline$r \cdot A$ & VA.V & $19-17$ \\
\hline rq. & va.r & الاجمالى \\
\hline
\end{tabular}

الانفتاح على التلفزيون والراديو والكتب

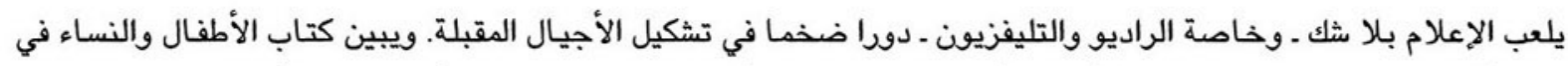

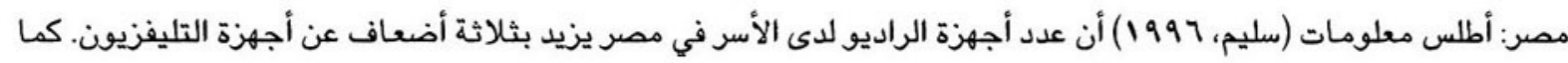

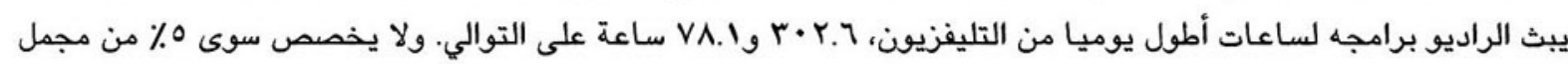

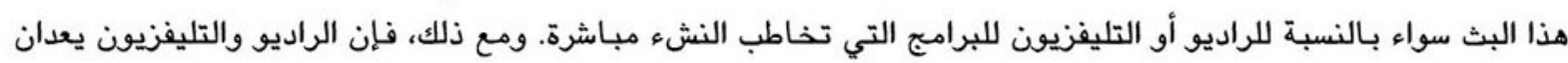

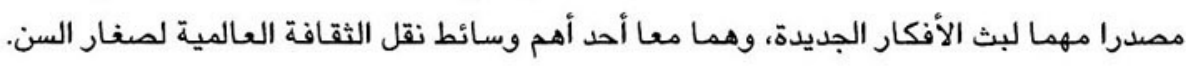

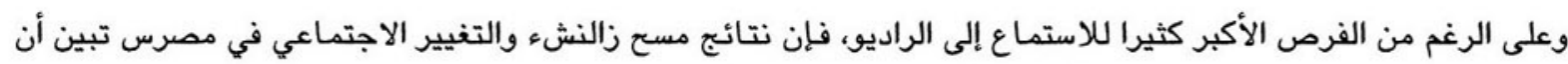

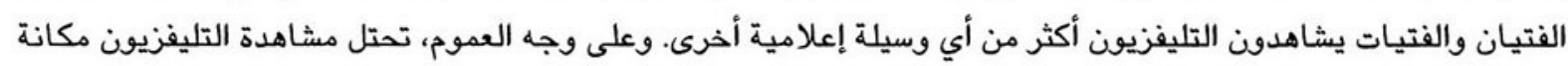

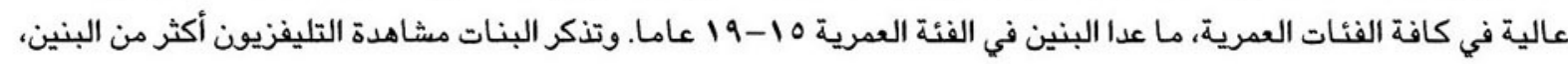

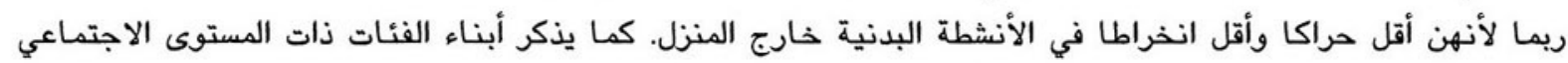

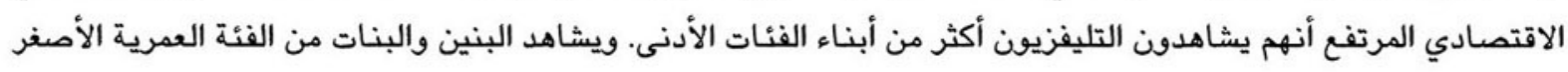


التليفزيون أكثر من أقرانهم من الفئة العمرية الأكبر. كما تزداد مشاهدة التليفزيون كثيرا في المحافظات الحضرية عنها في التيا

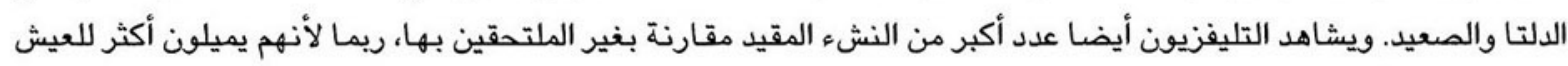
في منازل بها أجهزة تليفزيون.

وعلى الرغم من الشعبية الكاسحة للتليفزيون، فإن النشء المصرى لا زالوا يستمعون للراديو بأعداد كبيرة. وقد ذكر النشء الأكبر

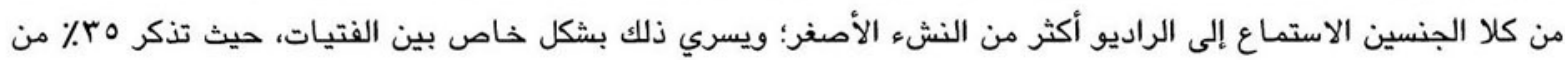

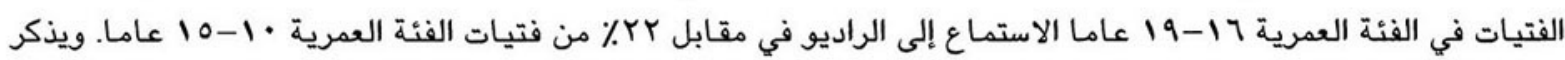

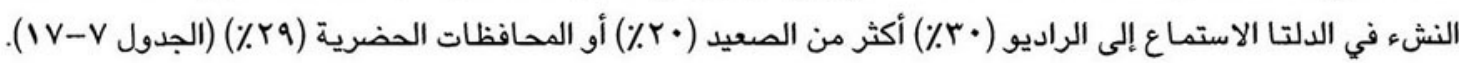

الجدول V-V ا النسب المنوية لانفتاح النشء من الذكور والإناث عاى وسائل الإعلام المختلفة

\begin{tabular}{|c|c|}
\hline \multicolumn{2}{|c|}{ الفتيان (حسب الفنة العمرية) } \\
\hline $19-17$ & $10-1$. \\
\hline$r \cdot r$ & $r \cdot .7$ \\
\hline 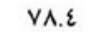 & $\wedge \cdot .7$ \\
\hline I\&.r & 11.9 \\
\hline
\end{tabular}

\begin{tabular}{|c|c|}
\hline \multicolumn{2}{|c|}{ الفتيات (حسب الفنة العمرية) } \\
\hline 19-19 ستة & "1-10 سنة \\
\hline r६.7 & rY.r \\
\hline$\Lambda \cdot . \Lambda$ & ᄉ1. \\
\hline $11 . r$ & 10.1 \\
\hline
\end{tabular}

يستمعوا الى الراديو

$\cdot 1$

iI. $r$

10.1

يشاهدون التليفزيون يقرأون الكتب

ما هي أنواع البرامج التي يفضلها النشء؟ عندما وجهت للمبحوثين أسئلة عما يشاهدونه، فإن برامج الترفيه والمسلسلات

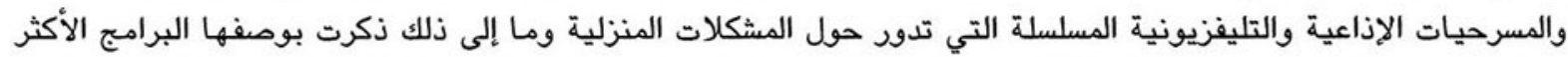

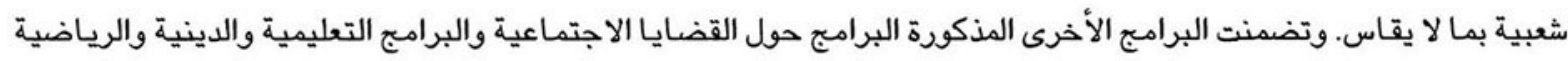

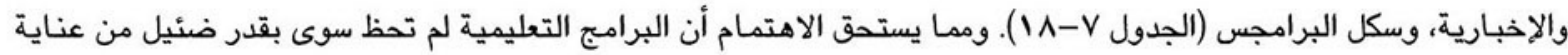

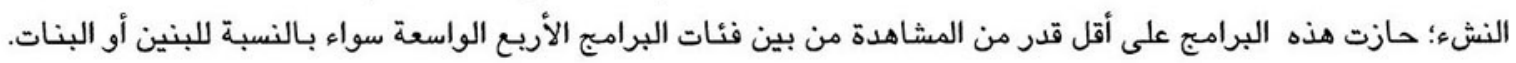

\begin{tabular}{|c|c|c|c|}
\hline \multirow{2}{*}{ قراءة الكتب } & الترفيه & الجدول V-1 إ: مقارنة بين مشاهدة التليفزيون (البرامج الترفيهية) والاستماع الى الى الراديو والقراءة & \multirow[b]{3}{*}{ 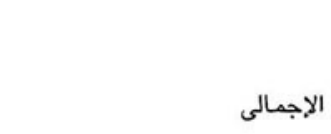 } \\
\hline & راديو & تلفزيون & \\
\hline $10 . \varepsilon$ & $7 r . \wedge$ & $9 \vee . r$ & \\
\hline ir.9 & 71.7 & $9 \vee .0$ & البنات \\
\hline 17.9 & $7 \cdot .7$ & १४. & البنين \\
\hline Iv.r & 71.1 & $9 \wedge .1$ & . \\
\hline Ir.A & 17. & 97.1 & 19-19 سنة \\
\hline 19.8 & $7 \cdot .9$ & $9 \vee .1$ & ملتحقون حاليا بالمدرسة \\
\hline$r .9$ & ir.s & $9 \vee . v$ & غير ملتحقون بالمدرسة \\
\hline $1 \cdot .7$ & $\dddot{u . v}$ & $9 \wedge .7$ & يعمل \\
\hline IV.o & $7 \varepsilon .7$ & 9ุ. & لا يعمل \\
\hline & & & المستوى الاقتمادى/ الاجتماعى \\
\hline ir.A & ir.7 & १४.१ & منخفض \\
\hline ir.\& & $u . v$ & $9 \vee .9$ & متوسط \\
\hline ir.s & $71 . r$ & $97 .{ }^{2}$ & مرتفع \\
\hline $1 \wedge . \varepsilon$ & $70 . \varepsilon$ & 97.0 & حضر \\
\hline ir.t & $\operatorname{Tr.\Lambda }$ & 91.7 & ريف \\
\hline$r \cdot . \wedge$ & iv. & $97 . \varepsilon$ & المحافظات الحضرية \\
\hline $1 \cdot . \wedge$ & ir.s & $9 \wedge$. & وجه بحري \\
\hline 11.0 & 71.0 & 97.9 & وجه قبلي \\
\hline
\end{tabular}


وتعد القراءة نشاطا يتخلف كثيرا وراء الأنشطة الإعلامية الأخرى. ويختلف ذلك وفقا للنوع والحالة الاجتماعية الاقتصادية،

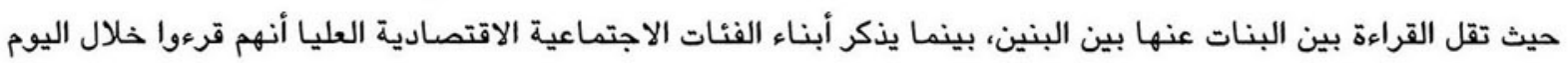

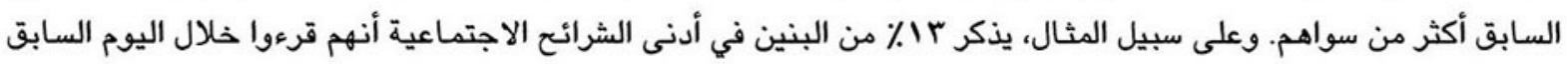

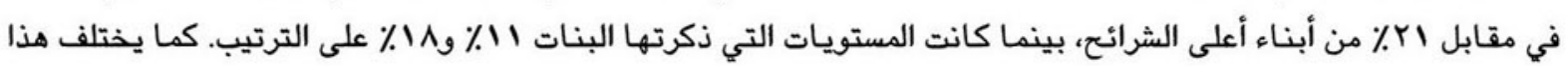

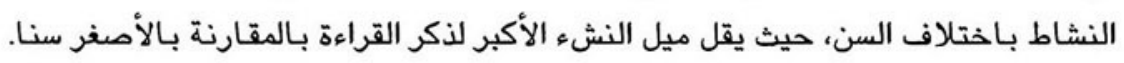

سأل المسح أيضا عن أنشطة وقت الفراغ التي تحتاج لدفع المال مثل الذهاب إلى السينما أو الأندية الاجتماعية. وكان هذا الإنا

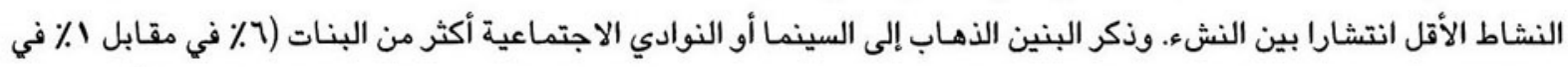

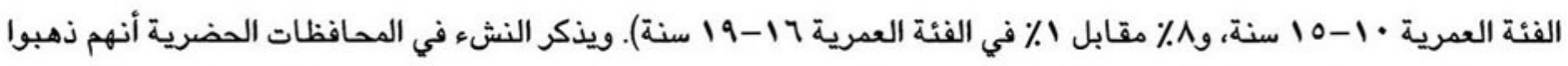

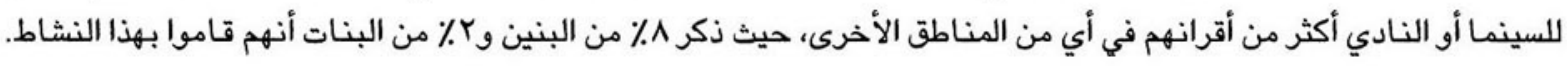

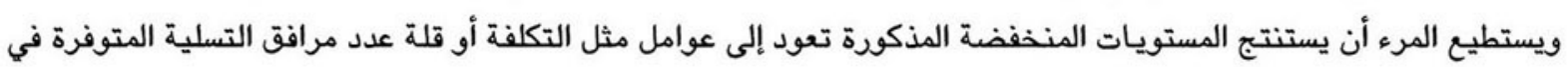
المجتمعات المحلية التي يعيش فيها النشء. بستئ.

\section{مشامد العنف في الاعلام}

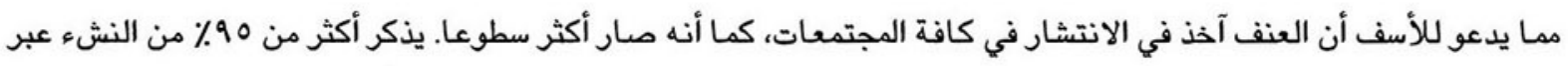

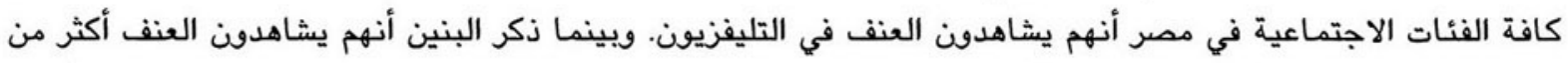

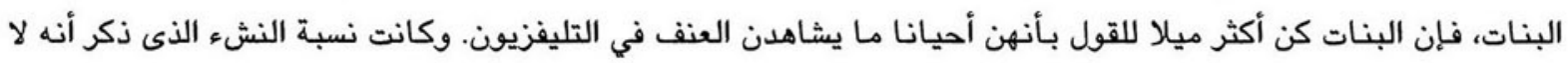

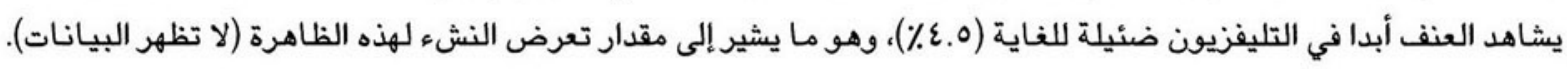

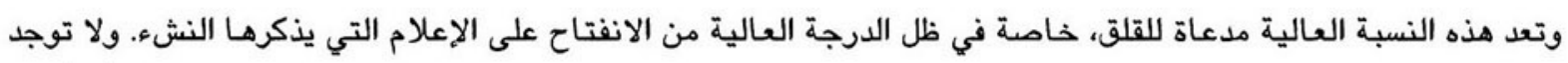

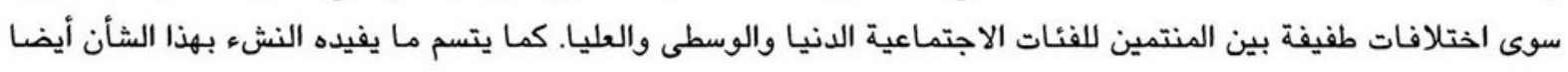
بالاتساق عبر المناطق الجغرافية وهو ما يؤكد شمولية التعرض لمشاهد العاجية العنف والوسطي والعليا.

وللتليص، فإن تحليل أنشطة وقت الفراغ المذكورة من جانب النشء يبين أن الراديو والتليفزيون يحتلان حيزا كبيرا من أنشطتهم

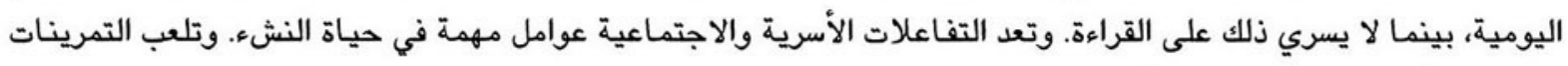

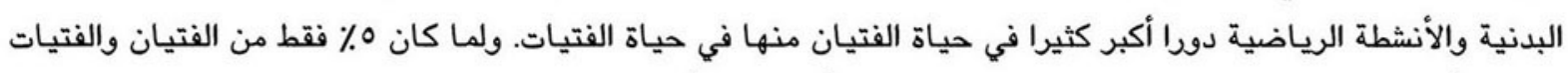

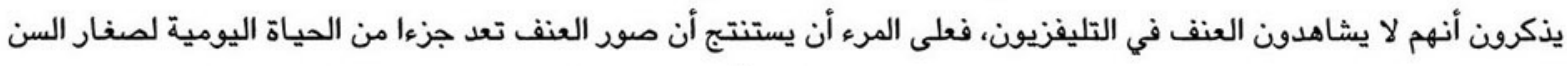
في مصر. ويمثل ذلك ظاهرة جديدة في مصر، وهي ظاهرة تحتاج لأن تدرس نظرا لـاني الصلاتها المحتملة بالسلوك العدواني.

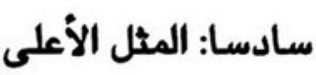

مع اقتراب الأشخاص في مقتبل العمر إلى حياة البالغين، يمكن أن يستنيروا بنموذج يحتذى يتمثل في فرد أكبر سنا، سواء كان

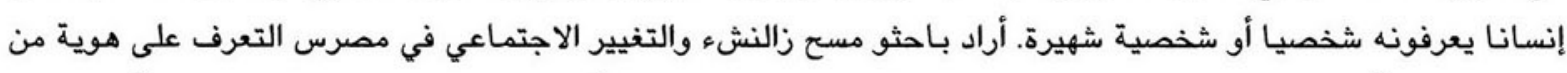

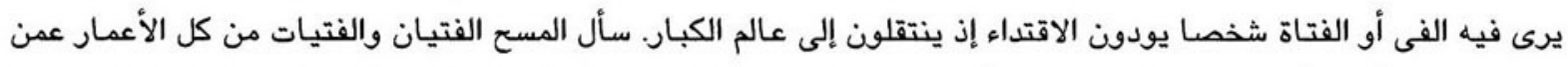

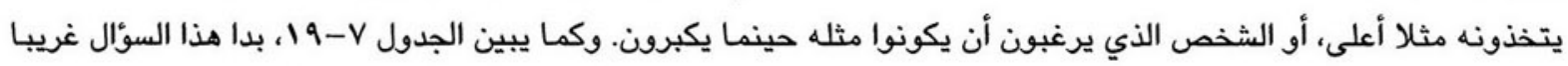

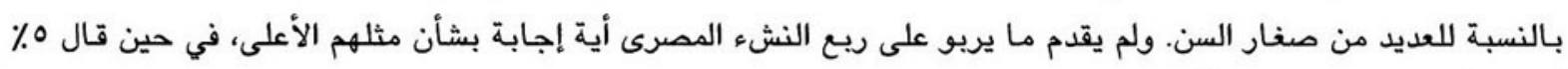
آخرون أنهم لا يعرفون مثلا أعلى. 


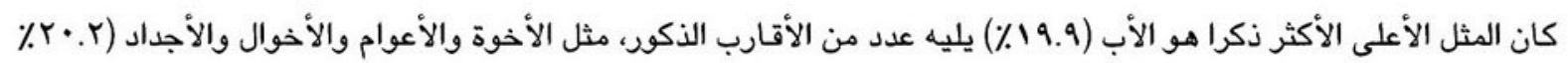

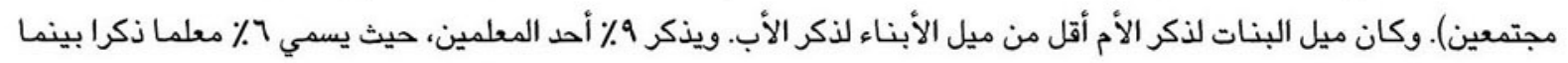
يختار ب٪ معلمة. كما ذكر ه٪ شخصيات عامة على صعيد المجتمع المحلي مثل العمدة أو أحد الشيوخ أو المهندسين.

ولما كان السؤال حول المثل الأعلى سؤالا مفتوحا، فقد كان بوسع المبحوثين أن يعطوا نطاقا واسعا من الإجابات الملفتة التي

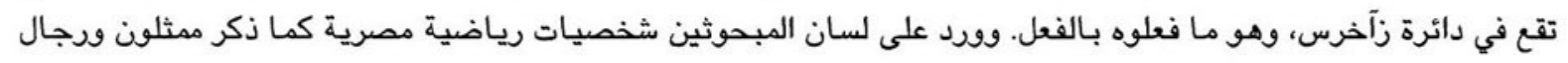

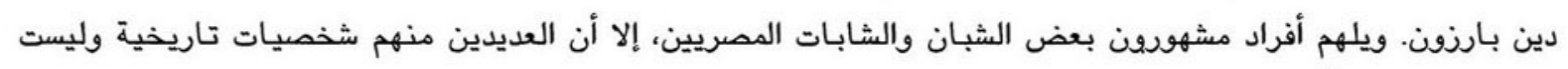

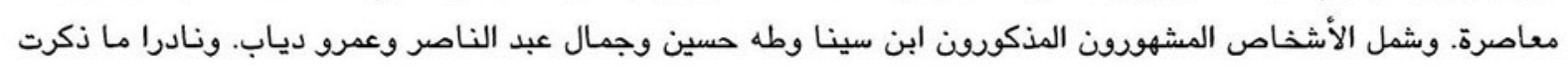
نساء مشهورات كنماذج تحتذى.

\section{الجدول V- 19 : الدثل الأعلى لدى الفتيان والفتيات: من الذين يعجبون بهم أو يرجون أن يكونوا مثلهم حين يكبرون؟}

\begin{tabular}{|c|c|c|c|}
\hline 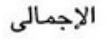 & بنين بن & بنات & \\
\hline ra.r & ro.0 & rr.v & لا يوجد لديهم مثل أعلى \\
\hline 19.9 & $r \varepsilon$ & 10.9 & الأب \\
\hline 7.1 & 1.1 & 11.9 & الأم \\
\hline 7.1 & $9 . \varepsilon$ & $r . r$ & 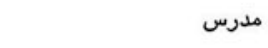 \\
\hline r.9 & $\cdot 1$ & 0.7 & مدرسة \\
\hline$r \cdot r$ & $r r . \varepsilon$ & $17 . \varepsilon$ & أحد الأقارب الذكور \\
\hline$r . v$ & $\cdot .9$ & v.० & إحدى القريبات \\
\hline $0 . r$ & V.r & $r . r$ & شخصية عامة فى المجتمع \\
\hline 0.9 & A.r & r.o & أخرى \\
\hline
\end{tabular}

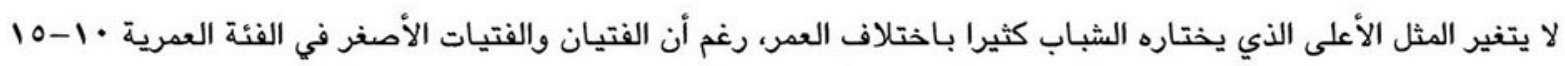

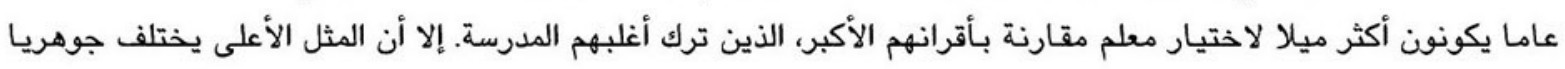

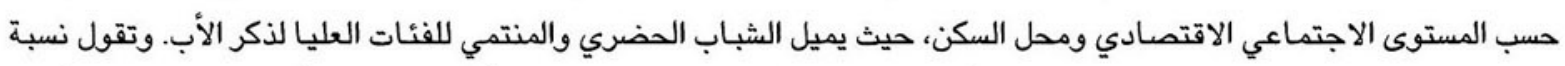

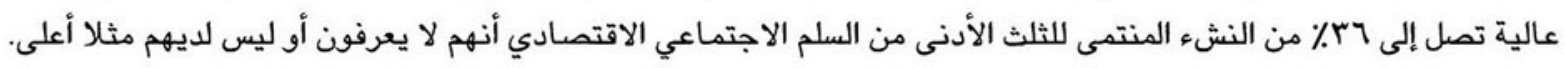

وتوجد أكثر الإجابات تنوعا بين النشء ذو مستويات التعليم المتنوعة، حيث تصل الفجوة إلى مداها بين من لم يلتحقوا

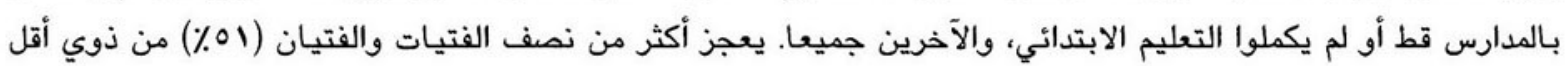

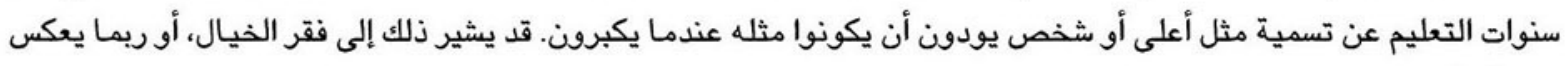

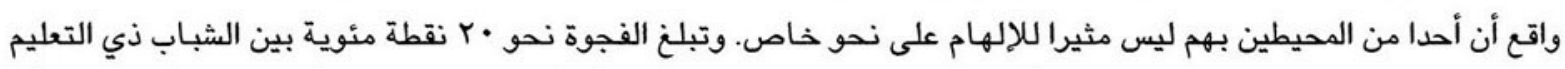

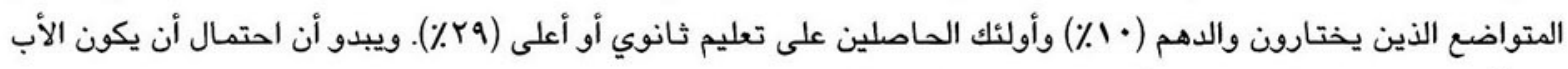
مثلا أعلى يزداد في حالة نجاح الأسرة اجتماعيا واقتصاديا.

يشير هذا التحليل إلى أن أفراد الأسرة يعدون نماذج تحتذى بين النشء في وضع اجتماعي أفضل؛ أما على وجه الإجمال فلعل حياة النشء في مصر اليوم تفتقر إلى "الأبطال". 
يبرز العامل الأسري كأهم عوامل التنشئة الاجتماعية التي تشكل وعي النشء. فهو يوفر نموذجا للدعم المتبادل ونطاقا واسعا

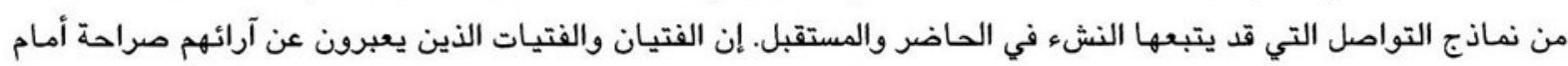

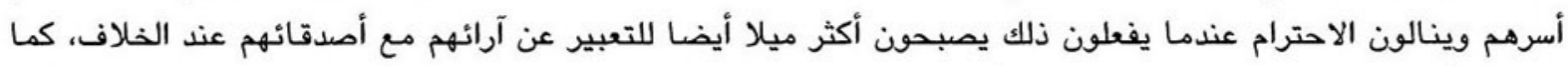

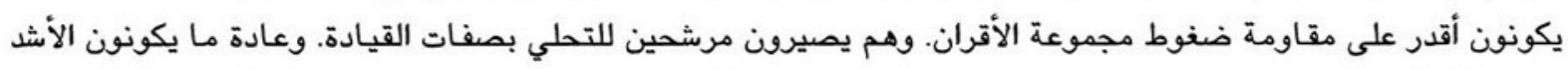

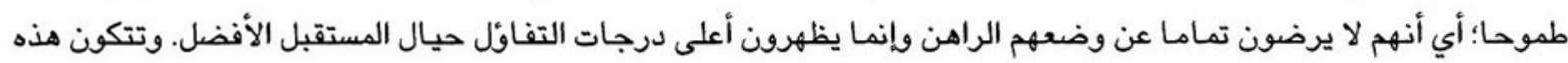

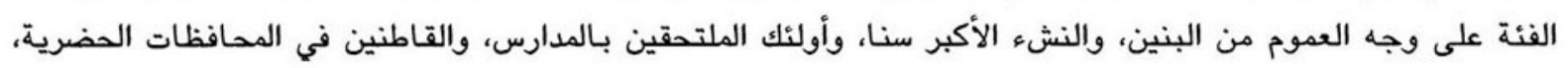
والمنتمين للأسر ذات المكانة الاجتماعية العالية.

وعلى الجانب الآخر، فإن الفتيات، والنشء غير الملتحق بالمدارس، والمنتمين للأسر ذات المكانة الاجتماعية المنخفضة،

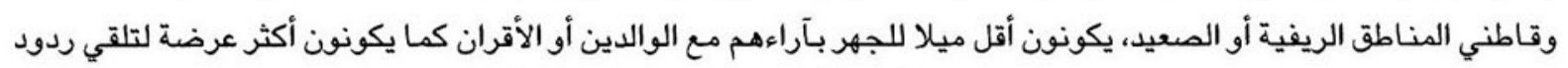

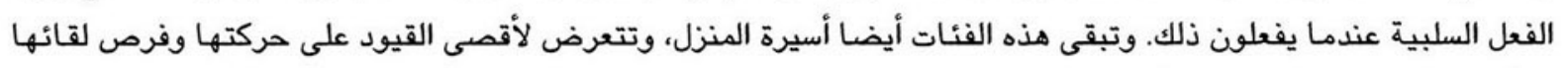

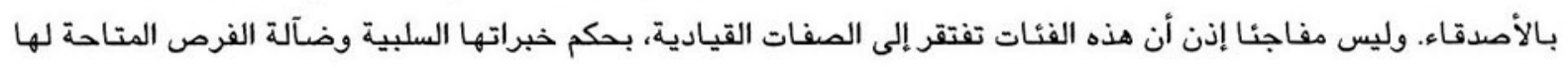

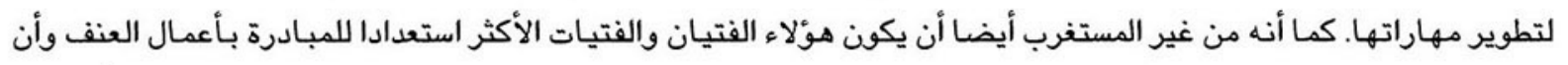

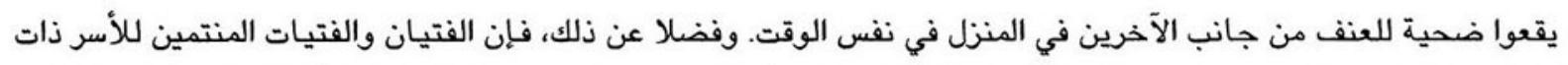

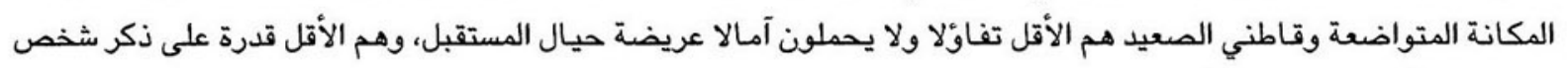
يقتدون به أو يتخذونه مثلا أعلى.

إن البيئة الأسرية الأقل تقييدا والأكثر تواصلا تبدو وثيقة الصلة بالتطور الإيجابي لشخصية النشء أو الفتاة، حيث تسهم في

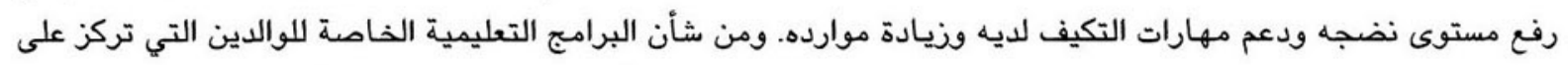

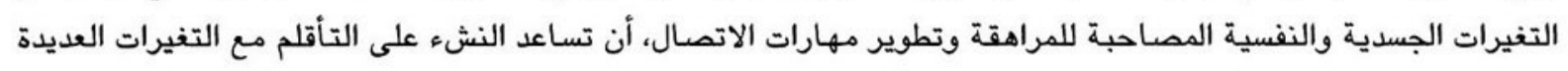

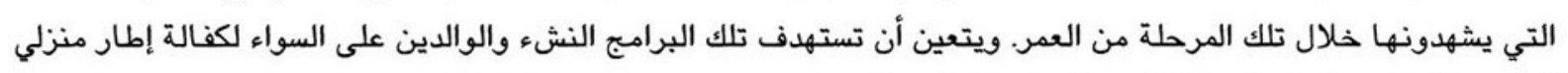
أكثر دعما وتقديرا لتلك المرحلة الحرجة من دورة الحياة. 


\section{الانتقال إلى النواج والأدوار الإنجابية}

إلى جانب التعليم والعمل، يشكل الانتقال إلى أدوار الكبار المتصلة بالإنجاب وتكوين الأسرة جزءا مهما من تجرية النمو الخاصة

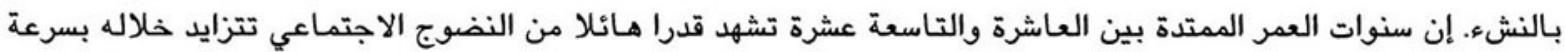

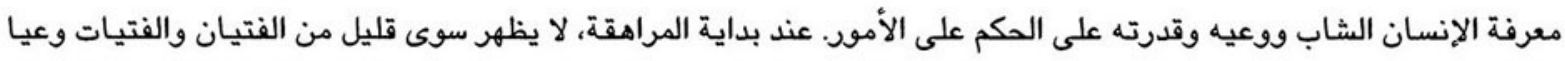

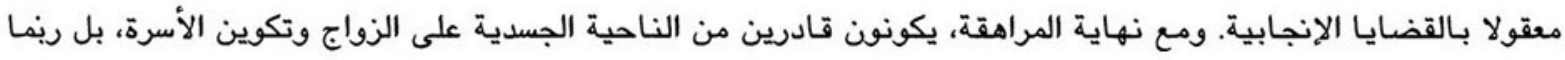

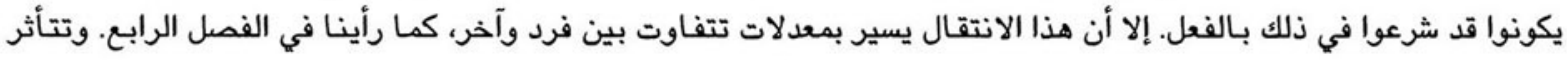

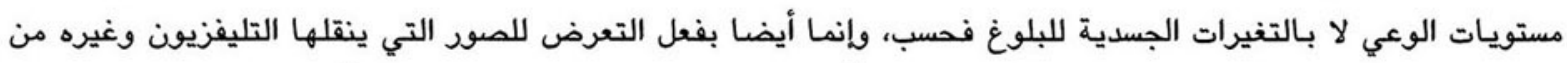

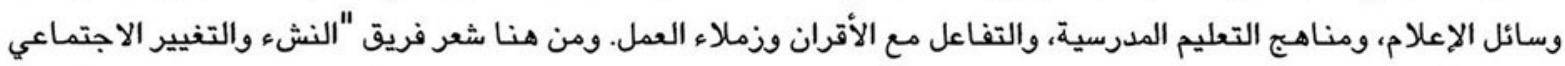
في مصر" بأهمية فهم توقيت وكيفية حصول الشباب صغير السن على المعرفة التي تؤهلهم لأدوار المستقبل كآباء وأمهات وشركاء في الزواج.

يستكشف هذا الفصل معرفة النشء والآراء التي يحملها الفتيات والفتيان حول بعض هذه الموضوعات، بما في ذلك الأدوار

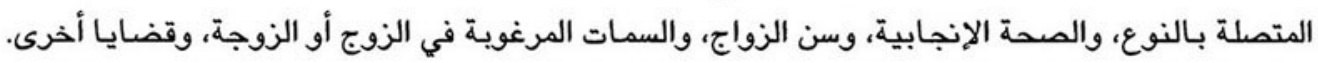

أولا: المعرفة بالمحة الإنجابية

لما كان الزواج والإنجاب يحتلان موقعا مركزيا في الحياة المصرية، فإن الاستعداد لحياة الزوجية يعد أحد أهم جوانب الانتقال

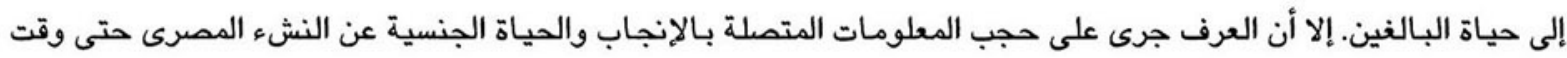

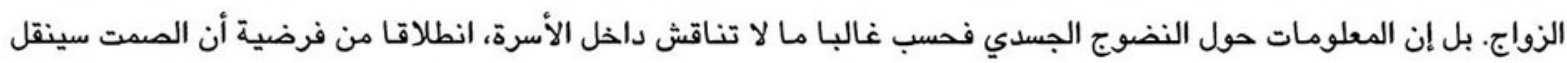

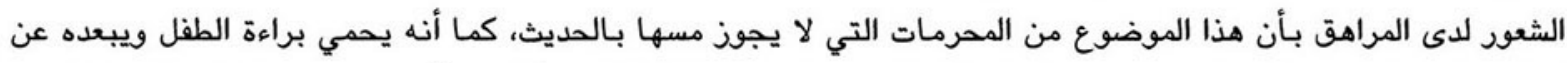

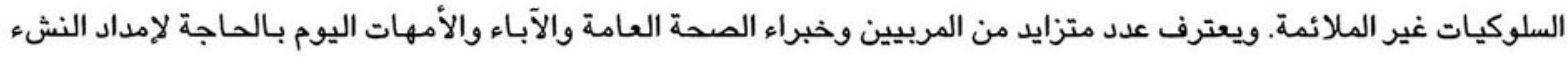

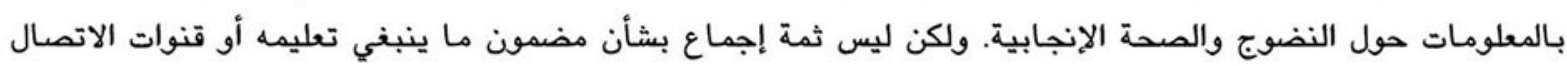
الملائمة التي يتعين اللجوء إليها.

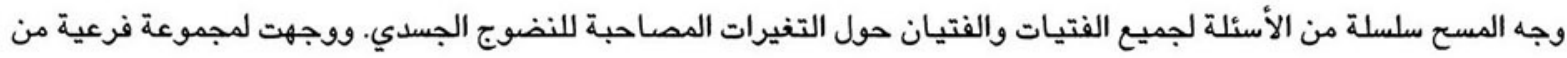

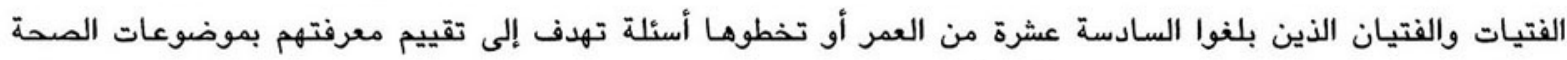

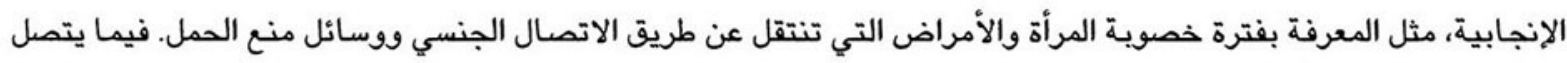

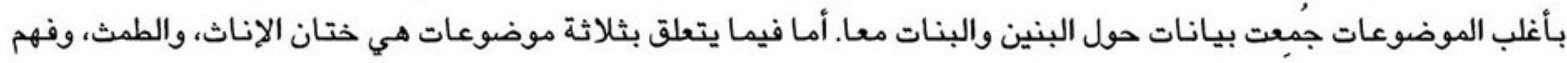

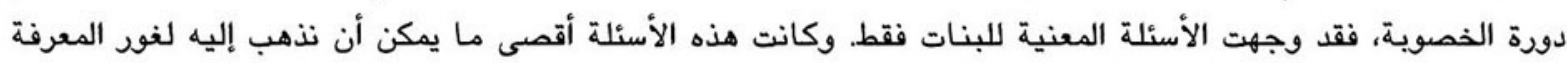

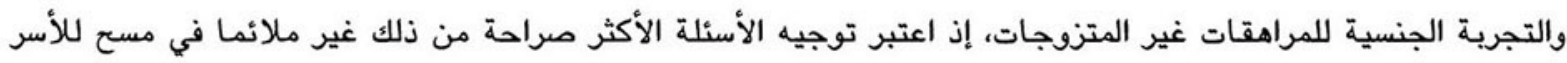
المعيشية يجري في مصر. 
ماذا يعرف النشء عن التغيرات الجسدية المصاحبة للنضوج وكيف يعرفونه؟ استطاعت قرابة • V٪ من البنات مقابل هع٪ فقط من البنين وصف التغيرات المصاحبة للبلوغ. وكما هو متوقع تزداد هذه المعرفة بشدة مع التقدم في العدر. بـالنسبة للبنات، لم

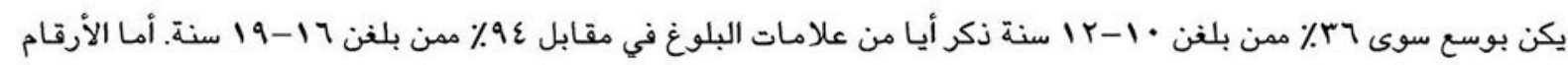

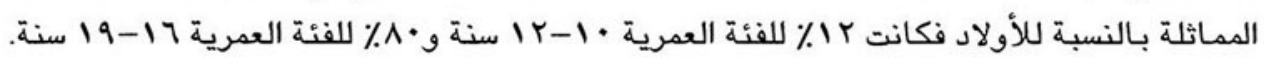

ما هي المصادر التي يذكر الفتيات والفتيان أنهم يستقون منها معلوماتهم؟ إن الغالبية العظمى من النشء في مصر يعرفون

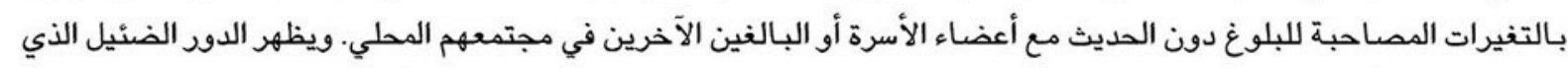

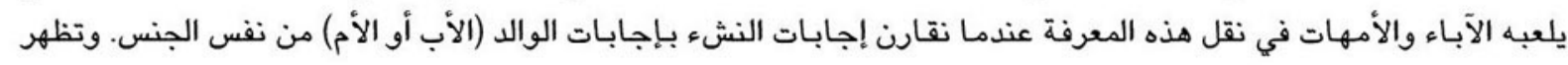

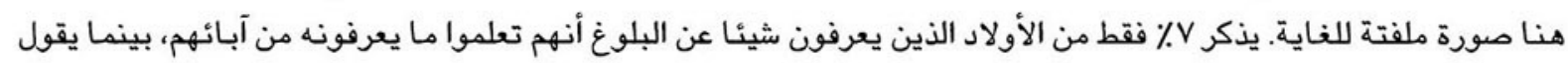

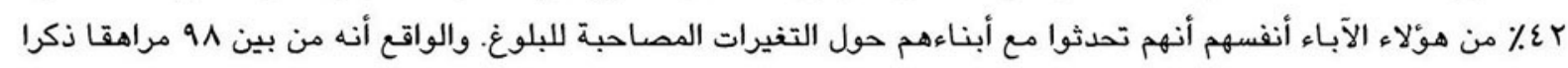

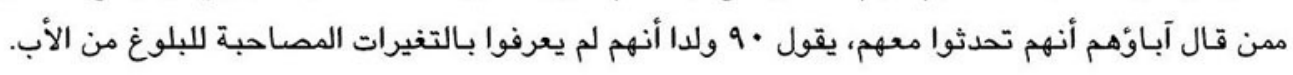

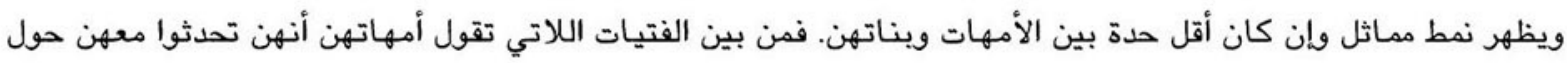

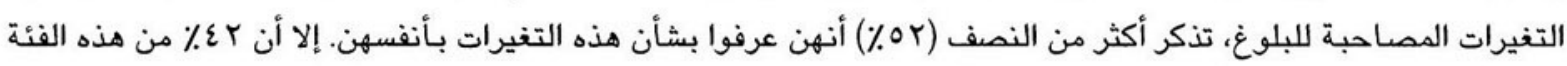

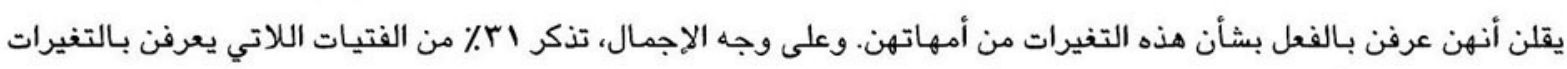
المصاحبة للبلوغ أنهن عرفن بها عن طريق الأم.

يبدو أن الآباء والأمهات يقرون بأنه ينبغي عليهم الحديث مع أبنائهم المراهقين حول هذه الموضوعات لكنهم لا يفعلون إما

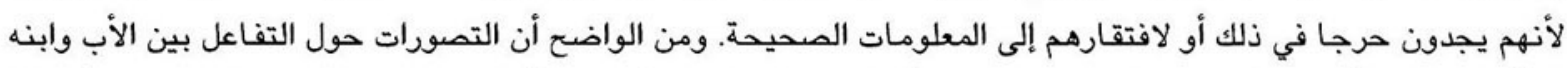

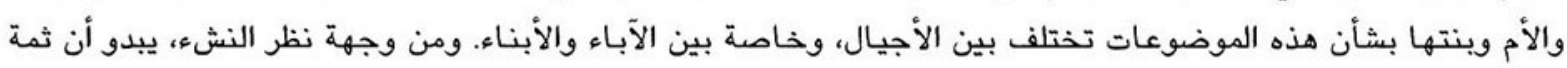

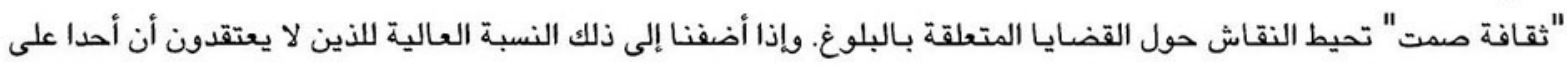

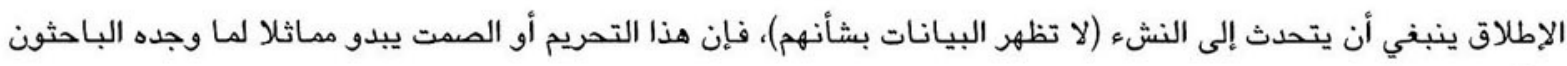

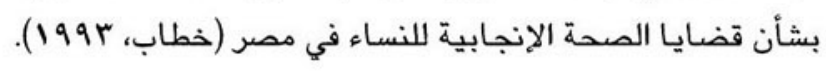

كانت الإجابة الأكثر ورودا على سؤال كيف عرفت بشأن التغيرات المصاحبة للبلوغ، هي "بنفسي/بالملاحظة" (79٪ من

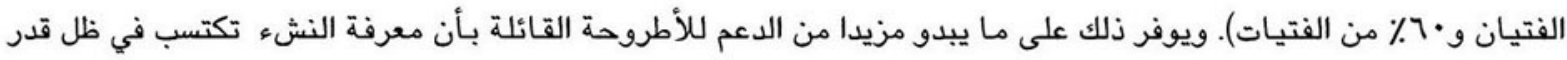

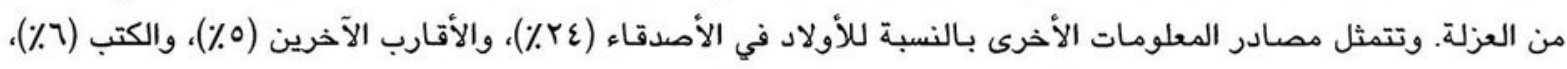

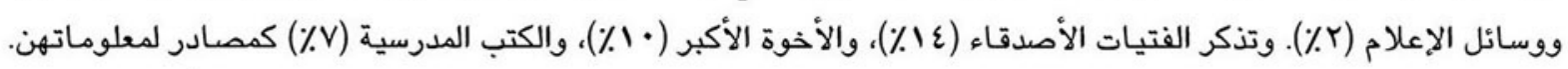

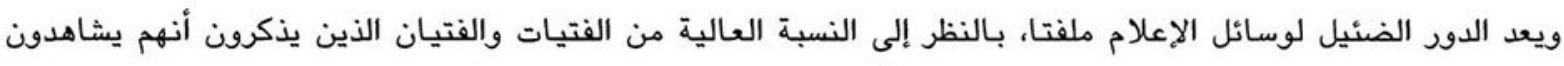

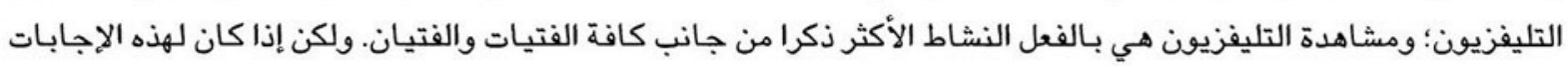

دلالة، فإنه لا يبدو أن التليفزيون يلعب دورا تعليميا بشأن الصحة الإنجابية.' 
اتخذ فهم دورة الخصوية عند الإناث مقياسا لمعلومات الفتيات الأساسية حول قضايا الإنجاب. سنلت فتيات الفئة العمرية

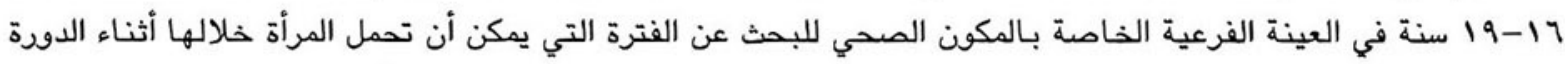

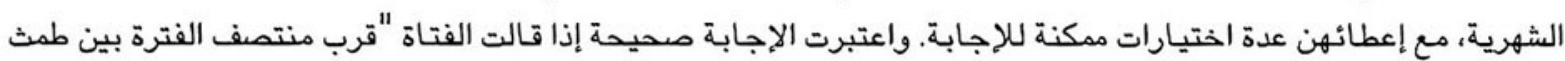

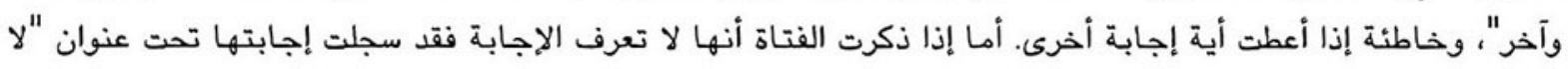

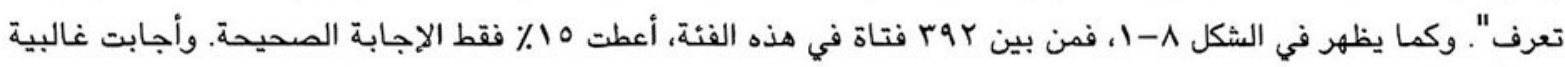

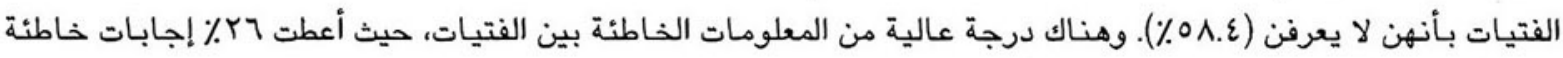
مثل "أثناء الطمث" أو"قبل الطمث مباشرة" أو غيرهـا (الشكل ^-1 (1).

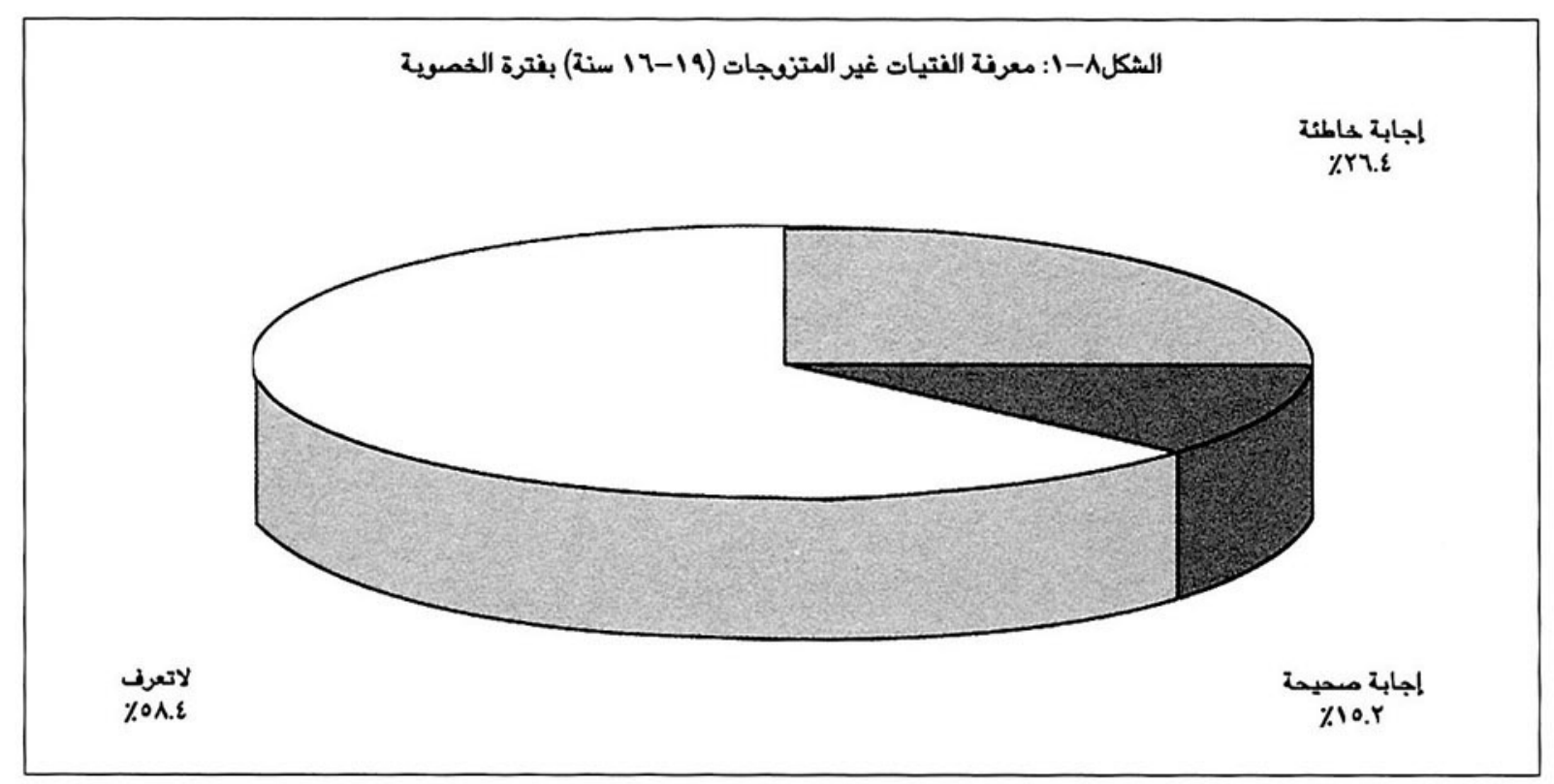

وتتوافر للفتاة معرفة أكبر بفترة الخصوية إذا كانت من أسرة حصل فيها أحد الوالدين على الأقل على تعليم فوق متوسط.

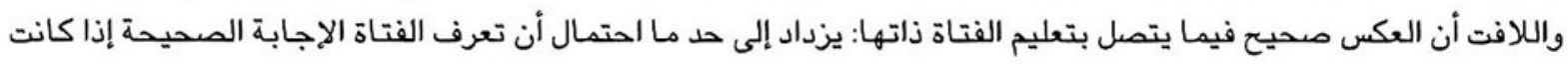

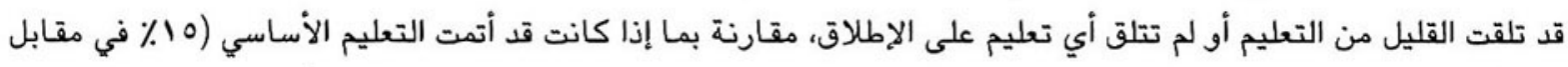

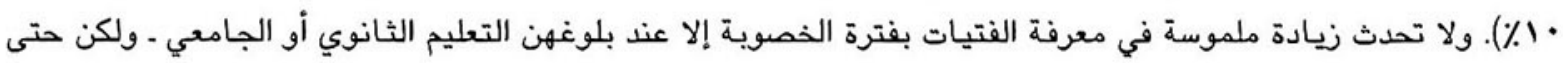

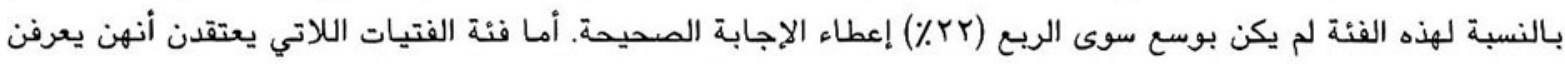

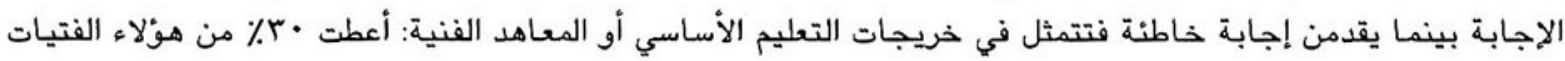

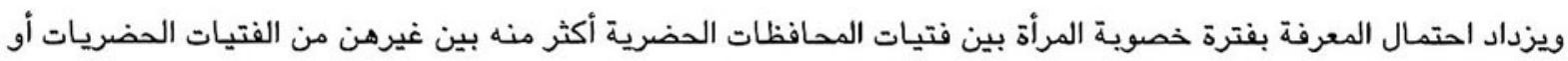

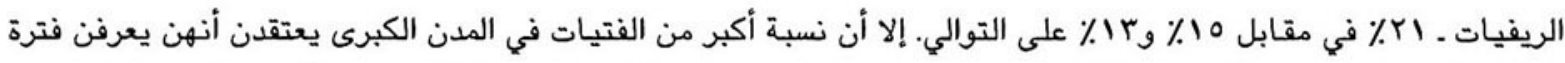

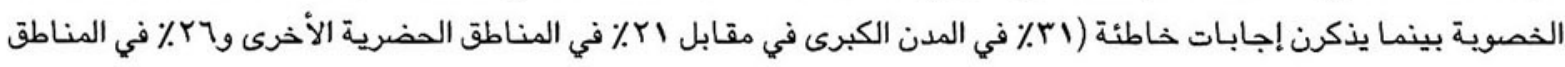




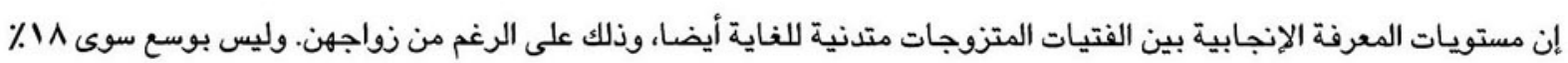

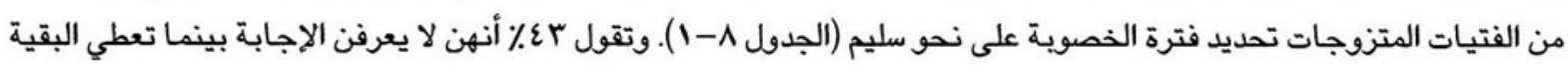

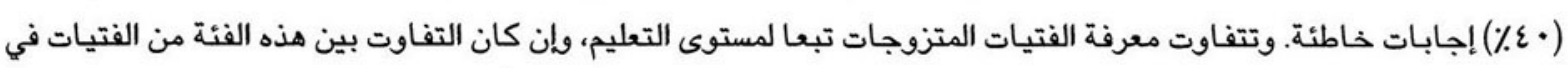

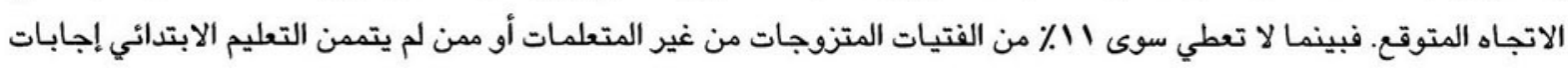

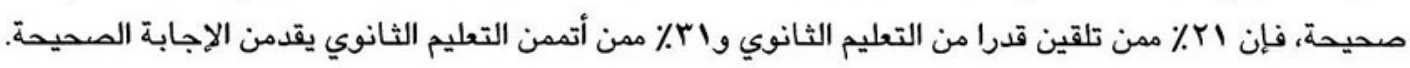

\begin{tabular}{|c|c|c|c|}
\hline ل الا لعرف & إجابة خاطئة & إجابة صحيحة & الجدول ^-1 ا الهعرنة بفعترة الخصوبة بين الفتيات المة \\
\hline$\varepsilon r . \wedge$ & $r 9.7$ & $1 \mathrm{V.7}$ & الإجمالى \\
\hline$\varepsilon 9 . \varepsilon$ & ra.r & $11 . \varepsilon$ & لم يلتحقوا بالتعليم/ لم يكملوا المرحلة الابتدائية \\
\hline$\varepsilon \varepsilon . r$ & $r \varepsilon .7$ & ri.r & أكملوا المرحلة الابتدائية/ لم يكملوا المرحلة الإعدادية \\
\hline rq.A & $\varepsilon \wedge .9$ & ri.r & أكملوا المرحلة الإعدادية/ لم يكملوا لمرحلة الثانوية \\
\hline ri.r & rv.o & ri.r & ثانوى أو أعلى \\
\hline rr.A & $\varepsilon \vee\urcorner$. & rA.T & المحافظات الحضرية \\
\hline$r \cdot r$ & 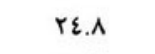 & 10. & وجه بحري \\
\hline$r \cdot . \wedge$ & 0.9 & IA.Y & وجه قبلي \\
\hline ri.v & rq.v & YA.T & حضر \\
\hline$\varepsilon 0.7$ & ra.7 & $\mid \varepsilon . \wedge$ & ريف \\
\hline
\end{tabular}

\section{الآثار الضـارة للنواج المبكر}

ينتشر الزواج والحمل المبكر في بعض أجزاء الريف المصري (أنظر الفصل التاسع). وأراد باحثو مسح "النشء والتغيير

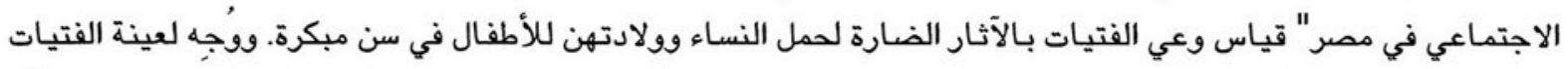

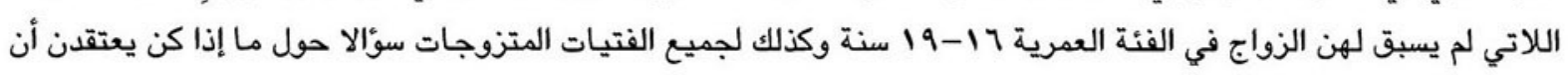
بإمكان امرأة في سن الخامسة عشرة أن تتحمل الحمل.

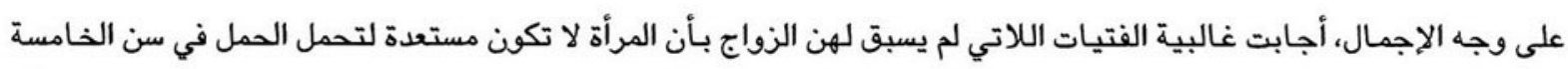

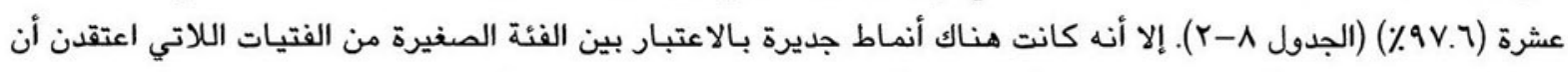

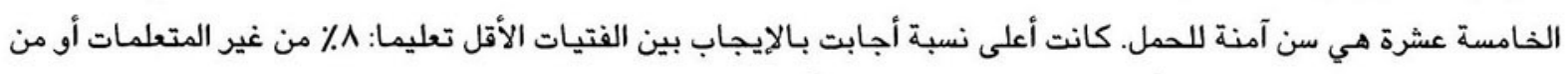

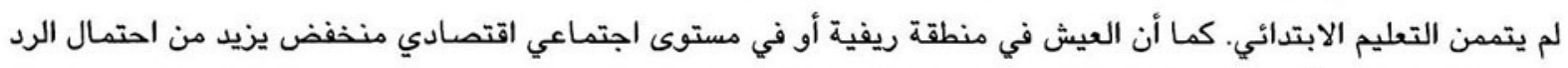

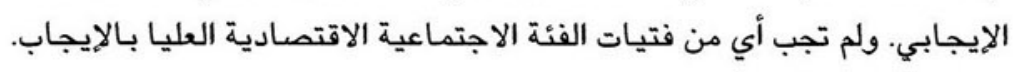

ولعله من غير المفاجئ أن عددا أكبر من الفتيات المتزوجات يعتقدن أن الفتاة تكون مستعدة للحمل في سن الخامسة عشرة

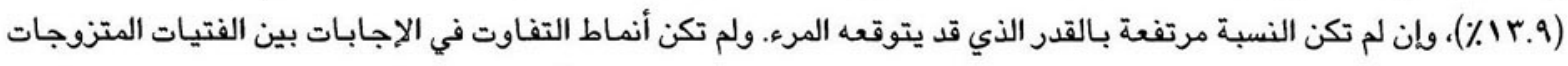

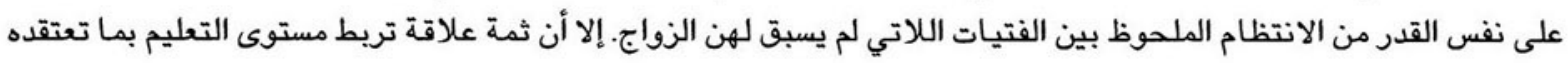

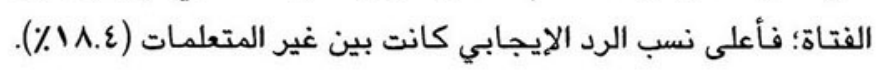




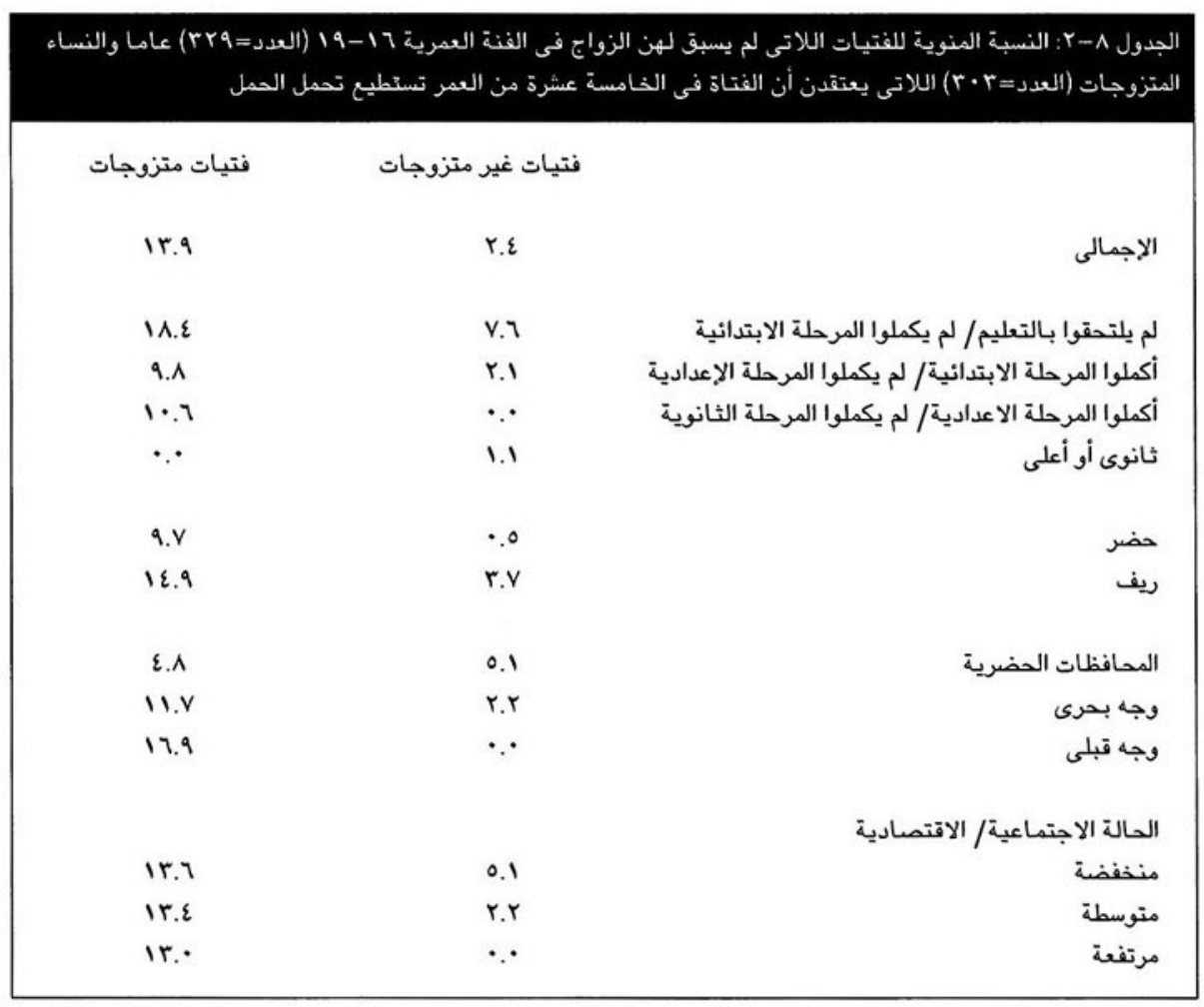

ويبدو بشكل عام أن الفتيات المصريات يدركن أن سن 1 اليست ملائمة للحمل. وإذا أضفنا إلى ذلك ارتفاع السن المثالي للزواج

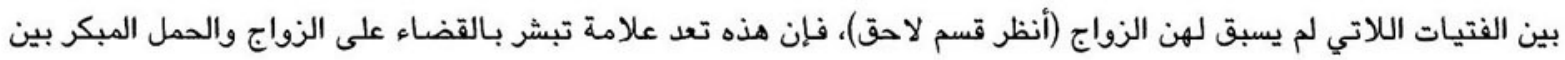
الفتيات المصريات في المستقبل.

\section{معنى تنظيم الأسرة}

شهدت مصر حملة نشطة لتنظيم الأسرة سبقت مولد هذه الفئة العمرية من الفتيات والفتيان. ولما كانت رسائل تنظيم الأسرة

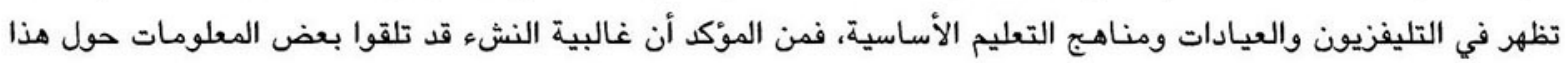

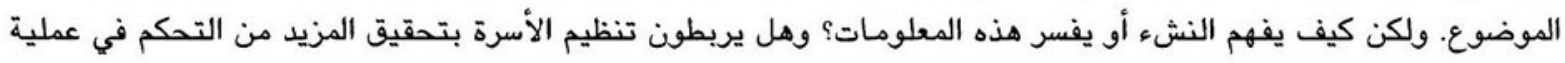

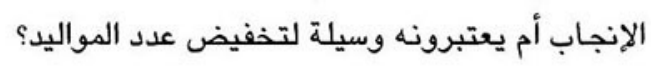

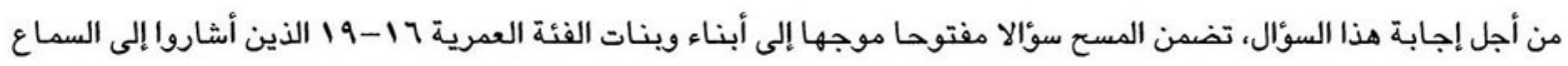

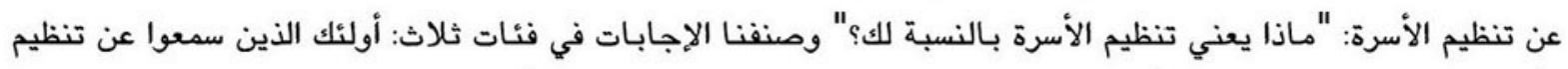

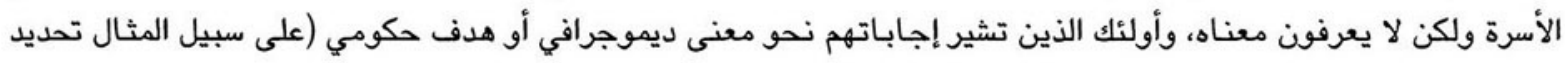

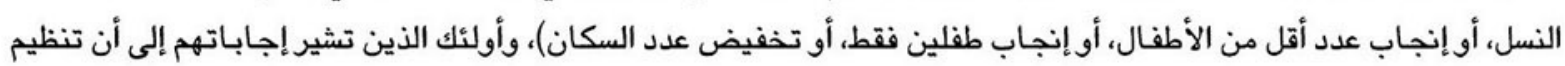

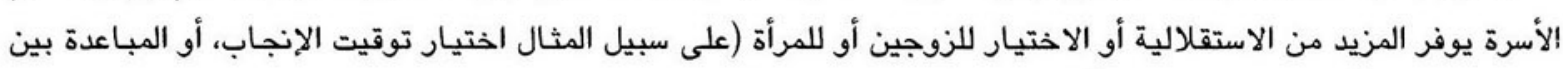

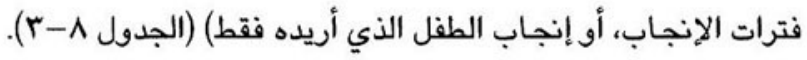

يكاد يذكر جميع الفتيات والفتيان في الفئة العمرية 17 -19 سنة يذكرون أنهم سمعوا عن تنظيم الأسرة، كما أن لأغلبهم آراء حول ما يعنيه. وعلى وجه الإجمال، يميل النشء نحو إعطاء معنى يتصل بالأهداف الديموجرافية أو بتنفيذ سياسة الدولة. 


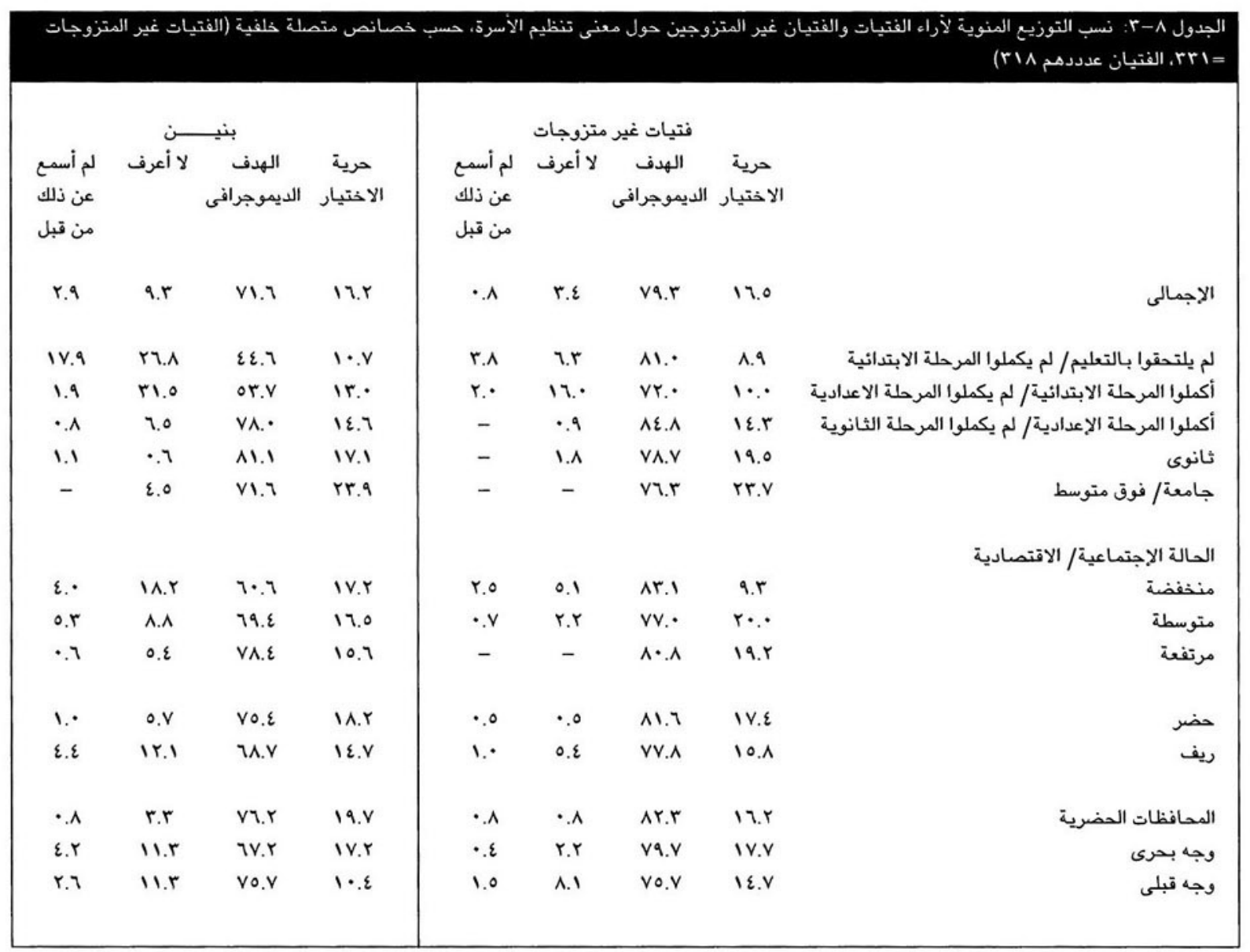

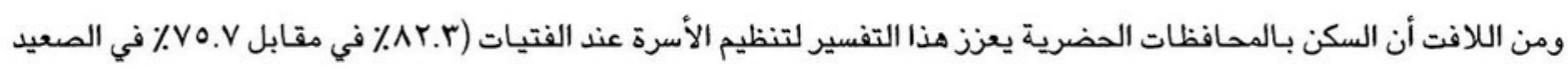

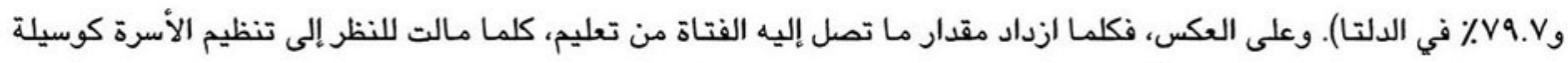

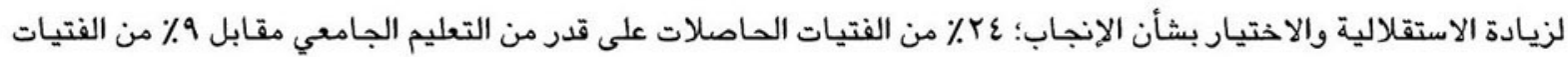

غير المتعلمات.

ويذكر عدد أكبر قليلا من الفتيان مقارنة بالفتيات أنهم لم يسمعوا مطلقا عن تنظيم الأسرة (9.ب٪)، كما أن الفتيان يميلون أكثر

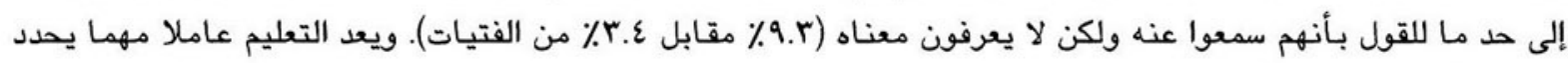

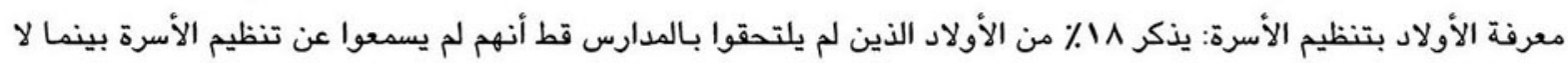

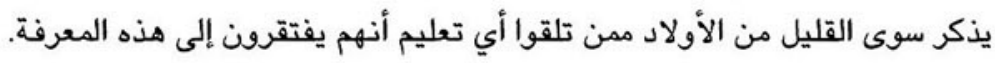

وعلى وجه الاجمال، يعطي الأولاد (مثل البنات) وزنا أكبر للتفسير الديموجرافي لتنظيم الأسرة مقارنة بتفسير الاختيار

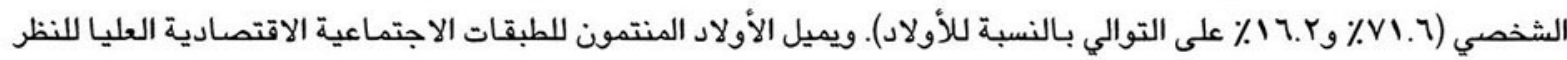

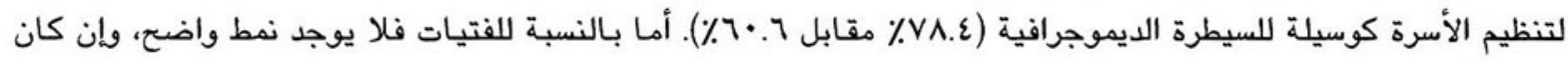

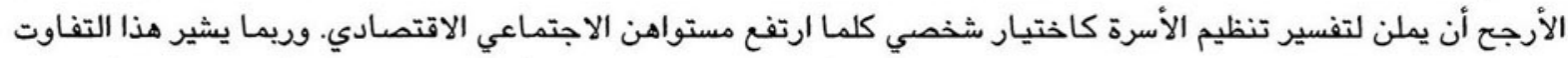

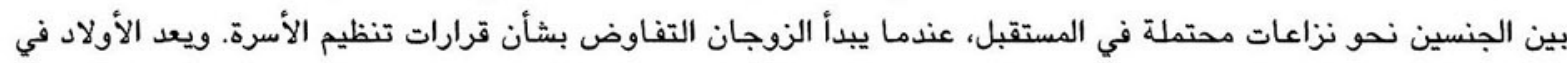

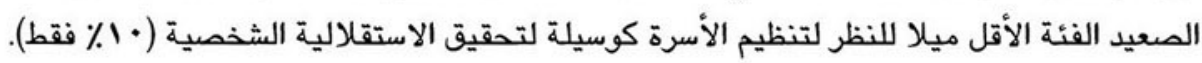


وتماثل الأنماط الخاصة بمعنى تنظيم الأسرة لدى الفتيات المتزوجات تلك الخاصة بـالفتيات غير المتزوجات، أي أن أغلبهن

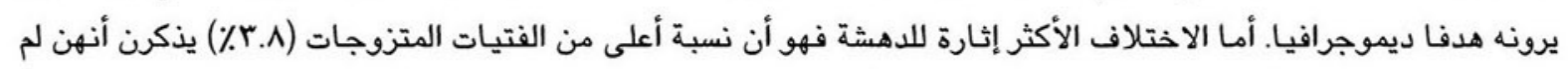

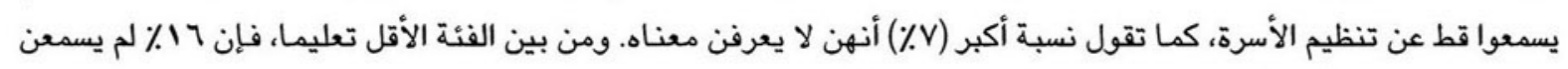

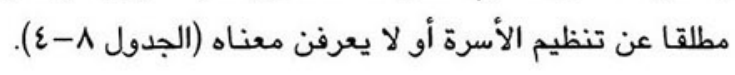

\begin{tabular}{|c|c|c|c|c|}
\hline $\begin{array}{l}\text { ل أعرف } \\
\text { v. }\end{array}$ & 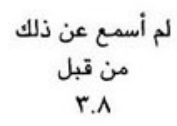 & الهدف الديموجرافى & حرية الختيار & 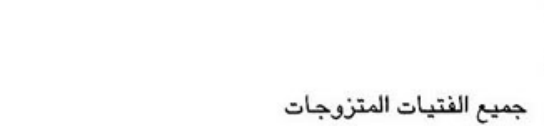 \\
\hline 0.9 & 7.0 & $\cdot r$ & ir.v & لم يلتحقوا بالتعليم/ لم يكملوا المرحلة الابتدائية \\
\hline A. & 1.1 & va.1 & I๕.A & أكملوا المرحلة الابتدائية/ لم يكملوا المرحلة الإعدادية \\
\hline$\because$ & $\because$ & wa.r & ri.v & مؤهل فوق متوسط/ عالى \\
\hline & & & & الحالة لاقتصادى/ الاجتماعى \\
\hline A.r & 0.0 & $v \because \cdot$ & 10.0 & منذفضة \\
\hline T.r & $r . \varepsilon$ & vr.o & 1A. & متوسطة \\
\hline$\because$ & $\because$ & vr. 9 & rา.1 & مرتفعة \\
\hline r. & $\because$ & vv.r & IA.Y & حضر \\
\hline A. & $\varepsilon . \Lambda$ & $v \cdot \cdot$ & iv.r & ريف \\
\hline ६.० & $\because$ & $\Lambda 7 . \varepsilon$ & 9.1 & الححافظات الحضرية \\
\hline 7.1 & 1.0 & vv.r & 10.r & وجه بحري \\
\hline A. & T.r & $7 \varepsilon .1$ & $r \cdot . \varepsilon$ & وجه قبلي \\
\hline
\end{tabular}

\section{المعرفة بوساثل منع الممل والأمراض التي تنتقل عبر الاتمال الجنسي}

\section{المعرفة بوساثل منع الممل}

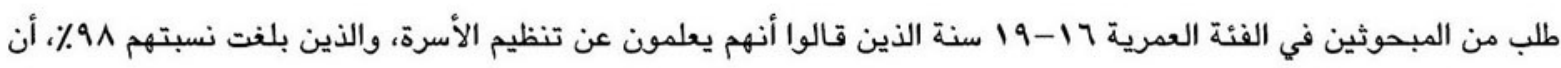

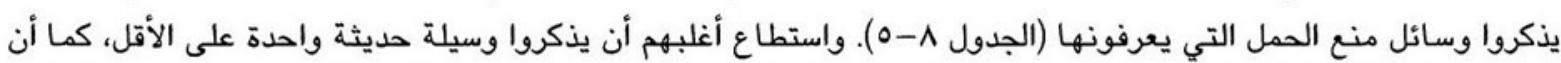

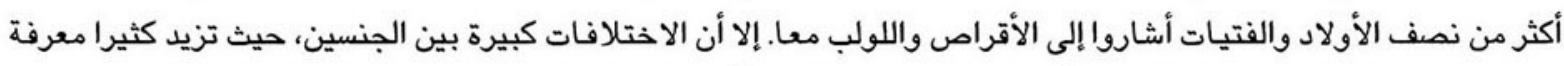

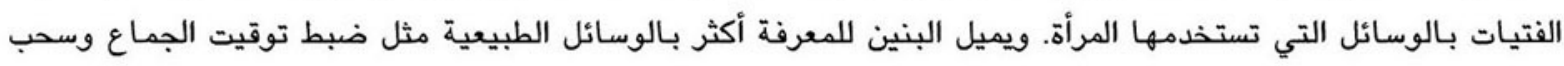

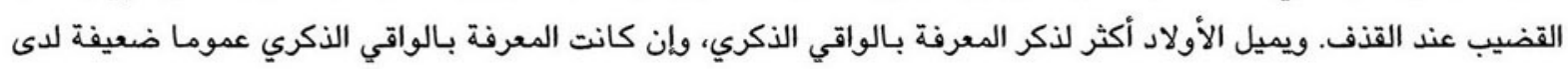

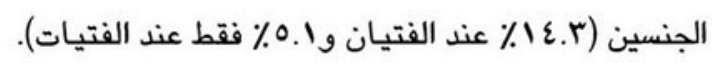

ترتبط معرفة الفتيان بوسائل منع الحمل بمستويات التعليم الأعلى على نحو أقوى مما هو الحال بالنسبة للفتيات. والواقي

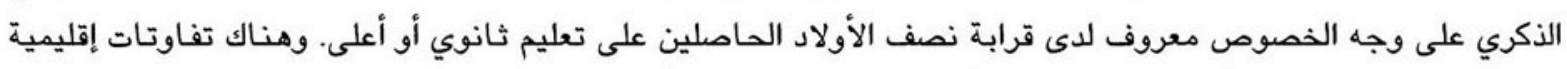

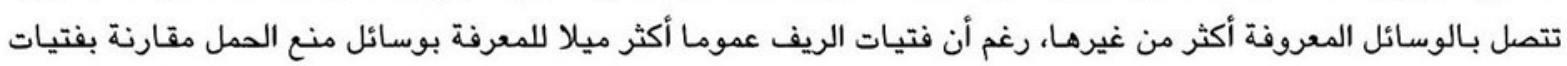
الحضر، بينما العكس صحيح في حالة الفتيان.

تشير هذه النتائج إلى نجاح حملة منع الحمل المصرية في الوصول إلى صغار السن، ليس فقط من خلال المناهج الدراسية وإنما

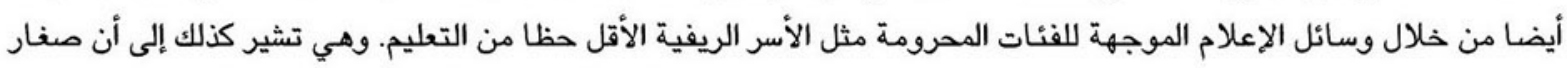

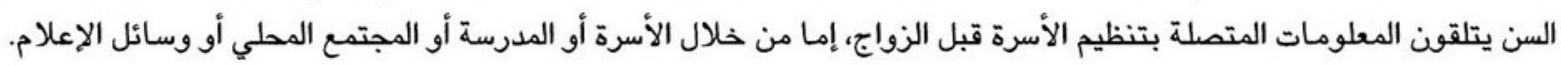


|الجدول 1-0 : النسب المذوية للنشء فى الفنة العمرية 17 - 19 عاما للجنسين الذين يعرفون بوسائل محددة لمنع الحمل (ممن أفادوا يمعرفتهم بتنظيم الأسرة)

\begin{tabular}{|c|c|c|c|c|c|c|c|c|c|c|}
\hline \multicolumn{2}{|c|}{ 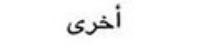 } & \multicolumn{3}{|c|}{ العازل الذكرى } & الحقر & \multicolumn{2}{|c|}{ 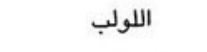 } & \multicolumn{2}{|c|}{ 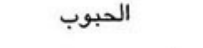 } & \\
\hline 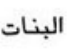 & 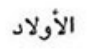 & 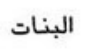 & 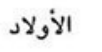 & 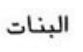 & الأولاد & 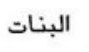 & 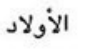 & 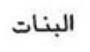 & الأولاد - اد & \\
\hline W.r & rr.o & 0.1 & IE.r & 77.1 & rn.o & $9 \cdot .1$ & vv. & $q Y . V$ & $\wedge 0 . V$ & الإجمالى \\
\hline & & & & & & & & & & الحالة التعليمية للنشء النش \\
\hline $1 \mathrm{~V} .1$ & rA.\& & 1. & - & $7 \cdot .7$ & rr.l & 10.9 & $\varepsilon\urcorner . r$ & $\wedge 7.9$ & $\wedge \varepsilon\urcorner$. & لم يلتحقوا بالتعليم/ لم يكملوا المرحلة الابتدائية \\
\hline$r .1$ & ro.r & - & v.V & vr.v & $r r .1$ & $9 \mathrm{r}$. & $\wedge 9 . \mathrm{V}$ & $91 . r$ & VA.r & أكملوا المرحلة الابتدانية/ لم يكملوا المرحلة الاعدادية \\
\hline $9 . r$ & ro.r & I.v & 1.1 & 71.9 & rA.A & 91.0 & $\checkmark 1 . \wedge$ & १६.। & $v v . v$ & أكملوا المرحلة الإعدادية/ لم يكملوا المرحلة الثانوية \\
\hline $1 . \varepsilon$ & ri.r & $0 . \varepsilon$ & 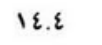 & vi.1 & rv.v & 19.1 & vา. & $97 . \varepsilon$ & $\wedge \wedge . \varepsilon$ & 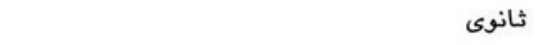 \\
\hline w.V & rา.7 & 17. & $r 0.9$ & $\operatorname{ir} . \wedge$ & $\varepsilon r . \wedge$ & 91.0 & Qr.r & 91.0 & $9 r . r$ & فوق متوسط/جامعة \\
\hline & & & & & & & & & & الحالة التعليمية لأولياء الأمود \\
\hline$\cdots . r$ & rา. & r.r & $\varepsilon . r$ & $r \varepsilon .1$ & $r \varepsilon .9$ & ^1.० & vr. & 91.9 & $\wedge 1.7$ & لم يلتحقوا بالتعليم/ لم يكملوا المرحلة الابتدائية \\
\hline v.1 & rv.r & 0.9 & $10 . r$ & vา. & rr.r & $\Delta r .9$ & V^.^ & $90 . r$ & 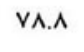 & أكملوا المرحلة الابتدائية/ لم يكملوا المرحلة الاعدادية \\
\hline r.v & $1 \because$ & $0 . \varepsilon$ & - & $v r$. & $1 \because$ & 91.9 & $v \cdot \cdot$ & $\cdots \cdot$ & $\wedge \cdot \cdot$ & أكملوا المرحلة الإعدادية/ لم يكملوا المرحلة الثانوية \\
\hline 9.1 & 10.9 & A.1 & ro. & u.r & $\varepsilon 0.0$ & 9 r.o & $\wedge 1 . \wedge$ & $9 \mathrm{r} .0$ & $9 \cdot .9$ & ثانوى \\
\hline หา.7 & $r 0.1$ & Ir.r & $\varepsilon 0.9$ & ir.r & o\&.1 & $9 r .9$ & 91.9 & $\wedge V . \Lambda$ & 91.9 & فوق المتوسط/جامعة \\
\hline $17 . r$ & $r v, r$ & ᄉ. & rา. & $.7 r$ & rA.o & $\wedge \wedge . \varepsilon$ & $\wedge r . \Lambda$ & $\wedge \wedge .9$ & $\wedge \vee\urcorner$. & حضر \\
\hline$\Lambda .1$ & $r r$. & $r \cdot r$ & $\varepsilon . \wedge$ & IV.A & $r \varepsilon . q$ & 91. & vr.r & १ะ.१ & $\wedge \varepsilon, r$ & ريف \\
\hline $17 . r$ & $r \varepsilon$. & v. & $r r . v$ & ir.o & $\varepsilon \wedge .1$ & 19.1 & 10.7 & ^७. V & $\wedge 9 . \varepsilon$ & المحافظات الحضرية \\
\hline 7.0 & $r \wedge . \varepsilon$ & $\varepsilon .1$ & $7 . r$ & 79.9 & $r r .1$ & $A v \cdot \cdot$ & $v 1.1$ & 90.9 & Ar.v & وجه بحرى \\
\hline $1 \varepsilon . \varepsilon$ & IV.A & $0 . \cdot$ & A.r & $7 r .1$ & $r+1$ & 90.7 & $\vee 9.1$ & $9 Y .0$ & $\wedge 0 . V$ & وجه قبلى \\
\hline
\end{tabular}




\section{المعرفة بالأمراض التي تنتقل عبر الاتمال الجنسي}

مع انتشار وياء الإيدز، صار المصريون أكثر تعرضا للحملات الإعلامية التي تشرح مخاطر الأمراض التي تنتقل عبر الاتصال

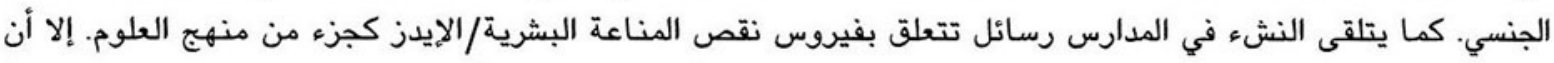

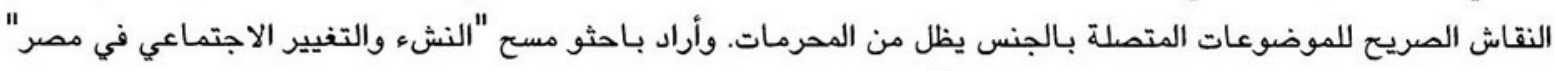

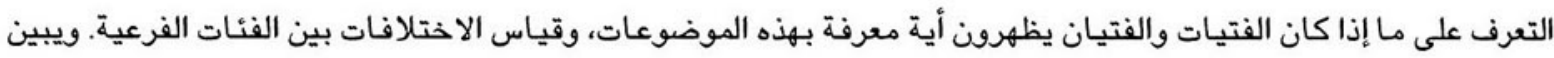

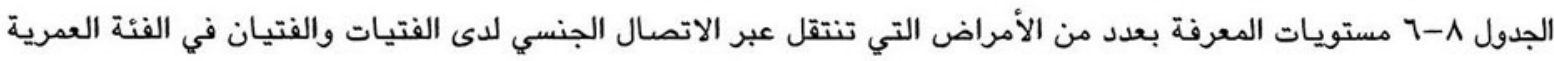

وعلى وجه الإجمال، كان فيروس نقص المناعة المكتسبة/الايدز هو المرض المعروف أكثر من غيره بين تلك الأمراض، حيث

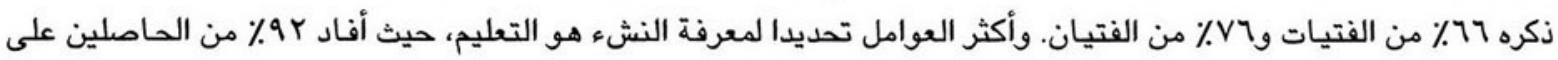

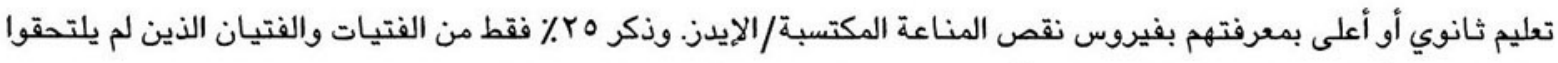

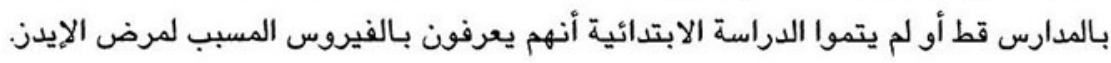

وتظهر الفتيات عموما معرفة أقل من الفتيان بالأمراض التي تنتقل عبر الاتصال الجنسي، باستثناء التهابات الجهاز التناسلي.

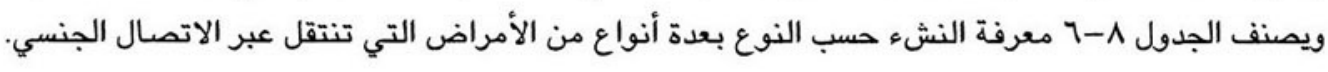

وكما ذكرنا من قبل، سمع الكثير من الفتيات والفتيان عن فيروس مرض الإيدز، إلا أن عددا أقل كثيرا يشير إلى معرفة واسعة

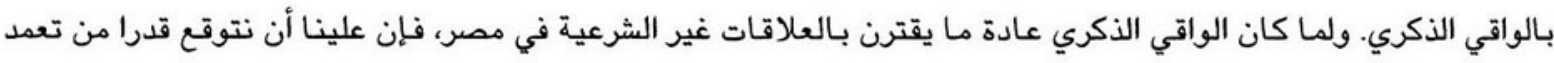

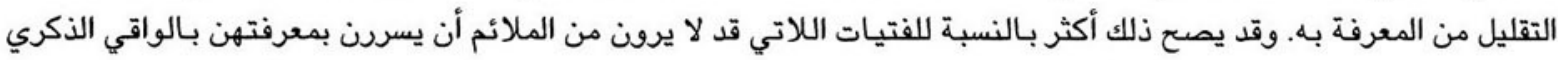

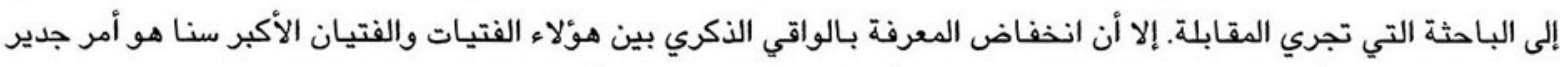

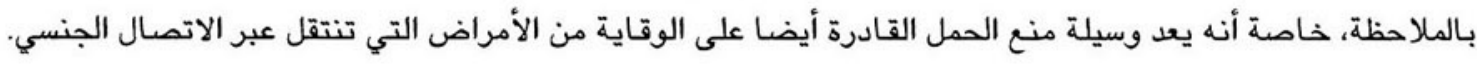




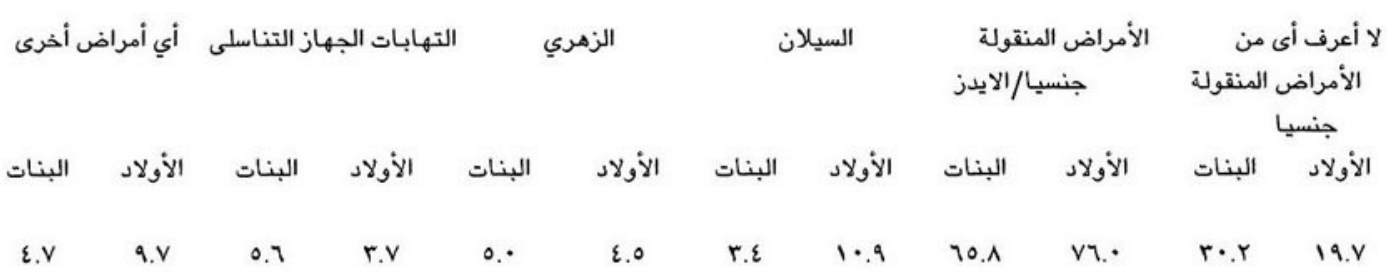

\begin{tabular}{|c|c|c|c|c|c|c|c|c|c|c|}
\hline V. $\varepsilon$ & $0 . \varepsilon$ & A.7 & 1.1 & - & - & - & 1.1 & YA.\& & rv.o & 77. \\
\hline r.. & O.r & $\varepsilon . \cdot$ & $r . \varepsilon$ & - & - & - & I.V & $\varepsilon \varepsilon .{ }^{\circ}$ & $0 \wedge .7$ & هา. \\
\hline r. & 9.r & r.o & r. 1 & - & r. & - & $9 . r$ & Ir.r & VV.o & rr.r \\
\hline v. 9 & Ir.o & $\varepsilon . \Lambda$ & 7.r & 0.0 & 0.1 & r. & Ir.o & VA.A & $10 . \wedge$ & IN.T \\
\hline - & $1 \cdot r$ & v.o & - & IV.Y & Ir.Y & 11.1 & ro. & $q \cdot r$ & q\{.1 & r.r \\
\hline
\end{tabular}

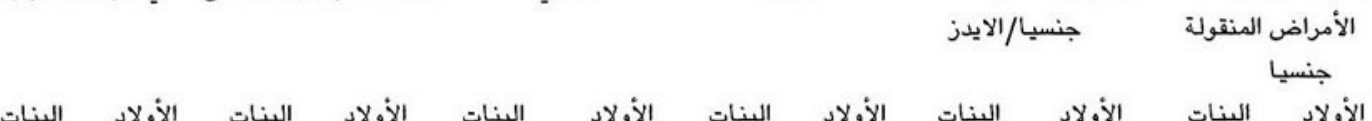

\begin{tabular}{|c|c|c|c|c|c|c|c|c|c|c|c|c|}
\hline$\varepsilon . \vee$ & $\varepsilon\urcorner$. & A.r & r.V & 1.7 & 1.0 & 1.7 & $0 . \varepsilon$ & $\circ \vee .7$ & \urcorner$\varepsilon . \varepsilon$ & rv.v & ri. & لم يلتحقوا بالتعليم/ لم يكملوا المرحلة الابتدائية \\
\hline A. 7 & rI.A & I.r & V.V & 9.9 & r.ı & T.r & $10 . \varepsilon$ & vi. & 91. & 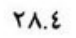 & $7 . \varepsilon$ & أكملوا المرحلة الابتدائية/ لم يكملوا المرحلة الاعدادية \\
\hline- & t.r & - & - & r.ı & - & - & ir.o & vา.9 & vo.e & rr.i & ro.e & أكملوا المرحلة الإعدادية/ لم يكملوا المرحلة الثانوية \\
\hline r. & $1 \cdot . r$ & - & $\varepsilon .1$ & Iध.r & ir.r & IE.r & $r$ r.\& & $\wedge 1.7$ & $9 r .9$ & A.r & $\varepsilon .1$ & 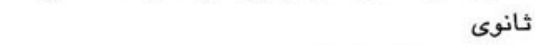 \\
\hline ר.r & ir.o & $1 \cdot \varepsilon$ & - & $1 \cdot \varepsilon$ & r.. & r.1 & ro.1 & vV.1 & $\cdots \cdot$ & 17.8 & - & فوق المتوسط/.جامعة \\
\hline $7 . \varepsilon$ & 9.1 & $\varepsilon .9$ & $r .9$ & V. 9 & $v . v$ & 0.9 & ri.7 & va.r & $\wedge \wedge .0$ & $17 . r$ & A.V & 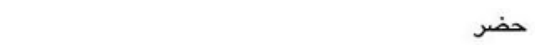 \\
\hline$r . r$ & $1 \because$ & 7. & $\varepsilon . r$ & r. & r.r & I.V & $r .9$ & o.v & 71.8 & ra.v & rA. & ريف \\
\hline 7.1 & 1.. & 7.1 & $\varepsilon . \vee$ & A.r & $9 . \varepsilon$ & 7.1 & ro.r & $\wedge \uparrow . \varepsilon$ & $9 r .1$ & 7.1 & $r .9$ & المحافظات الحضرية \\
\hline r.1 & $M . r$ & 0.7 & $r .9$ & $r . \varepsilon$ & $r .1$ & $r .1$ & $r .9$ & $\pi . \varepsilon$ & 77.9 & ry.1 & rq.r & وجه بحرى \\
\hline 1.0 & 0.1 & 0.1 & $\varepsilon . r$ & $\varepsilon . r$ & $\varepsilon . r$ & r.r & 11.9 & or. 7 & vv.1 & $\varepsilon r . \wedge$ & 17.9 & وجه قبلى \\
\hline & & & & & & & & & & & & الحالة الاجتماعية/ الاقتصادية \\
\hline r.o & $\varepsilon .9$ & v.o & $\varepsilon .9$ & $1 . v$ & 1. & I.v & 0.9 & or.o & vi.1 & $\varepsilon r .0$ & rr.o & منخفضة \\
\hline$\varepsilon . r$ & 11.7 & V.r & r.o & $r .9$ & $1 . v$ & $r .7$ & 11. & $09 . \varepsilon$ & TV. $\varepsilon$ & $r \varepsilon .1$ & rV.q & متوسطة \\
\hline 7.9 & $\Lambda . \wedge$ & $r .9$ & $r . \varepsilon$ & १.६ & $1 \because$ & $\varepsilon .9$ & 10.9 & VV.A & AV.I & 19.8 & 11.1 & مرتفعة \\
\hline
\end{tabular}

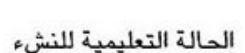

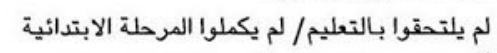

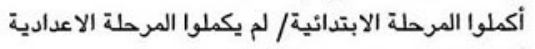

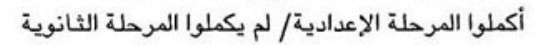
(1) الحالة التعليمية لأولياء الأمور

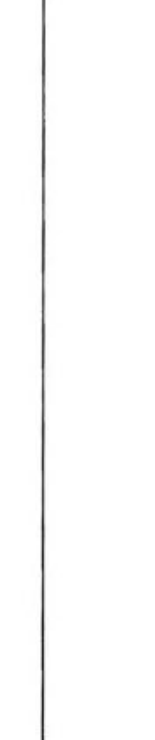




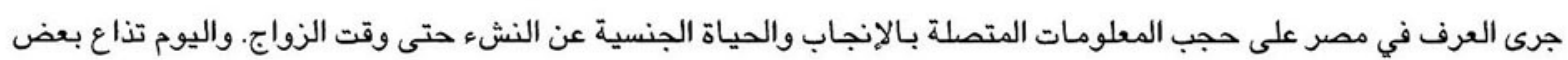

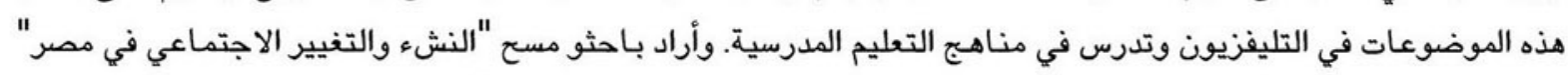

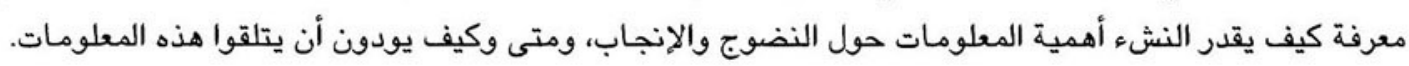

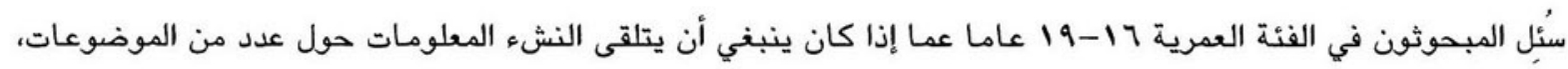

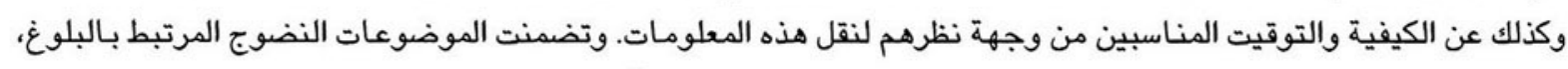

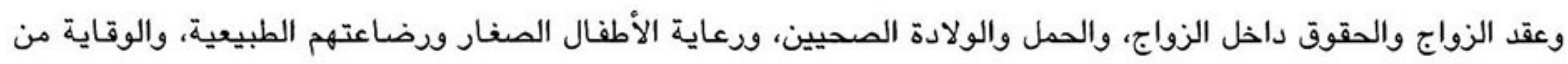

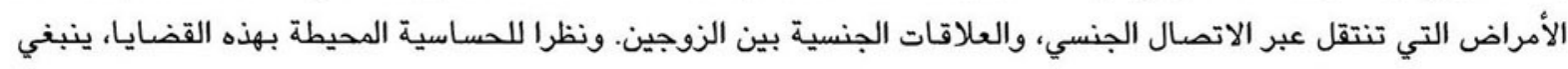

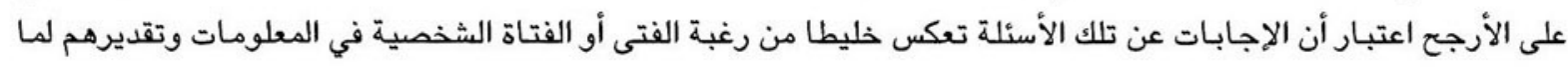

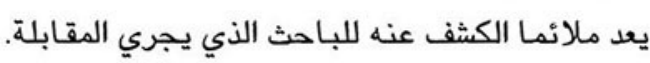

\section{ما هي المعلومات التي ينبغي أن يحمل عليها النشء؟}

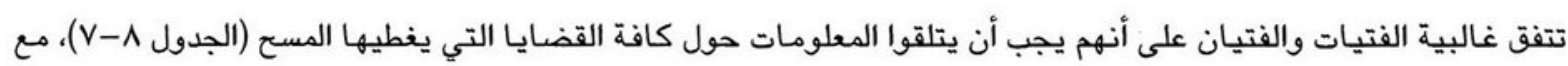

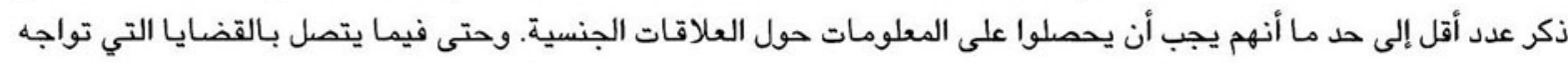

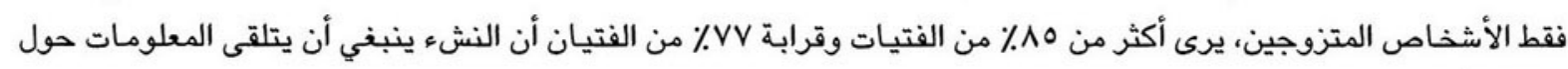
رعاية الأطفال الصغار ورضاعتهم الطبيعية.

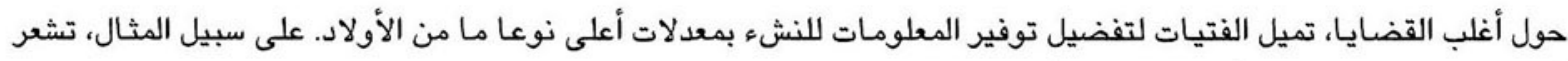

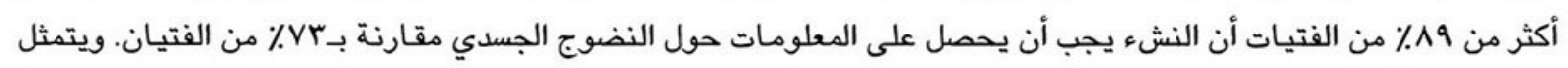

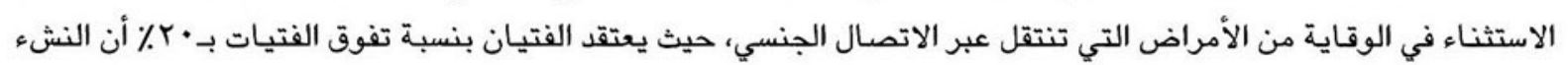

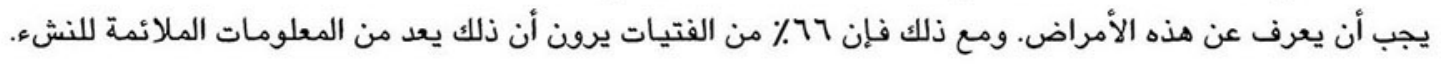

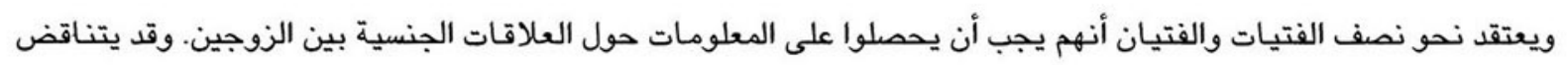

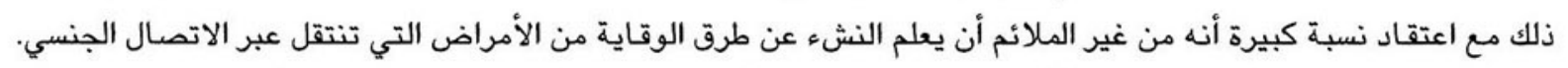

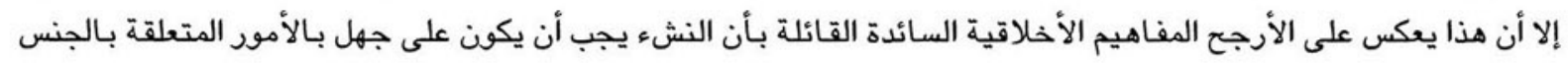
لحين الزواج.

تتأثر آراء النشء على ما يبدو بعدد من العوامل المتعلقة بالخلفية الاجتماعية. ويتعلق أحد الفروق غير المتوقعة بين الفتيات

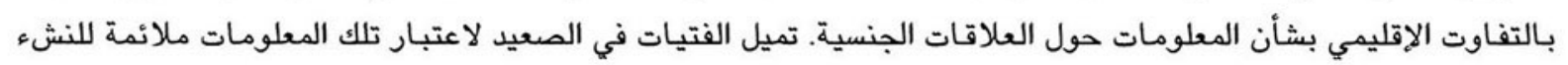

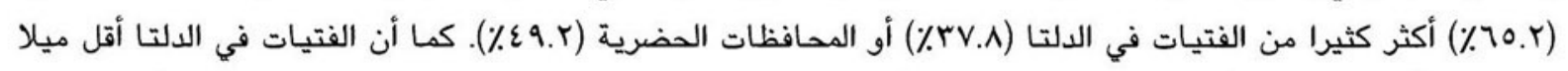

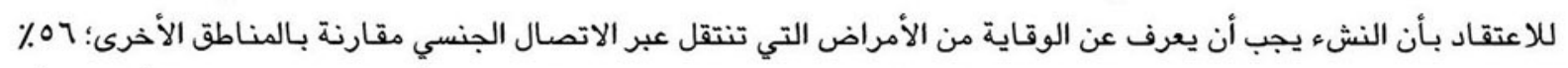

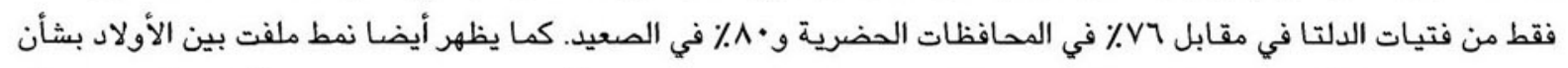

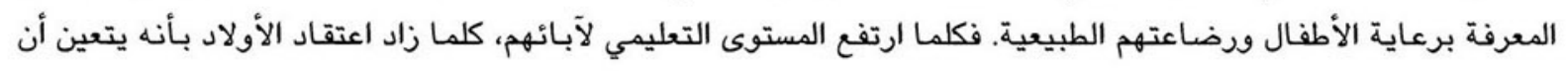

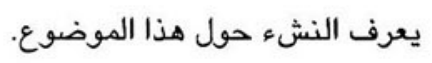




\begin{tabular}{|c|c|c|c|c|c|c|}
\hline \multicolumn{3}{|c|}{ التوقيت المناسب لعرض هذاسبة ما هلو المعلومات } & \multicolumn{3}{|c|}{ من يكون مصدر المعلومات مناسة } & \\
\hline البنات & الأولاد & 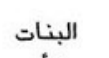 & ال الأولاد & البنات & الأولاد & \\
\hline قبل حدوث & 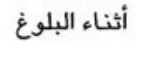 & الأم & الأب & А१. & Vr.o & التغيرات الفسيولوجية المصاحبة للنضوح \\
\hline بعل الطمث حدث & قبل البلوغ & & الصديق & & & \\
\hline ق قبل الزواج & ق قبل الزواج & الأأب & الأب & vา.A & $A \cdot . r$ & حقوق الزواج \\
\hline قأ أثناء الحمل & 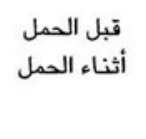 & الد الدكتور & الأكتور & $\Delta v .0$ & vir & الحمل والولادة \\
\hline 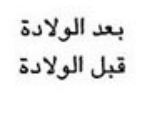 & قبل الولادة & الدكتور & الألب الأب & $\wedge \circ . \mathrm{V}$ & vา. 9 & الرضاعة والاهتمام بالطفل \\
\hline أثناء الخصوية & قبل الخصوية & الدكتور & الدكتور الأب & 70.1 & $\wedge \circ . \vee$ & الحماية من الأمراض المنقولة جنسيا \\
\hline 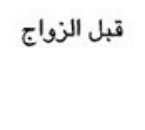 & 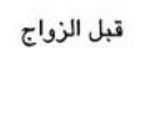 & الأم & الدالب & $\varepsilon \wedge . r$ & $\varepsilon\urcorner .0$ & العلاقة الجنسية بين الزوجين \\
\hline
\end{tabular}

\section{ما مو التوقيت السليم لحمول النشء على المعلومات؟}

وُجهت للنشء الذي أقر بأن الفتيات والفتيان يجب أن يحصلوا على المعلومات أسئلة حول التوقيت الذي يرونه ملائما للمعرفة

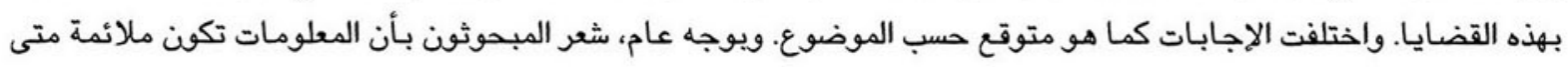

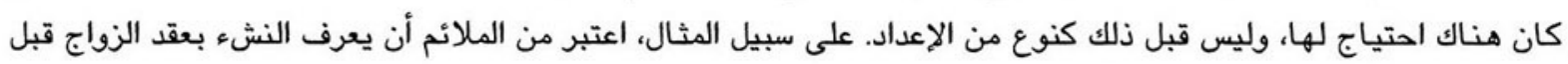

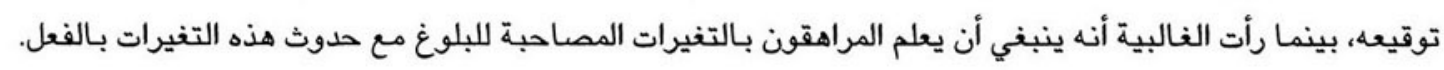

وكان عدد الفتيات اللاتي رأين أن الفتيات يجب أن يعرفن بالنضوج الجسدي قبل حدوث الطمث أكثر قليلا فقط ممن اعتقدن أن

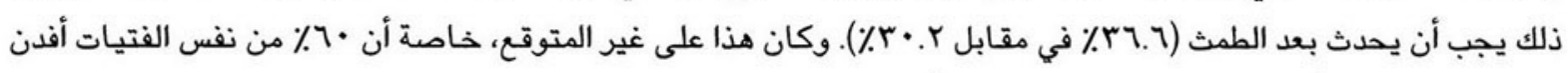
بشعورهن بالخوف أو الصدمة عند حدوث الطدث لأول مرة.

أما فيما يتعلق بالعلاقات الجنسية والوقاية من الأمراض التي تنتقل عبر الاتصال الجنسي، فيبدو أن النشء يرى أنه ينبغي

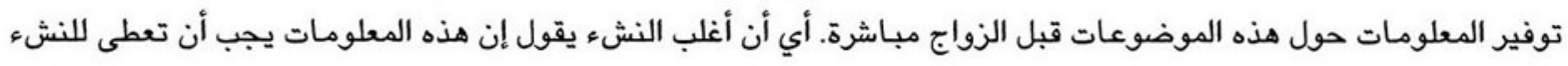

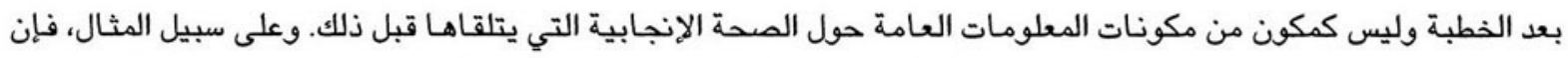

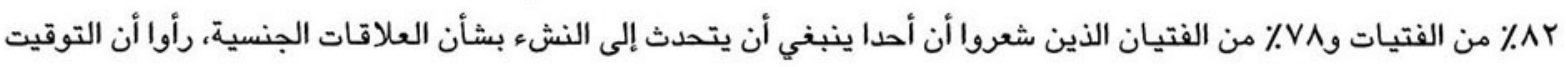
المناسب لتلك النقاشات هو قبل الزواج. 
أعطى الفتيات والفتيان الذين شملهم المسح رسائل واضحة تماما حول مصادر المعلومات المفضلة بالنسبة لهم. وعندما سئلوا

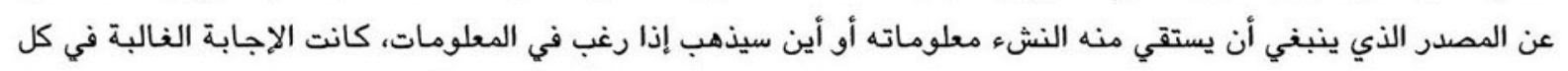

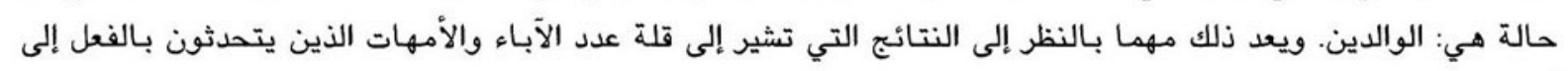

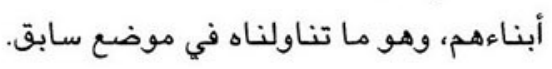

ويبدو أن العوامل المتعلقة باختلاف الخلفيات الاجتماعية تؤدي إلى تنوع تفضيلات النشء، وإن كان ذلك لا يحدث دائما بشكل

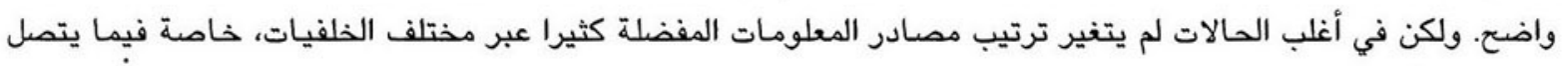

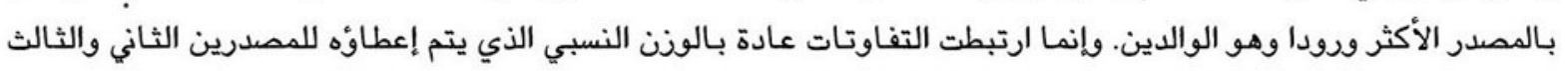

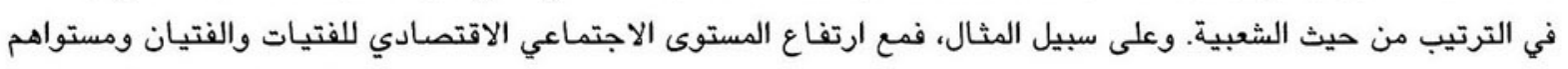

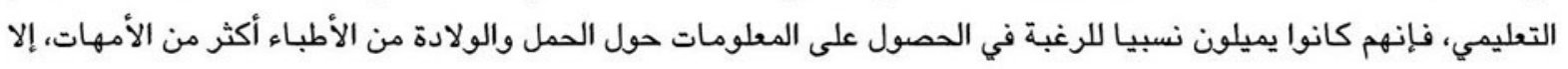

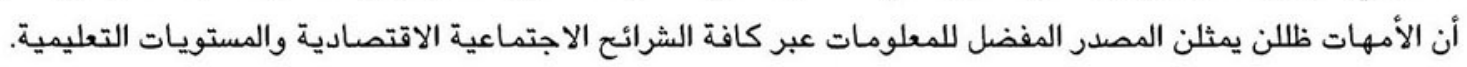

وحيث أن الأمور المتصلة بالحياة الجنسية والصحة الإنجابية تعتبر بصفة عامة من الدحرمات بالنسبة للمصريين غير

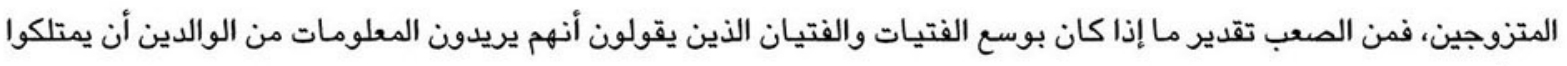

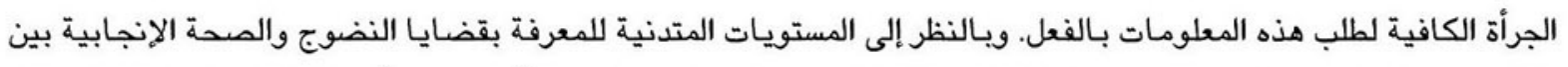

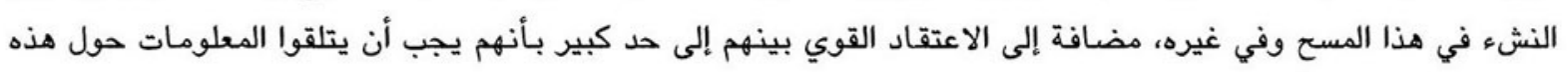

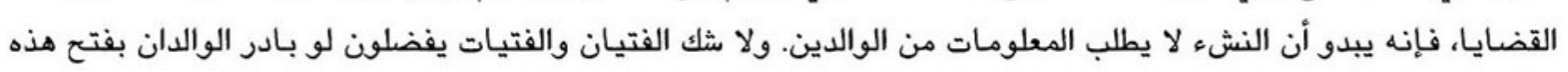

النقاشات.

\section{ثانيا: ممارسات الصحة الانجابية}

ختان الإناث

تنتشر ممارسة ختان الإناث في مصر، وهو يعد تقليدا عميق الجذور تشترك فيه بلدان وادي النيل وأجزاء أخرى من أفريقيا.

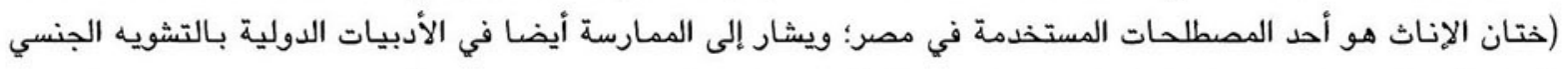

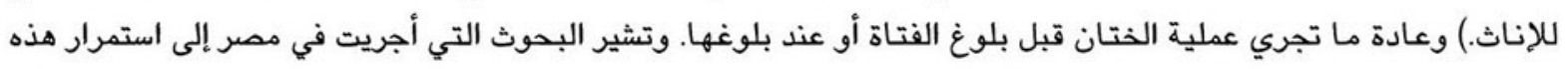

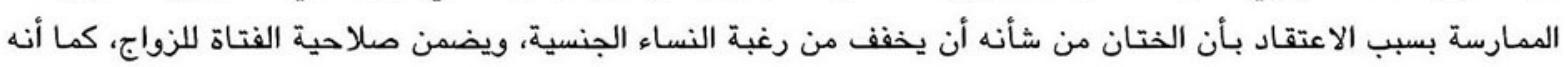

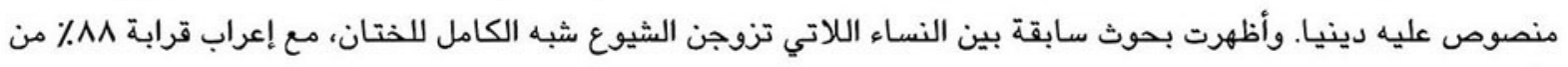

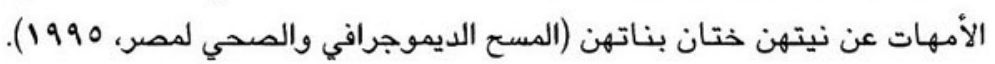

ويبين الجدول ^ی1 معدلات شيوع الختان الخاصة بالفتيات في سن r I سنة أو أكثر موزعة وفقا لعدد من السمات المتعلقة

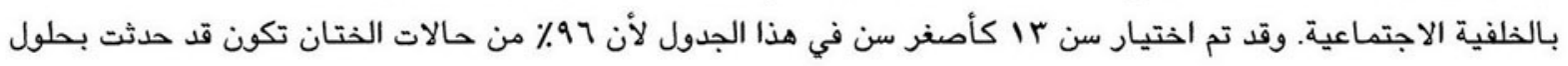




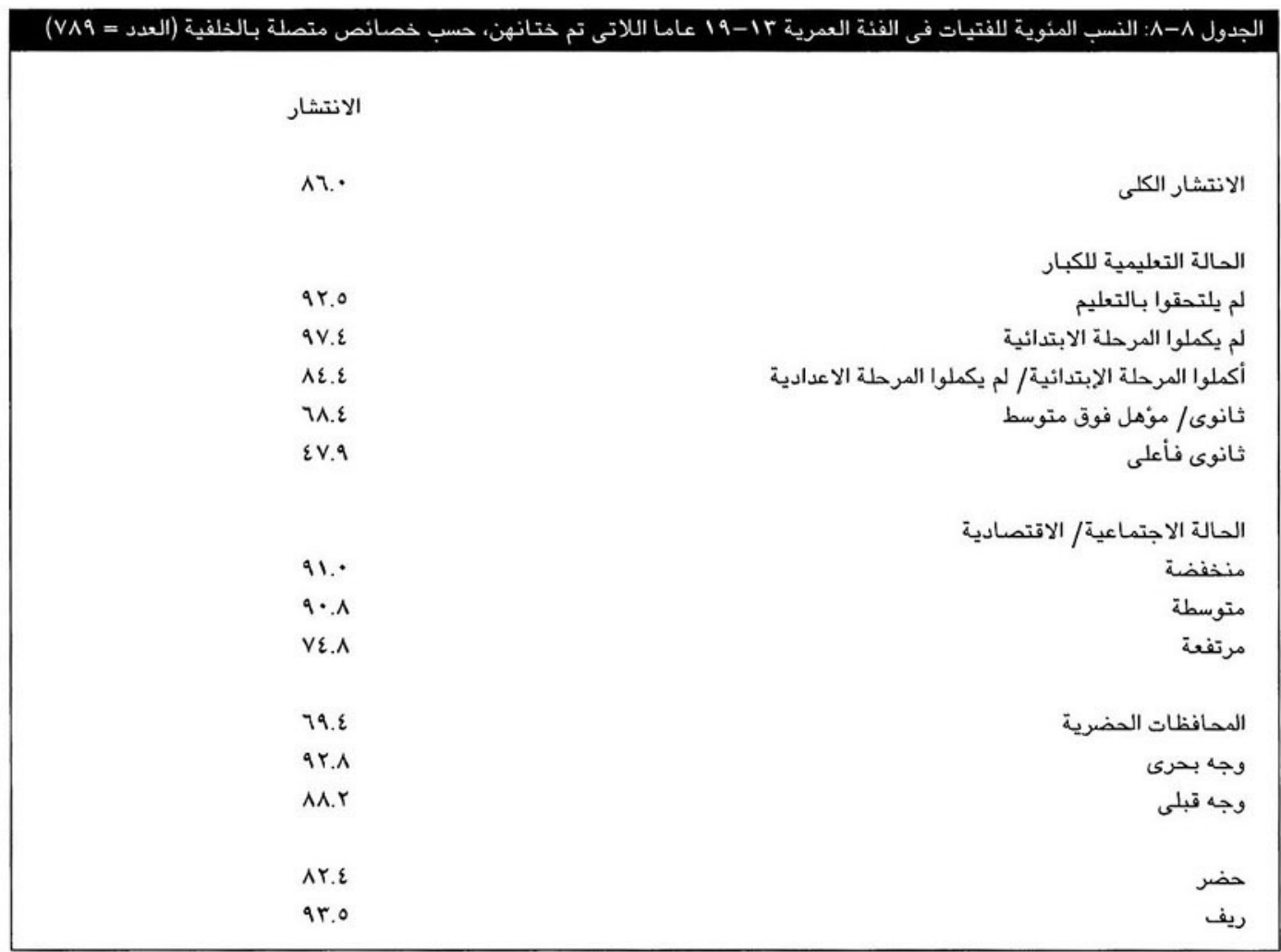

xمستوى المعنوية لاختبارات الفروق الفردية بين المستويات الداخلية لكل متغير من المتغيرات الخلفية >1...

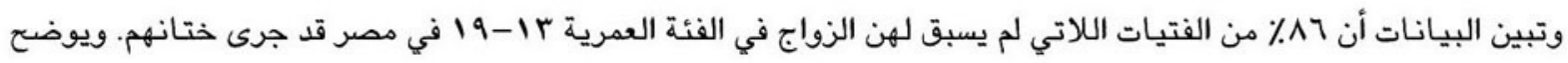

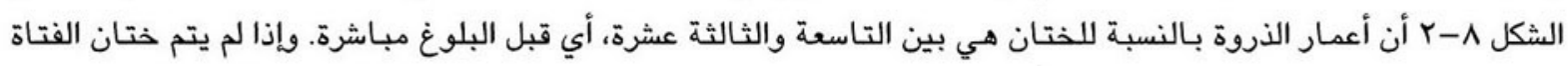

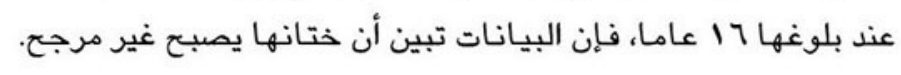

وتمثل نسبة ال 1 ٪ انخفاضـا مقداره عشر نقاط مئوية على الأقل مقارنة بنسبة الشيوع بين المتزوجات صغيرات السن في الفئة

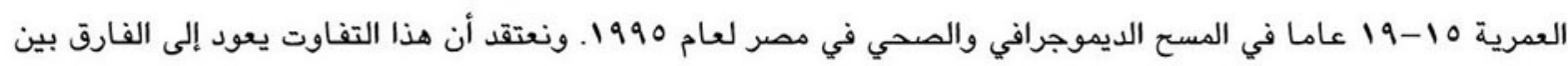

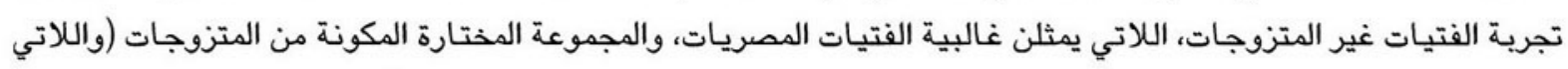

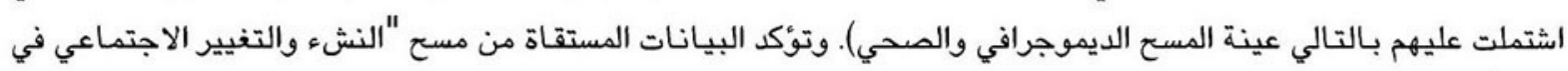

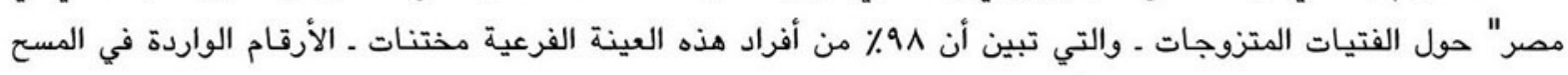

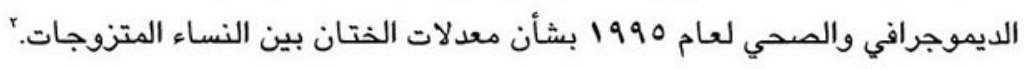

ونظرا للشيوع شبه الكامل لهذه الممارسة بين النساء الأكبر سنا، فمن الههم أن نتعرف على مكان حدوث التغيير بين الفئات

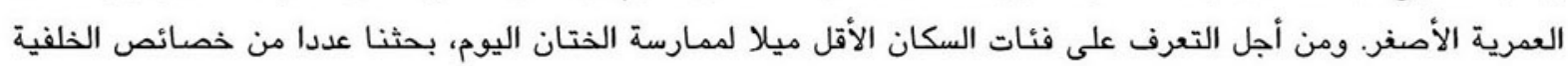
الاجتماعية لنرى أين يتركز الانخفاض. الاصن.

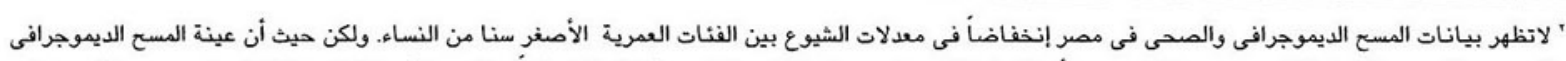

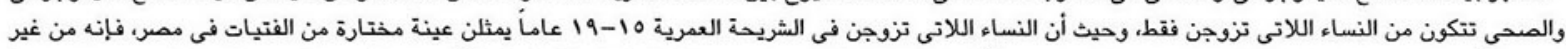

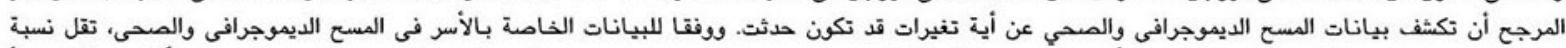

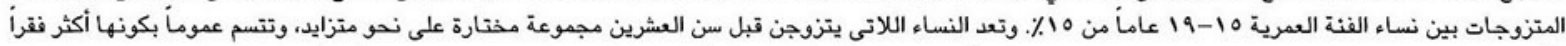

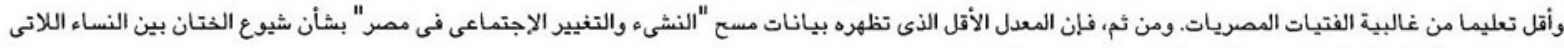
لم يسبق لهن الزواج لايدل على عدم الاتساق بين مجموعتى البيانات. 


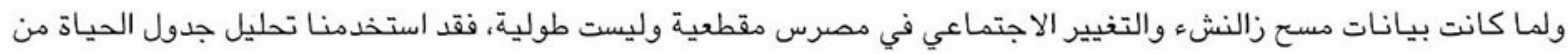

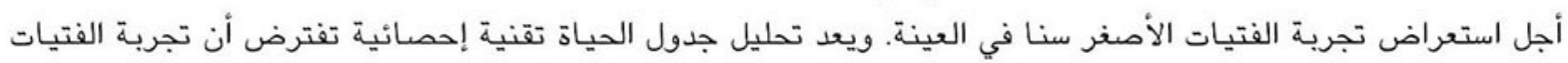

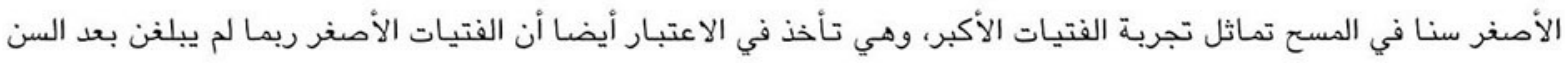

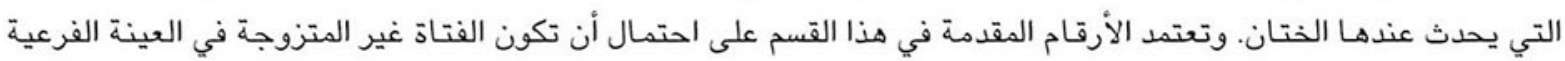
الصحية لمسح زالنشء والتغيير الاجتماعي في مصرس قد تم ختانها.

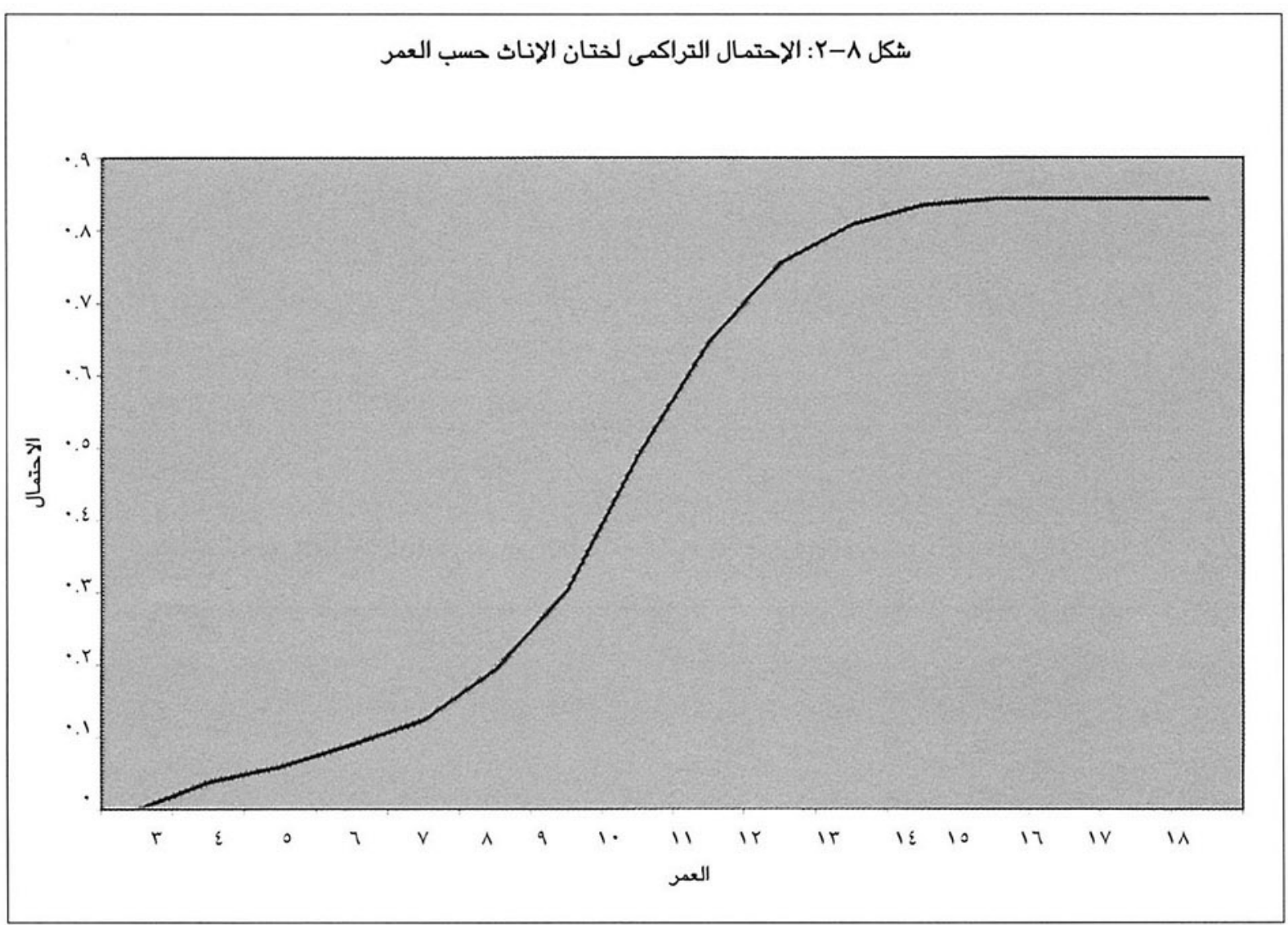

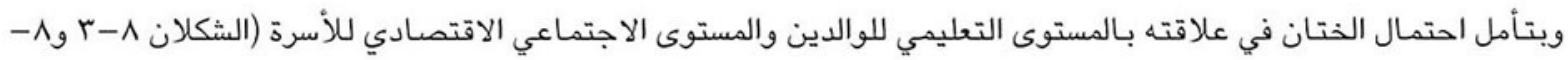

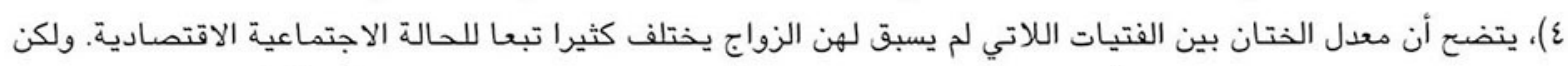

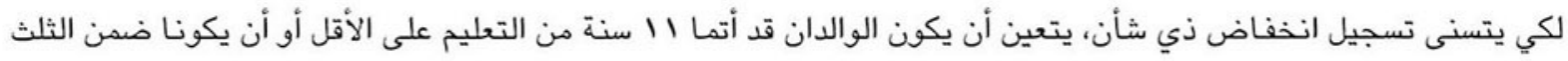

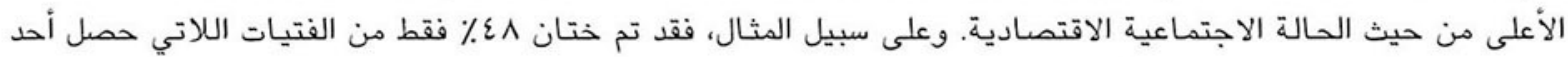

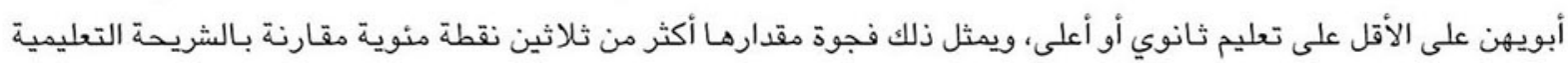

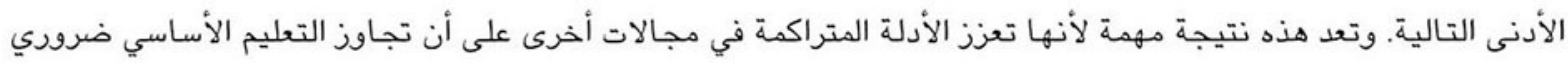

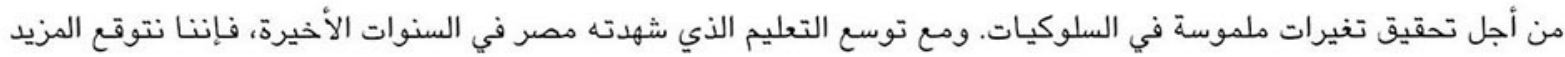
من الانخفاض في معدلات ختان الإناث في المستقبل. 

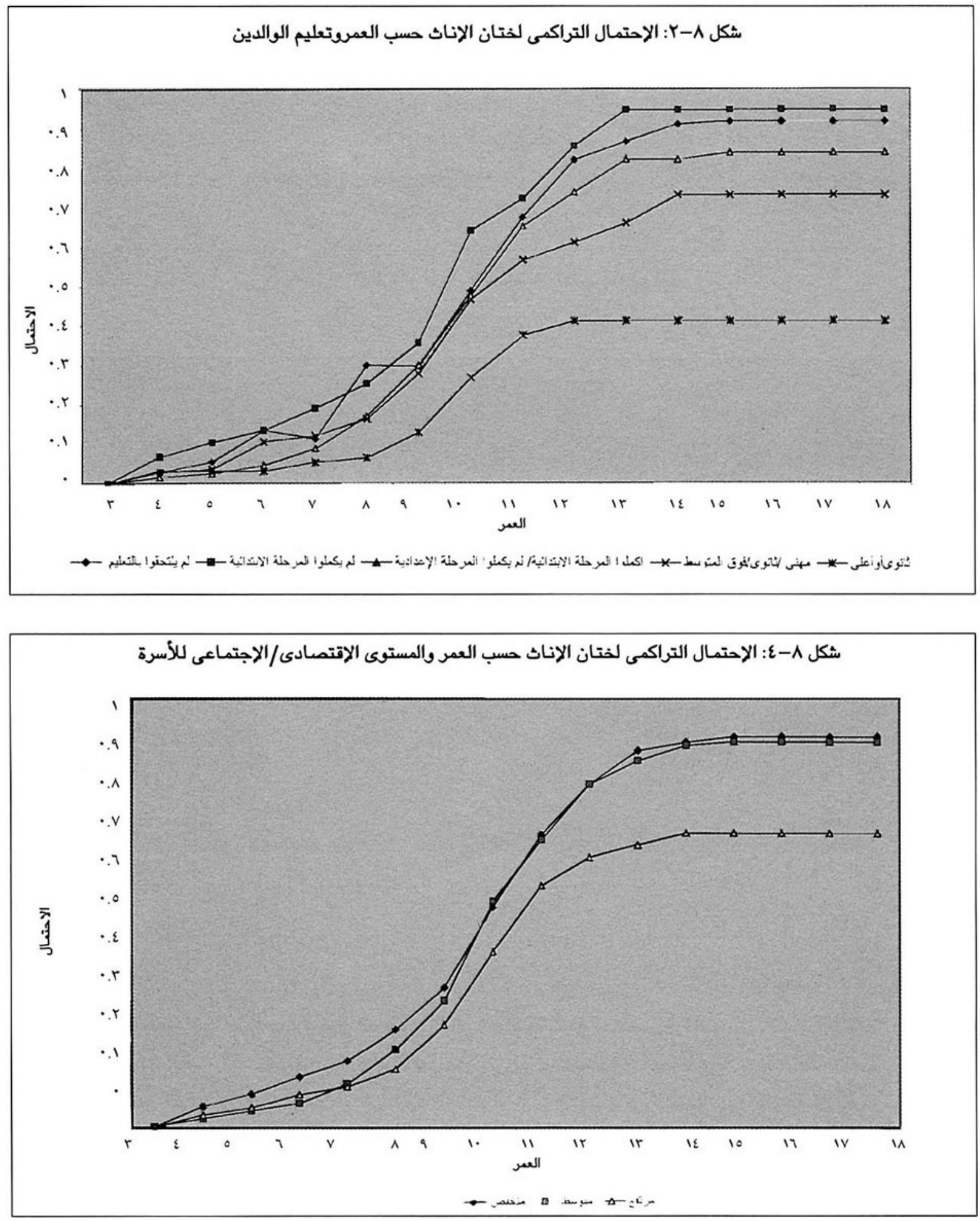

يصعب تحديد اتجاهـات عند التعامل مع البيانات المقطعية. على أننا نرى دليلا إضـافيا على الانخفاض في معدلات الختان عندما نقارن الفتيات الأصغر سنا بـالأكبر سنا مستخدمين تقديرات جدول الحياة. ويبين الشكل ی-ه أن فتيات الفئة العمرية

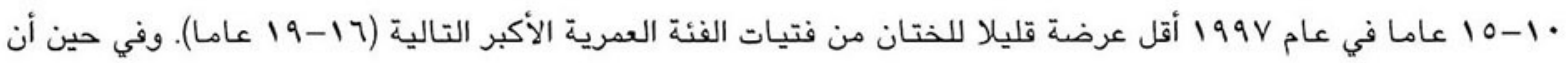
الاختلافات طفيفة، فإن اختلافا في معدل الشيوع مقداره r إلى ع٪ في هذه الفترة الزمنية القصيرة يشير إلى حدوث التفيير. ولكن حيث أن مستوى تعليم الوالدين استمر في الارتفاع على مدى عدة عقود على الأتل، فلماذا يظهر انخفاض واضح في معدل الختان بين هـاتين الفئتين من الفتيـات؟ 
لعل إحدى الفرضيات هي أن الوعي العام بختان الإناث ومدى تأييده قد شهد تغييرا بعد ع99 1، في أعقاب المؤتمر الدولي

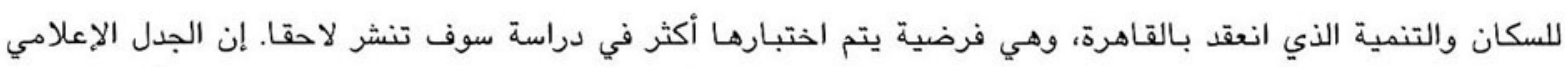

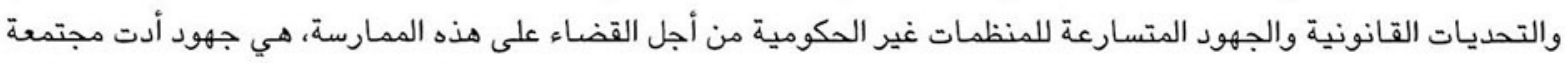

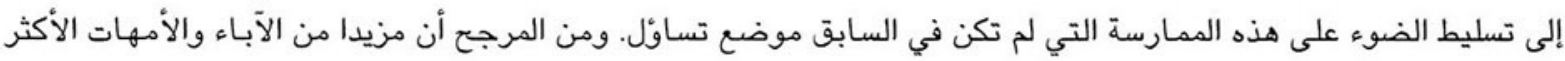

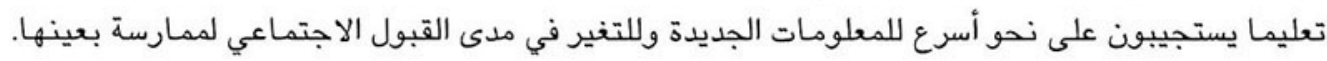

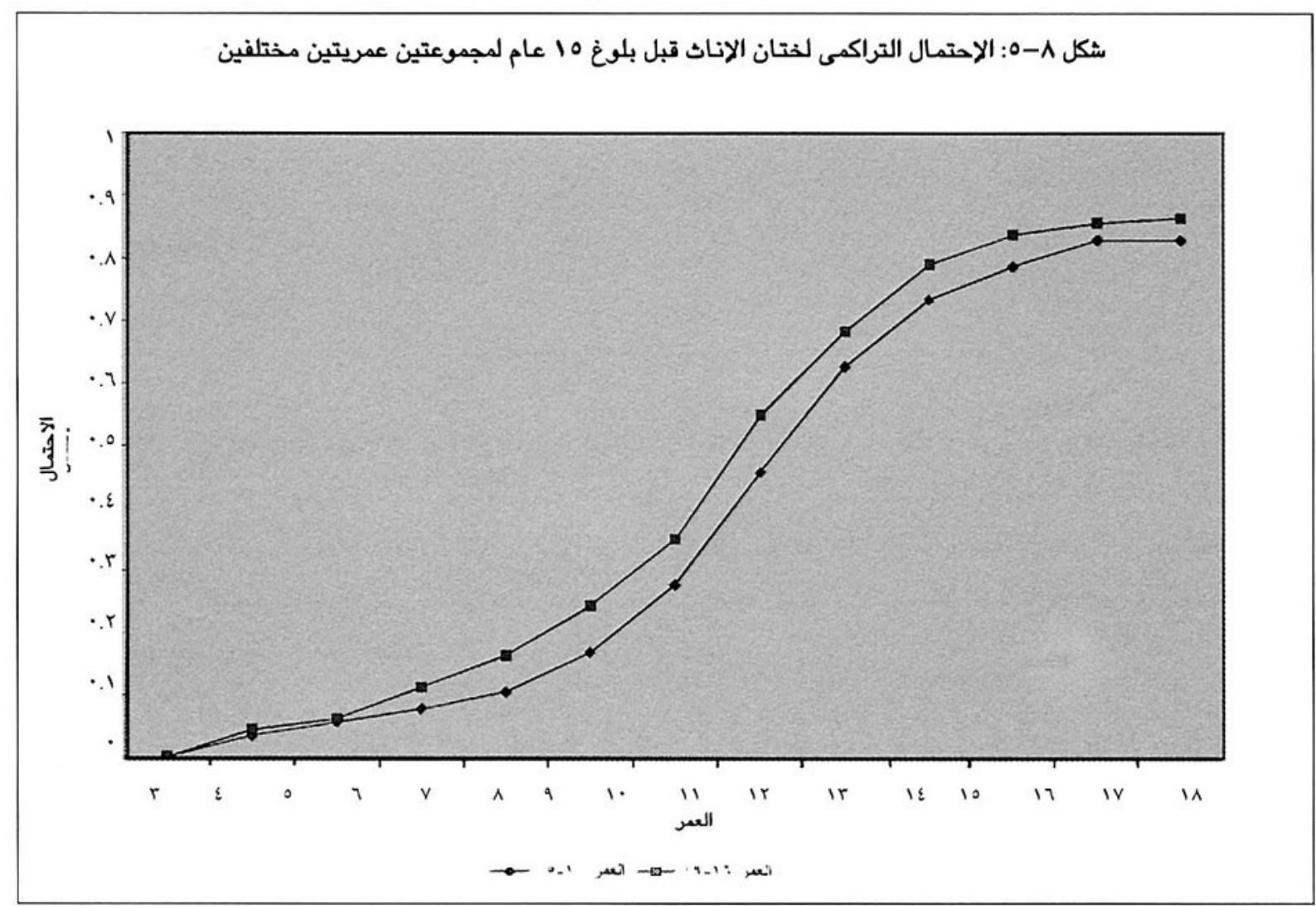

ويوفر مسح "النشء والتغيير الاجتماعي في مصر" أول تقدير على الإطلاق لمعدلات الختان على المستوى القومي بين الفتيات

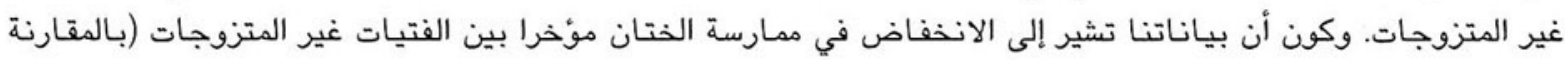

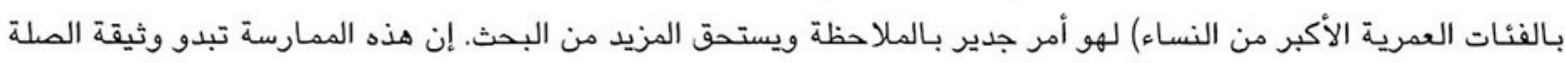

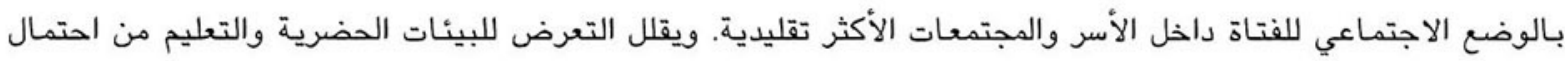

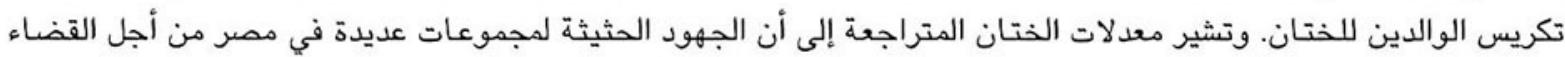
على هذه الممارسة ريما كان لها الأثر الإيجابي.

تأييد الختان

من المفاجئ أن الختان لا يحظى سوى بتأييد ضعيف بين الفتيات غير المتزوجات اللاتي تم ختانهن. سُّلت الفتيات عما إذا كن

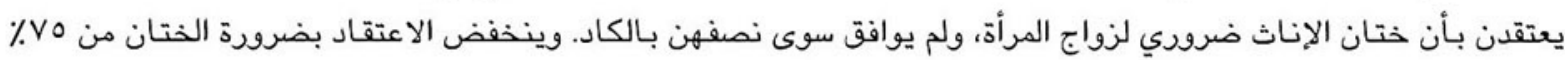

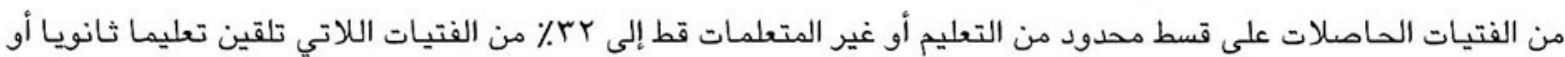

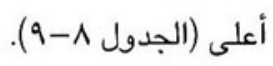




\begin{tabular}{|c|c|c|}
\hline ضرورة الثتان & كلاتى ت & 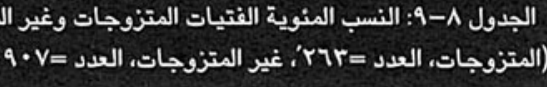 \\
\hline غير متزوجات & وجات & \\
\hline OV.V & A 1.7 & الإجمالى \\
\hline vo. & $90 . r$ & لم يلتدقوا بالتعليم/ لم يكملوا المرحلة الابتدانية \\
\hline ०^.£ & AN.r & أكملوا المرحلة الابتدانية/ لم يكملوا المرحلة الإعدادية \\
\hline o .r. & 71.9 & أكملوا المرحلة الاعدادية/ لم يكملوا المرحلة الثانوية \\
\hline ri.v & - & ثانوى / جامعت \\
\hline$\varepsilon \vee\urcorner$. & 17.0 & حضر \\
\hline Tr.A & 19.1 & ريف \\
\hline$\varepsilon 1.7$ & $1 \cdots \cdot$ & 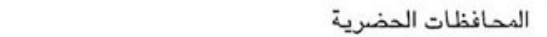 \\
\hline or.o & ᄉา. $\mathrm{r}$ & وجه بحرى \\
\hline$v \cdot .7$ & AN.V & وجه تبلى \\
\hline
\end{tabular}

توجد اختلافات كبيرة في مستويات التأييد الإيجابي للختان بين الفتيات المتزوجات واللاتي لم يسبق زواجهن ممن تم ختانهن

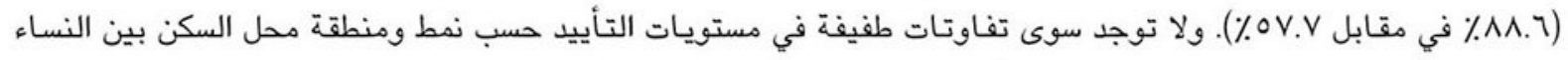

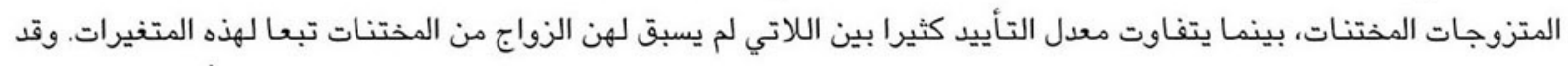

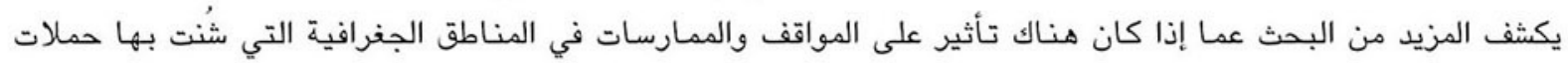

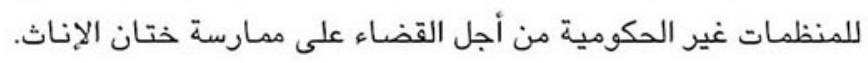

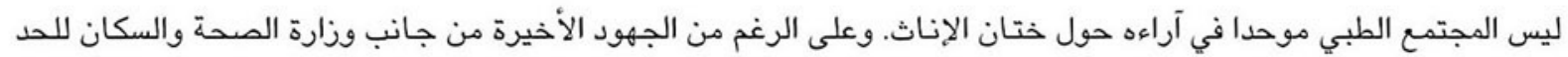

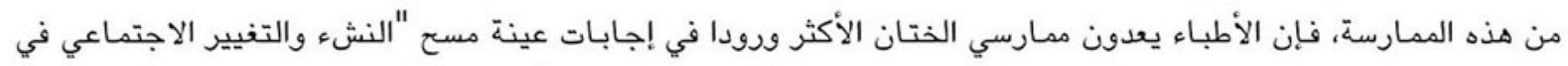

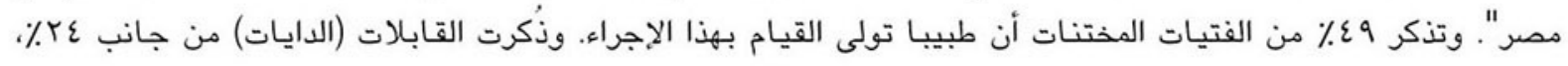

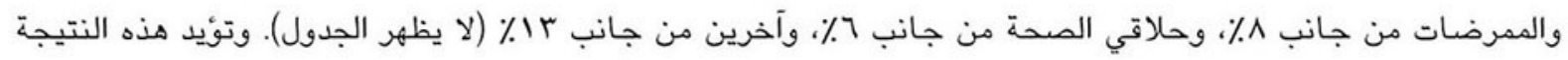

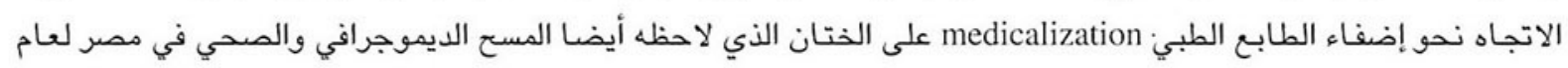

\section{التعامل مع الطمث}

يحدث الانتقال بين عالمي الطفولة والبلوغ تدريجيا على مدى عدة سنوات. إلا أن بدء الطمث يمثل حدثا بالغ التأثير بالنسبة للفتيات. وقد يكون رد فعل الفتيات على هذا الحدث المهم وكيفية تعاملهن معه بعد ذلك مؤشرا على كيفية مواجهتهن مستقبالا للأحداث الإنجابية الأخرى التي سيتعرضن لها على الى امتداد تجربتهن الإنجابية.

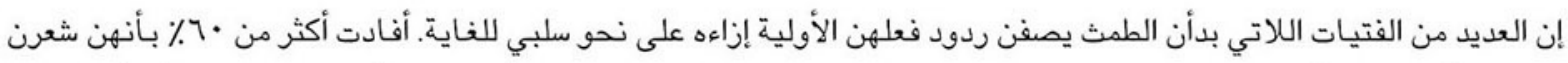

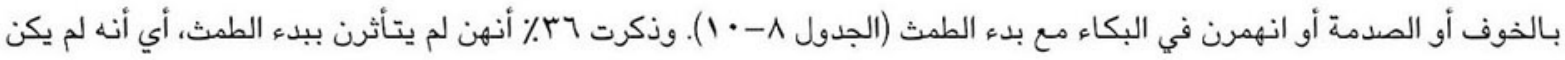

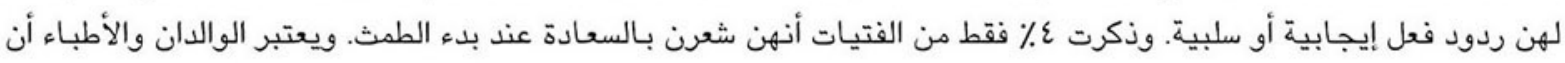

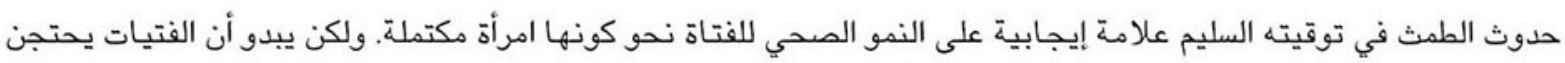

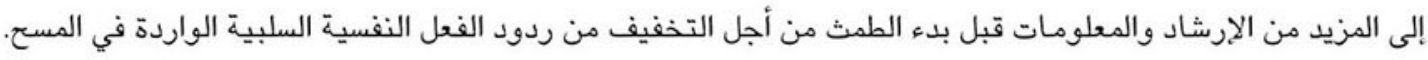




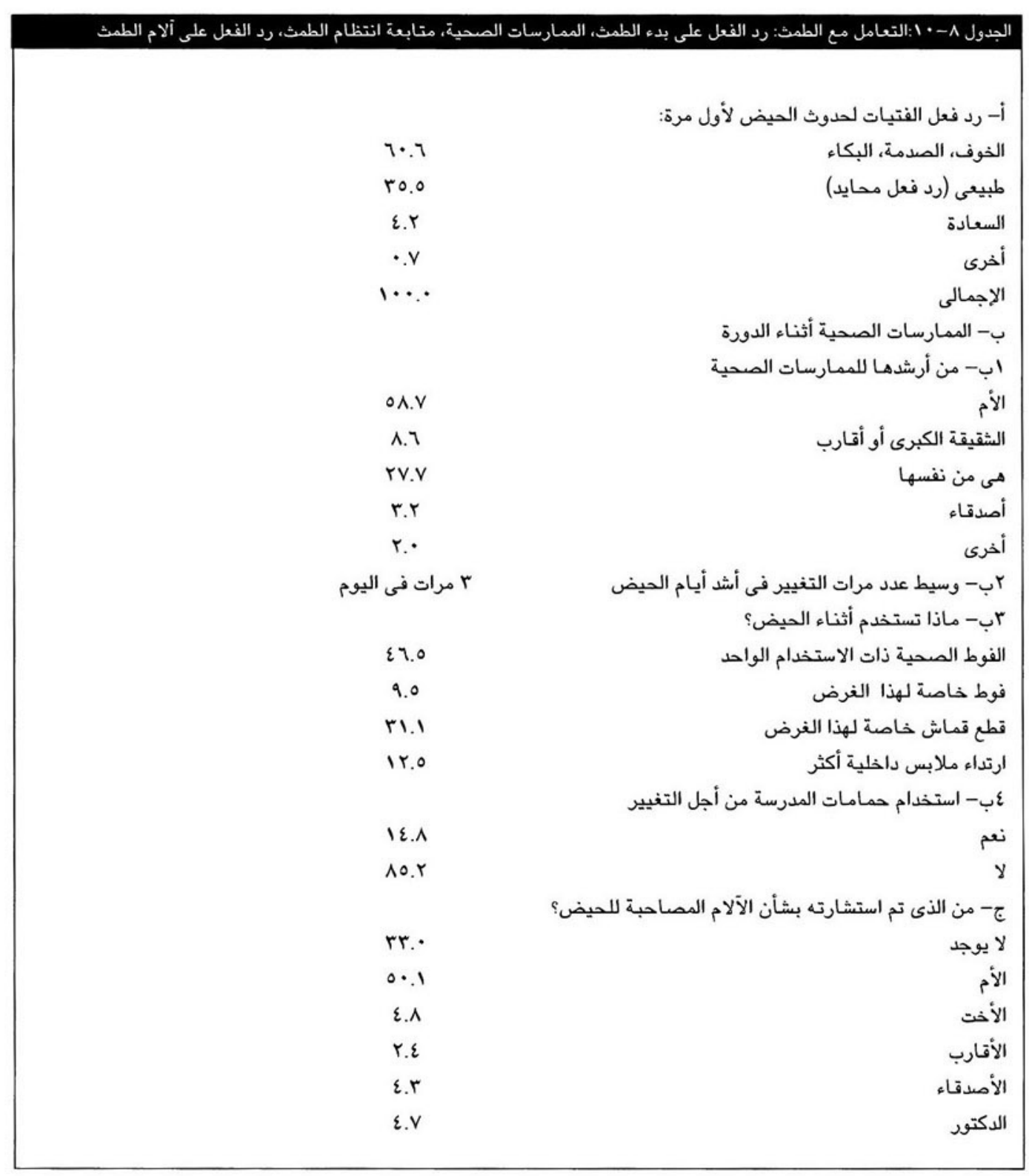

ومع بدء الطمث، تصبح الممارسات الصحية الإضافية جزءا من الأنشطة الاعتيادية للفتيات. وتساعد الممارسات الصحية أثناء

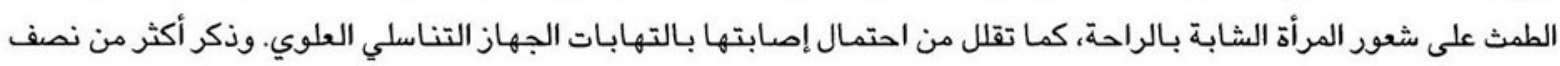

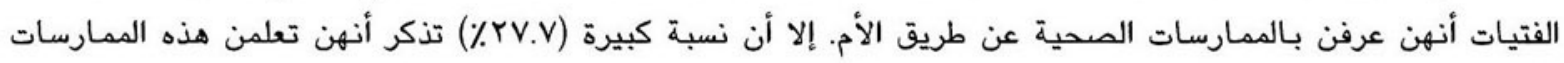

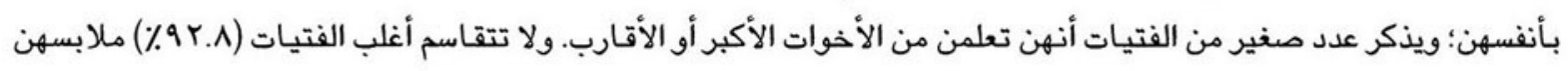

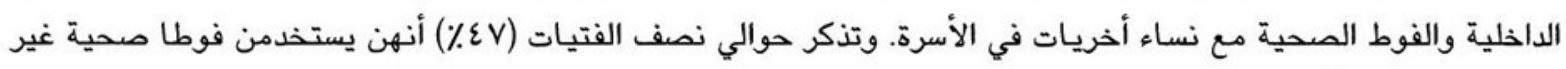

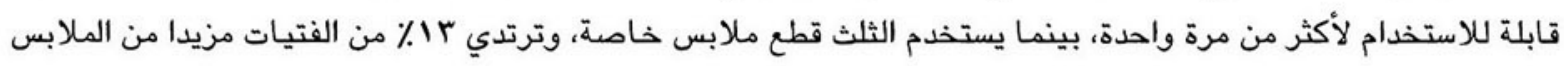

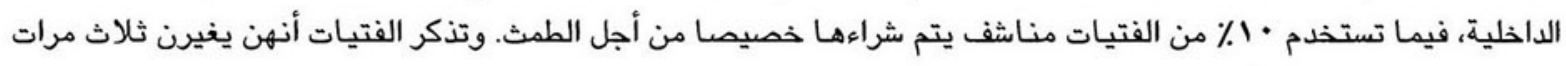
يوميا في المتوسط خلال أقصى حالات الطمث.

ومن النتائج الجديرة بالذكر أن 1 1٪ فقط من الفتيات يذكرن أنهن يستخدمن دورات المياه المدرسية لتغيير الفوط الصحية

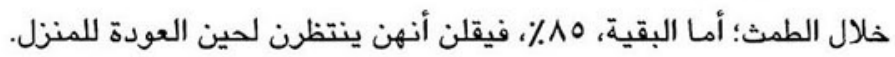


في الأدبيات الطبية، يحتسب طول الدورة الشهرية من اليوم الأول للطمث حتى بدء الطمث التالي. وتتراوح الدورات المعتادة بين

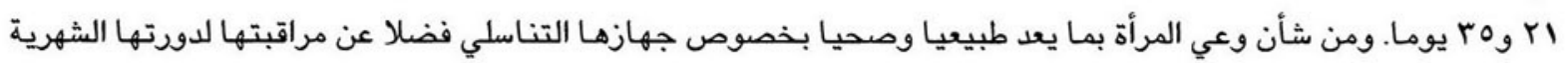

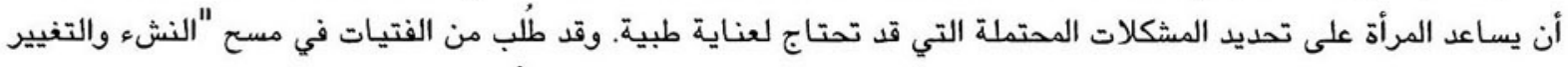

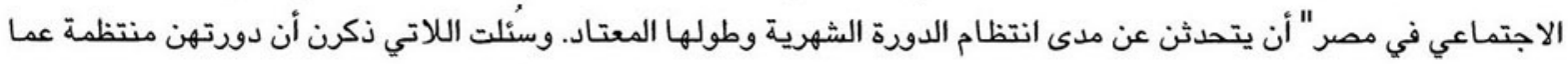

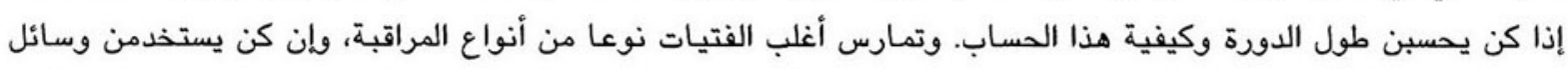

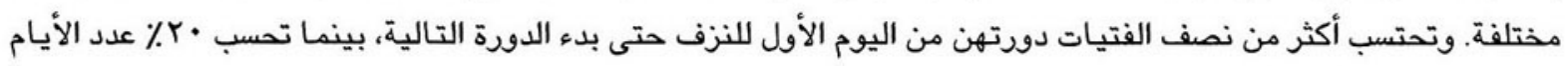

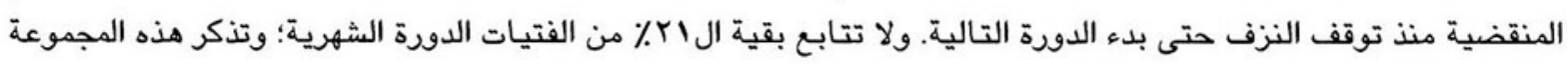

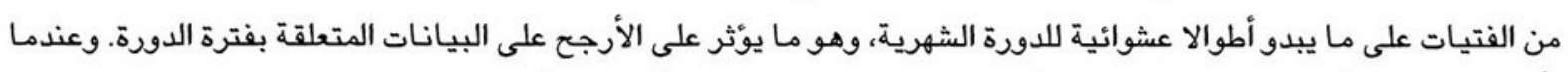

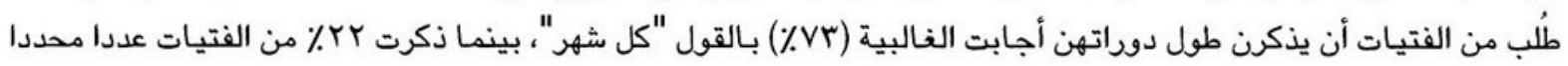

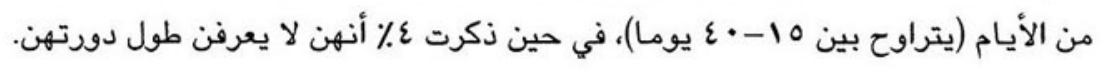

\section{عدم انتظام الميض وآلامه}

يمكن توقع بعض عدم الانتظام في الدورة قرب بدء ونهاية فترة خصوية المرأة. كما ينتشر حدوث عدم انتظام الحيض والآلام

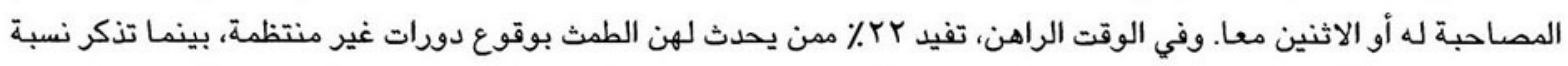

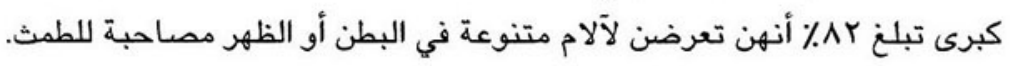

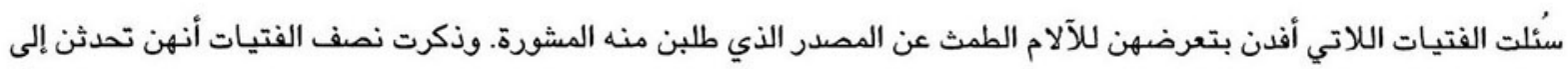

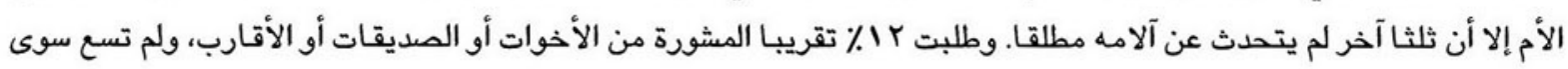

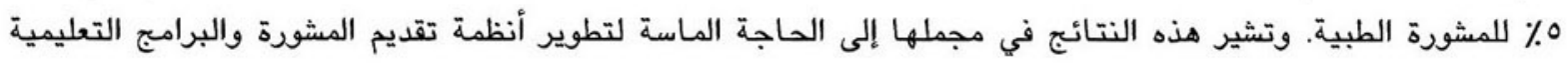

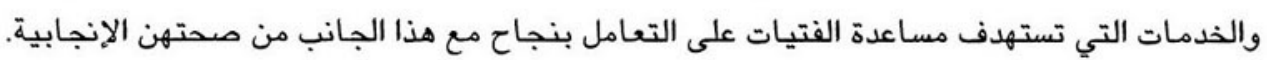

\section{ثالثا: المواقف والتوقعات إزاء الأدوار المتصلة بالنوع}

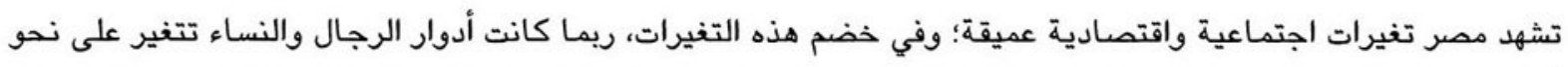

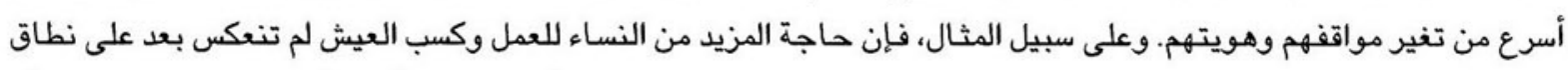

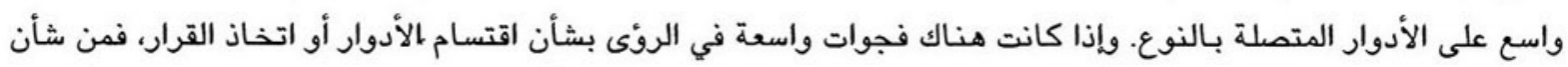

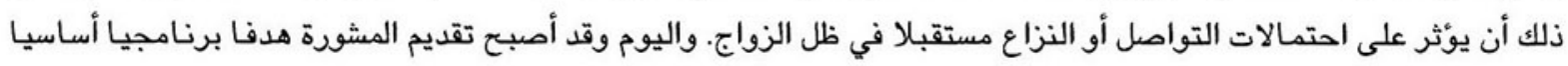

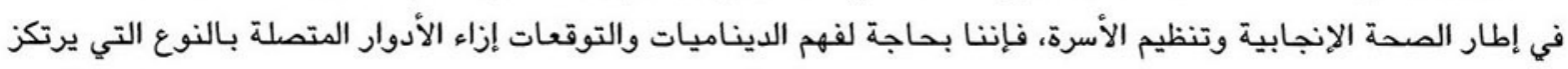

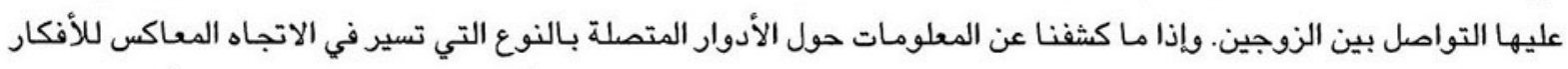

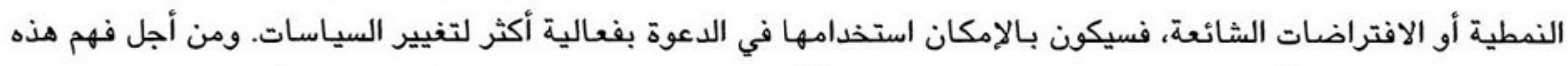

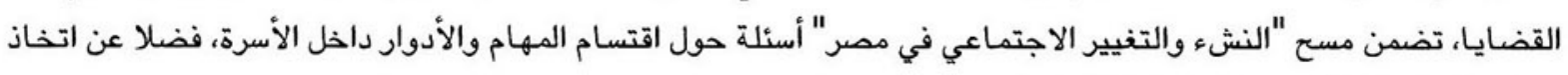
القرار والقضايا الأخرى التي قد تنشأ بين الزوجين. 
تليت على الفتيات والفتيان غير المتزوجين في السادسة عشرة أو أكثر قائمة بالمهام المنزلية، مثل تنظيف المنزل والتسوق

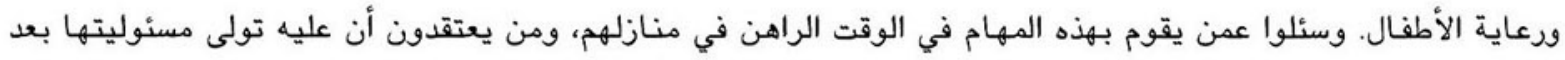

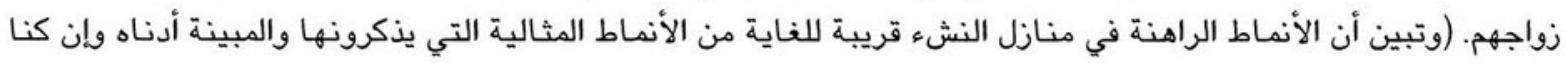

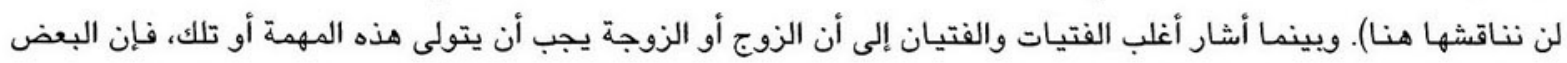

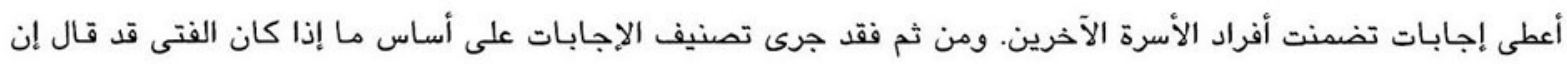

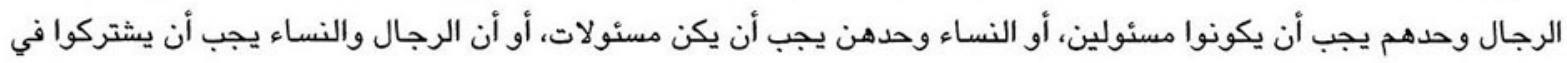

أداء المهام (الجدول 1-11) (1).

الجدول ^-11: اقتسام المهام: النسب المنوية للفتيات والفتيان الذين يعتقدون أن المهام يجب أن يقوم بها الرجال وحدهم، أو النساء وحدهن، أو أن يتقاسماها

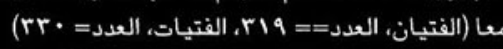

\begin{tabular}{|c|c|c|c|c|c|c|}
\hline \multicolumn{2}{|c|}{ مشاركة بين الرجل والمرأة } & \multicolumn{2}{|c|}{ السيدات فقط } & \multicolumn{2}{|c|}{ الرجال فقط } & \multirow[b]{3}{*}{ المسئول عن كسب العيش } \\
\hline 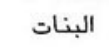 & الأولاد & 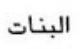 & الأولاد & البنات & الأولاد & \\
\hline I\&.9 & 11.7 & r.r & i.r & Ar.q & AV.r & \\
\hline 11. & 7.1 & $7 v .1$ & $v \cdot r$ & ri.9 & rr.t & شراء طلبات الأسرة \\
\hline r. & $\cdot r$ & 90.7 & $9 \wedge . V$ & .7 & 1.1 & غسل الملابس \\
\hline v.r & 7. & $9 r .0$ & $9 r .7$ & $\cdot r$ & $\cdot \varepsilon$ & تنظيف المنزل \\
\hline$\varepsilon . Y$ & 1.0 & $90 . r$ & $9 \vee .0$ & $\cdot .7$ & 1.1 & الطبخ \\
\hline IV.r & Ir.7 & vr.A & $7 \cdot \varepsilon$ & 9.9 & rv. & إحضـار المياه \\
\hline V.1 & rA.Y & v.1 & $r . \varepsilon$ & $\wedge \circ . V$ & $79 . \varepsilon$ & العمل بالأرض \\
\hline$\varepsilon .1$ & 1.1 & 90.1 & $\wedge \wedge$. & $\because .9$ & r. .9 & إطعام الأطفال \\
\hline$\varepsilon .9$ & r.r & 9E.r & $9 \vee . \wedge$ & $\because .9$ & $\because$ & حموم الأطفال \\
\hline$r \varepsilon . \wedge$ & rA.r & ir.v & o\&.r & 1.0 & v.o & اللعب مع/ مراقبة الأطفال \\
\hline rV.O & rר. & ri.r & ri. & $\varepsilon$. & or.1 & أخذ الأطفال من وإلى الددرسة \\
\hline $01 . \varepsilon$ & $\varepsilon r . r$ & rr.r & Yr.A & 17.1 & rr.s & مساعدة الأطفال على الإستذكار \\
\hline 01.1 & rV.I & IV.9 & ।ย.० & ri. & $\circ \wedge . \varepsilon$ & أحذ الأطفال إلى الطبيب أثناء مرضهم \\
\hline$r \varepsilon .0$ & $r \varepsilon . \wedge$ & IV.A & V.o & ०v. & $\circ \vee .7$ & مراعاة الزوجة أثناء مرضها \\
\hline ir.9 & $r \varepsilon . r$ & Ar.v & ०А.V & r.乏 & 7.9 & مراعاة الزوج أثناء مرضه \\
\hline
\end{tabular}

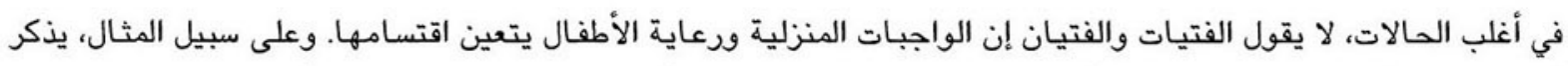

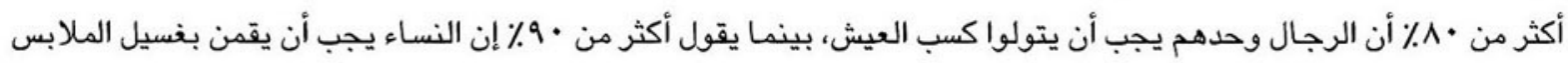

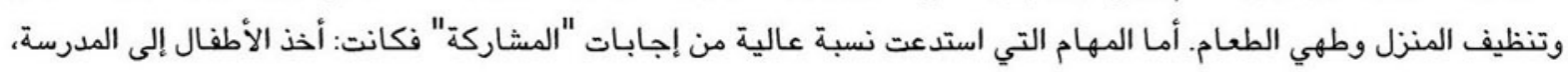

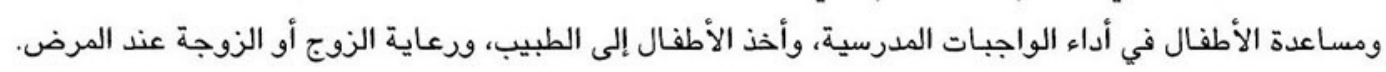


يوجد تفاوت في مقدار المشاركة الذي يقول به كل من الفتيات والفتيان، إلا أن هذه الاختلافات ليست دوما في الاتجاه ذاته.

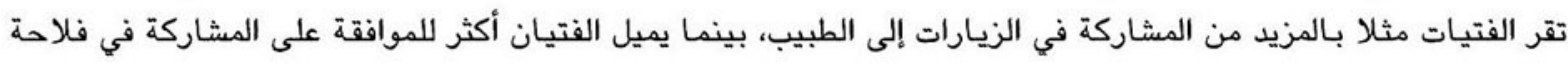

ويالنسبة لأنشطة وأدوار مختارة، بحثنا ما إذا كانت المواقف نحو المشاركة تتفاوت وفقا لمستوى تعليم النشء أو ولي الأمر،

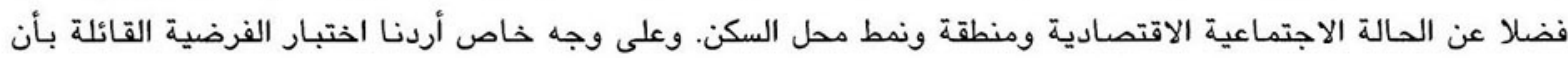

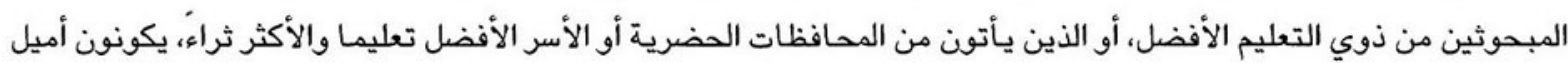

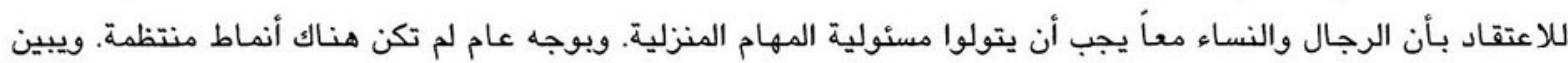

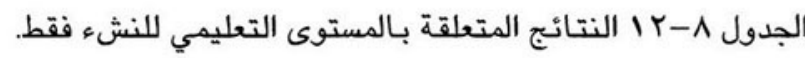

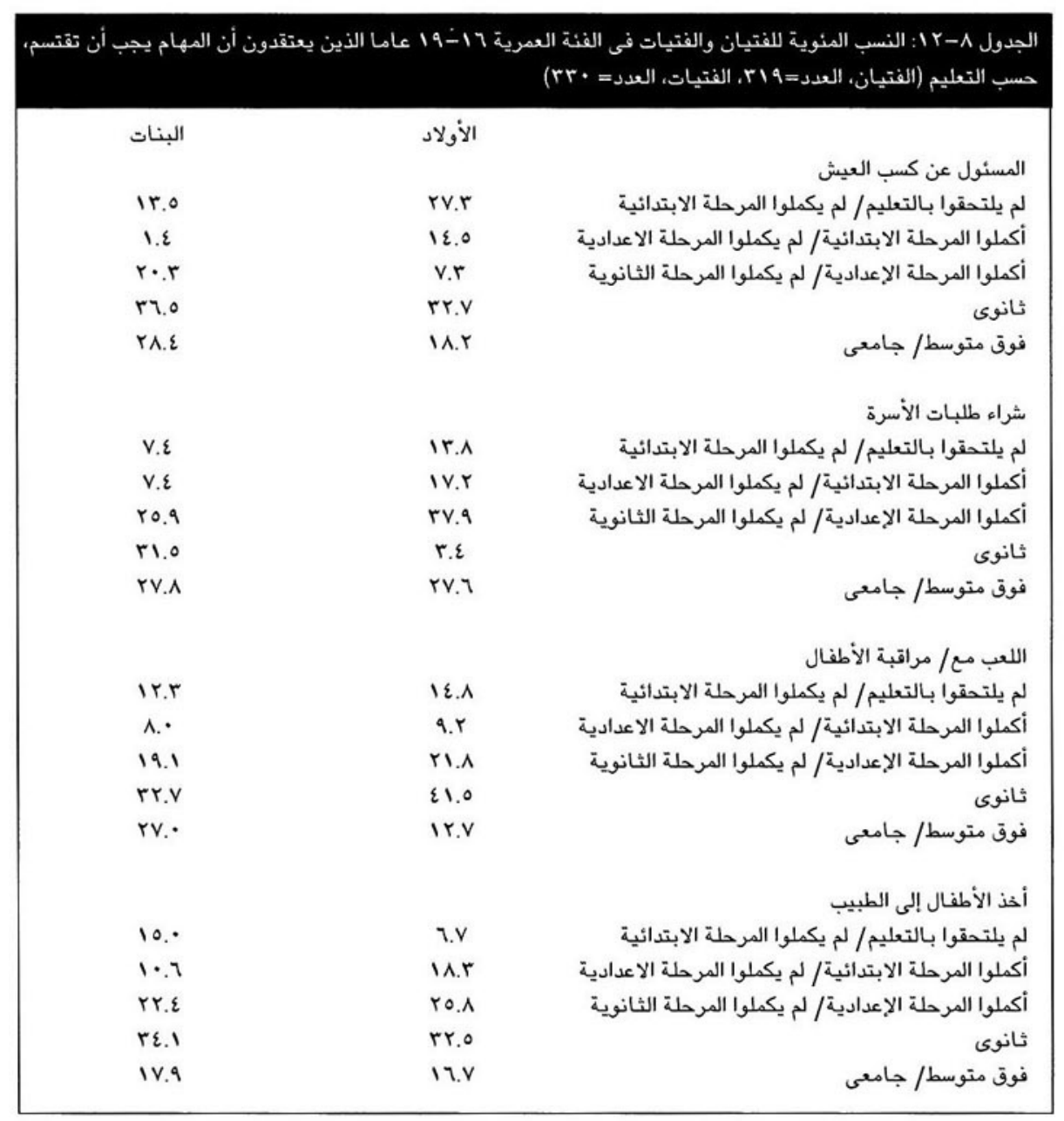

اتخاذ القرار

إلى جانب سؤالهم عن اقتسام الههام، سُئل الفتيان والفتيات أيضا عما إذا كان الزوج والزوجة يجب أن يشتركوا في اتخاذ

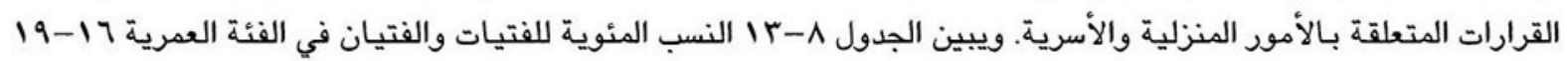

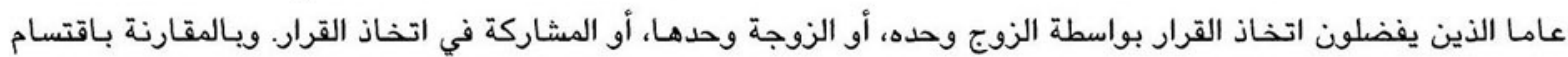

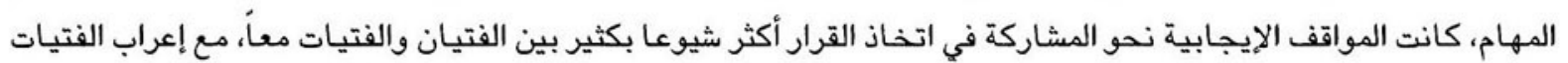
عن آراء أكثر ميلا إلى حد ما للمشاركة في اتخاذ القرار. 


\begin{tabular}{|c|c|c|c|c|c|c|}
\hline \multicolumn{2}{|c|}{ مشاركة بين الزوجين } & \multicolumn{2}{|c|}{ الزوجة فقط } & \multicolumn{2}{|c|}{ الزوج فقط } & \\
\hline 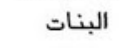 & الأولاد & البنات البنات & الأولاد & البنات البنات & الأولاد & \\
\hline ฟ.. & or.r & $0 . \varepsilon$ & $\varepsilon . \wedge$ & rr.q & $\varepsilon 1.9$ & ميزانية الأسرة \\
\hline OV.A & $r \varepsilon . r$ & $1 \cdot . r$ & r.q & rr.e & Ir.V & عمل الزوجة خارج المنزل \\
\hline 10.7 & ve.r & $\varepsilon .0$ & 1.0 & 9.9 & rE.r & وجود طفل آخر \\
\hline 10.7 & 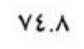 & r.A & I.V & V.A & rr.o & تعليم الفتاه \\
\hline ^९.V & vr.r & r.r & $\cdot . \wedge$ & A. & ro.A & 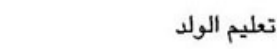 \\
\hline$\wedge r . \varepsilon$ & vo.1 & 1.7 & ir.r & १. & Ir.v & إستخذام وسائل منع الحمل \\
\hline Aヘ.V & $\wedge \varepsilon .1$ & 9. & v. & r.乏 & A.r & الرعاية الصحية للأطفال \\
\hline
\end{tabular}

ولكن فيما يتصل بمجالين مهمين، هما تحديدا ميزانية الأسرة ومسألة عمل المرأة خارج المنزل، يشعر البنين والبنات، والبنين

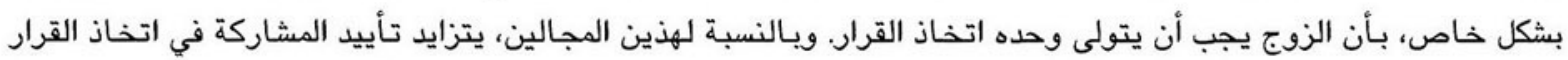

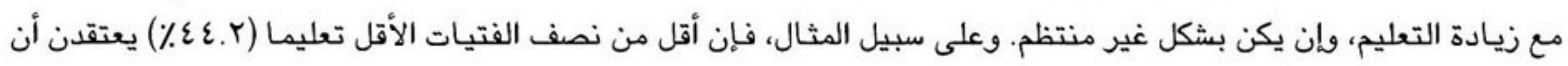

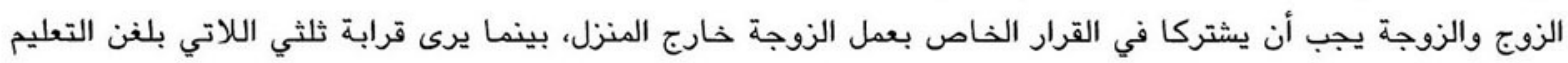

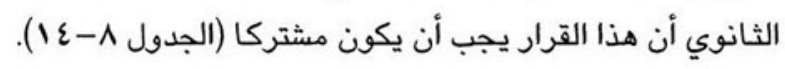

ومع ذلك، فإن للتعليم فيما يبدو تأثيرا مختلفا على كل من البنين والبنات فيما يتعلق ببعض المواقف إزاء الأدوار المتصلة

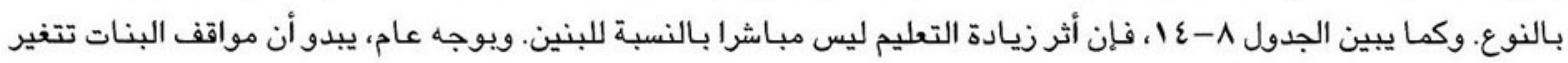

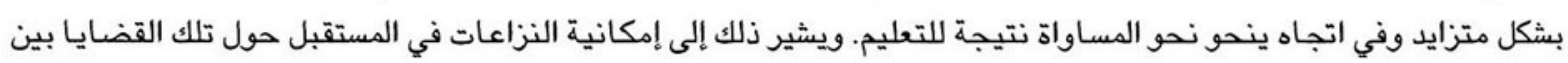
الأزواج من ذوي المستويات التعليمية المتماثلة.

\begin{tabular}{|c|c|c|}
\hline \multicolumn{3}{|c|}{ 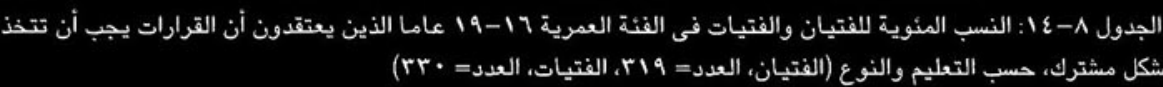 } \\
\hline 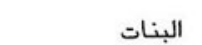 & 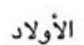 & \\
\hline ท.. & or.r & ميزانية الأسرة، الاجممالى \\
\hline TV. & $\varepsilon r . q$ & لم يلتحقوا بالتعليم/ لم يكملوا المرحلة الابتدائية \\
\hline ir.r & rV.A & أكملوا المرحلة الابتدائية/ لم يكملوا المرحلة الاعدادية \\
\hline TV.0 & 07.0 & أكملوا المرحلة الإعدادية / لم يكملوا المرحلة الثانوية \\
\hline$\vee \varepsilon . q$ & $7 \because$ & 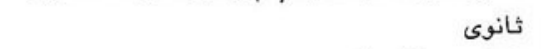 \\
\hline Ar.r & 09.1 & فوق متوسط/ جامعى \\
\hline ov.ı & $r \varepsilon . r$ & عمل الزوجة خارج المنزل، الإجمالى \\
\hline$\varepsilon \varepsilon, Y$ & rv.o & لم يلتحقوا بالتعليم/ لم يكملوا المرحلة الابتدائية \\
\hline$\varepsilon 9 .{ }^{2}$ & r9.7 & أكملوا المرحلة الابتدائية/ لم يكملوا المرحلة الاعدادية \\
\hline 07.1 & rr.r & أكملوا المرحلة الإعدادية/ لم يكملوا المرحلة الثانوية \\
\hline ir.o & rr.1 & 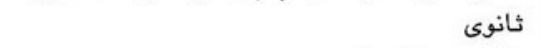 \\
\hline ท. & $\varepsilon r . \varepsilon$ & فوق متوسط/ جامعى \\
\hline
\end{tabular}


ولعله من المفيد أن نتأمل أسباب كون الأشخاص في مقتبل العمر مستعدين للمشاركة في اتخاذ القرار أكثر من اقتسام المهام

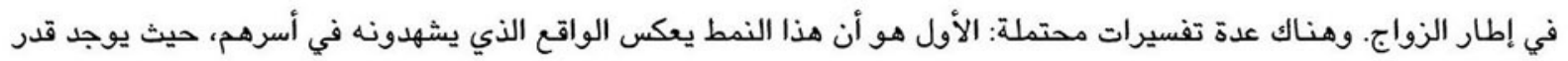

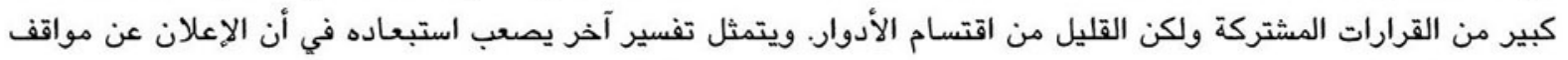

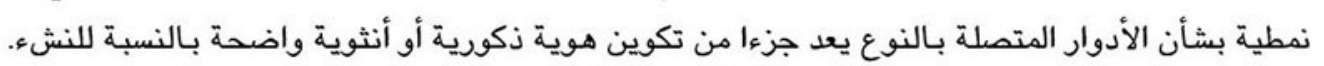

\section{ديناميات النوع الأخرى}

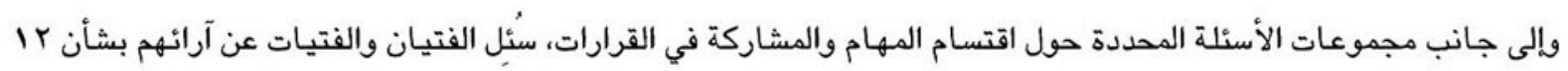

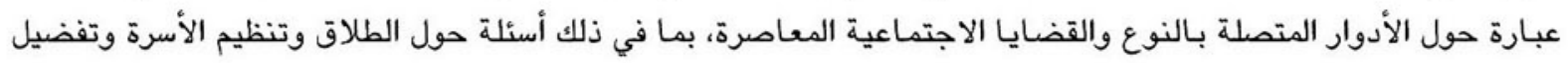

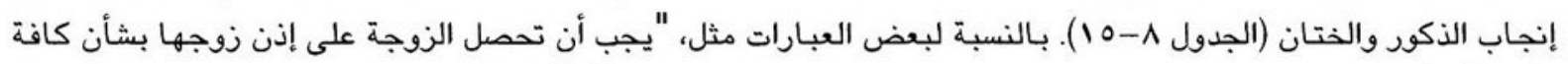

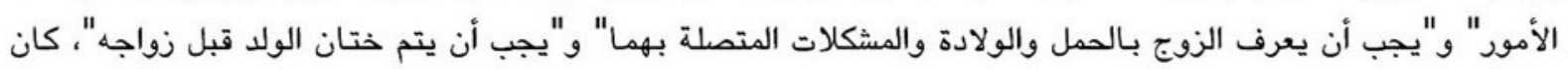
التأييد شاملا تقريبا، إذ وافق ما بين 9 هو و9 ٪ من البنين والبنات على هذه العبارات.

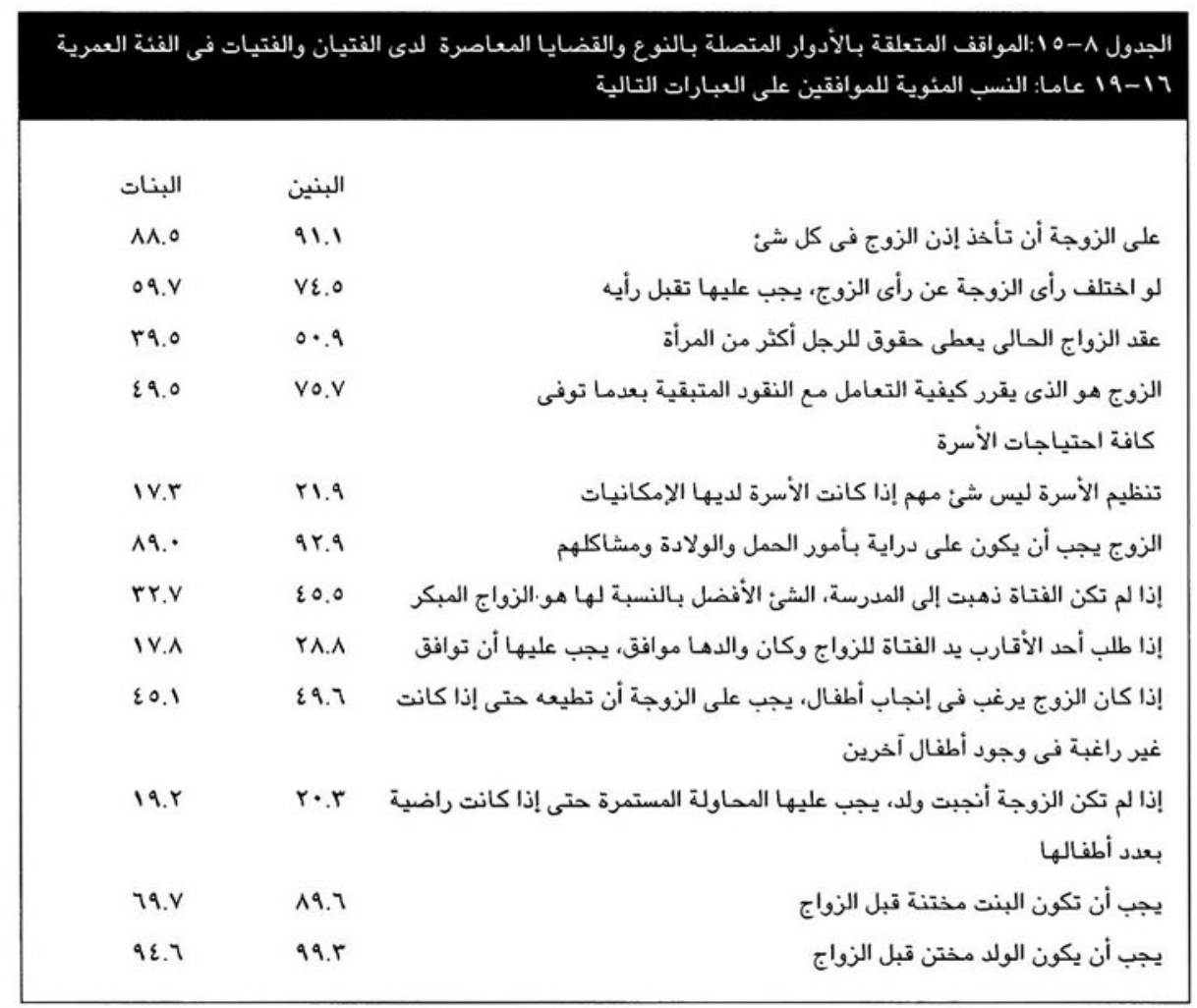

ويالنسبة لعبارات أخرى مثل، "تنظيم الأسرة ليس مهما إذا كانت الأسرة تمتلك الموارد الكافية"، و"إذا طلب أحد الأقارب يد

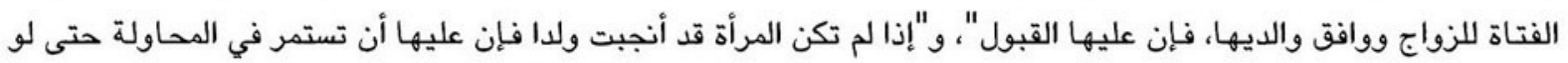

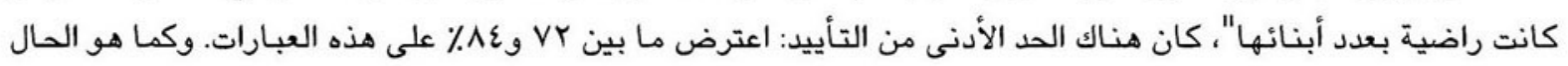

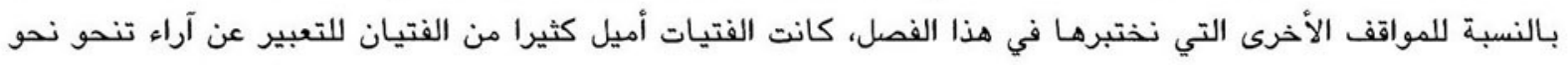

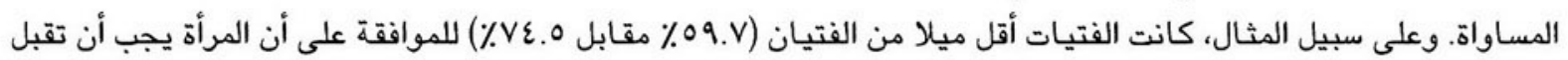

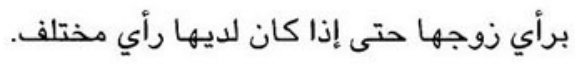


فيما يتعلق بالعبارتين اللتين كان الاختلاف بشأنهما بين البنين والبنات أوسع ما يكون، قمنا ببحث ما إذا كان التفاوت يرجع إلعا

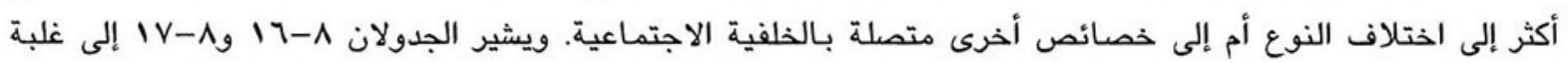

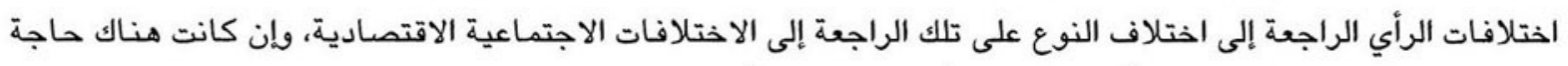

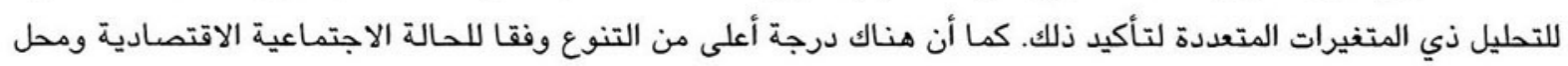

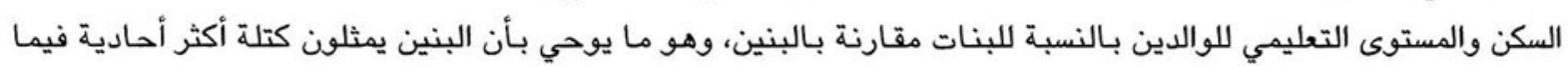

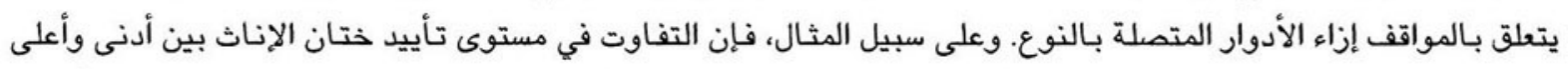

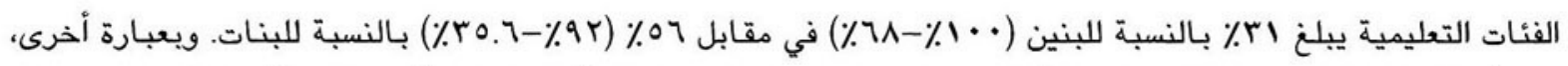

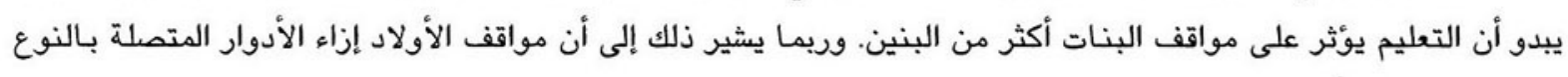
متجذرة على نحو أعمق.

الجدول ^-1 إيجب أن يقرر الزوج كيفية التصرف فى الأموال المتبقية بعد تلبية احتاجات الأسرة: النسب المنوية

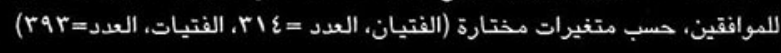

\begin{tabular}{|c|c|c|}
\hline \multirow[t]{2}{*}{ 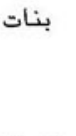 } & 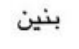 & \multirow[b]{2}{*}{ الحالة التعليمية للنشء } \\
\hline & & \\
\hline$v \cdot . v$ & 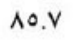 & لم يلتحقوا بالتعليم/ لم يكملوا المرحلة الابتدائية \\
\hline OA.V & 11.0 & أكملوا المرحلة الابتدائية/ لم يكملوا المرحلة الاعدادية \\
\hline or.o & $v r . \varepsilon$ & أكملوا المرحلة الإعدادية/ لم يكملوا المرحلة الثانوية \\
\hline$\varepsilon \cdot .0$ & vo.1 & 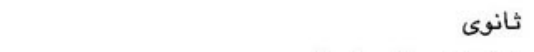 \\
\hline \multirow[t]{2}{*}{ rV.r } & $77 . \mathrm{V}$ & فوق متوسط/ جامعة \\
\hline & & الحالة التعليمية لأولياء الأمور \\
\hline or.r & va.^ & لم يلتحقوا بالتعليم/لم يكملوا المرحلة الابتدائية \\
\hline ov. & vo. & أكملوا المرحلة الابتدائية/ لم يكملوا المرحلة الاعدادية \\
\hline$r \varepsilon, 1$ & vo. & أكملوا المرحلة الإعدادية/ لم يكملوا المرحلة الثانوية \\
\hline rA.r & $\dddot{11 . V}$ & 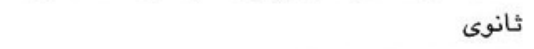 \\
\hline \multirow[t]{2}{*}{$r \varepsilon}$. & 09.0 & موهل متوسط/ جامعة \\
\hline & & الحالة الاقتصادية/ الاجتماعية \\
\hline $7 \cdot . r$ & 79.1 & منخفضة \\
\hline $0 \cdot \varepsilon$ & VV. $\varepsilon$ & 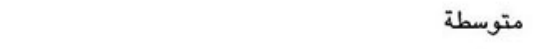 \\
\hline ra. & งา.० & 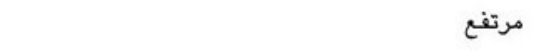 \\
\hline rv.r & 79.5 & 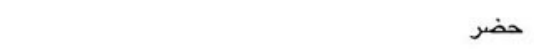 \\
\hline 07.0 & $\wedge \cdot v$ & ريف \\
\hline ro.A & TV.r & الححافظات الحضرية \\
\hline ०६.० & $\wedge \cdot .9$ & وجه بحرى \\
\hline or. & $v \varepsilon . r$ & وجه قبلى \\
\hline
\end{tabular}




\begin{tabular}{|c|c|c|}
\hline 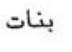 & بنين & \\
\hline & & الحالة التعليمية للنشء \\
\hline ar. & $1 \cdots$ & لم يلتحقوا بالتعليم/ لم يكملوا المرحلة الابتدائية \\
\hline $9 \cdot .7$ & 97.1 & أكملوا المرحلة الابتدائية/ لم يكملوا المرحلة الاعدادية \\
\hline$v \cdot .0$ & A9.r & أكملوا المرحلة الإعدادية/ لم يكملوا المرحلة الثانوية \\
\hline Mr. & 91.0 & ثانوى \\
\hline ro.t & 71.7 & مؤهل متوسط/ جامعة \\
\hline$\wedge \cdot \varepsilon$ & 90.1 & الحالة التعليمية لأولياء الأمور \\
\hline vr. & $\wedge \wedge .1$ & لم يلتحقوا بالتعليم/ لم يكملوا المرحلة الابتدائية \\
\hline $09 . \varepsilon$ & $v \cdot \cdot$ & أكمَلوا المرحلة الابتدائية/ لم يكملوا المرحلة الاعدادية \\
\hline $0 . .0$ & vo. & أكملوا المرحلة الإعدادية / لم يكملوا المرحلة الثانوية \\
\hline r.r & vo.9 & ثانوى \\
\hline \multirow[t]{2}{*}{ r.r. } & vo.9 & مؤهل متوسط/ جامعة \\
\hline & & الحالة الاقتصادية/ الاجتماعية \\
\hline Ar.q & 91.9 & منخفضة \\
\hline$v \varepsilon .7$ & qย.q & متوسطة \\
\hline 01.9 & V^.^ & مرتفعة \\
\hline$\varepsilon \cdot r$ & Ar.1 & حضر \\
\hline$\wedge 0 . \wedge$ & $9 \varepsilon .7$ & ريف \\
\hline$r \cdot .9$ & $\wedge 1.9$ & المحافظات الحضرية \\
\hline Ar. & 9 9r.A & وجه بحرى \\
\hline$\Lambda \cdot .7$ & А^. & وجه قبلى \\
\hline
\end{tabular}

\section{رابعا: المواصفات المثالية للزوج (النوجة)}

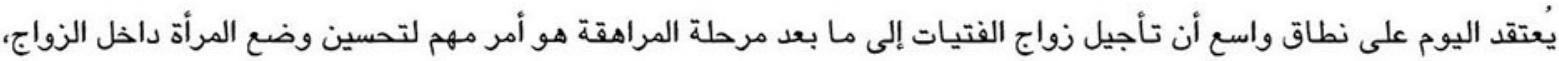

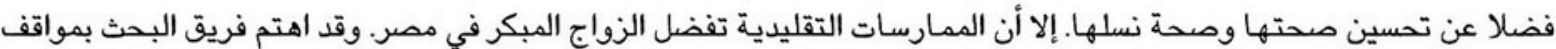
الفتيات والفتيان إزاء السن المناسب للزواج بالنسبة للفتيات والفتيان. ويشير الجدول ^-1 إلى متوسط السن المثالي لزواج

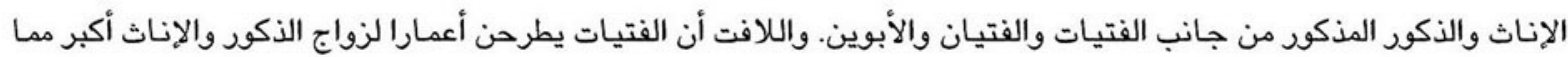

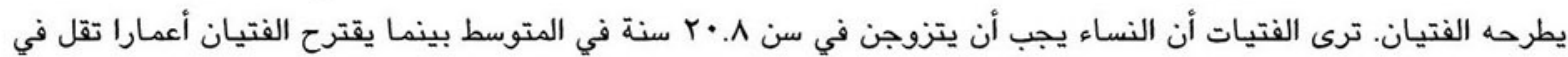

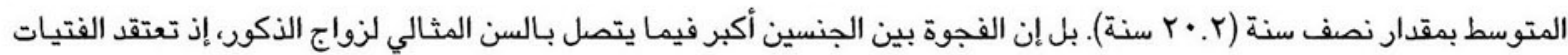

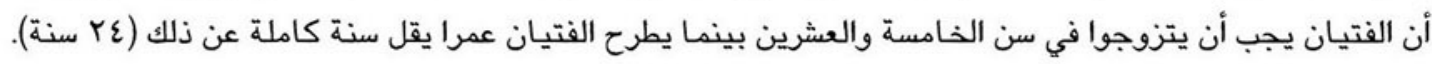

ويرى الوالدان، في المتوسط، أن الأفضل للفتيات هو أن يتزوجن في سن تقل عما يفضله أبناؤهم من الذكور والإناث على السواء؛

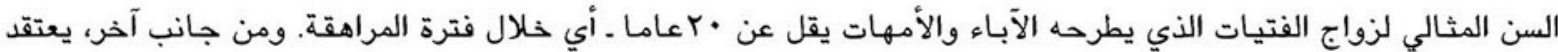

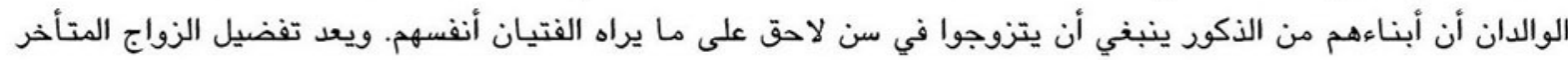

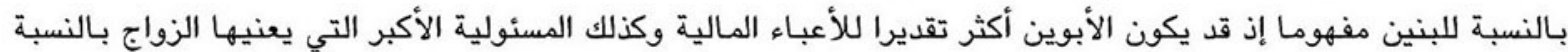

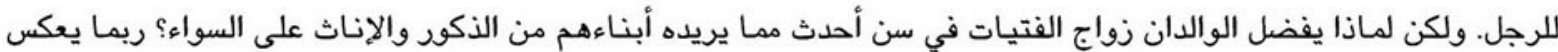

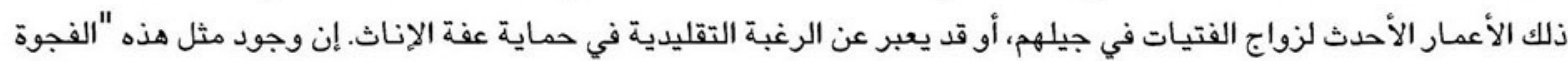

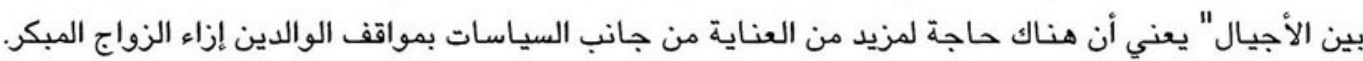




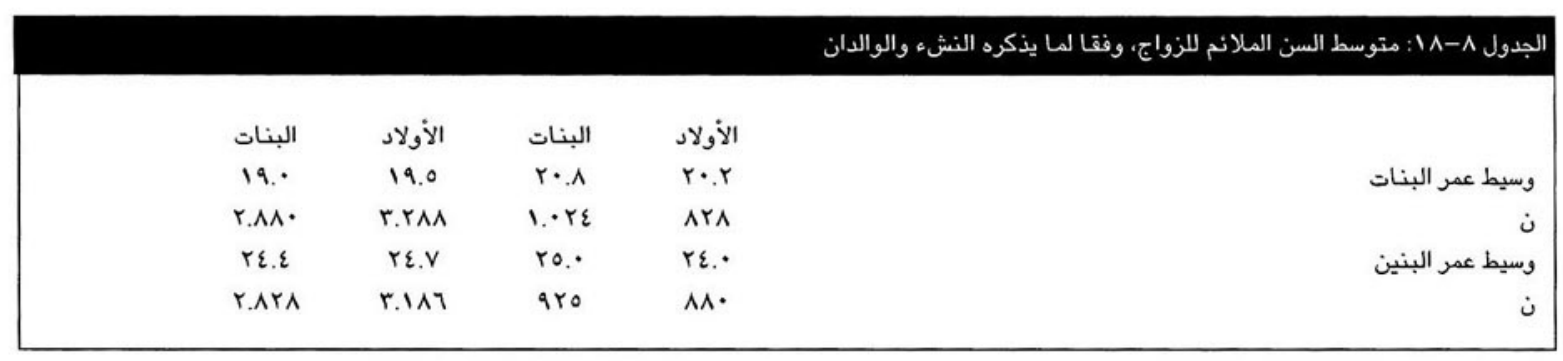

وكما هو متوقع، فإن الفتيات والفتيان المتعلمين، والمنحدرين من أسر متعلمة، والأكثر ثراء، والمقيمين في المحافظات

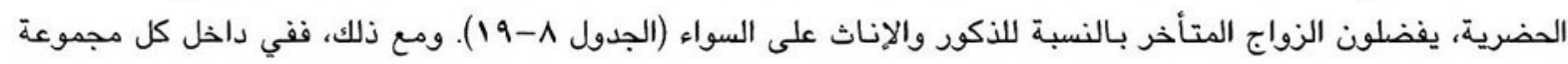

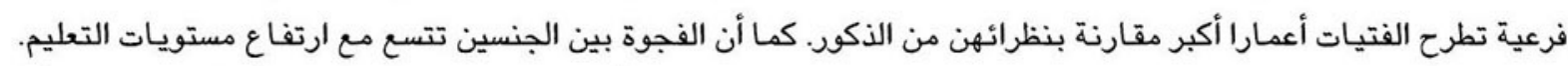

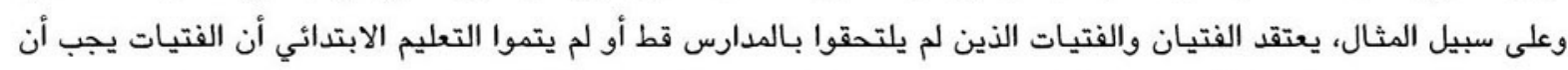

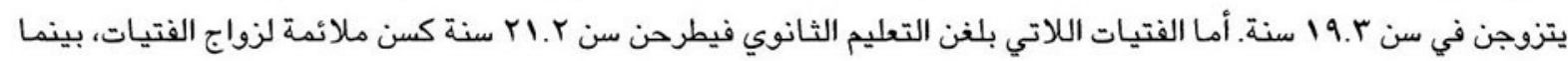

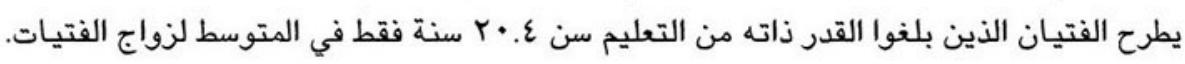

الجدول ^-19 1 : متوسط السن الملائم للزواج بالنسبة للإناث والذكور، وفتا لتقارير الفتيات والفتيان، حسب متغيرات مختارة

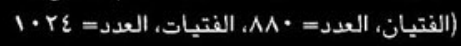

\begin{tabular}{|c|c|c|c|}
\hline \multicolumn{2}{|c|}{ سن الزواج للبنين } & \multicolumn{2}{|c|}{ سن الزواج للبنات } \\
\hline بنات & بنين & بنات & بنين \\
\hline$r \varepsilon . \varepsilon$ & rr.t & $r \cdot r$ & 19.9 \\
\hline ro.1 & rr.q & $r \cdot v$ & $r \cdot . \varepsilon$ \\
\hline Yo.乏 & ro. $\varepsilon$ & YI.1 & $r$. \\
\hline ro.7 & ro.r & ri.9 & r \\
\hline rV.E & ro.A & rr. & 1 \\
\hline
\end{tabular}

الحالة التعليمية لأولياء الأمور

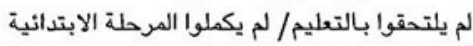

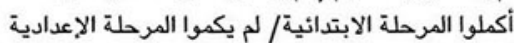

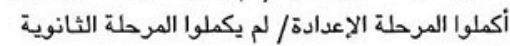

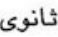
مؤهل متوسط / جامعة الحالة التعليمية للنشء

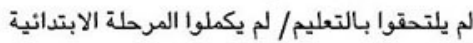

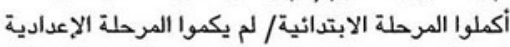

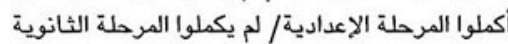
ثانوى مؤهل متوسط/ جامعة

ry r.A r. r. r. r. r.

الحالة الإقتصادية/ الإجتماعية

$\begin{array}{llll}\text { rr.A } & \text { rr.E } & 19.9 & 19.9\end{array}$

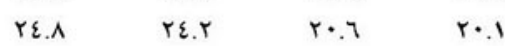

rI. rE.V rI.A $r \cdot .9$

منخفضة

متوسطة

مرتفعة

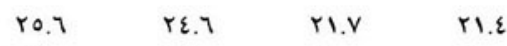

rE.O rr.O $r . . \quad r \cdot$

حضر

r.

المحافظات الحضرية

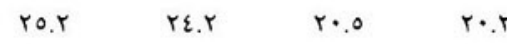

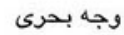

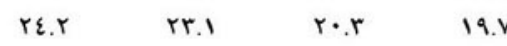

وجه قبلى

$\begin{array}{llll}r r . V & r r .0 & r \cdot . \Lambda & r \cdot .1\end{array}$

$1,1$.

10-11

$\begin{array}{llll}r 0 . & r \varepsilon . r & r \cdot . \Lambda & r \cdot r \\ r 0.9 & r \varepsilon . r & r . r & r . r\end{array}$

$19-17$ 
والخلاصة أن الفتيات لديهن مواقف أكثر تقدمية نوعا ما من الفتيان والوالدين إزاء تأخير الزواج. ويينما يحمل الفتيان أفكارا أكثر حداثة بشأن تأجيل زواج الفتيات مقارنة بآبائهم، فإنهم متلهفون على نوات زواجهم هم.

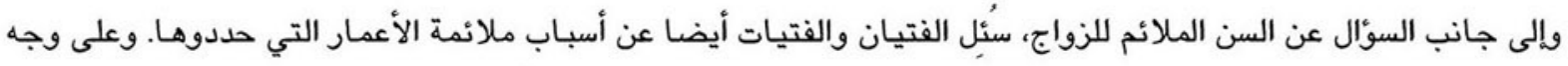

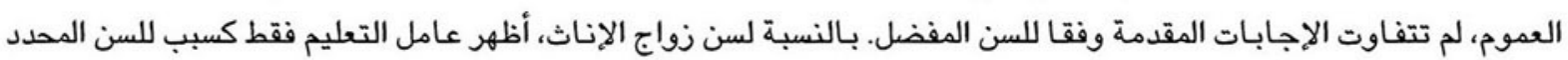

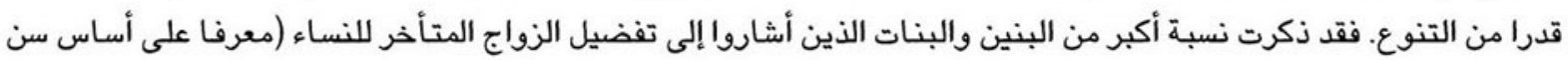

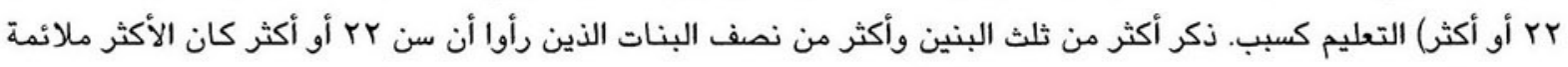

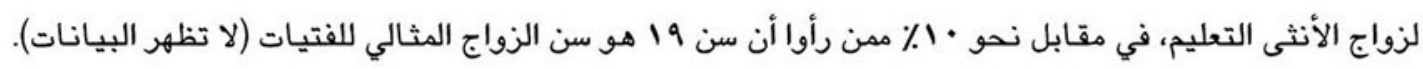

أما بالنسبة لزواج الذكور، فقد ظهر التعليم أيضا على نحو أبرز كثيرا كمبرر للزواج المتأخر (معرفا على أساس سن حب أو أكثر).

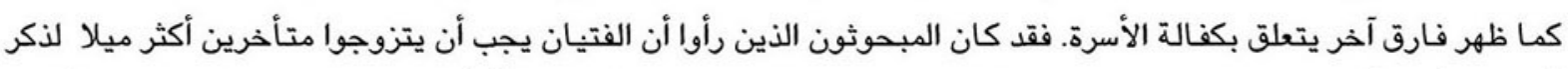

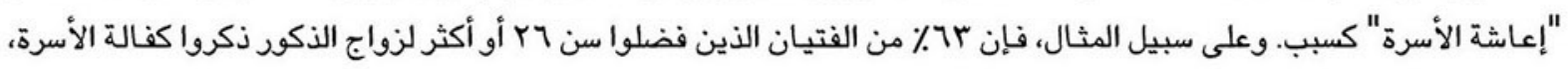

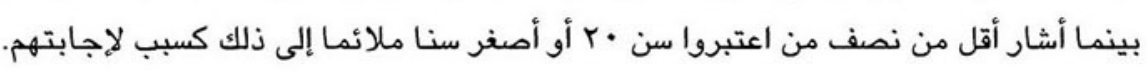

فارق السن بين النوجين

عندما تتزوج الفتاة في سن المراهقة، عادة ما يكون زوجها أكبر منها كثيرا (أنظر الفصل التاسع). وقد يؤدي فارق السن الكبير

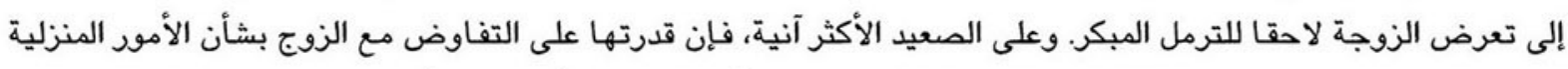

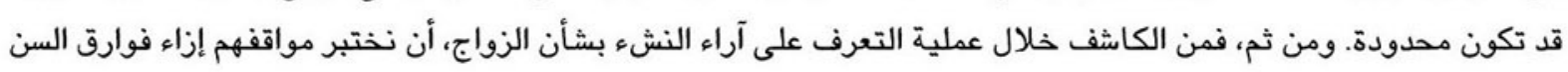

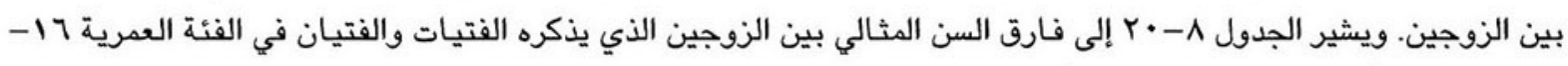

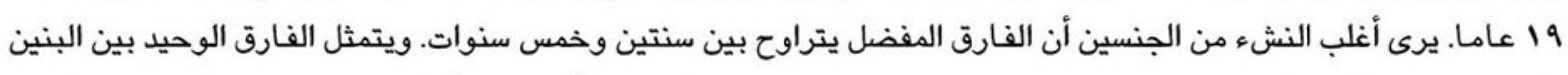

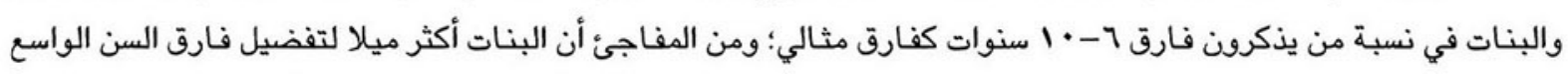

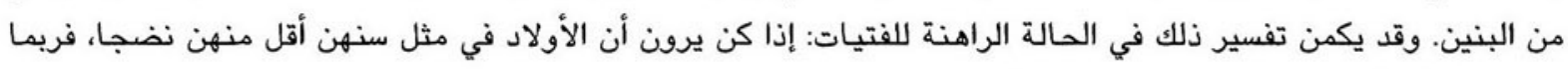
يستنتجن أن الأفضل لهن هو الاقتران بزوج أكبر سنا.

\begin{tabular}{|c|c|c|c|c|c|c|c|c|c|c|}
\hline & & \multicolumn{9}{|c|}{ 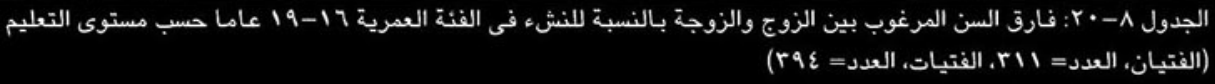 } \\
\hline \multicolumn{3}{|c|}{ مؤهل متوسط/ جامعة } & \multirow{2}{*}{ بنانوى } & \multicolumn{2}{|c|}{ ألكملوا المرحلة } & \multicolumn{2}{|c|}{ ألابكملوا المرحلة الإيتية / الاعدادية } & \multicolumn{2}{|c|}{ لم يلتحقوا بالتعليم } & \multirow[b]{2}{*}{ اختلاف الأعمار } \\
\hline بنات & بنين & بنات & & بنات & بنين & بنات & بنين & بنات & بنين & \\
\hline 1.9 & A. $\varepsilon$ & 19.5 & rr.o & ro. & ro.r & $17 . r$ & $19 . r$ & rv.o & IE.० & صفر- 1 سنة \\
\hline 17.1 & 10.1 & $r \varepsilon . r$ & $\varepsilon \cdot . \vee$ & 19.8 & $r \varepsilon . q$ & $1 \cdot .0$ & 9.1 & $1 \wedge .1$ & 9.0 & r-ه سنوات \\
\hline M.£ & rา.1 & M. & rา.1 & ro. & $\varepsilon .0$ & 9.7 & $\varepsilon . r$ & $\varepsilon .9$ & $\because \cdot$ & - •ا سنوات \\
\hline $1 . .0$ & 10.1 & rา.r & ru.r & rI.r & rI.1 & $\because$ & $\because \cdot$ & rI.7 & r..A & لا يوجد فرق \\
\hline
\end{tabular}


وعند اختبار فارق السن الففضل المذكور من جانب الفتيات والفتيان على نحو منفصل حسب مستوى التعليم، فإننا نكشف عن

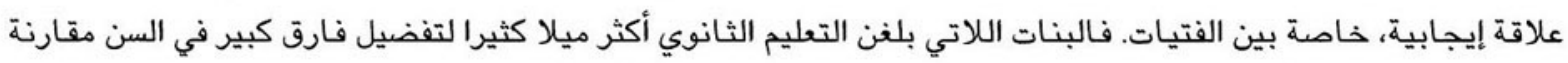

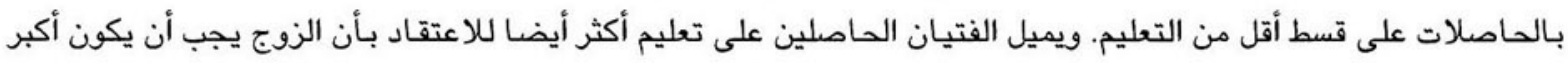

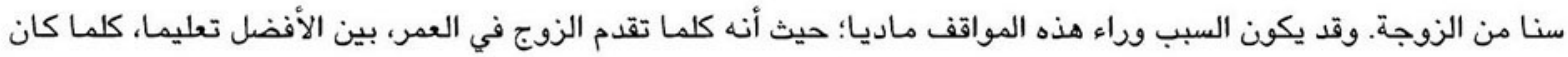

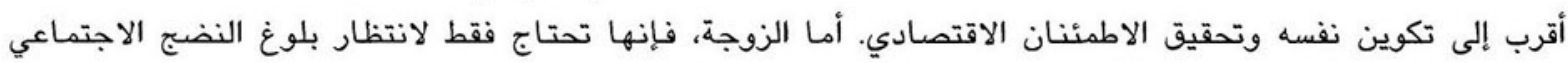

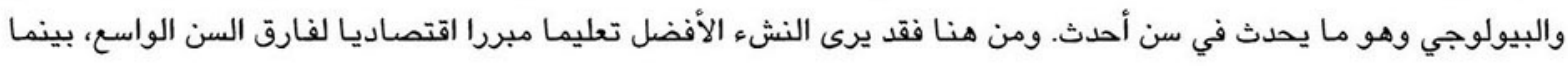

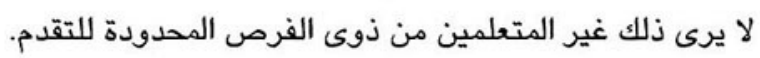

\section{المواصفات المثالية للزوج (النوجة)}

لما كان الزواج يخاض كعلاقة تدوم العمر كله، فإن التناسب بين الزوجين يصبح أمرا مهما يحدد ما إذا كان الزواج سيكون

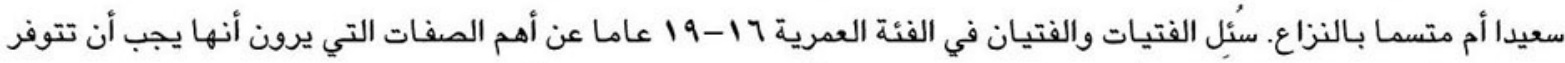

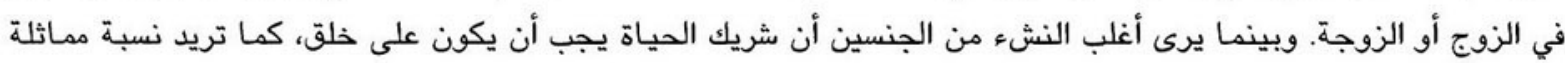

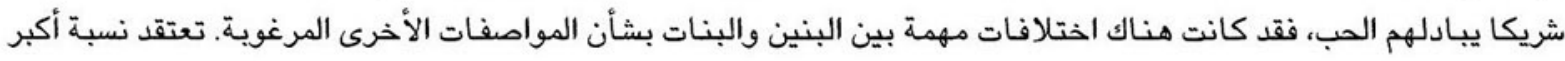

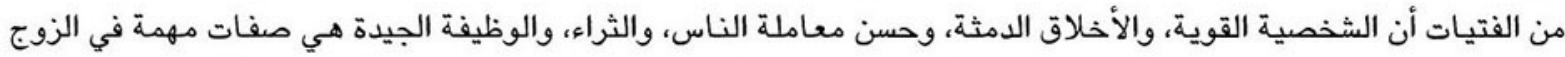

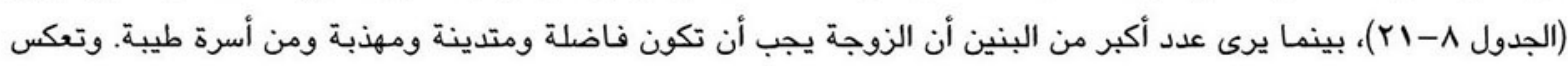

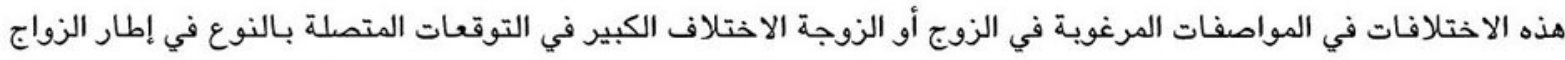

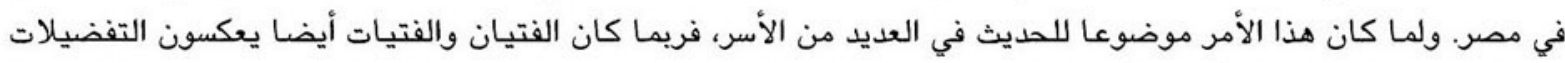

\begin{tabular}{|c|c|c|}
\hline \multicolumn{3}{|c|}{ 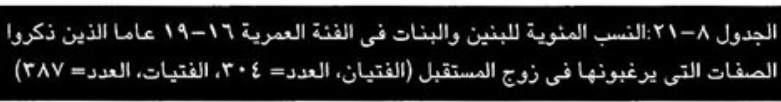 } \\
\hline بنات & بنين & المفة \\
\hline ro.1 & rr. & الحب \\
\hline rV.r & 0.0 & الشخصية القوية \\
\hline 9.1 & 9.9 & 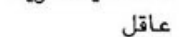 \\
\hline$\Lambda .1$ & $\mid \varepsilon .1$ & أصيل \\
\hline$r \varepsilon .7$ & $17 . r$ & حسن الطباع \\
\hline $1 V .7$ & 9.0 & المعاملة الحسنة \\
\hline ir.7 & r.r & الثراء \\
\hline$\cdot . v$ & $\cdot r$ & صاحب أرض \\
\hline IV.V & r.1 & الوظيفة الجيدة \\
\hline $1 \wedge .1$ & $r v . \varepsilon$ & العائلة الجيدة \\
\hline rq.V & rur & التعليِ \\
\hline r.० & Y.r & من الأقارب \\
\hline rr.A & $\varepsilon r . \varepsilon$ & متدين \\
\hline Ir.£ & va.r & مؤدب \\
\hline
\end{tabular}

والخيارات التي يعرب عنها أفراد الأسرة البالغين.

وعلى وجه العموم، لا تتفاوت المواصفات المرغوية

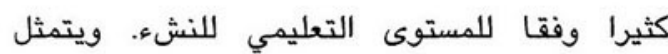
الاستثناء الوحيد، كما هو متوقع، في التعليم ذاته (لاتئه

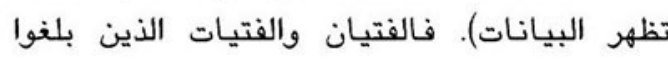
التعليم الثانوي يميلون أكثر كثيرا من نظرائهم الأقل

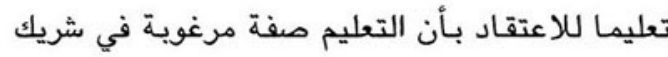
الحياة: يعتقد V\&٪ من البنين والبنات الذين تلقوا

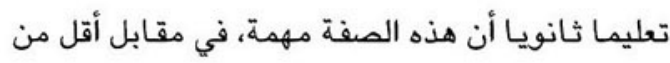

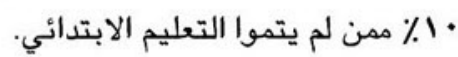

\section{خامساً: المعرفة بعقد النواج}

هل يتوفر للفتيان والفتيات، إذ يتطلعون للزواج، معلومات دقيقة بشأن الحقوق والواجبات المتضمنة فى عقد الزواج فى مصر؟

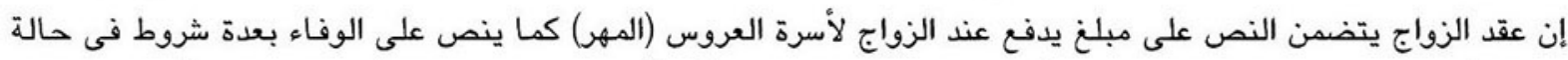

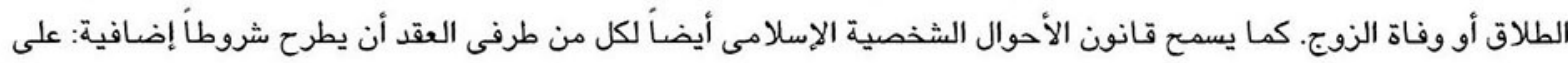

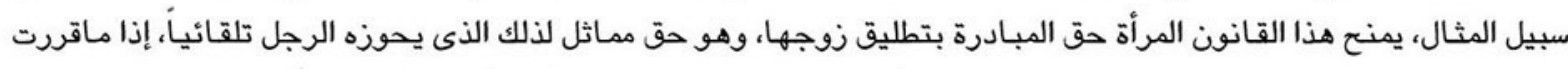

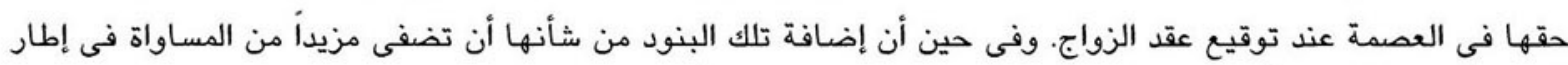

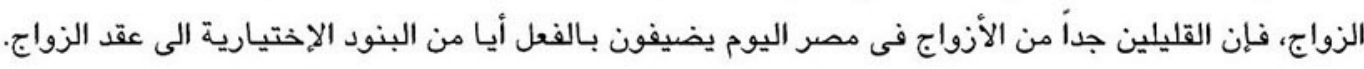




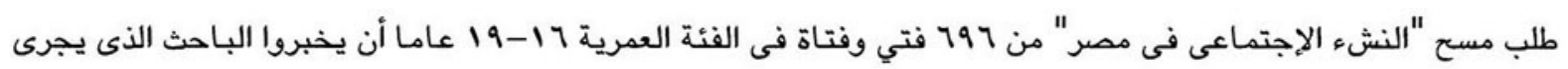

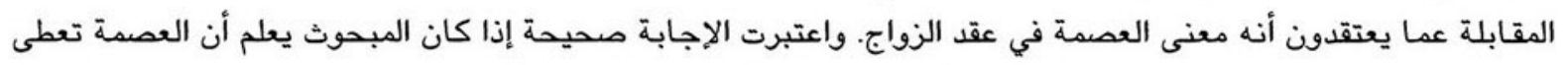

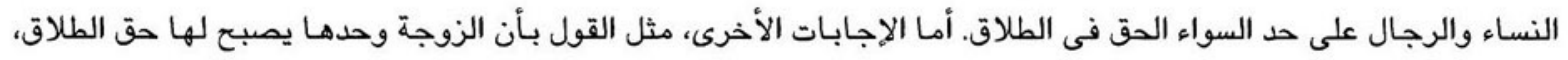

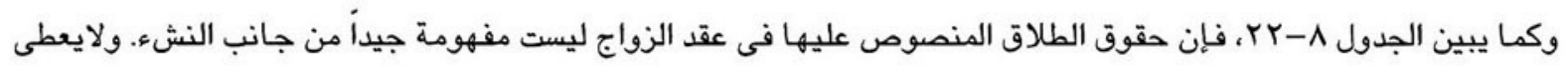

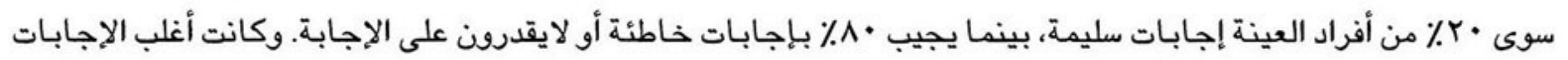

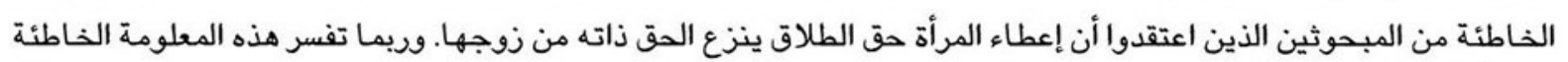

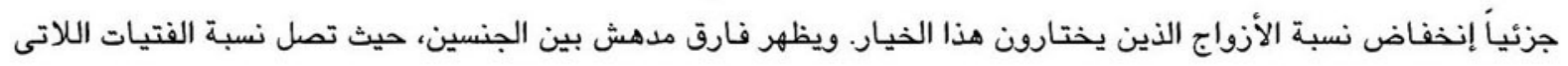
يفهمن معنى العصمة فهما سليما الى نحو ضعف الذي مثيلتها بين الفتيان.

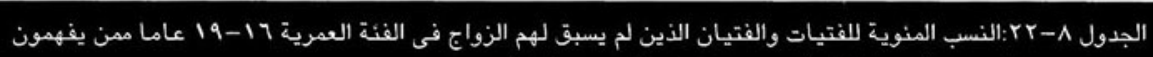

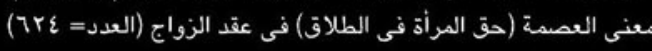

\begin{tabular}{|c|c|c|}
\hline لا يفهم المعنى & يفهم المعنى & \\
\hline va.v & $r \cdot r$ & 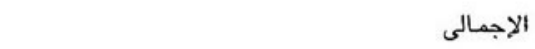 \\
\hline vr.r & rา.A & بنات \\
\hline ^..। & ir.9 & بنين \\
\hline vi.1 & rA. 9 & لم يلتحقوا بـالتعليم/ لم يكملوا المرحلة الابتدائية \\
\hline vv. & rr. & أكملوا المرحلة الابتدانية/ لم يكملوا المرحلة الاعدادية \\
\hline A.. & $1 \wedge . \wedge$ & أكملوا المرحلة الإعدادية/ لم يكملوا المرحلة الثانوية \\
\hline VA.A & ri.r & 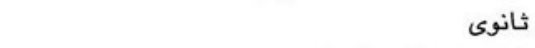 \\
\hline$\wedge \wedge .7$ & $\cdots . \varepsilon$ & فوق متوسط/ جامعة \\
\hline Ar.Y & IV. $\varepsilon$ & حضر \\
\hline vv.v & rr.r & ريف \\
\hline Ar. & iv. & المحافظات الحضرية \\
\hline$\Lambda \cdot r$ & 19.1 & وجه بحرى \\
\hline vo.\& & Y६.Т & وجه قبلى \\
\hline & & الحالة الاقتصادية/ الاجتماعية \\
\hline v9.६ & $r \cdot .7$ & منخفضة \\
\hline vV.\& & rr.Y & متوسطة \\
\hline$\wedge 1.1$ & $1 \wedge .9$ & مرتفعة \\
\hline
\end{tabular}


ولايبدو أن محل الإقامة أو المنطقة أو الحالة الإجتماعية والاقتتصادية تؤثر كثيرا على معرفة النشىء بهذا الموضوع. ومع ذلاك

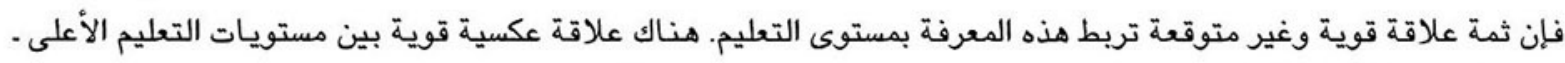

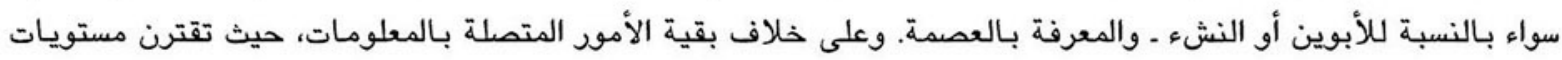

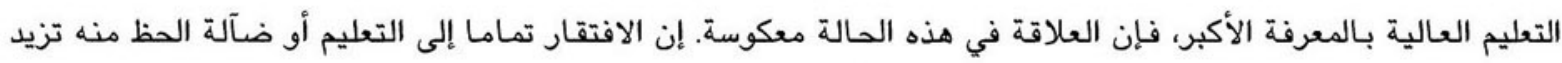
احتمال معرفة البنين والبنات الدقيقة لمعنى حقوق المرأة في الطلاق في عقد الزواج العاج.

هناك تفسيران محتملان لهذه النتيجة. الأول هو أن التجربة الأطول في نظام التعليم تعرض الطلاب للمعلومات أو المواقف

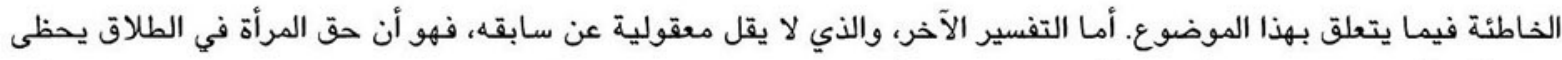

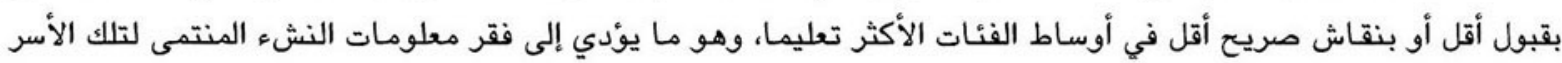
بشأن الموضوع.

\section{الفتيات المتنوجات}

أردنا أن نعرف ما إذا كان خوض تجرية الزواج يؤثر على مستوى دقة المعلومات بشأن عقد الزواج. وتبين النتائج أن الفتيات

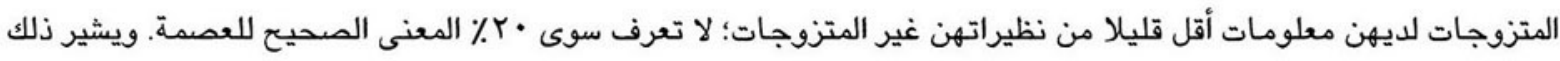

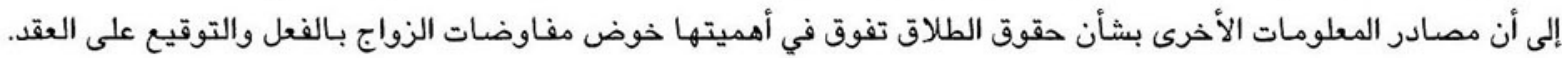

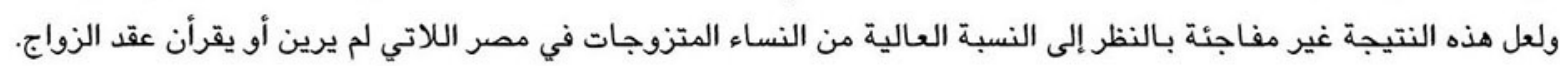

سادسا: الطلاق

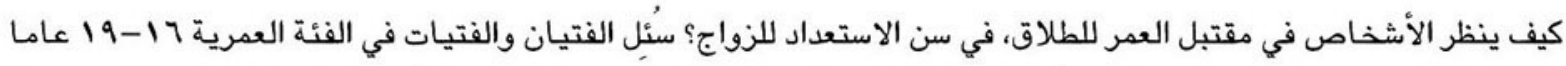

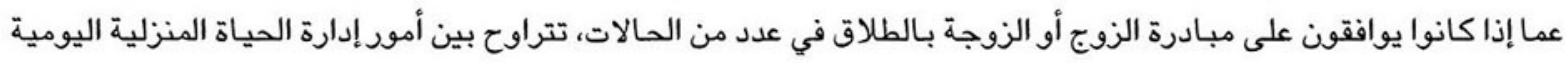
والمسائل الأكثر خطورة مثل العنف داخل الأسرة.

يقبل النشء من الذكور بالطلاق بشكل عام أكثر من الفتيات. أي أن البنين أميل من البنات، ماعدا في حالتين فقط، للقبول

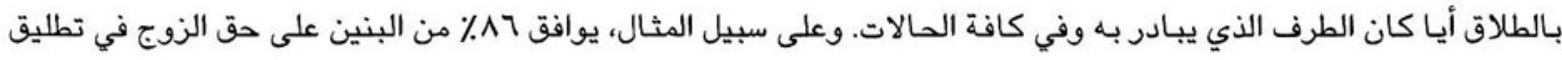

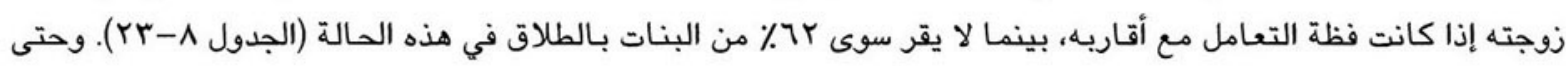

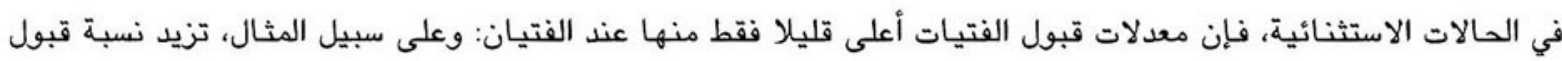

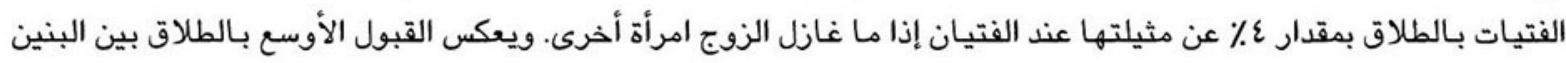

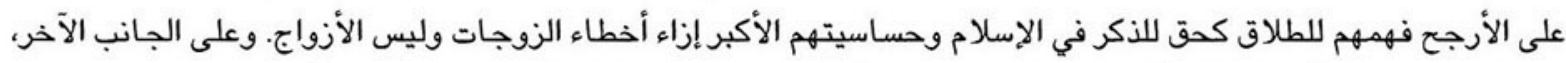

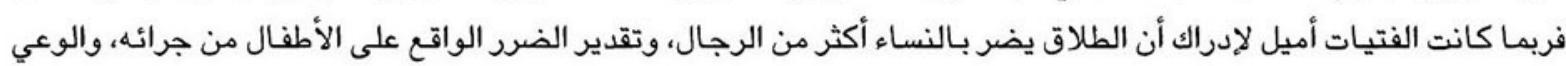
بالوصمة التي طالما توصم بها المرأة المطلقة في مصر.

إن انخفاض معدلات القبول بالطلاق بين الفتيات فيما يتصل بكل سبب من أسبابه تقريبا لأمر على درجة كبيرة من الأهمية:

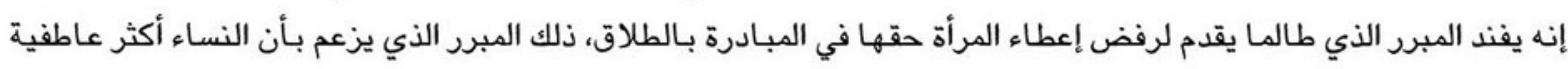

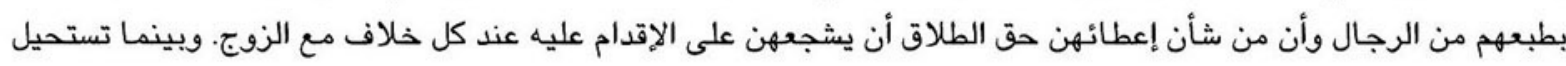

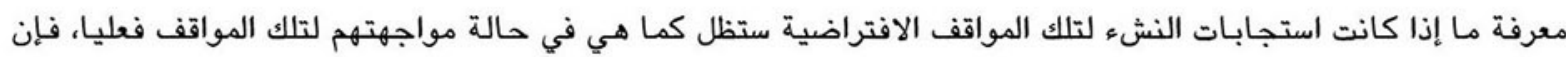
البيانات تشير ضمنا إلى أن الفتيات سيكن أقل ميلا من الفتيان للمبادرة بلـاتل الطلاق. 
يميل النشء من الجنسين للاقرار بحق الرجل في المبادرة بالطلاق أكثر من إقرارهم بالحق ذاته للزوجة في الحالات المماثلة.

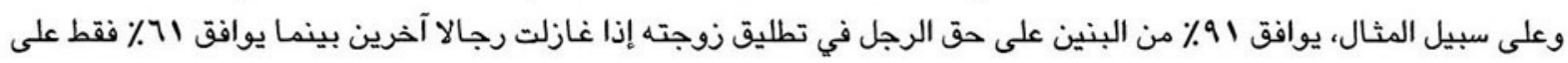

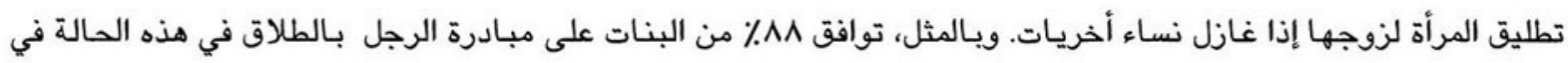
حين لا تقر سوى 70٪ منهن بالحق ذاته للمرأة لنفس السبب.

إلا أنه في بعض الحالات يكون الفتيان أميل كثيرا من الفتيات للإقرار بحق المرأة في المبادرة بالطلاق. وعلى سبيل المثال،

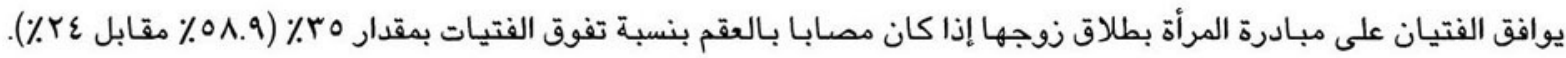

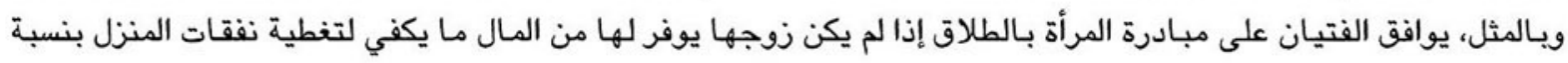

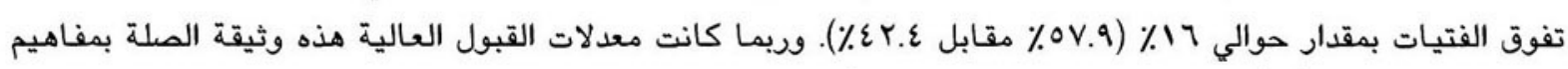

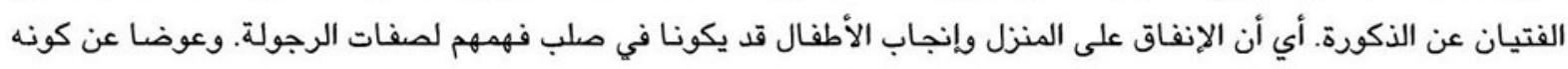
تعبيرا عن التعاطف مع النساء في تلك الحالات، فإن قبول الفتيان بالطلاق قد يعكس استجابة سلبية للمشكلات التي تمثل تحديا لمفاهيمهم عن الذكورة.

\begin{tabular}{|c|c|c|c|c|c|c|}
\hline \multicolumn{2}{|c|}{ الفتيات المتزوجات } & \multicolumn{2}{|c|}{ 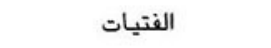 } & \multicolumn{2}{|c|}{ 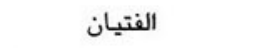 } & \\
\hline توافق على & توافق على & توافق على & توافق على & يوافق على & يوافق على & \\
\hline أن يبدأ & أن تبدأ & أن يبدأ & أن تبدأ & أن يبدأ & أن تبدأ & \\
\hline 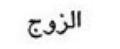 & 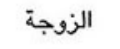 & 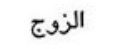 & الزوجة & 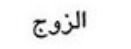 & الزوجة & \\
\hline بطلب بل & بطلب & بطلب & بطلب & بطلب & 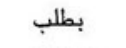 & \\
\hline \multirow[t]{2}{*}{ 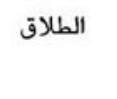 } & 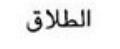 & 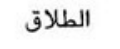 & 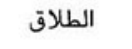 & 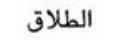 & 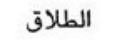 & \\
\hline & & & & & & الزوجة/ الزوج يوافق على الطلاق فى حالة \\
\hline$v \cdot .0$ & $\varepsilon r . V$ & Tr.Y & 00.1 & 10.7 & $\neg \because \cdot$ & إساءة معاملة أهل الزوج/ الزوجة \\
\hline$\wedge \varepsilon . \vee$ & $\varepsilon \wedge .0$ & $\wedge \vee, Y$ & $7 \varepsilon .9$ & $9 \cdot .0$ & $7 \cdot . \wedge$ & التحدث إلى / مغازلة الجنس الآخر \\
\hline ar.r & $\wedge \mathrm{v} . \varepsilon$ & $\wedge \varepsilon$. & VA.A & No.r & $\wedge \varepsilon, r$ & كراهية الطرف الآخر \\
\hline \multirow[t]{2}{*}{$\varepsilon \wedge\rceil}$. & $r \cdot .9$ & rA.V & $r \varepsilon$. & $\varepsilon \wedge . \wedge$ & $0 \wedge .9$ & عقم الطرف الآخر \\
\hline & & & & & & الزوجة توافق على الطلاق إذا كان زوجها \\
\hline لا ينطبق & re.v & لا ينطبق & or.9 & لا ينطبق & OA.V & يتجاهل رأيها \\
\hline لا ينطبق & $\varepsilon V . r$ & لا ينطبق & TV.V & ل لا ينطبق & vv.r & | يضربها \\
\hline لا ينطبق & rV.q & لا ينطبق & $\varepsilon r . \varepsilon$ & لا لا ينطبق & ov. 9 & لا يعطيها نقود كافية للإنفاق على الأسرة \\
\hline \multirow[t]{2}{*}{ لا ينطبق } & 认 . 0 & لا ينطبق & $\wedge \cdot v$ & لا ينطبق & vr.A & متزوج من زوجة أخرى \\
\hline & & & & & & الزوج يوافق على الطلاق إذا كانت زوجته: \\
\hline$\wedge r . \wedge$ & لا ينطبق & vV.r & ل ل ال ينطبق & ^९.v & لا ينطبق & غير مطيعة \\
\hline$\triangle 9.1$ & لا ينطبق & 7.7 & لا لا ينطبق & ทา. & لا ينطبق & تهُهل شئول البيت \\
\hline ov.r & لا ينطبق & $7 \cdot .9$ & ل الا ينطبق & VV.9 & لا ينطبق & تَهْل الأطفال \\
\hline
\end{tabular}

ومن اللافت أن النشء الذكور أكثر استعدادا للقبول بمبادرة الزوج بالطلاق في حالة عدم طاعة الزوجة منهم في حالة إهمالها

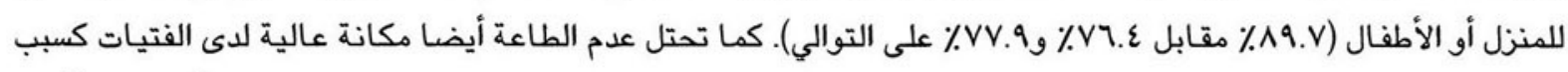

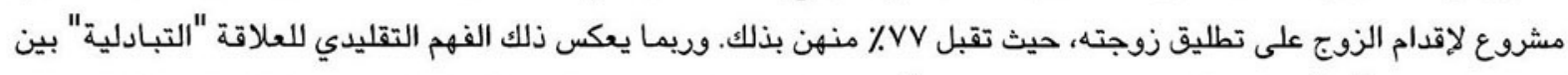
الزوج والزوجة؛ أي أن يكفل الزوج زوجته في مقابل أن توفر له احتياجاته غير المادية، مثل الاحترام والراحة والطاعة. 


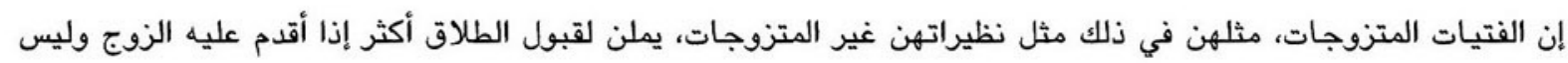

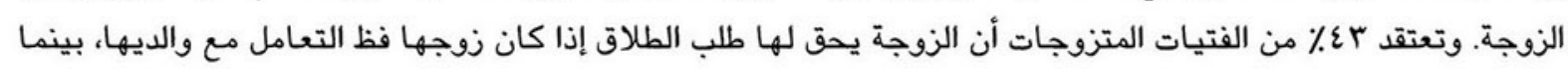

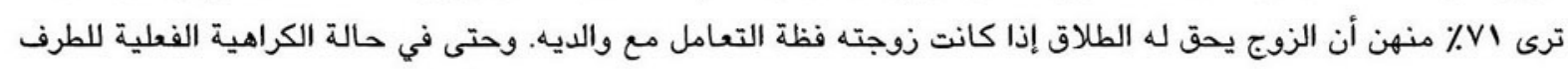

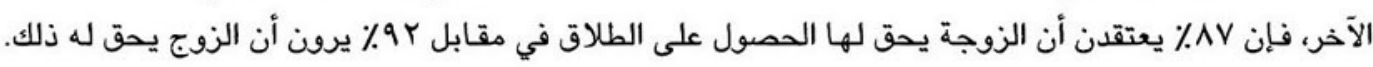

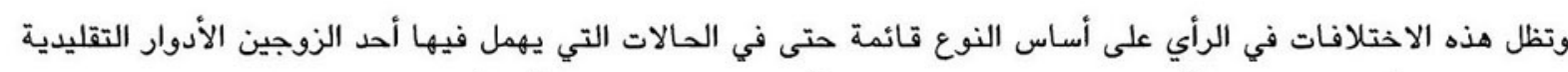

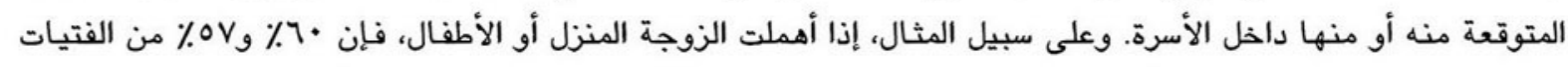

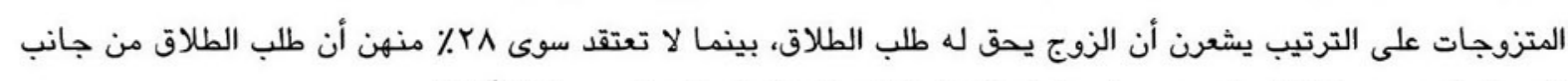

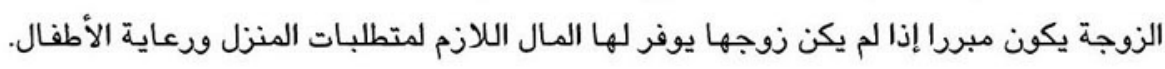

ومن النتائج الجديرة بالاعتبار العزوف النسبي للنساء المتزوجات عن الإقرار بحق المرأة في المبادرة بالطلاق إذا ضربها

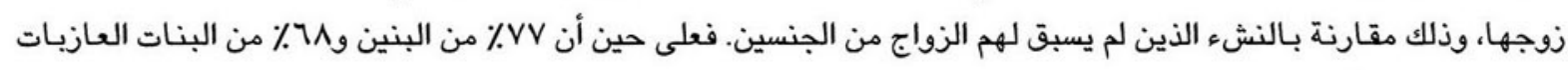

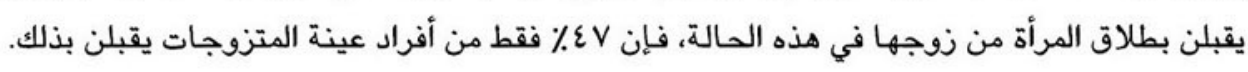

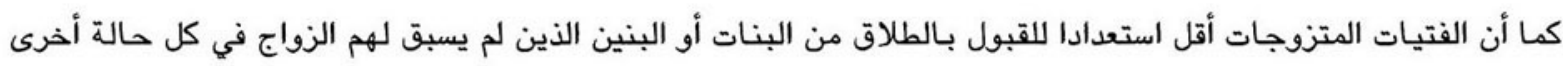

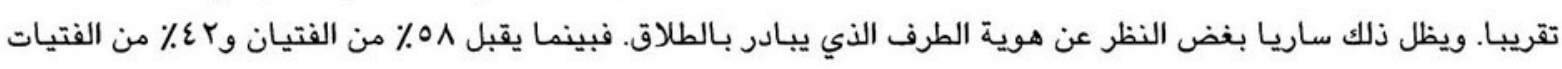

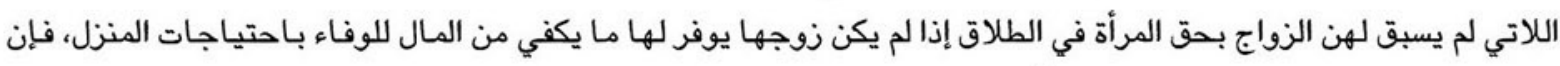

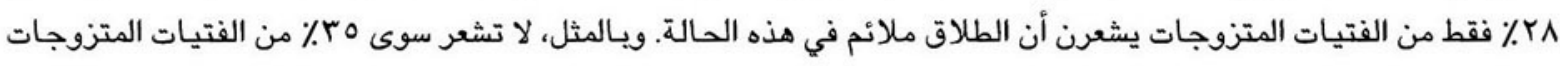

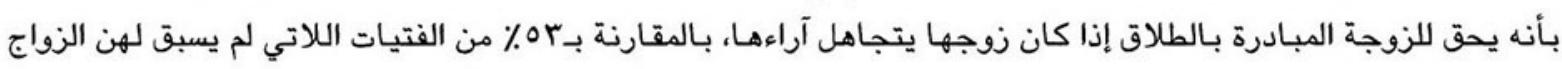

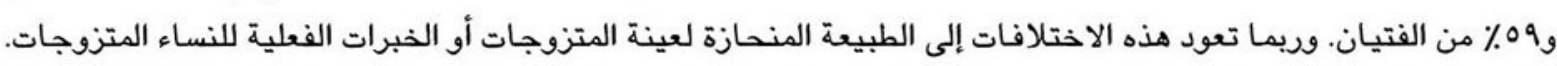

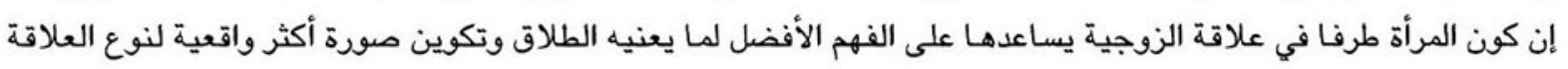

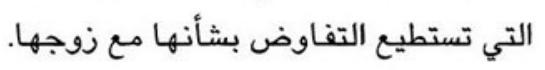

\section{سابعا: الاستنتاجات}

خلال انتقاله إلى الزواج والأدوار الإنجابية، يتعرض النشء للتغيرات الجسدية الخاصة بالنضوج وكذلك للتغيرات الاجتماعية

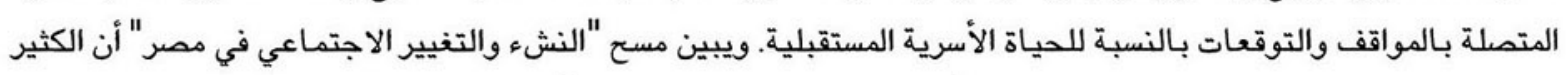

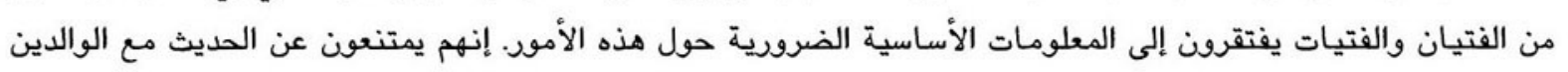
وغيرهم من البالغين، لكنهم في الوقت ذاته يرغبون في الحصول على المعلومات الأسات والإرشاد.

وتحتاج الفتيات خاصة للمزيد من المرافق الصحية المساعدة في المدرسة. وهناك معاناة غير ضرورية تنتج عن عدم سعي

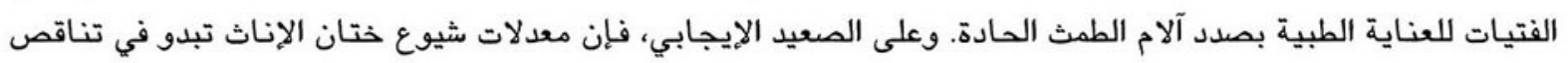
بين هذا الجيل من الفتيات.

فيما يتعلق بمواقفهم إزاء الأدوار المتصلة بالنوع، يفضل غالبية النشء التمييز بين أدوار الجنسين. إلا أن هناك اختلافات أبنات بين

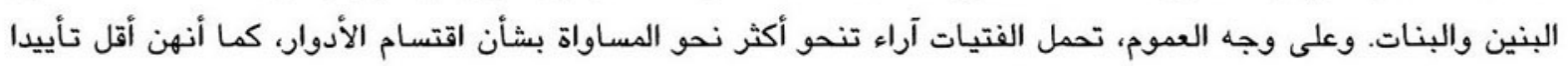

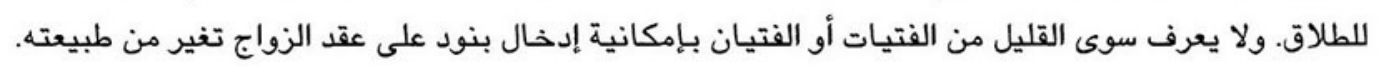




\section{نواج الفتيات}

خلال السنوات الأخيرة، أثمرت عدة عوامل اجتماعية وثقافية واقتصادية تغييرا بالغا في أنماط الزواج وتكوين الأسرة في مصر.

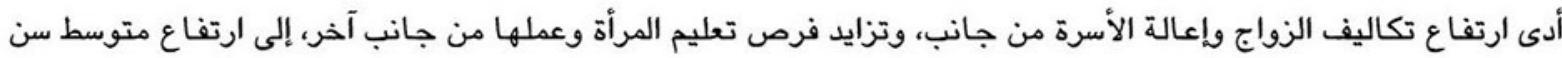

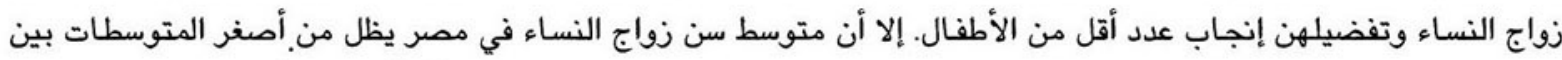

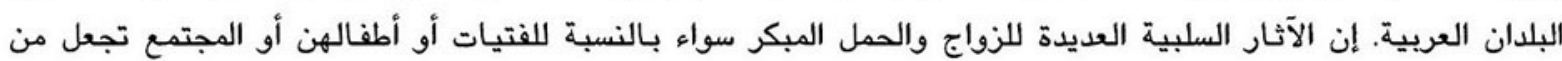

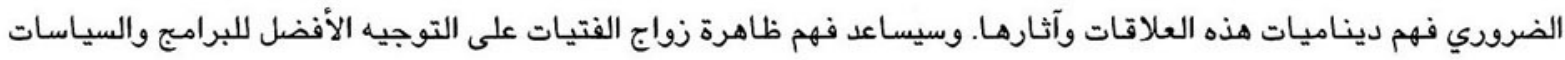
الهادفة إلى تقليل انتشار الزواج المبكر وتحسين الظروف المعيشية للاتي يتزوجن خلال سنوات المراهقة.

وكما جاء في الفمل الثاني، حاول المسح مقابلة جميع الفتيات المتزوجات اللاتي تم تحديدهن من خلال عملية حصر أفراد

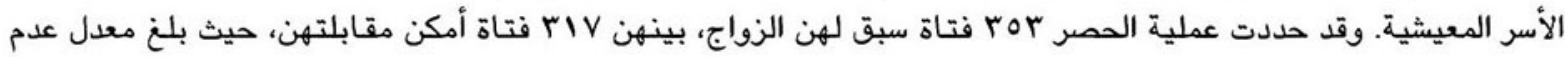

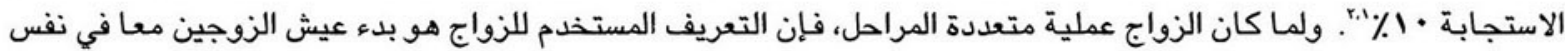
المنزل (الدخلة).

تمثل الفتيات المتزوجات فئة خاصة في مصر، لا تشترك سوى في سمات قليلة مع مجمل الفتيات. وفي بعض أجزاء التحليل

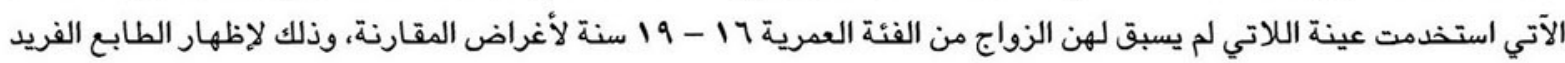
لعينة المتزوجات.

\section{أولا: تصنيف نواج الفتيات وتحديد مدى شيوعه}

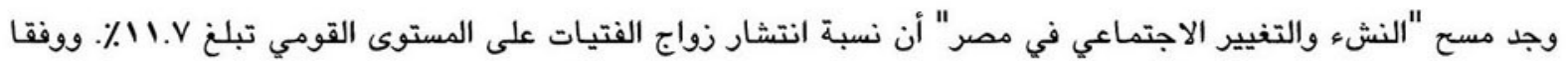

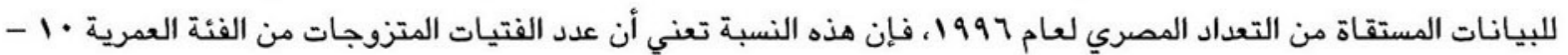

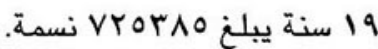

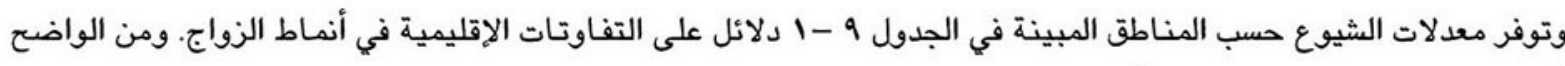

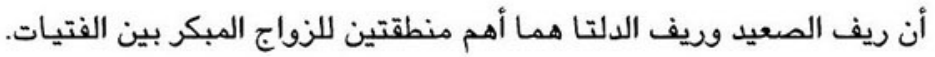

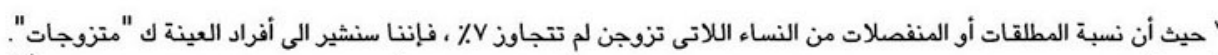

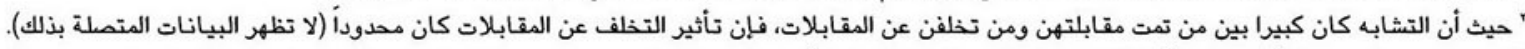

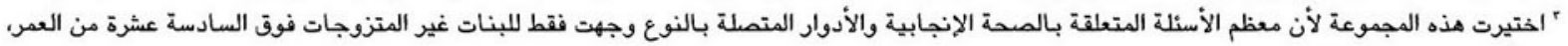
رغم أنها وجهت لكافة اللاتى تزوجن. 


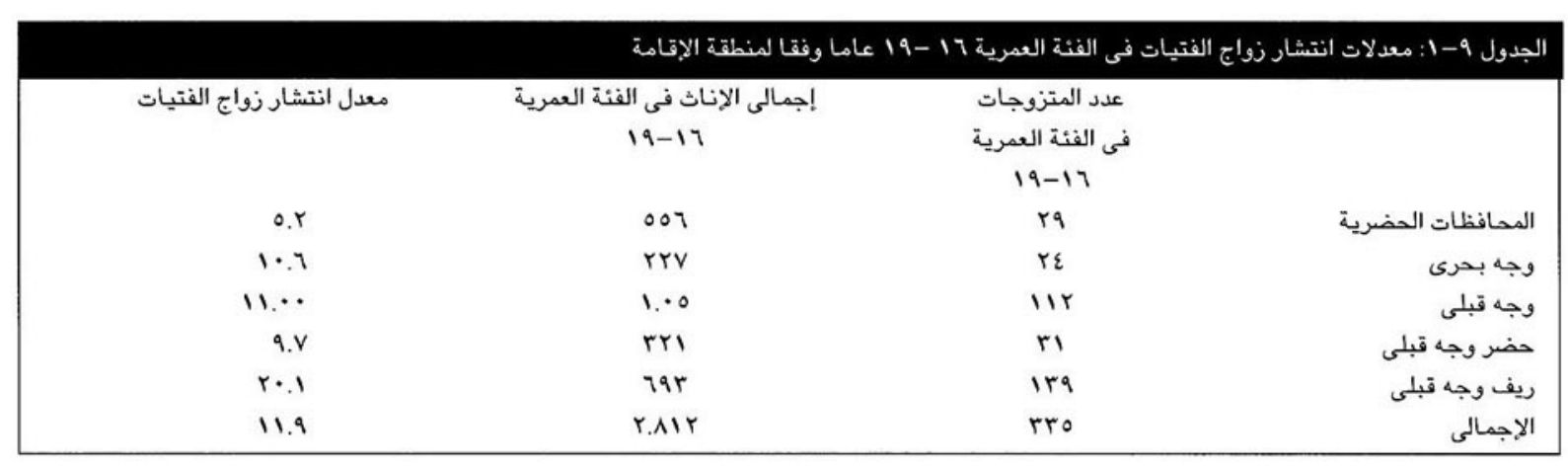

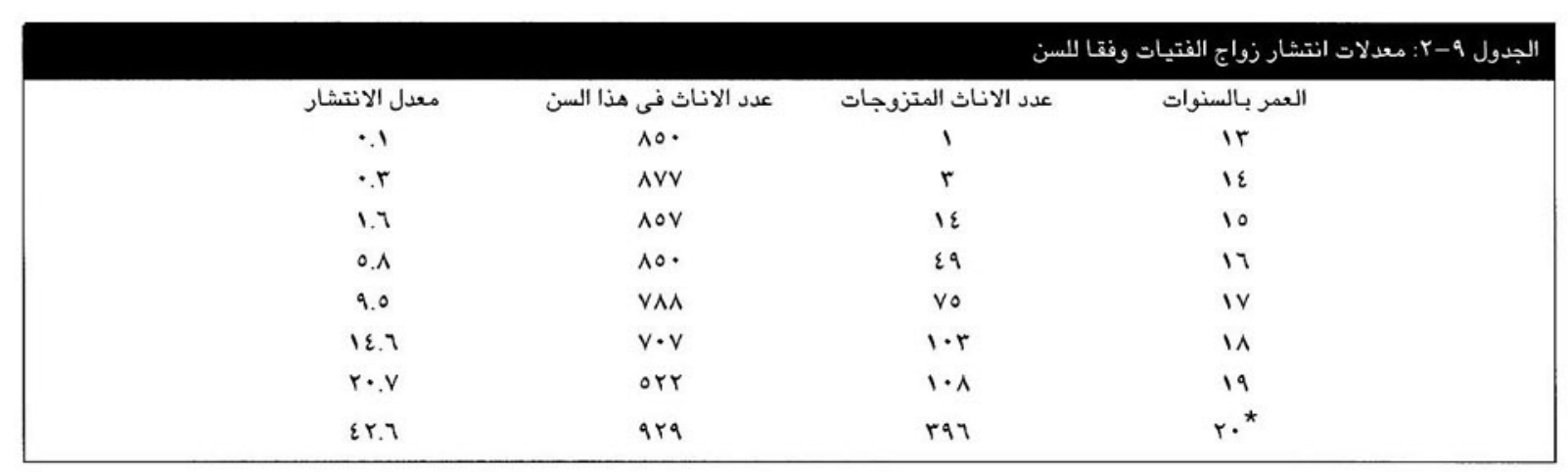

ويبين الجدول 9 - ك معدلات شيوع زواج الفتيات حسب السن في مصر، وذلك باستخدام عينة النساء اللاتي تزوجن ممن تم

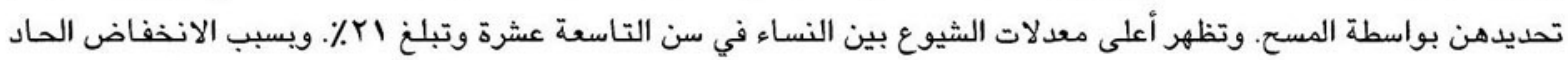
والمفاجئ في عدد النساء في سن التاسعة عشرة، والذى يغري عادة الى زيادة الإبلاغ من الأعمار المنتهية بصفر أو خمسة. فقد حسبنا أيضا معدل زواج النساء في سن العشرين، ووجدناه يبلغ بع٪٪. ومن ثم فـالأرجح أن الفارق في معدل الزواج بين النساء في التاسعة عشرة والعشرين من العمر فى واقع الأمر ليس كبيرا كما يبدو في الجدول و-r. وكن.

الزواج دون السن القانونية

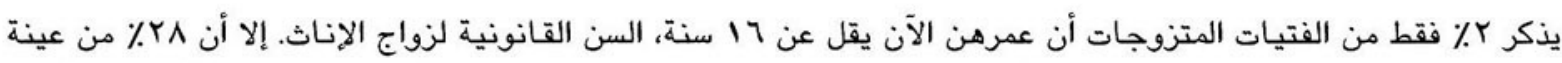

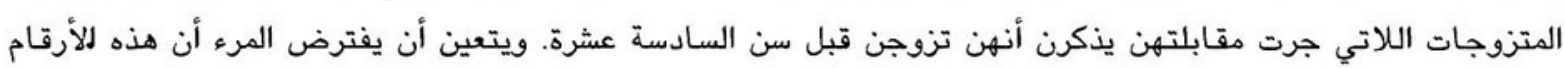

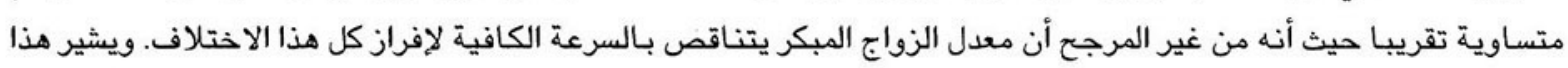

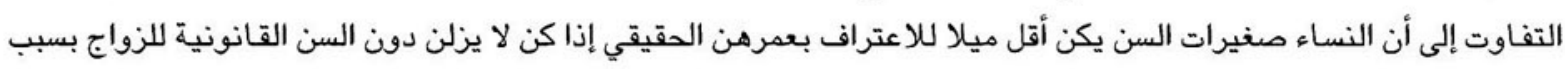

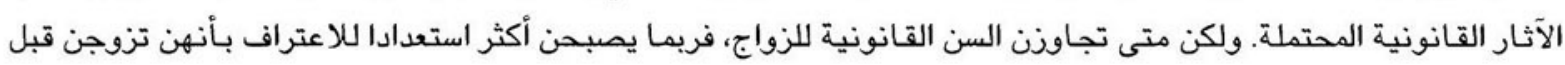

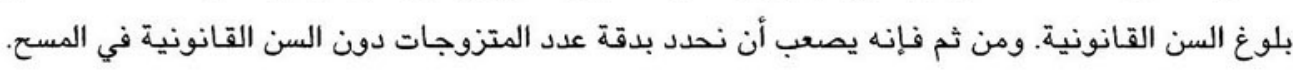

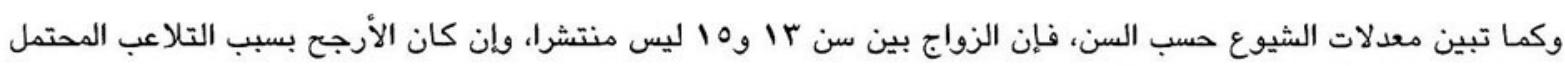

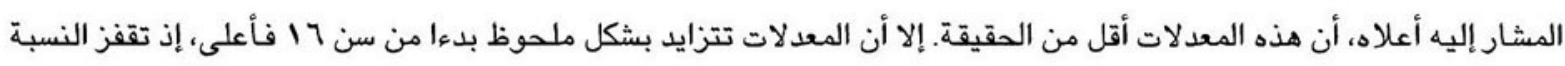

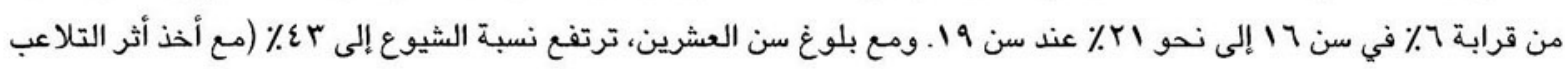

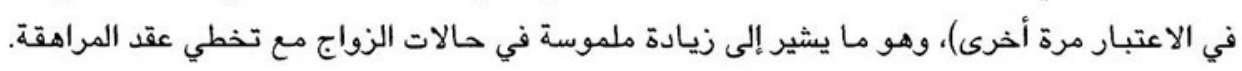




\section{العالة الاجتماعية الاقتمادية}

تم تكوين دليل اجتماعي اقتصادي على أساس توافر مقتنيات معينة في المنزل يُعتقد أنها تميز بين الأسر وفقا للحالة

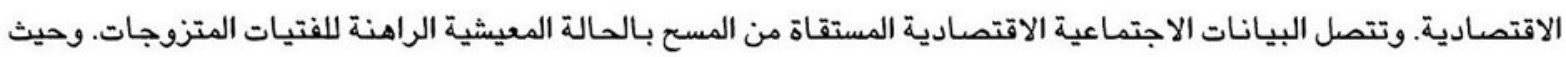

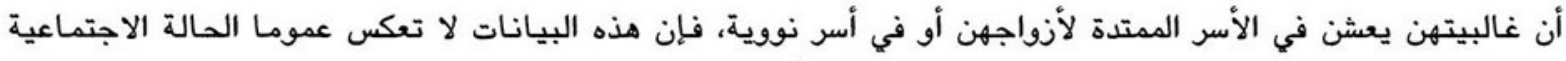

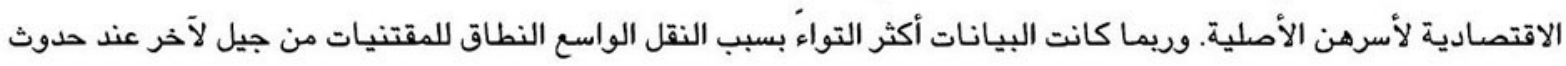
الزواج في مصر. ومع ذلك، فإن البيانات توفر معلومات حول الظروف المعيشية الراهنة للفتيات اللاتي تزوجن.

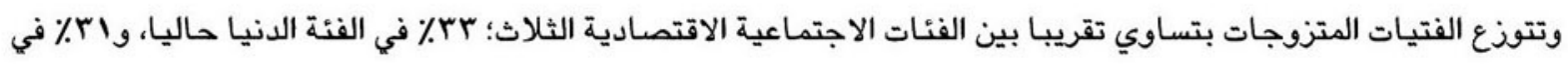

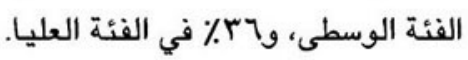

المستوى التعليمي

وكما هو متوقع، فإن المستوى التعليمي للفتيات المتزوجات أقل من مثيله بين غير المتزوجات. ويمكن تفسير ذلك بأن الفتيات

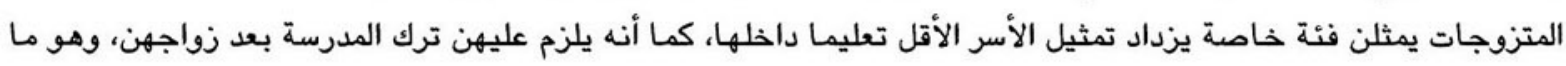

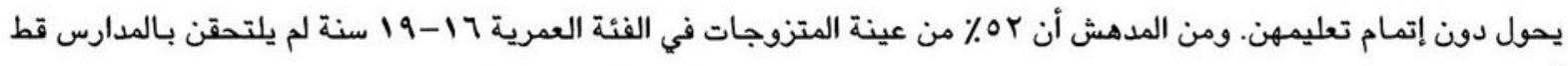

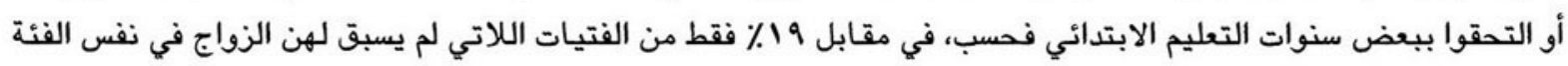

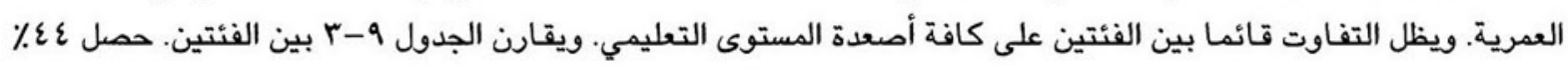

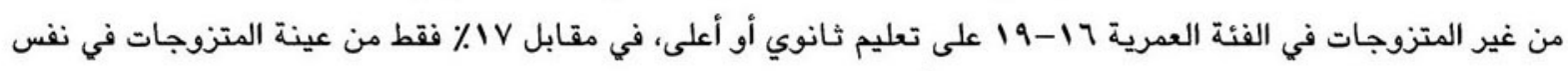

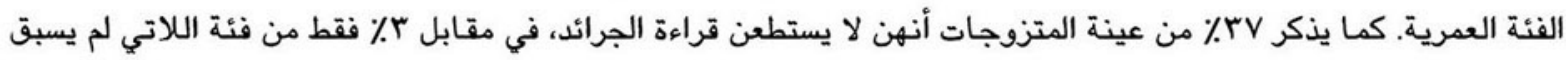

والتحقت 0 ا من النساء المتزوجات اللاتي لم يلتحقن بالمدارس قط بفصول محو الأمية. وفي وقت إجراء المسح، لم تذكر أية

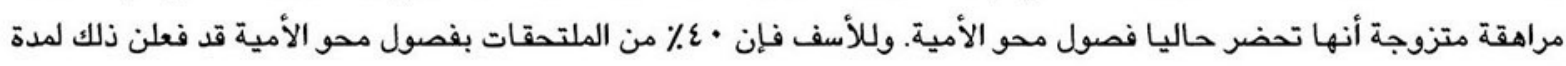

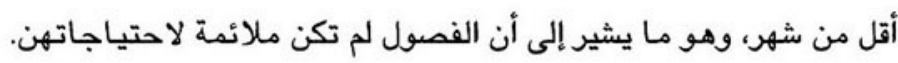




\begin{tabular}{|c|c|c|c|}
\hline \multicolumn{2}{|c|}{ الفتيات غير المتزوجات } & \multicolumn{2}{|c|}{ الفتيات المتزوجات فى } \\
\hline \multicolumn{2}{|c|}{ في الفئة العمرية } & \multicolumn{2}{|c|}{ الفنة العمرية } \\
\hline \multicolumn{2}{|c|}{ من 17-19 سنة } & \multicolumn{2}{|c|}{ من 17 -19 سنة } \\
\hline النسبة & النسبة & النسبة الن & النسبة \\
\hline التراكمية & الاجمالية & التراكمية & الإجمالية \\
\hline 19.9 & 19.9 & or.A & Or.A \\
\hline ro.1 & 10.9 & $\Lambda \cdot . \varepsilon$ & rY.o \\
\hline$v r . \varepsilon$ & rv. & $99 . \mathrm{r}$ & $1 / .9$ \\
\hline $1 \cdots$ & & $1 \cdots$ & $\cdot . v$ \\
\hline
\end{tabular}

لم يلتحقن بالتعليم/ لم يكملن المرحلة الابتدائية

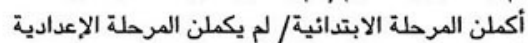

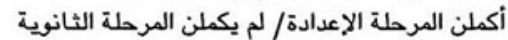

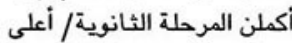

\section{أسباب تسرب النتيات المتزوجات من المدارس أو عدم التحاقهن بها قط}

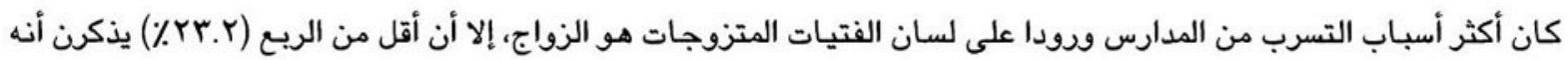

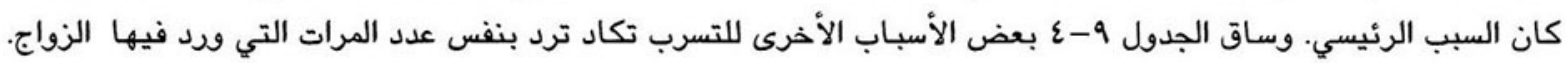

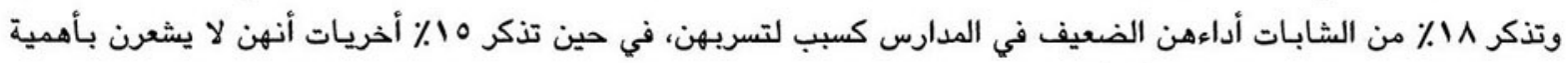

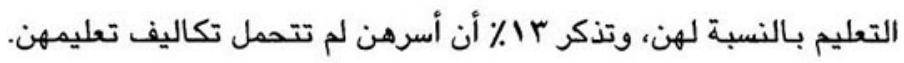

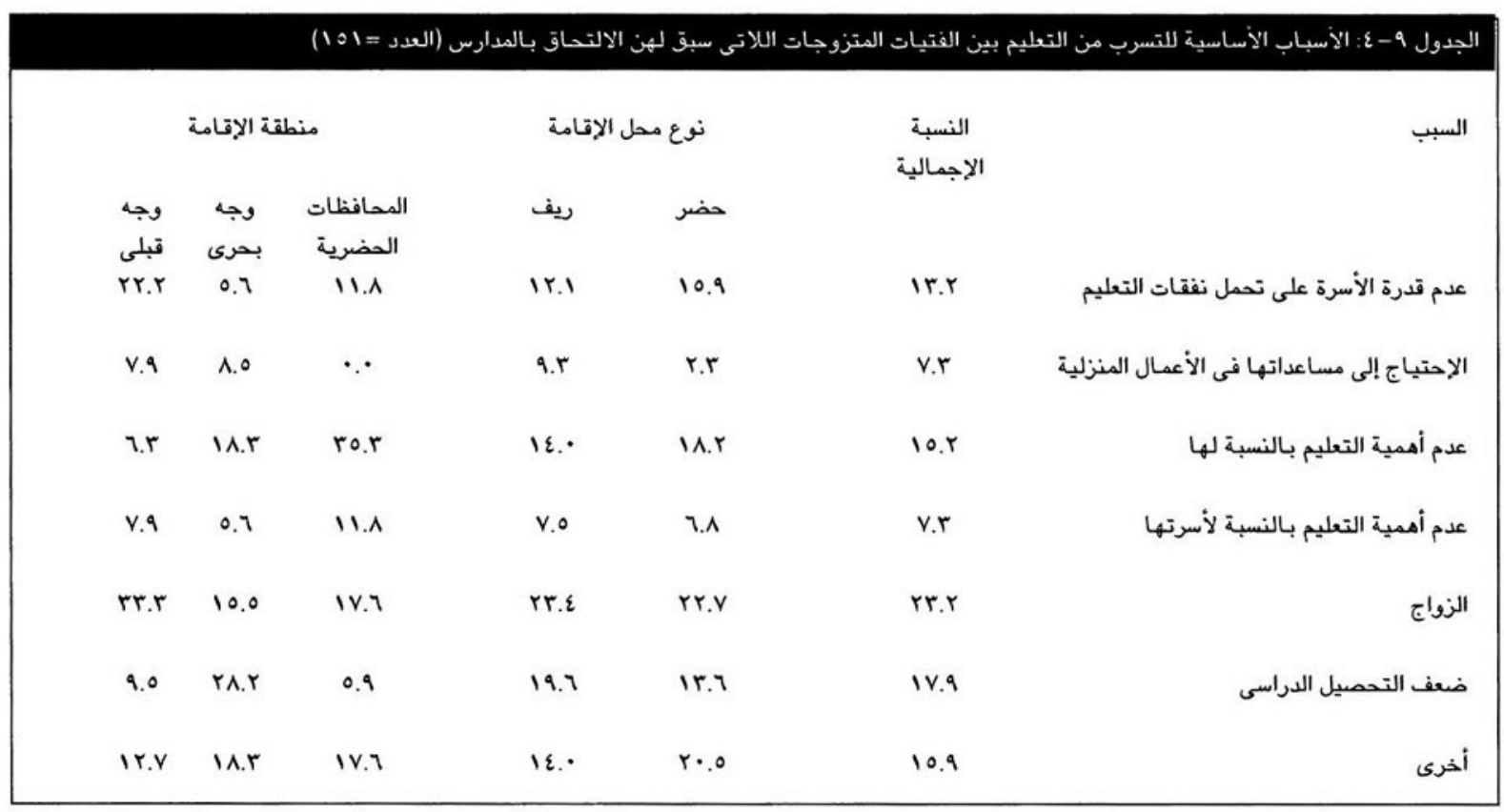

وجدير بالذكر أن الجدول و-ه يبين أن الشابات اللاتي يذكرن الزواج سببا للتسرب من المدارس كن في الواقع أكبر سنا بكثير

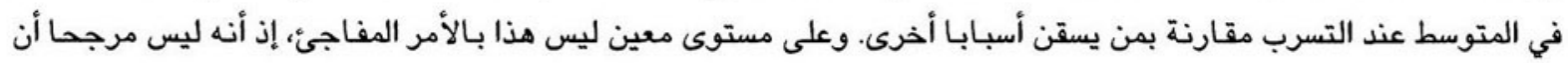

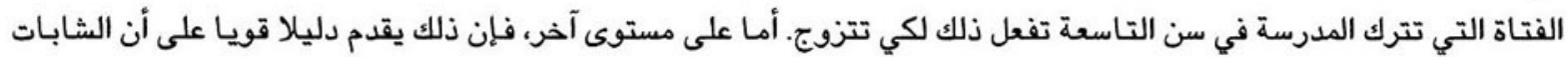

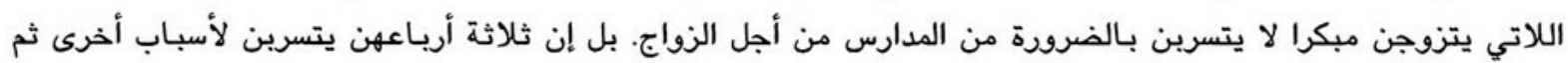

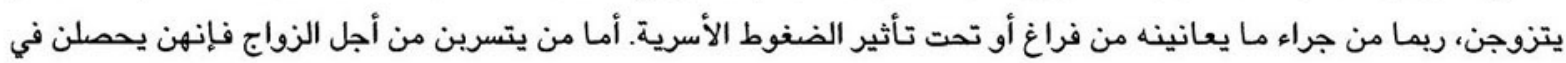

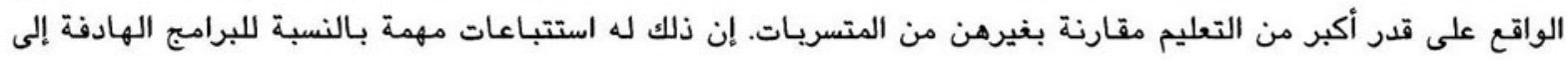




\begin{tabular}{|c|c|c|c|}
\hline النسبة الإجمالية & متوسط العمر & بـاتيات المتزوجـا & الجدول 9-0 : السن المتوسط للتسرب من التعليم بـ \\
\hline rr.r & $10 .$. & $10.1 \varepsilon$ & 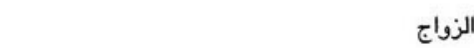 \\
\hline 18.9 & ir... & רוr.te & ضعف التحصيل الدراسى \\
\hline v.r & $11 . \cdots$ & ir... & عدم أهمية التعليم بالنسبة لأسرتها \\
\hline ir.r & ir... & 11.ro & عدم قدرة الأسرة على تحمل نفقات التعليم \\
\hline 10.r & $1 \cdots$ & $1 \cdot v \varepsilon$ & عدم أهمية التعليم بالنسبة لها \\
\hline v.r & $1 \cdots$ & $1 \cdot v r$ & لاحتياج إلى مساعدة الفتاة في الأعمال المنزلية \\
\hline 10.9 & ir... & ir.r. & 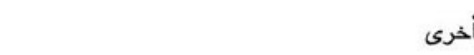 \\
\hline
\end{tabular}

ويبين الجدول 9-7 الأسباب الأساسية التي تعتقد الفتيات المتزوجات أنها كانت وراء عدم إرسالهن للمدارس من قبل الوالدين.

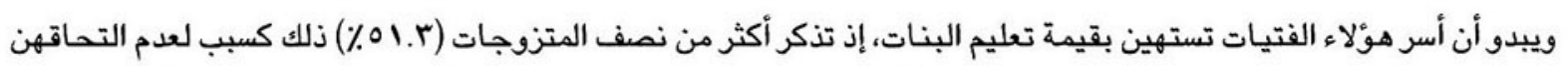

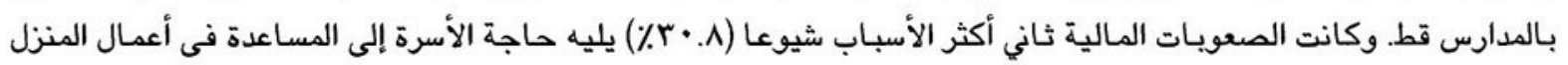

(\% $1 \vee .1)$

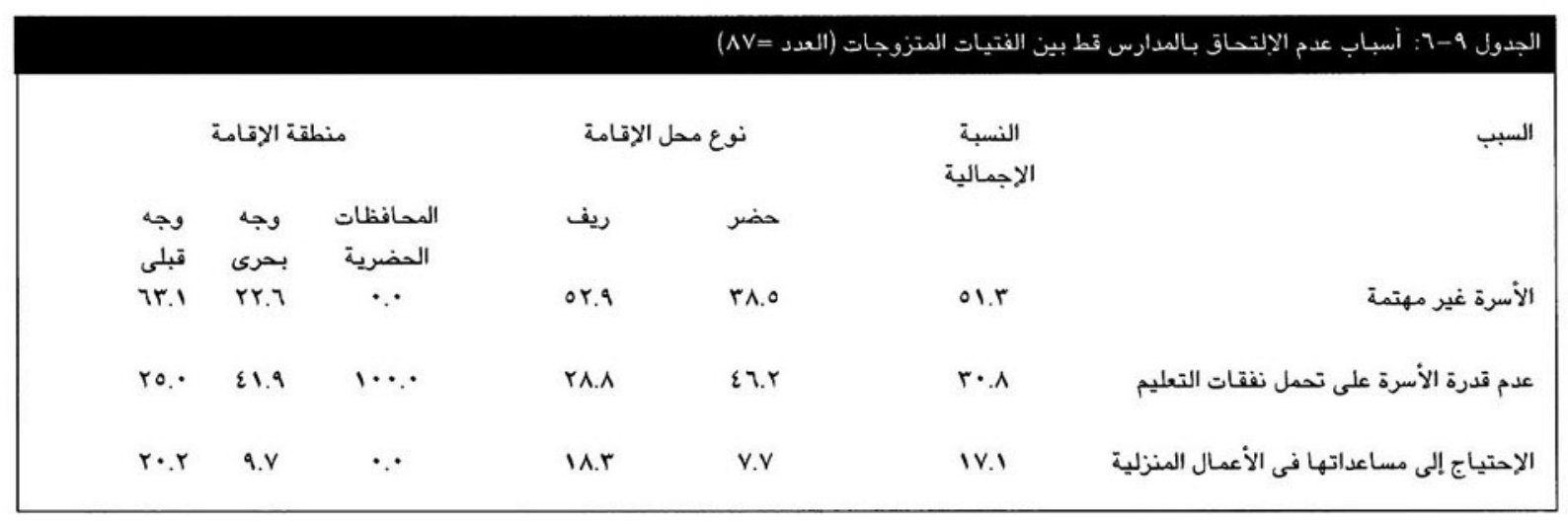

وتعد الأسباب الثلاثة الأساسية لعدم الالتحاق بالمدارس قط جوانب مختلفة لنفس الظاهرة المتصلة بالاقتصاد: التخصيص

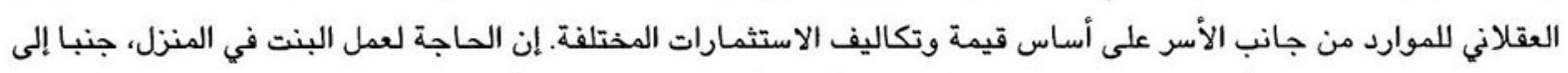

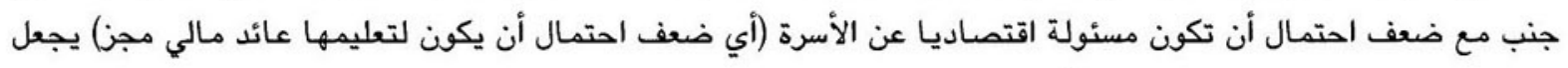

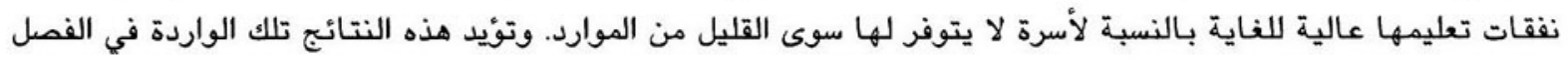

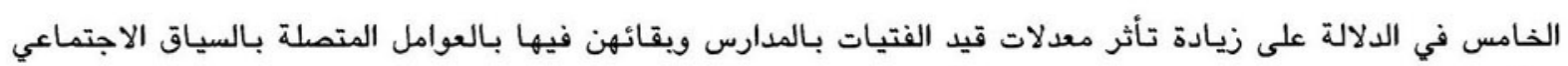

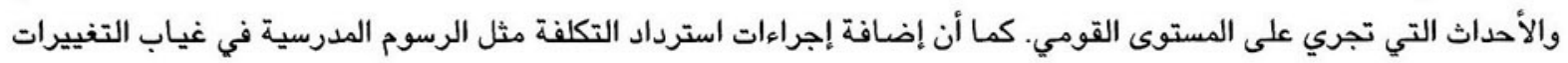
الأخرى من شأنه أن يجعل تعليم الفتيات فوق مقدرة بعض الأل الأسر.

\section{ثالثا: سمات نواج الفتيات}

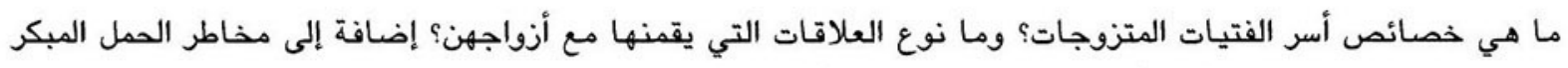

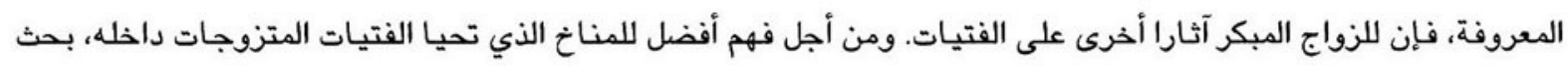

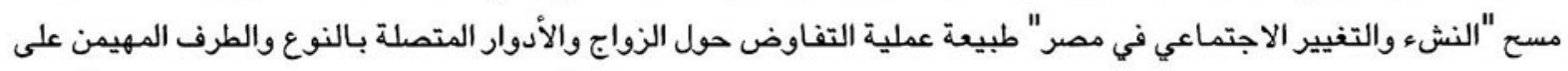

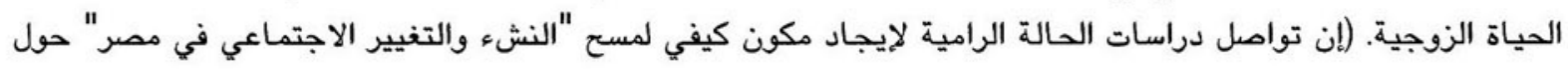

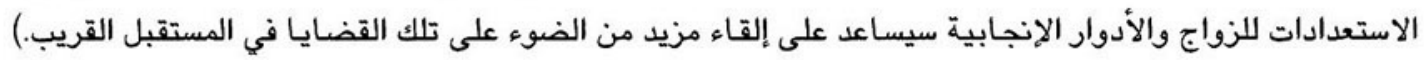




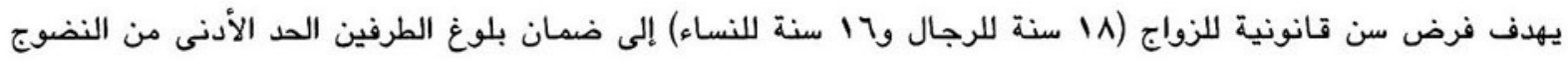

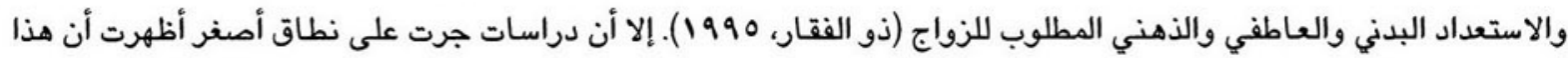

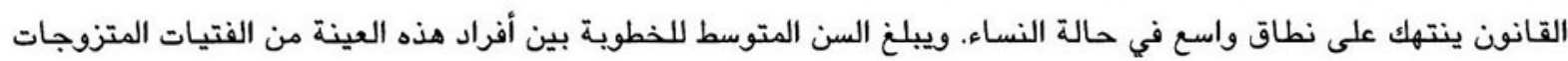

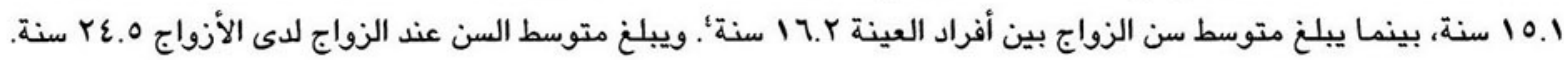
ويتفاوت ذلك حسب منطقة ونمط محل السكن، حيث يوجد فارق سنتين بين أعمار الأزواج في الصعيد والمحافظات الحضرية.

ويقارن الجدول Q- و بين أعمار الزواج الفعلية للفتيات المتزوجات وأزواجهن، وسن الزواج المثالي للاثنين من منظور الفتيات

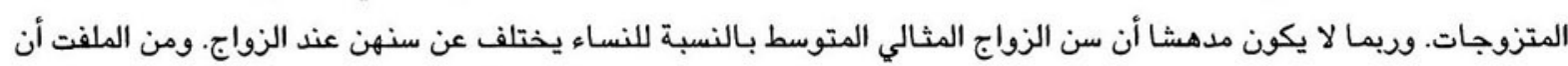

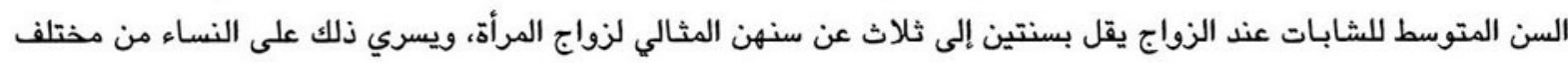

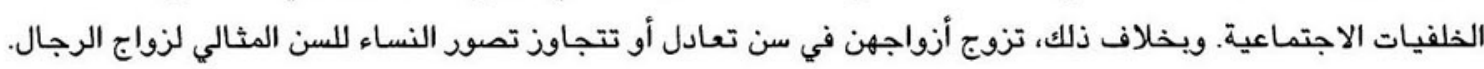

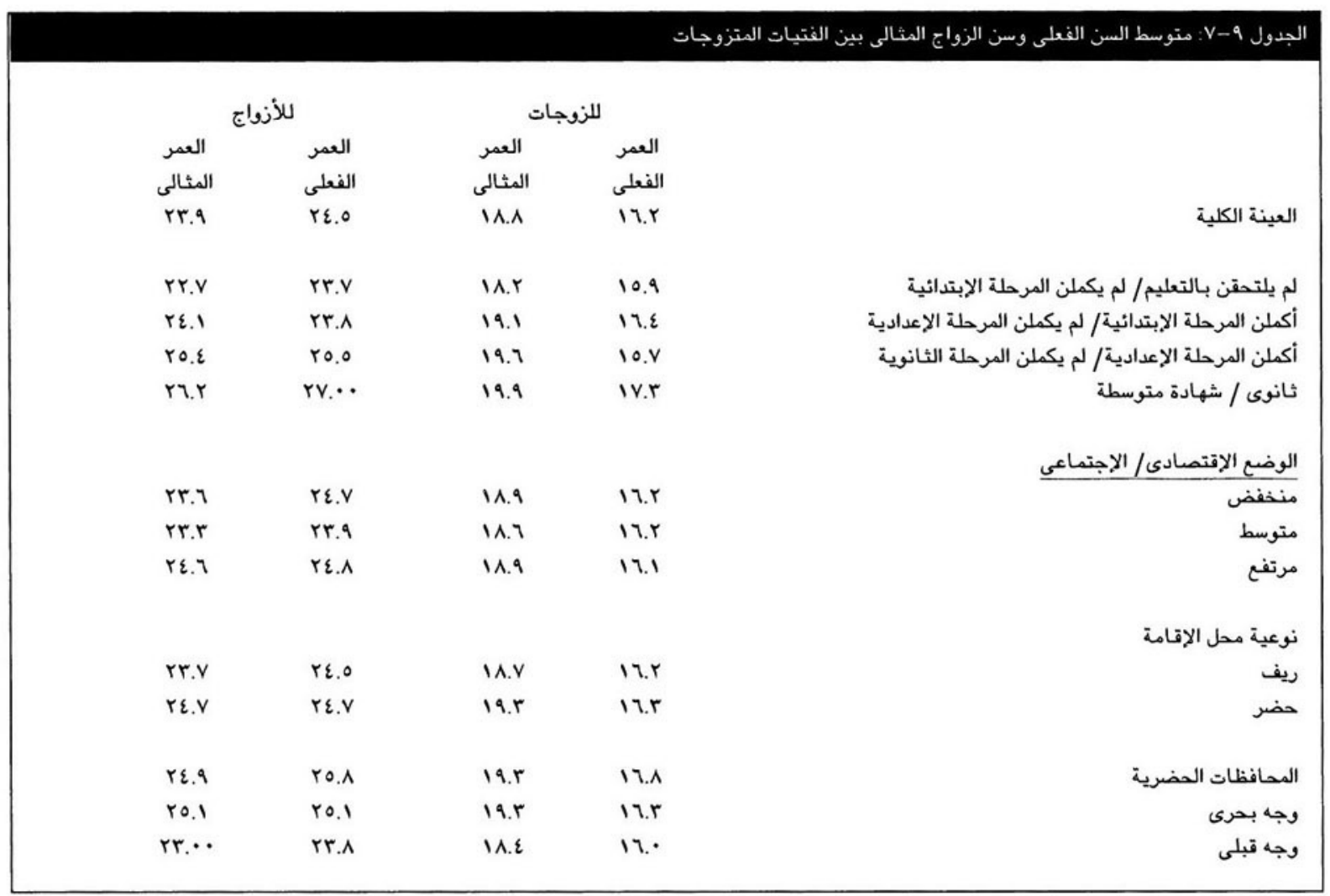

\section{فارق السن بين النوجين}

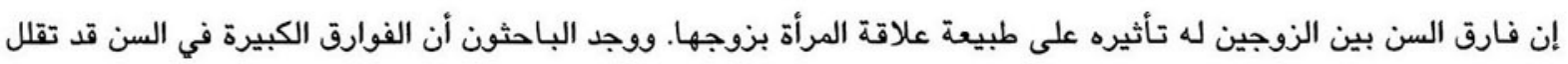

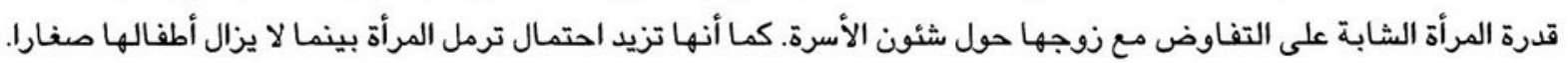


ولما كان المجتمع المصري لا يشجع النساء الأرامل على الزواج من جديد على أساس أن ذلك أفضل للأطفال، فإنه يرجح أن تحيا

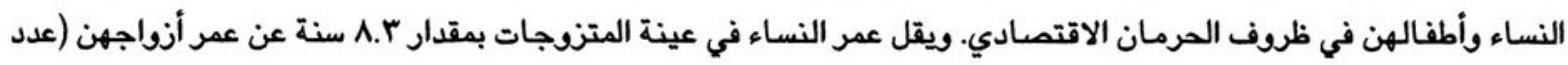

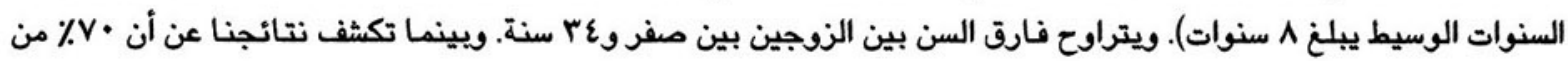

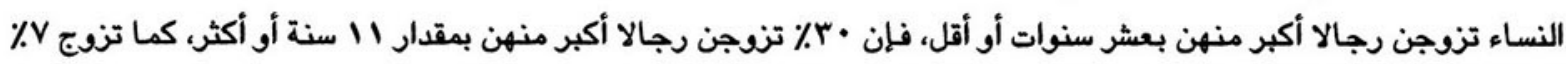

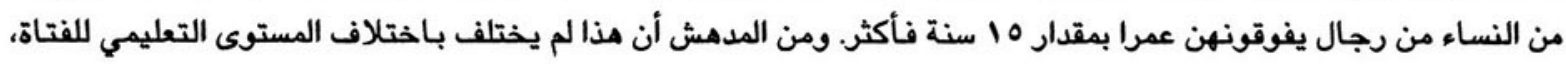
أو سنها عند الزواج، أو منطقة ونمط محل السكن.

تسمح لنا نتائج المسح الديموجرافي والصحي المصري لعام 1990 بمقارنة نتائجنا حول زواج الفتيات بتلك الخاصة بنساء

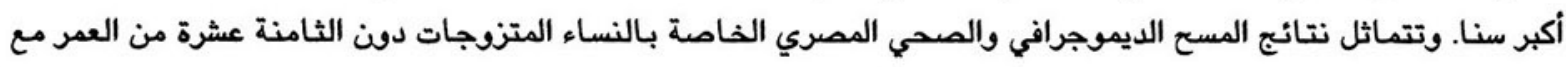

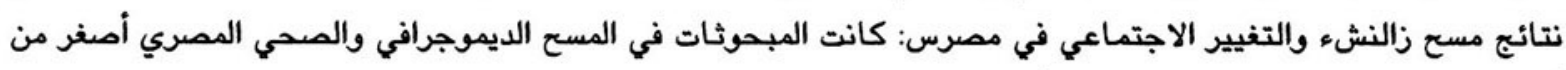

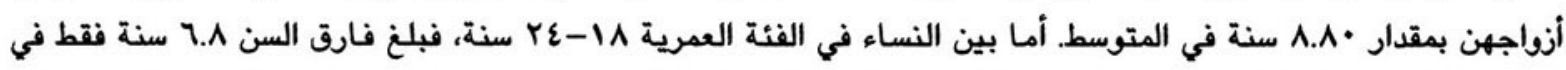

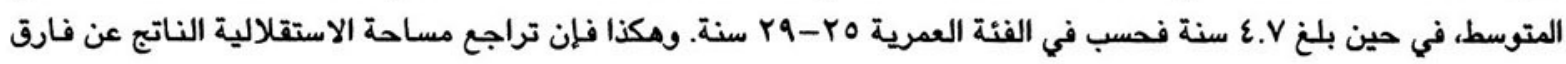

السن الكبير يزيد عند الفتيات المتزوجات عمن تكبرهن قليلا.

إن فارق السن الفعلي بين مؤلاء الشابات المتزوجات وأزواجهن يختلف كثيرا عن الحالة التي يرونها مثالية. تقول الفتيات

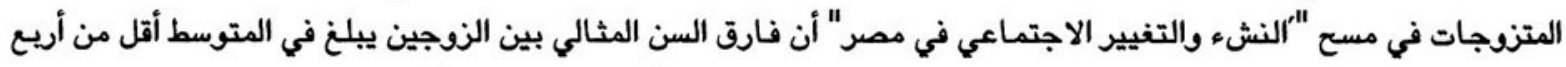

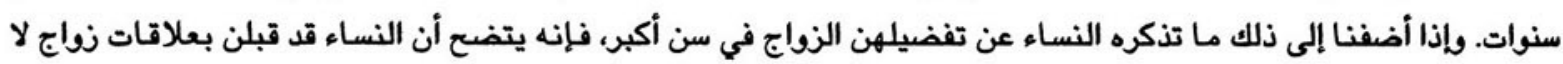
تنسجم وميولهن.

\section{الكلة الأهيرة بشأن النهاج}

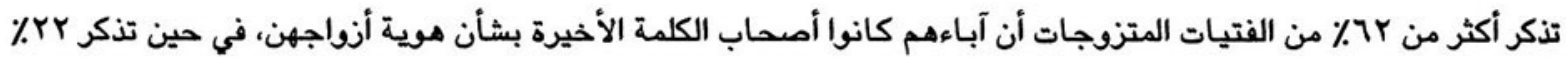

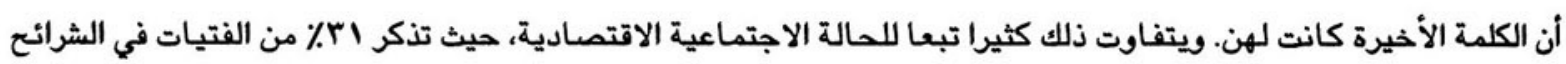

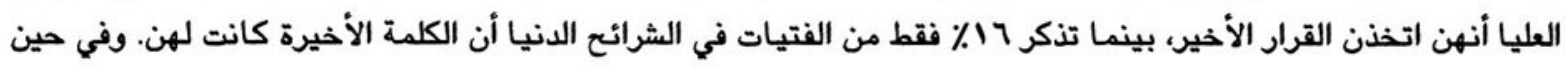

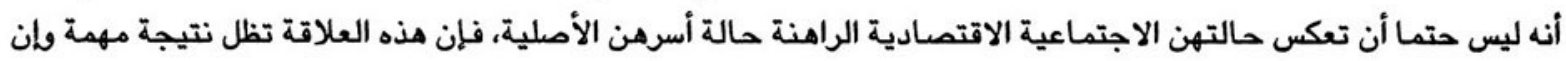

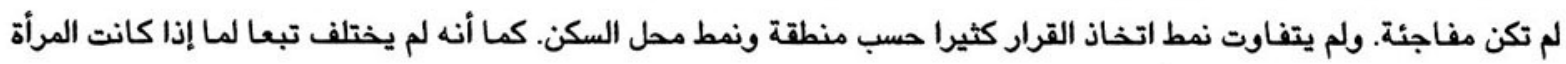
الشابة قد تزوجت من قريب لها أم لا.

والأرجح أن هؤلاء النساء لعبوا بالفعل دورا في عملية اتخاذ القرار بشأن زواجهن. إلا أن الزواج في مصر غالبا ما يشمل

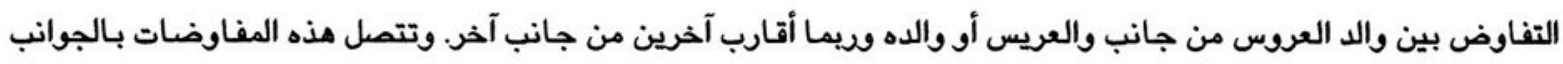

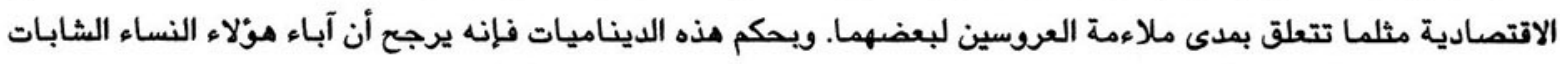
قد اتخذوا القرار الأخير بشأن الزواج، ولان لم يكن في غيبة التدخل من جانب الفئ الفتاة أو أمها. 
يوجد تراث عتيق من زواج الأقارب في مصر، مع تفضيل تاريخي لزواج أبناء العمومة. تزوجت أكثر من هو٪ من النساء

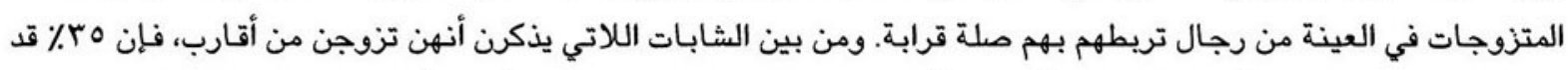

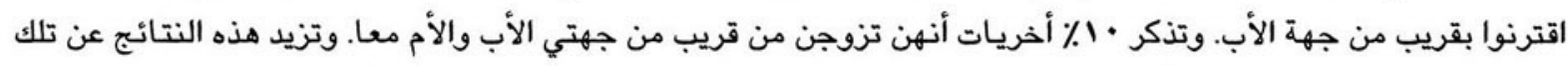

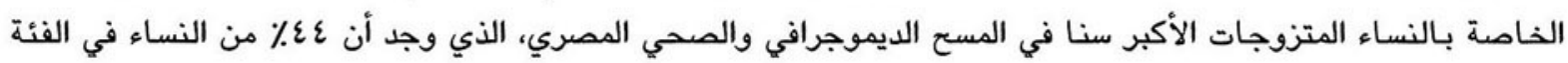

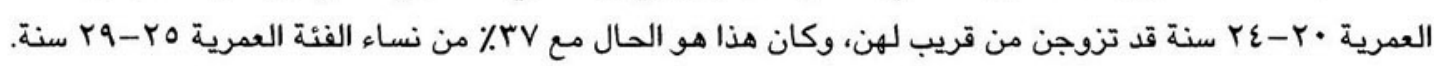

\section{الترتيبات المعيشية للفتيات المتنوجات}

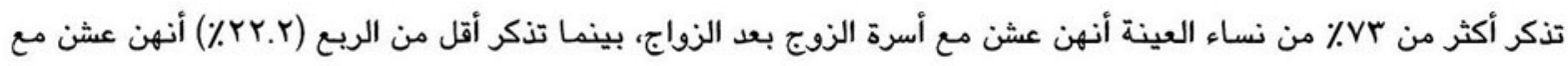

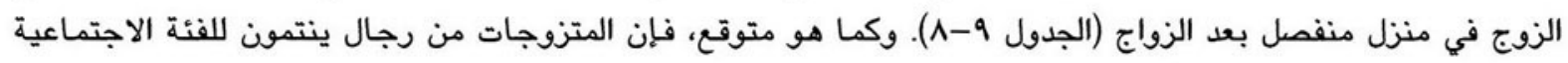

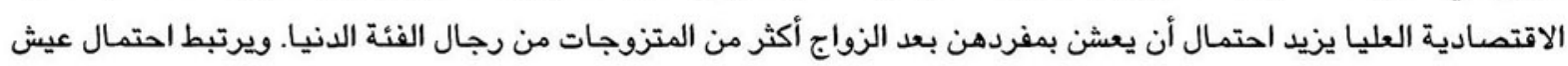

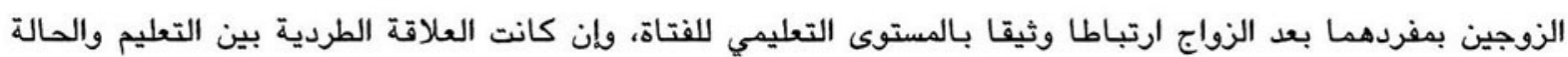
الاجتماعية الاقتصادية قد تشوه قوة تلك العلاقة.

\begin{tabular}{|c|c|c|c|}
\hline مع عائلة زوجها & مع العاثلة & 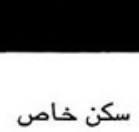 & جدول 9-1: نظام الدعيشة للفتيات المتزوجات بعد الزوا \\
\hline vr.l & $\varepsilon . \vee$ & rr.r & العينة الكلية \\
\hline$\Lambda$ Ar.A & r.7 & ir.7 & لم يلتحقن بالتعليم/لم يكملن المرحلة الإبتدائية \\
\hline $7 \varepsilon . r$ & $9 . \varepsilon$ & rา. & أكملن المرحلة الإبتدانية/ لم يكملن المرحلة الإعدادية \\
\hline 认.. & r.l & rq.A & أكملن المرحلة الإعدادية/ لم يكملن المرحلة الثانوية \\
\hline or.r & $7 . \varepsilon$ & $\varepsilon \cdot \varepsilon$ & ثانوى / شهادة متوسطة \\
\hline & & & الوضع الإقتصادى/ الاجتماعى \\
\hline vr.t & 7.1 & 19.1 & منخفض \\
\hline vr.r & r.r & re.V & متوسط \\
\hline Vr.T & 0.1 & rr.l & 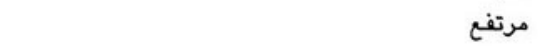 \\
\hline & & & نوعية محل الإقامة \\
\hline or. & $\because$ & $\varepsilon \vee \cdot$ & ريف \\
\hline VA. & ר. & 10.7 & حضر \\
\hline M.A & $\because$ & Wh. & المحافظات الحضرية \\
\hline$v \cdot .0$ & $\varepsilon .0$ & ro.e & وجه بحرى \\
\hline$\Lambda \cdot .9$ & 0.7 & ir.t & وجه قبلى \\
\hline
\end{tabular}

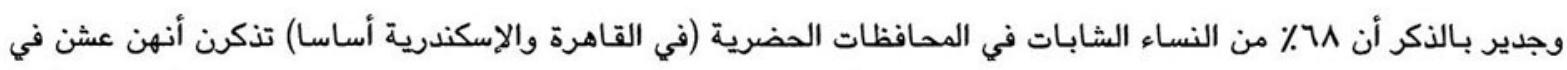

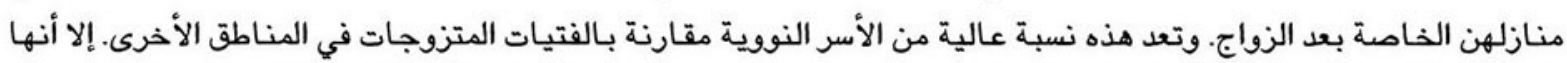

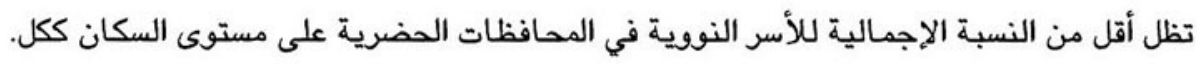


جمع المسح الديموجرافي والصحي المصري معلومات حول محل السكن عند بدء الزواج والسن عند الزواج بين النساء المتزوجات

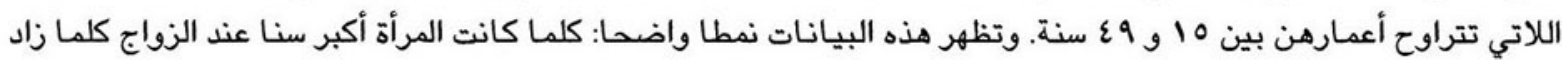

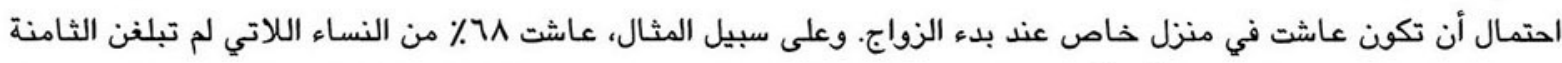

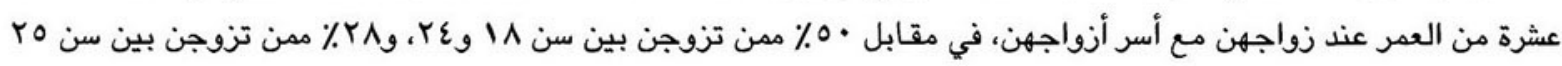

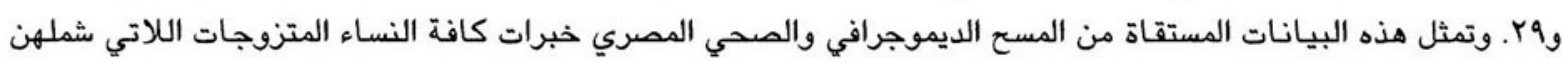

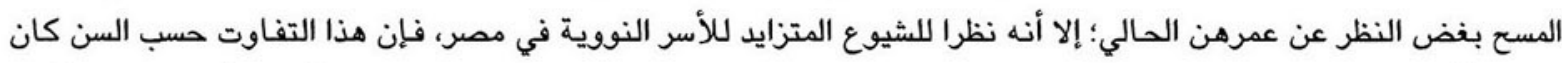

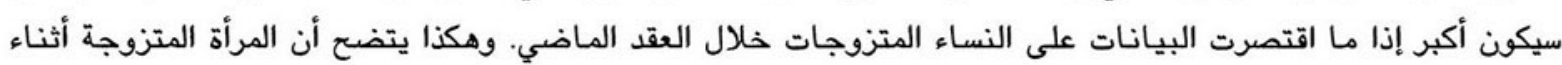

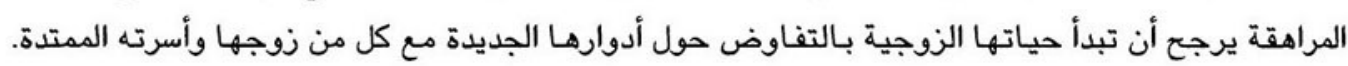

\section{رابعا: الأدوار المتملة بالنوع في الأسرة}

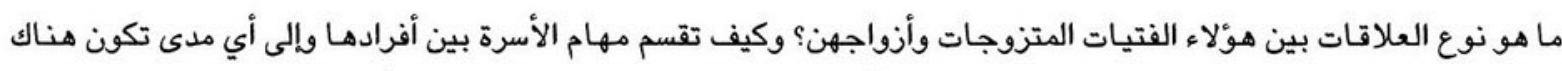

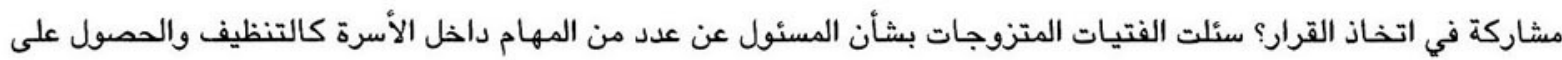
الدخل الأساسي ومن يتخذ القرارات بشأن الأمور المختلفة الخاصة بالأسرة بما في ذلك استخدام موانع الحمل العات وميزانية الأسرة.

\section{اشتراك النوجين في المهام}

هناك نمط من التقسيم التقليدي للعمل في أسر هؤلاء الفتيات المتزوجات. ولا أحد تقريبا يشير إلى اشتراك الزوجين في المهام

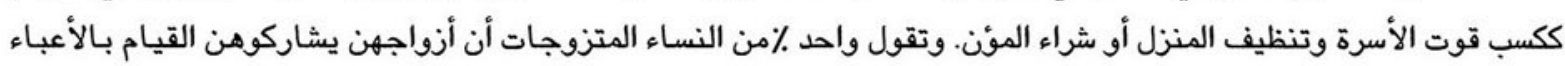

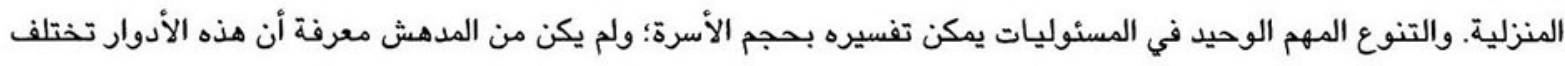

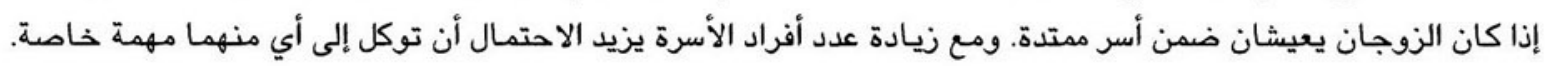

اتخاذ القرار في الأسرة يبدو اتخاذ القرار في الأسرة أقل تفردا من أداء المهام، وقالت نسب كبيرة من النساء المتزوجات أنهن يشتركن في صنع القرار في قضايا الأسرة المهمة.

ويبين الجدول 9-9 نسب المبحوثات اللاتي قلن أنهن يشاركن في صنع القرار في عدد من القضايا الخاصة بالأسرة وتختلف

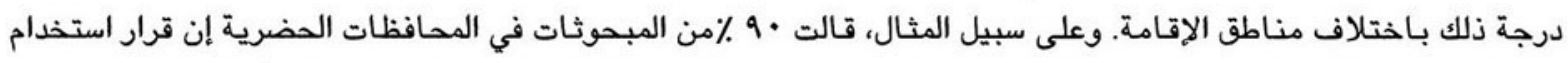

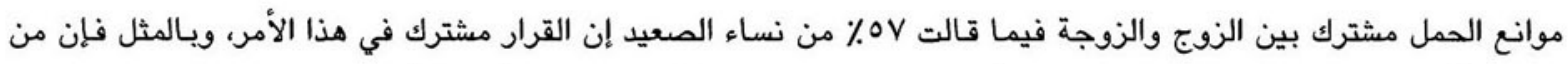

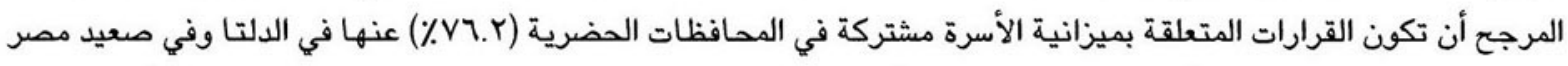

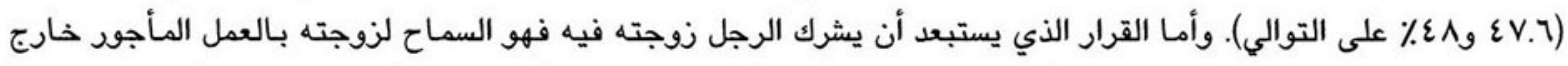

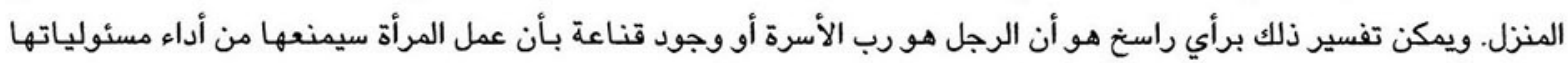
في الأسرة. 


\begin{tabular}{|c|c|c|c|c|}
\hline 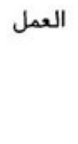 & وسيلة تنظيم & ميزانية الاسرة & آخجاب طفل & \\
\hline$r \cdot r$ & 77.1 & $0 . r$ & vi.r & العينة الكلية \\
\hline rv.r & $77 . \mathrm{r}$ & $\varepsilon \vee .0$ & vr.r & لم يلتحقن بالتعليم/ لم يكملن المرحلة الإبتدائية \\
\hline rA.A & 7า.V & o\&.r & vo. & أكملن المرحلة الابتدائية/ لم يكملن المرحلة الإعدادية \\
\hline r.. & ir.o & $\varepsilon\urcorner .0$ & $01 . \varepsilon$ & xأكملن المرحلة الإعدادية/ لم يكملن المرحلة الثانوية \\
\hline$\varepsilon 0 . V$ & vย.r & $0 \vee .9$ & Ar.r & ثانوى/ شهادة متوسطة \\
\hline rv.r & 19.0 & vา.r & vr.v & المحافظات الحضرية \\
\hline$\varepsilon \cdot v$ & vา. & $\varepsilon \vee\urcorner$. & Ar.r & وجه بحري \\
\hline rr.l & ov. I & $\varepsilon \wedge$. & $7 \cdot r$ & وجه قبلي \\
\hline
\end{tabular}

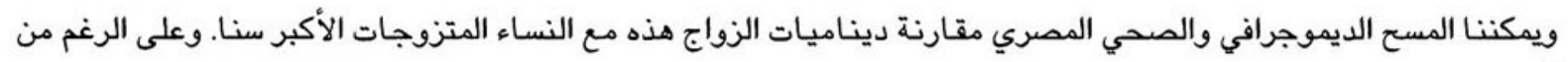

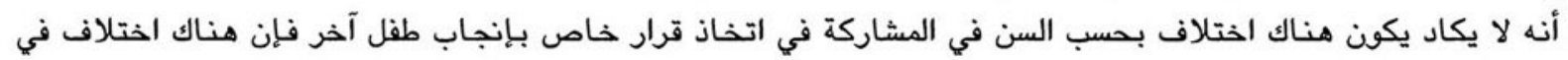

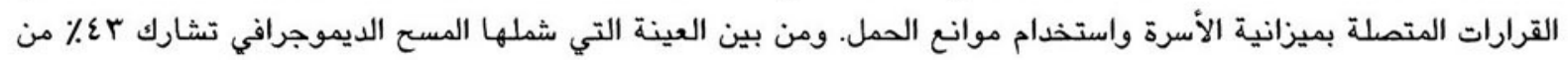

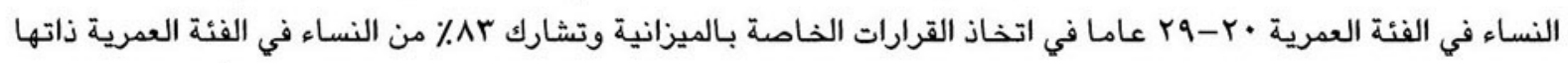

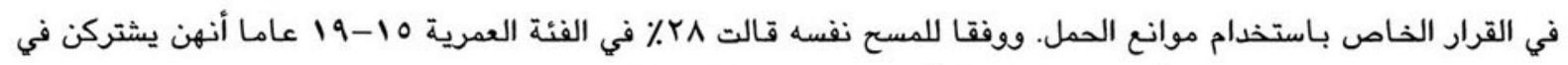

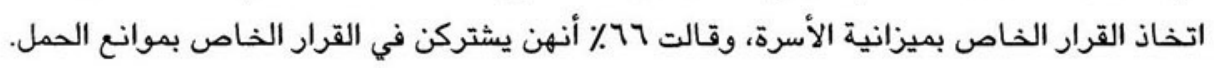

ديناميات النوع الأخرى

سئلت الفتيات المتزوجات العديد من الأسئلة الإضافية بهدف تقييم آليات النوع في علاقتهن الزوجية مثل عبارة "على الزوجة

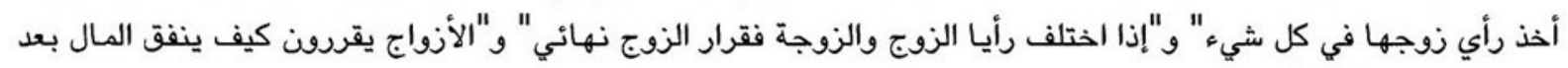

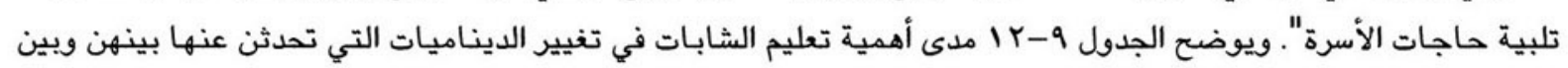

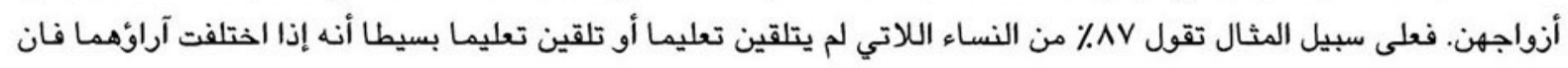

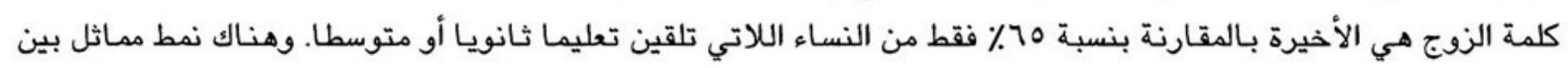
ردود الفعل للسؤالين الآخرين.

الاذن بالخرعج

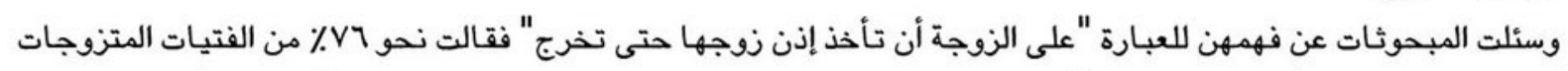

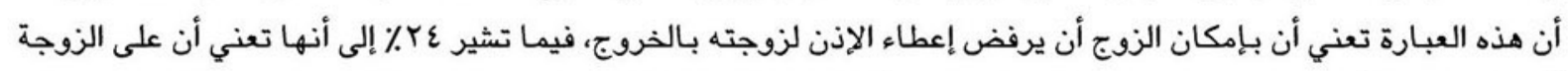

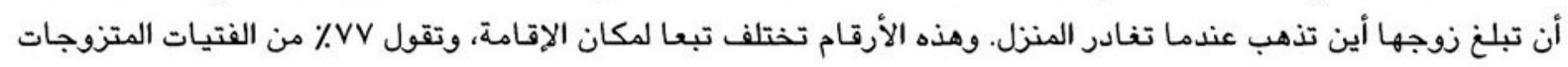

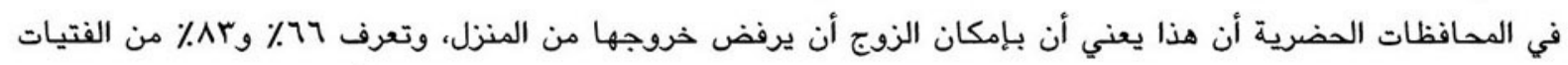

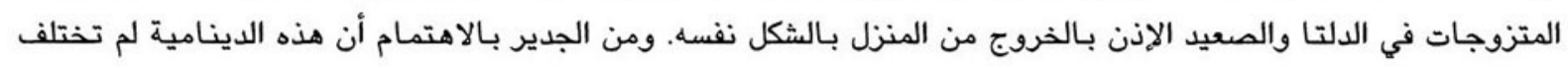
باختلاف مستوى تعليم الفتيات. 


\section{الجدول 9- • 1: النسب المنوية للفتيات المتزوجات اللاتى أجبن بالإيجاب على الأسنلة المتعلقة بديناميات النوع الأخرى بين النساء المتزوجات وأزواجهن}

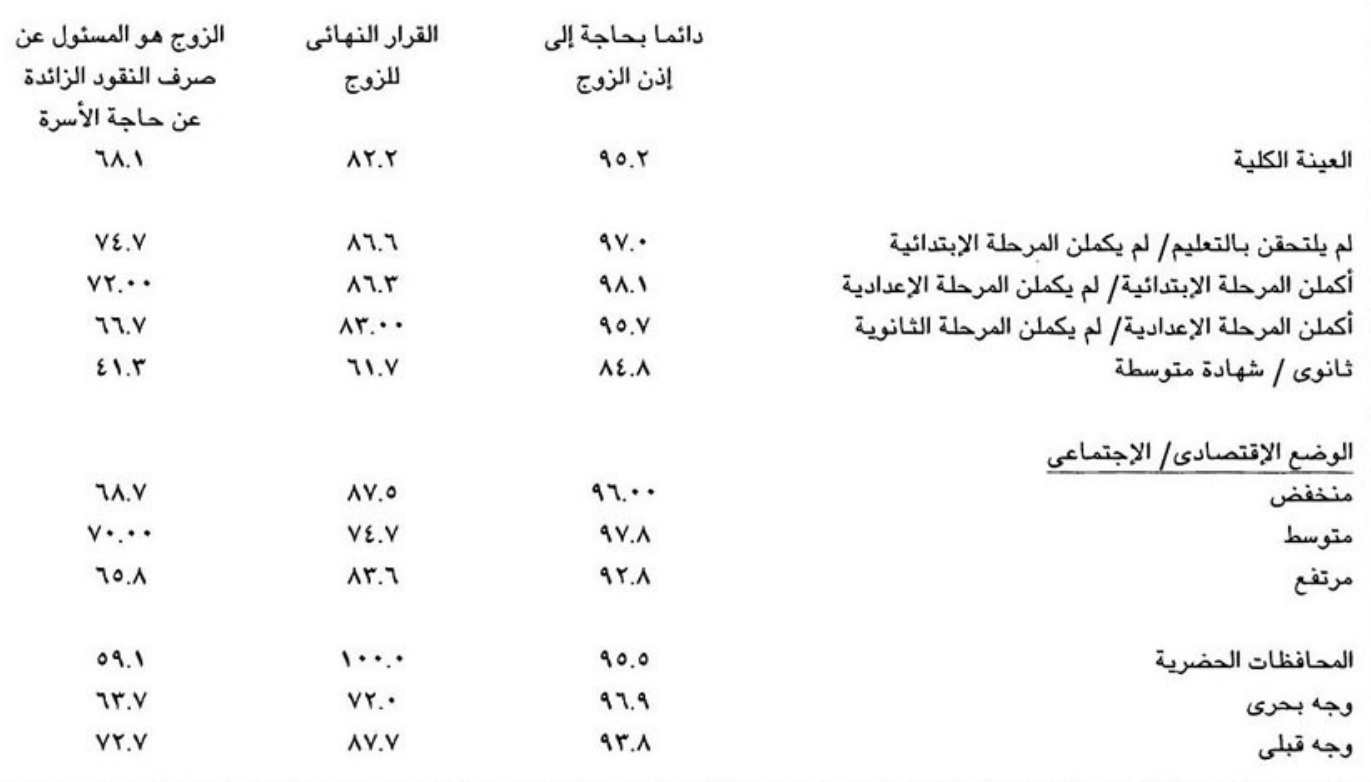

\section{خامسا: الصحة الانجابية}

تقول نحو \\%٪ من الفتيات المتزوجات أنهن ناقشن الحجم المثالي لأسرتهن مع أزواجهن. غير أن هذا المسلك يختلف بصورة

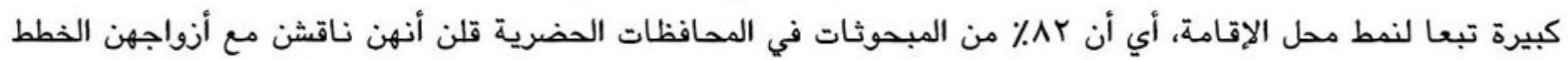

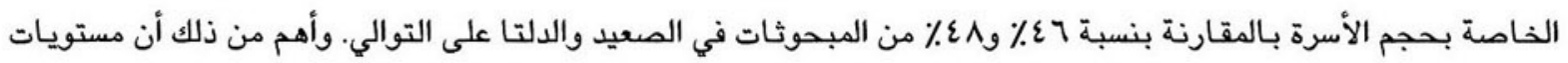

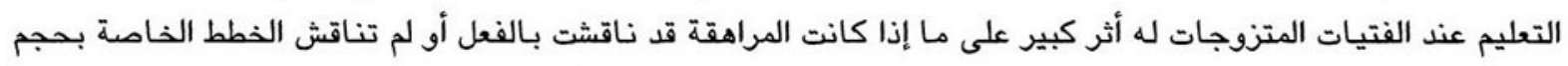

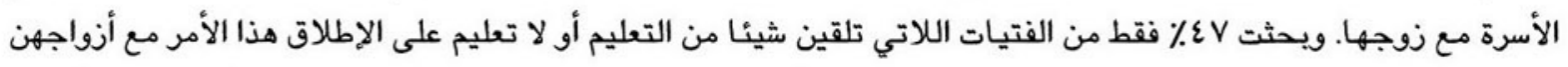

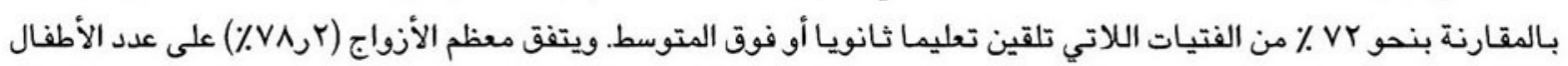

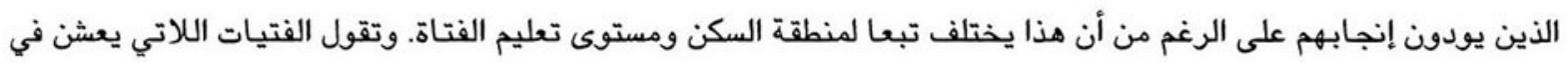

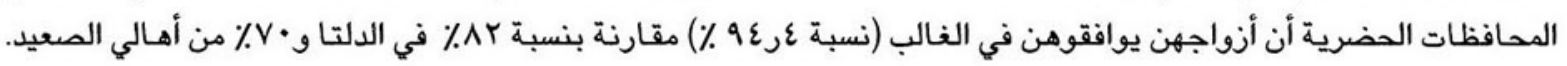

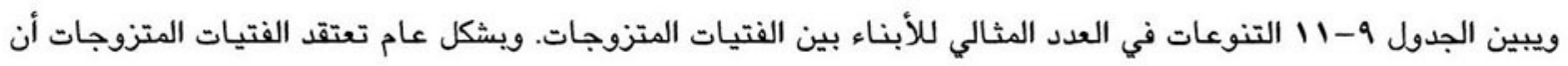

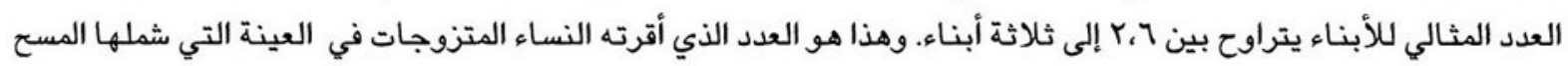

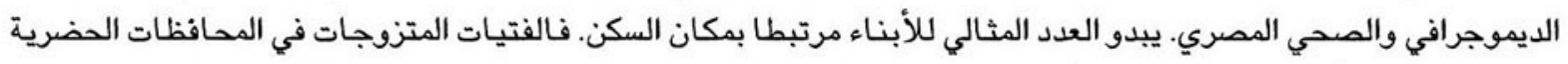

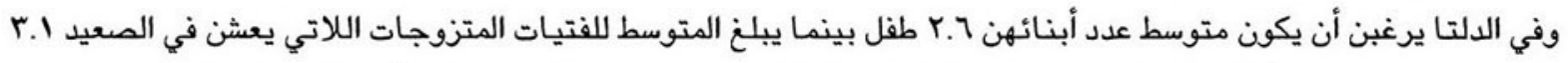

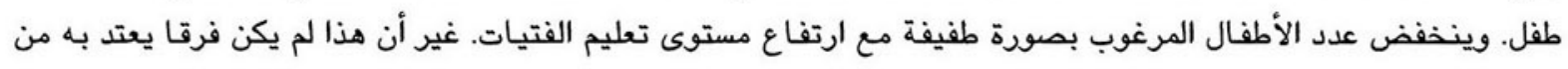
الناحية الإحصائية.

من بين النتائج الأكثر إثارة للدهشة بين هذه البيانات الأثر القوي لتعليم المرأة الشابة على آرائها الخاصة بدورها في اتخان 
القرار بشأن تنظيم أسرتها. ولدى سؤالهن عما إذا كن يوافقن على عبارة "إذا أراد الزوج الأطفال فلإن على الزوجة الإذعان حتى

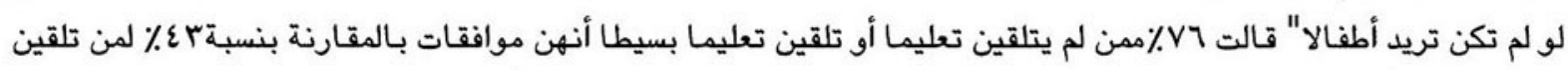

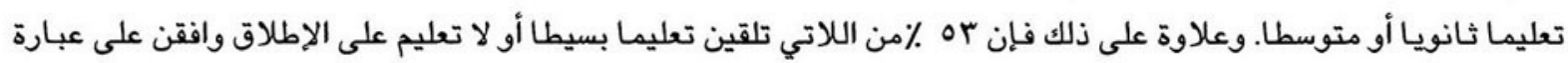

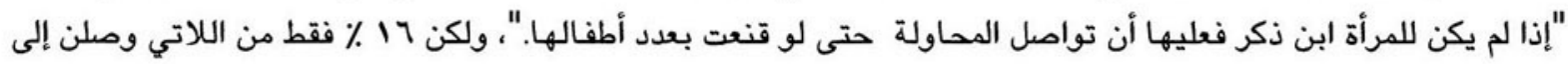

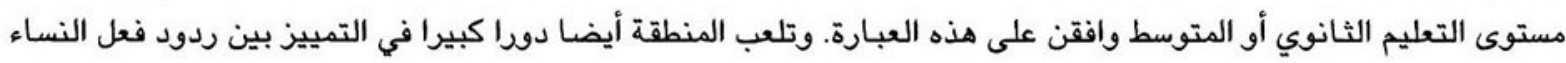

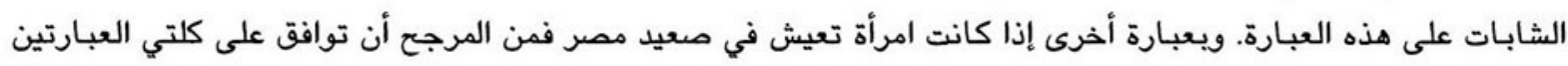

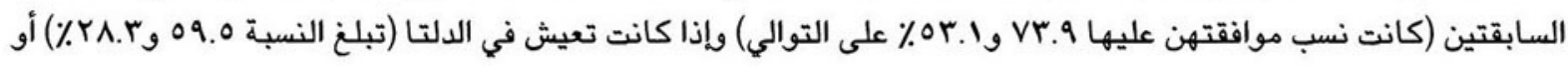

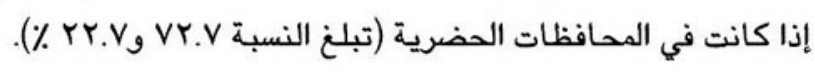

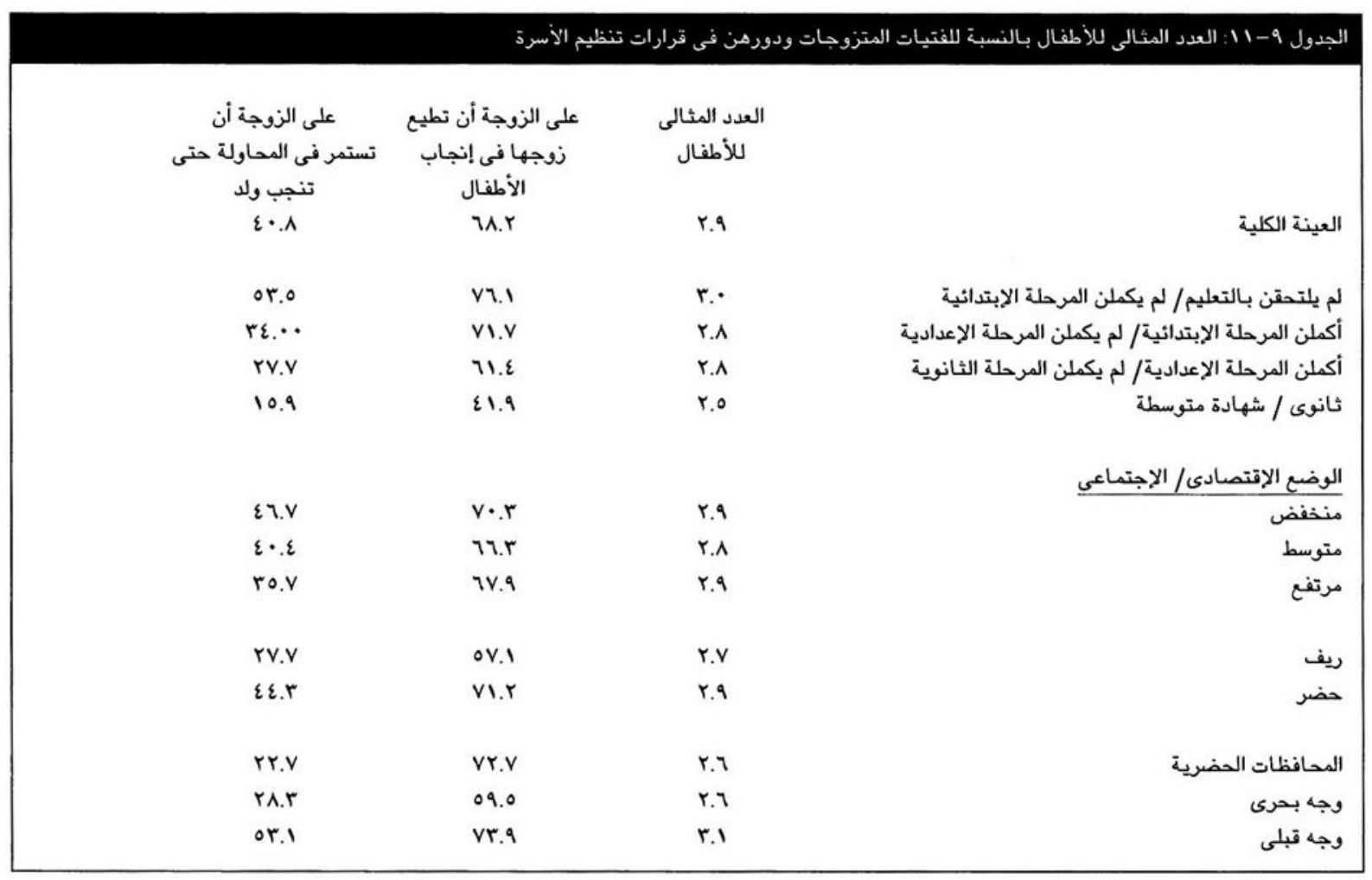

يحمل الحمل المبكر في طياته مخاطر صحية للأم وطفلها وكلما صغرت الأم زادت الخطورة. ولذلك فإن من المهم فهم آلية

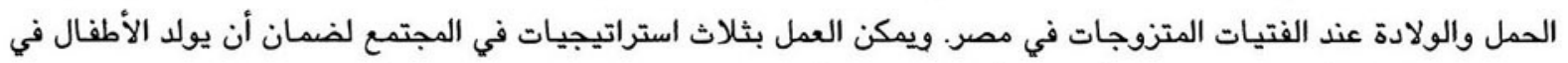

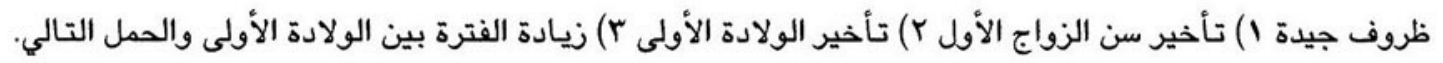

" بينما يتجاوز عرض هذا البحث نطاق هذا التقرير، فإن المسع الديموجرافى والصحى فى مصر لعام 1990 قد وثق هذه المخاطر جيداً بالنسبة للنساء والأطفال 


\section{السيطرة على النشاطلات الانجابية}

إذا تم الزواج بالفعل كما كان الحال بالنسبة لهذه العينة من الشابات فإن اثنتين من هذه الاستراتيجيات ستبقى صالحة. غير

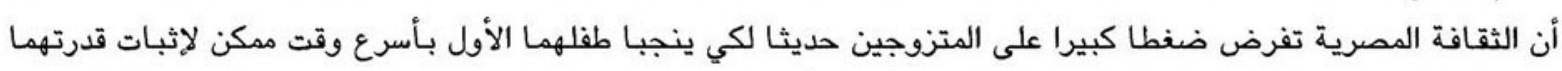

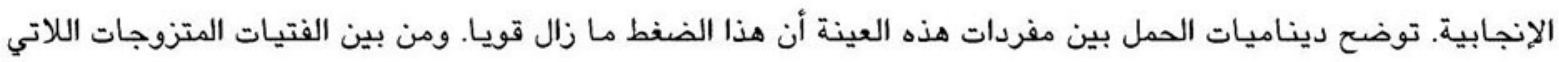

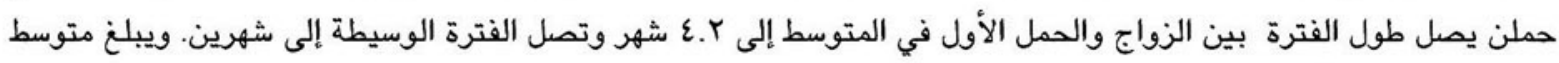

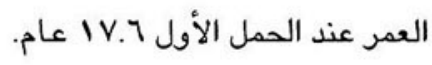

ويتمثل دليل آخر على هذا العرف الاجتماعي في تراجع مستويات استخدام موانع الحمل بين هذه الفئة من الشابات. وتستخدم

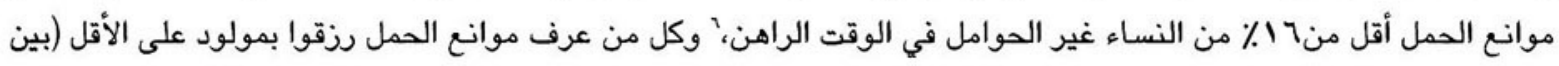

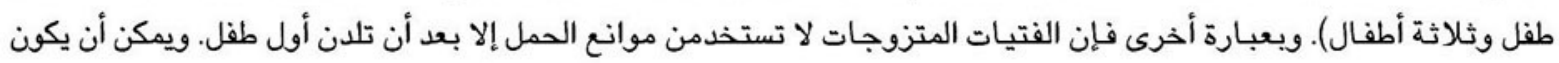

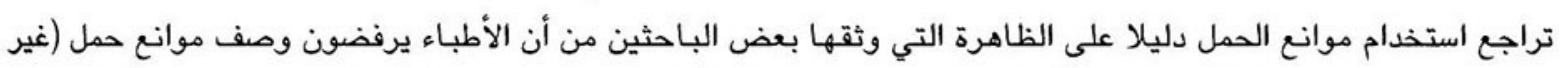

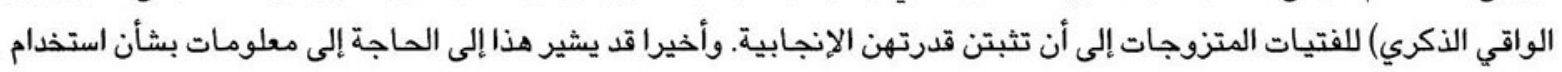

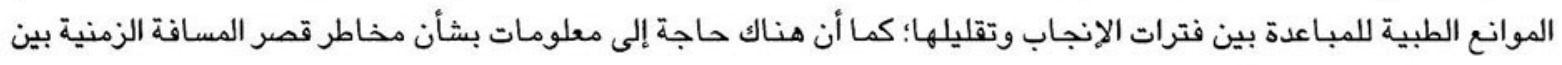
كل ولادة وأخرى على الأم وطفلها.

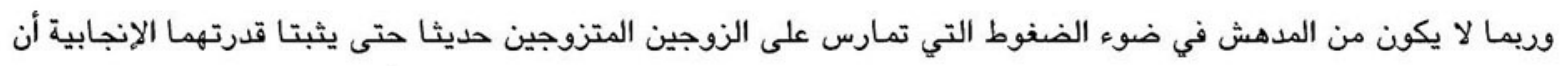

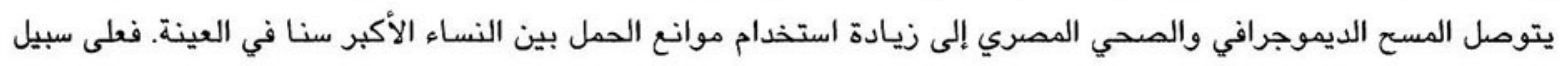

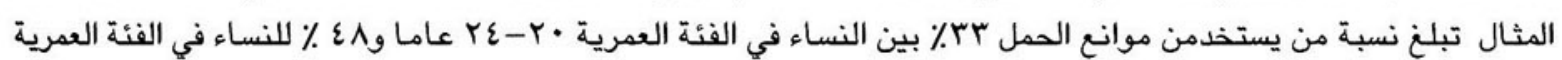

\section{الحالة الفسيولوجية الحالية}

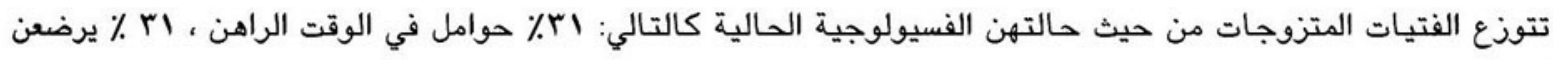

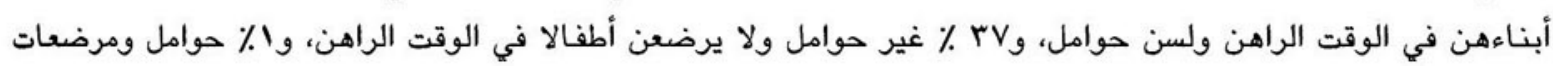

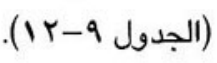

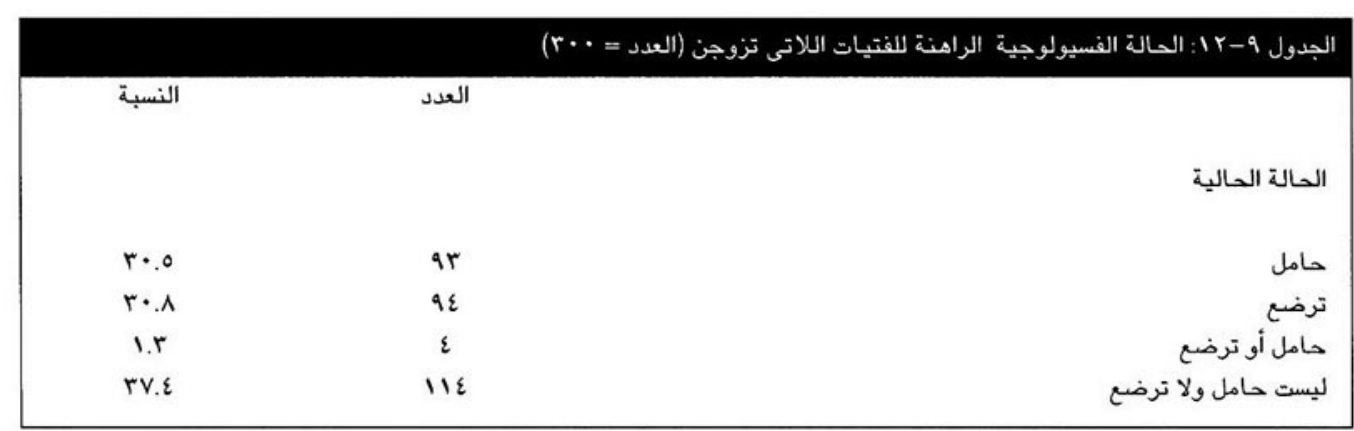

x من هؤلاء •9 فتاة لم يتعرض للحمل من قبل

يبلغ العدد الوسيط للحمل بين الفتيات المتزوجات الحوامل في الوقت الراهن أو اللاتي قد حملن في السابق طفل واحد ( يبلغ المتوسط حس. ا طفل) ويبلغ العدد الوسيط للأطفال في هذه المجموعة واحد أيضا (يبلغ المتوسط V. • ط طفل).

` يتسق هذا مع ماتوصل اليه المسح الديموجرافى والصحى المصري لعام 1990، الذى توصل الي وجود مستوى شبه متماثل من استخدام موانع الممل فى الغنة

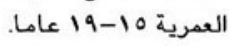


على الرغم من أن الحمل المبكر يحمل في طياته مخاطر صحية للأم وطفلها فإن الرعاية الملائمة خلال فترة ما قبل الولادة

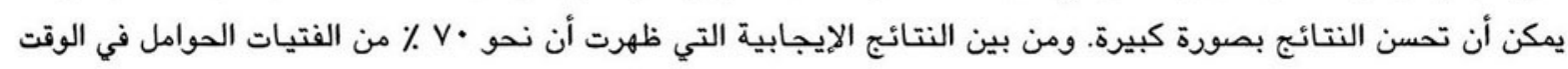

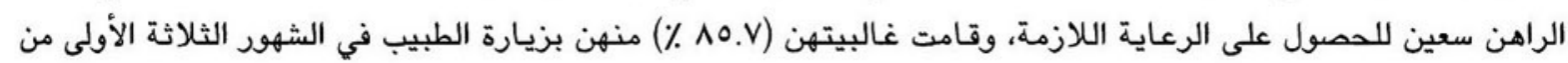

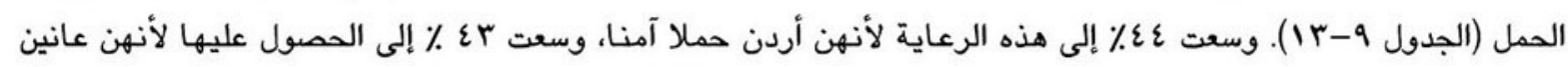

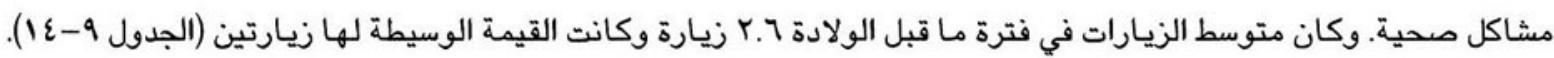

\begin{tabular}{|c|c|}
\hline 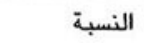 & \\
\hline$\wedge \circ . \vee$ & الثلاثة أشهر الأولى \\
\hline Ir.9 & الثلاثة أشهر الثانية من الحمل \\
\hline $1 . \varepsilon$ & الثلاثة أشهر الثالثة من الحمل \\
\hline
\end{tabular}

\begin{tabular}{|c|c|}
\hline 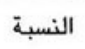 & سبب الزيارة الأولى \\
\hline$\varepsilon \varepsilon . r$ & 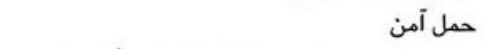 \\
\hline$\varepsilon r \cdot \wedge$ & شكاوى صحية (سخونة، إرهاق، قئ، ألم بالمعدة) \\
\hline $1 r .9$ & 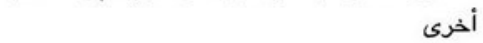 \\
\hline
\end{tabular}

نتائج حمل الفتيات المتنوجات

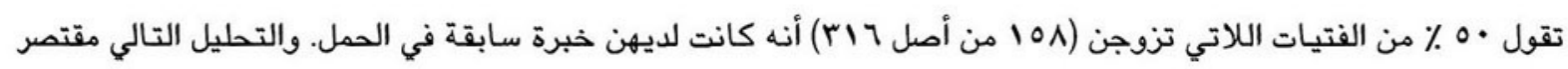

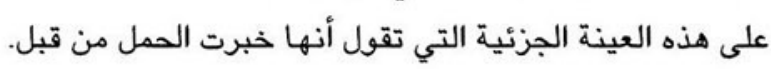

يمكن أن يكون للحمل ثلاث نتائج محتملة: مولود حي، إجهاض، أو ولادة جنين ميت. إن نسب كل من هذه النتائج بالنسبة

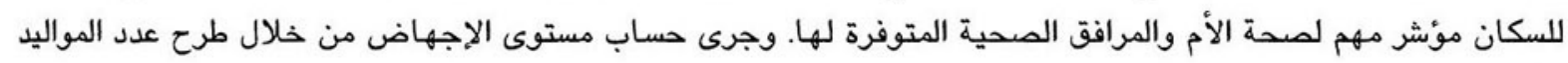

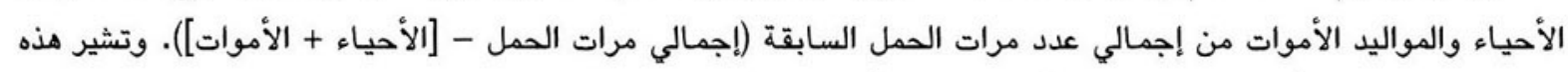

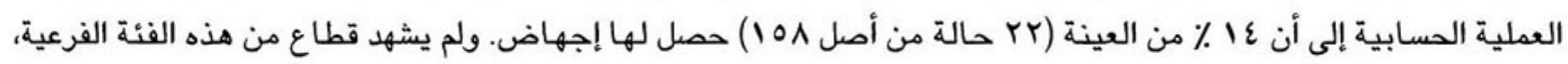

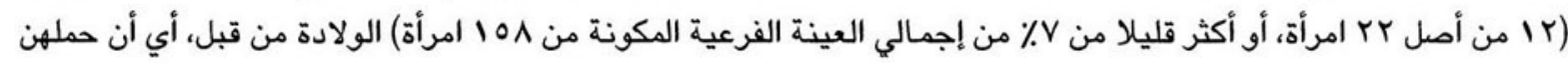

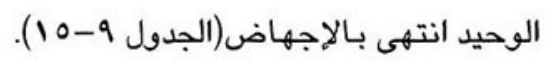

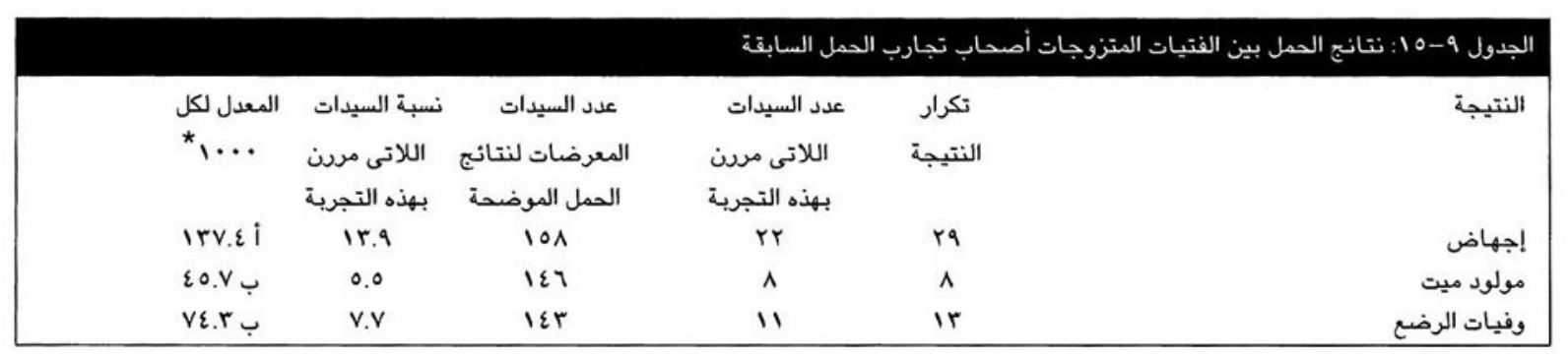

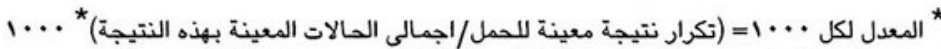

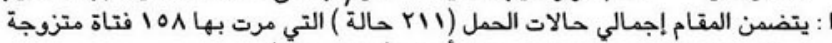

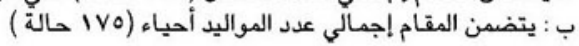

وعليه فإن جو ٪ من هذه العينة الجزئية خبرت الحمل والوضع. ويالنسبة لهؤلاء الفتيات تظل هناك نتيجتان محتملتان هما

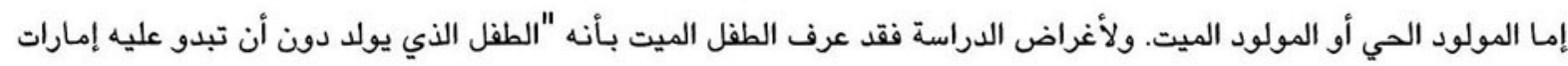


الحياة". وقالت أكثر من $\%$ من العينة (1 من أصل ح ع ) أنهن أنجبن طفلا ميتا؛ ويعني ذلك أن أقل قليلا من 90 ٪ من الفتيات

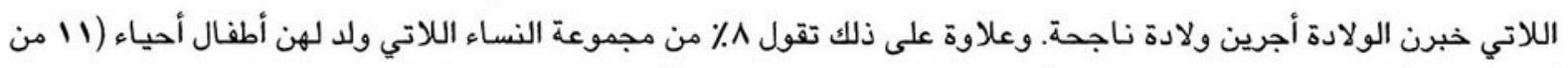

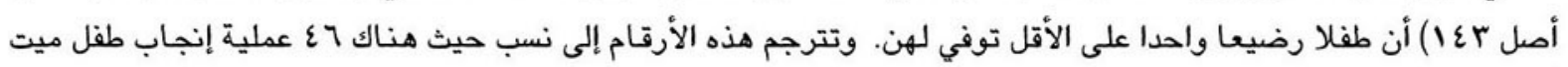

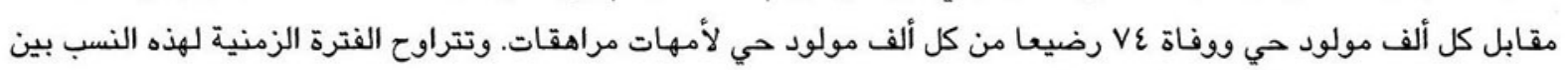

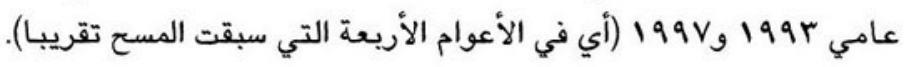

وعلى الرغم من صغر حجم عينة مسح "النشء والتغيير الاجتماعي في مصر"، فإن هذه النسب مرتفعة للغاية بالمقارنة

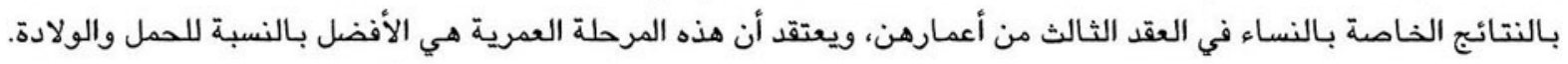

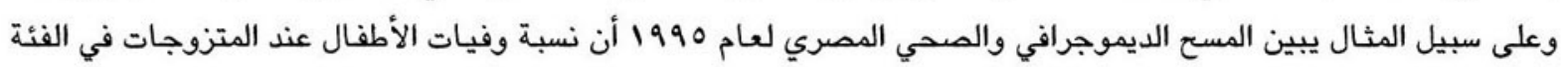

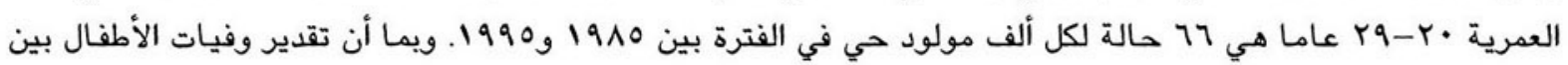

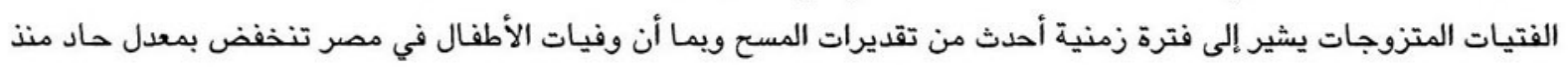

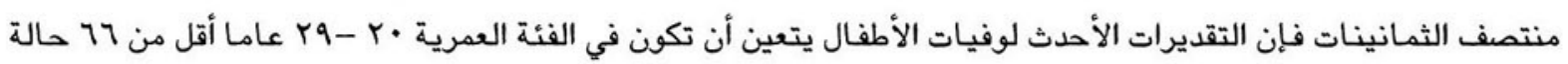

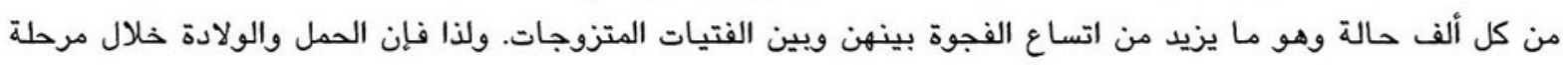

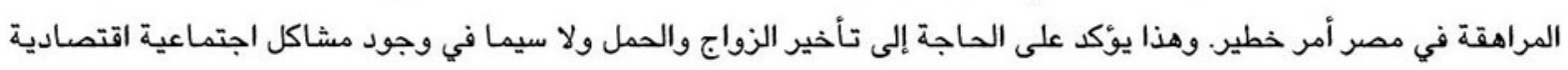
وصحية أخرى.

\section{خبرة الانجاب عند الفتيات}

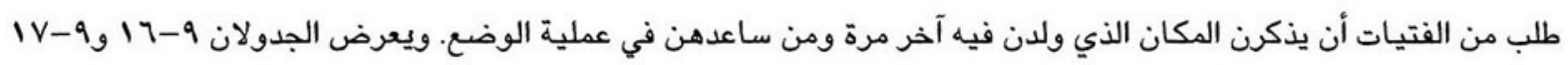

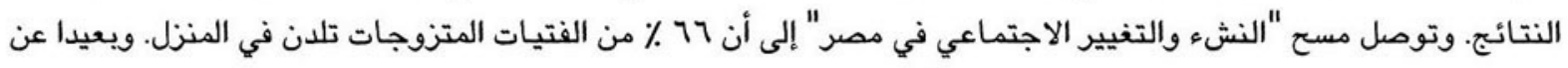

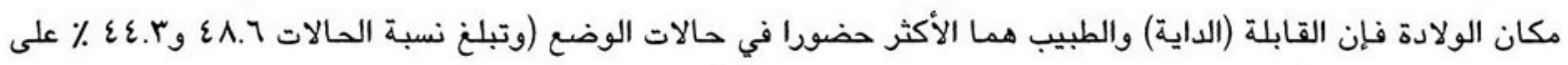

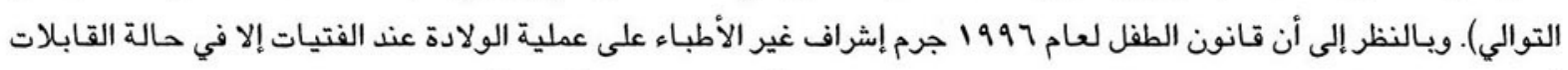

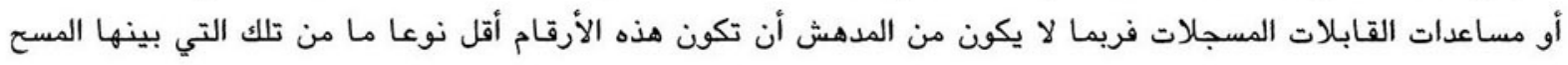

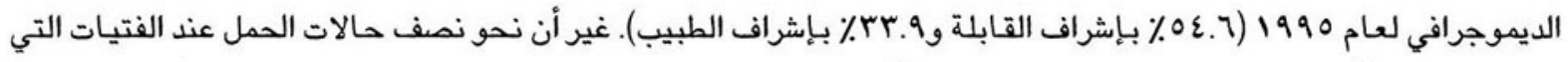

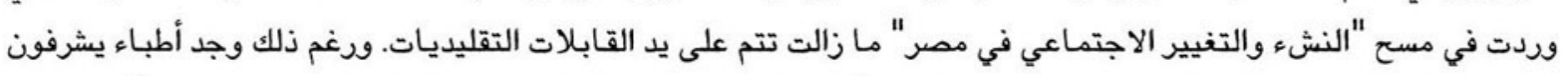

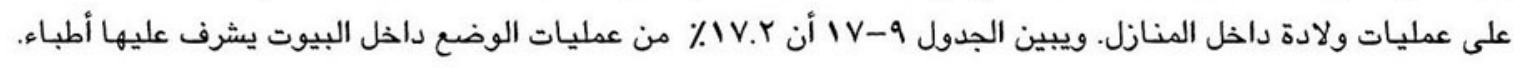

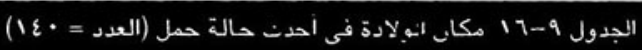




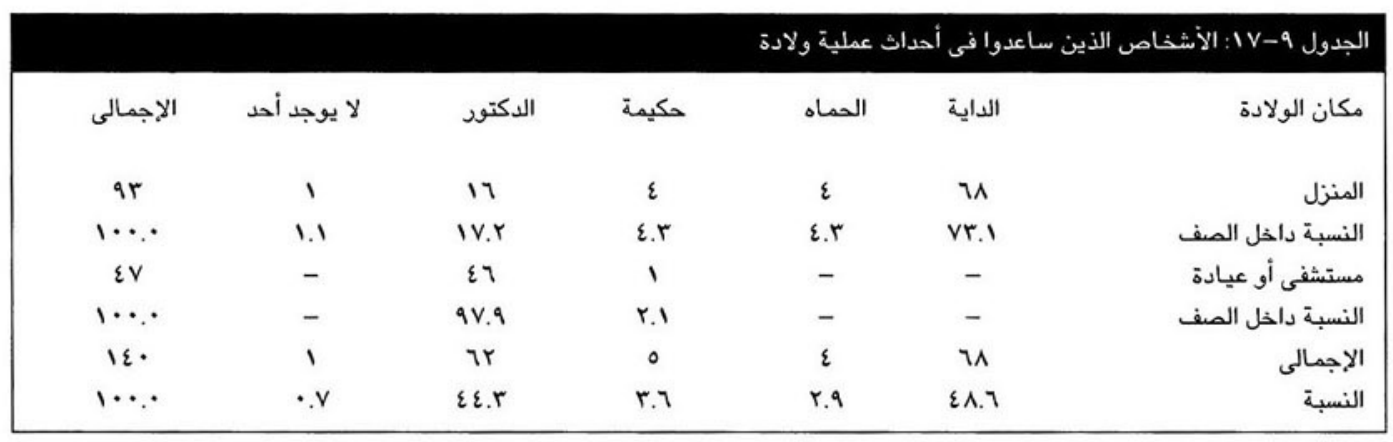

الرضاعة عند الأمهات الفتيات

إن الشروع المبكر في عملية الرضاعة الطبيعية عقب الولادة له فوائد عديدة بالنسبة للأم وللرضيع فهي تمد الرضيع بالمناعة.

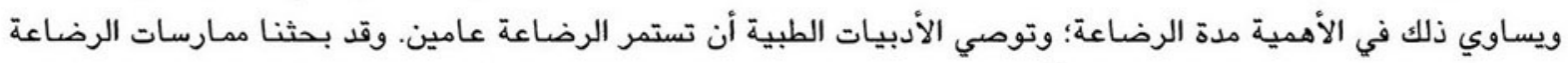

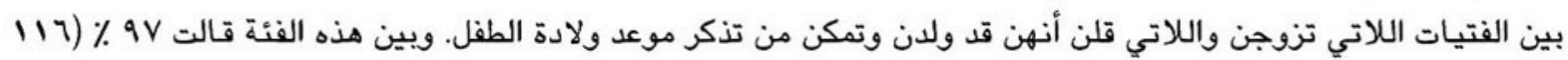

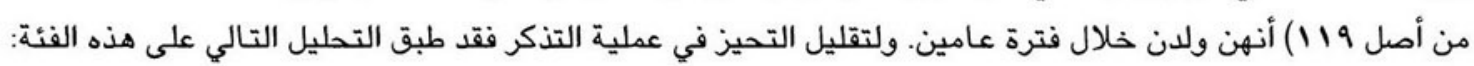

كان نمط الشروع في الرضاعة الطبيعية لكل النساء اللاتي قلن أنهن أرضعن أطفالهن (في الوقت الحالي أو في السابق) كالتالي:

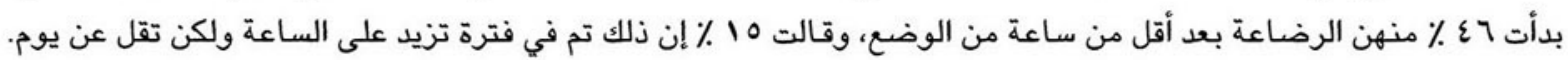

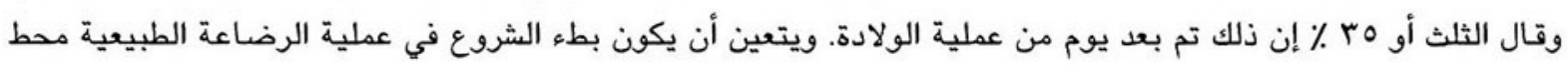

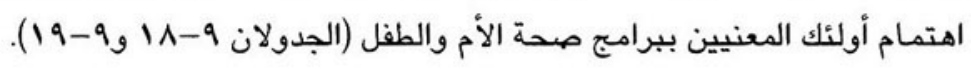

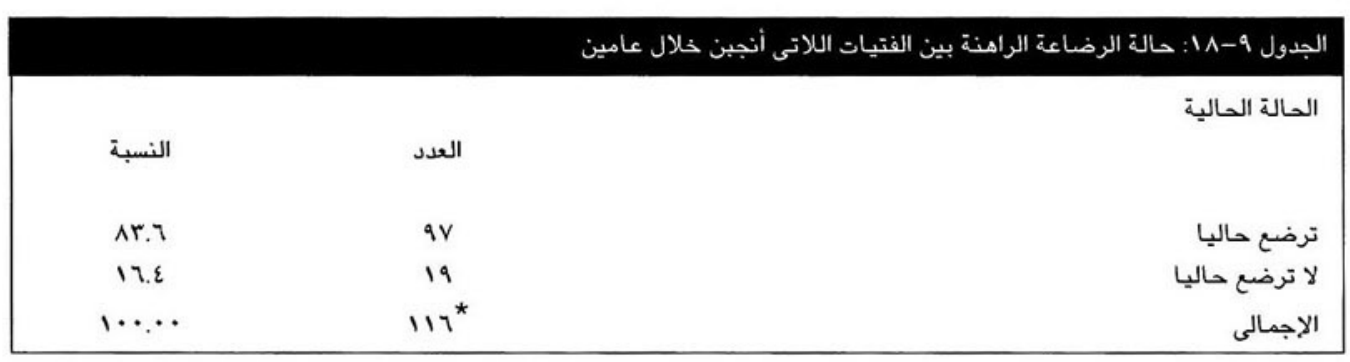

* يوجد 1 حالات لم يبدءوا الرضاعة ولم يمروا بتجربة نزول طفل حى من قبل.

\begin{tabular}{|c|c|}
\hline \multicolumn{2}{|c|}{ الجدول 9-19 : بدء الرضاعة بين الفتيات اللاتى أنجبن خلاز عامين } \\
\hline 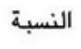 & 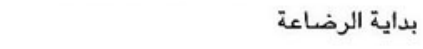 \\
\hline$\varepsilon 0 . V$ & خلال ساعة من الولادة \\
\hline 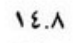 & أكثر من ساعة لكن أقل من يوم بعد الولادة \\
\hline$r \varepsilon .0$ & أكثر من يوم بعد الولادة \\
\hline
\end{tabular}

ونظرا لأن 19 امرأة فقط في هذه المجموعة لم تكن ترضعن أطفالا في فترة تطبيق المسح (أي ما يعادل ع.7 1 ـ )، فإن البيانات

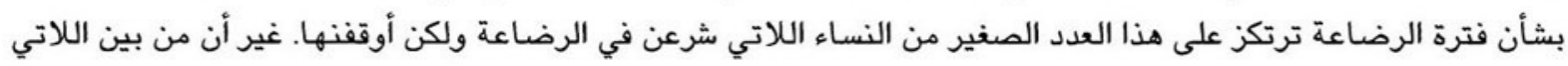

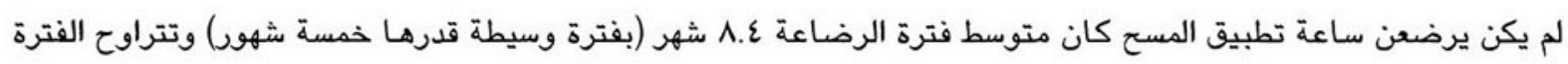

$$
\text { بين شهر و اب شهرا. }
$$




\section{سادساً: الاستنتاجات}

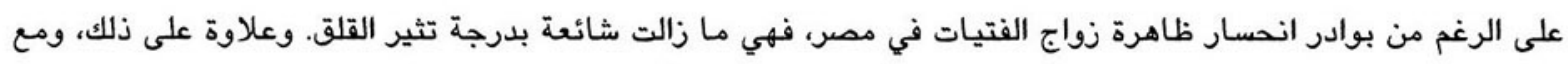

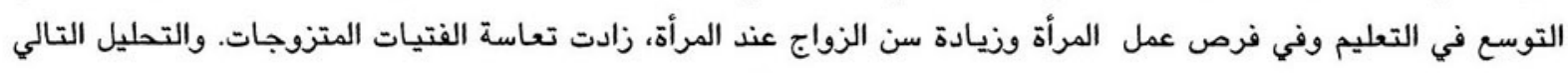

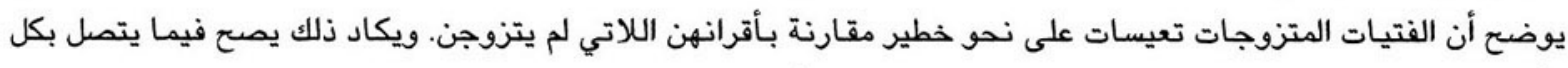
الأبعاد التي ستشكل الفرص والموارد المتاحة لهن الهن ويالتالي لأطفالهن.

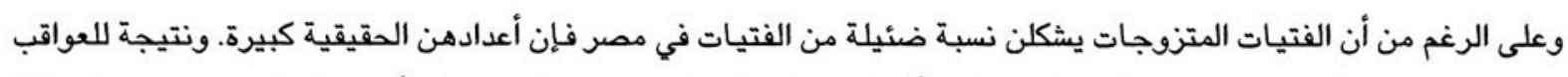

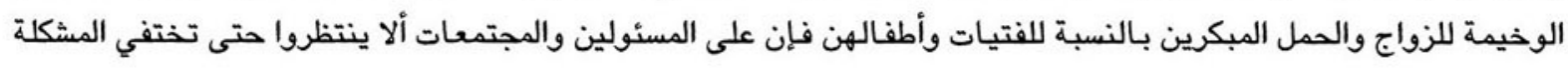

من تلقاء نفسها. 


\section{بعض الاستتباعات الخاصة بـالدعوة والعمل}

يقدم هذا التقرير نظرة عامة لحياة النشء في مصر اليوم. وتتضمن آفاق المستقبل بالنسبة للنشء عناصر إيجابية وأخرى الفرا

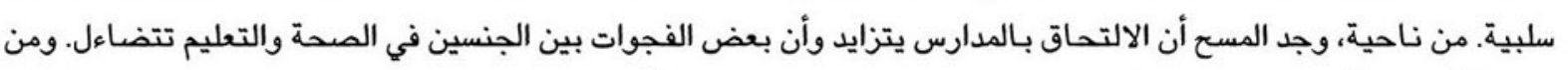

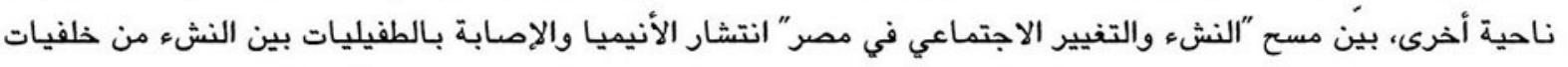

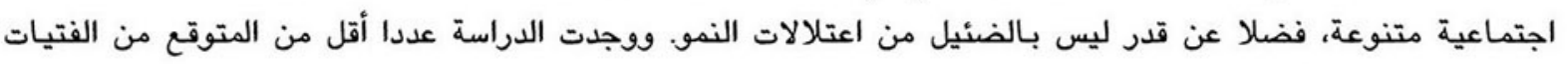
المتزوجات، إلا أنها أكدت أنهن يمثلن فئة محرومة تعاني من الآثار بالغة السوء لاعت للحمل.

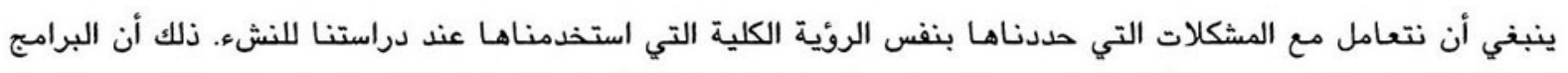

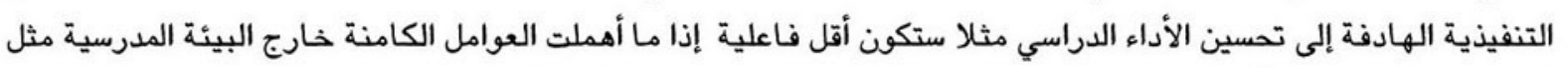

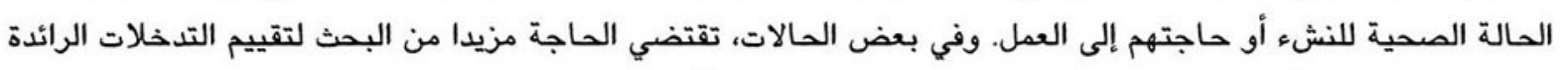

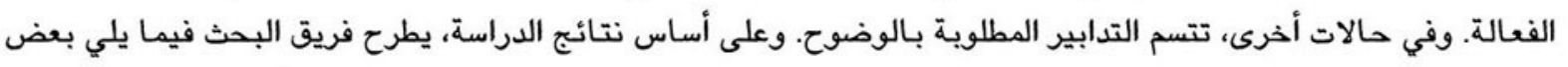

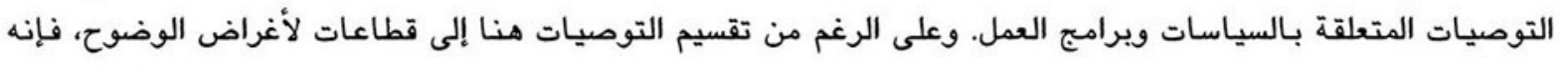

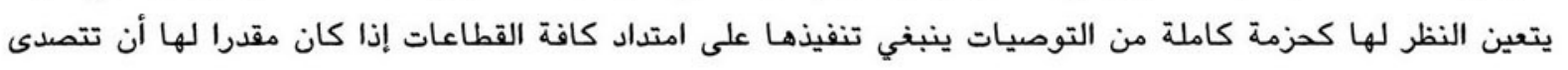

$$
\text { للمشكلات المطروحة. }
$$

\section{أولا: الأولويات الصحية}

\section{الأنيميا والطفيليات}

تعد الأنيميا والإصابة بالطفيليات، وهما مشكلتان متصلتان، أكثر الصالات الصحية شيوعا بين النشء. وبينما يكون لهذه الأه

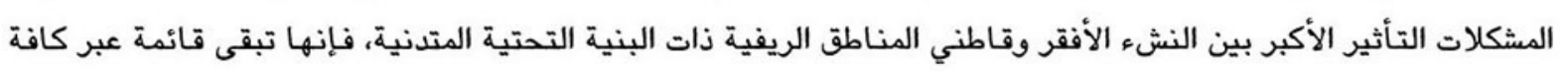
المناطق الجغرافية كما تنتشر على نحو مدهش حتى بين الفتيان والفئ الفتئيات الميسورين.

ومن هنا فإن الحملات التعليمية المتصلة بالتغذية والصحة يمكن أن تمثل خطوات أولية مهمة نحو القضاء على هذه المشكلات.

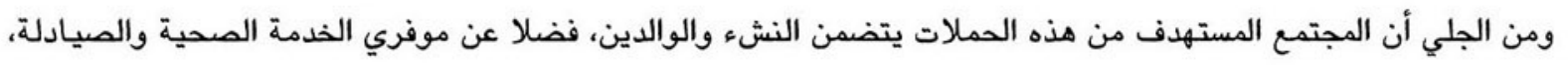

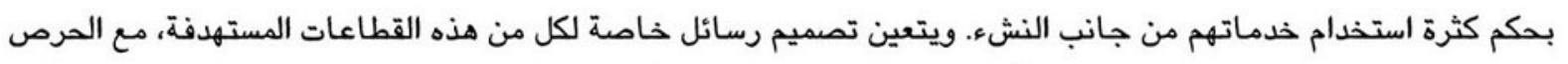

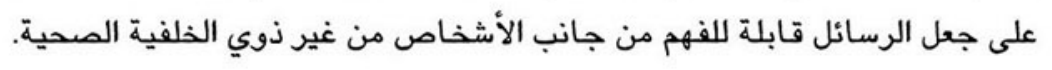

ينبغي أن تتناول الحملة أهمية الغذاء الصحي ومكوناته (مع التأكيد بشكل خاص على الطعام الغني بالحديد)، وكيف أن الفاكهة

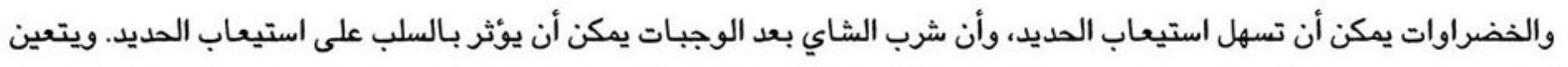

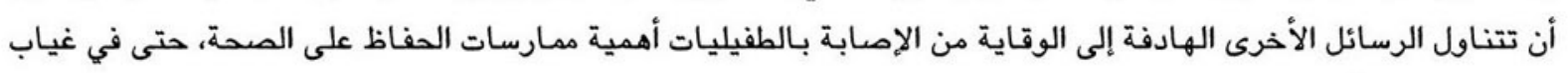

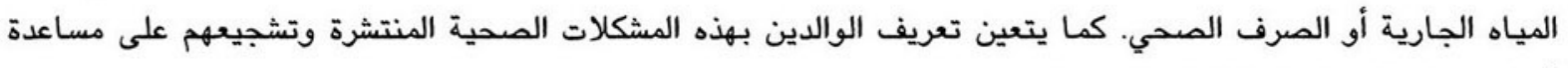
أبناءهم على اكتساب السلوكيات الصحية. 


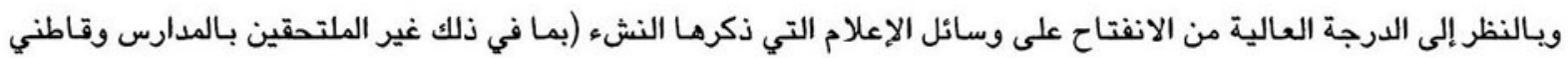

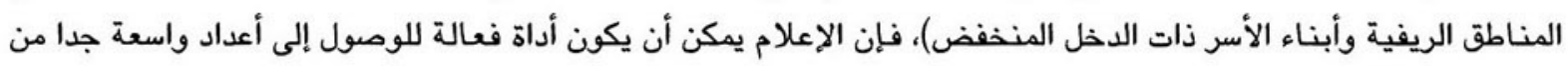

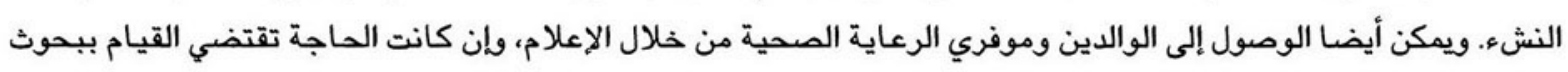
جماعية مركزة لتحديد سبل الوصول الأكثر فعالية للقطاعات المستهدفة.

ويتعين تطوير الرسائل الصحية بعناية من أجل إعلام النشء وتحفيزه. استخدمت الحملات في بلدان أخرى الرياضيين وغيرهم

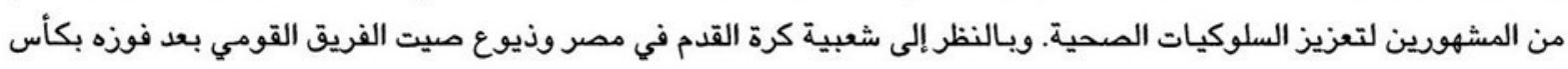

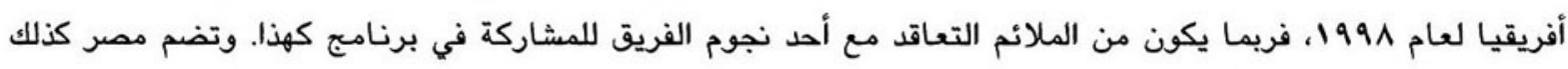

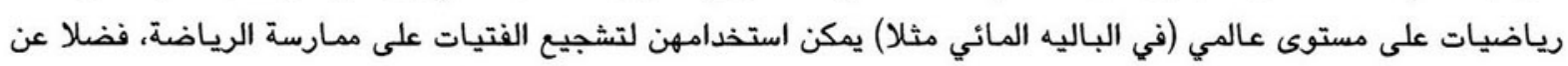
سلوك العادات الغذائية والصحية الجيدة.

وتعد المدرسة وسيلة منظمة أخرى للوصول إلى صغار السن، بحكم معدلات القيد المتزايدة في مصر. ومن شأن المزيد من العناية

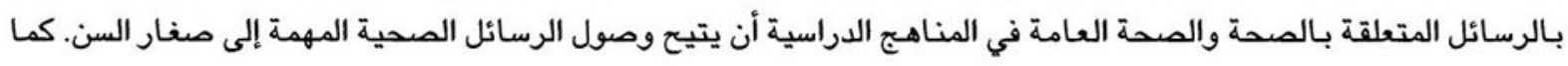

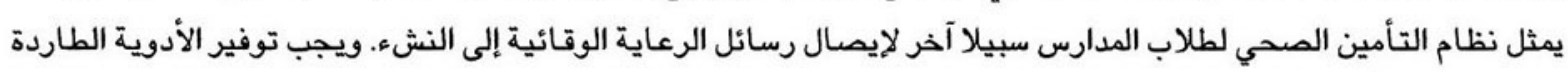

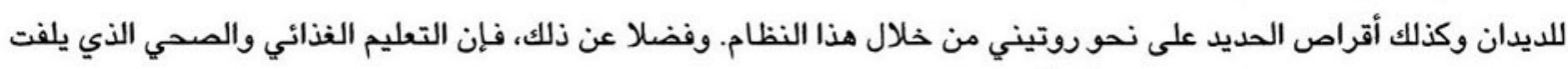

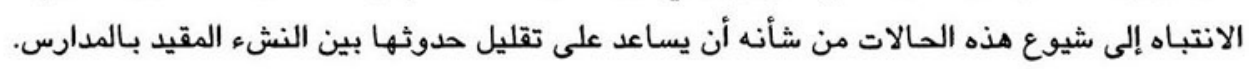

يمكن دعم الحملة التعليمية بواسطة جهد قومي يستهدف توفير أقراص الحديد المدعومة. وفي هذه الحالة فإن الحملة التعليمية

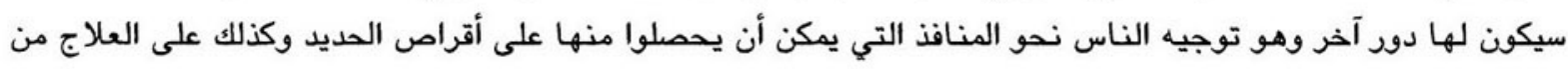

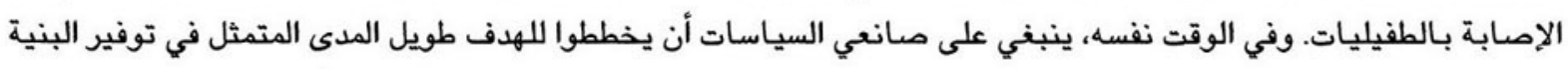

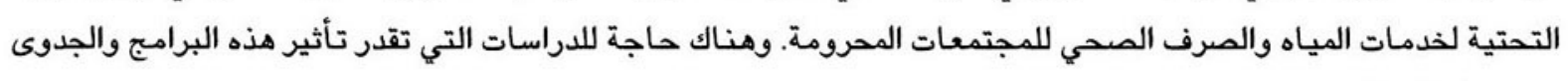

الاقتصادية لها.

إن علاج الحالات الصحية المزمنة والمنتشرة لن يؤدي فقط إلى تحسين رفاهية النشء وإنما أيضا إلى زيادة الإنتاجية وتحسين الأداء الدراسي ورفع معدلات الاستمرار في المدارس.

\section{نظام وخدمات الرعاية الممية}

وجد المسح أن القطاع الخاص هو الموفر الأساسي للخدمات الصحية للنشء وذلك على الرغم من توفر "نظام التأمين الصحي

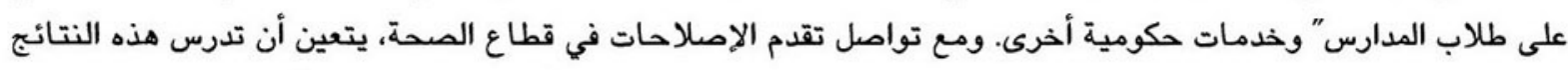

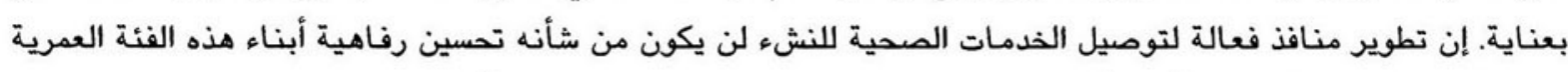

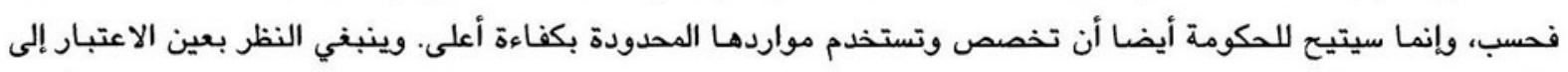
الأمور التالية من أجل توفير حزمة فعالة ومتكاملة من خدمات الرعاية الصحية لهذه الفئة العمرية، داخل إطار صحمة الأسرة.

تتمثل أولى القضايا التي ينبغي تناولها في المدخل الملائم لهذه الفئة العمرية إلى نظام الخدمة الصحية. وكما لاحظنا أعلاه، الصاه

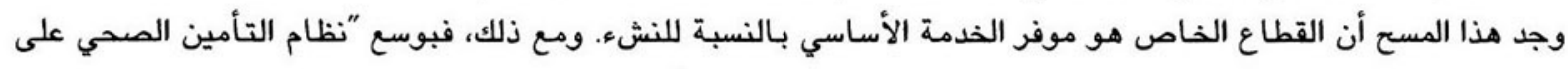

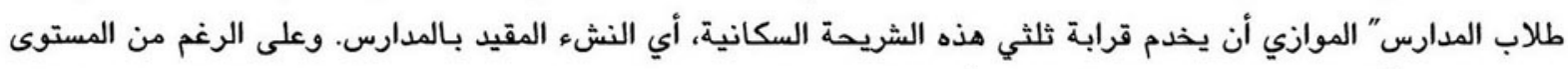

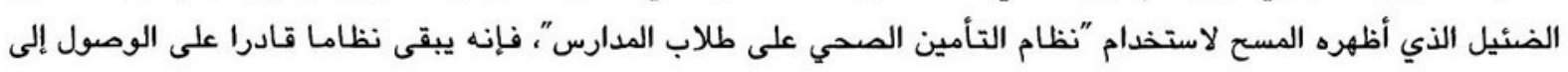




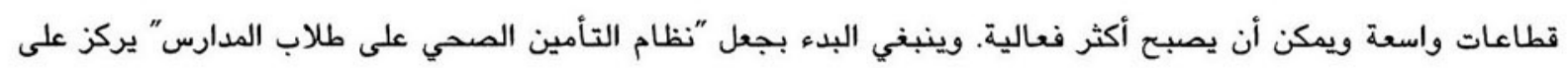

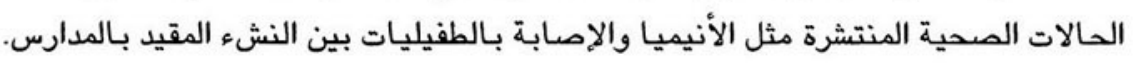

ولعل من المفيد أن تنظر وزارة الصحة بعين الاعتبار لإقامة حزمة من الخدمات الصحية للنشء داخل قطاع الرعاية الصحية

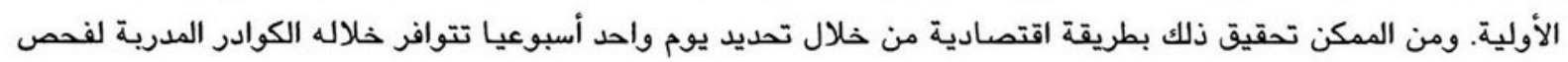

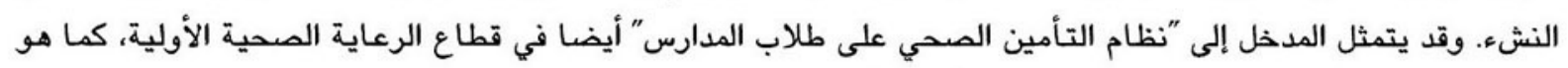

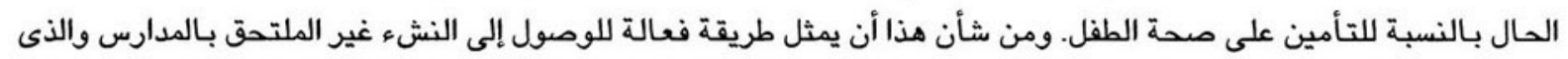

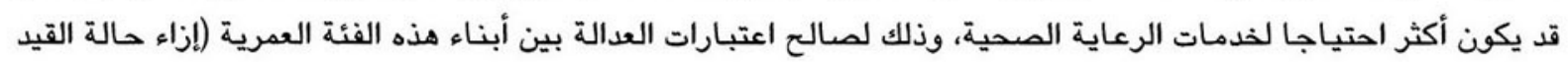
بالمدارس).

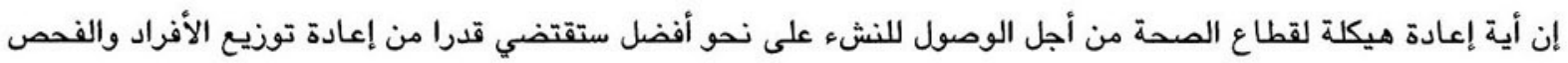

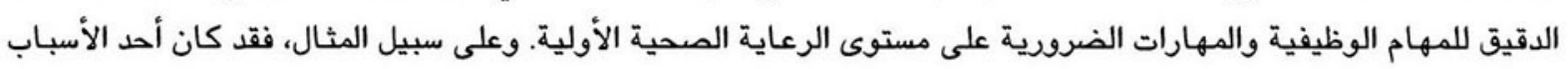

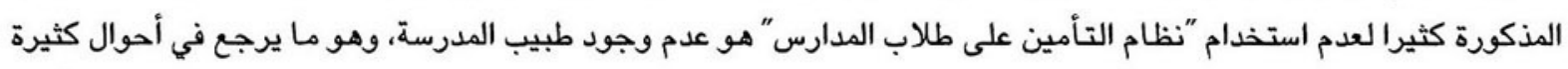

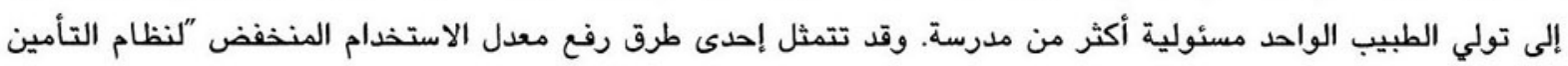

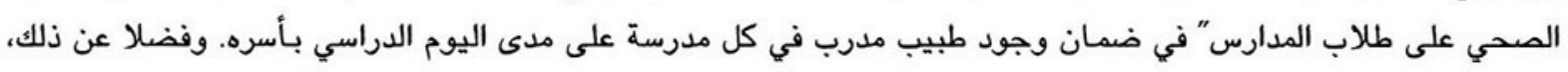

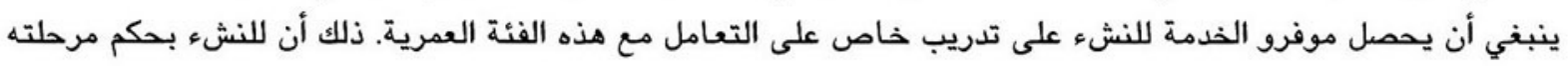

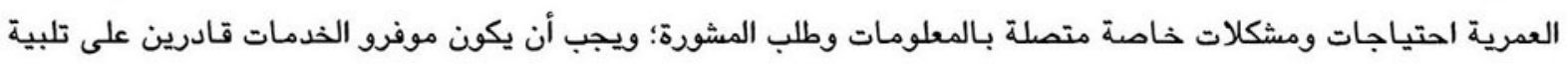
هذه الاحتياجات وإشعار النشء بالارتياح.

\section{البينة المصية في المدرسة}

هناك الكثير مما يمكن فعله لكي نجعل من المدارس بيئة تعليمية صحية لصغار السن. وفضلا عن تحسين الخدمات الصحية

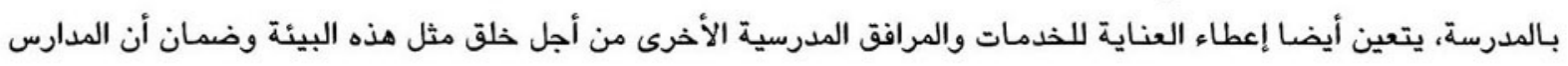
توفر مكانا ونموذجا للحياة الصحية.

وعلى سبيل المثال، ويالنظر إلى معدلات التدخين المرتفعة التي وجدت بين البنين في هذا المسح، فمن الممكن تنظيم حملة من

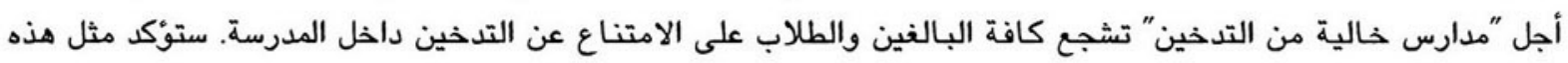

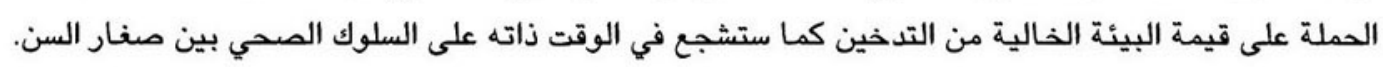

وتقتضي الحاجة أيضا العناية بالخدمات والمرافق الأخرى من أجل خلق بيئة صحية. وعلى سبيل المثال، لا يذكر سوى عدد

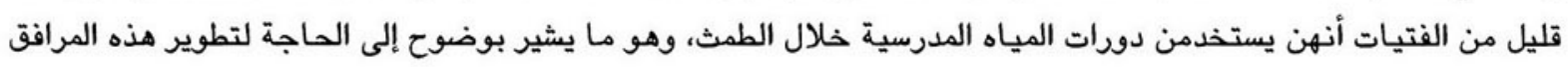
من حيث توفرها ونظافتها وكفالتها للخصوصية.

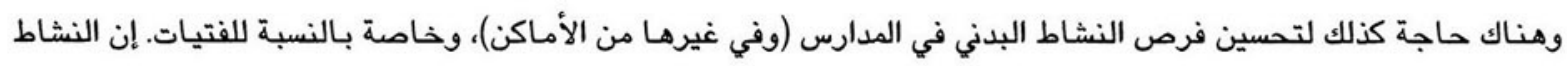

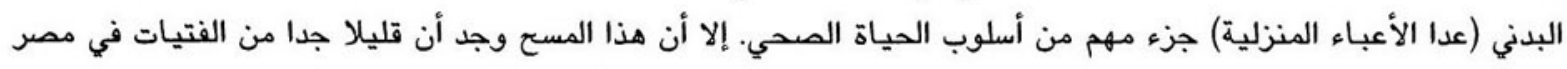

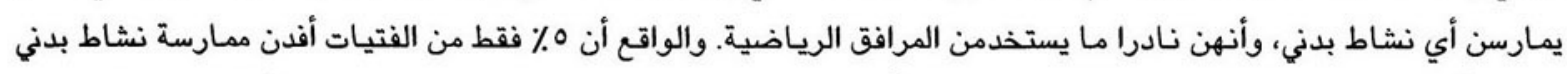

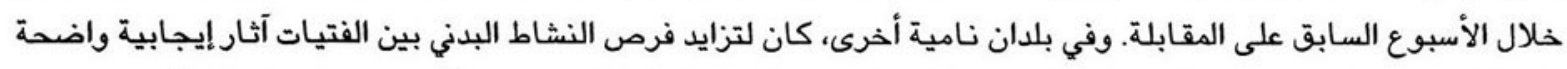

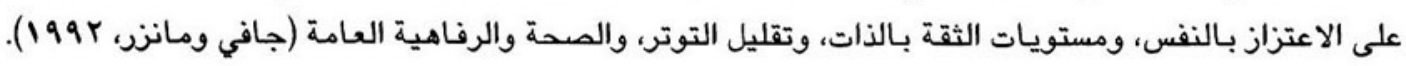


على المدارس أن تلعب دورا نشطا في تشجيع النشاط البدني بين جميع الفتيان والفتيات، وخاصة بين الفتيات. فبسبب القيود

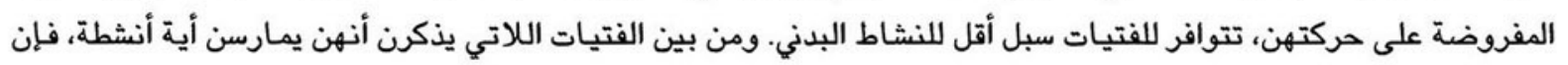

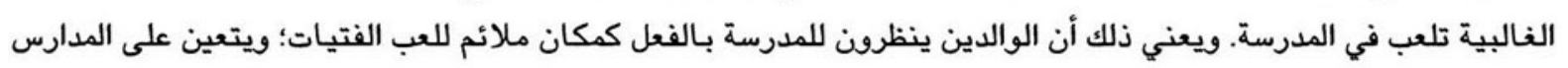

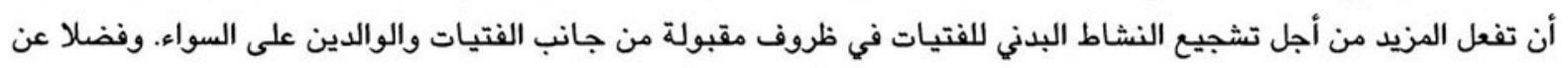

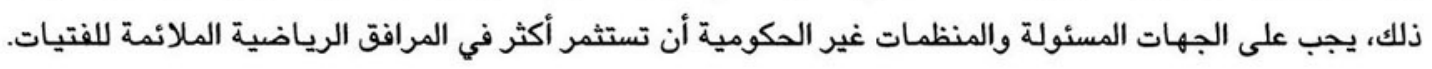

\section{ثانيا: التعليم}

على الرغم من تزايد معدلات الالتحاق بالددارس في مصر، فهناك حاجة لمزيد من الجهد لرفع وعي المجتمع والوالدين بأهمية

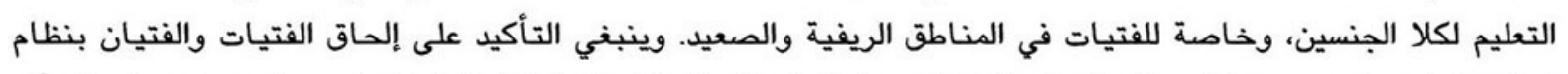

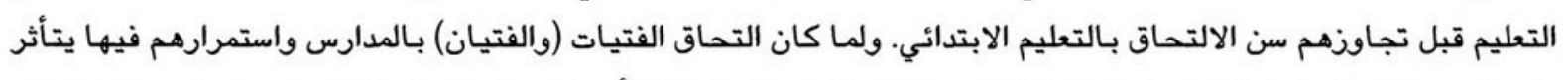

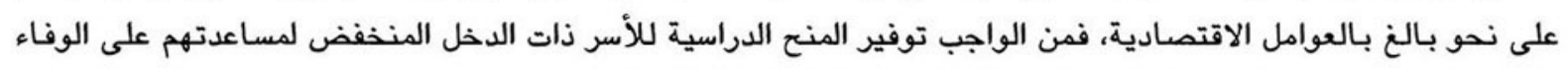
بالرسوم المدرسية، وتركيز هذه المنح على سنوات الدراسة الابتدائية والإعدادية.

مع التغير السريع في الأوضاع الاقتصادية في مصر، يتعين أن ترتبط المناهج الدراسية بشكل مباشر أكثر بسوق العمل والأدوار

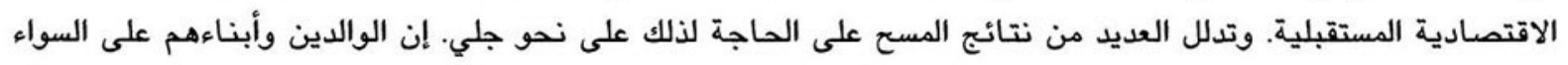

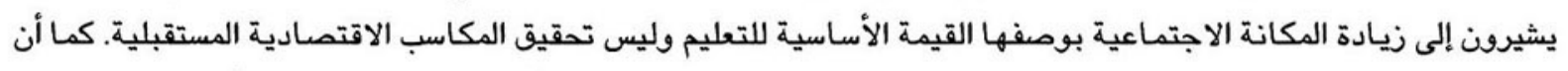

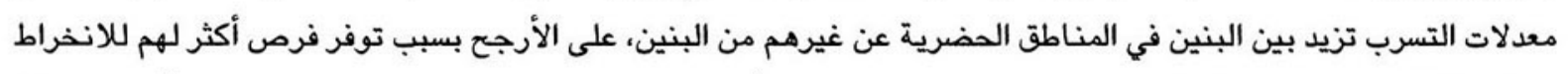

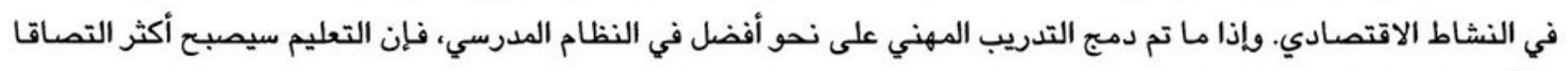

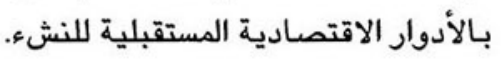

ومع الزيادة المطردة في معدلات الالتحاق والبقاء بالمدارس يمكن توجيه عناية أكبر الآن لتحسين نوعية التعليم، سواء فيما

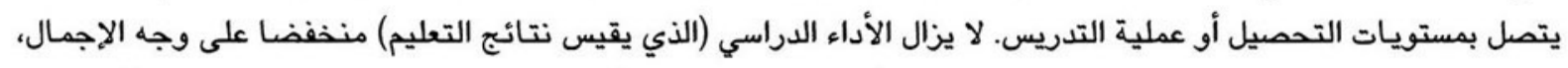

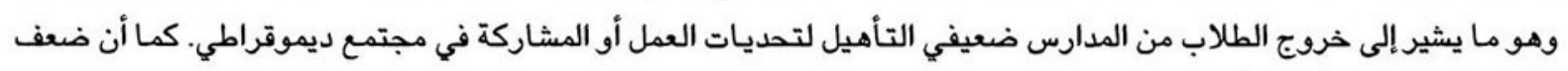

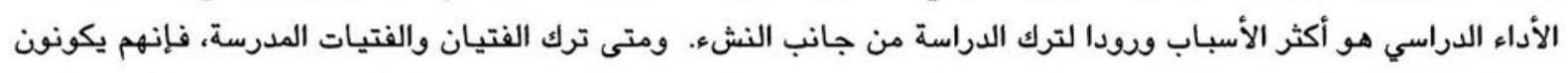

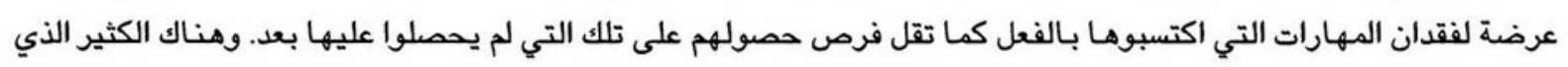

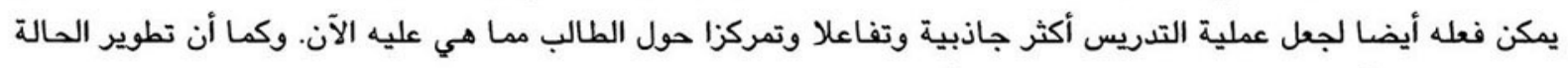

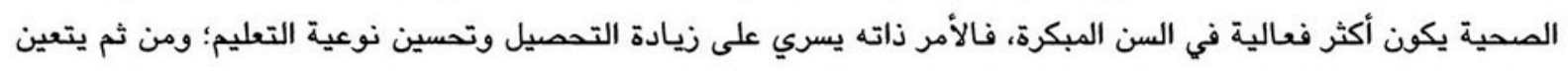
معالجة هذه القضايا بواسطة سياسات تركز على المرحلة الابتدائية.

\section{فمول محو الأمية}

فشلت فصول محو الأمية إلى حد كبير في الوصول للنشء خارج المدارس. وهناك حاجة لمزيد من البحث لتحديد أسباب هذا

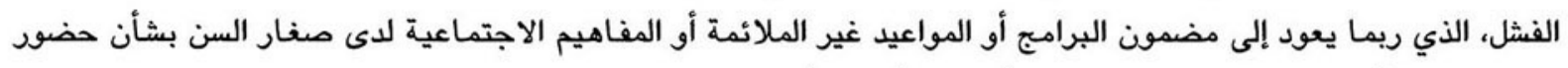

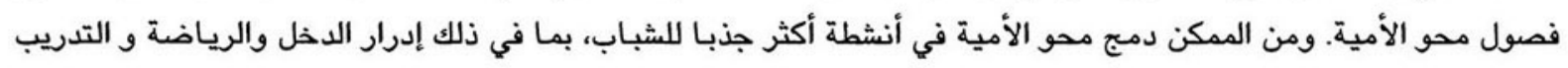

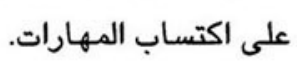




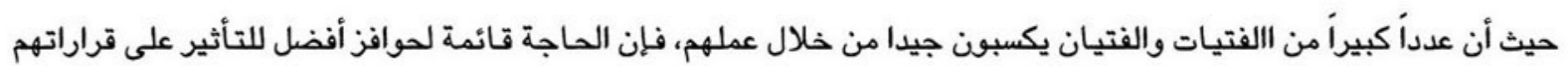

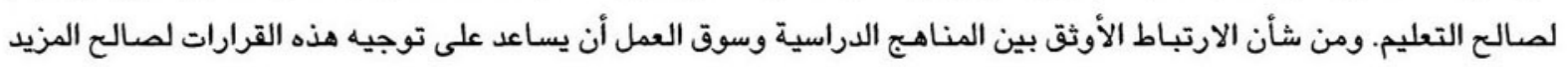

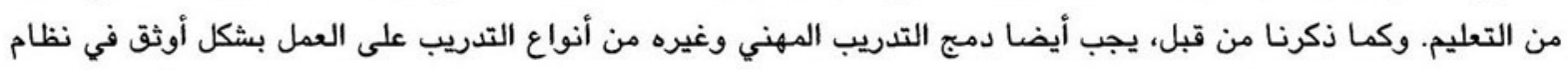

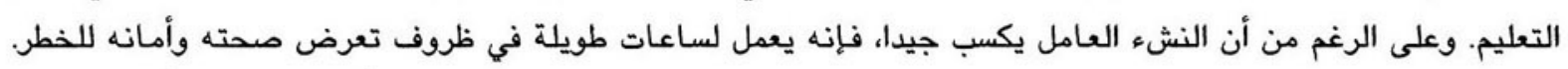

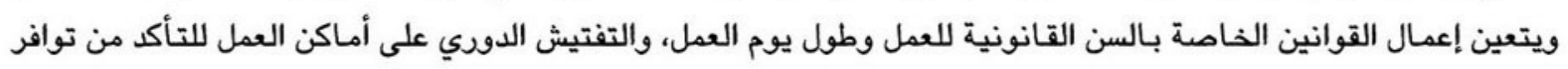

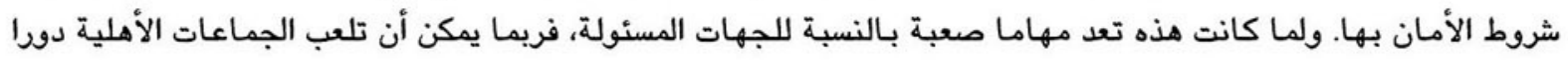
أكبر في الرقابة على صحة وأمان الشباب العامل. ولمان.

ويشير العدد الكبير من الشابات غير المتزوجات غير الملتحقات بالمدارس واللاتي لا يعملن إلى قدر ضخم من إهدار وقتهن.

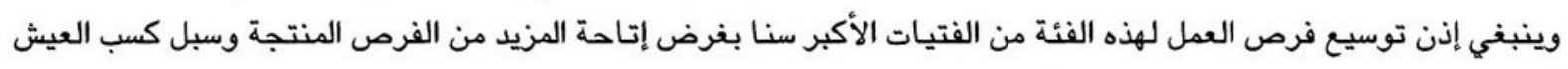

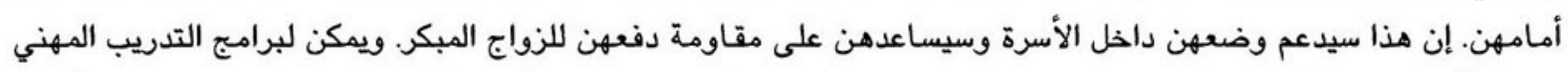

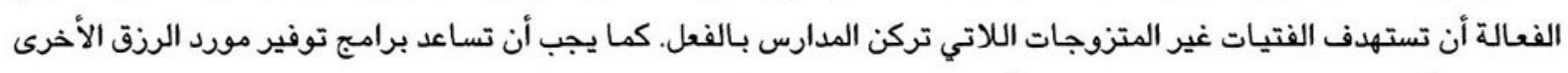

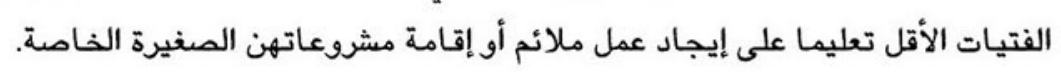

\section{رابعا: المدة الانجابية}

لا تتوفر للمراهقين المعلومات الضرورية الكافية عن أجسادهم أو نضوجهم أو غير ذلك من جوانب صحتهم الإنجابية؛ تلك ألك الكان

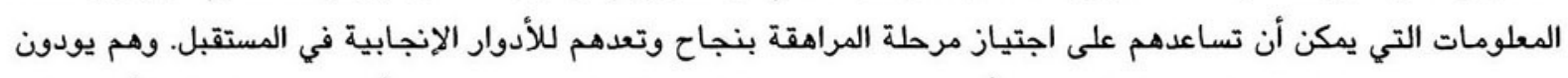

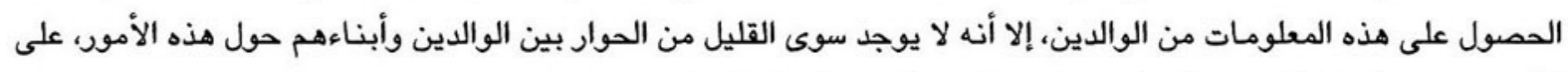

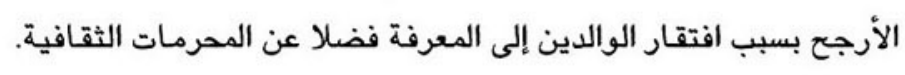

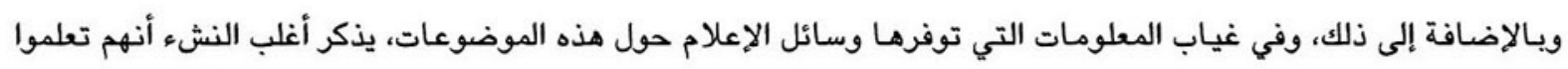

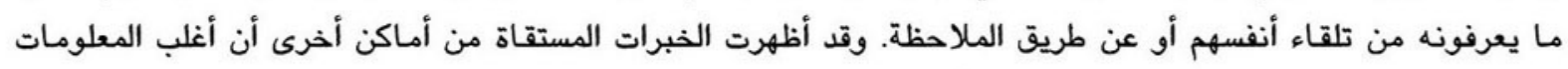

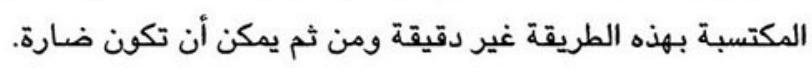

ويتعين على المنظمات غير الحكومية والبرامج العامة أن تسعى لإمداد الفتيات والفتيان بالمعلومات حول هذه المرحلة العمرية،

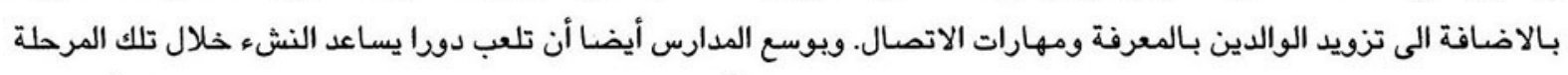

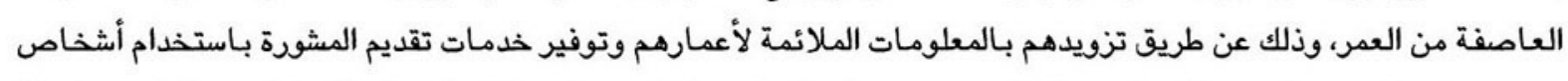

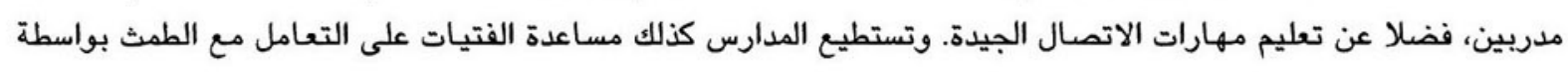
تحسين مرافق دورات المياه. 


\section{خامسا: نواج الفتيات}

على الرغم من أن زواج الفتيات آخذ في التراجع في مصر، فإنه لا يزال منتشرا بما يكفي لجعله مصدرا للقلق، خاصة لأن الحمل

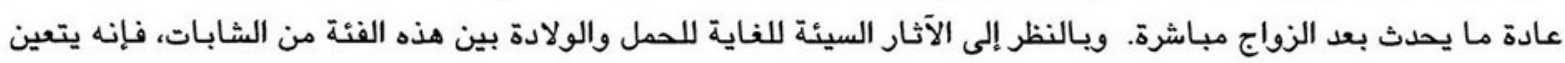
على المسئولين والمجتمعات المحلية عدم الاكتفاء بانتظار أن تُحل المشكلة من تلقاء المار نفسها.

إن العديد من النساء اللاتي يتزوجن أثناء المراهقة لم يلتحقن بالمدارس قط أو تسريوا منها في سن مبكرة. ومن ثم يجب استمرار

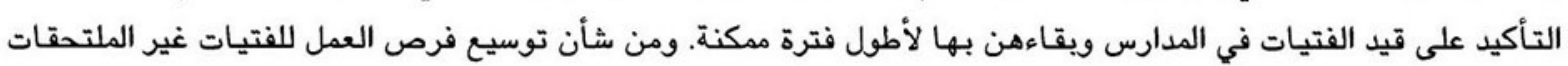

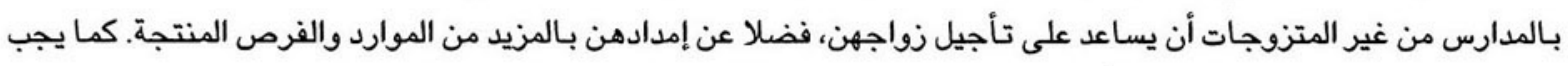

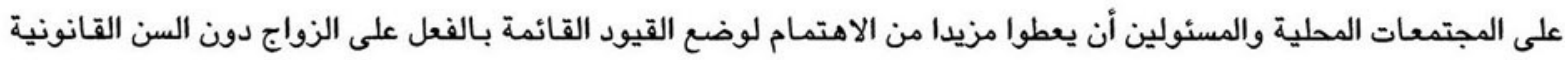

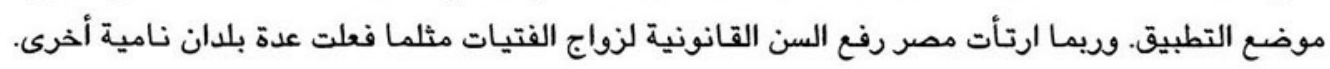

أما بالنسبة للفتيات اللاتي يتزوجن بالفعل أثناء سنوات المراهقة، فإن الاحتمال الكبير لحدوث الحمل بعد الزواج مباشرة

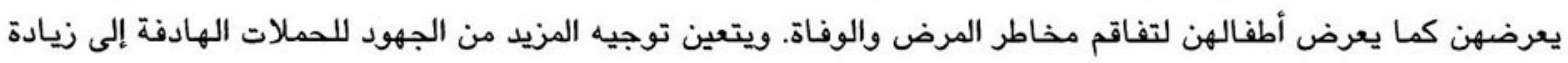

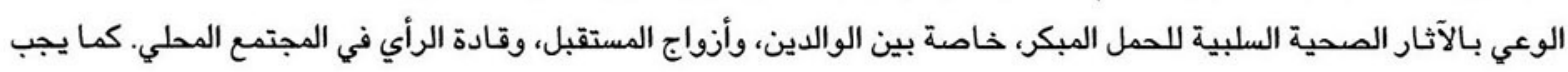

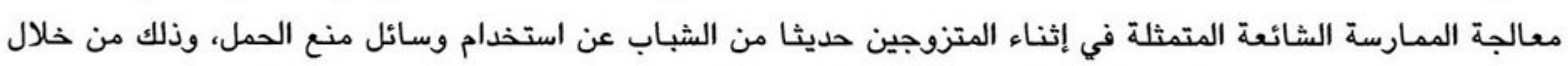

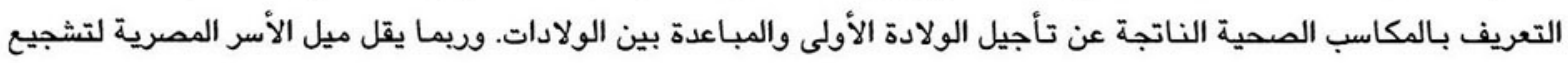

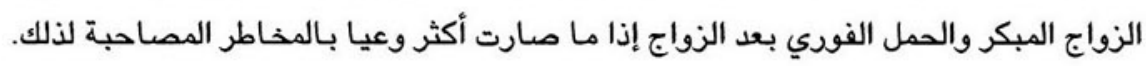

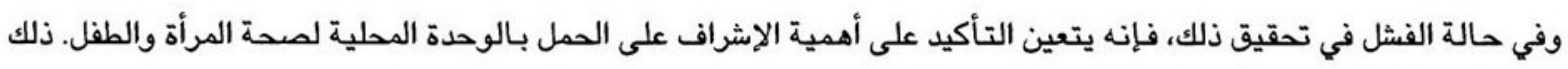

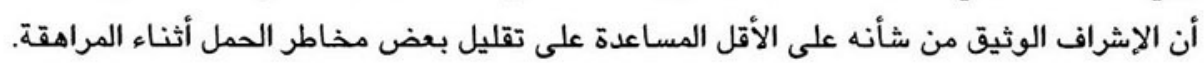

ولعل إحدى القنوات الواعدة للوصول إلى هذه الفئة تتمثل في المأذون، بوصفه المسئول المدني والديني عن إبرام وتسجيل عقد

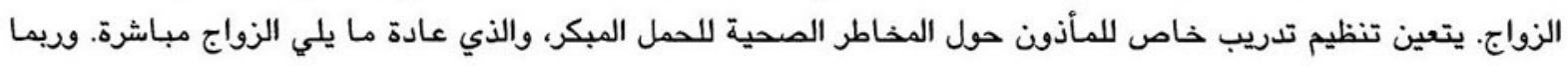

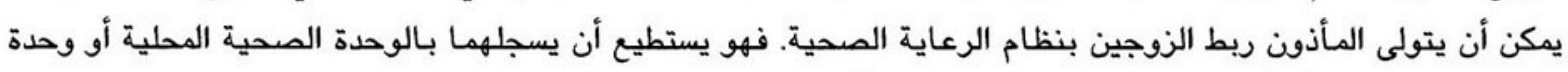

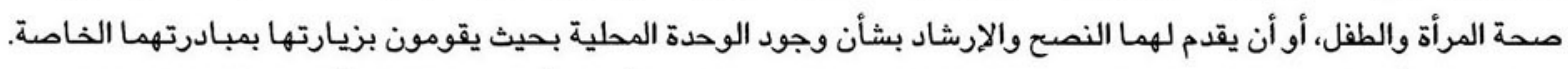

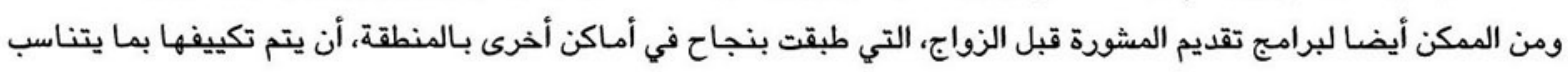
مع الواقع المصري.

وحيث أن ظاهرة زواج الفتيات توجد في جيوب محددة على امتداد البلاد، وخاصة ريف الصعيد والدلتا، فإن الوصول الفعال للفتيات المتزوجات يمكن أن يتحقق من خلال الحملات على المستوى المحلي التي تشتمل على رسائل موجهة بعدات إناية. 
إن مواجهة التحدي الهائل المتمثل في تحسين رفاهية النشء تقتضي استثمارات متكاملة في الصحة والتعليم والإعداد للعمل.

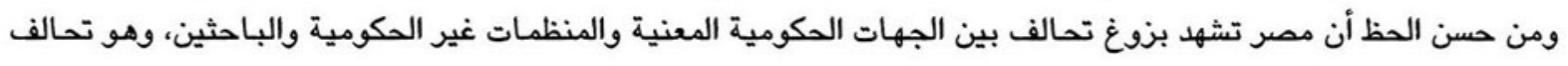

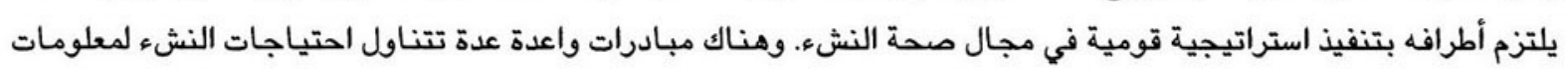

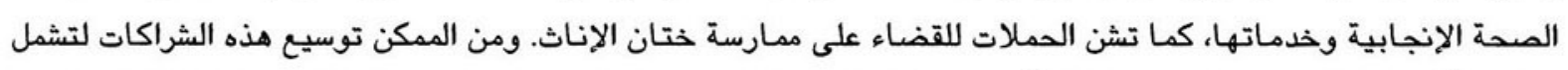

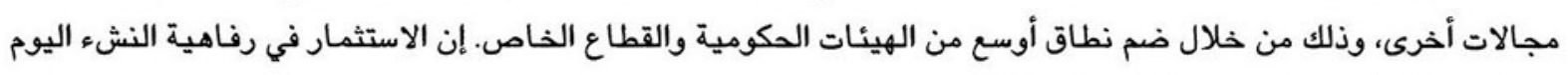
سيجلب منافع كبرى لمصر في العقود المقبلة. 


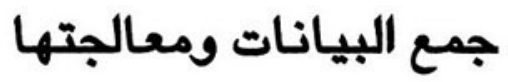

\section{مديرا العمليات الميدانية}

السيدة/زينب جمال - مركز البحوث الاجتماعية - الجامعة الأمريكية بالقاهرة

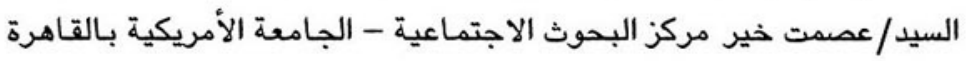

\section{المشرفون على العمل الميداني}

$$
\begin{aligned}
& \text { اعتماد عبد الرحيم الشريف، مدرس مساعد - كلية الطب - جامعة أسيوط }
\end{aligned}
$$

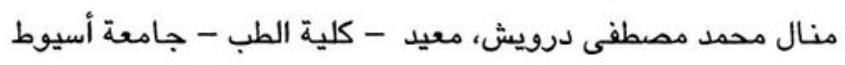

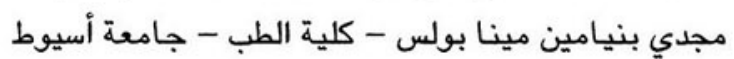

$$
\begin{aligned}
& \text { صابرة محمد أحمد - كلية الطب - جامعة أسيوط }
\end{aligned}
$$

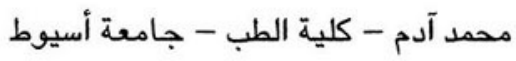

\section{فريق العمل الميداني (مركز البحوث الاجتماعية - الجامعة الأمريكية بالتامرة)}

$$
\begin{aligned}
& \text { لمياء سليمان } \\
& \text { محمود شحاتة } \\
& \text { مايسة عبده } \\
& \text { منال عبد العزيز } \\
& \text { منال عبد الحفيظ منال عبد العزيز } \\
& \text { مارسيل بطرس } \\
& \text { معاذ إبراهيم } \\
& \text { محمد عبد الفتاح } \\
& \text { محمد عطية الله } \\
& \text { محمد مرتضى } \\
& \text { محمد رزق محمدي } \\
& \text { منى عبد العزيز } \\
& \text { منى حفظي } \\
& \text { منى محمد محمود } \\
& \text { منى سامي } \\
& \text { نادية جابر بشر مامي } \\
& \text { نجوى محمد عبد الفتاح } \\
& \text { نسيبة خليل } \\
& \text { سماح عبد الرحيم }
\end{aligned}
$$

$$
\begin{aligned}
& \text { عبير أحمد مكاوي } \\
& \text { عبير إمام } \\
& \text { أحمد عبد الفتاح } \\
& \text { أحمد فتحي الشلا } \\
& \text { أحمد جلال } \\
& \text { أحمد حامد فهمي } \\
& \text { أحمد صلاح } \\
& \text { أحمد شورى أحمد صلاح } \\
& \text { أمل عبد الرحمن } \\
& \text { آمال رفعت أمل عبد الرحن } \\
& \text { أميرة ياسين } \\
& \text { أشرف سيد } \\
& \text { عزة مصطفى محمود } \\
& \text { دلال إبراهيم } \\
& \text { غادة عبد الله } \\
& \text { حميدة الشحات } \\
& \text { حميدة محفوظ } \\
& \text { هناء عباس } \\
& \text { حسن عبد الستار }
\end{aligned}
$$




$$
\begin{aligned}
& \text { سامح زين } \\
& \text { شيرين إسماعيل } \\
& \text { شيرين يوسف } \\
& \text { تحسين إبراهيم } \\
& \text { تامر محمد نبيل } \\
& \text { وائل محمد حسين } \\
& \text { وليد صابر } \\
& \text { ياسر عيد } \\
& \text { زينب الدمرداش } \\
& \text { د. حنان علي حسن } \\
& \text { د. زكريا عبد السميع } \\
& \text { دينا مجدي } \\
& \text { علياء زهران } \\
& \text { ميادة عارف } \\
& \text { رانيا صقر } \\
& \text { طاهرة عبد اللطيف }
\end{aligned}
$$$$
\text { هبة فتحي }
$$$$
\text { هويدا أبو الوفا }
$$$$
\text { إيهاب زكريا }
$$$$
\text { إقبال عبد النبي }
$$$$
\text { إلهام حسن }
$$$$
\text { إيمان الكاشف }
$$$$
\text { إيمان صلاح }
$$$$
\text { خديجة محمود }
$$$$
\text { خالد سعيد }
$$

المراجعة المكتبية والترميز

محمد أمين

زينب علي

إيمان فاروق

عبير فكري

المبرمجن

أمل صقر

سحر الشنيطي

إدحال البيانات

هناء محمد سند

إيمان حامد فهمي

عمرو شكري

معتز فتح الرحمن

\section{معالجة البيانات الاضفافية}

الضو عبد الله، مركز البحوث الاجتماعية، الجامعة الأمريكية بالقاهرة

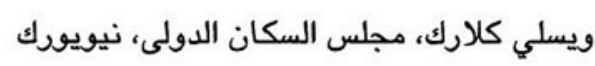




\section{الحاتمون على الفمص الطبي، مذارة المدة والسكان}

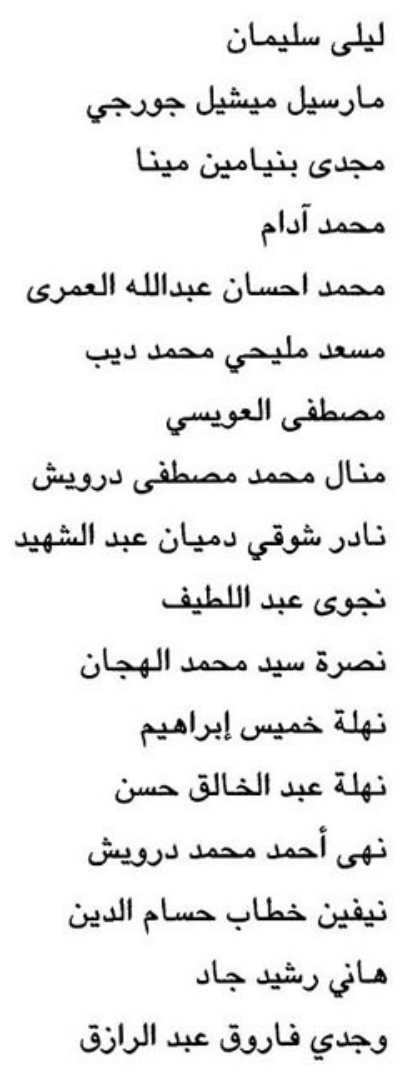

$$
\begin{aligned}
& \text { أنجيل وديع سوريال } \\
& \text { إيناس حلمي فرغلي } \\
& \text { إيناس محمود سامي } \\
& \text { ابتسام إبراهيم الدسوقي متعود مامي } \\
& \text { اعتماد عبدالرحيم الشريف } \\
& \text { ثروت ونيس نخلة } \\
& \text { جمال أبو المعاطي صالح } \\
& \text { حسام الدين إبراهيم الخليجي } \\
& \text { حسام الدين إبراهيم النجار إلبراهيم الخيجي } \\
& \text { حسن علي سعد سالم } \\
& \text { سلوى فايز فضيل } \\
& \text { سميحة عبد الدايم محمد عبد الدايم فيزيل }
\end{aligned}
$$

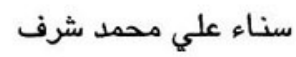

$$
\begin{aligned}
& \text { صلاح الدين علي السيد } \\
& \text { طه محمد عبد التواب } \\
& \text { عادل علي علي إسماعيل } \\
& \text { عزة حمدي حسن الغندور } \\
& \text { علي السيد }
\end{aligned}
$$

المستشارن والمراجعنف

وضع الحتبارات اللغة العربية والرياضيات وتقدير درجاتها د. مصطفى عبد السميع - جامعة القاهرة د. د. إبراهيم الشافعي - جامعة القاهرة

المشرف على تمليل عينات البول والبراز

د. أمل عبد الفتاح الصحن، المعهد العالي للصحة العامة، جامعة الإكندرية

استشارى علم النفس- خلال مرحلة تطوير أدوات الدراسة

د. جواد فطاير، قسم الاجتماع - الجامعة الأمريكية بالقاهرة 


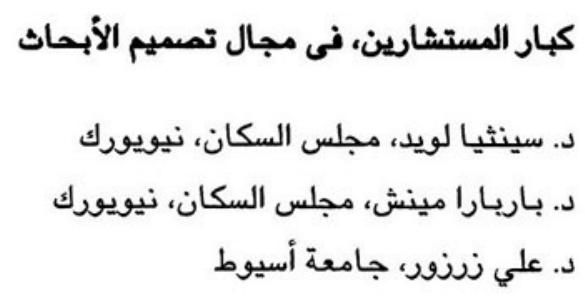

المراجعة الفنية

د. جوزيت عبد الله، (قسم علم النفس) - الجامعة الأمريكية بالقاهرة د. ل د ليلى الزيني، جامعة القاهرة

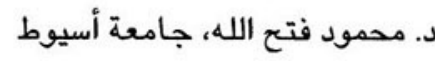
د. رون هيس، مركز برامج الاتصالات ، جامعة جونز هويكينز

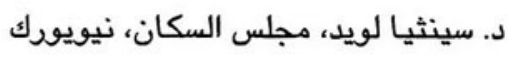

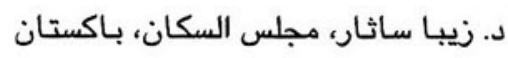




\section{اللجنة الاستشارية القومية}

$$
\begin{aligned}
& \text { وزارة الصدة والسكان } \\
& \text { المجلس القومي للسكان }
\end{aligned}
$$

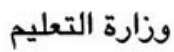

$$
\begin{aligned}
& \text { الجهاز المركزي للتعبئة العامة والإحصاء } \\
& \text { وزارة الصحة والسكان } \\
& \text { وزارة الصحة والسكان } \\
& \text { جمعية الشباب للسكان والتنمية }
\end{aligned}
$$

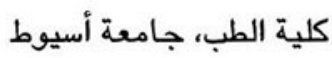

$$
\begin{aligned}
& \text { المجلس القومي للطفولة والأمومة } \\
& \text { سفارة هولندا } \\
& \text { صندوق الأمم المتحدة للأنشطة السكانية } \\
& \text { هيئة كير الدولية } \\
& \text { سيدا } \\
& \text { سيدا } \\
& \text { مركز البحوث الاجتماعية، الجامعة الأمريكية في القاهرة } \\
& \text { اليونسكو }
\end{aligned}
$$

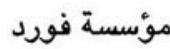

$$
\begin{aligned}
& \text { مركز التنمية والانشطة السكانية (سيدبا) } \\
& \text { اللجنة القومية للسكان والتنمية } \\
& \text { اليونيسيف }
\end{aligned}
$$

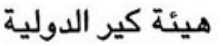

$$
\begin{aligned}
& \text { مؤسسة روكفيلر/جامعة أسيوط الدولية }
\end{aligned}
$$

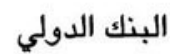

$$
\begin{aligned}
& \text { اللجنة القومية للسكان والتنمية/قوة العمل المناهضة لختان الإناث } \\
& \text { سفارة هولندا } \\
& \text { الوكالة الكندية للتنمية الدولية (سيدا) } \\
& \text { هيئة المعونة الأمريكية } \\
& \text { الهيئة القبطية للخدمات الاجتماعية الإنيكا } \\
& \text { وحدة تخطيط ومراقبة البرامج } \\
& \text { سيدا } \\
& \text { صندوق الأمم المتحدة للأنشطة السكانية } \\
& \text { هيئة المعونة الأمريكية } \\
& \text { اليونيسيف } \\
& \text { الهيئة القبطية للذدمات الاجتماعية }
\end{aligned}
$$

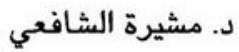

$$
\begin{aligned}
& \text { أ.د. ماهر مهران } \\
& \text { م. محمد رجب شرابي } \\
& \text { د. عبد اللطيف هنيدي } \\
& \text { د. عصمت منصور }
\end{aligned}
$$

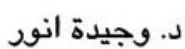

$$
\begin{aligned}
& \text { السيد/أحمد لطفي }
\end{aligned}
$$

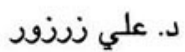

$$
\begin{aligned}
& \text { د. أمينة الجندي } \\
& \text { السيدة/أرليت عسيران الجنان } \\
& \text { السيد/عبد المنعم أبو نوار } \\
& \text { السيد/إيرل وول/عبد السنما إيوان } \\
& \text { السيدة/إيمان عمران } \\
& \text { السيدة/هـالة شنودة } \\
& \text { د. لـدى رشاد } \\
& \text { السيدة/إيناس الإبراشي دي رئاد } \\
& \text { د. جوسلين دي يونج } \\
& \text { السيدة/جولي هنسن سوانسن } \\
& \text { د. كمال لولح } \\
& \text { د. ل د. ليلى بشارات } \\
& \text { السيدة/ماجي محروس بلمات } \\
& \text { د. محمود فتح الله } \\
& \text { د. محمود جمال الدين } \\
& \text { السيدة/ماري أسعد } \\
& \text { السيدة/ماريك بوت } \\
& \text { السيد/ مارتن سوتر } \\
& \text { السيدة/ملون تناملي } \\
& \text { السيد نبيل صمويل } \\
& \text { د. ل دادية جمال } \\
& \text { السيدة/نائلة رفعت جمال } \\
& \text { السيدة/سهير عبد الهادي } \\
& \text { السيدة/سالي باتون } \\
& \text { السيدة/فانيسا تويين } \\
& \text { السيدة/وفاء وليم }
\end{aligned}
$$




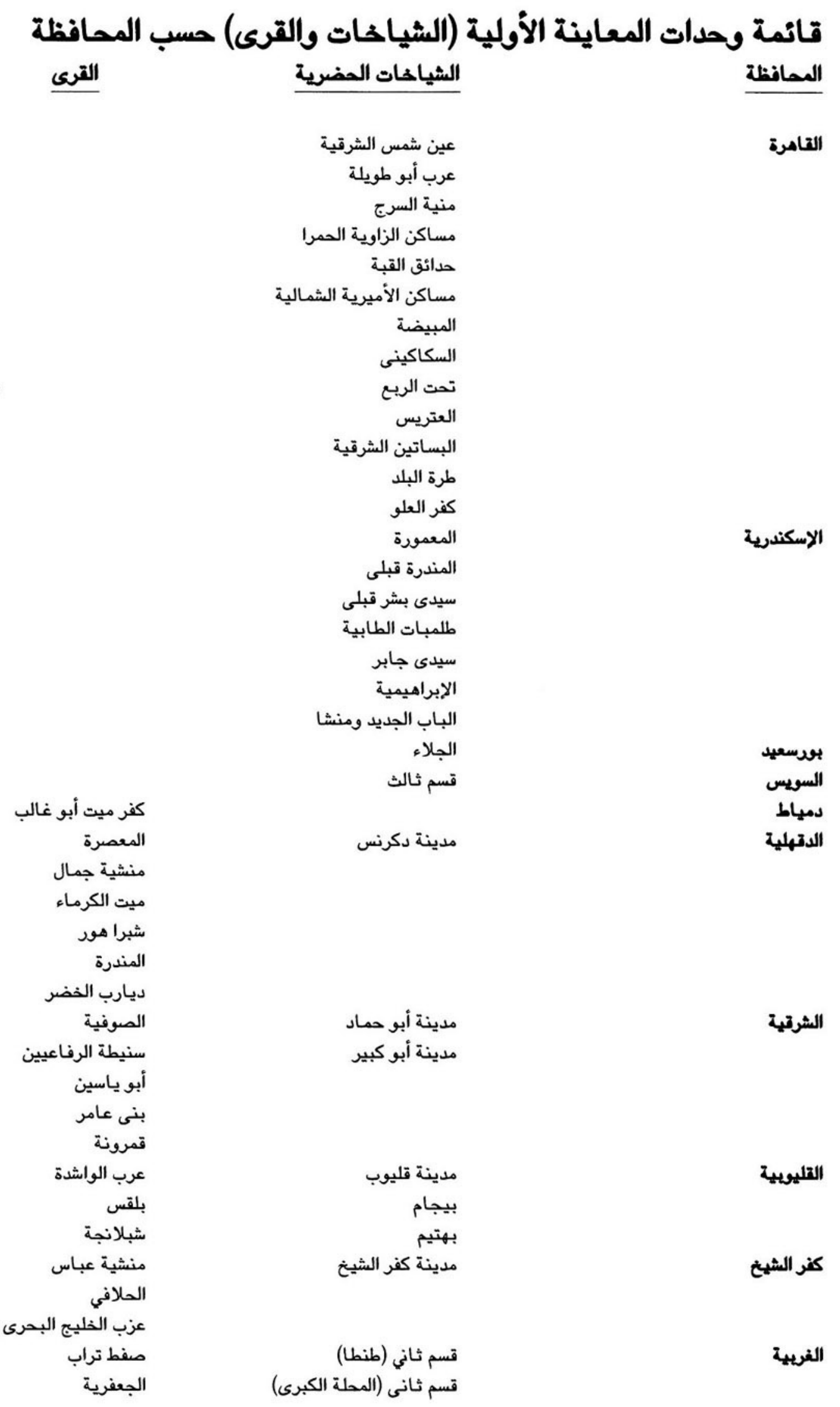




\begin{tabular}{|c|c|c|}
\hline \multicolumn{3}{|l|}{ بنوفر ب } \\
\hline منشية عاصم ومنشية السلام & مدينة أشمون & المنوفية \\
\hline تلوانا & & \\
\hline 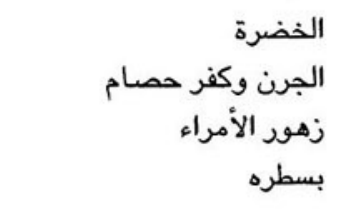 & مدينة دمنهور (نقرهـا) & 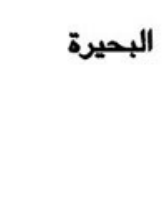 \\
\hline سرابيوم & & الاسماعيلية \\
\hline القبابات & 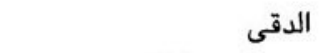 & الجيزة \\
\hline الطرفاية & جزيرة إمبابة & \\
\hline أبو غالب & جدينة أوسيم الدهب & \\
\hline كفرم جمعة واضفي وسيدي سالم & مدينة بني سويف & بنى سويف \\
\hline التوفيقية & مدينة الفيوم (قسم أول) & 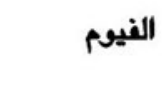 \\
\hline جزيلا الشرقية شارونة & مدينة المنيا (قسم رابع) & المنيا ال \\
\hline ريدة منشة الذهب البحرية & & \\
\hline جدام & مدينة ديروط & أسيوط \\
\hline فزارة محمد الشهابية & مدينة المنشأة & سوماج \\
\hline 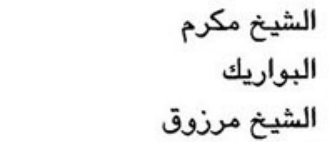 & & \\
\hline 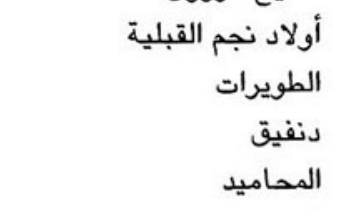 & مدينة أرمنت & قنا \\
\hline الحجز بحرى & مدينة أسوان (شياخة أولى) & أسوان \\
\hline
\end{tabular}




\section{جودة ودقة البيانات}

نظرا للطابع المبتكر للدراسة وتعقيد تصميم العينة، كان من المهم تقييم نوعية البيانات التي تم جمعها. وتتمثل ثلاث قضايا

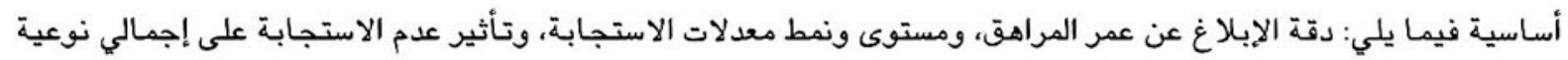

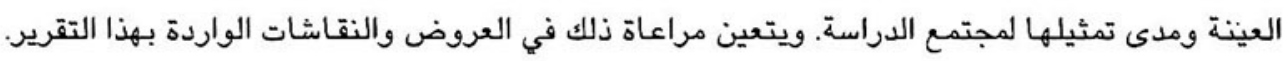

\section{دقة الإبلاغ عن العمر}

يبين الشكل ا توزيع أعمار أفراد الفئة العمرية 9- •r سنة في كافة الأسر التي شملتها العينة والتي تم حصرهـا لأغراض المسح.

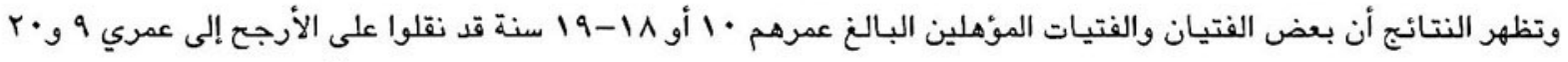

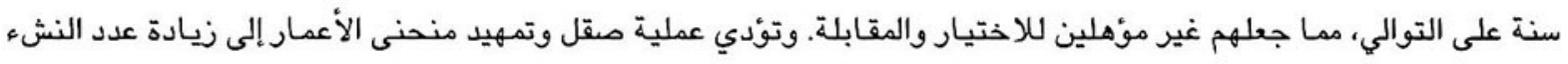

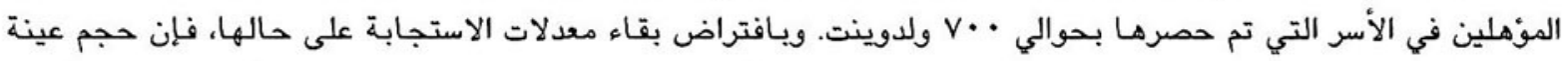

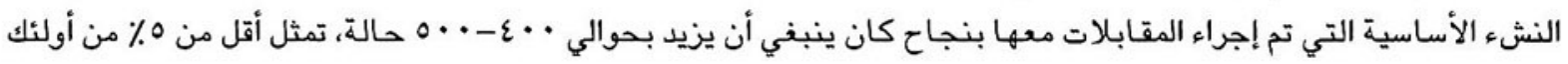

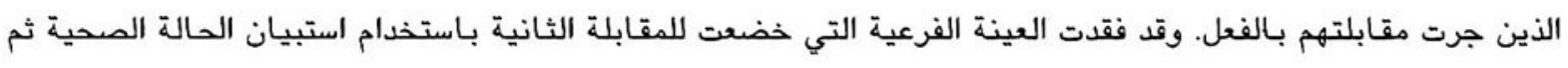

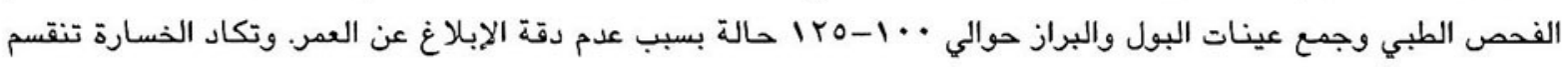

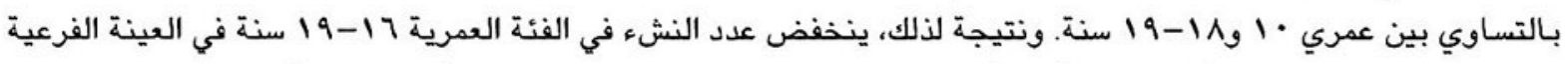

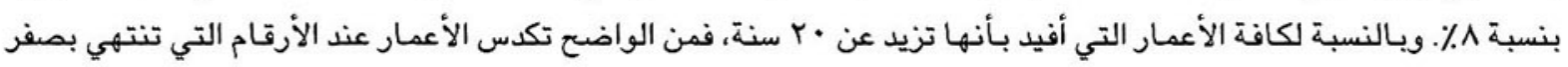

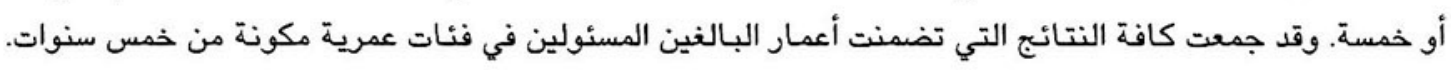

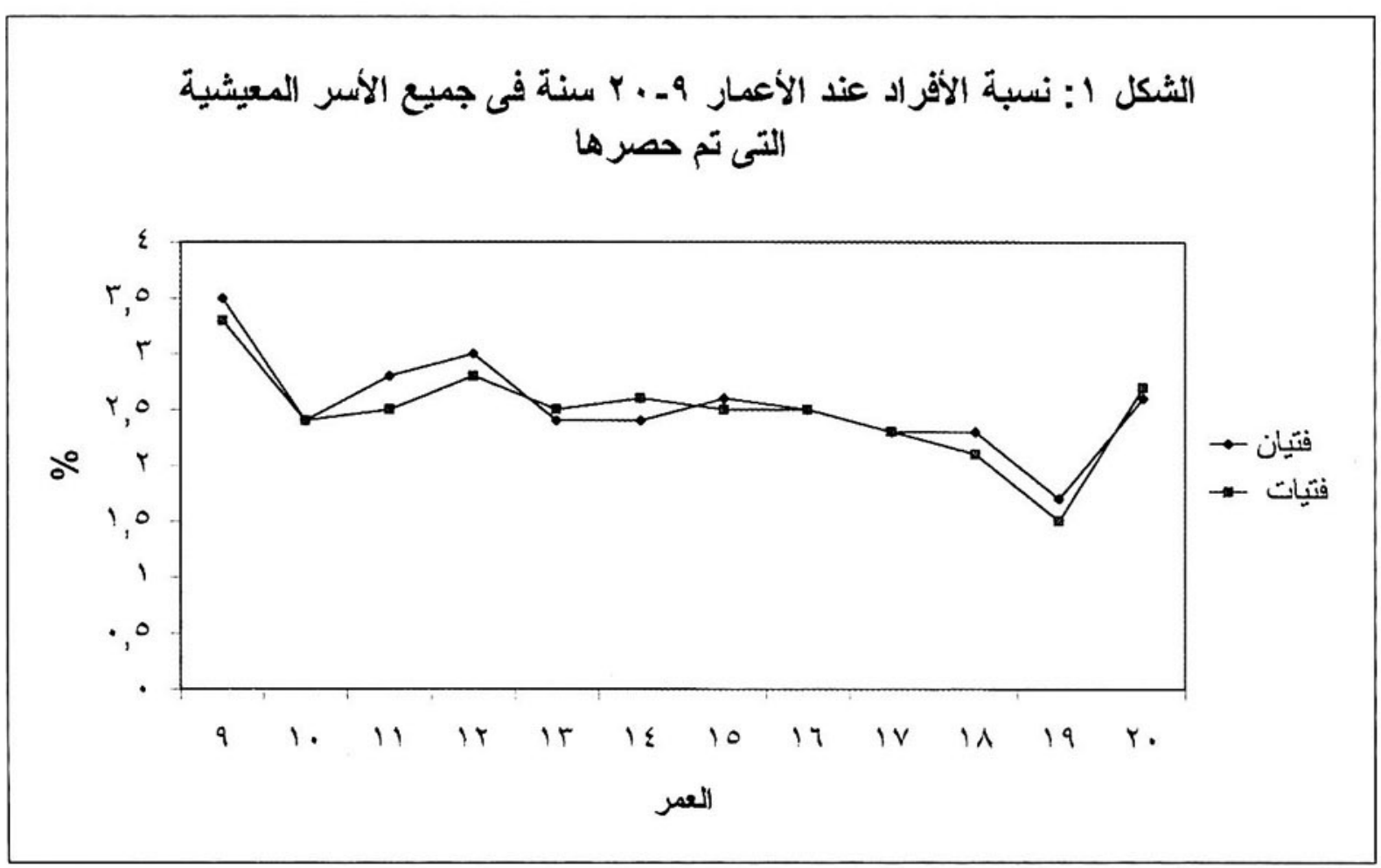


يوضح الجدول ا معدل الاستجابة، وعدد الفتيات والفتيان الذين جرت مقابلتهم بنجاح، وعدد الدختارين أصلا حسب أداة الاستبيان، والنوع، ونمط محل الإقامة ما بين حضرل وعري الإندات وريفي.

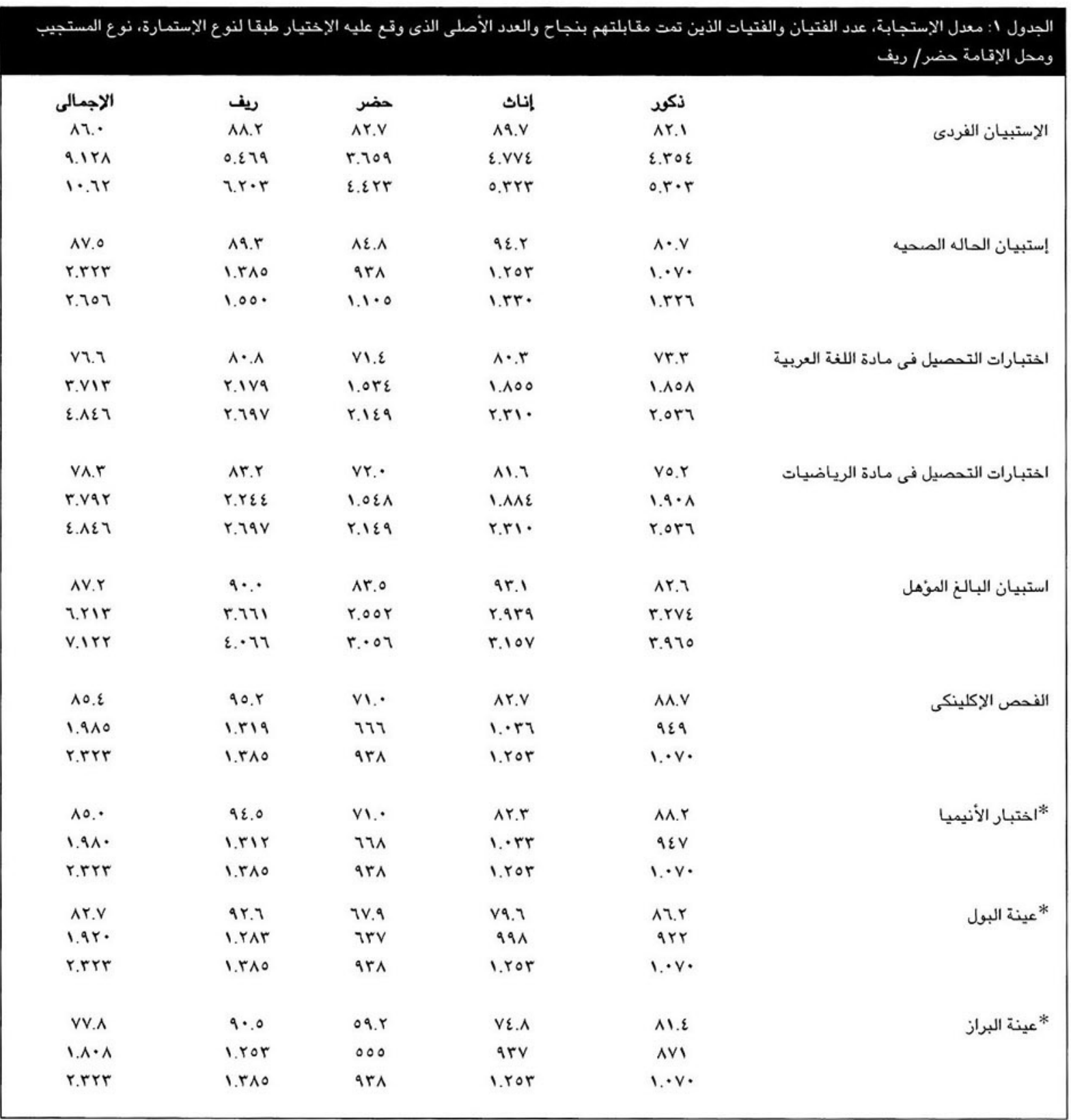

*معدل الإستجابة يتم حسابه كنسبة منوية من العينة التى أكملت إستمارة الإستبيان الصحى بنجاح

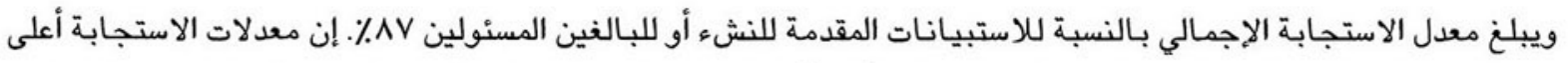

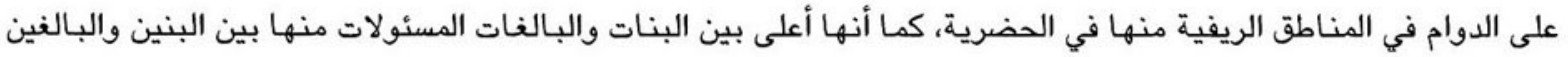

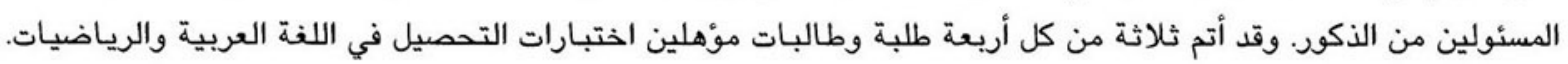

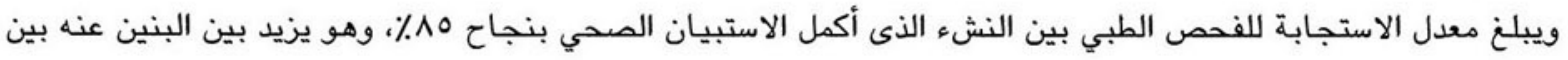
البنات كما يزيد في المناطق الريفية عنه في الحضرية. 
ويوضح الجدول r التباينات في معدلات الاستجابة بين الفتيان والفتيات المختارين عشوائيا للمقابلة الفردية الأساسية

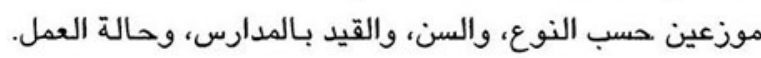

الجدول r: التباينات فى معدل الإستجابة بين النشء الذي وقع عليه الإختيار العشوائى لإستكمال الإستبيان الغردى طبقا لبعض المتغيرات الخلفية

\begin{tabular}{|c|c|c|c|}
\hline الاجمالى & بنات & بنين & العمر - ل العر \\
\hline 91.9 & 91.9 & 91.1 & 1. \\
\hline 91.0 & १ย.r & А९.r & 11 \\
\hline$\wedge 9.7$ & $9 \varepsilon . r$ & ^०.. & ir \\
\hline$\wedge \Lambda .0$ & $9 \cdot . v$ & ה.r. & ir \\
\hline$\wedge 9 . \wedge$ & $9 r .9$ & No.r & $1 \varepsilon$ \\
\hline ᄉ..1 & $9 \cdot .0$ & $\wedge 1 . \wedge$ & 10 \\
\hline Aı.V & 10.9 & vา. 9 & 17 \\
\hline$\wedge r .1$ & Av.r & V^.1 & iv \\
\hline vา.1 & Ar.r & $v \cdot .0$ & in \\
\hline \multirow[t]{2}{*}{ vย. } & $\wedge \cdot \cdot$ & 71.1 & 19 \\
\hline & & & الالتحاق بالمدرسة \\
\hline A 1.7 & 91.7 & 10.9 & ملتحق \\
\hline \multirow[t]{2}{*}{$\Lambda \cdot . \diamond$} & ^५. & $\vee 1.0$ & غير ملتحق \\
\hline & & & العمل بأجر \\
\hline$\Lambda \cdot .0$ & 14.Y & va.r & نعم \\
\hline \multirow[t]{2}{*}{ ᄉา. } & 19.1 & $\Delta r . q$ & y \\
\hline & & & العل بدون أجر \\
\hline 9r. & $90 . r$ & $q \cdot \varepsilon$ & نعم \\
\hline 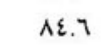 & $\wedge 9$. & va.\& & $y$ \\
\hline
\end{tabular}

تبدأ معدلات الاستجابة عند مستوى عال يبلغ بو٪ بين البنين والبنات في العاشرة من العمر. وتزيد المعدلات بين البنات عنها

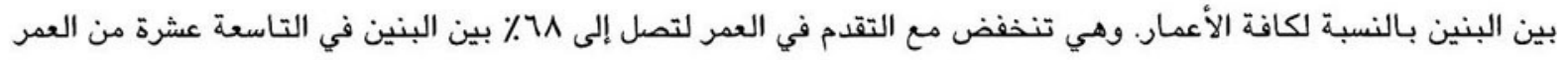

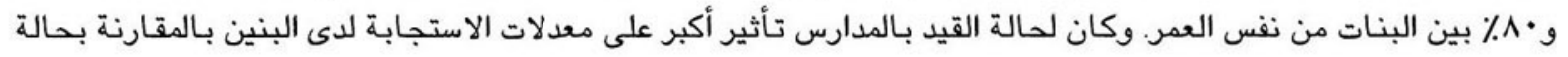

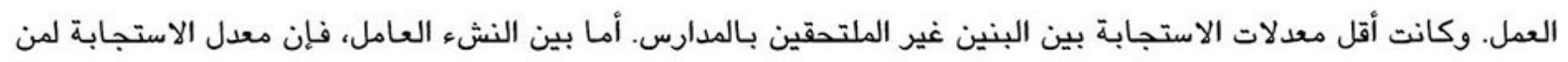

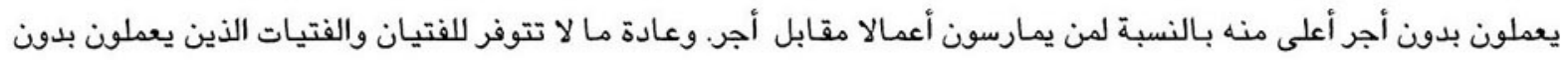

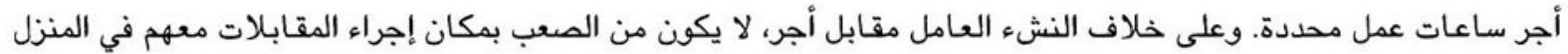
أو في مكان عمل الأسرة القريب أو في الحقل. 


\section{المراجع}

Allen, AVH and DS Ridley, 1970. Further observations on the formol-ether concentration technique for fecal parasites. Journal of Clinical Pathology, 23: 545-546.

Attallah, NL. 1977. Age at menarche of schoolgirls in Egypt. a short report. London, UK: Department of Growth and Development, Institute of child Health, University of London.

Dunn FL. 1968. The TIF direct smear as an epidemiological tool. World Health Organization (WHO) Monograph Series, No. 39: 439-449. Geneva, Switzerland: WHO.

El-Zanaty, F; Hussein, EM; Shawky, GA; Way, A; and Kishor, S. 1996. Egypt demographic and health survey 1995. Calverton, MD: National Population Councl (Arab Republic of Egypt) and Macro International, Inc.

Galal, O; Harrison, G; and Qureshi, A. 1991. Socioeconomic and nutritional status effects of pubertal development in Egyptian girls. Clinical Research, January 1991, 43-51.

El-Hammamsy, L. 1994. Early marriage and reproduction in two Egyptian villages. Occasional Monograph. The Population Council/ UNFPA, Cairo, Egypt.

Jaffe, L and Manzer, R. 1992. GirlsÕ perspectives: Physical activity and self-esteem. Melpomene, 11, 3: 14-28.

Jelliffe, DB. 1966. The assessment of the nutritional status of the community (with special reference to field surveys in developing regions of the world). WHO Monograph Series, No. 53: 64-69.

Khattab, HAS. 1992. The silent endurance: Social conditions of womenÕs reproductive health in rural Egypt. Cairo, Egypt: UNICEF and The Population Council.

Makhlouf, H and Amin, SZ. 1995. Enquiring the knowledge of Egyptian youth on reproductive health: Summary of final results. Cairo, Egypt: Cairo Demographic Center and The Egyptian Family Planning Association.

Must, A; Dallal, GE; and Dietz, WH. 1991. Reference data for obesity: 85th and 95th percentiles of body mass index (wt/ ht2)- a correction. American Journal of Clinical Nutrition, vol. 54: 773 .

Papanek H and Ibrahim B. 1981. Economic participation of Egpyptian women: Implications for labor force creation and industrial policy. Report to U.S. Agency for International Development (Cairo, Egypt), December 1981.

Richardo, FO; hassan, F; Cline, BL; El-Alamy, MA. 1984. An evaluation of quantitative techniques for S. haematobium eggs in urine preserved with carbol fuchsin. American Journal of Tropical Medicine and Hygien, 33: 857-861. 
Selim, S. 1996. Children and women in Egypt. An information atlas. Cairo, Egypt: National Council for Childhood and Motherhood.

Shafey, H. 1998. Adolescence and state policy in Egypt. Cairo, Egypt: The Population Council.

Tanner, JM. 1975. Growth and endocrinology of the adolescent. In LI Gardner (Ed.), Endocrine and Genetic Diseases of Children and Adolescents. 2nd ed. Philadelphia, PA: WB Saunders.

World Health Organization (WHO). 1996. The health of youth: A cross-national survey. WHO Regional Publications, European Series, No. 69.

-. 1995. Physical status. The use and interpretation of anthropometry. Report of a WHO Expert Committee. WHO Technical Report Series, No. 854: 263-311.

- 1983. Measuring change in nutritional status. Geneva, Switzerland: WHO.

1968. Nutritional anemias: report of a WHO Scientific Group. WHO Technical Report Series, No. 405. Geneva, Switzerland: WHO.

Zulficar, M. 1995. Women in develpment: A legal study. Cairo, Egypt: UNICEF. 


\section{المؤلفون}

\section{الباحثون الأساسيون}

د. سحر الطويلة باحث مشارك بمركز البحوث الاجتماعية، الجامعة الأمريكية في القاهرة. حاصلة على شهادتي الماجستير

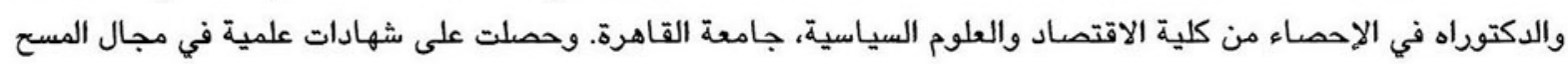

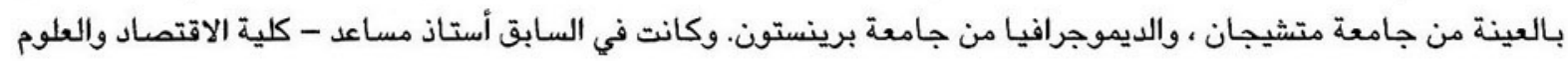

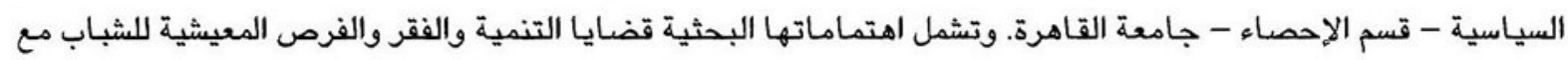
تركيز خاص على التعليم.

د. أميمة الجبالي محاضر بقسم الصحة العامة وطب المجتمع، جامعة أسيوط. مدير مركز الصحة الأولية والرعاية الاجتماعية، جامعة أسيوط. حاصلة على شهادتي الماجستير والدكتوراه في المحة العامة وعلى بكالوريوس الطب من كلية طب أسيوط.

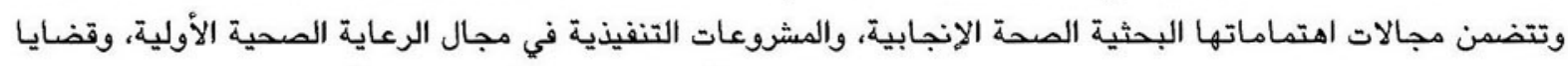

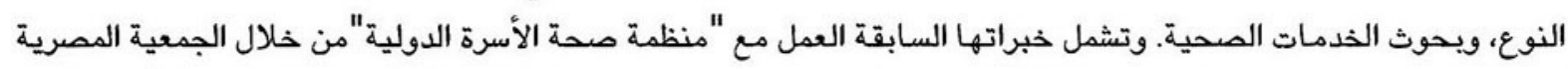

للخصوية واليونيسيف ومؤسسة فورد، فضلا عن عملها الحالي مع مكتب مجلس السكان لمنطقة غرب آسيا وشمال أفريقيا.

د. باريارا إبراميم المدير الإقليمي لمجلس السكان الدولي في منطقة غرب آسيا وشمال أفريقيا بالقاهرة. حاصلة على شهادة

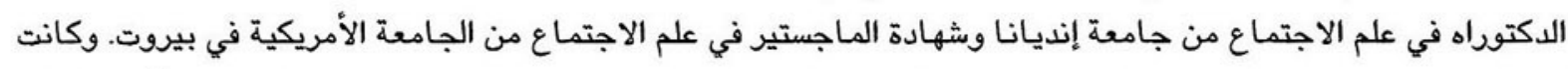

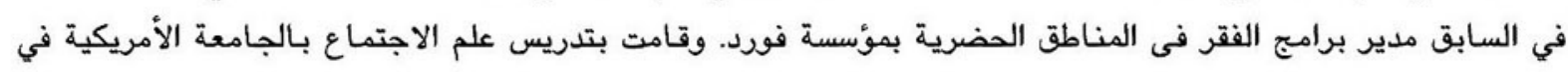

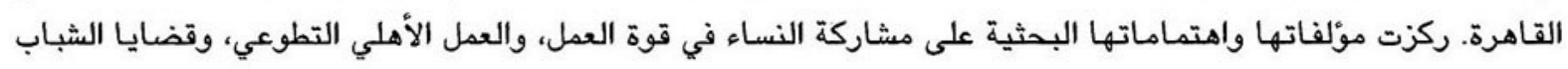

والتغيير الاجتماعي.

د. فكرات المدن أستاذ علم التغذية بالمعهد العالي للصحة العامة، جامعة الإسكندرية. حاصلة على شهادة الدكتوراه في

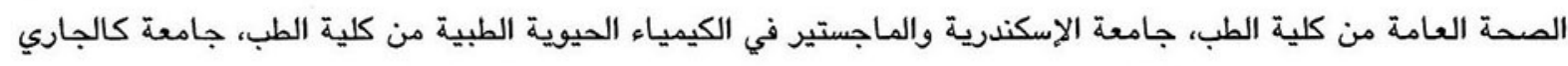

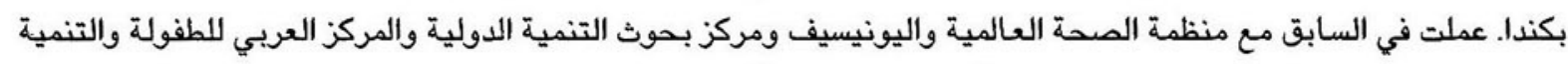

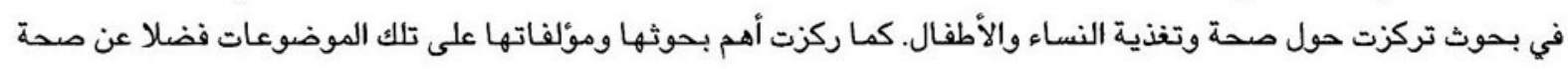

وتغذية الكبار.

د. ساني سلام أستان علم الأويئة ووكيل المعهد العالي للصحة العامة لشئون البيئة وخدمة المجتمع، جامعة الإسكندرية. حاصلة

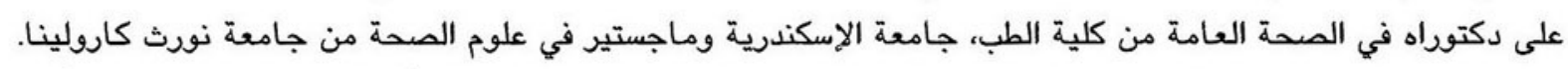

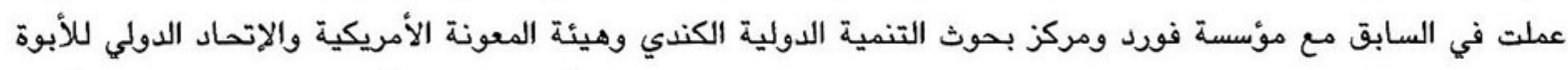
المخططة وغيرها من المنظمات الدولية والوطنية المصرية، حيث تركز عملها بالأساس حول الأمراض المعدية وتنظية الأنظيم الأسرة. وتشمل اهتماماتها الحالية صحة المراهقين والصحة الإنجابية والتنمية. 
سوذان لى زميل باحث بمكتب مجلس السكان لإقليم غرب آسيا وشمال أفريقيا بالقاهرة. حاصلة على شهادة الماجستير في

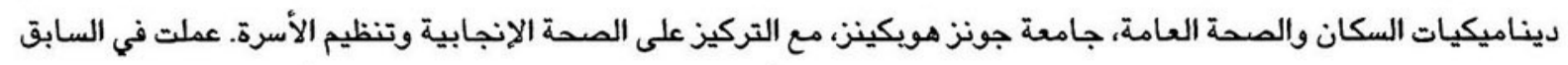

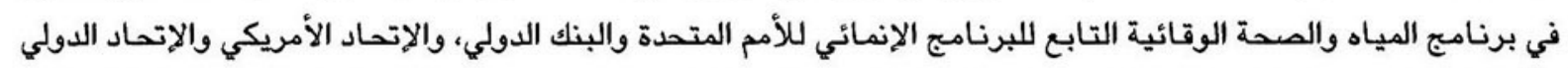

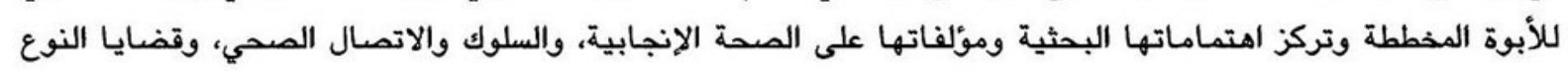
المتصلة بإمدادات خدمات المياه والصحة الوقائية.

د. باريارا مينث خبير مشارك بقسم بحوث السياسات بالمقر الرئيسي لمجلس السكان بنيويورك. وعلى مدى السنوات الأريع

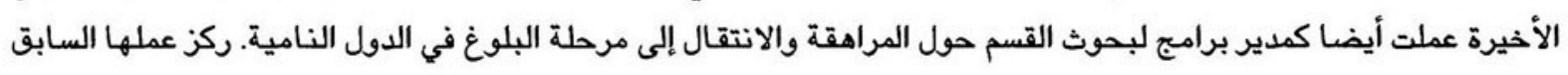

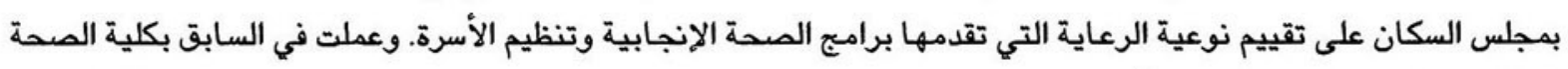

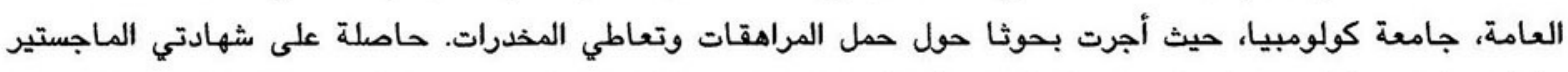

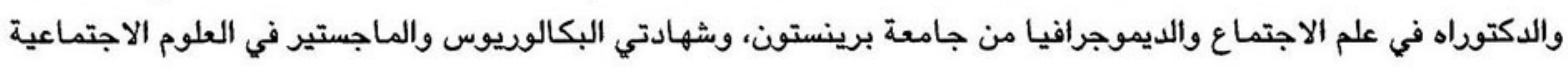

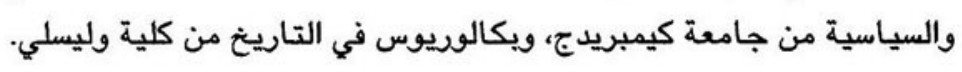

أ. مند وامف باحث مشارك بمكتب مجلس السكان لاقليم غرب آسيا وشمال أفريقيا بالقاهرة. حاصلة على شهادتي الماجستير

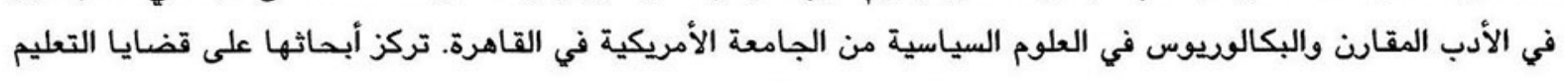

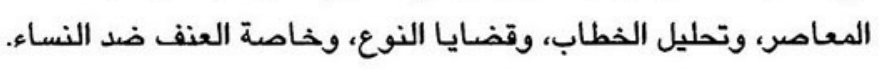

أ. سارة بخاري مسئولة ادارية عن برنامج النوع والأسرة والتنمية بمجلس السكان لإقليم غرب آسيا وشمال أفريقيا بالقاهرة.

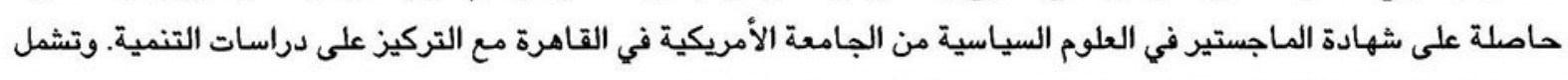
اهتماماتها البحثية التشويه الجنسي للاناث وتنمية المجتمعات الماتية المحلية.

د. عثمان جلال أستاذ علوم الصحة العامة بكلية الصحة العامة، جامعة كاليفورنيا. حصل على شهادة الدكتوراه من جامعة

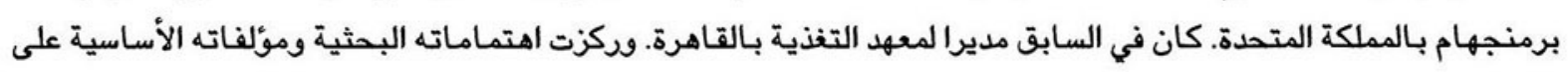
صحة ونمو الطفل. 